\title{
MONOGRAPH
}

THEORETICAL FOUNDATIONS OF THE FUNCTIONING OF EDUCATION.

WAYS TO IMPROVE THE

EFFECTIVENESS

\section{OF EDUCATIONAL ACTIVITIES}

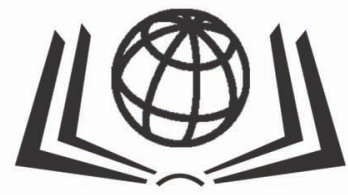

INTERNATIONAL SCIENCE GROUP

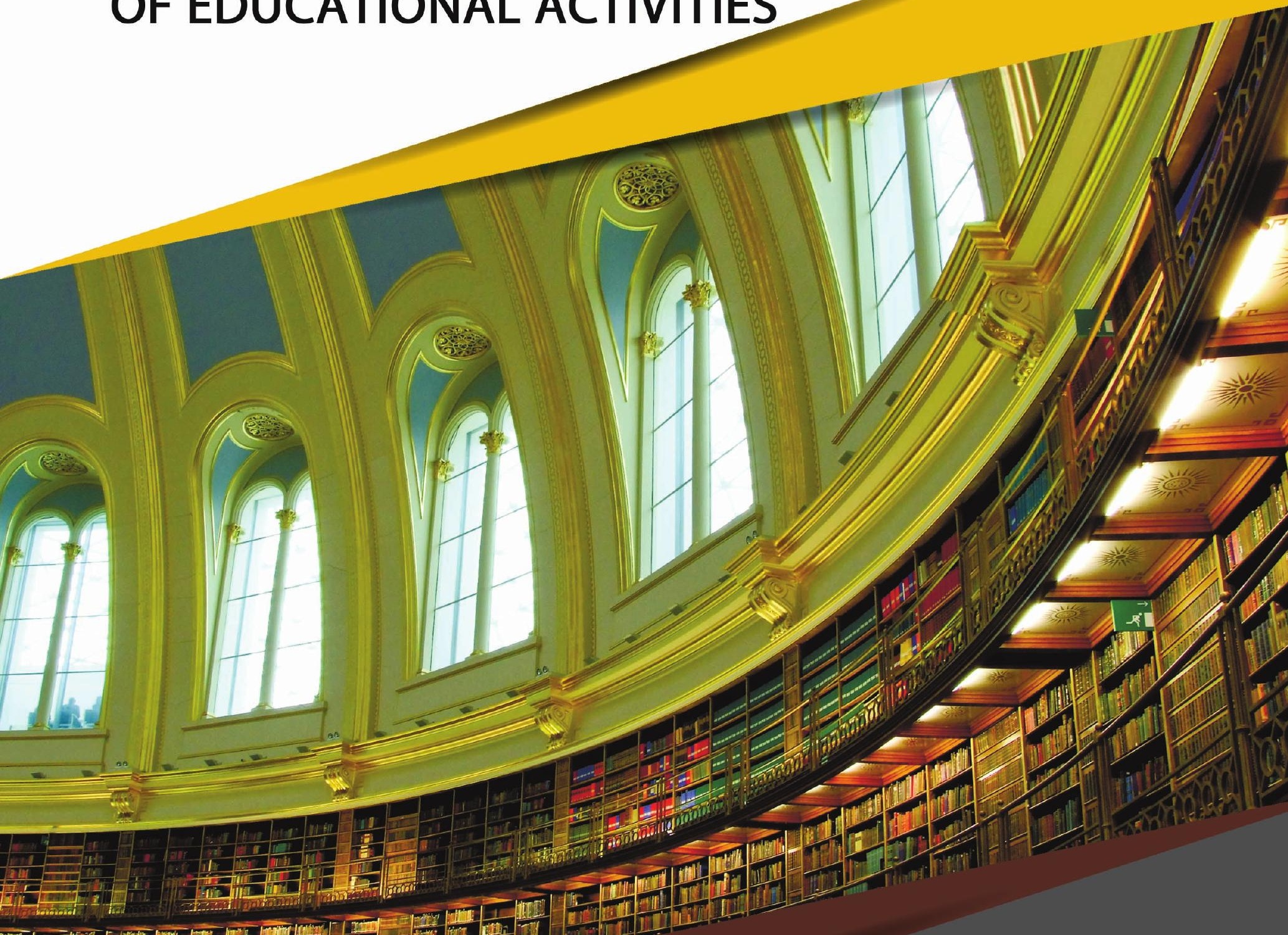

Tin

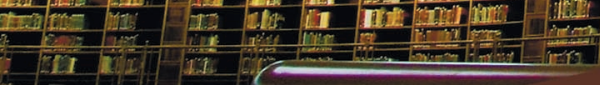

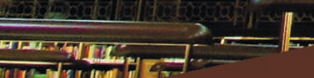

DOI 10.46299/ISG.2021.MONO.PED.II

ISBN 978-1-63848-668-8

BOSTON (USA) - 2021

ISG-KONF.COM 
ISBN - 978-1-63848-668-8

DOI- 10.46299/ISG.2021.MONO.PED.II

Theoretical foundations of the functioning of Education. Ways to improve the effectiveness of educational activities

Gollective monograph

Boston 2021 
Library of Congress Cataloging-in-Publication Data

ISBN - 978-1-63848-668-8

DOI - 10.46299/ISG.2021.MONO.PED.II

Authors - Baranovska O. Kondratska H., Chepelyuk A., Budynkevych S., Lappo V., Moskalyova L., Gurova T., Mosiakova I., Nozdrova O., Bartienieva I., Радченко O., Файдевич В., Андрійчук Ю., Констанкевич В., Чиж А., Чіжова Н., Антоненко І., Ayupova G., Bolsynbekova G., Болсынбекова Г.А., Аюпова Г.Т., Демус Я., Самсонова О.О., Чорна Г.В., Скірко Г.З., Чорна Г.В., Фазан Т., Фазан В., Ходунова В., Гребцова И., Akimov I., Sergacheva V., Gulbs O., Dekhtyarenko S., Kuzmina V., Zhuk E., Gurevych R., Habriichuk L., Herasymenko N., Opushko N., Hamska N., Kovalevska O., Oleynik O., Kolesnyk A., Rumyantseva E., Yatsyshyn N., Більченко Є., Дуднік В., Тухтарова Т., Дзіговський М., Есенгабылов И.Ж., Алдабергенова А.О., Исаева Г.Б., Коваль Г.М., Куруц Н.В., Гасинець Я.С., Карбованець О.І., Мельник О., Федотова О., Томаз І., Хмельникова Л., Маслак Г., Слєсарчук В., Шиман О., Dekusar G., Davydova N., Мельничук B.О., Назаревич B.В., Bocheliuk V., Pozdniakova O., Pozdniakova-Kyrbiatieva E., Panov N., Dzhezhelei O., Diakova Y., Levandovska H., Ilchenko O., Kotova O., Hryhorieva V., Tatochenko V., Hniedkova O., Poleva J., Poliakova J., Stepanov A., Lisna T., Toryanik L., Kovalenko Z., Chernyshenko О., Івченко В., Андрейко О., Бабінцева Л.Ю., Видиборець С.В., Горяінова Н.В., Булавіна О.А., Білозерська С., Мащак С., Гриценко Н.Л., Чалий О.В., Стучинська Н.В., Есенғабылов И.Ж., Елепбергенова А.У., Криванкова Л.С., Оразбаева А.А. Коваленко О., Люльченко В., Сусло Л., Орлова О., Панфілов О., Онипченко П., Тимошенко О., Марков А., Громико О., Радомська В., Самойленко О.М., Свстрат'єв С.В., Силюга Л., Ковалевич I., Снігірьова А., Тарасов А., Стотика І., Власенко Е., Стотика О., Удовиченко I.

Published by Primedia eLaunch

https://primediaelaunch.com/

Text Copyright (C) 2021 by the International Science Group(isg-konf.com) and authors.

Illustrations (C) 2021 by the International Science Group and authors.

Cover design: International Science Group(isg-konf.com). C

Cover art: International Science Group(isg-konf.com). (C)

All rights reserved. Printed in the United States of America. No part of this publication may be reproduced, distributed, or transmitted, in any form or by any means, or stored in a data base or retrieval system, without the prior written permission of the publisher. The content and reliability of the articles are the responsibility of the authors. When using and borrowing materials reference to the publication is required. 
Collection of scientific articles published is the scientific and practical publication, which contains scientific articles of students, graduate students, Candidates and Doctors of Sciences, research workers and practitioners from Europe and Ukraine. The articles contain the study, reflecting the processes and changes in the structure of modern science.

The recommended citation for this publication is:

Theoretical foundations of the functioning of Education. Ways to improve the effectiveness of educational activities: collective monograph / Baranovska O. - etc. International Science Group. - Boston : Primedia eLaunch, 2021. 674 p. Available at : DOI - 10.46299/ISG.2021.MONO.PED. II 
THEORETICAL FOUNDATIONS OF THE FUNCTIONING OF EDUCATION. WAYS TO

IMPROVE THE EFFECTIVENESS OF EDUCATIONAL ACTIVITIES

TABLE OF CONTENTS

\begin{tabular}{|c|c|c|}
\hline 1. & EDUCATION & \\
\hline 1.1 & $\begin{array}{l}\text { Baranovska О. } \\
\text { ТЕОРЕТИКО-МЕТОДОЛОГІЧНІ ОСНОВИ } \\
\text { ІНДИВІДУАЛІЗАЦЇ̈ НАВЧАННЯ В ПОЧАТКОВІЙ ШКОЛІ } \\
{ }^{1} \text { Institute of Pedagogy of the National Academy of Pedagogical Sciences of Ukraine }\end{array}$ & 16 \\
\hline 1.2 & $\begin{array}{l}\text { Kondratska H. }{ }^{1} \text {, Chepelyuk A. }{ }^{1}, \text { Budynkevych S. } \\
\text { SPORT IN THE PRESENT ERA } \\
{ }^{1} \text { Department of sport disciplines and tourism } \\
\text { Drohobych State Pedagogical University I. Franko }\end{array}$ & 24 \\
\hline 1.3 & $\begin{array}{l}\text { Lappo V. }{ }^{1} \\
\text { STRUCTURAL COMPONENTS OF THE PROCESS OF } \\
\text { FORMING THE SPIRITUAL VALUES OF STUDENT YOUTH } \\
{ }^{1} \text { Department of Pedagogyand Psychology of Kolomyia Educational Scientific } \\
\text { Institute of the Vasyl Stefanyk Precarpathian National University }\end{array}$ & 36 \\
\hline 1.4 & $\begin{array}{l}\text { Moskalyova L. }^{1} \text {, Gurova T. } \\
\text { VOLITIONAL OR AUTONOMOUS BEHAVIOR } \\
\text { MANAGEMENT: THEORETICAL ASPECTS FOR } \\
\text { PEDAGOGICAL PRACTICE } \\
{ }^{1} \text { Department of Preschool Education and Social Work, Bogdan Khmelnitsky } \\
\text { Melitopol state pedagogical university } \\
{ }^{2} \text { Department of Teaching Methods of Germanic Languages, Bogdan Khmelnitsky } \\
\text { Melitopol state pedagogical university }\end{array}$ & 46 \\
\hline 1.5 & $\begin{array}{l}\text { Mosiakova I. }^{1} \\
\text { UPDATING THE IDEAS OF THE REPRESENTATIVES OF } \\
\text { THE NEW SCHOOL OF SCIENTIFIC MANAGEMENT TO } \\
\text { IMPROVE THE EDUCATIONAL MANAGEMENT OF } \\
\text { MULTIDISCIPLINARY INSTITUTIONS OF } \\
\text { EXTRACURRICULAR EDUCATION } \\
{ }^{1} \text { Department of Preschool Education and Social Work Melitopol State Pedagogical } \\
\text { University named after Bohdan Khmelnytsky }\end{array}$ & 53 \\
\hline
\end{tabular}


THEORETICAL FOUNDATIONS OF THE FUNCTIONING OF EDUCATION. WAYS TO

IMPROVE THE EFFECTIVENESS OF EDUCATIONAL ACTIVITIES

\begin{tabular}{|c|c|c|}
\hline 1.6 & $\begin{array}{l}\text { Nozdrova O. }{ }^{1} \text {, Bartienieva I. }{ }^{1} \\
\text { FEATURES OF FORMATION OF CIVIC COMPETENCIES OF } \\
\text { JUNIOR SCHOOLCHILDREN IN THE SYSTEM OF } \\
\text { TRAINING OF FUTURE PRIMARY SCHOOL TEACHERS IN } \\
\text { HIGHER EDUCATION INSTITUTIONS } \\
{ }^{1} \text { Senior Lecturer at the Department of Pedagogy, } \\
\text { South Ukrainian National Pedagogical University named after K. D. Ushynsky, } \\
\text { Odessa, Ukraine }\end{array}$ & 65 \\
\hline 1.7 & $\begin{array}{l}\text { Радченко О. }{ }^{1}, \text { Файдевич В. }{ }^{1}, \text { Андрійчук Ю. }{ }^{2}, \text { Констанкевич В. }{ }^{2}, \\
\text { Чиж А. } \\
\text { ОСНОВНІ ШЛЯХИ ПОПЕРЕДЖЕННЯ НАРКОМАНІЇ СЕРЕД } \\
\text { ПІДЛІТКІВ ТА МОЛОДІ ЗАСОБАМИ ФІЗИЧНОЇ } \\
\text { КУЛЬТУРИ Й СПОРТУ } \\
{ }^{1} \text { Луцький національний технічний університет, } \\
{ }^{2} \text { Луцький педагогічний коледж }\end{array}$ & 75 \\
\hline 1.8 & $\begin{array}{l}\text { Чіжова Н. }{ }^{1}, \text { Антоненко І. }{ }^{1} \\
\text { ПРОФЕСІЙНА ПІДГОТОВКА МАЙБУТНІХ СПЕЦІАЛІСТІВ } \\
\text { В ТЕХНІЧНОМУ УНІВЕРСИТЕТІ: ОСНОВНІ ЗАВДАННЯ } \\
{ }^{1} \text { Національний технічний університет України «КПІ ім. Ігоря Сікорського» }\end{array}$ & 81 \\
\hline 2. & GENERAL AND PRE-SCHOOL PEDAGOGY & \\
\hline 2.1 & $\begin{array}{l}\text { Ayupova G. }{ }^{1}, \text { Bolsynbekova G. }{ }^{1} \\
\text { ЖОҒАРЫ МЕКТЕП ОКЫТУШЫСЫНЫН ТҰЛҒАЛЫК } \\
\text { ДАМУ ЕРЕКШЕЛІКТЕРІН ТИПОЛОГИЯЛЫК ЖІКТЕУ } \\
\text { ТЕОРИЯЛАРЫ } \\
{ }^{1} \text { Kazakh Humanitarian and Legal Innovation University, Republic Kazakhstan, } \\
\text { Semey }\end{array}$ & 90 \\
\hline 2.2 & $\begin{array}{l}\text { Болсынбекова Г.А. }{ }^{1}, \text { Аюпова Г.Т. }{ }^{1} \\
\text { ПОДХОДЫ К ФОРМИРОВАНИЮ ГОТОВНОСТИ } \\
\text { БУДУЩИХ ПЕДАГОГОВ К ИННОВАЦИОННОЙ } \\
\text { ДЕЯТЕЛЬНОСТИ } \\
{ }^{1} \text { Казахский гуманитарно-юридический инновационный университет } \\
\text { г. Семей, РК }\end{array}$ & 103 \\
\hline
\end{tabular}


THEORETICAL FOUNDATIONS OF THE FUNCTIONING OF EDUCATION. WAYS TO

IMPROVE THE EFFECTIVENESS OF EDUCATIONAL ACTIVITIES

\begin{tabular}{|c|c|c|}
\hline 2.3 & $\begin{array}{l}\text { Демус } \text { Я. }^{1} \\
\text { ОСОБЛИВОСТІ РОБОТИ ПСИХОЛОГА І ТРЕНЕРА У } \\
\text { ПРОЦЕСІ СТАНОВЛЕННЯ СУЧАСНОГО СПОРТСМЕНА } \\
{ }^{1} \text { Postgraduate student at Poltava V.G. Korolenko National Pedagogical University }\end{array}$ & 115 \\
\hline 2.4 & $\begin{array}{l}\text { Самсонова О.О.․, Чорна Г.В. } \\
\text { ТЕОРЕТИЧНІ ОСНОВИ КОНЦЕПЦІЇ ПЕДАГОГІЧНОГО } \\
\text { ВПЛИВУ НА РОЗВИТОК ПРОФЕСІОНАЛІЗМУ } \\
\text { МАЙБУТНІХ ВИХОВАТЕЛІВ } \\
{ }^{1} \text { Кафедра дошкільної та початкової освіти, Запорізький національний } \\
\text { університет }\end{array}$ & 122 \\
\hline 2.5 & $\begin{array}{l}\text { Скірко Г.3. }{ }^{1} \text { Чорна Г.В. }{ }^{1} \\
\text { ПРОФЕСІЙНА ПІДГОТОВКА МАЙБУТНІХ ПЕДАГОГІВ ДО } \\
\text { ІННОВАЦІЙНОЇ ДІЯЛЬНОСТІ В ІНКЛЮЗИВНИХ УМОВАХ } \\
\text { ЗАКЛАДІВ ДОШКІЛЬНОЇ ОСВІТИ } \\
{ }^{1} \text { Кафедра дошкільної та початкової освіти, Запорізький національний } \\
\text { університет }\end{array}$ & 131 \\
\hline 2.6 & $\begin{array}{l}\text { Фазан Т. }{ }^{1}, \text { Фазан В. }{ }^{1} \\
\text { ХРИСТИЯНСЬКА ПЕДАГОГІКА - ОСНОВА СІМЕЙНОГО } \\
\text { ВИХОВАННЯ ДИТИНИ } \\
{ }^{1} \text { Poltava V.G. Korolenko National Pedagogical University }\end{array}$ & 139 \\
\hline 2.7 & $\begin{array}{l}\text { ХодУнова В. }{ }^{1} \\
\text { РОЗВИТОК ПРОФЕСІЙНОЇ КОМПЕТЕНТНОСТІ } \\
\text { ПЕДАГОГЧНИХ ПРАЦВНИКІВ ЗАКЛАДІВ ДОШКІЛЬНОЇ } \\
\text { ОСВІТИ ЗАСОБАМИ МУЛЬТИМЕДІЙНИХ ТЕХНОЛОГІЙ } \\
\text { (НА ПРИКЛАДІ ФІНЛЯНДІЇ, ШВЕЦЇ̈, НОРВЕГЇ̈, ДАНЇ̈) } \\
{ }^{1} \text { кафедра педагогіки і психологї̈ дошкільної освіти } \\
\text { Національний педагогічний університет імені М.П. Драгоманова }\end{array}$ & 148 \\
\hline \multicolumn{3}{|c|}{ HISTORY } \\
\hline 3.1 & $\begin{array}{l}\text { Гребцова И. }{ }^{1} \\
\text { ОСОБЕННОСТИ ФОРМИРОВАНИЯ } \\
\text { ЦЕНТРАЛИЗОВАННОЙ СИСТЕМЫ ОБРАЗОВАНИЯ В } \\
\text { РОССИЙСКОЙ ИМПЕРИИ В ПЕРВОЙ ТРЕТИ ХІХ СТ. } \\
{ }^{1} \text { Department of the World History, } \\
\text { Odessa I. I. Mechnikov National University }\end{array}$ & 154 \\
\hline
\end{tabular}


THEORETICAL FOUNDATIONS OF THE FUNCTIONING OF EDUCATION. WAYS TO

IMPROVE THE EFFECTIVENESS OF EDUCATIONAL ACTIVITIES

\begin{tabular}{|c|c|c|}
\hline 4. & INN & \\
\hline 4.1 & $\begin{array}{l}\text { Akimov I. }{ }^{1}, \text { Sergacheva V. } \\
\text { ИННОВАЦИОННЫЕ АСПЕКТЫ ПРОФЕССИОНАЛЬНОЙ } \\
\text { ДЕЯТЕЛЬНОСТИ ПЕДАГОГА } \\
{ }^{1} \text { Department of Psychology, "Samara branch of St. Petersburg State University of } \\
\text { trade unions» }\end{array}$ & 165 \\
\hline 4.2 & $\begin{array}{l}\text { Gulbs O. }{ }^{1} \text {, Dekhtyarenko S. }{ }^{1}, \text { Kuzmina V. }{ }^{2}, \text { Zhuk E. }^{3} \\
\text { РОЗВИТОК ЕМОЦІЙНГО ІНТЕЛЕКТУ СТУДЕНТІВ У } \\
\text { НАВЧАЛЬНОМУ ПРОЦЕСІ } \\
{ }^{1} \text { Department of Psychology, of Umansky State Pedagogical University named after } \\
\text { Pavel Tychina } \\
{ }^{2} \text { Department of Psychology, Gorlovsky Institute of foreign languages "Donbass State } \\
\text { Pedagogical University" } \\
{ }^{3} \text { Department of Psychology, "National Medical University named after Alexander } \\
\text { Bogomolets" }\end{array}$ & 188 \\
\hline 4.3 & $\begin{array}{l}\text { Gurevych R. }{ }^{1}, \text { Habriichuk L. }{ }^{2}, \text { Herasymenko N. }{ }^{2} \text {, Opushko N. }{ }^{1} \text {, } \\
\text { Hamska N. } \\
\text { ТРАНСФОРМАЦІЯ ПЕДАГОГІЧНОЇ ОСВІТИ В ХХІ } \\
\text { СТОЛІТТІ } \\
{ }^{1} \text { Science-educational Institute of Pedagogy, Psychologyand Training of Masters of } \\
\text { High LevelVinnytsia Mykhailo Kotsiubynskyi State Pedagogical University, } \\
\text { Vinnytsia, Ukraine } \\
{ }^{2} \text { Vinnytsia National Technical University, Vinnytsia, Ukraine }\end{array}$ & 209 \\
\hline 4.3 .1 .1 & $\begin{array}{l}\text { ПРОФЕСІЙНА ПЕДАГОГІЧНА ОСВІТА В ХХІ СТОЛІТТІ: } \\
\text { ПРОБЛЕМИ, ВИКЛИКИ, ПЕРСПЕКТИВИ }\end{array}$ & 209 \\
\hline 4.3 .1 .2 & $\begin{array}{l}\text { РОЗВИТОК СУЧАСНОЇ ПЕДАГОГІЧНОЇ ОСВІТИ: ДЕЯКІ } \\
\text { ПРОБЛЕМИ І ШЛЯХИ ЇХ ВИРІШЕННЯ }\end{array}$ & 216 \\
\hline 4.3 .1 .3 & $\begin{array}{l}\text { РОЛЬ ІНТЕГРАЦЇ̈ ЗМІСТУ НАВЧАННЯ В ПІДГОТОВЦІ } \\
\text { ВЧИТЕЛЯ }\end{array}$ & 226 \\
\hline 4.3 .1 .4 & $\begin{array}{l}\text { ФОРМУВАННЯ В МАЙБУТНІХ ПЕДАГОГІВ НАВИЧОК } \\
\text { ДОСЛІДНИЦЬКОЇ ДІЯЛЬНОСТІ }\end{array}$ & 237 \\
\hline 4.3 .1 .5 & $\begin{array}{l}\text { ВПЛИВ ЦИФРОВІЗАЦІЇ СУСПІЛЬСТВА НА РОЗВИТОК } \\
\text { СУЧАСНОЇ ОСВІТИ }\end{array}$ & 246 \\
\hline 4.4 & $\begin{array}{l}\text { Kovalevska O. } \\
\text { ENGLISH AS A LINGUA FRANCA IN BUSINESS } \\
\text { CONTEXTS: TEACHING LANGUAGE STRATEGIES } \\
{ }^{1} \text { Department of Ukrainian Studies and Foreign languages } \\
\text { Dnipropetrovsk State University of Internal Affairs }\end{array}$ & 255 \\
\hline
\end{tabular}


THEORETICAL FOUNDATIONS OF THE FUNCTIONING OF EDUCATION. WAYS TO

IMPROVE THE EFFECTIVENESS OF EDUCATIONAL ACTIVITIES

\begin{tabular}{|c|c|c|}
\hline 4.5 & $\begin{array}{l}\text { Oleynik O. }{ }^{1} \text {, Kolesnyk A. }{ }^{1} \\
\text { PROBLEMS AND PROSPECTS OF ONLINE EDUCATION IN } \\
\text { HIGHER EDUCATIONAL INSTITUTIONS } \\
{ }^{1} \text { Dnepropetrovsk State University of Internal Affairs }\end{array}$ & 261 \\
\hline 4.6 & $\begin{array}{l}\text { Rumyantseva E. }{ }^{1} \\
\text { IDENTIFICATION OF PHD STUDENTS’ SUBJECT SPECIFIC } \\
\text { AND GENERIC COMPETENCES AND THEIR INTEGRATION } \\
\text { IN EAP SYLLABUS } \\
{ }^{1} \text { Department of Foreign Languages for Natural Sciences Faculties, } \\
\text { Odesa I.I. Mechnikov National University }\end{array}$ & 268 \\
\hline 4.6 .1 & INTRODUCTION & 268 \\
\hline 4.6 .2 & METHODS OF THE STUDY & 271 \\
\hline 4.6 .3 & RESULTS & 272 \\
\hline 4.7 & 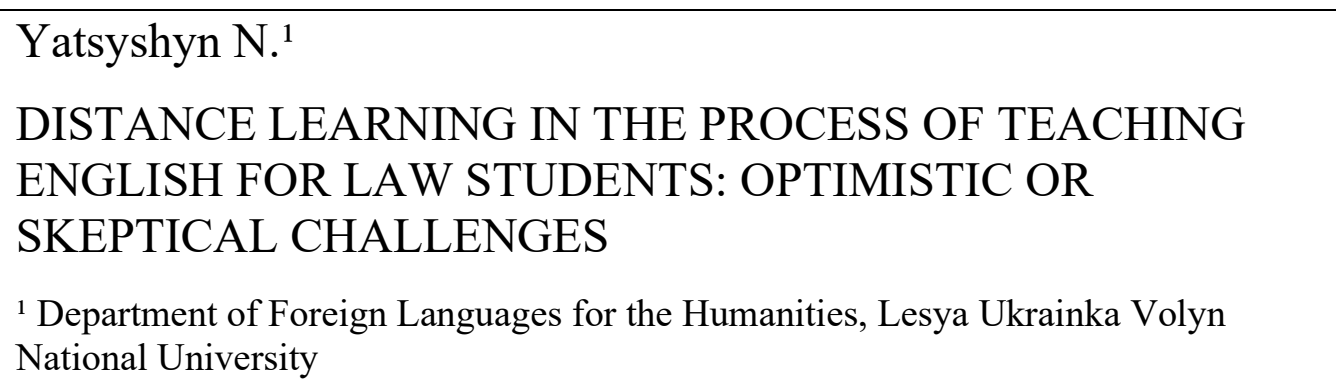 & 280 \\
\hline 4.8 & $\begin{array}{l}\text { Більченко С. } \\
\text { ДІАЛОГО-КУЛЬТУРОЛОГІЧНИЙ ПРОЕКТ ОСВІТИ: } \\
\text { ВІТЧИЗНЯНА ЛОКАЛЬНІСТЬ В ГЛОБАЛЬНОМУ } \\
\text { КОНТЕКСТІ } \\
1 \text { кафедра культурології та філософської антропології } \\
\text { Національного педагогічного університету імені М.П. Драгоманова, } \\
\text { Інститут культурології НАМ України, Київ }\end{array}$ & 288 \\
\hline 4.9 & $\begin{array}{l}\text { Дуднік В. }{ }^{1}, \text { Тухтарова Т. }{ }^{1}, \text { Дзіговський М. }{ }^{1} \\
\text { ТАЙМ-МЕНЕДЖМЕНТ ТА ЙОГО РОЛЬ В СИСТЕМІ } \\
\text { ДИСТАНЦІЙНГО НАВЧАННЯ ЗАКЛАДУ ОСВІТИ } \\
{ }^{1} \text { Науково-дослідна лабораторія інформаційних технологій та дистанційного } \\
\text { навчання, Дніпро, Комунальний заклад вищої освіти «Дніпровська академія } \\
\text { неперервної освіти» }\end{array}$ & 307 \\
\hline
\end{tabular}


THEORETICAL FOUNDATIONS OF THE FUNCTIONING OF EDUCATION. WAYS TO IMPROVE THE EFFECTIVENESS OF EDUCATIONAL ACTIVITIES

\begin{tabular}{|c|c|c|}
\hline 4.10 & $\begin{array}{l}\text { Есенгабылов И.Ж. }{ }^{1}, \text { Алдабергенова А.О. }{ }^{1}, \text { Исаева Г.Б. }{ }^{2} \\
\text { КОНЦЕПЦИЯ ПРИМЕНЕНИЯ СРЕДСТВ } \\
\text { ИНФОРМАЦИОННО-КОММУНИКАЦИОННЫХ } \\
\text { ТЕХНОЛОГИЙ В ОБУЧЕНИИ ФИЗИКЕ } \\
{ }^{1} \text { Жетысуский университет им.И.Жансугурова, Казахстан, г.Талдыкорган } \\
\text { ² Казахский Национальный педагогический университет им.Абая, Казахстан, } \\
\text { г.Алматы }\end{array}$ & 314 \\
\hline 4.10 .1 & $\begin{array}{l}\text { ПСИХОЛОГО-ПЕДАГОГИЧЕСКИЕ ОСНОВЫ } \\
\text { ИНФОРМАТИЗАЦИИ ФИЗИЧЕСКОГО ОБРАЗОВАНИЯ }\end{array}$ & 314 \\
\hline 4.10 .2 & $\begin{array}{l}\text { ДИДАКТИЧЕСКИЕ ВОЗМОЖНОСТИ СРЕДСТВ } \\
\text { ИНФОРМАЦИОННО-КОММУНИКАЦИОННЬХ } \\
\text { ТЕХНОЛОГИЙ В ФИЗИЧЕСКОМ ОБРАЗОВАНИИ }\end{array}$ & 320 \\
\hline 4.11 & 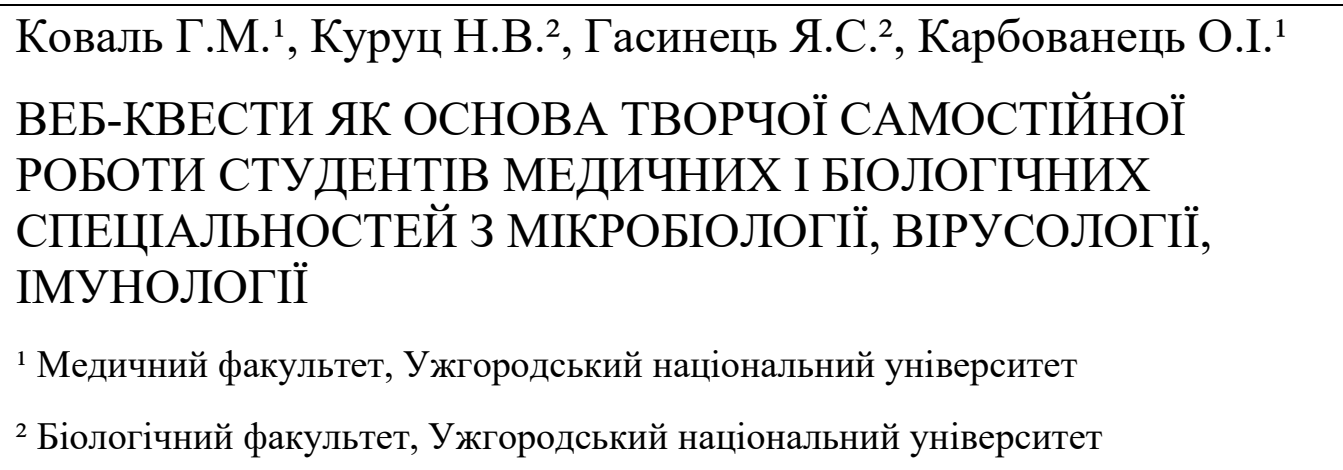 & 326 \\
\hline 4.12 & $\begin{array}{l}\text { Мельник О. } \\
\text { ВИКЛАДАННЯ ГУМАНІТАРНИХ ДИСЦИПЛІН У } \\
\text { ТЕХНІЧНИХ ЗАКЛАДАХ ВИЩОЇ ОСВІТИ УКРАЇНИ } \\
{ }^{1} \text { Таврійський державний агротехнологічний університет імені Дмитра } \\
\text { Моторного }\end{array}$ & 337 \\
\hline 4.13 & $\begin{array}{l}\text { Федотова О. }{ }^{1}, \text { Томаз І. }^{1} \\
\text { ПОНЯТТЯ ПЕРЕВЕРНУТОГО КЛАСУ. ПЕРЕВЕРНУТЕ } \\
\text { НАВЧАННЯ ЯК ІННОВАЦІЙНИЙ ПЕДАГОГІЧНИЙ ПІДХІД } \\
\text { FLIРРЕD СLASS } \\
{ }^{1} \text { Кафедра іноземних мов, Національний аерокосмічний університет } \\
\text { «Харківський авіаційний інститут» }\end{array}$ & 344 \\
\hline 4.13 .1 & $\begin{array}{l}\text { ПЕРЕВЕРНУТИЙ КЛАС } \\
\text { ЗМІШАНОГО НАВЧАННЯ }\end{array}$ & 347 \\
\hline 4.13.2. & IННОВАЦІЙНІ АКЦЕНТИ FLIPPED CLASS & 348 \\
\hline
\end{tabular}


THEORETICAL FOUNDATIONS OF THE FUNCTIONING OF EDUCATION. WAYS TO IMPROVE THE EFFECTIVENESS OF EDUCATIONAL ACTIVITIES

\begin{tabular}{|c|c|c|}
\hline 4.13.3. & 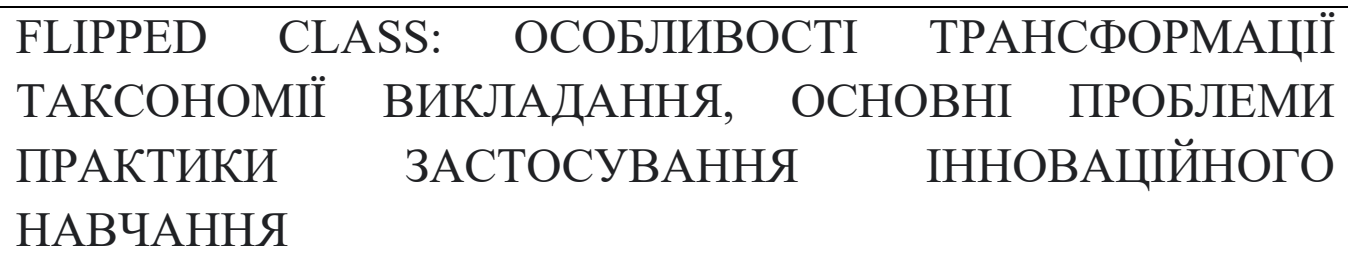 & 349 \\
\hline 4.13 .3 .1 & $\begin{array}{l}\text { ТАКСОНОМІЯ ОСВІТИ БЕНДЖАМІНА БЛУМА I FLIPРЕD } \\
\text { CLASS }\end{array}$ & 350 \\
\hline 4.13 .3 .2 & $\begin{array}{lll}\text { ПРОБЛЕМИ } & \text { ПРОЦЕСУ } & \text { «ПЕРЕВЕРТАННЯ } \\
\text { ТРАДИЦІЙНОГО НАВЧАННЯ } & \end{array}$ & 352 \\
\hline 4.13 .3 .3 & $\begin{array}{l}\text { ЕФЕКТИВНІ ФОРМИ П ПОДАЧІ } \\
\text { НАВЧАЛЬНОГО МАТЕРІАЛУ }\end{array}$ & 354 \\
\hline 4.13.3.3.1 & $\begin{array}{llll}\text { ВАЖЛИВІСТЬ І П ПЕРЕВАГА } & \text { ВІДЕО-ЛЕКЦІЙ } & \text { У } \\
\text { ЗМІШАНОМУ НАВЧАННІ } & & \end{array}$ & 354 \\
\hline 4.13.3.3.2 & $\begin{array}{l}\text { ОСОБЛИВОСТІ ТЕСТУВАННЯ В СИСТЕМІ НАВЧАННЯ } \\
\text { МЕТОДОМ ПЕРЕВЕРНУТОГО КЛАСУ }\end{array}$ & 355 \\
\hline 4.13 .4 & $\begin{array}{l}\text { ПЕРЕВЕРНУТИЙ КЛАС - ПЕРЕДОВА ФОРМА ОСВІТИ ХХІ } \\
\text { СТОЛІТТЯ }\end{array}$ & 356 \\
\hline 4.14 & $\begin{array}{l}\text { Хмельникова Л. }{ }^{1}, \text { Маслак Г. }{ }^{1}, \text { Слєсарчук В. }{ }^{1} \\
\text { ДОСВІД ТА ПЕРСПЕКТИВИ ВИКЛАДАННЯ ХІМІЧНИХ } \\
\text { ДИСЦИПЛІН В УМОВАХ ДИСТАНЦЙНОГО НАВЧАННЯ } \\
\text { ' Дніпровський державний медичний університет }\end{array}$ & 359 \\
\hline 4.15 & $\begin{array}{l}\text { Шиман О. } \\
\text { ПІДГОТОВКА ВЧИТЕЛІВ СВРЕЙСЬКОЇ ДІАСПОРИ } \\
\text { УКРАЇНИ ДО ВПРОВАДЖЕННЯ ДИСТАНЦІЙНОГО } \\
\text { НАВЧАННЯ В ПОЧАТКОВУ ЛАНКУ } \\
\text { ' кафедра педагогіки і психології ВНЗ «Міжнародний гуманітарно-педагогічний } \\
\text { інститут «Бейт-Хана», м. Дніпро, Україна }\end{array}$ & 366 \\
\hline 5. & SOCIAL PEDAGOGY & \\
\hline 5.1 & $\begin{array}{l}\text { Dekusar G. }{ }^{1} \text {, Davydova N. }{ }^{1} \\
\text { IS PANDEMIC THE EDUCATIONAL SYSTEM COLLAPSE OR } \\
\text { AN IMPACT TO OPTIMIZE IT? } \\
{ }^{1} \text { Department of Ukrainian Studies and Foreign languages, } \\
\text { Dnepropetrovsk State University of Internal Affairs, Dnipro }\end{array}$ & 376 \\
\hline
\end{tabular}


THEORETICAL FOUNDATIONS OF THE FUNCTIONING OF EDUCATION. WAYS TO

IMPROVE THE EFFECTIVENESS OF EDUCATIONAL ACTIVITIES

\begin{tabular}{|c|c|c|}
\hline 5.2 & $\begin{array}{l}\text { Мельничук В.О. } \\
\text { СОЦІАЛЬНО-ПЕДАГОГІЧНИЙ ПОРТРЕТ } \\
\text { НЕПОВНОЛІТНІХ ЗАЛУЧЕНИХ ДО КОМЕРЦІЙНОГО } \\
\text { СЕКСУ } \\
{ }^{1} \text { відділ наукового та навчально-методичного забезпечення змісту позашкільної } \\
\text { освіти та виховної роботи } \\
\text { Державна наукова установа «Інститут модернізації змісту освіти» } \\
\text { м.Київ, Україна }\end{array}$ & 383 \\
\hline 5.3 & $\begin{array}{l}\text { Назаревич В.В.' } \\
\text { СУЧАСНІ ПАРАДИГМИ РОЗУМІННЯ ОСТРАКІЗАЦІЇ В } \\
\text { ОСВІТНЬОМУ СЕРЕДОВИЩІ } \\
{ }^{1} \text { Рівненський державний гуманітарний університет }\end{array}$ & 394 \\
\hline 6. & THEORY, PRACTICE AND TEA & \\
\hline 6.1 & $\begin{array}{l}\text { Bocheliuk V. }{ }^{1} \text {, Pozdniakova O. }{ }^{2}, \text { Pozdniakova-Kyrbiatieva E. }{ }^{3} \text {, } \\
\text { Panov N. } \\
\text { PSYCHOLOGICAL FEATURES OF STUDENTS’ FATIGUE AT } \\
\text { THE STAGE OF ADAPTATION TO STUDY IN HIGHER } \\
\text { EDUCATION INSTITUTIONS (ON THE EXAMPLE OF } \\
\text { APPLICANTS FOR HIGHER EDUCATION SPECIALITY } 016 \\
\text { SPECIAL EDUCATION) } \\
{ }^{1} \text { Department of Social Work and Psychology, «Zaporizhzhia Polytechnic» National } \\
\text { University } \\
\text { ² Department of special pedagogy and special psychology of Municipal Institution of } \\
\text { Higher Education «Khortytsia National Educational Rehabilitation Academy» of } \\
\text { Zaporizhzhia Regional Council } \\
{ }^{3} \text { Department of Social and Humanitarian Disciplines } \\
\text { Municipal Institution of Higher Education «Khortytsia National Educational } \\
\text { Rehabilitation Academy» of Zaporizhzhia Regional Council }\end{array}$ & 402 \\
\hline 6.2 & $\begin{array}{l}\text { Dzhezhelei O. }{ }^{1} \text {, Diakova Y. }{ }^{1}, \text { Levandovska Н. }{ }^{1} \\
\text { МОВЛЕННСВА ПРОФЕСІЙНА ПІДГОТОВКА СТУДЕНТІВ } \\
\text { У СИСТЕМІ ФІЛОЛОГІЧНИХ ДИСЦИПЛІН } \\
{ }^{1} \text { Department for Theory and Methodology of Teaching Philological Disciplines in } \\
\text { Primary, Preschool and Specialized Education of H. S. Skovoroda Kharkiv National } \\
\text { Pedagogical University }\end{array}$ & 419 \\
\hline
\end{tabular}


THEORETICAL FOUNDATIONS OF THE FUNCTIONING OF EDUCATION. WAYS TO

IMPROVE THE EFFECTIVENESS OF EDUCATIONAL ACTIVITIES

\begin{tabular}{|c|c|c|}
\hline 6.3 & $\begin{array}{l}\text { Ilchenko O. } \\
\text { FORMATION OF PROSPECTIVE TEACHER PROFESSIONAL } \\
\text { MOTIVATION IN THE DEVELOPMENT OF THE NEW } \\
\text { UKRAINIAN SCHOOL } \\
{ }^{1} \text { Department of General Pedagogy and Andragogy } \\
\text { Poltava V.G. Korolenko National Pedagogical University, Poltava, Ukraine }\end{array}$ & 426 \\
\hline 6.4 & $\begin{array}{l}\text { Kotova O. }{ }^{1}, \text { Hryhorieva V. }{ }^{1}, \text { Tatochenko V. }{ }^{1}, \text { Hniedkova O } .^{2} \\
\text { SOFTWARE PACKAGE MATHLAB IN LINEAR ALGEBRA } \\
\text { TEACHING } \\
{ }^{1} \text { Department of Algebra, Geometry and Mathematical Analysis, Kherson State } \\
\text { University } \\
{ }^{2} \text { Department of Informatics, Software Engineering and Economic Cybernetics, } \\
\text { Kherson State University }\end{array}$ & 437 \\
\hline 6.5 & $\begin{array}{l}\text { Poleva J. } \\
\text { FEATURES OF STUDYING THE DISCIPLINE "BASIS OF } \\
\text { ECOLOGY" BY STUDENTS OF BIOTECHNOLOGY } \\
{ }^{1} \text { Associate Professor of Aquatic Bioresources and Aquaculture Dnipro State Agrarian } \\
\text { and Economic University }\end{array}$ & 450 \\
\hline 6.6 & $\begin{array}{l}\text { Poliakova J. }{ }^{1} \text {, Stepanov A. }{ }^{2} \text {, Lisna T. } \\
\text { SOCIOCULTURAL COMPETENCES AS ESSENTIAL } \\
\text { COMPONENTS IN TEACHING ENGLISH } \\
{ }^{1} \text { Department of International Economic Relations, Lviv University of Trade and } \\
\text { Economics } \\
{ }^{2} \text { Department of Foreign Languages, Lviv University of Trade and Economics } \\
{ }^{3} \text { Department of Applied Linguistics, Lviv Polytechnic National University }\end{array}$ & 458 \\
\hline 6.7 & $\begin{array}{l}\text { Toryanik L. }{ }^{1}, \text { Kovalenko Z. }{ }^{1}, \text { Chernyshenko O. }{ }^{1} \\
\text { THE METHODOLOGICAL POTENTIAL OF INTERACTIVE } \\
\text { APPROACH IN THE CONTEXT OF TEACHING ENGLISH IN } \\
\text { PROFICIENCY AT THE UNIVERSITY EDUCATION } \\
{ }^{1} \text { Department of foreign languages, Kharkiv National Pharmaceutical University }\end{array}$ & 468 \\
\hline 6.8 & $\begin{array}{l}\text { Івченко В. }{ }^{1} \\
\text { КРИТИЧНЕ МИСЛЕННЯ ТА ЕКО-ТВОРЧИЙ АУДИТ ЯК } \\
\text { БАЗИС ПРОФЕСІЙНОЇ ІНТЕРПРЕТАЦІЙНӦ̈ ДІЯЛЬНОСТІ } \\
\text { У СФЕРІ ДИЗАЙНУ } \\
{ }^{1} \text { Кафедра педагогіки, Криворізький державний педагогічний університет }\end{array}$ & 475 \\
\hline
\end{tabular}


THEORETICAL FOUNDATIONS OF THE FUNCTIONING OF EDUCATION. WAYS TO

IMPROVE THE EFFECTIVENESS OF EDUCATIONAL ACTIVITIES

\begin{tabular}{|c|c|c|}
\hline 6.9 & $\begin{array}{l}\text { Андрейко О. } \\
\text { ОСОБЛИВОСТІ МОДЕЛЮВАННЯ ХУДОЖНЬО- } \\
\text { ВИКОНАВСЬКОЇ ТЕХНІКИ МУЗИКАНТА } \\
{ }^{1} \text { Кафедра скрипки, Львівська національна музична академія імені М.В.Лисенка }\end{array}$ & 483 \\
\hline 6.10 & $\begin{array}{l}\text { Бабінцева Л.Ю. }{ }^{1}, \text { Видиборець С.В. }{ }^{1}, \text { Горяінова Н.В. } \\
\text { ЛЕКЦІЙНЕ ЗАБЕЗПЕЧЕННЯ НАВЧАЛЬНОГО ПРОЦЕСУ } \\
\text { НА КАФЕДРАХ ФАКУЛЬТЕТУ ПІДВИЩЕННЯ } \\
\text { КВАЛІФІКАЦІЇ ВИКЛАДАЧІВ НАЦІОНАЛЬНОГО } \\
\text { УНІВЕРСИТЕТУ ОХОРОНИ ЗДОРОВ’Я УКРАЇНИ ІМЕНІ } \\
\text { П.Л. ШУПИКА } \\
{ }^{1} \text { НаціонаЛьний університет охорони здоров’я України імені П. Л. Шупика } \\
{ }^{2} \text { ДУ «Інститут гематологї та трансфузіології НАМН України }\end{array}$ & 492 \\
\hline 6.11 & $\begin{array}{l}\text { Булавіна О.А. } \\
\text { МЕТОДИКА ПРОФЕСІЙНОГО НАВЧАННЯ ТА } \\
\text { ЕКОНОМІЧНА ДИДАКТИКА: ТАКТИКА І СТРАТЕГІЯ } \\
\text { ФОРМУВАННЯ ПРОФЕСІЙНОЇ КОМПЕТЕНТНОСТІ } \\
\text { ПЕДАГОГІВ ПРОФЕСІЙНОГО НАВЧАННЯ/ФАХІВЦІВ } 3 \\
\text { ЕКОНОМІКИ } \\
{ }^{1} \text { кафедра педагогіки та психології ДВНЗ «Київський національний економічний } \\
\text { університет імені Вадима Гетьмана» }\end{array}$ & 500 \\
\hline 6.12 & $\begin{array}{l}\text { Білозерська С. }{ }^{1} \text {, Мащак С. } \\
\text { АКСІОЛОГІЧНІ ЗАСАДИ ФОРМУВАННЯ ПРОФЕСІЙНИХ } \\
\text { ОРІЄНТИРІВ МАЙБУТНІХ ПЕДАГОГІВ } \\
{ }^{1} \text { кафедра психології, Дрогобицький державний педагогічний університет імені } \\
\text { Івана Франка }\end{array}$ & 513 \\
\hline 6.13 & 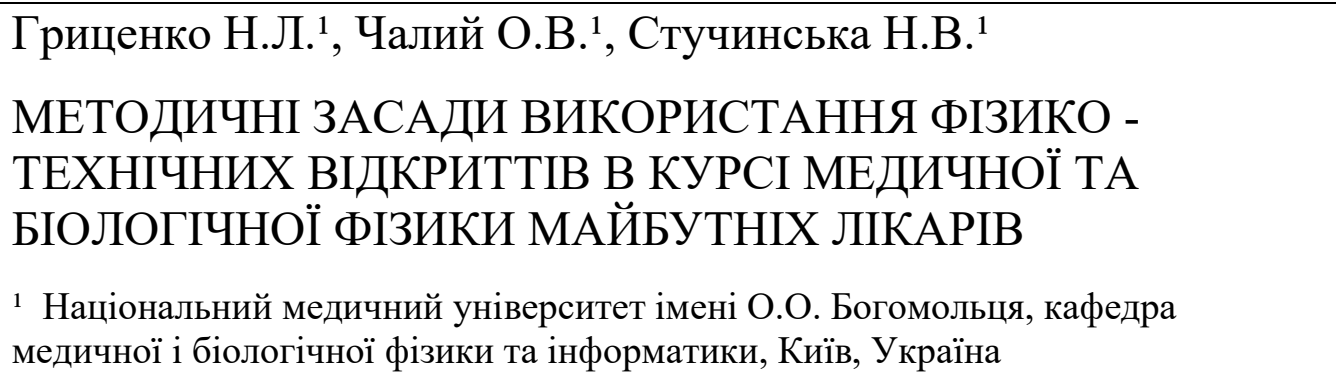 & 523 \\
\hline 6.14 & $\begin{array}{l}\text { Есенғабылов И.Ж. }{ }^{1} \text { Елепбергенова А.У. }{ }^{1}, \text { Криванкова Л.С. }{ }^{1}, \\
\text { Оразбаева А.А. } \\
\text { КОМПЬЮТЕР - ОКУШЬНЫН МАТЕМАТИКАНЫ ОКЫП- } \\
\text { БІЛУ ІС-ӘРЕКЕТІНІН НЕГІЗГІ БІР ҚҰРАЛЫ } \\
{ }^{1} \text { І.Жансугуров атындағы Жетісу университеті, Қазақстан Республикасы, } \\
\text { Талдықорған қ. }\end{array}$ & 532 \\
\hline
\end{tabular}




\begin{tabular}{|c|c|c|}
\hline 6.15 & $\begin{array}{l}\text { Коваленко О. }{ }^{1} \\
\text { МОДЕЛЬ ДОДАТКОВОЇ ПРОФЕСІЙНОЇ ПІДГОТОВКИ } \\
\text { МАЙБУТНІХ ФАХІВЦІВ ТУРИСТИЧНОГО СУПРОВОДУ } \\
\text { ДО РЕАЛІЗАЦІЇ ПРОГРАМ КУЛЬТУРНО-ПІЗНАВАЛЬНОГО } \\
\text { ТУРИЗМУ } \\
{ }^{1} \text { Кафедра образотворчого мистецтва, музикознавства та культурології, } \\
\text { Сумський державний педагогічний університет імені А. С. Макаренка }\end{array}$ & 545 \\
\hline 6.16 & $\begin{array}{l}\text { Люльченко В. }{ }^{1}, \text { Сусло Л. }{ }^{1}, \text { Орлова О. }{ }^{1} \\
\text { ФОРМУВАННЯ САНІТАРНО-ГІГІЄНІЧНОЇ } \\
\text { КОМПЕТЕНТНОСТІ У ІНЖЕНЕРА-ПЕДАГОГА } \\
\text { ХАРЧОВОГО ПРОФІЛЯ ЯК НЕОБХІДНА УМОВА } \\
\text { ЕФЕКТИВНОЇ ПРОФЕСІЙНОЇ ДІЯЛЬНОСТІ } \\
{ }^{1} \text { Кафедра техніко-технологічних дисциплін, охорони праці та безпеки } \\
\text { життєдіяльності, Уманського державного педагогічного університету імені } \\
\text { Павла Тичини }\end{array}$ & 554 \\
\hline 6.17 & $\begin{array}{l}\text { Панфілов О. }{ }^{1}, \text { Онипченко П. }{ }^{2}, \text { Тимошенко О. }{ }^{3}, \text { Марков А. }{ }^{3}, \\
\text { Громико О. } \\
\text { ФІЛОСОФСЬКО-ПЕДАГОГІЧНІ АСПЕКТИ ПІДГОТОВКИ } \\
\text { ВІЙСЬКОВИХ ЛЬОТЧИКІВ } \\
{ }^{1} \text { Кафедра соціології та політології, Національний юридичний університет імені } \\
\text { Ярослава Мудрого } \\
\text { ² Кафедра тактики авіації, Харківський національний університет Повітряних } \\
\text { Сил імені Івана Кожедуба } \\
{ }^{3} \text { Кафедра льотної експлуатації та бойового застосування вертольотів, } \\
\text { Харківський національний університет Повітряних Сил імені Івана Кожедуба } \\
{ }^{4} \text { Кафедра філософії, Харківський національний університет Повітряних Сил } \\
\text { імені Івана Кожедуба }\end{array}$ & 561 \\
\hline 6.18 & $\begin{array}{l}\text { Радомська В. }{ }^{1} \\
\text { АРТПРОЕКТИ В СИСТЕМІ ДИЗАЙН-ОСВІТИ } \\
{ }^{1} \text { Кафедра дизайну та основ архітектури, Національний університет «Львівська } \\
\text { політехніка» }\end{array}$ & 569 \\
\hline 6.19 & $\begin{array}{l}\text { Самойленко О.М. }{ }^{1}, \text { Свстрат’єв С.В. }{ }^{1} \\
\text { ШЛЯХИ ВПРОВАДЖЕННЯ ФАХОВИХ ЦИФРОВИХ } \\
\text { ТЕХНОЛОГІЙ ПРИ ПІДГОТОВІЦ МОЛОДШИХ } \\
\text { БАКАЛАВРІВ } 3 \text { АГРОНОМІЇ } \\
{ }^{1} \text { кафедра інформаційних і дистанційних технологій, НУБіП України }\end{array}$ & 578 \\
\hline
\end{tabular}


THEORETICAL FOUNDATIONS OF THE FUNCTIONING OF EDUCATION. WAYS TO

IMPROVE THE EFFECTIVENESS OF EDUCATIONAL ACTIVITIES

\begin{tabular}{|c|c|c|}
\hline 6.20 & $\begin{array}{l}\text { Силюга Л. }{ }^{1}, \text { Ковалевич I. } \\
\text { МЕТОДИЧНІ ПРИЙОМИ ФОРМУВАННЯ У МОЛОДШИХ } \\
\text { ШКОЛЯРІВ НАВИЧОК САМОКОНТРОЛЮ У ПРОЦЕСІ } \\
\text { РОЗВ’ЯЗУВАННЯ СЮЖЕТНИХ ЗАДАЧ } \\
{ }^{1} \text { Факультет початкової та мистецької освіти, Дрогобич, державний } \\
\text { педагогічний університет імені Івана Франка }\end{array}$ & 585 \\
\hline 6.21 & $\begin{array}{l}\text { Снігірьова А. }{ }^{1}, \text { Тарасов А. } \\
\text { ІНФОРМАЦІЙНІ ТЕХНОЛОГІЇ В НАВЧАННІ ФАХІВЦІВ } \\
\text { ПСИХОЛОГО-ПЕДАГОГІЧНОГО НАПРЯМУ } \\
{ }^{1} \text { Фізико-математичний факультет Південноукраїнський національний } \\
\text { педагогічний університет імені К.Д. Ушинського, Одеса, Україна }\end{array}$ & 593 \\
\hline 6.22 & $\begin{array}{l}\text { Стотика I. }{ }^{1}, \text { Власенко Е. }{ }^{1}, \text { Стотика О. }{ }^{1} \\
\text { МЕТОДИЧНИЙ СУПРОВІД ФОРМУВАННЯ } \\
\text { ІНСТРУМЕНТАЛЬНО-ВИКОНАВСЬКОЇ } \\
\text { КОМПЕТЕНТНОСТІ МАЙБУТНІХ УЧИТЕЛІВ } \\
\text { МУЗИЧНОГО МИСТЕЦТВА } \\
{ }^{1} \text { Мелітопольський державний педагогічний університет імені Богдана } \\
\text { Хмельницького }\end{array}$ & 608 \\
\hline 6.23 & $\begin{array}{l}\text { Удовиченко І. }^{1} \\
\text { АКТУАЛЬНІСТЬ ФОРМУВАННЯ ІНФОРМАЦІЙНОЇ } \\
\text { ГРАМОТНОСТІ УЧНІВ ЗАКЛАДІВ ЗАГАЛЬНОЇ } \\
\text { СЕРЕДНЬОЇ ОСВІТИ НА УРОКАХ ГЕОГРАФІЇ } \\
\text { ПРОФІЛЬНОГО РІВНЯ } \\
\text { ' Департамент освіти і науки Сумської облдержадміністрації, Сумський } \\
\text { обласний інститут післядипломної педагогічної освіти }\end{array}$ & 623 \\
\hline & REFERENCES & 631 \\
\hline
\end{tabular}




\section{SECTION 1. EDUCATION}

DOI 10.46299/ISG.2021.MONO.PED.II-16-23

\section{1 Теоретико-методологічні основи індивідуалізації навчання в початковій шкколі}

Одною 3 актуальних загроз на сучасному етапі розвитку масових технологій навчання $€$ загострення небезпеки втрати унікальності кожної людини, ï здатності обирати власну життєву траєкторію. Шкільна освіта має сприяти формуванню в учнів цілісної уяви про земну цивілізацію, закладати основи розуміння сучасних проблем, в той же час стверджувати ідею ціннісності і унікальності людської особистості.

Індивідуалізація навчання як психолого-педагогічна проблема: історичний ракурс. Вивчення та аналіз першоджерел через призму технологізації та індивідуалізації свідчить про давній інтерес до особистості учня, розвитку його індивідуальності. Проаналізовані технології «Виховання джентльмена» Д. Локка, «Вільного виховання» Ж-Ж. Руссо, «Школа радості» В. О. Сухомлинського та інші дали можливість зрозуміти, що такі підходи завжди існували у будь-якому суспільстві (i як пріоритетні, i як альтернативні). Вивчення історії педагогіки, а саме - навчально-виховних систем, заснованих на основах індивідуалізації навчання, просвітницькій діяльності, життєвих етапах видатних педагогів минулого дало можливість визначити базові принципи індивідуалізованого навчання. Навчання до появи в XVII столітті класноурочної системи носило в тій чи іншій мірі індивідуальний характер, тому проблема індивідуалізації навчання практично не піднімалася. Діти отримували освіту в колі сім'ї або в навчальних закладах, які були створені для людей 3 різним (в основному з достатнім) матеріальним рівнем. В таких закладах не було фіксованого віку дитини для початку навчання, тому існувала можливість переходу з однієї ступені навчання на іншу в індивідуальному темпі в залежності від здібностей, нахилів і матеріальних можливостей. Здобутки з індивідуалізації навчання і виховання в доробку педагогів минулого представлено в таблиці 1. 
Таблиця 1

Педагогічні системи індивідуалізованого навчання в доробку педагогів минулого

\begin{tabular}{|c|c|}
\hline Педагог & Педагогічна система та основні праці \\
\hline $\begin{array}{l}\text { Я. - А. } \\
\text { Коменський }\end{array}$ & $\begin{array}{l}\text { розробив чітку систему навчання і виховання; розкрив сутність основних їі } \\
\text { принципів (наочності, свідомості, активності, послідовності, систематичності } \\
\text { знань, міцного оволодіння знаннями і навичками); вивчив досвід навчання } 3 \\
\text { урочної системи; зробив теоретичне обгрунтування класно-урочної системи } \\
\text { шкільного навчання і сформулював її основоположні принципи; відзначав, що в } \\
\text { центр навчання потрібно поставити дитину зії інтересами, здібностями, життєвим } \\
\text { досвідом, потребами, активністю. Вікова періодизація: чотири вікових періоди по } \\
6 \text { років в кожному. Для кожного періоду було запропоновано свою систему } \\
\text { (школу): дитинство: (від народження до } 6 \text { років) - материнська школа; отроцтво } \\
\text { (6-12 років) - школа рідної мови; юність (12-18 років) - латинська школа чи } \\
\text { гімназія; змужнілість (18-24 років) - академія чи університет. Другим ступенем є } \\
\text { школа рідної мови, навчання в якій повинно проводитись рідною мовою, а } \\
\text { учитися повинні всі діти обох статей, незалежно від станів, віросповідань і } \\
\text { національності. Основна праця: «Велика дидактика». }\end{array}$ \\
\hline А.-В. Ді & 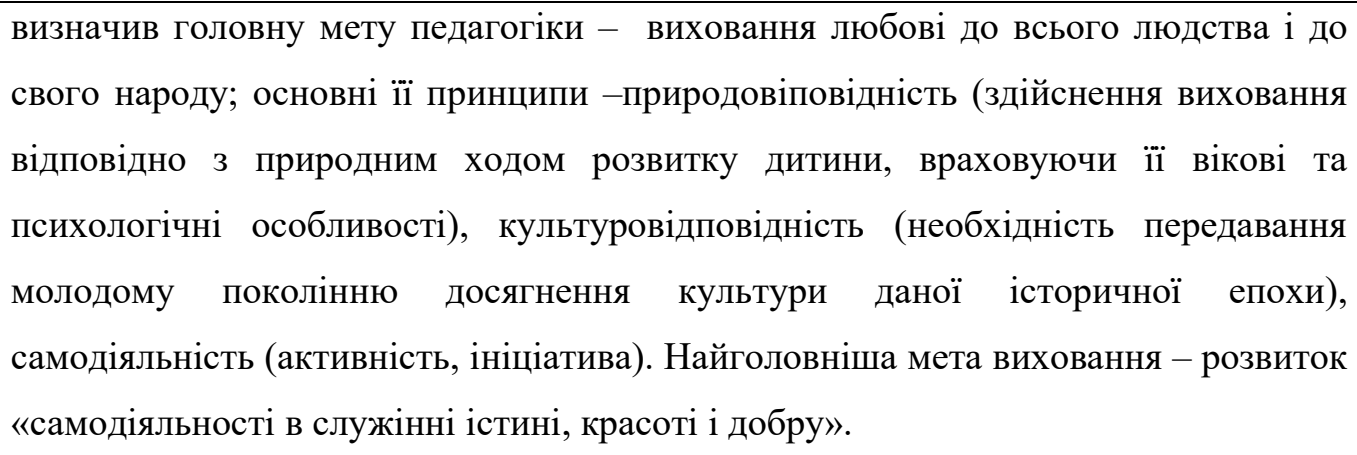 \\
\hline $\begin{array}{l}\text { Й. Г. } \\
\text { Песталоцці }\end{array}$ & $\begin{array}{l}\text { узагальнив власний педагогічний досвід у творах: головна увага на особистості } \\
\text { вихованця як центральної точки всіх виховних дій. Головні положення: моральні, } \\
\text { розумові та фізичні сили людської природи (сили серця, розуму і руки) мають } \\
\text { властивість до діяльності і саморозвитку; основним у вихованні дитини є принцип } \\
\text { природовідповідності (тобто починати з найпростішого і поступово підніматися } \\
\text { до складнішого); роль наочності у розвитку логічного мислення дитини під час } \\
\text { навчання, психологічне обгрунтування. Виходячи із загальнодидактичних } \\
\text { положень, обгрунтував ази методики початкового навчання. Основною вимогою } \\
\text { методики було ведення дитиною спостережень і розвиток власних здібностей. } \\
\text { Вважав необхідним розбуджування та скріплювання духовних сил дитини, ії } \\
\text { морального і суспільного ушляхетнювання. Основні твори: «Лінгард і Гертруда» } \\
\text { (1781-1787), «Як Гертруда вчить своїх дітей» (1801), «Лебедина пісня» (1826). }\end{array}$ \\
\hline
\end{tabular}


THEORETICAL FOUNDATIONS OF THE FUNCTIONING OF EDUCATION. WAYS TO

IMPROVE THE EFFECTIVENESS OF EDUCATIONAL ACTIVITIES

\begin{tabular}{|c|c|}
\hline $\begin{array}{l}\text { К.Д. } \\
\text { Ушинський }\end{array}$ & $\begin{array}{l}\text { основні позиції: для правильної організації навчального процесу треба } \\
\text { систематизувати основні положення і принципи дидактики, грунтовно вивчити та } \\
\text { узагальнити індивідуальні та психологічні особливості розвитку дітей різних } \\
\text { вікових категорій, які випливають із закономірностей процесу пізнання. Вважав, } \\
\text { що педагогіка може стати наукою та мистецтвом, якщо буде тісно пов'язана } 3 \\
\text { життям, виражати потреби суспільства і спиратися на дані наук про людину. } \\
\text { Знаковими є його слова, що коли педагогіка хоче виховувати людину у всіх } \\
\text { відношеннях, то вона повинна взнати його тежу всіх відношеннях. Основні праці: } \\
\text { підручники для початкового навчання «Дитячий світ» (1861), «Рідне слово» } \\
\text { (1864), статті «Три елементи школи» (1867), «Недільні школи» (1861), «Про } \\
\text { початкове викладання російської мови» (1864). }\end{array}$ \\
\hline $\begin{array}{l}\text { Рудольф } \\
\text { Штайнер } \\
\text { (австрійський } \\
\text { філософ } \\
\text { педагог) }\end{array}$ & $\begin{array}{l}\text { сформулював теоретичні і практичні основи вальдорфської педагогіки. Перша } \\
\text { вальдорфська школа була заснована ним у } 1919 \text { році для дітей робітників фабрики } \\
\text { «Вальдорф-Асторія» в г. Штутгарті (Німеччина). Р. Штайнером розроблено } \\
\text { філософське вчення - антропософія, згідно } 3 \text { яким сформульовано основне } \\
\text { завдання педагогіки - привести дитину до пізнання світу, розвинути їі приховані } \\
\text { здібності і можливості; в основу концепції закладено ідею поступального і } \\
\text { цілісного розвитку дитини. Вікова періодизація: дитинство умовно ділиться на } \\
\text { три семирічні стадії, кожна з яких вимагає особливого підходу від педагога: } 1 \\
\text { стадія (0-7 років) - розвиток дитини через співпереживання, імітацію } \\
\text { навколишнього світу (світ добрий); } 2 \text { стадія (7-14 років) - навчання через } \\
\text { пояснення і заняття мистецтвами, які розвивають сферу почуттів (світ } \\
\text { прекрасний); } 3 \text { стадія (14-21 рік)-пізнання світу через власні судження і критичне } \\
\text { мислення (світ правдивий). Тому метою вальдорфських навчальних закладів є не } \\
\text { накопичення знань дитиною, а виховання людини, орієнтованого на навколишній } \\
\text { світ, чутливого до нового, здатного здійснювати усвідомлений вибір і брати на } \\
\text { себе відповідальність за нього. }\end{array}$ \\
\hline M. Mo & $\begin{array}{l}\text { три провідних положення характеризують сутність педагогічної теорії 1) } \\
\text { виховання повинно бути вільним; 2) виховання повинно бути індивідуальним; 3) } \\
\text { виховання повинно спиратися на дані спостережень за дитиною. Реалізувала ідеї } \\
\text { раннього розвитку і вільного виховання, виділила провідну роль духовного } \\
\text { моменту: педагог повинен уміти звертатися до людини, яка дрімає в душі дитини. } \\
\text { Матеріали, що впливають на почуття, спонтанна активність, нові цікаві іграшки, } \\
\text { а також можливість і свобода вчитися за індивідуальною програмою становить } \\
\text { основу методу Монтессорі. }\end{array}$ \\
\hline
\end{tabular}


THEORETICAL FOUNDATIONS OF THE FUNCTIONING OF EDUCATION. WAYS TO

IMPROVE THE EFFECTIVENESS OF EDUCATIONAL ACTIVITIES

\begin{tabular}{|l|l|} 
Василь & Педагогічна система являла собою концептуальну основу особистісно \\
зорієнтованого підходу, що знаходить відображення в компетентнісно \\
орієнтованій освіті. Ця авторська школа являла собою школу радості, спрямовану \\
на виховання всебічно розвиненої особистості, школу співдружності поколінь. \\
Головними суб'єктами цієї системи є учитель, учень та родина, метою - \\
формування всебічно розвиненої особистості, складовими всебічно розвиненої \\
особистості - розумове, моральне, громадянське, трудове, фізичне, естетичне, \\
патріотичне, ідейно-політичне виховання. Гуманістичними основами системи \\
Василя Сухомлинського є: створення для дитини «радості буття»; формування \\
культури бажань, культури почуттів; формування почуття власної гідності; \\
створення атмосфери успіху; перевага позитивних стимулів і реакцій на поведінку \\
дитини над негативними; взаємодія школи, сім'ї, громадськості тощо.
\end{tabular}

Доробок педагогів-гуманістів поступово вплинув на зміни підходів до навчання та виховання дітей i педагогічна наука підтвердила важливість гуманістичного підходу, де основним тезисом є те, що людина - головна цінність, мета і результат організації навчально-виховного процесу.

\section{Індивідуалізація навчання як психолого-педагогічна проблема:}

\section{сучасні підходи.}

Детальніше з провідних позицій гуманітаризації освіти можна виокремити такі: орієнтацію видів діяльності та типу спілкування учнів на гуманістичні ідеали; створення умов для розвитку учнів, актуалізації їхнього потенціалу, стимулювання до особистісного зростання; постійне насичення і збагачення освітнього середовища соціокультурним контекстом, інноваційний розвиток; гуманітаризацію змісту освіти та підручників; розвиток гуманітарної культури і гуманітарного мислення учнів. Усі напрямки гуманізації та гуманітаризації навчання містили в собі цю складову - індивідуальний розвиток дитини, плекання іï особистості. У сучасній педагогічній науці гуманістична освітня парадигма передбачає повну і завершену підготовку здобувача освіти до життя здебільшого через розвиток його індивідуальності та формування особистості (Барановська О., Бех I., Бондар С., Зязюн I., Кизенко В., Корсакова О., Липова Л., Момот Л., Ничкало Н., Паламарчук В., Рибалка В. Савченко О., Трубачева С., Шелестова Л. та ін.). Гуманістична парадигма навчання і виховання особистості перш за все містить індивідуальний підхід до неї, розглядає індивідуалізацію 
THEORETICAL FOUNDATIONS OF THE FUNCTIONING OF EDUCATION. WAYS TO IMPROVE THE EFFECTIVENESS OF EDUCATIONAL ACTIVITIES

навчання як обов’язкову складову процесу навчання. Н. Дічек розглянула внесок вітчизняної експериментальної педагогіки в обгрунтування необхідності індивідуалізації та диференціації навчально-виховного процесу з кінця ХІХ до 1917 року; узагальнила доробок українських психологів у розвиток індивідуалізації навчання школярів (з 40-х по 80-ті роки ХХ століття) [1]. Аналіз розвитку педагогіки в аспекті дитиноцентризму, поглибленні принципу індивідуалізації навчання, засвідчив поступове збільшення таких досліджень на відрізку від 40 до 80-х років і значне збільшення наукових досліджень в 90-2000 роки XX ст. Не зважаючи на деякі відмінності в трактовках, можливості індивідуалізації навчального процесу розглядалися радянськими авторами переважно в рамках колективних форм класно-урочної системи через різноманітні форми та методи навчання. В існуючих на пострадянському просторі педагогічних енциклопедіях та словниках визначення поняття «індивідуалізація навчання» базувалося на врахуванні індивідуальних особливостей дитини i створенні потенційних можливостей в навчальновиховному процесі для їх реалізації; поняття «індивідуальний підхід» визначалося як принцип педагогіки, за якого в навчально-виховній роботі в класі досягається педагогічна взаємодія 3 кожною дитиною, яке базується на знанні його рис особистості та умов життя, розуміння неповторної індивідуальності дитини.

В сучасній психології важливе місце займають концепції соціалізації та індивідуалізації, різноманітні трактовки поняття «індивідуалізація психічного розвитку», яке лежить в основі будь-якого визначення «індивідуалізація навчання». Відзначимо, що поняття індивідуалізації та диференціації навчання розкриваються у багатьох педагогічних дослідженнях, а також дослідженнях на стику педагогіки та психології: А. Кірсанов, І. Осмоловська, В. Паламарчук, Є. Рабунский, Ф. Рафікова, О. Савченко, М. Скаткін, І. Смирнова, І. Унт та ін. Розглянемо дослідження поняття «індивідуалізація» в психологічних та педагогічних дослідженнях радянських та сучасних науковців в аспекті досліджуваної проблеми (таблиця 2). 
Поняття «індивідуалізація» в дослідженнях радянських психологів

\begin{tabular}{|l|l|}
\hline Науковці & Основні напрямки дослідження \\
\hline Л. Виготський & $\begin{array}{l}\text { обгрунтував важливу закономірність розвивальна мета індивідуального } \\
\text { розвитку учнів - це формування і розвиток іхніх інтелектуальних, творчих } \\
\text { здібностей, які мають спиратися на зону найближчого розвитку учня, яка в } \\
\text { подальшому реалізується в реальному часі. }\end{array}$ \\
\hline Д. Ельконін [3] & $\begin{array}{l}\text { вважав, що навчальна діяльність єпровідною в шкільному віці тому, що через неї } \\
\text { здійснюються основні відносини дитини з суспільством; здійснюється } \\
\text { формування основних якостей особистості дитини шкільного віку, окремих } \\
\text { психічних процесів; виникають основні новоутворення, які неможливо зрозуміти } \\
\text { поза аналізом процесу формування навчальної діяльності та ііі рівня. }\end{array}$ \\
\hline В. Давидов [4] & $\begin{array}{l}\text { акцентував на тому, що навчальна діяльність молодших школярів формується } \\
\text { саме в цьому віці, всередині неї виникають відповідні психологічні } \\
\text { новоутворення, вона визначає в даному віці характер інших видів діяльності } \\
\text { (суспільно-організаційної, художньої, спортивної, навчальної, трудової). }\end{array}$ \\
\hline $\begin{array}{l}\text { О. Запорожець } \\
\text { [5] }\end{array}$ & $\begin{array}{l}\text { впроваджував гуманістичну психолого-педагогічну концепцію ампліфікації, } \\
\text { збагачення розвитку дитини, коли оптимальні умови для реалізації потенційних } \\
\text { можливостей дитини створюються не форсованим навчанням, а завдяки } \\
\text { збагаченню змісту навчання іграми, спілкуванням, образотворчою та } \\
\text { предметною діяльністю. } \\
\text { розглядала индивідуалізацію як граничний варіант диференціації, коли } \\
\text { навчальний процес будується з урахуванням особливостей не груп, а кожного } \\
\text { окремо взятого учня. }\end{array}$ \\
\hline
\end{tabular}

У сучасній педагогічній науковій літературі виділяють такі різновиди індивідуальної форми роботи: індивідуальна, індивідуалізована та індивідуалізовано-групова. Індивідуальну форму роботи застосовують на всіх етапах процесу навчання. Вона передбачає самостійне виконання учнями однакових завдань у єдиному темпі. Індивідуалізована форма характеризується такою організацією роботи, при якій кожен учень виконує специфічне завдання 3 урахуванням його навчальних можливостей. Індивідуалізовано-групова форма $€$ додатковою формою навчальної роботи, завдяки якій є можлиість не допустити відставання у навчанні слабких i створити кращі умови для розвитку обдарованих учнів. Серед видів індивідуальної роботи науковці виділяють: 
THEORETICAL FOUNDATIONS OF THE FUNCTIONING OF EDUCATION. WAYS TO IMPROVE THE EFFECTIVENESS OF EDUCATIONAL ACTIVITIES

діяльність окремого учня; виконання роботи учнем одночасно з іншими учнями класу, групи; різна тривалість виконання навчального завдання; виконання загальнокласної навчальної роботи; виконання окремого завдання. Індивідуальна форма роботи на уроці дає змогу враховувати темп навчання кожного учня, його підготовленість, створює можливості для диференціації завдань, контролю та оцінювання результатів, забезпечуючи відносну самостійність, але потребує значних затрат часу і зусиль учителя. В останні роки з явилися терміни «індивідуалізація навчання», «індивідуалізоване навчання», «індивідуальне навчання». Ми розглядаємо індивідуалізаџію навчання як принцуип здійснення індивідуального підходу до учнів у прочесі навчання; як форму організачії навчальної діяльності учнів на урочі; як освітню технологію, щзо трунтується на принц̧ипі індивідуалізащиї. «Індивідуалізоване навчання - вид навчання, що здійснюється на засадах індивідуалізації із застосовуванням відповідних технологій, метою якого $\epsilon$ розвиток індивіда згідно 3 його здібностями і в притаманному для нього темпі [7-11].

3 основних проблем, щзо виникають під час експериментальної роботи, ми відзначали такі: у багатьох учителів відсутні достатні знання про шляхи здійснення диференційованого та індивідуального підходу (30\%); виникають труднощі у виборі оптимальних способів і засобів диференціації (30\%); вчителі помиляються під час вибору варіанта навчальної діяльності учнів на різних етапах навчального процесу (15\%); не використовують варіативність застосування форм навчальної діяльності учнів (40\%); витрачають багато часу на власну підготовку до застосування складних форм організації навчальновиховного процесу та подальшу організацію навчальної діяльності учнів (80\%); відсутність у деяких підручниках чіткого поділу завдань різного рівня (45\%); швидкий темп навчання, перенасиченість зайвою інформацією (90\%). Дослідження розподілу часу на уроці, який реально займає у середньому кожна з основних форм навчальної діяльності (фронтальна, групова та індивідуальна) показало, що основне місце на уроці посідає фронтальна форма, яка охоплює біля 60\% уроку; груповій формі надається біля 25\%; індивідуальній - 15\% [11]. 
Отже, практика показала, що диференціація та індивідуалізація навчання забезпечують організацію особистісно орієнтованого підходу до учнів. Вивчення теоретичних основ індивідуалізації та диференціації навчання дає можливість вирішити основні дидактичні проблеми в будь-який період розвитку суспільства. 
DOI 10.46299/ISG.2021.MONO.PED.II-24-35

\subsection{Sport in the present era}

Abstract. The article analyzes the issue of gender policy value in student sports.

The structural components of gender competence of students in choosing a sport are revealed.

A selection system of sports in higher education institutions has been developed.

The value of sports for self-expression is defined.

It is shown that gender equality has been achieved in sports and it is the natural process of development of human civilization, sportsmen with a large number of human characteristics choose only those that are identified in a particular sport as acceptable to men and women.

It is proved that the system of education and sports can be separated in the formation of values of gender policy among the students.

Keywords: gender policy, sports, students, components, development, selfexpression, gender equality.

Анотація. У статті проаналізовано питання цінність гендерної політики у студентському спорті. Розкрито структурні складові гендерної компетентності студентів у виборі виду спорту.

Розроблено систему вибору видів спорту у закладах вищої освіти. Визначено цінність видів спорту для самовираження.

Показано, що у спорті досягнуто гендерної рівності і це є закономірним процесом розвитку людської цивілізації, спортсмени 3 великої кількості людських характеристик вибирають лише ті, які визначені у конкретному виді спорту які прийнятні для чоловіків і жінок.

Доведено, що система освіти та спорт можуть бути відокремлені у формуванні цінності гендерної політики серед студентської молоді.

Ключові слова: гендерна політика, спорт, студенти, компоненти, розвиток, самовираження, гендерна рівність.

Introduction. Sport as a social phenomenon is an important component of human education. Its origin can be classified as the beginning of human society. Sport 
has long had its place in the formation of society and the human. This is motivated by efforts to achieve the best performance and leads a person to a high mobilization of physical and mental strength, overcoming obstacles and improving physical fitness.

The development of modern theory of sports training is currently impossible without knowledge of psychology, pedagogy, biological sciences of man: anatomy, histology, biochemistry, physiology, biomechanics, which in the XXI century have accumulated great scientific potential for such a phenomenon as sports. The achievements of these sciences must be combined into a single model of the human body, which operates in training and is the main subject of study in the theory of sports training. This holistic theoretical model of man (cells, tissues, organs, organ systems, body) should guide specialists in physical culture and sports, the choice of methods of scientific knowledge of sports by different groups [27].

The problems of professional training of future specialists in physical culture and sports in modern conditions are due to the need to overcome a number of contradictions that arise between the requirements of society and the training of future specialists and their qualifications. Empirical research methods reveal the problem of low public awareness of the importance of sports in human life; also the lack of a childcentric approach to physical education in schools and free educational institutions of various degrees, insufficient attention to the dual approach has led to a decline in interest in sports. There is also no motivation to play sports, because not everyone has information about the benefits of physical activity and methods of self-exercise in shaping the health of each person in particular.

Based on the theoretical analysis of the scientific literature, the conclusion is substantiated that the concept of gender approach to professional training of future specialists in physical education and sports is aimed at forming the semantic paradigm of the future specialist of physical education and sports in the pedagogical environment of higher education. The future specialist in physical education and sports is considered as a person who purposefully acquires qualifications in HEI in accordance with a certain educational level in the process of specially organized educational activities aimed at preparing for further professional activities to maintain the appropriate level 
of higher sports results at the Olympic, global or regional arenas in team or individual dimensions[22].

Professional training of future specialists in physical education and sports is

considered as a process that reflects scientifically and methodically sound measures of free economic education aimed at forming during the training level of professional competence of the individual, sufficient for physical education of different segments of the population and successful work in all sports. taking into account the modern requirements of the labor market.

Modern society exposes its rights and responsibilities for the formation of a healthy person. Changes in the views of young people lead to the distribution of functions among the members of society. Gender policy has its advantages and disadvantages. Gender determines affiliation of a person to one of the social communities. Sport is one of the means of formation of healthy person. Gender policy in sports is determined not only by kinds of sports but also other features[30].

The issue of gender equality is not new for Ukraine, but it is still relevant. Unfortunately, it should be noted that many areas of socio-economic life of the country have discrimination on the grounds of sex. Therefore, gender policy has a positive shift in sports. The result of socio-economic transformations of Ukrainian society was the depolarization of traditional social roles of women and men. There is a large number of scientific studies that prove that a woman differs from a man not only in biological characteristics but also in personal characteristics, thinking, imagination, which affects the sporting achievements of women. The changes that have taken place in the attitude towards women during sports have a long history. Sport as a social phenomenon provided an opportunity to realize their own abilities for both men and women.

The basis of higher education is the priority on personal orientation and on development of personality as a subject of one's own life, creative, self-sufficient person who meets the relevant principles of the gender approach to the process of physical education.

The implementation of a gender approach in physical culture and sports is an important component of bringing the system of physical education in line with 
European requirements. The integration of a gender approach in the system of physical education is necessary not only for compliance with international and national laws and the introduction of gender ideology in sports[20].

It is important to implement the gender approach in physical activity of students, which is seen as an activity that contributes not only formation of physical, moral and mental qualities of the person, but also helps to identify ways of formation in the educational process of psychological differences between persons of different sexes, determine the role of physical activity in gender socialization.

The aim of the study. Uncover the value of gender policy in student sports.

Research methods. Observation of participation in competitions. Analysis of different sports. Distribution of sports by gender.

Physiological features, psychological abilities and inclinations determine choice of sport.

Testing students helps to determine the system of sports selection.

Analysis of research and publications. Gender policy as integral component of formation of competence of students considered many Ukrainian and foreign researchers I. Zaiganov (2007), O. Kikinezhdi (2003), L. Kovalchuk (2008).

The formation of gender culture of university students studied O. Vasylchenko (2008), G. Kondratska (2017), O. Kulish (2009).

The scientist S. Shcherbyna (2016) in her works covers the gender approach in educational process.

The specifics of the gender approach in the educational process in higher educational institutions considered M. Gogol-Savriy (2011), T. Doronina (2012), Yu. Ivchenko (2012), R. Lionchuk (2010).

Gender aspect of formation of values of physical training of students in higher educational institutions are described by O. Marchenko (2013), L. Mazur (2005), A. Chepelyuk (2017).

Research results. The gender approach in professional training is characterized by a rather complex content and structure and includes psychological, scientifictheoretical, practical, psychophysical and physical readiness. And the professional 
profile of the coach includes: knowledge of the properties and characteristics of the athletes; features of psychological and pedagogical, special and physical training of athletes; requirements for their professional culture. These components are closely interrelated and require a gender perspective in the model of the athlete's personality[12].

In our opinion, the gender approach should take into account the gender characteristics of sportsmen / girls and sportsmen / boys. These are gender characteristics that are observed in adolescence of girls, boys: weight, height, physiological and psychological differences. Of particular importance is the development of gender identity and modeling of training plans for physical activity of the individual, choosing the principles, forms, methods and means of implementing the planned amount of training[14].

The gender approach in the training process is essentially individual, in other words, one that will allow the sportsman to reveal his identity. It provides a person with greater freedom of choice and self-realization, helps the child to be perfect and be able to use possible ways to achieve sports results. Assimilation of gender-role representations by the individual occurs through the categorization of a certain cognitive structure - a gender sheme that organizes and directs the perception of the individual.

Sportsmen with a large number of human characteristics choose only those that are identified in a particular sport as acceptable to men and women.

Gender education takes place in the student sports. Gender competence of students is necessary for the choice of type of sports, which motivates the student to regular training.

The definition of "competence" as fundamental is given in a number of various international documents, we have considered several options definition of competence to be interpreted:

- as the ability of the individual to perceive and respond to individual and social needs; set of attitudes, values, knowledge and skills (International Commission of the Council of Europe); 
- also the ability to apply knowledge and skills in new situations (experts of the European Union);

- a combination of knowledge, skills, values and attitudes necessary for daily life (UNESCO);

- ability to perform activities in a qualified manner (IDSLAE - International Department of Standards of learning, achievement and education)[16].

The gender approach as a methodological tool of analysis is substantiated by us as a certain social mechanism of involvement of the athlete's personality in the existing gender distribution of the formation of the training system, appropriate individual-typological argumentation, as well as a certain technology of physical activity distribution and high sports achievements.

The content of the gender approach is the realization that social, anatomical, physiological phenomena affect men and women in different ways, cause different reactions. The gender approach offers another way of cognition the reality of nongender, physiology and nature, but gender determines the psychological qualities, abilities, activities, interests, needs, occupations of girls and boys. The formation of these differences takes place through socialization, personality formation, through physical culture and sports, legal and ethical norms of a particular society[17].

For physical culture and sports, the existing biological differences are not decisive, but are the basis for the formation of male and female personality.

Gender approach in sports is one of the conceptual principles that requires changing the traditional vector of action - not to reduce the real diversity of boys / girls to the same typologies of male / female, but to understand the manifestation of options differently tolerate physical activity, respond to victories and failures, helps to determine an individual approach. The gender approach does not reject the differences between women and men, considers gender as a product of socialization of the individual, which is formed during life in interaction with various social institutions.

The study suggests that men and women do not always have the same views and needs. Each of them has a different attitude to sports. Women are more persistent and systematic, men are more resilient and bold. Therefore, it should be noted that the 
outlined personal qualities may belong to both women and men.

In the context of the problem of our study, the use of post-classical methodology allows us to analyze the gender approach in sports as a system of processes for obtaining high sports achievements by both men and women. In the post-classical approach, the highest credo of cognition of the world is (knowledge-goal), the anthropic principle of knowledge is a means.

The gender approach meets the requirements of modern science, which provide forecasting and planning, both global and local processes, at the level of objective necessity and subjective indirectness[13].

The gender approach in physical culture and sports makes it possible to ensure the effectiveness of men / women quite dynamically.

Gender policy requires the development of a system for the distribution of sports.

The dominance of men in coaching teams can be one of the factors that negatively affects girls' attendance at sports schools. In addition to psychological barriers, opportunities to face sexual harassment and violence, girls may lack successful stories and examples of women's behavior in sports.

At the same time, gender-based leadership and an increase in the number of women coaches can increase the involvement of girls and women in physical education and debate, as well as eliminate gender stereotypes in sports.

On the other hand, it is sport that makes it possible to achieve equality between men and women by establishing common rules and values, such as fair play, nondiscrimination, teamwork, and so on. Involvement of women and girls in sports promotes the development of their leadership skills, independence, activity, competitiveness, self-confidence. All these qualities contribute to the empowerment of girls and women and give them the opportunity to build their professional and family life of their choice. The field of sports includes both professional sports, or highachievement sports, and mass sports, or sports as active recreation and a way to maintain good physical shape. Today, more and more women and men go in for sports to spend their free time and improve their health.

Very often, women's participation in training and sports activities is limited by 
the lack of time, which is associated with a double burden on women - additional work for them to care for children and relatives. It is clear that the lack of accessible social and medical infrastructure and services reduces the free time that women could devote to sports.

Despite the significant increase in the participation of girls and women in sports and the growing audience interested in women's professional sports, there are still significant differences in the coverage of women's and men's activities in the media, where the achievements of male athletes receive much more media attention than achievements of women athletes[19].

Although women have recently been actively involved in sports, there are still some kinds of sport that are characterized as more male or female. Aggressive physical contact is part of men's sports, whereas grace and elegance are the features of a typical female athlete. There are kinds of sport related to stereotypes of masculinity (courage, toughness, strength, aggression in interaction with the opponent), which include various types of martial arts. Whereas femininity need softness, emotionality, artistry (for example, ballroom dancing, figure skating)[26].

But often, women involved in sports characterized as "Masculine", are perceived as "masculine", then as men who are not interested in physical education and sports, are considered as "feminine". On the other hand, it is sport that makes it possible to achieve equality between men and women by establishing common rules and values, such as fair play, non-discrimination, teamwork, etc. Involving women and girls in sports promotes development of their leadership skills, independence, activity, competitiveness, self-confidence[28]'

Note that the classification of sports can be conducted on various grounds. For example, by the nature of the interaction of rival athletes: antagonistic nature (sports in which the opponent responds to the action of the athlete by counteraction); synergetic nature (sports in which the opponent responds to the action of the athlete with a similar action); autonomous nature (sports in which the opponent responds to the action of the athlete by a predetermined autonomous action); complex nature (sports in which the opponent responds to the action of the athlete with different options for their actions in 
the complex). In general, sport forms the will to win, courage, determination, strengthens physical strength, emotional stability.

Therefore, regardless of whether sports represent the image of femininity or masculinity (the main stereotypical differences in sports), sport is considered a man's business: it forms an androgynous type of personality.

These provisions determine the relevance, scientific and practical significance of the fundamental study of the gender approach to the personality of the athlete. Conceptually, it is important to develop psychological concepts of gender development of the athlete, as well as gender-oriented approach to his psychological support, which constitute a holistic gender psychological architectonics of professional development of athletes of both sexes.

Since it is known that there are different divisions of sports into groups: group and individual; cyclic, acyclic, mixed; aerobic and anaerobic, etc.

That is why, according to the results of testing the students of the faculty of physical education in the choice of sports, we came to the following division of sports: men, women and common according the gender equality (Fig. 1).

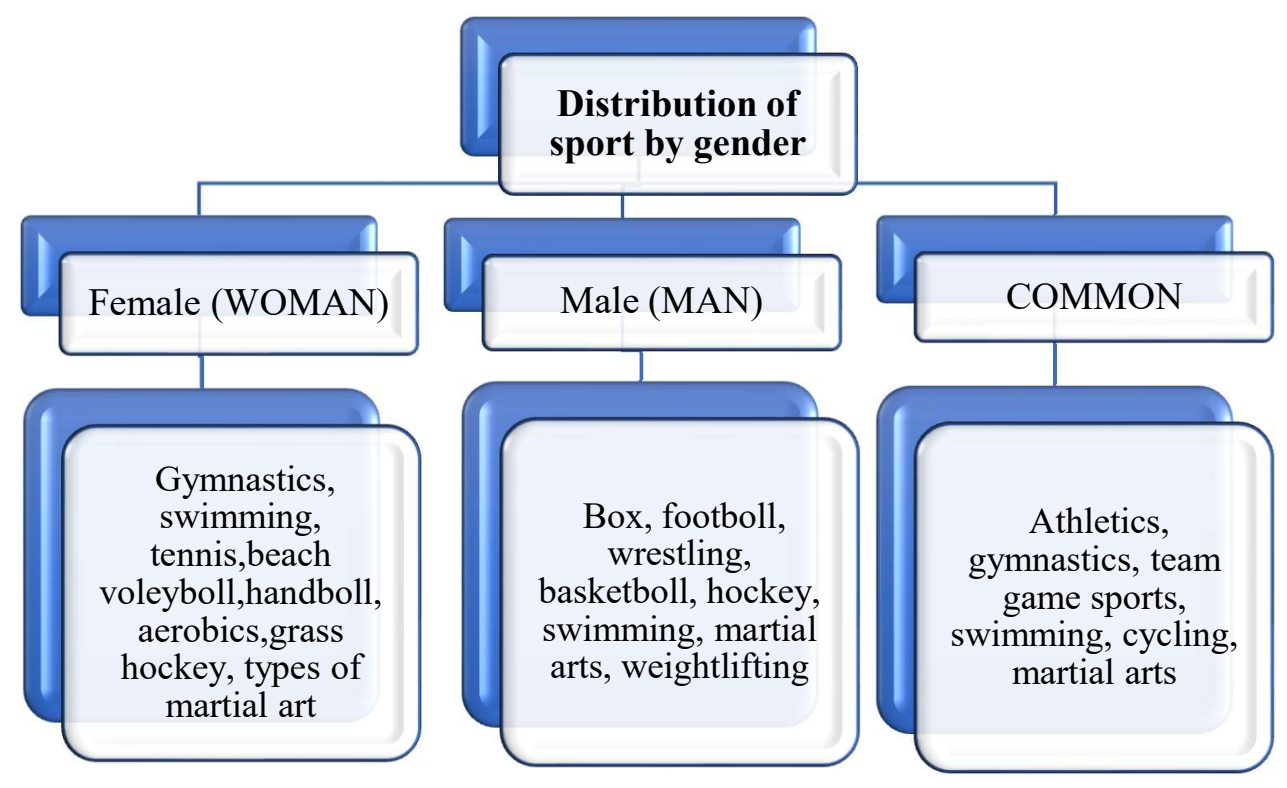

\section{Figure 1. The system of distribution of sports by gender.}

We determine the following main components of gender competence: value- 
personal, cognitive, behavioral, reflexive. Our system is based on the structure of activities of the individual, the structure of key competencies, which are represented in scientific sources.

Foreign researcher I. Zagainov[18] was one of the first to identify gender competence as the basic competence of the teacher represented as the set of knowledge about the essence of the gender approach in education, skills to implement gender strategy in the organization of pedagogical process and experience of using gender knowledge and skills as a basis gender interaction in the educational system.

As we can see, in the given definition lacking such a significant component, as value-personal. In our opinion, it is not just important, but defining, because only under the condition of internalization of gender values the teacher can productively use the gender approach in his own professional activity. In this article, we try to track why the question of gender competence has arisen, why gender values in general appeared on the agenda of social life.

Analyzing the indicators we note popular kinds of sport: aerobics, volleyball, athletics, swimming, gymnastics and basketball. We note that last years it is noticeable girls' interest in such sports as football and various sports is growing martial arts, which are considered as "male" sports. That is why in modern society there is a tendency to expand the scope of girls' interests in sports. In the process of analyzing the results of the survey show that $60 \%$ of boys - play football as the most popular kind of sport and which is considered as "male". Important factor in choosing a sport for boys is its affiliation with men and the interests in certain sports are more stable than for girls. We note that for female students these factors don't have such value. That is why there is an increase in the number of girls who want to do men's sports: football, wrestling and different types of martial arts[13].

The gender culture of the future teacher is a complex concept that includes the formation of personality through the gender awareness, formed personal qualities (egalitarian consciousness, gender sensitivity).

We have identified the criteria of gender culture of the future teacher (Fig. 2). 


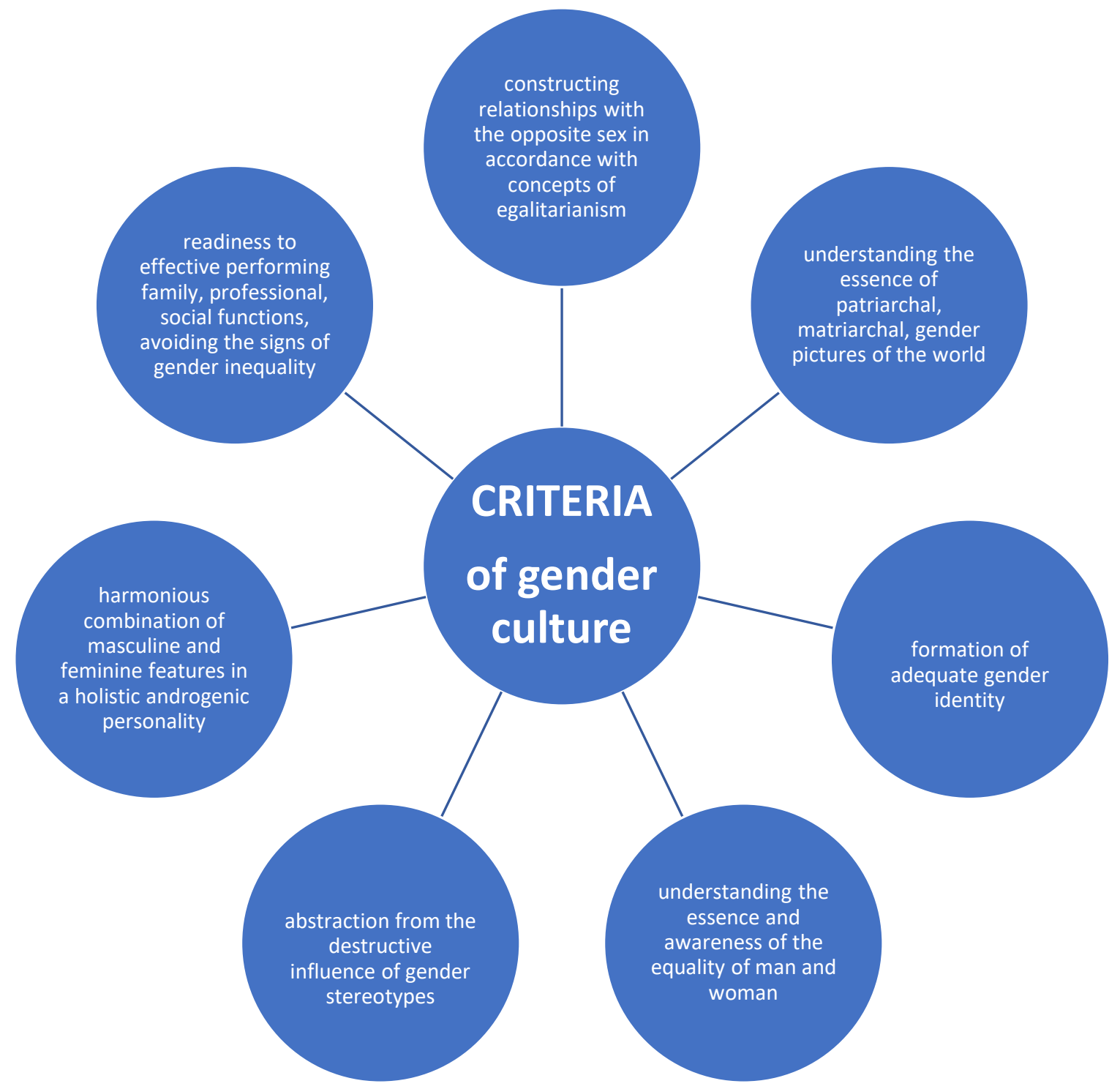

Figure 2. Criteria of gender culture of the future teacher.

Consider each of the selected components of gender competence in more detail.

The value-personal component is determined by the nature of the attitude of future teacher to the problems of gender, which expresses in levels of formation (non formation) of gender sensitivity. The aspect of value is central in the philosophical definition of gender culture. Gender values are the keys to understanding of gender culture in the past and in the present[21].

The reflective component of gender culture provides development and selfdevelopment, realization of reflective ability, promotes the creative approach in professional activity of the specialist and achievement of its efficiency.

The cognitive component provides opportunities to apply a gender approach in their practice on the basis of acquaintance with key concepts of gender ideology, gender 
system of knowledge and formed gender (egalitarian) consciousness [23].

The practical component of gender culture is determined by the degree of formation of the system of skills, which determine the traditional (modern) character of his gender behavior. Definitely it is first of all a system of communicative skills and abilities that allow to establish the level of formation of gender culture of the specialist[27].

Notisable is the fact that this division of the structure of gender culture is largely conditional, but in epistemological terms it is appropriate and justified because it allows a deeper understanding of the essence and structure of the phenomenon of gender culture. It should be noted that all the components are closely connected and interact with each other.

Conclusions. We have made the following assumptions: the value of gender equality in sports is not a phenomenon invented by someone, but a natural result of historical development of human civilization. Values of gender equality in sports will take root in our society gradually with it socio-economic development.

The study proved the relevance of gender equality, which prepares students for adult life. But understanding the values of gender competence of student is still doubtful, this is a great field for the work of all interested and conscious of the importance of such changes. 
DOI 10.46299/ISG.2021.MONO.PED.II-36-45

\subsection{Structural components of the process of forming the spiritual values of student youth}

In modern conditions, the student is the main subject of the reform and innovative development of higher education and society, which is why the issue of the formation of spiritual values in student youth is becoming important.

At the same time, the analysis of pedagogical theory and educational practice demonstrates the disadvantages of the preparation of high school teachers for the implementation of the relevant educational activities, the inadequate level of orientation of educational programs and the involvement of public organizations in solving this problem is observed. Therefore, personally oriented educational influences should be directed to the process of formation of spiritual values, where the student is a priority.

The purpose of the article is seen in the definition of the structural components of the spiritual values of the personality, psychological mechanisms and pedagogical background of their formation during the period of study in a higher education institution.

We define the concept of "spiritual values of student youth" as an integral personal formation aimed at other people (responsibility, tolerance, mercy) and on myself (dignity, self-sufficiency), which makes constructive behavior and ensures the possibility of realizing the subject-subject interaction, adaptation and self-realization of the personality in society.

The analysis of the scientific makes it possible to conclude that the student's age is optimal for the development of value-semantic structures of consciousness of the personality and is characterized as the final stage of preparation for entry into independent professional activity. At this age, moral instincts will manifest themselves in the future as value orientations in the practice and behavior of the personality. It is at this age that the role of persuasion and responsibility for one or the other life choices and for values grows, such qualities as ambitiousness, determination, perseverance, independence, initiative, ability to manage yourself are strengthened, and the interest in spiritual and moral problems is increased. 
Formation of spiritual values in students requires consideration of their structural components - it is a question of the content structure of this integral entity. It can be represented by interconnected and interdependent components: cognitive, emotional and value-based, and praxical.

The definition of structural components is conditioned by the conceptual provisions on the dialectical unity of the intellectual and emotional factors of consciousness. After all, without knowledge of spiritual values it is impossible to form a relation to them. At the same time, without emotional perception, positive attitude and interest in spiritual values, difficulties will arise in mastering knowledge. This explains the isolation of the cognitive component, which determines the capture of beliefs and knowledge about the phenomenon.

The acquired beliefs and knowledge provide the opportunity to form a person's attitude towards the subject of knowledge. An emotional (positive or negative) adjustment is formed, subjective evaluation criteria that will determine susceptibility to the formation of spiritual values are formed. So, the emotional and value-based component implies a positive attitude to the content and manifestations of spiritual values.

The acquired knowledge and positive attitude are reflected in practice. Therefore, the ability to realize spiritual values in everyday life and professional activities determines the emphasizing of the praxical component. At the same time, it should be borne in mind that spiritual values are accumulated in such qualities of personality as: responsibility, mercy, tolerance, dignity, self-sufficiency. The appropriation of such values by young boys and girls ensures the effectiveness of interaction, communication with peers, relatives and acquaintances, their successful self-realization and adaptation in society.

The emotional and value-based component of the students' spiritual values is manifested through the value attitude of young boys and girls to themselves, others, surrounding reality and is a benchmark in their spiritual growth. It also implies a humanistic interaction adjustment; detection of tolerance, mercy, responsibility; developed empathy; positive "I-concept"; emotional self-regulation. 
Formation of spiritual values in students is impossible without emotional experiences, because they are developing a value relation to this phenomenon. This is due to the fact that at the young age a significant experience of emotional life is already acquired. Student youth not only can manage its emotions, give a moral assessment of aspirations, but also deliberately tries to educate itself in high moral feelings. Selfesteem of actions and feelings, aspiration for a moral ideal - all this develops and deepens the most important of moral feelings - a sense of duty, produces the ability to give a moral assessment - conscience.

Spiritual values are semantic entities directed at other people and itself. That is why they are always connected with the emotional contact between the two subjects. Properly reflecting the feelings of another person, we signal how we understand its internal state. Productivity of interaction and understanding depends in such cases not so much on actual information, but from sets, feelings, emotional manifestations.

Given this, the ability to respond emotionally to the experiences of others, to show mercy, tolerance, the ability to use emotional expression as a means of communication, to express emotions purposefully, to control their manifestation arbitrarily, the ability to adequately perceive, evaluate and understand their own emotions and emotions of other people, be aware of, reflect emotional states, control emotions, etc., is very important in the process of interaction.

Due to the growth in the student's age of self-control and self-criticism of their behavior, forms of manifestation of feelings change. Changes and new formations in feelings are evidence of the maturity of young people, their spiritual growth. They are a manifestation of the formation of their consciousness and self-consciousness, their interests, in particular the interest in themselves, other people, in their own and others' experiences. Student youth has the ability to empathize, understand and respond to the experiences of another person. It is worth noting that the feeling of personality is not simply experienced by it, but expresses its subjective attitude to certain phenomena of reality, persons, they become the motives of its actions.

Spiritual values are considered, first of all, as the personal formation of the student, which is reflected in its beliefs, views, needs, motives, feelings, and 
interactions. They are a tool for self-realization of a student in a relationship with other people. Important in the development of the emotional and value-based component is the awareness of young people of their own abilities, needs, motives of behavior, valuebased orientations.

The aspiration for self-determination, self-affirmation, self-realization belongs to one of the most important needs of students and is a condition for their harmonious spiritual development. The notion of itself, its "I" inevitably gives rise to the need to realize its capabilities and abilities.

The emotional and value-based component of spiritual values is a complex of motives that motivate young people to interact, establish an active life position, selfunderstand, self-improve. First of all, external motives of spiritual values include social motives widely represented (desire to occupy a certain place in society, increase social status, motives of personal self-realization and prestige) and narrowly represented (desire to have a certain status in a particular social group). The internal ones include cognitive motives, self-affirmation, identification with another person, selfdevelopment and self-actualization (this refers to the desire for self-improvement, the desire to increase its individual capabilities, to realize individual potential), affiliation (the desire to establish relationships with other people), personal growth (the ability to have self control in any situation).

Formation of spiritual values of students is conditioned by a complicated hierarchical system of socially meaningful and personal motives; in it the higher level of motivation is the transformation of the need into conscious interest, personal value, and the value - into the purpose of the activity. The development of the motives of spiritual values is carried out in the direction from external impulses to the appearance of their own motivational entities. But the formation of the spiritual values of students should be spoken only when in the process of interaction or communication another person acts for them as an object of value attitude, manifested in recognition of its needs, interests; orientation towards positive in a person.

An important condition for the successful formation of students' spiritual values is identification, empathy. In the process of identification, there primarily takes place 
interpersonal regulation of the behavior of boys and girls, assimilation, identification of partners in communication and, as a consequence, - mutual understanding. The phenomenon of identification belongs to the most significant and most vivid processes of human communication. In particular, M. Herbert considers identification as a process by which one subject is likened to another, accepting its values, views, sets, life experiences, as well as specific forms of its behavior.

One of the mechanisms that mediates the formation of spiritual values for students is empathy. In the aspect of interpersonal interaction or communication, the empathy is regarded by scientists as fulfilled for another person introspection or the ability to feel, see, distinguish, reproduce and respond to feelings and experiences of other people. It has a complex structure, including cognitive, emotional and behavioral components. As a cognitive phenomenon, empathy is a way of understanding another person, aimed at analyzing its personality, and not only meaningful, but also intuitive knowledge of its emotional experiences. It is the ability to penetrate the affective orientation of another person, it is a sympathy for its experiences, the ability to be attached to the emotional life of another person, to share its emotional states, to experience emotional well-being or trouble. And, finally, the behavioral component manifests itself in the ability to "put" yourself into another person and influence the changes in its personality, its support and active assistance.

So, we see empathy as an important factor in the student's spiritual development. It is an effective means of disclosure, assimilation and balance of the internal content of interpersonal relationships and social norms. Without it, adequate understanding is hardly possible. The manifestation of empathy in the communication process indicates the general set not only for understanding the formal part of communication, but for entering its hidden meaning, the state of another person that appears primarily by nonverbal means - intonation, gestures, postures. That is there is a direct correlation: the higher is the overall culture of the personality, the more intense is the ability to empathize, sympathize with people. The egocentric emotions here are replaced by altruistic motives. Acting complicity in the fate of another person, compassion for another's grief enrich and develop interpersonal relationships. Actualization of 
empathic processes (development of emotional susceptibility, feeling of internal promotion to another person) is realized in the process of interaction, communication of senior pupils, the meaning of which is the care of another person, which manifests itself in compassion and empathy to it. Ability to sympathize with and empathize and be happy for another person, and therefore, to be able to put yourself in its place - the main thing that defines a good person. These abilities can be developed, this can be taught by student youth.

In this way, under the condition of identification and empathy, the behavior of another person is taken into account, but the result of the joint actions will be different: one thing is to understand the partner in communication, taking its position, acting in accordance with it (identification); the other is to understand it, taking into account ita point of view, even to sympathize with him, but to act in its own way (empathy).

For the development of the emotional and value-based component of spiritual values students must form a humanistic set for interaction, communication, interest in another person, willingness to engage with it in interaction; develop empathy, identification, interest in its own inner world, positive "I-concept", as well as promote awareness by young people of motives of their own behavior, improvement of the structure of their value-based orientations.

It should be noted that spiritual values are based on a certain level of knowledge, the content of which is revealed in the understanding by the students of the essence of the spiritual values of the personality (responsibility, mercy, tolerance, dignity, selfsufficiency). One of the important components of the cognitive component is reflection. Reflection involves not only the knowledge of the subject about itself and its activities, but also the idea of how it and its activities are perceived by others. Reflection as the ability to self-knowledge, self-esteem, self-conception, selfeducation, self-regulation provides an opportunity for a personality to explore its own mental life as if from the side. In the process of reflection the object of analysis is the results of the acquired spiritual experience. Reflection as self-analysis is a tool of selfcontrol, manifestation in the behavior of responsibility, dignity, tolerance, mercy, selfsufficiency of the personality. 
According to Bech, reflection unfolds as reasoning of the subject not only in the plane of its life today with its personal values, desires, aspirations, but also in the plane of attaining possible higher spiritual achievements. And the deeper and more diverse the reflection is, the more differentiated the "I" is. On the depth of reflection there depends the emotional attitude of the personality to objects that belong to the sphere of its spiritual entities (the values of knowledge, activity, communication). At the same time, those positive emotions that arise may become a new self-sufficient motivation "I will independently change myself spiritually". Knowledge of spiritual values is a necessary, but insufficient condition for their formation in boys and girls. This knowledge should become their beliefs. With this in mind, researchers emphasize the emotional and value-based basis of knowledge, because only then the knowledge is internally absorbed when students experience them as a value, become their internal motives for behavior.

The praxical component of the spiritual values of students characterizes the manifestation of two (cognitive and emotional-value) components in their behavior. First of all, it is a collection of practical actions, through which students realize the object of spiritual values or take the means for this. Spiritual values in the context of this aspect of the study are seen as the choice and implementation by the students of ways to interact with the outside world, the search for meaning in this interaction, expressed in the unity of knowledge, skills and abilities of responsibility, tolerance, mercy, dignity, self-sufficiency, accumulation in the process of subject-subject interaction.

In this regard, the praxical component of the students' spiritual values is represented through the acquisition by them of a certain experience consisting of five components:

1. Valuable experience: interests, ideals, beliefs, social norms. It directs the efforts of young boys and girls to form spiritual values (in this case, it is an expression of a moral ideal and a model of a pupil with a high level of development of spiritual values). 
2. Experience of reflection: the correlation of knowledge about its capabilities, about itself with the requirements of activity (in the context of our study - with the requirements of social and communicative activities).

3. Experience of usual activation: adaptation to a certain situation, communication, interaction, changing conditions, focusing on certain conditions in the achievement of success (helps to adapt its efforts in order to solve important tasks, in particular, readiness for personal and life self-determination).

4. Operational experience: ability of responsibility, tolerance, mercy, dignity, self-sufficiency, as well as self-regulation skills (the combination of specific tools for transforming the situation and its capabilities).

5. Experience of cooperation: it is formed in relations and communication of students with peers, other people, helps to unite efforts, jointly solve tasks and provides subject-subject interaction.

All five components of subjective experience constitute an integral system of student life experience as a subject of interaction, communication, life selfdetermination.

Praxical component of spiritual values is formed in the process of communication of students and is associated with a variety of activities that is expressed in the ability of pupils to use in interactions or communication their social and communicative properties, in skills related to the understanding, considering in interpersonal interactions or communication features of another person, the ability to establish, maintain contact, send and intercept the initiative in communicating, constantly stimulate both their own activity and the interlocutor's activity; to predict the possible development of a situation within which communication takes place; to be able to overcome psychological barriers; to choose an appropriate style of behavior, gestures, facial expressions, etc.

Significant role in the formation of students' spiritual values belongs to socially significant joint activities. It is referred to a leading reference group in which interpersonal relationships are due to its content. The joint activity involves a system of interaction between peers and promotes the establishment of positive relationships 
between them, enables their spiritual, personal growth and is a means of expanding students' social contacts and their successful social adaptation. In this regard, according to Orban-Lembryk, it is in the group that the most favorable situation occurs for the spiritual development of the student. First of all, joint group activity involves a system of interaction between group members, between a particular student and a group as a joint subject, the condition and means of forming of which is communication. Accordingly, a system of interactions of individual and collective needs, interests, values, motives, goals regulating the development of certain rules and norms of behavior, is formed. And if the nucleus of the direction of collective activity is the goals, the significance of which is well understood by all and the dominant motives of activity, then the source of collective goals and motives is the value orientations that are formed in the process of acceptance by the group of the values of society.

The praxical component of spiritual values is also reflected in the levels of formation and sustainability of the spiritual qualities of student youth (dignity, mercy, tolerance, responsibility, self-sufficiency) that make their behavior constructive, as well as is an expression of their ability to be responsible for their actions, control their own emotional states, live in society, cooperate, choose the situation on the basis of reflection, show tolerance in relationships. This component is also related to the need to form students' emotional self-regulation, behavior in communication, interaction. The main function of the activity is that it helps to acquire social experience, the experience of the students' treating towards themselves, people, the world, to form social and communicative skills. To organize the constructive activity of students, it is first of all to form an awareness of the need and the desire to identify the social and communicative culture in daily interpersonal relationships, as well as to master its mechanisms.

The manifestation of spiritual values by students synthesizes the possibilities of choosing a variety of behaviors, modes of activity that are adequate to the specific relationships and the conditions under which they are realized. In each case, choosing behavior or kind of activity, the student must establish new relationships with other people, so any meaningful act of choice, however individual it may seem, is at the same 
time the moment of functioning of the community to which it is included, an indicator of its needs in communication, interaction. That is why relationships, communication cannot be imposed outside. They need to be born and developed as a result of the activity of the person itself, who realized the need and responsibility for their improvement.

Consequently, the spiritual values of students are determined by their value orientations, moral beliefs, relationships with others, the ability to act in accordance with socially accepted norms of conduct. They reflect the attitude towards themselves, other people and the outside world. It can be argued that the moral qualities unite the society and the pupil, representing spiritual values in an emotionally fixed form. 
DOI 10.46299/ISG.2021.MONO.PED.II-46-52

\subsection{Volitional or autonomous behavior management: theoretical aspects for pedagogical practice}

Nowadays one of the key problems in the educational process is managing the behavior of a person. This problem is insufficiently disclosed both in theory and practice of pedagogy (especially when it comes to the development of a strong-willed, autonomous personality). This problem is associated with the phenomenon of the concept of spiritual and moral development of the individual, where the basis is the autonomous spirit, volitional choice, pragmatic action, which is consistent with the society values.

Recently, the study of various aspects of this problem has appeared in the pedagogical literature. Thus, there appear such positions as teacher autonomy in its relationship with self-efficacy (Soobin Choi, Xinyi Mao, 2021) [36], the implementation of autonomy in pedagogical practice (Xuan Nhat Chi Mai Nguyen, Ian Walkinshaw, 2018) [37], the ability of the learner to autonomous and critical thinking (José FO Granjo, Maria G. Rasteiro (2020) [38], social, individual and cultural dimensions of autonomy in teaching (Biljana Ivanovska, 2015) [39], autonomy with respect to teaching methodology, instructional materials, course content, assessment, lesson planning (Cirocki, Andrzej, Anam, Syafi'ul, 2021) [40], autonomy as a central component of learning, teaching (Diane Railton, Paul Watson, 2005) [41], the impact of autonomy on student well-being (Arielle Bonneville-Roussy, Emese Hruska, and Hayley Trower, 2020) [42] and others.

We find an important conclusion about the support of autonomy in the work of authors such as Arielle Bonneville-Roussy, Emese Hruska, and Hayley Trower: «It is important to emphasize that autonomy support relates to promoting autonomy within a given structured environment. That is, autonomy support is not synonymous to a laissez-faire or hands-off form of teaching. Autonomy-supportive teachers recognize that students are in charge of their own learning but also acknowledge that to master skills, certain tasks need to be accomplished within a given structure accompanied by 
guidance. That is, autonomy-supportive teachers provide both choice and structure» [7, p. 99].

From our point of view, to solve the problem of managing the behavior of a person, a scientific concept of spiritual and moral development is needed, which will take into account the position of goal-setting, the basic principles of self-government, the main forms of expression of individual autonomy of the individual. This problem changes our understanding of the inner work of the individual on himself and the understanding of the laws of upbringing for further pedagogical practice.

It is worth noting that there is a wide variety of approaches, ideas, concepts in pedagogy that allow us to consider the positions of behavior management. However, despite their application in the cultural and educational practices of the teacher, there are many ambiguous decisions that do not allow to fully understand how to develop the personality better, how to improve the pedagogical process.

One of the central approaches used in the pedagogical process is activity-based approach. It gives an opportunity to consider the actions of an individual, his intentions and motivation, the impact of various forces (both external and internal) on the development of the individual. In this case, we can also consider the concept of authorship of an individual's actions in the direction of his spiritual and moral development. At the same time, it should be noted that an action must be conscious for spiritual and moral development, that is, it should be one that has passed through the feeling and mind of the individual, through his/her experiences and reflection.

There is no doubt, the pedagogy of action, which includes the disclosure of the processes associated with the formation of volitional and autonomous behavior, is based on the idea of a number of religious (divine will) and philosophical (reasonable desire, will as the initial basis of human activity) studies, psychological problems (autogenetic and heterogenetic theories of will, volitional influences and efforts, etc.).

Currently, they develop methods in pedagogical researches that train the ability of a person to achieve a goal, that is, goal-setting in this regard is a primary element which must be taken into account in order to solve problems of spiritual and moral development. It should be noted that this process, seemingly imperceptible, is essential 
for the pedagogical space in which it unfolds. Thus, pointing to the issues of selfmanagement of the individual, we mean that the development of the problem of educating volitional or autonomous behavior becomes obvious.

The difference between strong-willed behavior and behavior based on instinct can be seen in the comparative characteristics of game situations in team sports. In games, we can observe the coach's conscious work with the players when building a plan to achieve the goal, developing and adjustg the program of actions that are aimed at the result. We can also observe the chaotic actions of a spontaneously assembled team that has no plan, no organization, no structure and no idea of the rules of the game. In a spontaneous team, as in a spontaneous society, there are main characteristics such as a conflict, misunderstanding, lack of the main goal and practical guidance, and, accordingly, there is no result. We can observe in this case the manifestations of ataraxia (the opposite of will), i.e., weak will, intemperance.

However, if we are talking about the spiritual and moral development of the individual, then the team of players is of the person's close environment, and much in the development of the growing personality depends on whose goals are pursued in behavior. It is difficult to say with certainty that the close environment of the growing personality as a whole has the goals of spiritual and moral development, or that the autonomy of the spirit is clearly revealed in their behavior. Although we can note that in some communities there may be a focus, a certain dynamic of development aimed at improving the quality of life in general, but most decisions, even in organized societies, are more focused on improving the material rather than the spiritual side of life.

It is noteworthy that in the spiritual and moral development of the individual, the goals are not always conscious and clearly formulated, and the results are not fully thought out and, thus, are not always achievable. In this regard, for the formation of strong-willed or autonomous behavior of a person, it is necessary to develop and implement special technologies and techniques, since each person is unique in its characteristics and has a certain experience, knowledge and skills. Also, the personality develops not separately, but in a specific culture, which has an impact on the formation 
of sociability, stereotypes, and generally accepted views. By agreeing with the rules and laws of a particular society, the individual partially gives up his autonomy, obeying ethical considerations. However, the acceptance of the ethical considerations of society should not be confused with the weakening of the will, which leads to a weakening of the desire, a loss of responsibility for the earlier decision to act.

In order to develop volitional or autonomous behavior of the individual, it is necessary to create an environment that will be focused on all subjects of the process of spiritual and moral development, which makes special demands. The management of autonomous behavior can be described in various situations of interaction in the systems «a teacher and a student», «a student and a student», «a teacher, a parent and a student». In such situations, you can see new opportunities for building a conscious plan for your own development, which will mark the beginning of the autonomy. If each participant in the educational process consciously creates a plan, and implements it in his life, taking into account personal motives and the ability to act, then autonomy will acquire an individual dimension. It is also necessary to avoid extremes - the autonomy of the spirit, independence and critical judgment has nothing to do with asociality or antisociality. We are talking about a mandatory component of autonomous behavior - mutual support of the Other, which provides the disclosure of the cultural and educational space for the development of autonomous behavior.

Understanding the processes of controlling volitional or autonomous behavior is an important issue for both parents and teachers. Most teachers can offer recommendations that will help develop respect for the student, his individual characteristics, which include both scientifically based psychological and pedagogical facts, and the reality of the manifestation of feelings and experiences observed by the teacher for a certain period of time.

At the same time, we can note that most teachers understand the development of volitional processes of behavior and are able to manage autonomous students, but teachers themselves are not always sure of their own autonomy when they have to make a decision (especially in an environment where interpersonal conflicts break out). Such violations acquire an unnatural character, since the demonstration of free will can be 
taught by a person who is autonomous himself, and if there are exceptions, this makes a negative impression on the trainees.

That is why it is important to have certain laws of relations between autonomous personalities, which are established through dialogical practices. The array of opportunities for dialogic communication that accompanies relationships in the systems of students and their parents, students and teachers, students and students, shows what new things can be learned about yourself in the spiritual dimension.

It can be noted that a high level of autonomous behavior will be revealed both individually and in certain communities, and the demonstration of autonomy is one of the first steps that lead to an increase of this level. The development of a high level of autonomous behavior is possible in different environments of pedagogical culture, and here one of the important factors will be educational traditions and cultural differences, pedagogical experience of interaction with strong-willed people, and educational contexts that facilitate the understanding of the values of an organized society.

A. Bergson, considering the concepts of morality, the moral obligation of a person to society, wrote: «Society, inherent in each of its members, has requirements, each of which, both large and small, expresses the integrity of its life force. Human society is a combination of free beings. The duties imposed by society, which allow it to exist, introduce into it an order that is simply similar to the steady order of the phenomena of life» (Bergson, 1994) [43, p.7].

We believe that the entire educational process should take into account the line of spiritual and moral education, and all educational influences should include aspects of the development of autonomous behavior. Without such education, pedagogical processes lose their meaning, and the contribution that the teacher makes to the preservation of the autonomy of the student's spirit would be significantly limited. In our opinion, it is wrong to separate the various elements that make up the entire complex process of managing autonomous behavior. And the purpose of this process is not only to reveal to teachers new knowledge about the autonomy of the spirit and its relationship with spirituality and morality, but also to promote the emergence of the practice of managing autonomous behavior. It should be noted that this knowledge has 
been collected in different cultures for centuries, and in addition to promoting the development of the autonomy of the spirit, knowledge about different cultural practices in different countries also provides teachers with different forms and methods of education. Thus, the management of autonomous behavior in modern pedagogy should include scientific knowledge, educational methods, technologies that contribute to the development of social and individual action, the organization of interaction in various cultural environments in such a way that both the material and intangible heritage of humanity, developed by free will, increases.

The crisis of spirituality around the world can be called a consequence of the crisis of scientific knowledge about spirituality, the questioning of religious doctrines by the consumer society, in which the education of public morality was fundamental. Having discarded the knowledge of religious figures about a man, about his spirit, many societies were not offered anything new in return, and therefore various occult practices began to be introduced into such societies, denying religion and its content of morality. To solve this problem, it is necessary to review the existing models of human behavior management in the consumer society and to acquire knowledge about the person in the spiritual, social and biological dimensions. Accordingly, this requires the creation of new methodologies, new pedagogical solutions that should take into account the new needs of the younger generation. Such approaches will help to develop an understanding of the management of autonomous behavior of the individual, and the development of new auxiliary materials should be aimed at helping teachers to support the participation of students in their spiritual and moral development, which will bridge the gap between the meanings of the life of an autonomous person and the content of education. That is why volitional or autonomous behavior management should be considered as an activity tool of the teacher, which is an integral part of the pedagogical process, which considers the ways of interaction, the needs of the individual and the needs of society.

Therefore, such a tool can help to raise students' awareness of their spiritual dimension, which will make it possible to identify the problems of their further selfdetermination and self-realization. This, in our opinion, can later lead to thinking about 
the need to change the behavior patterns that promote ataraxia (weak will, intemperance), as well as to understanding the need to reproduce the system of moral actions as an autonomous line of behavior. It should also be borne in mind that teachers also have their own values and personal interests, their own attitudes, they have their own way of understanding the autonomy of the spirit, and therefore, such experience should be studied and used later as a tool, the skillful use of which can make positive changes in the very life of each person and a new, organized society. 
THEORETICAL FOUNDATIONS OF THE FUNCTIONING OF EDUCATION. WAYS TO IMPROVE THE EFFECTIVENESS OF EDUCATIONAL ACTIVITIES

DOI 10.46299/ISG.2021.MONO.PED.II-53-64

\subsection{Updating the ideas of the representatives of the new school of scientific management to improve the educational management of multidisciplinary institutions of extracurricular education}

Over the past decades, we have seen a number of transformations in the education system and in its separate subsystem - extracurricular education. In our opinion, these radical changes will be one of the most significant events for the life of the future generation. Significant changes are made with the help of external and internal factors. An external factor of transformation is in the discovery of ideas for the transformation of additional, in-depth, non-formal education outside the walls of ordinary schools; an internal factor is a deep study of these ideas and their reflexive implementation in practice. Understanding the pedagogical work of the representatives of extracurricular activities in Ukraine, the implementation of educational management both at the regional, national and international levels - all these are qualitative historical changes that affect extracurricular education in terms of form, processes, and technology of problem solving.

We believe that the current state of educational management development as a separate science and practical activity indicates imperfect procedures and insufficient study of practices for the adoption of new models in management by heads of extracurricular educational institutions. The situation is aggravated by the socioeconomic crisis, which forces the manager of an educational institution to be not just a «teacher of teachers», but also to have an idea of various management functions, which today are extremely difficult for educational activities, because extracurricular education faces the mutual influence of various organizations and shows both the achievements and best experience, and also the shortcomings of educational policies.

Nowadays the educational management of multidisciplinary institutions of extracurricular education goes beyond the existing knowledge of management and it is currently in search of the best theories, concepts and models. To improve this process, it is necessary to conduct an analysis of the ideas presented by the best representatives of the new school of management science, which include such scientists as R. Akoff 
and D. Greenberg [44, c. 2, c. 3], S. Beer [48], L. Bertalanfi [47]. The contribution of this school to management as a science in general and as for the educational management of a multidisciplinary institution of extracurricular education in particular is invaluable. It is explained by the fact that these scientists were the first who noted the concretization of the descriptive process of Management in models and symbols. They directed the solution of problems to the study of quantitative values, statistical data, which provides an opportunity to use new scientific knowledge for practical purposes.

We took into account that the achievements of these scientists are based on the following areas: the use of systematic, procedural and situational approaches, and the management process itself is considered from the point of view of working in the social system. Representatives of the new school of scientific management were the first to use a cybernetic approach, which provided for the widespread use of mathematical methods. In particular, Stafford Beer, revealing management issues in cybernetic terms, formulated the idea of general principles for managing any probabilistic system: a computer as an inanimate complex system; an organization in which people interact - a complex living system. S. Bir's idea is fundamental regarding the four reasons for recognizing the system: 1) combination within a certain experience; 2) survival in time by a certain appropriate definition of continuing identity; 3) achievement of goals is regulated by prescribed rules of activity that are acceptable for continuing existence; 4) assimilation of one's own experience, self-regulation of learning, adaptation and evolution processes [48, p. 167]. The idea of an English scientist about the need to draw up concepts, develop mechanisms and laws that should be effective in designing or redesigning systems for management by managers is still relevant. The scientist wrote: «if cybernetics is the science of control, management is the profession of control. Every manager ... faces identical problems. He faces the realization that maintaining a viable system is much more difficult than he personally can understand. And the beginning of wisdom in management at any level is to understand the viability of systems that are mostly self-regulating and even self-organizing» [48, c. 168]. 
The most important concept of educational management is the viability of the system. At the same time, S. Beer appeals to the following main characteristics: 1) the results of activities should be under control: we need to know how to do this, manipulate the system so as to get the desired effect; 2) the system as a whole should be ultra - stable, because instability is the main symptom of an organization that is poorly managed; 3 ) for the growth and evolutionary development of the system, it is necessary to generate innovations that make you learn and adapt, increase «muscle» tone [48, p. 173]. In our opinion, this argument is quite balanced and can be extrapolated to the practice of managing multidisciplinary institutions of extracurricular education.

It is known from scientific sources that L. Bertalanfi is one of the outstanding scientists who started the study of general systems theory. He pointed out that there are certain problems in any field that can be ignored by classical science. He mentioned: «There is an urgent need to extend the means of science to those areas that go beyond physics and have specific features of biological, behavioral and social phenomena. This means that new conceptual models must be built. Each science is in the broad sense of the word a model, that is, a conceptual structure that aims to reflect certain aspects of reality» [47, p. 23]. Given this opinion, we point out that the issues of improving the educational management of multidisciplinary institutions of extracurricular education should leave the field of view of purely practical activities and acquire a transformation, a new structural description that should streamline the process of managing creative people who in their activities should lead the future generation to axiological guidelines.

General systems theory provides an opportunity to describe the educational management of multidisciplinary institutions of extracurricular education through such concepts as "integrity", "organization", "teleology", "direction of movement or functioning". These concepts are extremely important tools for scientific analysis, which involves rethinking of management procedures and building new models of educational management. In other words, we are talking about a new vision of extracurricular education, inventing its ideal future. The changes should come from 
rethinking the status of educational management. The need to introduce a systematic approach to management in general is noted in the book «Management of the XXI century» (by Russell Ackoff). The author deduces the position of management as a fundamental function of the manager. According to his opinion, the manager should manage not actions, but interactions: «1) the interactions of those divisions and people who he is responsible for; 2) the interactions of his divisions with other divisions within his organization; 3 ) the interactions of his divisions with other organizations or their divisions related to the environment» [46, p. 19].

Speaking about social systems (corporations, educational institutions, etc.), Russell Akoff pointed out that the management of such systems should be subjected to certain rules, since each social system has a corresponding goal. That is, a multidisciplinary institution of extracurricular education, as a social system, has a clearly defined goal and, accordingly, the functioning of this institution occurs through following this goal. In the management of such an institution, it is important to rely on the principle of autonomy, which enriches the professional activity of teachers, and at the same time is the beginning of the transformation of the world of this type of Education.

In working with social systems, as Russell Ackoff proved, techniques for managing «organizational» systems are useful. A democratic organization, according to the author, cannot be modeled from the point of view of an "organizational" system, since such modeling will not be able to take into account the ability of individual parts to make a certain choice. Autocratic systems will experience a number of difficulties (if the number of its members increases, the number of technologies that provide solutions to their problems increases and the variety of requirements imposed on them increases).

In other words, the complication of situations around the functioning of extracurricular institutions, the uncertainty of the prospects for out-of-school education, the introduction of new technological solutions - that is all that accompanies the process of out-of-school education today, thus forcing us to reconsider the issue of educational management in a new way. Appropriate in this case is the pattern that was 
derived by the scientist: «the better those who are managed know how to perform their functions, the less effective is autocratic control on the part of those who manage them» [46, p. 38].

Consequently, in contrast to the autocratic management of a multidisciplinary institution of extracurricular education, there should come a system of democratic governance, where all subjects involved in providing and acquiring the necessary competencies for life will be allowed to have the opportunity of choice and freedom.

Autonomy, freedom, and the ability to choose are the main values that the head of a multidisciplinary institution of extracurricular education should take into account. These ideas are based on the correct statement of Russell Ackoff and Daniel Greenberg about ideal educational institutions. In the book «Transformation of education», the authors pointed out that ideal educational institutions should be autonomous and at the same time have the funding that is necessary for their existence. Only collective decisions and the realities of the environment can impose some restrictions, but self management is the main principle for the development of an institution. In their opinion, education performs two functions - external and internal. The external (instrumental) function, according to Russell Ackoff and Daniel Greenberg, is to encourage and promote the development of students, help them become useful to others and gain independence in society. That is, this function helps to develop the ability to learn what students need to know in order to make a personal contribution to improving the viability of society. The internal function of education is to provide students with the ability to enjoy activities that do not have instrumental value, but meet cultural needs, entertainment and recreation needs, namely: enjoying music, art, literature, games, etc. According to them, getting pleasure from work, pleasure from studying is one of the universal values in the life of a modern person in the post-industrial world [45, p. 15-17]. And all this is true, because the transformation of extracurricular education should begin with activating the process of understanding its actual goals. The goal in institutions of extracurricular education should be in acquiring competencies, the real learning process, and not the teaching process. That is why the focus of attention should be shifted to the very essence of the educational process, that 
is, to include the necessary competencies in the multi-channel process of obtaining information by pupils to formalize the overall picture of the world, create characteristic qualities and humanize personal traits, and so on.

Taking these ideas into account, we emphasize the potential for revealing the universal ideal content of extracurricular education, which, according to the law of Ukraine «About extracurricular education», «is aimed at developing the abilities and talents of pupils, students and listeners, meeting their interests, spiritual requests and needs for professional identification». We emphasize that extracurricular education in Ukraine is part of continuing education, in such institutions scientific knowledge should be provided, «skills according to interests» should be formed, «the needs of the individual for creative self-realization and intellectual, spiritual and physical development» should be provided, as well as preparation «for active professional and social activities» should be carried out, «conditions for social protection and organization of meaningful leisure activities in accordance with the abilities, talents and health status of pupils, students and listeners» should be created. That is, to update the purpose of the activity of a multidisciplinary institution of extracurricular education, such conditions should be created so that each pupil can cover the unity of knowledge that is valuable to him, and each teacher can turn this knowledge into a certain and understandable system that makes up the real world. In this regard, Russell Ackoff and Daniel Greenberg agree that there are two different worlds in which the concept of «education» is used differently. In one - standardization, learning according to the model, and in the other - the transfer of wisdom: «one world consists of schools, colleges and universities that make up our educational complex, in which standardization prevails. In this world, the megastructure of industrial training seeks to produce identical samples of products, which are called «people who were educated for the XXI century». The second world is a world of information, knowledge and wisdom, in which the real population is located, and is not in the prison, as in schools. In this world, learning takes place as always, and teaching consists in transmitting wisdom to free listeners» [45, p. 27]. The process of passing on wisdom to free listeners contradicts existing approaches, where a pupil must thoroughly study the material that 
others have talked about. Control and credit procedures also contradict the real world. So, the material should be firmly memorized and reproduced during the exam without any help, in complete isolation: «schools and universities at each level try to determine, if not measure, how much knowledge students have learned through exams and tests... At the same time, students should work in complete isolation ... And such a scenario is diametrically opposite to what is required of them in the real world» [45, p. 41].

We emphasize that multidisciplinary institutions of extracurricular education have a world of «information, knowledge, wisdom», which is different, in contrast to a regular school, where there is a certain set of competencies that must be obtained as a tool for survival in the world. In our opinion, in multidisciplinary institutions of extracurricular education, other competencies are acquired - transversal, which are necessary for real life. It is important to acquire the ability to use the obtained knowledge together with friends and translate it into specific real situations, and this, in our opinion, should be evaluated and appreciated. And the wider the list of profiles in such an institution, the more opportunities students have for Poly-subject use of new information to make personal growth possible. That is why it is legitimate to say that it is outside the walls of the classroom that education is revealed as what is needed in the real world, and that knowledge, in contrast to instrumental knowledge, is valued much more, because it is obtained for a full life.

In the context of improving the functioning of multidisciplinary institutions of extracurricular education, it is impossible not to touch on the ideas of autocracy and democracy in educational management. Let us point out a sharp criticism of autocracy in the management of educational institutions in many countries. Among the main characteristics that prevent a breakthrough in extracurricular education as a sphere of creating humanity, we can name the following: hierarchy, a clear scheme of control, unlimited power of each level over the level below, finding students at the lowest level of the hierarchy, the lack of regular means of appeal, the publication of rules and instructions without the need for their discussion or approval, and so on. These characteristics hinder the self-realization of subjects of extracurricular education, their full disclosure of spiritual, mental, and social potential. Russell Ackoff and Daniel 
Greenberg were among the first to point out the laws of the autocratic system of Educational Management. They described the results of autocracy in educational management as follows: the entire education system is riddled with resentment and hatred, and at every level a lot of effort is spent breaking or avoiding the rules. Large groups of pupils do not do what is interesting and meaningful, but what is necessary from the point of view of teachers: «the architects of our educational system have obviously forgotten about one big rule of political democracy: laws are created with the consent of those who they will be applied to, the management with the consent of those managed, enjoys respect and a high level of compliance with the rules, which no other system can achieve, even one that is supported by mass terror. The law that you helped create, you would be the last to break» [45, p. 85].

Consequently, the inability to be free in an educational institution, that professes an instrumental approach, devalues the educational process itself. It forces those who are managed to commit violations, since the most important thing is violated - the student's right to a decent choice. In the future, it may lead to a disregard for the values of a democratic society, since, as the authors mention, when the management is carried out autocratically, it «deprives students of the opportunity to learn democracy from their own experience. » It causes further problems in society, because students are «not ready to participate in democratic organizations...» [45, p. 109].

So, educational management in multidisciplinary institutions of extracurricular education should be characterized by the prospect of spreading a democratic system of relationships, which is guided by the value of each person's free choice. Classes in such institutions are held in a completely different way, because students have an opportunity to choose the program, the course that they want to study, which really meets cultural needs, the needs for pleasure and recreation. Students socialize and form themselves as a valuable, autonomous person with positive human qualities without using given patterns.

It is appropriate to improve the educational management of multidisciplinary institutions of extracurricular education by revealing the main elements that will create an ideal educational environment. Let us list the positions that were identified by 
American scientists: the learning process is determined by self-motivation and selfgovernment; all interests have the same status; students' academic performance is determined only by their self-assessment; there is freedom to turn to external assessment; the creation of student groups (classes) based on common interests; there are no artificial differences between students and teachers; all members of the education community take an active part in regulating the learning process and various activities. Individual freedom is the main value in such a learning process, and students should be prepared for activities in a democratic world. The main feature in management is participation, and the value is respect for the rights of everyone: «Rules of conduct, use of property, cost planning, hiring employees, arbitration procedures everything is determined by discussions and decision making in democratic legislative bodies of the school» [45, p. 149].

Russell Ackoff and Daniel Greenberg do not ignore the existing problems of additional education, which should be built on «competency support» programs which take into account the real picture of the world. The authors put forward special requirements for the content of such programs, namely: providing opportunities to discuss, taking into account the cultural environment, constant updating of information, interaction with users of such programs, etc. [45, p.158]. We fully agree with the authors' opinion that over the time there should be more and more of such programs, and this idea gives a certain impetus to the teams of multidisciplinary institutions of extracurricular education in our countries, which today have an incentive to develop the setting up of creative author programs by specialists. These programs should complement instrumental education, using cultural and leisure elements that are interesting for the person himself/herself.

In this context, it is appropriate to distinguish between the roles of heads of institutions of extracurricular education. There is still an opinion in the society as to the difference in the content of the concepts of «leader», «manager», «administrator». Here we get in the work of Russell Ackoff and Daniel Greenberg a clear distinction between the outlined roles of managers, their significant difference. So, to administrators the authors refer those who manage others to achieve goals using some 
means. At the same time, both goals and means are determined by a third party (managing a group of clerks who perform routine tasks such as taking orders, preparing to receive orders, etc.). To managers the authors refer those who manage others to achieve the goals set for them using means. The means are chosen by the manager himself, although many of those who are called managers are actually administrators. The authors deduce the following pattern: the more autocratic an organization is, the fewer managers and more administrators it has. The authors refer to leaders those who lead others to achieve goals using means, and both goals and means are chosen by those who lead the leader, that is, they follow the leader voluntarily. In case when the leader is not followed voluntarily, because of his power and the ability to punish for disobedience, he is considered to be a commander. Leadership, according to Russell Ackoff and Daniel Greenberg, is a practice that cannot be taught. This is a special talent and skill that cannot be taught, but only corrected and allowed to develop [45, p. 129].

Also, according to Russell Ackoff, the management of the social system will be unsuccessful if you use the organizational command and control function of management. And it should change the approach to management itself: «system management is interaction management. It is based on the knowledge that the system is not the sum of the work of its parts, but the product of their interactions with each other and with the external environment. There comes the authority of the leader as the replacement of supervision, orders and teams» [44, p. 437].

Among the main management models used in various organizations, the author attributed reactive (managing by the «parent»), passive (managing crises) and preventive (overcoming problems that may appear due to constant planning of actions that should reach the goal). At the same time, the author promoted a new model of interactive management, which will allow creating the future not by planning actions that will allow somebody to reach the goal, but on the contrary - from the goal of an imaginary ideal to the present. That is why it is very important for a manager, according to Russell Ackoff, to have a projection of the future of the organization: «the projection of the future reveals not only what can happen, but also suggests what can be done to avoid approaching it. This gives the organization the ability to control a significant part 
of its future or at least influence it. If it does not plan the implementation of its future it will become an object of interference from others». [46, p. 107].

To summarize the ideas, we can get a structuring of knowledge for the educational management of a modern multidisciplinary institution of extracurricular education on the following issues: what aspects of the functioning of the institution can be interfered with, what procedures can be reworked or developed again? How can the structure of the institution be improved, and how can the rules used by teachers be improved? These positions, in our opinion, still need to be justified in each situation, according to the specifics of the work of the institution.

In general, a critical analysis of the developments of the new school of scientific management indicates that it is possible to synthesize several rules of educational management in institutions of extracurricular education. So, in a multidisciplinary institution of extracurricular education, the head needs to have specific knowledge of educational management and be able to promote pedagogical activities, motivate teachers to work with students with creative inspiration and try to develop them. In other words, educational management should be built in such a way to make the organization be self-managed and self-regulated. Since teachers have a certain level of education according to their profile, the manager should focus them on improving their knowledge and improving the educational process with students every day. It is also important to manage the interaction of teachers in the institution but not the activities that are created by teachers themselves with students. In other words, the head of a multidisciplinary institution of extracurricular education should manage the interaction of employees in the institution and their interaction with representatives of external organizations.

Planning the activities of teachers should be done, having an imaginary ideal - a model of the future multidisciplinary institution of extracurricular education. This approach will help to reveal new forms and methods of work, new ideas and new directions for development. Such planning includes several positions, namely: the mission declaration, which defines the ideals and goals of a multidisciplinary institution of extracurricular education, which will allow the institution not to survive, 
but to develop and flourish; determining the main properties of the institution, its ideal and unique behavior in society, cultivating participation in the management of the pedagogical process of all subjects (both pupils, their parents and people replacing them, and teachers themselves); creating such a project of the institution, which is considered ideal for expressing creative ideas of both teachers and pupils; creating the fastest possible course of action that can get closer to the ideal project of an educational institution - an institution that is trusted, respected, constantly improving, learning new and progressive things, and so on. For such an institution, it is necessary not only to reform, but also to transform, to show a spirit of autonomy, to be open to ideas, which will allow achieving multidirectional mutual agreement.

Multidisciplinary institutions of extracurricular education will not have the ability to provide high-quality educational services that form transversal competencies if representatives of educational management cannot adapt to the requirements of the XXI century. That is why the management system that actualizes the processes of achieving the ideal should focus on gaining independence, order, and presentation. In our opinion, in the near future, the heads of institutions of extracurricular education will be interested in creating such ideal management models that will allow them to make their own decisions. For this purpose, nowadays in such institutions there are processes of self-organization of professional life, which significantly enriches the experience of creating an original worldview. In our opinion, due to such educational management the future generation will not be limited to instrumental education, but will learn to comprehend, experience and create. 
THEORETICAL FOUNDATIONS OF THE FUNCTIONING OF EDUCATION. WAYS TO

IMPROVE THE EFFECTIVENESS OF EDUCATIONAL ACTIVITIES

DOI 10.46299/ISG.2021.MONO.PED.II-65-74

\subsection{Features of formation of civic competencies of junior schoolchildren in the system of training of future primary school teachers in higher education institutions}

One of the priority areas of work in a modern school is civic education - the process of forming a conscious citizen, a person with such qualities and character traits, worldview and way of thinking, feelings, actions and behavior, which are aimed at developing civil society in Ukraine. Every educator today clearly understands the need to create such an environment in secondary schools, in higher education institutions, where human rights and children's rights would be considered as a pedagogical direction, because students must learn democracy through school experience.

Ensuring the formation of civic competence in the modern content of primary school education is carried out through educational programs that provide four crosscutting content lines - environmental security and sustainable development, civic responsibility, health and safety, entrepreneurship and financial literacy. In particular, the cross-cutting line "Civil Responsibility" ensures the development of social and civic competencies, reveals the essence of the concept of "responsible citizen", defines the vectors of its activities [52, p. 3].

Teachers often have some difficulties in implementing curricula. The difficulty is that we need to develop and use tools to, without overloading children with a huge amount of additional information (because the programs are already saturated), to form in them the skills, attitudes and values needed by citizens, because if we want to form a new citizen, we must understand that this person must not only have knowledge, skills of a general nature, but he must clearly position himself in society, understand what it is, be able to interact in society and be an active member. That is why this industry is very important now. In our opinion, it is leading if we want to achieve not only a new quality of education, but also a new quality of society.

The relevance of this research topic is defined in the Constitution of Ukraine (1996), in the "Recommendations of the European Parliament and the Council of Europe" "On core competencies for lifelong learning" (2016), the Council of Europe Charter on Education for Democratic Citizenship and Human Rights (2017), in the Law 
of Ukraine "On Education" (2017), in the "Concept of Civic Education" (2016), in the Concept "New Ukrainian School" (2016), school curricula. I. Bekh, V. Kuz, O. Zakharenko, V. Sukhomlynsky, O. Sukhomlynska, O. Semenog, G. Shevchenko study the problem of formation of civil responsibility of students, value attitude of the person to language, culture, democracy, the state, civil rights and freedoms, G. Filipchuk and others. [53, p. 30].

To a large extent, the issue of forming the personality of a citizen who adheres to civic duty, is tolerant of other people's opinions, respects national history, culture and the culture of other peoples, takes an active part in social processes relevant to modern primary school. The role of Ukrainian language lessons and reading is important in the formation of civic responsibility, because "it is through language," $\mathrm{T}$. Usatenko rightly remarks, that the self-consciousness and self-awareness of the people themselves as a nation grows; such a nation becomes self-sufficient" [54, p. 3].

Based on the concept of the "New Ukrainian School" and the recommendations of the Council of Europe in the field of education for democratic citizenship and human rights, the reform of the Ukrainian school lays radically new approaches to the educational process.

The State Concept of Civic Education states that the defining feature of a person should be citizenship. Citizenship is a person's willingness to exercise their rights and responsibilities, to respect the rights and freedoms of other citizens, to understand the responsibility to society and the state for their actions. Obviously, this understanding allows us to define it as a psychological trait, a characteristic of personality. Civic competence by researchers is one of the key ones. Therefore, the civic competence of the primary school student, we will understand as a set of educational elements, consisting of a set of knowledge, skills, experiences, emotional and value orientations, personal beliefs that help people realize their place in society, duty and responsibility to compatriots, homeland and state [54, p. 74].

O. Pometun notes that the components of the structure of civic competence of junior students are three components: value (attitude, value orientations, experiences), 
activity (skills) and procedural or personal-creative (concerning the sphere of selfrealization) [53, p. 30].

Each of the components can be represented as an integrated quality of personality. That is, the school should consist not only of knowledge, but of the ability to apply this knowledge in practical situations, for personal and professional development, as well as to apply values that help to navigate in the modern information space. This requires a new content of education, new teaching methods, a new educational environment. Therefore, in the process of learning the Ukrainian language, reading lessons, the development of social and civic competencies can occur through learning at three levels: learning "learning about...", "learning to develop understanding and attitudes", as well as "learning through experience" [55, p. 45].

The formation of civic competence in the modern content of primary school education aims to promote the formation of a system of democratic civic education in Ukraine through the dissemination of European experience, to bring Ukraine closer to the European educational, socio-political, economic and legal space. To bring up a student's civic competence means to form in him a set of personal qualities and character traits, which is the basis of a specific way of thinking and the motivating force of everyday actions, deeds, behavior [52, p. 77].

This is patriotic self-awareness, civic responsibility and courage, readiness to work for the development of the state, to defend it, to raise international prestige. It is respect for parents, their pedigree, traditions and history of the native people, awareness of their independence as its representative, heir and successor. This is discipline, diligence, perseverance, creativity, a sense of caring owner of their land, care for its nature, ecology. These and other qualities and traits are formed in the process of assimilation by junior students of the spiritual heritage of the native people, purposeful national education as a system of ideas, views, beliefs, traditions, customs and other forms of social policy of the Ukrainian people, natural and historical development of material and spiritual culture of the nation. 
Thus, civic education is based on the ideological richness of the people, their moral and ethical values, educational wisdom, which is transformed in their pedagogical experience. In order for children to become a nation, creators of their destiny, it is necessary that during their studies, upbringing in the family, school, they firmly assimilate the history of their state, spirituality, culture of the native people, deeply imbued with its national spirit, way of thinking and living. [50, p. 67].

Formation of communicative competence is one of the main tasks of formation of a person adapted to modern conditions. This competence is formed in terms of direct interaction, so it is the result of communication experience.

To form the communicative competence of junior schoolchildren in practical classes on the methods of teaching the Ukrainian language for primary school students, higher education students were offered different types of speech activities: listening, writing, speaking, reading. Developed the ability to conduct a proper educational dialogue. They practiced dialogic expressions of different nature: dialogue-exchange of ideas, dialogue-questioning, dialogue-motivation, dialogue of etiquette character. We consider situational tasks that were used in a certain sequence taking into account the topic, content, stage of the lesson, and class readiness to be an effective means of forming communicative competence.

The program material of Ukrainian language lessons in 4th grades, during which the requirements of the school curriculum provide for the teaching of syntax on the basis of personality-oriented, activity and competence approaches, allowed to more successfully form behavioral norms in junior students to solve life problems; ability to convincingly express one's own opinion, to lead a reasoned controversy; respond by language to a range of social and cultural phenomena, prevent and resolve conflicts, reach compromises; to adapt to new conditions, to solve non-standard problems; work in a group, in a team.

Among the main tasks were: creating an emotionally comfortable learning environment for literacy, developing the ability of each individual to realize responsibility for their learning, the need to acquire the program knowledge, skills and abilities that were important for forming a communicatively competent person. 
For example, some components of civil responsibility are presented in Volodymyr Monomakh's "Teaching Children", which emphasizes obedience to the law: "do not be jealous of those who commit lawlessness, because the villains will be exterminated" and in the works of Feofan Prokopovich, who argued that respect for the state it is important to use the Word of God, "because when the state is weak, and therefore the law, then there is another law hidden deep in the heart of man" to love and fear God, to save his life - not to do to others what you do not want, to honor your father and his mother" [53, p. 134].

Ukrainian philosopher, poet, pedagogue and educator Hryhoriy Skovoroda and Taras Shevchenko defended the ideas of democracy, freedom, philanthropy and charity, patriotism. He defined the freedom, liberty and independence of Ukraine as the highest value: Great ruin, unravel, fraternize, do not look for in another's land, do not ask what is not in heaven, and not only in another's field. In his house his truth, and strength, and will" [54, p. 234].

Analyzing the curriculum in the Ukrainian language for primary school (textbooks M. Bilchuk, A. Savchuk, G. Sapun), we stated that much attention was paid to the content line "Civil Responsibility". In particular, it is planned to study the following topics in the lessons: Ukraine is a European state; Ukrainian language and problems of bilingualism in Ukraine, multilingualism; history and modernity lessons; the earth is our common home; Ukrainian ideal: traditional and modern understanding; friendship, love, family, intergenerational relationships, culture. For example, the topic "Language is the most important means of communication, cognition and influence" was aimed at teaching younger students to understand and respect human rights and freedoms, to be able to explain their position on human rights, to realize that human rights are the basis for everyone to live with dignity. find ways to solve socially important issues, the ability to argue and competently express their own opinions.

For the 4th grade, more global issues were proposed for consideration, including: Ukraine on the world map; Constitution of Ukraine, language rights and responsibilities of citizens; history pages. For example, while studying the topic "Text as a unit of speech and a product of speech activity" they had to learn to show interest 
in the promotion of human rights, to express judgments about people in need of special protection. Exercises and tasks were characterized by traditional categories (history of the Ukrainian people and the formation of its statehood; language as a characteristic feature of self-identification of Ukrainian society; customs and traditions as an integral part of the nation's identity; love for the native land through the prism of art; Ukraine through prominent figures; symbols of the Ukrainian people - its national sign), and taking into account the requirements of the Concept "New Ukrainian School".

As the analysis shows, the texts for exercises and tasks in the category "History of the Ukrainian people and the formation of its statehood" in textbooks for 4th grade (O. Davydova, O. Danylko) are based on information about the history of Ukrainian society, historical stages of Ukrainian national identity. Such tasks were quite relevant, they contributed to the understanding of younger students of the history of their people, the origins of Ukrainian statehood and the formation of an independent conciliar Ukraine.

The category "Language as a characteristic feature of self-identification of Ukrainian society" contained exercises and tasks, which revealed the meaning of the Ukrainian language in a broad and narrow sense; the place of the native language in the life of society, the means of its enrichment and preservation for further development. The exercises presented in the textbook formed in students admiration for the beauty of the native language, its melodiousness, the breadth of use of artistic means in the text.

The category "Love for the native land through the prism of artistic creativity", as evidenced by the analysis of textbooks M. Bilchuk, O. Danylko contains samples of texts of artistic creativity (Song of Baida), journalism (excerpt from the works of V. Sukhomlinsky), in which the beauty of the native land reveals love for the native land, a sense of civic duty to their state, respect, respect for their homeland.

The category "Ukraine through the eyes of prominent figures" includes texts about famous historical figures of our country: writers, public figures, artists, sculptors, musicians and more. Textbooks A. Savchuk, G. Sapun for 4th grade contain exercises based on work with a journalistic text (for example, a text about Taras Shevchenko). 
The category "Symbols of the Ukrainian people - its national sign" is presented, in particular, in the textbook by S. Yermolenko, V. Sychova with texts about the national flag and coat of arms, bird symbols (swallow as a symbol of prosperity and happiness). Thus, textbooks on Ukrainian language and reading for primary school generally contain a source base for learning about the Ukrainian language as the state language of the Ukrainian people, a defining feature of our state, a treasury of cultural heritage of the nation and humanity, a means of interpersonal and interethnic communication, state symbols and values; cultural and spiritual values of Ukrainian and other peoples, the essence of civil society, democracy, rights, freedoms and responsibilities of man and citizen.

We believe that the primary school has ample opportunities for civic education of students. Civic education should be at the heart of all school activities, both in the learning process and in extracurricular activities.

Extracurricular activities are less regulated than educational activities, which makes it possible to vary its content, organizational forms and methods. We note that in extracurricular educational work effective forms of civic education. Its effectiveness depends primarily on the actual recognition by teachers of the student's personality as the main goal of education, the most important priority, the greatest primary school students are: educational hours; historical window; traditional and family holidays; dictionary box; folk wreath; grandmother's tale; Cossack entertainment; quizzes; competitions of national dishes, songs, dances, clothes; competitions of drawings, products from a natural material; club classes; educational and cognitive excursions to the regional museum of local lore, etc.

In the course of the research it was determined that one of the effective means of civic education of junior schoolchildren is local lore work. According to the practice of primary school, direct acquaintance of junior schoolchildren with historical and memorable places of the native land, with its nature, outstanding people, participation of schoolchildren in campaigns and excursions, collection and registration of materials about heroes and their feats, meetings with veterans, discussion books about significant historical events - all this contributes to the education of citizenship of primary school 
children. Thus, it is through local lore that the systemic ideas of junior schoolchildren about their native land, historical and cultural environment are formed.

Homeland studies begins with local lore - historical, ethnographic, geographical, folklore, literary. Taking an active part in the multifaceted local lore work, children from early school age join the heroics of past eras, labor exploits, deeds and artistic traditions of grandparents and great-grandparents.

Complex comprehensive local lore work allows to study and holistically perceive the national color of the native land: the original way of life of Ukrainians, their style of behavior, original way of thinking, art, national psychology, etc. Local lore activities create conditions for students to deeply master the regional features of national life (ethnographic, folklore, language, etc.). Due to this, younger students are deeply aware of themselves as part of the people, they cultivate a love for their home village, city, and region.

Prominent figures, famous people who are patriotic, able to overcome life's difficulties and go to their own goal - become a model for students to develop their own life strategies.

K.D. Ushinsky in his works, defines that true love for the Motherland must be combined with knowledge of language, art, the best traditions and customs of the people [51].

The native language is the best expression of the spiritual culture of the Ukrainian people. The child, mastering the language of his parents, joins the native culture, by means of which the "root of spirituality" is formed. [52] In the article "Native word" Ushinsky wrote about the importance of the native language: blooms again, the color of his whole spiritual life, which begins far beyond history. The language inspires the whole nation and its entire homeland "[51].

S. Rusova noted: "All education - should be national, grow on the native land, among the native language" [52].

Therefore, an important component of the content of civic education is love and respect for the native Ukrainian language, understanding the need for perfect command of the state language. 
The foundations of patriotism and a sense of national belonging and consciousness are laid in the family. The interaction of educational influences of the family and the school is important. Therefore, we note that it is necessary to constantly maintain close ties with parents, to involve parents in the school life of children. Creative cooperation of parents, children and teachers has a positive effect on the formation of the class team, the education of students in humanity, respect for elders, a friendly attitude to peers. The purpose of the article is to form a person with a deep sense of their roots, family, family, people; in the development of the best mental traits of the child, in the awakening of interest and instilling a deep love for the native language, literature, history, respect for the symbols, traditions and customs of Ukrainians.

Thus, civic education in the modern educational process of primary school is extremely important. The full formation of the personality of a junior schoolchild cannot be positively realized without a civic basis. Today it is more important than ever to direct children to choose civic - national ideals and value orientations in their lives. Comprehensive education of the growing personality in our time does not make sense without the civic component.

Conclusions. Our time is a time of radical changes in society. Right now Ukraine needs citizens who are able to make non-standard decisions, to solve various problems; citizens with well-developed critical thinking, who know how to work creatively. Therefore, we consider it necessary to form the social competence of primary school students in Ukrainian language and reading lessons. And given that the influence of the teacher's personality on the formation of students' life competence is special, we clearly understand that the teacher must work effectively, improve professionally and grow creatively, because the teacher is not only the one who teaches all his life, but also the one who learns all his life.

In this context, the use of material on patriotic self-awareness, civic responsibility in the educational process of a modern institution of higher pedagogical education in practical classes on the methodology of the Ukrainian language and reading in primary school is considered quite effective, as it involves research activities of higher 
education students. development of creativity, initiative, critical thinking, independence, self-control, personalization of learning, prevents and helps to overcome the alienation of students from the educational process, helps to build their individual educational trajectories in the educational space. 
DOI 10.46299/ISG.2021.MONO.PED.II-75-80

\section{7 Основні шляхи попередження наркоманії серед підлітків та молоді засобами фізичної культури й спорту}

Поширення наркоманії в Україні прийняло катастрофічні розміри і набуло рис соціального лиха, що загрожує національній безпеці країни [57, с. 3, с. 16]. Це явище надає вкрай негативний вплив на соціально-психологічну атмосферу суспільства, економіку, політику, правопорядок, здоров'я нації і входить практично у всі сфери життєдіяльності особистості і держави [69, с. 15].

Світовий і вітчизняний досвід показує, що засоби фізичної культури і спорту володіють універсальної здатністю вирішувати проблеми підвищення здоров'я населення, виховання та освіти молодих людей, формувати здоровий моральнопсихологічний клімат у суспільстві [64, с. 10].

Розумінню того, що майбутнє країни неможливо без здорових фізично і духовно розвинених членів суспільства, сприяє посиленню ролі фізичної культури і спорту в діяльності по зміцненню держави [73, с. 20]. Величезний соціальний потенціал фізичної культури і спорту необхідно використовувати в профілактиці наркоманії, оскільки це найменш витратний i найрезультативніший важіль морального i фізичного оздоровлення підростаючого покоління [58, с. 6].

Мета дослідження - намітити шляхи попередження наркоманії серед підлітків та молоді в процесі занять руховою активністю.

На сьогоднішній день в Україні спостерігається стійка тенденція до значного зростання споживання алкогольних напоїв, наркотичних та токсичних речовин. Темпи зростання наркотизації українського суспільства, пов’язаної 3 наркотиками, справедливо розглядаються як одна з реальних загроз національної безпеки країни [67, с. 19].

За останні п’ять років кількість споживачів наркотиків зросла більш ніж у три рази. Розширення внутрішньовенного введення наркотиків призводить до швидкого поширення ВІЛ-інфекції та інших важких захворювань. За швидкими темпами росте смертність від вживання наркотиків. Так, кількість смертей серед 
THEORETICAL FOUNDATIONS OF THE FUNCTIONING OF EDUCATION. WAYS TO

IMPROVE THE EFFECTIVENESS OF EDUCATIONAL ACTIVITIES

осіб, що склалися на наркологічному обліку, зросла за останні 5 років на 31 \%, в тому числі від передозування - на 47 \% [60].

Очевидний зв’язок росту соціально-економічних проблем, зловживання алкоголем, наркотиками та злочинності неповнолітніх. В стані сп'яніння підлітки виконують 50 \% всіх правопорушень. Основний вік першого знакомства 3 наркотиками - 11-14 років (41 \%) і 15-18 років (51\%). До підліткового віку понад 10 \% учнів вже спробували наркотичні засоби.

В умовах, що склалися роль фізичної культури i спорту (ФКС) як ефективного засобу профілактики наркоманії постійно зростає. Водночас, за даними соціологічних досліджень [68, с. 18], більше 3 млн. дітей відсторонені в школах від занять фізичною культурою. Із загальної кількості школярів в спортивних секціях займаються дещо більше 20 відсотків.

За результатами анкетування виявлено, що до основних причин, що стримує використання ФКС в профілактиці наркоманії, слід віднести: відсутність належного фінансування; брак спортивних баз; недооцінювання можливостей спортивної діяльності з боку держструктур поза сферою ФКС; недолік інформації і пропаганди здорового способу життя; зниження внеску наукових і освітніх установ в розвиток спорту і перепідготовку фахівців; відсутність цілеспрямованої роботи 3 фізичного виховання, особливо в дошкільних установах; низькі темпи розвитку клубної системи занять ФКС з урахуванням потреб і можливостей населення; нестача кваліфікованих кадрів і низький рівень їх матеріального забезпечення.

Можливими передумовами початку вживання наркотиків можуть бути як соціальні причини: неблагополучна сім'я, відсутність реальної програми дозвілля, зайнятості неповнолітніх, так і індівідульно-психологічні чинники: наслідування старшим або авторитетним одноліткам, спроба нейтралізувати негативні емоції, аномальні риси особистості, цікавість, підпорядкування тиску і загрозам.

Шляхи профілактики наркоманії повинні складатися 3 трьох взаємопов’язаних блоків: психолого-педагогічної діагностики особливостей 
THEORETICAL FOUNDATIONS OF THE FUNCTIONING OF EDUCATION. WAYS TO

IMPROVE THE EFFECTIVENESS OF EDUCATIONAL ACTIVITIES

особистості; засобів і методів формування інтересу до систематичних занять ФКС; диференційованого застосування ФКС для корекції психоемоційного стану, підвищення рівня рухових здібностей і функціонального стану організму.

Вивчення особистісних особливостей вимагає підбору методик, що дозволяють не тільки вивчити особистісні особливості індивіда, але й встановити причини девіантної, асоціальної поведінки. Підбір діагностичних методик повинен передбачати вивчення: особливостей поведінки підлітків, їх здібностей, самопочуття, ставлення до навчання, стосунків у сім'ї, потреб та інтересів (в тому числі i негативних), фізичного розвитку i фізичної підготовленості, ставлення до фізкультурно-спортивної діяльності і пріоритетним видам цього роду занять.

Методика фізичного виховання 3 педагогічно запущеними підлітками i схильними до вживання психоактивних речовин має свої специфічні особливості, так як, поряд із завданнями оздоровлення організму і підвищення моторного потенціалу, вирішуються завдання корекції психоемоційного стану та моральної сфери особистості [61, с. 9, с. 14].

Важливим етапом профілактичної роботи слід вважати залучення дітей і підлітків до занять спортом, враховуючи мотиви початку занять в секції, ведучі та лімітуючі ланки в структурі різних сторін підготовленості [63].

В ході навчально-виховного та навчально-тренувального процесів підбір засобів і методів тренувань необхідно здійснювати виходячи з інтересів і потреб підлітків, застосовуючи диференційований підхід при формуванні групи дітей, які займаються: навчальний матеріал повинен бути зрозумілий i доступний підліткам, але засвоювати його вони повинні з певним зусиллям, оскільки в іншому випадку процес навчання втрачає свою привабливість; ускладнення вправ, збільшення навантаження здійснюються поступово, у міру формування інтересу до занять і підвищення рівня підготовленості; своєчасно застосовувати методи примусу, покарання, заохочення; в процесі занять необхідно здійснювати контроль за виконанням завдань тренера, стежити за дисципліною, зовнішнім виглядом, відвідуваністю уроків. 
THEORETICAL FOUNDATIONS OF THE FUNCTIONING OF EDUCATION. WAYS TO

IMPROVE THE EFFECTIVENESS OF EDUCATIONAL ACTIVITIES

Важливе значення в навчально-виховному i навчально-тренувальному процесі, спрямованому на профілактику прийому наркотичних речовин, відводиться корекції психоемоційного стану дітей і підлітків, при використанні наступних методичних прийомів: створення педагогічних умов, в яких важкі підлітки могли б діяти впевнено, без зайвого напруження і страху (полегшені умови виконання вправ); при невпевненості учня мати кілька варіантів виконання завдання, заохочуючи їх за працьовитість, самостійність і т.п.; надання агресивним підліткам провідних ролей при проведенні естафет, здачі нормативів, показі вправи, тестуванні; здобуття максимальної користі 3 невдалого виконання вправи агресивними підлітками; проведення групових бесід, які акцентують увагу на позитивних сторонах діяльності учнів; підтримувати ініціативу, самостійність і взаємодопомогу при освоєнні нових рухових навичок.

Основними засобами залучення дітей і підлітків в фізкультурно-спортивну діяльність є: на початковому (спонукальному) етапі - бесіди, переконання, перегляд відеофільмів, змагань, ознайомлення 3 особливостями i характеристиками видів спорту; на етапі формування стійкого інтересу до ФКС - бесіди, переконання, контроль за відвідуванням занять, успішністю в школі, дисципліною, виконанням доручень тренера-вчителя, участь в змаганнях і їх суддівстві; на етапі інтересу, який стійко сформувався до занять фізичною культурою або виду спорту - контроль тренера i педагогів за діяльністю підлітків, заохочення, нагородження, участь в змаганнях, клопотання про зняття з обліку в органах поліції.

Будь-які завдання профілактики наркоманії засобами ФКС вирішуються тренером-педагогом спільно 3 психологами, вчителями, працівниками соціальних служб і правоохоронних органів, керівництвом установ. Шляхи профілактики наркоманії серед молоді засобами ФКС повинні спиратися на Державну концепцію розвитку фізичної культури i спорту, що передбачає шляхи, засоби і методи «формування у населення стійкого інтересу і потреби в 
THEORETICAL FOUNDATIONS OF THE FUNCTIONING OF EDUCATION. WAYS TO IMPROVE THE EFFECTIVENESS OF EDUCATIONAL ACTIVITIES

регулярних заняттях фізичної культури і спортом, навичок здорового способу життя, моди на спорт, особливо серед підростаючого покоління».

Серед першочергових завдань профілактики наркоманії засобами фізичної культури і спорту слід розглядати: підвищення відповідальності батьків за здоров’я дітей і рівня їх освіти в галузі ФКС; наділення належним статусом системи фізичного виховання в дитячих садах і яслах; фізична культура як освітня галузь і навчальний предмет має бути включена в план усіх освітніх установ; обсяг рухової активності на всіх вікових етапах повинен становити не менше 6-8 годин на тиждень.

Механізм реалізації фізичного виховання і спорту повинен здійснюватися через: визначені форми занять в освітніх установах, починаючи 3 ясел i закінчуючи вузами; додаткові, позаурочні форми занять в сім’і, секціях, спортивних клубах; спортивно-масові та фізкультурно-оздоровчі заходи (туризм, спартакіади школярів).

Слід розвивати систему пропаганди ФКС через засоби масової інформації, i особливо телебачення, оскільки для більшості дітей і підлітків саме телебачення є основним джерелом інформації. Доцільно збільшити час, що відводиться на демонстрацію уроків з розвитку сили, витривалості, спритності, які повинні проводити відомі спортсмени та тренери.

Проведене нами дослідження підтверджує та доповнює численні результати [58, с. 9 , с. 11 , с. 18$]$ спеціальної літератури. Чому ми розглядаємо в одній зв'язці наркоманію та фізичну культуру і спорт? Тому що між ними є органічний зв’язок, але зв'язок зворотний. Там, де володарюють фізична культура і спорт, наркоманії привитися не так легко. Наркоманія формуються не тільки через недостатнє морально-етичне виховання, але дуже часто i як наслідок занедбаності фізкультурно-оздоровчої роботи, однієї з основних складових здорового способу життя [61, с. 12].

Наші результати підтверджують дані інших досліджень [69, с. 16]: специфіка фізичної культури й спорту - комплексна дія на особистість, яка включає зміну поведінки (великі фізичні навантаження істотно змінюють 
психоемоційну сферу), задоволення природних потреб в самоутвердженні, самореалізації. На відміну від всіх інших форм дозвільної діяльності, спорт, крім інтелектуальної і психоемоційної, має і фізичну складову і тим самим є більш сильним засобом дії на молодий організм. Фізичні навантаження, які надають формуючу дію на різні системи організму, задовольняють і природну потребу молодої людини в русі. В цьому відношенні спортивна діяльність може розглядатися як альтернатива наркоманії, яка пропонує замість ілюзорного вирішення проблем особистого становлення реальний шлях формування сильної і здорової особистості.

Узагальнення результатів дослідження підтвердило [64], що багатий досвід i яскраві зразки фізкультурно-оздоровчої та спортивно-масової діяльності свідчать про широкі можливості виховання таких психологічних якостей i особливостей підлітків і молоді, які здатні забезпечити стійке негативне відношення до асоціальної поведінки. Різноманітність видів спорту, форм організації занять, спектру фізкультурних інтересів дозволяє вирішувати не тільки специфічні задачі фізичного виховання, але й задачі соціалізації особистості, що особливо важливо при формуванні надійних і стійких позицій у відношенні до нетипової поведінки [70].

Таким чином, впровадження основних шляхів попередження наркоманії в навчально-виховний та тренувальний процеси повинен сприяти значному збільшенню кількості дітей, підлітків та молоді, регулярно займаються фізичною культурою i спортом, як ефективними засобами запобігання подальшого зростання наркоманії серед даної категорії населення. 
THEORETICAL FOUNDATIONS OF THE FUNCTIONING OF EDUCATION. WAYS TO IMPROVE THE EFFECTIVENESS OF EDUCATIONAL ACTIVITIES

DOI 10.46299/ISG.2021.MONO.PED.II-81-89

\section{8 Професійна підготовка майбутніх спеціалістів в технічному університеті: основні завдання}

Економічні та соціальні зміни, які мають місце в нашій країні, пред’являють до майбутніх фахівців високі вимоги, тому зростає відповідальність закладів вищої освіти за якість професійної підготовки. Освітнім установам надаються повноваження при визначенні стратегії розвитку, концепцій, організаційних методів роботи в навчанні студентів, а це додаткова відповідальність за результати своєї освітньої діяльності. Таким чином навчальні заклади стоять перед необхідністю розробки програм, які б гарантували досягнення поставлених цілей в освітньому процесі.

Необхідною є підготовка професіоналів, яка відповідає вимогам галузевих ринків та важливим є формування особистості, здатної вирішувати проблеми, планувати та реалізовувати плани. Розвиток суспільства i, як наслідок, зміна структури промисловості в Україні ставить перед вчорашніми школярами нелегкий вибір - вибір спеціальності. Як слушно помітив А. Адлер професійна діяльність (так як дружба і любов) є найкращою цінністю людини. В той же час I. Бех зауважив, що найбільш чутливий до соціальних, економічних, політичних та моральних перетворень є вік юності [78, с. 245].

Відомий американський психолог Е. Еріксон, аналізуючи 8 етапний життєвий цикл людини, багато уваги приділив кризі ідентичності особистості саме в юнацькому віці (11 - 20 років). Під ідентичністю вчений розумів процес психічної діяльності, завдяки якій людина оцінює себе 3 точки зору оцінок іï іншими, особливо групами однолітків; це пошук свого власного "Я", серія соціальних та індивідуально-особистісних виборів, ідентифікація та самовизначення. Для молодої людини не просто проаналізувати та узагальнити все, що вона знає про себе та об’єднати ці знання в ідентичність своєї особистості, яка дає можливість усвідомити своє минуле і майбутнє, яке логічно випливає з нього. Процес формування особистості в студентському віці трьохкомпонентний: внутрішній план (молода людина сама створює свій імідж), зовнішній план (інші значущі люди бачать ідентичність та цілісність 
THEORETICAL FOUNDATIONS OF THE FUNCTIONING OF EDUCATION. WAYS TO IMPROVE THE EFFECTIVENESS OF EDUCATIONAL ACTIVITIES

особистості), узгодженість внутрішніх та зовнішніх планів. Розмитість ідеалів характеризується повним або частковим несприйняттям цінностей, світогляду та ідеології сім’ї та інших авторитетів молодою людиною. На формування ідентичності іноді негативно впливають соціальні групи 3 якими людина ідентифікує себе (зірки шоу бізнесу, відомі спортсмени, політичні діячі), оскільки нівелюється унікальність особистості і таким чином обмежується формування їі ідентичності.

Нездатність молодих людей до формування їхньої ідентичності - криза ідентичності - призводить до проблем 3 вибором кар'єри, продовженням навчання, виникає відчуття власного незадоволення, душевного розладу i безцільності. Іноді молоді люди мають негативну ідентичність - вони не хочуть дотримуватись норм свого суспільства і однолітків та обирають негативні моделі поведінки для наслідування. Успішний вихід 3 кризи періоду юності характеризується вірністю, яка розуміється як здатність молодої людини бути вірним своїм прихильностям і обіцянкам, незважаючи на неминучі протиріччя в ii системі цінностей (Е. Еріксон). Вірність - наріжний камінь ідентичності, здатність молоді приймати і дотримуватися моралі, етики та цінностей суспільства [83].

Неабияке значення в студентському віці має здатність до побудови особистісних перспектив - спрогнозувати та уявити своє майбутнє усвідомлюючи всі труднощі та проблеми на шляху по досягненню бажаного результату і готовність подолати всі перешкоди до поставленої мети. К. Абульханова-Славская підкреслює, що особистісна перспектива є показником зрілості людини та їі здатності організувати час [77, с. 24].

Формування поглядів студентів залежить від виховання, переконань та набутих знань, але життєві позиції можуть змінюватись, тому правильний вибір професії є основною умовою успішної кар'єри. Успішною професійна кар’єра буде лише у тому випадку, якщо студент не просто знає чого хоче, але й навіщо це йому, як досягнути мети та буде спрямувати активні дії в досягненні успіху в професійній діяльності. 
Аналізуючи власні здібності та уподобання абітурієнт не схильний до технічних наук не вибере IT- спеціальність, і в свою чергу, випускник школи, який захоплювався математикою та інформатикою, навряд чи буде поступати в університет на історичний чи юридичний факультет. На вибір університету та спеціальності впливає багато чинників. Згідно з опитуванням, проведеним О. Кучерук серед студентів та викладачів факультету прикладної математики та комп'ютерних технологій Хмельницького національного університету на питання « Які фактори найбільше вплинули в свій час на Ваш вибір професії?» були отримані результати, представлені на рисунку $1[81$, с.65].

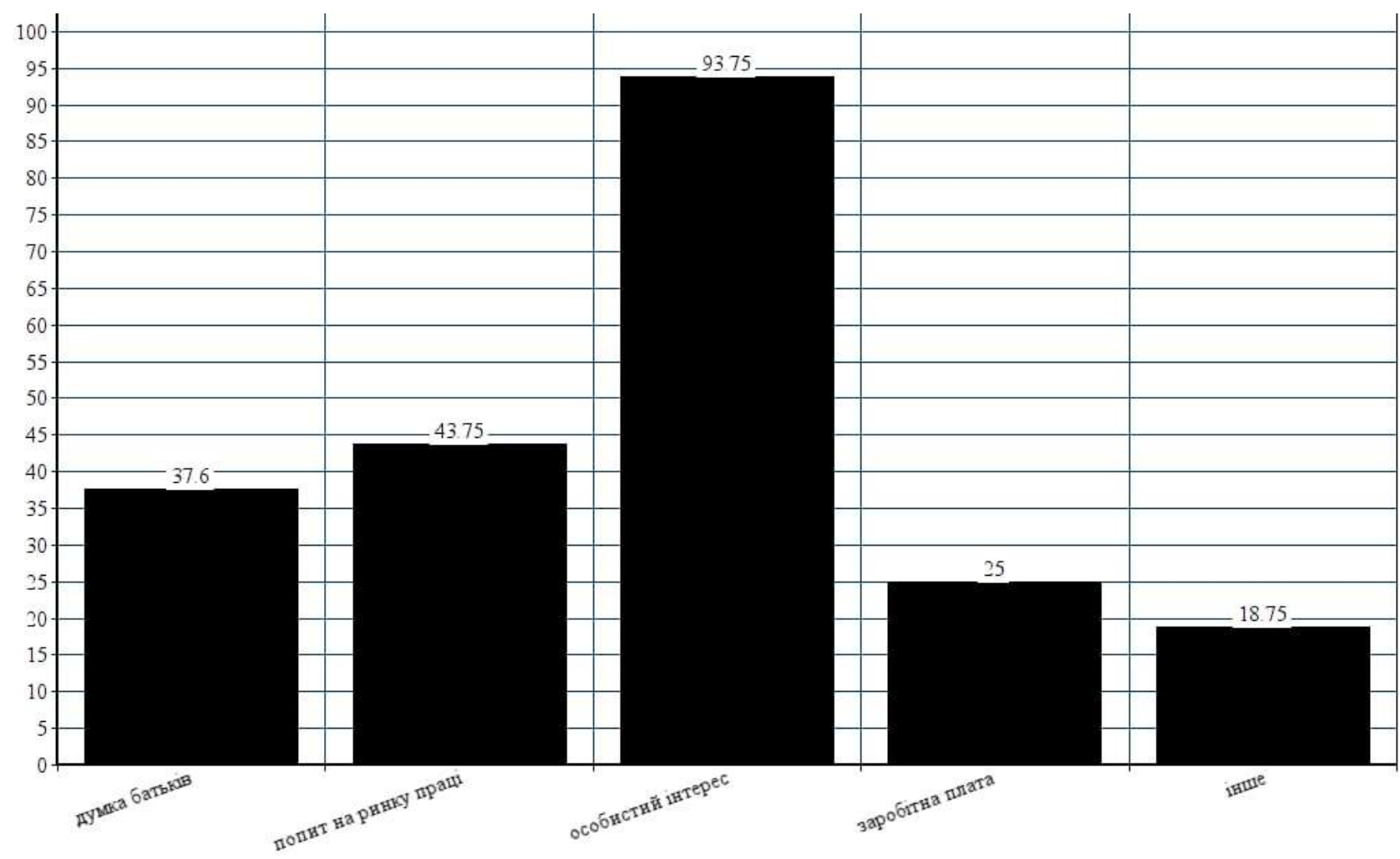

Рис.1 Фактори, які впливають на вибір професії.

Вчена Ю. Корницька в рамках свого дослідження опитала студентів чотирьох технічних університетів різних міст України (Києва, Одеси, Донецька та Черкас) з чим у них асоціюється успіх. Відповіді студентів з усіх вишів були однакові: на перше місце було поставлено матеріальне забезпечення, потім кар'єра, далі - набуття влади, потім: громадське визнання, особисті досягнення, висока кваліфікація. На останньому місці була творча самореалізація [79, с.151.]. 
THEORETICAL FOUNDATIONS OF THE FUNCTIONING OF EDUCATION. WAYS TO

IMPROVE THE EFFECTIVENESS OF EDUCATIONAL ACTIVITIES

Однак аналізуючи питання виховання студентів I. Бех писав, що професійну діяльність треба розглядати як пошук покликання, життєвого призначення та особистої самореалізації, а не як невідворотний тягар життя [ 78, с. 245].

Таким чином, перше завдання вищої освіти - виховати професіонала, який в своїй діяльності буде бачити шляхи самореалізації, а не шляхи заробітку чи збагачення.

У 2018 році серед студентів 4 курсу факультету прикладної математики НТУУ «КПІ ім. Ігоря Сікорського» спеціальностей: «Комп’ютерна та системна інженерія», «Програмна інженерія», «Інженерія програмного забезпечення» було проведене опитування. На запитання «Визначте до чого Ви прагнете в своїй майбутній професійній діяльності» були запропоновані наступні відповіді: матеріальне забезпечення, повага оточуючих, самореалізація, професійне зростання, кар'єра.

В результаті 69\% респондентів надали перевагу самореалізації, а не матеріальному забезпеченню. Ми вбачаємо в цьому свідоме ставлення до майбутньої професії та деякий вже існуючий досвід професійної діяльності. Студенти усвідомлюють, що одноманітна рутинна робота не зможе задовольнити їх потреби в постійному саморозвитку. Тільки займаючись цікавою та складною справою майбутні спеціалісти зможуть підвищити свій професійний рівень та як результат отримати матеріальну винагороду.

В той же час, по матеріалам досліджень Г. Міхненко, 78\% опитаних нею студентів НТУУ «КПІ ім. Ігоря Сікорського» вважають, що в результаті навчання вони отримують те, до чого прагнули, вступаючи до вишу, але наряду 3 цим 46\% опитаних студентів вважають, що головне - це отримати диплом, а оцінки і рівень знань не мають значення [82, с. 48]. На нашу думку, зі студентами, які не розуміють цінності знань та навичок набутих під час навчання має проводитись виховна та роз'яснювальна робота. Оскільки конкуренція на ринку праці дуже жорстока, то наявність диплома без грунтовних знань не забезпечить людину роботою по спеціальності. Студентські роки - безцінний час для 
THEORETICAL FOUNDATIONS OF THE FUNCTIONING OF EDUCATION. WAYS TO

IMPROVE THE EFFECTIVENESS OF EDUCATIONAL ACTIVITIES

ефективної акумуляції знань з їх подальшим застосуванням під керівництвом викладачів.

До речі, дослідниця Т. Котмакова наводить дані, що на запитання: “Чи пов’язана Ваша майбутня спеціальність з творчою діяльністю” більш ніж 75\% опитаних нею студентів відповіли заперечно, а на запитання: “Ви творча людина?” ствердно відповіли лише $36 \%$ опитаних студентів [80, с. 116].

Ми в 2020 задали студентам факультету прикладної математики НТУУ «КПІ ім. Ігоря Сікорського» схоже запитання: «Чи стикаєтесь Ви під час навчання з завданнями, які потребують творчого підходу? Наведіть приклади.» В результаті 97\% студентів вважають, що творчий підхід необхідний не тільки для гуманітарних а і для технічних предметів - розрахункові, курсові та лабораторні роботи потребують нестандартного підходу та творчого мислення.

В той же час Г. Міхненко наводить, у своїй роботі [82, с. 62.], перелік загальних та професійних компетентностей студентів НТУУ «КПІ ім. Ігоря Сікорського» спеціальності “Електромеханічні системи автоматизації та електропривод”, де на рівні з вимогами відносно теоретичних та технічних знань та знань технічного обладнання, окремо зазначена здатність до ділових комунікацій та ділового спілкування. Таким чином, другим завданням вишу є навчання студентів діловому спілкуванню.

Навчатися діловому спілкуванню означає, що ваші дії повинні відповідати встановленим діловим регламентом правилам і обмеженням, які визначаються різними факторами, ступенем офіційності ситуації, яка обумовлює дотримання певних правил спілкування. Для майбутніх фахівців важливо володіти культурою ділового спілкування, яка сприяє встановленню і розвитку відносин співробітництва між колегами, керівниками i підлеглими, партнерами i конкурентами. Для успішного вирішення завдань, що стоять перед співробітниками, визначається спрямованість ділового спілкування на забезпечення умов для плідної співпраці. На дотримання правил впливають також національні та культурні особливості учасників, а також цілі і завдання конкретної зустрічі, бесіди, презентації, конференції. Отже, варто проводити 
THEORETICAL FOUNDATIONS OF THE FUNCTIONING OF EDUCATION. WAYS TO

IMPROVE THE EFFECTIVENESS OF EDUCATIONAL ACTIVITIES

навчання ділового спілкування в певних формах (ділова розмова, ділове обговорення, ділові переговори) з використанням ділового етикету та етикетних мовних зворотів. Кожній ролі учасників спілкування відповідають певні завдання, які необхідно враховувати і вести себе відповідно до вимог, що пред'являються конкретною обстановкою, щоб спілкування було ефективним, воно повинно базуватись на правилах, які сприяють розвитку співпраці.

У зв’язку з глобалізацією світової економіки та ринку праці постає нагальна потреба у володінні іноземною мовою. Визначимо трете завдання: навчання студентів іноземної мови на новому рівні, як інструменту без якого спеціаліст не може виконувати свої професійні функції.

В багатьох сферах життя відбуваються суттєві зміни 3 розвитком та вдосконаленням технологій, дізнатись про які першим можна володіючи англійською мовою - мовою інтернаціонального спілкування. Вся наукова спільнота обмінюється думками та відкриттями на сторінках англомовних наукових видань. Отже для того, щоб бути обізнаним з останніми здобутками видатних вчених в певній сфері та самому представляти свої ідеї та відкриття на світовому ринку молодому спеціалісту необхідно вільно володіти іноземною мовою.

На українському ринку працює багато компаній з іноземним капіталом, співбесіда на стажування в які відбувається іноземною мовою. Тобто володіння іноземною мовою із додаткової позитивної якості кандидата на посаду перетворюється на обов’язкову вимогу.

Четверте завдання - створити впевнену в собі, ініціативну людину, яка здатна буде навчатись все життя i, при потребі, змінити не лише місце роботи, а й спеціальність. А для того потрібно аби вона навчалась із задоволенням i відчувала викладача не як вчителя з японських фільмів, а як доброго старшого наставника 3 американських. Тобто кожен студент має відчувати себе в університеті комфортно, знаходячись в атмосфері доброзичливості та допомоги - ідеальному середовищі для саморозвитку та самовдосконалення. 
THEORETICAL FOUNDATIONS OF THE FUNCTIONING OF EDUCATION. WAYS TO

IMPROVE THE EFFECTIVENESS OF EDUCATIONAL ACTIVITIES

Для викладача така позиція “старшого товариша” та радника складніша, ніж позиція “фельдфебеля”, якому всі повинні підкорятися, якого треба боятися бо він може поставити низький бал, чи взагалі не поставити жодного. “Старший товариш" собі такого дозволити не може, бо студенти не підлеглі, а «колеги», i кожного треба зацікавити своїм предметом, провести заняття так, аби не було монологу, аби всі присутні приймали активну участь у занятті. Ми цілком згодні 3 думкою Ю. Корницької, щодо необхідності “демократизації учасників педагогічного процесу”[79]. Цю ідею розвиває Г. Міхненко підкреслюючи, що потрібна “зміна функцій учасників освітнього середовища університету, коли викладач $€$ не лише транслятором знань, а й модератором інтелектуальної діяльності студентів, за якої останні стають активними перетворювачами інформації...” [82, с. 10]. Але чи дійсно все залежить від викладача? Чи досить підготувати кольорові слайди, чи зробити захоплююче слайд-шоу або відео щоб захопити увагу студента?

Сучасний викладач намагається викладати свій предмет таким чином, щоб задовольнити потреби студентів, акцентуючи на використанні тих чи інших тем в їх подальший практичній діяльності. Щоб оптимізувати навчальний процес викладачу варто провести опитування серед студентів щодо їх потреб та знайти шляхи їх задоволення. Таким чином студенти будуть залучені до створення вектору викладання, відчують, що їх думка важлива для викладача і сприятлива атмосфера взаємоповаги та взаєморозуміння буде створена.

В сучасному університеті відбуваються демократичні перетворення і більше залучення студентів не тільки до навчального процесу, а й до роботи університету в цілому. Представники студентської ради та профспілкового комітету студентів входять до складу вченої ради, студенти також приймають участь у виборах деканів своїх факультетів та ректора університету.

На постійній основі за ініціативою студентського активу на всіх факультетах НТУУ «КПІ ім. Ігоря Сікорського» проводяться опитування серед студентів 3 приводу якості викладання дисциплін викладачами. Результати опитувань представлені діаграмами і доступні на сайтах факультетів. Основна 
мета опитувань - надати зворотній зв'язок, показати над чим викладачу потрібно замислитись, що змінити в своїй роботі, як удосконалити певні якості, щоб студентам було ефективніше та комфортніше навчатись. За результатами опитувань студенти, які ще не знайомі з викладачем можуть уявити собі його. Наведемо основні критерії оцінювання, які студенти вважають найсуттєвішими:

1. Актуальність матеріалу.

2. Ввічливість.

3. Своєчасність та достатність інформування.

4. Доступність матеріалів.

5. Об'єктивність оцінювання.

6. Пунктуальність.

7. Змістовність занять.

8. Володіння матеріалом з дисципліни.

Базуючись на відповідях студентів створюються два графіки: задоволення викладанням дисципліни та самооцінка власних знань після проходження курсу. Після ще двох показників: предмет викладача не можна закрити без знань та система оцінювання викладача, підводиться підсумок: наскільки студенти ( у відсотках) задоволені роботою викладача в цілому.

Також в університеті існує офіційне опитування, яке проводиться на внутрішньо університетському сайті. Воно складається із 5 запитань: 1) Об'єктивність оцінювання. 2) Вміння донести матеріал до студентів. 3) Вміння налагодити партнерські стосунки зі студентами. 4) Доброзичливість та тактовність по відношенню до студентів. 5) Використання засобів дистанційного спілкування ( засоби відеозв'язку, месенджери тощо). Студенти оцінюють викладачів за 5 бальною системою. Відповіді анонімні, результати представлені по курсах та в цілому.

3 розвитком соціальних мереж студенти можуть написати подяку чи навпаки описати проблемну ситуацію, яка виникла 3 викладачем в певних телеграм чатах. Така миттєва зворотна реакція сприяє в деякій мірі уникненню 
THEORETICAL FOUNDATIONS OF THE FUNCTIONING OF EDUCATION. WAYS TO

IMPROVE THE EFFECTIVENESS OF EDUCATIONAL ACTIVITIES

конфліктів, хоча на нашу думку в суперечливій ситуації завжди можна досягти компромісу, не виносячи іï на загальне обговорення в соціальних мережах.

Таким чином, для роботи сучасної вищої школи має відбуватись постійне самовдосконалення та саморозвиток як студентів так i викладачів. Для оптимізації навчально-виховного процесу відносини між його учасниками слід будувати на основі партнерства, поваги та взаємодопомоги. 
THEORETICAL FOUNDATIONS OF THE FUNCTIONING OF EDUCATION. WAYS TO

IMPROVE THE EFFECTIVENESS OF EDUCATIONAL ACTIVITIES

\section{SECTION 2. GENERAL AND PRE-SCHOOL PEDAGOGY}

DOI 10.46299/ISG.2021.MONO.PED.II-90-102

\section{1 Жоғары мектеп оқытушысының тұлғалық даму ерекшеліктерін типологиялық жіктеу теориялары}

Педагогикалық, психологиялық зерттеуде кәсіби маңызды тұлғалық қасиеттердің интеграцияланып, синтезделуінен жинақталатын және әрбір тұлғаның жеке даралығын сипаттайтын композицияны педагогтың «типологиялық» ерекшеліктері немесе «типтік» ерекшеліктері деп анықталады.

Типтік талдау, типология гректің «tipos» деген сөзінен шыққан. Бұл термин бір заттың немесе құбылыстың ерекшеліктеріне байланысты қалдырған ізі, бейнесі, формасы, үлгісі мағынасын білдіреді.

Ғылыми еңбектерде типология арқылы танымдық әдіс анықталып, ғылыми тұрғыдан типологиялық тұрғы екі түрлі үдерісті сипаттайды:

1) типология - жүйені құрамдарға ажыратып, талдау;

2) құрамдарды идеалды түрде белгілі бір модельге, типке сәйкес топтастырып, сипаттау.

Адамның тұлғалық құрылымын қарастыратын типологиялық тұрғының көптеген теориялары бар. Мысалы, адам дамуындағы ерекшеліктерді типтерге бөлуде гуморальдік (Гиппократ, П. Лесгафт), конституциялық немесе физикалық (Э. Кречмер, У. Шелдон), психофизиологиялық (И.П. Павлов, Б.М. Теплов, В.С. Мерлин, т.б.), психоанализдік (3. Фрейд, К. Юнг, т.б.), мінез бітісіне байланысты (Хейманс, Ле-Сенн, К. Леонгард, А.Е. Личко, т.б.), тұлғалық (К. Юнг, т.б.), психогеометриялық (С. Деллингер), т.с.с.

Психологиялық-педагогикалық ғылымдарда педагогтарды типтерге жіктеудің бірнеше түрлері мен олардың негіздемелері бар.

Бірақ, педагог тұлғасындағы типтік ерекшеліктерді анықтап, сипаттау оңай болмайды. Өйткені, педагог тұлғасы «адам-адам» саласындағы басқа да мамандар сияқты білім алушылардың, ата-аналардың, әкімшіліктің, ғылымның, қоғамның талаптарына сәйкес аса күрделі құрылымнан тұрады. Бұл туралы Ф.П. Гоноболин «Жақсы педагог туралы әрқашан ол әркезде қатал немесе жұмсақ, 
THEORETICAL FOUNDATIONS OF THE FUNCTIONING OF EDUCATION. WAYS TO IMPROVE THE EFFECTIVENESS OF EDUCATIONAL ACTIVITIES

белсенді немесе енжар, т.с.с. деп айту мүмкін емес. Ол жағдайға байланысты анандай да, мынандай да бола алады. Адамдармен қатынас жасауда жылылық керек. Бірақ аздап суық қатынас та қажет болады. Педагогтың көмегі оқушыларға дербестік берумен үйлесуі тиіс. Мұғалімнің алғашқы бастамашылығы біртіндеп оқушыларға өтуі керек» деп жазған [84, 109 б.].

Педагогикалық, психологиялық зерттеулердің көбінде педагогтардың кәсіби мінез-құлық ерекшеліктерін жеке-дара қабілеттер анықтайтыны негізге алынады. Мысалы, педагогтардың типтерін ажыратуда олардың кәсіби ісәрекеттегі қарым-қатынас жасауға қабілеті немесе өз пәні арқылы білім алушыларды қызықтыра алуы немесе педагогтардың психологиялық ерекшеліктерінің даму деңгейлері қарастырылады.

К. Левиннің іс-әрекеттегі жеке даралығы бойынша тұлғаны авторитарлық стиль, либералды стиль және демократиялық стиль бойынша жіктемесі нағыз классикалық типология болып табылады. Бұл стильдер бойынша типтер сипаттамасы педагогикалық-психологиялық зерттеулерде қолданылады. Осыған байланысты А.А. Бодалевтың, А.А. Леонтьевтің зерттеулерінде педагогтардың кәсіби-тұлғалық типтері авторитарлық стиль, либералды стиль және демократиялық стиль негізінде сипатталады. Мұнда педагогтардың типтік ерекшеліктері кәсіби іс-әрекет барысында қарым-қатынасты ұйымдастыру мен жүзеге асыруы арқылы анықталады.

В.А. Кан-Калик кәсіби педагогикалық қарым-қатынас стилін әлеуметтік және адамгершілік тұрғысынан қаралатын категория деп анықтап, педагогикалық қарым-қатынас стильдерін типтік ерекшеліктер ретінде анықтайды: «қарым-қатынас стилін педагог пен білім алушылардың әлеуметтікпсихологиялық өзара әрекеттесуінің жеке дара типологиялық ерекшеліктері деп түсінеміз» [85, 97 б.]. В.А. Кан-Каликтың 5 типтік жіктемесіне сәйкес педагогтың қарым-қатынас стилімен анықталатын жеке дара типологиялық ерекшеліктерді тұлғалық қасиеттерге байланысты қарастырылады: 
THEORETICAL FOUNDATIONS OF THE FUNCTIONING OF EDUCATION. WAYS TO

IMPROVE THE EFFECTIVENESS OF EDUCATIONAL ACTIVITIES

1. Бірлескен іс-әрекетке мүдделі болу негізіндегі қарым-қатынас. Қарымқатынастың бұл типі педагогтың жоғары кәсіби этикалық бағдарларына негізделеді; тұтастай кәсіби іс-әрекетке қатынасына негізделеді.

2. Достық негіздегі қарым-қатынас. Мұнда педагог тәлімгерлік, жолдастық қатынаспен бірге іскерлік бағыттылық бойынша ерекшеленеді.

3. Дистанция сақтау қарым-қатынасы. Бұл қарым-қатынас стилінде педагогтың мәртебелі болуды, кәсіпқой ретінде көрінуді, өмірлік тәжірибесі мен жас ерекшелігін алға қоюы бейнеленеді. Сонда бұл қарым-қатынас стилі педагогтың тұлғалық дамуындағы мәселені көрсетеді.

4. Үрейлендіру қарым-қатынасы. Бұл жас педагогтарға, бірлескен ісәрекетті шығармашылықпен ұйымдастыруға қабілеті жеткіліксіз педагогтар типіне сәйкес негативті қарым-қатынас стилі болып табылады.

5. Әзілдесу қарым-қатынасы. Бұл танымал болуға тырысатын жас педагогтардың жалған, арзан бедел жинауға, педагогикалық әдепті ұстанбауы арқылы сипатталатын типологиялық ерекшелік.

Әдебиетте бұдан басқа да педагог типтерінің жіктемесі бар. Солардың арасында М. Таленнің педагог типтерін 7 топқа жіктеуі кең таралған. Ол педагогтарды қызмет барысында тек өздерінің қажеттіліктеріне байланысты белгілі бір қарым-қатынас, іс-әрекет стилін таңдап алуы бойынша қарастырады. М. Таленнің жасаған жіктемесін А.Р. Ерментаеваның еңбегі [86, 138-140 бб.] бойынша көрсетеміз.

1) «Сократ». Бұл - сабақта әдейі пікірталасқа, пікірсайысқа қозғау салатын, оған әуестігімен ерекшеленетін педагог. Мұндай педагогтің оқу процесіне жекедаралық, жүйесіздік тән. Алайда, педагогтің бұл ұстанымы білім алушылардың өз көзқарастарын дәлелдеп, айта алуына жағдай жасайды; олардың ақыл-ой дербестіктерін күшейтеді.

2) «Топтық пікірсайыс жетекшісі». Бұл ұстанымда оку-тәрбие процесінде білім алушылармен келісе отырып, ынтымақтаса жұмыс істеуге аса мән беріледі. Мұнда педагог пікірсайыстан шығатын нақты нәтижені емес, білім алушылармен демократиялық түрде келісуді бәрінен артық қояды. 
THEORETICAL FOUNDATIONS OF THE FUNCTIONING OF EDUCATION. WAYS TO

IMPROVE THE EFFECTIVENESS OF EDUCATIONAL ACTIVITIES

3) «Шебер». Аталмыш ұстаным бойынша педагог үлгі ретінде болады. Сондықтан, оқу процесінде, жалпы, өмірдің барлық жағдайында оның айтқандары мен әрекеттерін білім алушылардың мүлтіксіз қайталау шарты қойылады.

4) «Генерал». Бұл ұстаным екі ұштылықтан аулақ, талапқойғыш, өзіне қатаң түрде бағындыратын педагогке тән. Ол өзінің айтқандары мен әрекеттерін әрқашан дұрыс санап, білім алушыға берген әмірін екі етпей орындауын міндеттейді.

5) «Менеджер». Аталмыш мәнер сыныптағы іс-әрекеттің табысты болуына, білім алушылардың бастамашылығын және дербестігін мадақтауға, қолдауға бағдарланады. Педагог әрбір білім алушының атқаратын міндетінің маңызын түсіндіріп, талдауға; әрқайсысының іс-әрекетін қалтқысыз бақылауға және қол жеткен нәтижелерін бағалауға тырысады.

6) «Жаттықтырушы». Бұл ұстаным бойынша сыныптағы қарым-қатынасқа корпорациялық рух тән. Мұнда білім алушылардың бір команданың ойыншылары сияқты жеке-дара жетістіктері емес, бірлескен іс-әрекеті маңызды болады. Ал, педагогке тек нәтиже, табыс, жеңіс ең басты мақсат болып табылады. Сондықтан ол топтық жұмысты жандандырушы, рухтандырушы рөлін атқарады.

7) «Гид». Білмейтіні жоқ, «энциклопедия» рөліндегі педагог қарымқатынастың осы мәнерімен сипатталады. Ол - әрқашан ұстамды, жинақы. Мұндай педагогтің қоятын сұрақтары да, кез келген сұраққа жауабы әзір тұрады. Оның іс-әрекетін мінсіз деуге тұрарлық.

M. Таленнің типологиясы педагогтардың кәсіби жұмысында өз қажеттіліктері, өз мүдделері негізге алынып жасалған.

Бірқатар зерттеушілер педагог типологиясын жасауда оның негізіне қарым-қатынас стилі мен нақты бір қабілеттің дамуын алады. Мысалы Б.П. Ковалев [87, 25б.] педагог типтерін екі белгі бойынша ажыратады:

- педагогтардың рефлексияға қабілеттілігі;

- педагогтардың қарым-қатынас стилі. 
THEORETICAL FOUNDATIONS OF THE FUNCTIONING OF EDUCATION. WAYS TO

IMPROVE THE EFFECTIVENESS OF EDUCATIONAL ACTIVITIES

Осыған байланысты зерттеуші педагогтарды 5 топқа бөліп, сипаттайды.

Бірінші топ педагогтарының өзін-өзі бағалауы білім алушылардың қатынасына сәйкес келеді. Бұл педагогтар қарым-қатынаста демократиялық стильмен ерекшеленеді.

Екінші топтағы педагогтар өздерін бағалауын дұрыс болжамдайды. Бірақ олардың өзін-өзі бағалауы адекватты бола қоймайды. Осыған байланысты бұл педагогтар қарым-қатынаста басыңқы, үстем қарым-қатынасты ұстанады.

Үшінші топтағы педагогтардың өзін-өзі бағалауы адекватты болады. Бірақ олар өздерін бағалауда дұрыс болжам жасамайды. Бұл педагогтар білім алушылармен қарым-қатынаста енжар болады және олармен мейірммен қатынас жасайды.

Төртінші топтағы педагогтардың өзі туралы түсініктері мен өзін-өзі бағалауы адекватты емес. Олар өзі туралы пікірді білім алушылардан білуге тырысады. Бірақ, бұл педагогтар қарым-қатынас жасауға икемді бола қоймайды. Бұл топтағы педагогтар қарым-қатынаста басым болады немесе олардың қарымқатынасына ситуациялық сипат тән.

Бесінші топтағы педагогтардың өздері туралы түсініктері білім алушылардың пікіріне қарама-қарсы келеді. Сондықтан бұл педагогтар қарымқатынаста әлдеқайда үлкен қиындықтарды кешеді.

Олай болса, бұл типологияда педагогтың да, білім алушылардың да педагог туралы ұстанымдары негізге алынған.

Ғылыми зерттеулерде педагог типтері кәсіби маңызды қасиеттер мен кәсіби бағыттылықтың дамуы бойынша да ажыратылады. Осыған байланысты Е.И. Рогов [88, 23 б.] педагогтардың негізгі 4 типін анықтаған, олар: «Ұйымдастырушы» педагог. Бұл педагог талап қою, ұйымдастыру, күшті ерікжігер, куаттылық сияқты қасиеттермен ерекшеленеді. Ұйымдастырушы педагогтар кәсіби іс-әрекетте орындаушы, жұмылдырушы қызметтерін жоғары деңгейде орындай алады.

1. «Сабақ өткізуші» педагог. Бұл педагогтарға байқампаздық, шығармашылық, кәсіби құзіреттілікке ұмтылу қасиеттері тән болады. Олар 
THEORETICAL FOUNDATIONS OF THE FUNCTIONING OF EDUCATION. WAYS TO IMPROVE THE EFFECTIVENESS OF EDUCATIONAL ACTIVITIES

рационалист ретінде білім алудың қажеттілігі мен білімнің өмірдегі маңызына ерекше назар аударады. «Сабақ өткізуші» педагог кәсіби іс-әрекетте конструктивті, әдіскерлік, білім беруші, бағдарлаушы қызметтерін тиімді жүзеге асырады.

2. «Коммуникатор» педагог. Оның ең басты қасиеттеріне қарымқатынастағы ашықтық, мейірімділік, тартымдылық, адамгершілік, эмоционалдық және жұғымды мінез-құлық жатады. «Коммуникатор» педагогтер эмпатиялық қабілетпен, білім алушыларды бөліп-жармай, оларға құнды қатынаспен ерекшеленеді.

3. «Зиялы» («ағартушы») педагог. Бұл педагогтар зиялылықтың, жалпы мәдениеттіліктің, ізгіліктіліктің жоғары деңгейімен ерекшеленеді. Олар талапшыл, мораль нормаларын қатаң ұстанатын тұлғалар. «Зиялы» педагог кәсіби іс-әрекетте гностикалық, тәрбиелеуші, ақпараттық, дамытушы, зерттеуші қызметтерін оңай үйлестіріп, атқарады. Сонымен қатар, бұл педагогтар өзін-өзі дамыту мәселесіне ерекше назар аударады.

Е.И. Рогов педагогтардың бұл басты типтерінің арасында қосалқы аралық типтер де болатынын ескертеді.

Қазіргі кезде педагогтың кәсіби құзіреттілігін анықтауда эмпатияны маңызды құрылым ретінде қарастыратын психологиялық-педагогикалық зерттеулер жеткілікті. Солардың арасында осы эмпатиялық қабілет арқылы Р. Атаханов пен М.Г. Бобкова [89, 316.] педагог типологиясын сипаттайды. Мұнда авторлар педагогтың білім алушылармен өзара әрекеттестікте эмпатиялық тәсілге бағдарлануды негізге алады. Осыған байланысты педагогтардың 5 типі қарастырылады.

1) Белсенді, оң кәсіби бағдарлы педагогтар. Бұл педагогтар білім алушылардың жай-күйіне эмоционалдық қатынас таныта алады. Олар білім алушылармен, әріптестерімен де ынтымақтастыққа негізделген қарым-қатынас құра алады.

2) Функционалды кәсіби бағдарлы педагог. Бұл педагогтарда оқушылардың жай-күйіне эмоционалдық қатынасы жеткіліксіз болады. Олар 
THEORETICAL FOUNDATIONS OF THE FUNCTIONING OF EDUCATION. WAYS TO IMPROVE THE EFFECTIVENESS OF EDUCATIONAL ACTIVITIES

нұсқау беру арқылы педагогикалық іс-әрекетті жүзеге асыратындықтан кәсіби тәжірибесінде ынтымақтастық болмайды, таңдамалы қарым-қатынас жасайды.

3) Бейтарап-енжар кәсіби бағдарлы педагог. Бұл педагогтар экспрессия арқылы эмоцияны тани алмағандықтан, вербалды қарым-қатынастың мазмұнына ерекше назар аударады. Олар іскерлік, ресми түрде қарым-қатынас жасауға бағытталып, білім алушылардың спонтанды тілдесуіне себепкер болады.

4) Ситуациялық кәсіби бағдарлы педагог. Бұл педагогтарда эмоционалдық жоғары болады, білім алушылардың жай-күйіне аяушылық сезіммен эмоционалдық қатынас білдіреді. Мұндай педагогтардың көңіл-күйі аумалытөкпелі боуына байланысты білім алушылармен өзара қатынасы да құбылмалы келеді.

5) Жасырынды теріс кәсіби бағдарлы педагог. Бұл педагогтар оқушылардың жай-күйіне эмоционалдық қатынас білдіре алмайды. Олар эмоцияның вербалды емес белгілерін тани алмайды.

Бұл типология педагогтардағы эмпатияның дамуын олардың білім алушыларға эмоционалдық қатынасы арқылы анықтап, қарастырады.

А.П. Панфилова [90, 32б.] педагогтарды «трансакциялық» және «трансформациялық» деп сипаттайды. «Трансакциялық» педагогтар ақпарат алмасу үдерісін ұйымдастырып, жүзеге асырады. Олар жұмысында сабақ беріп, міндетін ресми түрде атқарып кете беретін педагогтар болып табылады. Ал, «трансформациялық» педагогтар кәсіби іс-әрекетте маңызды бетбұрыстар мен өзгерістерді жүзеге асыруға қабілетті болады. Бұл педагогтар білім алушылардың дамуына, білім беру орнындағы мінез-құлық мәдениетінің бекуіне, білім беру технологияларын қолдануға байланысты оңды өзгерістер енгізеді. «Трансформациялық» педагогтар әр оқушының болашағына назар аударады. Бұл педагогтар білім берушілер мен әріптестер арасындағы ынтымақтастықты нығайтуға ұмтылады.

Олай болса, мұнда педагогтар кәсіби іс-әрекетті құзіреттілікпен жүзеге асыруға байланысты типтерге бөлінген. 
THEORETICAL FOUNDATIONS OF THE FUNCTIONING OF EDUCATION. WAYS TO

IMPROVE THE EFFECTIVENESS OF EDUCATIONAL ACTIVITIES

Көбінде педагогикалық іс-әрекеттің басты мақсаты білім алушының дамуы, тәрбиесі, оқу үдерісіндегі табыстылығы бойынша педагогтар типологиясы жіктеледі. Осыған байланысты, кейбір еңбектерде окушы тұлғасына бағыттылығы негізге алынып, педагог типтері ажыратылады.

В.Н. Сорока-Росинский $[91,456$.$] педагогикалық іс-әрекеттегі мұғалімнің$ бағыттылықтары мен олардың типтерін бөліп, сипаттауда олардың бағыттылығын негізге алады. Осыған байланысты мұғалімнің 2 түрлі бағыттылығы анықталған:

пәнге негізделу, сабақ мазмұнына шегенделу - «пәнге центризм»;

окушыларға бағытталу - «педоцентризм».

Осыдан педагогтардың сәйкесінше 2 типі ажыратылып, олардың ерекшеліктері сипатталады:

1) «логотроптар» - эмоционалдық реакциялары оқушының сабақтағы ісәрекеті мен жауабына байланысты жағымды-жағымсыз болып құбылмалы келеді; олар пән бойынша білімді ең басты көрсеткіш ретінде санайды;

2) «педотроптар» - оқушылардың жан-дүниесін терең түсінуге қабілетті; олармен бірге қуанып, бірге күйіне алатын; оларды аналық мейірімге бөлейтін; көмектесіп, қолдауға әрқашан дайын тұратын тұлға.

Сонымен қатар А.К. Мынбаева педагог тұлғасының бағыттылығына, ұстанатын позициясына байланысты 2 типке бөліп қарастырып,оларды бірбірімен салыстыра сипаттап, «педагог-қамқоршы» және «педагог-менеджер» деп ажыратады [92, 69-70 бб.]. Ол үшін педагогтың балаларға қатысты позициясы, ықпал етудегі стратегиялық тұрғысы, балаларға ықпал ету шараларын таңдауы, оқу материалын ұсыну тәсілін таңдауы, бағалау тұрғысы және қорытынды бағалау тәсілі педагог типтерін ажырату көрсеткіштері болып табылады. Автордың «педагог-қамқоршы» және «педагог-менеджер» позициялық типтеріне берген сипаттамасынан педагогтың тұлғалық қасиеттері айқын анықталады.

Жоғары мектеп оқытушысының типтік жіктемелерін И.Б. Назарова [93, 58б.] сауалнама жүргізу арқылы анықтаған. Бұл зерттеуде типология негізіне 
THEORETICAL FOUNDATIONS OF THE FUNCTIONING OF EDUCATION. WAYS TO IMPROVE THE EFFECTIVENESS OF EDUCATIONAL ACTIVITIES

жоғары мектеп оқытушыларының педагогикалық іс-әрекетке тұлғалық қатынасы алынады. Сонымен қатар оқытушылардың типтерге жіктелуінде олардың жалпы түрде еңбек етуге қатынасы, қосымша табыс табуға қатынасы басшылыққа алынған. Олтиптер былайша сипатталады:

«Титан» оқытушылар үшін «алдымен - ғылым, бірақ оқыту ісін қоймаймын, себебі кімге не оқу керектігін өзім таңдаймын» деген қатынаста болады. Олар ғылымда да, оқытуда да жеке жетістіктерімен де, еңбектерінің ақталуымен де барлық мүмкіндіктерге қолы жеткен адамдар. Материалдық тұрғыдан қамтамасыз етілген, әрқашан қызықты жұмыстары бар және үнемі қызықты ұсыныстар жасалып, қандай жұмысты істейтінін, қандайын істемейтінін таңдай алады. Олардың өздеріне қызықты іспен айналысуға жағдайлары бар. Жүктемелері көп емес, аптасына бір рет қана ЖОО-ға келеді. Өздерін қызықтырмайтын болғандықтан, олар жоғары мектепте болып жатқан жағдайлардан бейхабар. Олар үшін жоғары білім берудің өзгермегені жақсы. Олар ештеңені өзгерткілері келмейді әрі олар үшін бұл кеш. Олар өз өмірлерін қайта бастаса осы жолды таңдайтын болады.

1) «Академик» оқытушылар «мен оқытушы емеспін, мен оқытуға уақыт өткізгім келмейді, бірақ өзімнің тәжірибем мен білімімді жеткізуім керек» деген қатынаспен анықталады. Бұл тип өкілдері үнемі ғылыммен айналысып, бірақ ақырында жастарға өз білімін жеткізуді қажет деп санйды. Олар ғалым ретінде көпшіліктен мықты болғанмен, сабақ беруі ондай дәрежеге жетпейді.

2) «Өмір бойы» оқытушы типіндегі тұлғалар «оқыту - менің негізгі мамандығым, мен бурлак секілді өмір бойы осымен кеттім» деген қатынасты танытады. Олардың білім деңгейі жоғары, ғылыми дәрежесі, ғылыми атағы болады. Бұл топты өздерінің кәсіби тағдырын өзгерткісі келмейтін оқытушылар құрайды.

3) Көптеген жұмысқа қамтылған оқытушылар типі «мен барлық жұмысты істей аламын, себебі отбасының негізгі асыраушысымен, маған ақша табу керек және мансабымды өсіру керек» деген қатынаспен сипатталады. Бұл топтағы оқытушылар оқытуда да, ғылымда да көп жүктеме алады. 
THEORETICAL FOUNDATIONS OF THE FUNCTIONING OF EDUCATION. WAYS TO

IMPROVE THE EFFECTIVENESS OF EDUCATIONAL ACTIVITIES

4) «Тірегі мықты» оқытушылар үшін «ақша мені қызықтырмайды, бірақ маған университеттің оқытушысы ретінде танылған тартымды болады» деген қатынас алға қойылады. Олар өмір бойы оқытумен айналысуға дайын болады. Жұмысын, білім алушыларды жақсы көреді. Бұл оқушылар жақсы білім алғандар, оқыту және зерттеу жұмыстары бойынша тәжірибелері болады.

5) «Аяқтап қалған» оқытушылар «енді бірнәрсені өзгерту кеш, пенсияға қосымша болсын деп көп емес жүктемем бар, құрмет пен қарым-қатынас бар» деген қатынаспен сипатталады. Олардың тәжірибелері көп, сондықтан сабаққа дайындалмай келеді. Және өздерінің ғылыми жетістіктері, ғылыми дәрежелері мен ғылыми атақтарына үстеме алып, сабақ бергенді ұнататын оқытушы типтері.

6) «Практик» оқытушы типтері шенеунік, саясаткер, кәсіпкер тұлға ретінде «мен нақты экономикалық жағдайды білемін, заманауи бизнес әлемінен тәжірибе бере аламын, мені шақырған соң келгенмін» деген қатынас бойынша топ құрайды. Бұл оқытушылар сабақ беру мен ғылыми жетістіктерге байланысты регалийлер алу үшін жанталаспайды.

7) «Статус адамдарының» типі бойынша жіктелетін оқытушылар «менің ата-тегімнің тұсында директор деп қана жазылмай, экономика ғылымдарының докторы деп тұрғанын қалаймын» деген қатынаспен ерекшеленеді. Олардың бизнесте аса табысты болса да, ғылым мен оқытуда жетістіктері болғанын қалайды. Олар үшін ғылыми атақ, ғылыми дәреже алу маңызды. Сол үшін ақша төлеп, біреулермен бірігіп монографиялар шығарып жүреді. Сабақ беруге уақыты жоқ болғандықтан үнемі өзін алмастыратын әріптестер іздеуде болады.

8) «Бизнес-леди» оқытушы типі университетте өз бизнесі мен оқытуды сабақтастыру ниетімен, жоғары мектепте білім берумен ермек үшін айналысатын топтағы тұлғалар. Олар жоғары мектепте тұрақталып жұмыс істей алмайды.

9) «Ғылыми-педагогикалық тандем» типіндегі оқытушылар «екеуіміз де университеттеміз, ғылыми жұмыспен айналысамыз» деген қатынасты көрсетеді. Олар үшін ЖОО-дағы қызмет негізгі болып саналады. 
THEORETICAL FOUNDATIONS OF THE FUNCTIONING OF EDUCATION. WAYS TO

IMPROVE THE EFFECTIVENESS OF EDUCATIONAL ACTIVITIES

Бұл жоғары мектеп оқытушыларының типолдогиясы қазіргі қоғамдық жағдайдың ерекшеліктерін ескереді. Сондықтан мұнда сипатталған оқытушы типтерін әлдеқайда заманауи және реалды деп санаймыз.

А.В. Юревич [94, 67б.] жоғары мектеп оқытушыларын типологиялық жіктемесін тұлғалық негізде құрып, студенттерге қатынасы мен өз пәні бойынша білім берудегі қаталдығы бойынша оқытушылардың 6 типін анықтап, келесідей сипаттаған:

- Өзін-өзі көрсетіп қалуға ұмтылатын оқытушылар студенттер үшін аса қолайсыз болады. Олар студенттерді қорқыту арқылы немесе бағаны жоғарылатып қою арқылы өзін құрметтетуге тырысады.

- Педант оқытушы да студенттерге қолайсыз болады. Олар қырсықтықпен, догматизм мен таяздықпен ерекшеленеді. Емтихан кезінде дәлме-дәл жауап күтіп, білім алушылар тарапынан шығармашылыққа, тапқырлыққа жол бермейді.

- Немқұрайлық оқытушы типі субъективті маңызды жұмыстарды алға қояды. Студенттердің аты-жөні, кесте бойынша сабақ, объективті білім бағалау оның назарын аудармайды. Есесіне өзі шетелге іс-сапар, өзінің кітаптарын шығару, грант алу сияқты мәселелер маңызды болып табылады.

- Жалқау оқытушы типі пән бойынша дайындалмайтын, салақ, ұқыпсыз жүретін, жаман әдеттермен ерекшеленетін тұлға болып табылады. Бірақ ондай оқытушы мейірімді, бағаға жомарт келеді.

- Ағайыншылықпен сипатталатын оқытушы типі студенттерге барынша жақын болуға тырысатын, оларды жаман әдеттерге тартатын, жастар сленгісін қайталайтын тұлға. Бұл типтің өкілдері тек «жақсы» және «өте жақсы» деген бағаны ғана білетін секілді. Бірақ бағалауда олар әрқашан әділетті болмай, өте жақсы жауапты төмендетуі де мүмкін.

- Студенттердің ерекше ұнататындары романтик оқытушылар типінің өкілдері болады. Ол үшін ең бастысы тәртіп пен баға емес, студенттердің шығармашылығы мен ойлауы болып табылады. Оның лекциялары мен семинар сабақтары диалог арқылы жүргізіледі. Бұл типтің өкілдері өз мамандығына, 
THEORETICAL FOUNDATIONS OF THE FUNCTIONING OF EDUCATION. WAYS TO

IMPROVE THE EFFECTIVENESS OF EDUCATIONAL ACTIVITIES

ғылымға ерекше қатынасы байқалып, онымен студенттерді шабыттандырып отырады.

Бұл типология жоғары мектептегі оқытушының іс-әрекетінде, қарымқатынасында, өзіне және басқаларға қатынасында аса күрделі психологиялық, педагогикалық және әлеуметтік мәселе бар екенін көрсетеді.

Қазіргі кездегі жоғары мектеп оқытушыларының басқа адамдар секілді әр түрлі қасиеттермен ерекшеленетіні Л.Д. Столяренконың [95, 119б.] типологиясында көрінеді. Автор оқытушылардың студенттермен қарым-қатынас кезіндегі мінез-құлқын жүйелеген. Осыған байланысты жоғары мектеп оқытушыларының типологиялық жіктемесінде мінез-құлықтың 8 моделін қамтиды. Л.Д. Столяренконың анықтаған оқытушы модельдері төменде келтірілген.

«Монблан» студенттерге жақындамайтын, өз білгеніне масаттанып, студенттермен тұлғааралық өзара қатынастарды қажет етпейтін диктатор оқытушы типі болып табылады.

«Қытай қабырғасы» дейтін типтерге студенттермен қарым-қатынасқа тосқауыл қоятын, сабақта диологты құрмайтын, студенттерді менсінбейтін оқытушылар жатады.

«Локатор» типіндегі оқытушылардың өкілі студенттерді таңдап, өзара қатынас орнататын, оларды алалап, контакт жасайтын тұлғалар.

«Құр» немесе «саңырау құр» өз әлемінде, өзімен өзі жүретін; басқаларға құлақ аспайтын, монологты сөйлейтін оқытушының типін сипаттайды.

«Гамлет» типі өзінің қалай қабылдайтынына, іс-әрекетінің дұрыстығына, студенттердің өзіне деген қатынасына ерекше көңіл аударатын оқытушылар тобын құрайды.

«Робот» типі студенттермен қарым-қатынасы оку бағдарламасының аясынан шықпайтын, олардың психологиялық ерекшеліктерін есепке алмайтын оқытушыларға сәйкес келеді.

«Мен-өзім» типі бойынша оқыту-тәрбиелеу үдерісінде әрқашан өзін ғана басшы және инициатор ретіндегі жалғыз тұлға көретін оқытушы анықталады. 
THEORETICAL FOUNDATIONS OF THE FUNCTIONING OF EDUCATION. WAYS TO

IMPROVE THE EFFECTIVENESS OF EDUCATIONAL ACTIVITIES

«Одақ» типіне қамтылатын оқытушылар студенттермен диалог арқылы қарым-қатынас жасайды, достық негізде жанашырлық көрсете алады.

Қазіргі кезде педагогикалық, психологиялық зерттеулерде педагогтың кәсіби іс-әрекетінің жалпыланған, ықпалдасқан сипаттамалары типологияның бір ғана негізі ретінде қаралмайды. Ғылымдағы педагогтардың типологиялық жіктемелерінде көбінесе жеке-дара кәсіби қабілеттер болатын тұлғалық құрылымдар басты параметр болып табылады. Сонымен қатар, ғылыми зерттеулерде педагогтар типологиясына маманның кәсіби іс-әрекет барысында қарым-қатынас жасауға қабілеті немесе өз пәні арқылы білім алушыларды қызықтыра алуы немесе педагогтардың психологиялық жекедара қасиеттерінің ерекше даму деңгейлері сияқты тұлғалық интеграцияланған құрылымдар қарастырылады.

Жоғары мектеп оқытушысының тұлғалық даму ерекшеліктеріне байланысты олардың типологиялық жіктелуі педагогикалық-психологиялық мәселе ретінде жан жақты зерттеуді қажет етеді. 
THEORETICAL FOUNDATIONS OF THE FUNCTIONING OF EDUCATION. WAYS TO IMPROVE THE EFFECTIVENESS OF EDUCATIONAL ACTIVITIES

DOI 10.46299/ISG.2021.MONO.PED.II-103-114

\section{2 Подходы к формированию готовности будущих педагогов к инновационной деятельности}

В современных условиях роль институтов образования существенно возрастает. Становление и развитие инновационной экономики и общества, основанного на знаниях, невозможно без опережающего инновационного развития системы образования. В свою очередь, это определяет необходимость масштабного развертывания в системе образования инновационных процессов, которые, по мнению многих исследователей, становятся одной из его важнейших характеристик. По сути, инновационные преобразования практически всех составляющих образовательной системы выступают сегодня стержнем ее модернизации. Широкомасштабные реформы в образовательной сфере кардинальным образом меняют смысл и содержание педагогической деятельности, приводят к усложнению задач, стоящих перед педагогами, росту социальной значимости и ответственности их труда. Кроме того, в условиях реализации стратегии устойчивого социально-экономического развития и реформирования образования возрастает потребность в педагогических кадрах, которые не только готовы принимать, но и способны создавать инновации и активно включаться в процессы их внедрения. Успех перехода образования на путь инновационных преобразований определяется сбалансированным развитием двух базовых составляющих: развертыванием в системе образования инновационных процессов и формированием кадрового потенциала образовательных инноваций, причем второе направление выступает условием реализации первого, первое же, в свою очередь, становится средой, в которой аккумулируется инновационный потенциал, выступающий сегодня высшей формой человеческого капитала. А.В. Хуторской отмечает, что обусловленность инновационного характера современной педагогической деятельности определяется рядом обстоятельств [106]:

- необходимостью обновления системы образования, изменения методологии и технологии организации учебно-воспитательного процесса, где инновационная направленность деятельности педагогов, включающая в себя 
THEORETICAL FOUNDATIONS OF THE FUNCTIONING OF EDUCATION. WAYS TO IMPROVE THE EFFECTIVENESS OF EDUCATIONAL ACTIVITIES

создание, освоение и использование педагогических новшеств, выступает источником развития педагогической теории и образовательной практики;

- гуманитаризацией и индивидуализацией содержания образования, непрерывным изменением объема, состава учебных дисциплин, что требует постоянного поиска новых организационных форм и технологий обучения;

- изменением характера отношения педагогов к факту освоения и применения педагогических новшеств;

- становлением рынка образовательных услуг, возникновением конкуренции в сфере образования. Можно сформулировать основные идеи, лежащие в основе инновационного обновления системы образования:

- создание условий для инновационного развития образовательного учреждения и проявления творческих способностей педагогов и обучающихся;

- укрепление сотрудничества образовательного учреждения;

- ориентация на удовлетворение требований общества, государства, экономики к образованию;

- ориентация на удовлетворение образовательных потребностей личности, которые, в свою очередь, тесно связаны с требованиями различных социальных слоев, общностей людей, национальных, региональных и других особенностей;

- учет влияний, оказываемых на систему образования факторами внешней среды.

В современных условиях в системе образования ощущается острая нехватка кадров, обеспечивающих неразрывность инновационной цепочки, без чего невозможно обеспечить реальное и качественное, а не формальное обновление образовательной деятельности. Дефицит инновационных кадров требует перестройки системы непрерывного профессионально-педагогического образования и, в первую очередь, системы подготовки будущих педагогов в вузе. Одним из важнейших факторов развития инновационных процессов в образовании становится, таким образом, формирование готовности к инновационной деятельности будущих педагогов. Готовность к инновационной деятельности - это многоаспектный и многоплановый феномен, который 
THEORETICAL FOUNDATIONS OF THE FUNCTIONING OF EDUCATION. WAYS TO IMPROVE THE EFFECTIVENESS OF EDUCATIONAL ACTIVITIES

затрагивает как личностные, так и деятельностные характеристики. В.С. Лазарев определяет готовность к инновационной деятельности как совокупность качеств будущего педагога, определяющих его направленность на развитие собственной педагогической деятельности и деятельности всего коллектива, а также на его способность выявлять актуальные проблемы образования обучающихся, находить и реализовать эффективные способы их решения [99]. По мнению Н.Ю. Посталюк, феномен готовности к нововведениям - личностное проявление творческого стиля деятельности педагога, в котором своеобразным образом сочетаются антиконформизм интеллекта, личностная направленность как стремление, потребность реализовать новые педагогические идеи, практические умения осуществлять новые способы и формы профессиональной деятельности [102]. А.И. Пригожин полагает, главная характеристика субъекта инноваций его деятельное самосознание, т.е. понимание своей личной инициативы как субъективно возможной и общественно принимаемой основы собственного существования [103]. Необходимо отметить, что сегодня исследователи различают два типа инновационных феноменов в образовательной сфере: педагогическую инноватику (инновации в системе образования) и инновационное обучение. Если педагогическая инноватика связана с перестройкой, модификацией, усовершенствованием, изменением системы образования или ее отдельных элементов, свойств и аспектов, а инновационное обучение определяется как принципиально новый тип организации образовательного процесса, новые технологии овладения знаниями, изменившийся характер взаимодействия субъектов образовательного процесса. Поэтому, когда говорим о готовности педагогов к инновационной деятельности, должны иметь в виду, это понятие включает их способность работать в новых условиях, условиях инновационных изменений в системе образования, с другой стороны, характеризует их способность создавать и осваивать новые педагогические практики, т.е. осуществлять инновационное обучение. А также следует обратить внимание на что инновационная деятельность - это не особый вид или особая сфера труда, а его качественная характеристика, 
THEORETICAL FOUNDATIONS OF THE FUNCTIONING OF EDUCATION. WAYS TO

IMPROVE THE EFFECTIVENESS OF EDUCATIONAL ACTIVITIES

подчеркивающая специфичный характер деятельности. Инновационную деятельность невозможно очертить какой-либо предметной областью, поскольку любая деятельность и в любой сфере может быть инновационной, если в нее привносится новое (знания, технологии, приемы, подходы) для получения результата, отличающегося высокой востребованностью. Говоря о готовности к инновационной деятельности, надо ясно понимать ее общую структуру, а не только предметное содержание. Раскрывая содержание инновационной деятельности, А.В. Хуторской подчеркивает единство трех составляющих инновационного процесса: создание, освоение и применение новшеств [106]. В.С. Лазарев выделяет в структуре инновационного процесса четыре элемента [99]:

1. Создание новшеств:

- анализ образовательной деятельности и выявление потребности в изменениях;

- проектирование новшеств;

- экспериментальное апробирование новшеств;

- экспертиза новшеств.

2. Распространение новшеств:

- подготовка к распространению;

- информирование о новшествах;

- поддержка освоения новшеств;

- анализ распространения и освоения новшеств.

3. Освоение новшеств:

- анализ образовательной деятельности и выявление потребности в изменениях;

- поиск новшеств;

- оценка и выбор новшеств;

- проектирование желаемого будущего образовательной системы;

- внедрение новшеств;

- анализ и оценка результатов изменений; 
THEORETICAL FOUNDATIONS OF THE FUNCTIONING OF EDUCATION. WAYS TO

IMPROVE THE EFFECTIVENESS OF EDUCATIONAL ACTIVITIES

- институализация нововведений.

4. Обновленная образовательная деятельность. Соответственно этой структуре, формируя и оценивая готовность будущих педагогов к инновационной деятельности, должны осознавать, способность к осуществлению ее на каком из этих этапов. По мнению В.А. Сластенина, готовность к инновационной деятельности «должна включать в себя различного рода установки на осознание определенной задачи, модель вероятностного поведения, определения специальных способов деятельности, оценку своих возможностей в их отношении с предстоящими трудностями и необходимостью достижения определенного результата» [104]. С учетом этого формирование готовности будущих педагогов к инновационной деятельности предусматривает:

- способность анализировать мотивы и диспозиции педагогической деятельности;

- критическое отношение к педагогическим нормативам;

- рефлексию и построение системы смыслов;

- открытость среде и профессиональным новшествам;

- творчески преобразующее отношение к миру, выход за пределы нормативно заданного;

- стремление к самореализации, к воплощению в профессиональной деятельности своих намерений и образа жизни; субъективирование элементов содержания образовательной деятельности, наделение ее личностным смыслом [104]. В исследованиях В.А. Сластенина и Л.С. Подымовой раскрываются следующие компоненты готовности к инновационной деятельности: мотивационный, когнитивный, технологический, рефлексивный [104]. Мотивационный компонент при этом включает: интерес к новшеству, его принятие, готовность к освоению; стремление будущих учителей к изменению своей позиции в образовательном процессе; осознание цели и необходимости инновационной деятельности; стремление и потребность ее осуществлять. Мотивационная сфера традиционно выделяется как важнейший элемент продуктивной деятельности, который обусловливает целенаправленный, 
THEORETICAL FOUNDATIONS OF THE FUNCTIONING OF EDUCATION. WAYS TO IMPROVE THE EFFECTIVENESS OF EDUCATIONAL ACTIVITIES

сознательный характер действий человека и определяет его потенциал. Потребность в том или ином виде деятельности, в совершенствовании личности как субъекта этой деятельности выступает активным стимулом профессионального и личностного развития. Когнитивный аспект готовности к инновационной деятельности предполагает высокий уровень владения концептуальными и теоретическими основами исследовательской деятельности, ориентацией в современных подходах к решению педагогических проблем, наличие базирующейся на научных знаниях собственной педагогической философии, на основе которых происходит формирование соответствующих профессиональных умений. Технологический компонент формирования готовности к инновационной деятельности связан с организацией образовательного процесса, обеспечивающей приобретение в процессе обучения опыта инновационной деятельности, способности проектировать модели поведения, умений осуществлять выбор инновационной проблемы и темы исследования, уметь составлять программу экспериментальной и поисковой работы, владеть разнообразными способами введения новшеств в педагогический процесс, методикой диагностики и отслеживания результатов экспериментальной работы. Рефлексивный компонент готовности будущих педагогов к инновационной деятельности характеризует уровень осмысления, осознания мотивов, целей деятельности, развитие способностей к самоанализу своей деятельности и возникающих педагогических проблем, включает обращенность к своему внутреннему миру, опыту жизнедеятельности. Рефлексивный компонент готовности требует признания субъектности будущего педагога, учета приоритета субъект-субъектных отношений в процессе профессионально-педагогической подготовки. Многими исследователями отмечается необходимость формирования психологической готовности к инновационной деятельности, представляющей единство когнитивного, аффективного и конативного (деятельностного) компонентов [104]. Представляет интерес структура психологической готовности, выделенная С.П. Ивановой [96]. По мнению С.П.Ивановой, психологическая готовность к 
THEORETICAL FOUNDATIONS OF THE FUNCTIONING OF EDUCATION. WAYS TO IMPROVE THE EFFECTIVENESS OF EDUCATIONAL ACTIVITIES

деятельности может быть представлена четырьмя компонентами, в каждом из которых есть стартовая установка к тому или иному виду деятельности и одновременно способность к достижению необходимого результата: установка и способность к полному включению в деятельность; установка и способность к нестереотипной деятельности; установка и способность принятия обоснованного решения; установка и способность выдержать испытание стрессом. Е.П. Кораблина отмечает, что формирование готовности к инновационной деятельности включает в себя, кроме психологической готовности, становление профессиональной компетентности, готовность педагогов к решению профессиональных задач [105]. Ориентация на модель профессионального и личностного развития лежит в основе поведенческой модели подготовки будущих педагогов, которая реализуется по нескольким направлениям. Первое из них основано на метакогнитивной стратегии профессиональной деятельности, под которой понимается проектирование такого профессиональнообразовательного маршрута подготовки будущего педагога, результатом которого является получение знаний, опыта деятельности не только в рамках предметной области, но главным образом в рамках «общепредметного содержания» (В.В. Краевский, А.В. Хуторской). Второе направление определяется ценностными основаниями профессионально-педагогической деятельности. Третье направление связано с пониманием будущими педагогами содержания профессионально-педагогической деятельности, их готовностью к реализации собственной системы деятельности, конструированием собственного образовательного пространства, в котором воплощаются их профессиональные замыслы. Четвертое направление определяет способы осуществления педагогической деятельности в рамках локальной профессиональной среды, связано с «ансамблевым» видением организации образовательного процесса, в котором происходит обогащающее взаимодействие субъектов образовательной деятельности. В.А. Сластенин, подчеркивая важность социального взаимодействия для осуществления инновационной деятельности, отмечает, что педагог как субъект инновационной 
THEORETICAL FOUNDATIONS OF THE FUNCTIONING OF EDUCATION. WAYS TO IMPROVE THE EFFECTIVENESS OF EDUCATIONAL ACTIVITIES

деятельности и ее организатор вступает во взаимодействие с другими членами педагогического сообщества в процессах создания, использования и распространения новшества [104]. А.Н. Леонтьев указывает, что деятельность «...предполагает не только действия отдельно взятого человека, но и действия его в условиях деятельности других людей, т.е. предполагает некоторую совместную деятельность» [100]. Такое взаимодействие обеспечивает актуализацию инновационной культуры личности, так как вне его культура выступает лишь потенциальной возможностью инновационной деятельности. Очевидно, что процесс подготовки будущих педагогов к инновационной деятельности должен быть проектируемым и управляемым. Основными источниками информации при проектировании и создании системы подготовки будущих педагогов к инновационной деятельности могут выступать: социальный заказ общества; зарубежный и отечественный опыт подготовки специалистов к инновационной деятельности и изучение тенденций его развития; компетентностная модель современного педагога; теоретические концепции, раскрывающие проблемы подготовки будущих педагогов к инновационной деятельности; практический опыт подготовки педагогов к инновационной деятельности и пр. Управляемость и эффективность процесса подготовки будущих педагогов к инновационной деятельности обеспечивается специально созданными условиями, такими, в частности, как: преемственность всех этапов многоуровнего педагогического образования; ориентация обучения на обобщенную модель подготовки педагога к инновационной деятельности; организация мониторинга и диагностики готовности будущих педагогов к инновационной деятельности; формирование у будущих педагогов творческой активности и мотивационно-целостного отношения к педагогическим инновациям; взаимосвязь методологической, специальной, общепедагогической, методической подготовки будущего педагога; осуществление междисциплинарных взаимодействий, интеграция знаний проблем педагогической инноватики; формирование у будущих педагогов инновационной культуры, восприимчивости к новому; обеспечение 
THEORETICAL FOUNDATIONS OF THE FUNCTIONING OF EDUCATION. WAYS TO

IMPROVE THE EFFECTIVENESS OF EDUCATIONAL ACTIVITIES

системообразующих функций педагогической практики в ee единстве с исследовательской подготовкой; изучение и оценка динамики освоения инновационной деятельности будущими педагогами. Целенаправленное формирование готовности будущих педагогов к инновационной деятельности требует, создания условий, как:

- высокий уровень сформированной готовности к инновационной деятельности преподавателей, осуществляющих процесс подготовки будущих педагогов;

- включение будущих педагогов в реальную практику инновационного образования путем чередования индивидуальных (творческие задания), групповых (лекции, семинары) и коллективных (ролевые игры, дискуссии, тренинги) форм организации подготовки, направленной на формирование готовности к инновационной деятельности;

- овладение будущими педагогами приемами рефлексивного анализа собственной деятельности;

- применение в образовательном процессе информационных технологий для создания контекстных, проективных образовательных ситуаций.

Создание условий формирования готовности будущих педагогов к инновационной деятельности диагностируется через:

- уровень мотивации будущих педагогов к инновационной деятельности;

- степень их включенности в различные формы инновационной, проектной, исследовательской, опытно-экспериментальной деятельности;

- овладение ими приемами рефлексивного анализа инновационных процессов в системе образования и собственной деятельности;

- освоение и применение на практике современных моделей, технологий и инструментов инновационной деятельности.

Главная задача подготовки будущих педагогов к инновационной деятельности заключается, в том, чтобы способствовать самораскрытию обучающегося, «вытягивать» его потенциальные возможности, которые становятся основой активного профессионального и личностного саморазвития. 
THEORETICAL FOUNDATIONS OF THE FUNCTIONING OF EDUCATION. WAYS TO IMPROVE THE EFFECTIVENESS OF EDUCATIONAL ACTIVITIES

Объем знаний, которыми должен обладать современный педагог, весьма велик и разнообразен. Он включает в себя как проверенные временем научные истины и отработанные методы, непрерывно обновляющуюся и расширяющуюся информацию, появляющуюся в ответ на развитие педагогической науки и педагогической практики. Поэтому сегодня качество программ подготовки будущих педагогов к инновационной деятельности оценивается по способности построить образовательный процесс на основе синтеза науки и практики, обеспечить интеграцию исследовательского и учебного процесса, более того суметь вовлечь в исследовательскую работу. Современное образование знаменует собой переход от знаниевой к компетентностной модели, от информационно-сообщающего к интерактивному, деятельностному и практикоориентированному обучению. Компетентностный подход в подготовке специалиста к разнообразному спектру профессиональных задач обеспечивает учет социокультурного контекста и реализуется через набор продуктивных технологий подготовки:

- исследовательский характер профессиональной деятельности;

- проектные формы реализации профессиональных замыслов;

- ориентация на развитие субъектности будущего педагога в профессиональной деятельности. Достижение этой цели привносит в подготовку будущих педагогов компоненту, которая отсутствует в традиционном обучении, а именно: выработку и закрепление соответствующих навыков посредством тренингов, обучения действием, через решение реальных проблем, проектное обучение, организацию педагогических практик и т.п. Кроме того, центр тяжести перемещается с освоения книжного и даже «кейсового» материала на самообучение в группах, формирование навыков решения конкретных и актуальных проблем профессионально-педагогической деятельности посредством разработки и практической реализации прикладных проектов, проведения индивидуальных консультаций, обучения способам выдвижения и реализации инновационных идей, решения реальных профессиональных задач. Подготовка будущих педагогов к инновационной деятельности связана не 
THEORETICAL FOUNDATIONS OF THE FUNCTIONING OF EDUCATION. WAYS TO IMPROVE THE EFFECTIVENESS OF EDUCATIONAL ACTIVITIES

только и столько с передачей новых знаний, сколько с приобретением новых систем ценностей и качеств, необходимых для успеха инновационных процессов в образовании. Сегодня формирование личностных качеств, активной жизненной позиции, инновационного мышления становится приоритетом. Не менее важнее значение имеют социальная ответственность, осознание этических и нравственных норм и готовность им следовать, принятие и использование на практике гуманитарных технологий, понимание важности своей профессии, принадлежности к одному из наиболее значимых социальных институтов. Огромный потенциал имеют внедряемые в педагогический процесс современные образовательные технологии. При этом необходимо стремиться использовать разнообразные способы обучения, среди которых - групповые, игровые, рефлексивные методы, методы на основе полярностей, концептуальные методы, творчески конструктивные и иррациональные методы, решение реальных проблем, обучение на опыте, обучение на рабочем месте, обучение посредством анализа успехов и неудач, экспериментирование, выполнение исследовательских проектов и т.д. Большое значение имеет организация самостоятельной работы обучающимся. Учитывая особенности инноваций в образовании и требования, предъявляемые к современному педагогу, можно выделить два основных направления подготовки будущих педагогов к инновационной деятельности:

- связанное с планированием и организацией инновационного образовательного процесса;

- связанное с развитием личностных и профессиональных качеств будущего педагога, необходимых для инновационной деятельности. Первое направление предполагает формирование у будущих педагогов соответствующих профессиональных компетенций, обеспечивающих готовность проектировать новое учебное содержание, технологии и конкретные методики обучения. К необходимым умениям будущего педагога следует отнести умения осваивать ресурсы образовательных систем и проектировать их развитие, внедрять инновационные приемы в педагогический процесс с целью 
создания условий для эффективной мотивации обучающихся, выстраивать и реализовывать перспективные линии профессионального саморазвития с учетом инновационных процессов в образовании. Второе направление включает следующие аспекты:

- организация работы с информацией;

- самостоятельная разработка проектов и поиск источников их финансирования, развитие исследовательских навыков и умений;

- развитие умений самопрезентации;

- профессиональная самореализация;

- креативность;

- рефлексия и самооценка инновационной деятельности;

- диссеминация инновационного опыта.

Мы абсолютно убеждены, что переход от традиционной системы подготовки педагогических кадров к инновационному образованию - это, прежде всего, смена парадигм, отказ от стереотипов, устаревших схем мышления и действия, переход к формированию качественно нового образовательного пространства, которое создает условия для комплексного, гармоничного и непрерывного развития будущих педагогов в стратегическом контексте. 
THEORETICAL FOUNDATIONS OF THE FUNCTIONING OF EDUCATION. WAYS TO IMPROVE THE EFFECTIVENESS OF EDUCATIONAL ACTIVITIES

DOI 10.46299/ISG.2021.MONO.PED.II-115-121

\section{3 Особливості роботи психолога і тренера у процесі становлення сучасного спортсмена}

Становлення сучасного спорту передбачає необхідність психологічного супроводу спортсмена в ході тренувальної та змагальної діяльності. Часто фізично і технічно добре підготовлені спортсмени програють тільки через психологічну неготовність. Багато фахівців у сфері фізичної культури і спорту вважають, що і тренер, і спортсмен повинні самостійно виконувати функції психолога. Однак практика показує, що не лише спортсмен потребує психологічної допомоги, а й тренер. Недооцінка значущості такого виду роботи в професійній діяльності психолога часто призводить до поразок на змаганнях високого рівня. Аналіз досліджень в галузі спортивної психології () показав, що, незважаючи на те, що є велика зацікавленість до ролі тренера в підготовці спортсмена, багато аспектів його професійної діяльності залишаються невивченими. Успішна взаємодія в системі «тренер-спортсмен-психолог» можлива лише при всебічному вивченні кожного компонента цієї системи.

Значна кількість діячів фізичної культури і спорту зробили внесок у розвиток психології спорту. Основоположниками цієї науки стали: Триплетт Н., який працював в Індіанському університеті і був прихильником велосипедного спорту, провів перший експеремент і помітив, що велосипедисти швидше проходять дистанцію в гонці з суперником, ніж у гонці на час.; Лесгафт П.Ф. опублікува першу у світі науково обгрунтовану концепцію фізичного виховання, що спирається на анатомо-фізіологічні, гігієнічні та психологічні основи, Нечаєв О.П. став родоначальником лабораторії експериментальної педагогічної психології і психотехніки; Чиж В.Ф. вивчав проблеми психології різних соціальних явищ; П’єр де Кубертен був організатором конгресу спортивних психологів, який відбувся в Лозанні (Швейцарія) у 1913 р.; Рудік П.А. - доктор психологічних наук, під керівництвом якого були проведені дослідження у галузі спортивної психології; Пуні А.Ц. - у Ленінградському інституті фізичної культури імені П.Ф. Лесгафта ввів і читав лекційний курс «Психологія фізичного 
THEORETICAL FOUNDATIONS OF THE FUNCTIONING OF EDUCATION. WAYS TO

IMPROVE THE EFFECTIVENESS OF EDUCATIONAL ACTIVITIES

виховання і спорту» (1946/47 н.р.); Ноель-Бейкер Ф. президент Міжнародної ради 3 питань спорту та фізичного виховання; Ферруччо Антонеллі був ініціатором I установчого конгресу Міжнародного співтовариства спортивних психологів 1965 р. в Римі. Також наразі добре відомі праці зарубіжних психологів спорту: Ванека М., Васілевскі Е., Кретті Б. Д., Мацака І., Мюллера 3., Навроцкой Б., Рокушфалві П., Шіллінг Г., Яффі М. та ін.

Психологія спорту - напрям психологічної науки, предметом дослідження якої є вивчення закономірностей прояву і розвитку психіки людини, а також групових взаємодій в умовах змагальної та тренувальної діяльності. (Корносенко, 2000, с. 5)

Психологія спорту розробляє психологічні основи навчання й виховання спортсменів в умовах змагального процесу, розкриває закономірності вироблення спортивних навичок та вмінь, досліджує поведінку спортсменів в умовах змагального процесу, розкриває закономірності формування вольових та моральних якостей, необхідних для досягнення перемоги у спортивних змаганнях. (Гогунов, 2002. с.5).

Психологія спорту - спеціальна галузь психологічної науки, предметом якої є психологічні особливості спортивної діяльності в їі різноманітних видах і психологічні особливості особистості спортсмена. Психологія спорту як спеціальна галузь психологічної науки вивчає закономірності прояву й розвитку психіки діяльної особистості у специфічних умовах фізичного виховання i спорту. (Гогунов, 2002. с.5).

Визначення ролі психолога у спорті займає чільне місце, до цього в якості психолога виступав тренер, який займався зі спортсменом, це зумовлено тим, що в Радянському союзі психологічна освіта отримала масовий характер лише в кінці XX ст., а організація підготовки психологів за кордоном орієнтується на традиції психологічного освіти, що склалися в США

в кінці XIX ст.(Гогунов, 2000, с. 47) Безумовно, хороший тренер володіє основами психології. Однак у тренера все ж головне завдання - це спортивні досягнення вихованців: голи, секунди, метри. Спортивний психолог, у свою 
THEORETICAL FOUNDATIONS OF THE FUNCTIONING OF EDUCATION. WAYS TO IMPROVE THE EFFECTIVENESS OF EDUCATIONAL ACTIVITIES

чергу, в процесі тренувань і змагань звертає увагу на підвищення стресостійкості спортсмена. Допомога психолога у спорті відноситься до галузі класичної психології (Гогунов, 2000, с. 47). Якісне регулярне консультування спортивного психолога налагоджує всі сфери: тренувальний процес, спілкування з людьми в повсякденному життя.

Робота спортивного психолога носить різнобічний характер: питання підвищення результатів, ефективності спортивної діяльності дають відповіді, які виходять за межі спорту i змагань. Перед спортивним психологом стоїть завдання розуміння і оцінки власних дій i їх наслідків, можливих способів кооперації з іншими фахівцями та досягнення продуктивних відносин зі спортсменом.( Яковлев, 2014, с. 145)

Головним суб’єктом такої кооперації є- тренер. У спорті тренер, безумовно, найголовніший наставник, причому для юного спортсмена він є ще й орієнтиром в становленні особистості. Спостерігаючи за розвитком професійного спорту в нашій країні, можна зробити висновок, що тренеру, крім прямих професійних обов'язків, доводиться виконувати функції менеджера, адміністратора i, звичайно, психолога. Але основними причинами, чому тренер не може повністю замінити психолога, полягає в тому, що проблема може бути непомітною для недосвідченого ока. По-друге, базові знання з психології, які отримані під час навчання у ЗВО або здобуті з популярної літератури, нерідко створюють ілюзію про здатність вирішити будь-яку психологічну проблему, а неграмотне застосування психотехнік може призвести до негативних наслідків. Сказане, звичайно, не відноситься до тих людей, хто серйозно намагається зрозуміти і розібратися в механізмах роботи психіки та способи впливу на неї. Адже більшість спортивних психологів - це спортсмени або тренери, які глибоко знають і спорт, і психологію. Основною метою роботи психолога є «буферізація» між тренером і гравцем. Якщо тренер налаштовує спортсмена на перемогу, розвиваючи спортивну злість і інші види поведінки, які викликають стрес, то психолог, маючи в арсеналі сучасні методики, пом'якшує тиск, не впливаючи при цьому на досягнення хорошого результату. У системі «тренер-спортсмен- 
THEORETICAL FOUNDATIONS OF THE FUNCTIONING OF EDUCATION. WAYS TO

IMPROVE THE EFFECTIVENESS OF EDUCATIONAL ACTIVITIES

психолог» саме спортсмен є ключовою фігурою. Мотивація до спортивної діяльності виступає в ролі системоутворюючого фактору, а механізм зворотного зв’язку - є успішний результат спортсмена. Саме формування мотивації до спортивної діяльності, до досягнення високих результатів $є$ однією 3 найважливіших задач психолога i тренера. Лише цілеспрямована взаємодія психолога і тренера може дозволити дійти до успішного фінішу.

Взаємозв’язок у системі «тренер-спортсмен-психолог» доцільно розглядати через функції, які виконує кожен із суб'єктів процесу тренування (Табл. 1).

Таблиця 1

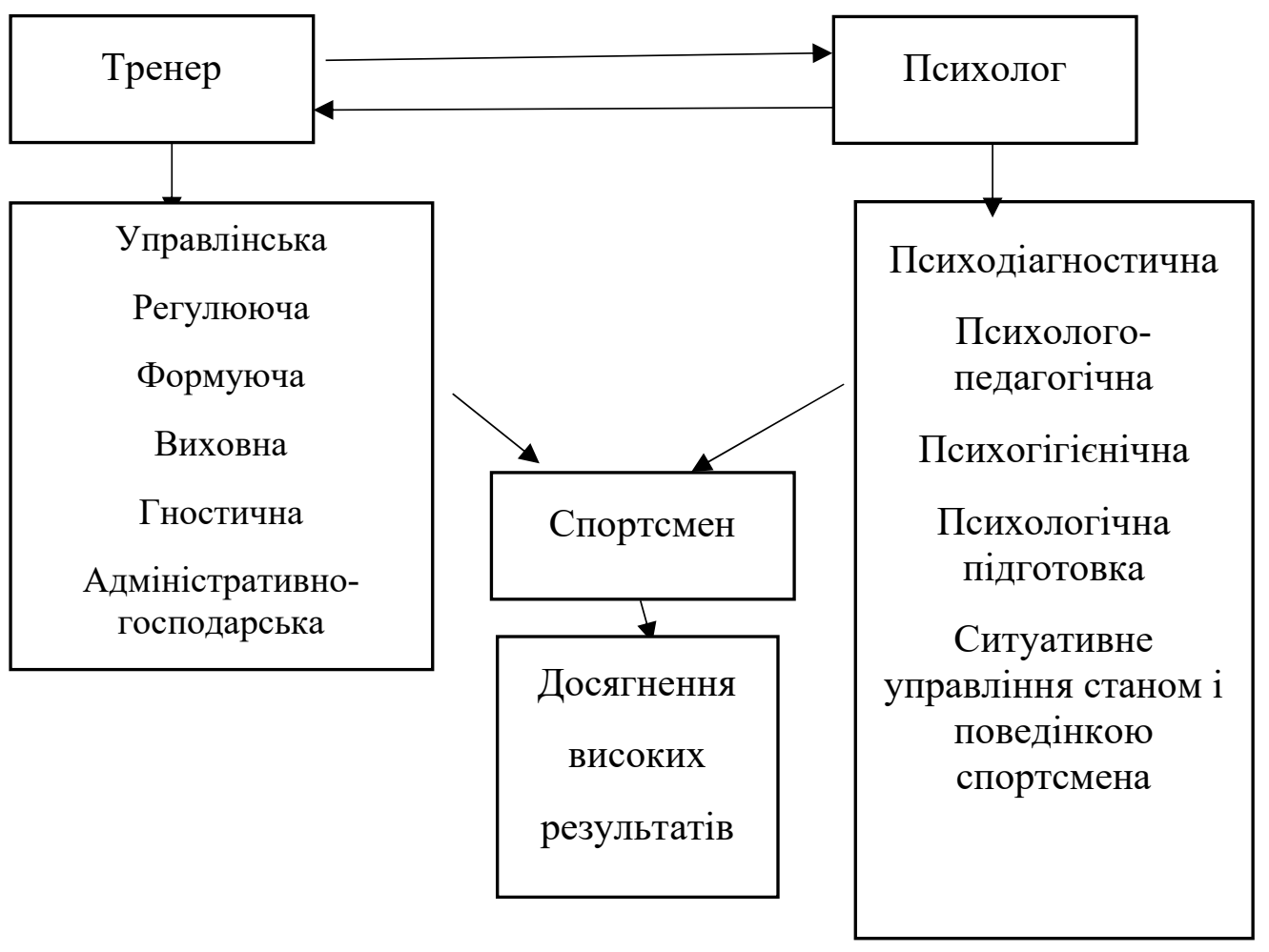

Управлінська функція тренера передбачає аналіз інформації для приймання управлінських рішень, від правильності яких залежить успіх його вихованців. Завдяки цій функції, саме тренер є головнокомандувачем у системі «тренер-спортсмен-психолог», який своїми діями впливає на кінцевий результат спортсмена, а також на подальшу діяльність психолога. Саме управлінська 
THEORETICAL FOUNDATIONS OF THE FUNCTIONING OF EDUCATION. WAYS TO

IMPROVE THE EFFECTIVENESS OF EDUCATIONAL ACTIVITIES

функція тренера дає змогу психологу формувати вольову готовність до виступу на змаганнях.

Виконуючи регулюючу функцію, тренер тісно взаємопов'язаний iз психологом. Напередодні змагань спортсмен перебуває в стані близькому до психічних зривів, до перевтомлення. Основним завданням і психолога, і тренера є знайти причини зриву, максимально переключити увагу на сприятливі думки, за допомогою психорегулюючих вправ і методик відновлення спокою.

За допомогою формуючої функції тренер забезпечує організацію навчально-педагогічного процесу, а завдання психолога максимально сприяти розвитку психічних функцій (уваги, мислення, пам’яті, сприймання). Для успішного кінцевого результату формування рухових якостей і психічних явищ здійснюється в екстремальних умовах тренувальної і змагальної діяльності. Цей процес проходить на базі автоматизованого управління діями, що складаються 3 певної системи рухів.

Психолого-педагогічна функція психолога i виховна тренера тісно взаємопов’язані. Тренер разом 3 психологом має сформувати дружний згуртований колектив, в якому кожен окремий його член відчуває загальну підтримку, турботу. Як тренер, так і психолог мають володіти якостями i навичками, необхідними для педагогічної і тренерської діяльності.

Психологічна підготовка і гностична функція мають спільну мету надання спортсмену необхідних знань i умінь, стимулювання його до пізнавальної активності, до загальної психологічної підготовки тренувань і змагань, до корекції психічних процесів на завершальному етапі підготовки до змагань.

Адміністративно-господарська функція тренера має безпосередній вплив у системі «тренер-спортсмен-психолог». Завдяки ій відбувається матеріальне забезпечення тренувального процесу, пошук і фінансування змагань.

Важливу роль у розвитку особистості спортсмена і на подальшу діяльність тренера відіграє психодіагностика. Завдяки саме психодіагностиці відбувається формування психолого-педагогічних i психогігієнічних рекомендації, 
THEORETICAL FOUNDATIONS OF THE FUNCTIONING OF EDUCATION. WAYS TO

IMPROVE THE EFFECTIVENESS OF EDUCATIONAL ACTIVITIES

планування системи дій на спортсменів. Психодіагностика ставить за мету вивчення спортсмена. Тренер в цьому процесі допомагає об’єктивно оцінити особистість спортсмена.

Психогігієнічні рекомендації психолога і тренера мають тісний зв'язок. Адже в системі «тренер-спортсмен-психолог» вони напряму впливають на психічний стан спортсмена.

Виходячи з вищезазначеного, можна сказати, що тісна співпраця тренера $\mathrm{i}$ психолога забезпечить досягнення результатів спортсмена. Значна кількість фахівців фізичної культури, які задіяні у процесі підготовки спортсменів до змагань, розуміють значення психологічних факторів, які впливають на ефективність і результативність спортсмена. Але мало хто вважає за необхідне приділяти постійну увагу знанням теорії i практики психології спорту у тренувальній і змагальній діяльності спортсмена. Тенденцію обов’язкової присутності психолога в команді в періоди підготовки або під час проведення змагань можна спостерігати у зарубіжних країнах, де психолог - штатний працівник.

Беручи до уваги спостереження за спортсменами нашої держави, варто зазначити, що зараз все ще не приділяється уваги системній роботі психолога у підготовці спортсмена. Існує декілька причин, які призвели до появи недовіри 3 боку тренерів до психолога. По-перше, так відбувається, коли тренер змушує розібратися в проблемі спортсмена в короткочасний період, нехтуючи спланованим курсом психологічної підтримки. По-друге, це відмінності в установках тренера та спортсмена. Так відбувається тоді, коли тренер вимагає від психолога виконання конкретних завдань стосовно підготовки спортсмена, але сам не співпрацює з ним, не виконуючи поради та рекомендації. По-третє, у особистості психолога має поєднуватися специфічні особливості спортивної діяльності та психологічні моменти кожного конкретного виду спорту.

Різноплановість у роботі тренера, важливість низки допоміжних функцій у роботі останнього (адміністрування, регулювання, управління) не дає можливості адекватно оцінювати проблеми та негаразди спортсмена як 
особистості. Саме в цьому полягає завдання спортивного психолога - створити атмосферу цілковитої довіри та взаєморозуміння, встановити контакт зі спортсменом для розкриття особистих проблем, який дозволить ефективно вплинути на його стан.

Таким чином, взаємозв'язок тренера і психолога у процесі професійної діяльності має велике значення на кар'єру спортсмена. Роль психолога у спорті $\epsilon$ багатогранною, яка спрямована на підготовку спортсмена до змагань.

Психологічна підтримка 3 боку психолога носить профілактичний i коригуючий характер, спираючись на психопедагогічні функції. У тісному взаємозв'язку психолога i тренера спортсмен має можливість оволодіти прийомами аутопідтримки та аутокорекції. Це дасть можливість самостійно вирішувати нагальні психологічні потреби.

Подальші наукові дослідження можуть стосуватися розроблення методик впливу на психіку спортсмена у передзмагальний і змагальний період. 
DOI 10.46299/ISG.2021.MONO.PED.II-122-130

\section{4 Теоретичні основи концепції педагогічного впливу на розвиток професіоналізму майбутніх вихователів}

Дошкільна освіта $є$ первинним елементом освітньої системи України. Адже, основа майбутньої особистості закладається ще у ранньому віці. Саме тому, виховання здорової та компетентної особистості, забезпечення якісної та доступної дошкільної освіти є головними пріоритетами сучасної політики держави. Дійсно, дошкілля є тим самим фундаментом сучасної системи безперервної освіти, який вкрай необхідно зробити міцним. Відтак, дошкільна освіта має трансформуватися в гнучку, науково обгрунтовану й варіативну систему, яка реалізує державне замовлення та відповідає запитам споживачів дошкільних освітніх послуг, що належать до різних соціальних груп.

Спрямованість дошкільної освіти на кінцевий педагогічний результат всебічний розвиток особистості дитини та забезпечення іiі успішності на наступних ступенях навчання, передбачає високий рівень професіоналізму вихователів закладів дошкільної освіти.

У зв'язку з цим, модернізація системи освіти в умовах сьогодення висуває нові вимоги до професійної діяльності педагогів дошкільних навчальних закладів. Їх зміст полягає в забезпеченні розвитку інноваційних процесів та їх запровадження в професійну діяльність. Ці вихідні концептуальні положення закладено у таких документах, як: Державна національна програма «Освіта» («Україна ХХІ століття») (1994р.) Законах України «Про освіту» (1996р.), «Про дошкільну освіту (2003р.), Національна стратегія розвитку освіти в Україні на 2012-2021 pp. (2012 р.), галузева Концепція розвитку неперервної педагогічної освіти (2013 р.), Концепція Державної цільової програми розвитку дошкільної освіти на період до 2017 року.

Враховуючи наведені вихідні положення, визначимо сили, які, на нашу думку, зумовлюють прогресивний розвиток особистості вихователя. По-перше, це висока внутрішньо диференційована вмотивованість у здійсненні продуктивної педагогічної праці; по-друге, оформлення власної ціннісно- 
THEORETICAL FOUNDATIONS OF THE FUNCTIONING OF EDUCATION. WAYS TO

IMPROVE THE EFFECTIVENESS OF EDUCATIONAL ACTIVITIES

смислової свідомості; по-третє, оптимізація культурно-освітнього простору, який сприятиме збереженню соціальної цілісності та особистісної самореалізації фахівця дошкільної педагогіки.

Одним із базових, інтегрувальних складників готовності майбутнього педагога-вихователя є мотивація до професійного самовдосконалення, адже саме вона забезпечуватиме прогресивний розвиток особистості відповідно до вимог професійної діяльності.

Тобто, зі зміною мотиваційної сфери майбутнього фахівця дошкільної освіти починає знаходити своє відображення ціннісне ставлення до професіоналізму педагогічних працівників, поява більшої здатності мобілізувати себе на подолання труднощів, більш об'єктивне оцінювання своїх сильних i слабких сторін, уміння аналізувати успіхи, невдачі, можливості, творчий підхід та ініціативність в професійній діяльності, сформованість емоційноспонукальних чинників самоосвітньої діяльності.

Метою діяльності вихователів закладів дошкільної освіти є досягнення ними максимально можливого рівня підготовленості до акмесинергетичного професійного самовдосконалення, що, своєю чергою, детермінується актуалізацією рефлексивно-аксіологічного потенціалу.

Таким чином, орієнтуючись на реалізацію незадіяного в роботі особистісного потенціалу педагогів-вихователів, очікується їхня спрямованість на продуктивну професійну діяльність саме від процесу ціннісно-смислової самоорганізації: набуття мотивів розвитку професіоналізму, усвідомлення сутнісних екзистенціальних характеристик професійної діяльності, прояв суб'єктної активності стосовно себе, глибоке і всебічне самопізнання, критичне рефлексування власного життєвого шляху.

Зауважимо, що потреба майбутнього вихователя в розвитку педагогічного професіоналізму визначається актуалізацією певних характеристик цього процесу (рівень розвитку самосвідомості, самовизначення, самопрогнозування, самовиявлення тощо) й забезпечується базовим рівнем особистісного саморозвитку, насиченістю життя особистості педагога та виникає при зміні 
THEORETICAL FOUNDATIONS OF THE FUNCTIONING OF EDUCATION. WAYS TO IMPROVE THE EFFECTIVENESS OF EDUCATIONAL ACTIVITIES

змістової структури індивідуальної свідомості й трансформації смислових утворень. У зв’язку з цим, психолого-педагогічним умовами, що забезпечуватимуть успішність цього процесу, вважаємо: наявність чітко усвідомленої мети самоздійснення (врахування особистісних, професійних i життєвих цілей) як орієнтира самовдосконалення та активної життєвої стратегії якісних самозмін.

Виходячи $з$ того, що сьогодні в центр будь-яких перетворень поставлено особистість, то існуюча система вищої освіти ще 3 більшою оперативністю покликана реагувати й перебудовувати свою діяльність відповідно до людиноцентристського підходу: визнання людини як найвищої соціальної цінності, повага до особистості, іiі гідності, інтересів, створення оптимальних умов для прогресивного розвитку творчої індивідуальності.

Навчання педагогічних кадрів на засадах гуманізму як фундаментальних загальнолюдських цінностей гарантує забезпечення гуманістичного самовизначення вихователів, набуття ними теоретичних знань і умінь, так необхідних для успішної реалізації свого гуманістичного потенціалу у професійній діяльності. Адже вершиною гуманоцентризму $\epsilon$ реалізація принципу людяності. Навіть у системі післядипломної освіти є потреба нагадувати викладачам про особливості індивідуального підходу до слухачів. Будь-яке знання, за яким прийшла людина, може бути сприятливим за умов розуміння особливостей iї індивідуальних інтересів та уподобань, iі ідеалів та мpiï.

Так, А. Роботова зазначає, що викладач є найкомпетентнішим фахівцем, який володіє мистецтвом перетворення людини. Він активно, повсякденно, цілеспрямовано впливає на розум і знання особистості, рухаючи їі від темряви до світла; почуття, за допомогою яких пробуджується й розвивається позитивне ставлення до прекрасного, доброго, довічного [114, с. 18].

Розмірковуючи подібним чином, ми дійшли висновку, що гуманоцентризм $\epsilon$ системою взаємосприятливих, доброзичливих, гармонійних людських відносин, основу яких складає людяність, справедливість, віра, доброта. Тому 
THEORETICAL FOUNDATIONS OF THE FUNCTIONING OF EDUCATION. WAYS TO

IMPROVE THE EFFECTIVENESS OF EDUCATIONAL ACTIVITIES

саме гуманоцентризм має бути визнаним сучасною фундаментальною парадигмою педагогічної діяльності, що потребує концептуальної розвиненості й інституціалізації.

Тому, наступним закономірним кроком у побудові концепції педагогічного впливу на розвиток професіоналізму педагогів-вихователів закладів дошкільної освіти виступатиме висвітлення такого явища як фасилітація (facilitate полегшувати, сприяти, допомагати, створювати сприятливі умови). Під фасилітацією в системі вищзӧ освіти розуміють недирективну форму педагогічного впливу, що надихає та стимулює майбутніх вихователів до особистісно-професійного зростання.

Цілі, завдання та принципи вищої освіти висувають високі вимоги до викладача університету. Це - педагог, який має дослідницькі, аналітичні та викладацькі здібності, вміє практично інтерпретувати сучасні наукові досягнення, насамкінець, володіє даром професійного передбачення.

В умовах глибоких концептуальних змін у системі підготовки i педагогічних кадрів та їі корегування, задачі діяльності викладача мають бути зорієнтовані на:

- гуманізацію відносин в освітньому просторі, забезпечення просування та розвитку в рефлексивно-інноваційному середовищі ціннісносмислових орієнтирів: базових загальнолюдських цінностей добра, любові, свободи, гідності, міжнаціональної злагоди, толерантності й терпимості;

- підготовку майбутніх вихователів до адаптації своїх індивідуальнопсихологічних особливостей у відповідності 3 вимогами до педагогічної діяльності, безперервного розвитку соціально-моральних та інших властивостей особистості;

- організацію навчання на базі яскравих i талановитих фахівців дошкільної освіти області, які консультують або навчають на власному досвіді у своєму закладі дошкільної освіти;

- $\quad$ підвищення рівня загальнодидактичної та методичної підготовленості педагога-вихователя; 
THEORETICAL FOUNDATIONS OF THE FUNCTIONING OF EDUCATION. WAYS TO IMPROVE THE EFFECTIVENESS OF EDUCATIONAL ACTIVITIES

- діагностику специфічних тенденцій в освітньому середовищі, професійних та особистісних змін;

Ми дійшли висновку, що інтенсифікація розвитку педагогічного професіоналізму майбутніх вихователів закладів дошкільної освіти залежить від багатьох чинників, у тому числі й від того, наскільки ефективно буде організована фасилітативна взаємодія між суб' єктами освітнього процесу.

Слід зазначити, що здатність викладачів до фасилітуючого спілкування дає змогу здійснювати максимальне наближення до конкретних потреб майбутніх педагогів-вихователів, що надихає і мотивує їх до інтенсивного, свідомого самооновлення у відповідності до особистісно пріоритетних сенсів самоорганізації, тим самим актуалізуючи процес його спрямованого i продуктивного розвитку професіоналізму.

Психолого-педагогічне пояснення такого екофасилітативного підходу знаходимо в наукових доробках Т. Сущенко, яка розглядає це явище як процес взаємного духовного збагачення викладачів і студентів в умовах психологічнокомфортних відносин, інтелектуальної співтворчості й бездоганної діалогічної культури. На думку, дослідниці, така взаємодія є складовою зазначеного процесу і являє собою цілеспрямовану діяльність, що передбачає прагнення до зближення та злагоди між учасниками процесу; уміння викладачів запропонувати студентам таку форму життєтворчості, яка захоплює, дивує та вражає; таке ставлення до людини, яке сприяє розкриттю його самобутності, вихід з простору вимушеного спілкування й поетапний розвиток духовного потенціалу особистості педагога $[115$, c. 463$]$.

Підсумовуючи вищезгадане, зазначимо, що дотримання викладачем у навчальному процесі пріоритетних фасилітуючих принципів створює особливу атмосферу духовної критики, взаємної поваги та підтримки, що сприяє максимальній розкутості та самовираженню курсантів, а педагогічний процес у такому разі природно й непомітно для студенрів перетворюється в науковий пошук. Зробимо спробу доповнити наявні концептуальні підходи перспективою ще одного напряму, який надасть змогу по-іншому підійти до розуміння 
THEORETICAL FOUNDATIONS OF THE FUNCTIONING OF EDUCATION. WAYS TO

IMPROVE THE EFFECTIVENESS OF EDUCATIONAL ACTIVITIES

категорії професіоналізму вихователя закладу дошкільної освіти й оцінки його педагогічної діяльності. Загальновідомим є той факт, що освіта, яку здобуває фахівець 3 опорою на особистісний досвід, $є$ найбільш ефективною i продуктивною формою навчання. Освіта, яку отримує майбутній вихователь в процесі навчання передбачає оволодіння теоретичними знаннями, професійними вміннями та навичками, педагогічними якостями, які педагог має показати у процесі своєї подальшої професійної діяльності. Педагогічна вища освіта майбутніх вихователів має бути націлена на збільшення кількості годин практики, як навчальної так і виробничої, адже під час практики відбувається занурення майбутніх педагогів у світ дошкільної освіти, здобувачі вищої освіти навчаються встановлювати контакт 3 дітьми, планувати освітню діяльність, організовувати освітній процес, здійснювати навчання та виховання дошкільників. Викладачі закладу вищої освіти як керівники практики мають здійснювати супровід, підтримку майбутніх педагогів, надавати відповідні консультації, методичні рекомендації. Саме за умови злагодженої діяльності студентів та викладачів може бути позитивний результат навчання. Враховуючи сучасні зміни в освіті та зміни ролей педагогів, викладач має бути i консультантом, організатором, фасилітатором, ментором, коучем тощо. Викладач має бути партнером для студента у навчанні, але при цьому мати свій авторитет серед студентської спільноти.

Враховуючи сучасні зміни в освіті викладач має використовувати нові підходи до навчання студентів. Враховуючи стрімкий розвиток інформаційних технологій сучасний освітній процес вже не сприймається здобувачами освіти якщо він відбувається без використання проектору, мультимедійної дошки, різноманітних онлайн-технологій. Також враховуючи зміни у розвитку молодого покоління викладач має використовувати на заняттях інтерактивні вправи, ділові ігри, різноманітні форми практичної роботи студентів. Сучасні здобувачі освіти прагнуть щоб іх думка була почута, а ідеї - реалізовані. Тому в організації 
THEORETICAL FOUNDATIONS OF THE FUNCTIONING OF EDUCATION. WAYS TO

IMPROVE THE EFFECTIVENESS OF EDUCATIONAL ACTIVITIES

освітнього процесу із молодими вихователями постає питання про створення умов навчального середовища.

Наше бачення розв’язання проблеми диференціації полягає у необхідності створення оптимальних умов для творчого та професійного розвитку особистості майбутнього вихователя, реалізації особистісно орієнтованої моделі організації навчальної роботи, яка передбачає відмінності у змісті та формах навчання, визначення рівнів навчання та навченості, реалізації своїх потенційних задатків і можливостей під час розроблення індивідуальних програм саморозвитку тощо.

Відтак, стає зрозумілим, що зміст навчального матеріалу та форми його реалізації необхідно обирати залежно від початкового рівня компетентності студента, його психологічних особливостей, індивідуальних потреб, сформованих практичних навичок. Ми виходимо з усвідомлення диференціаціï прощесу навчання як полівекторності підходів (індивідуальних, групових, колективних) до реалізації змісту освіти та досягнення фундаментальної мети: активне якісне перетворення майбутнім педагогом-вихователем власного внутрішнього світу, орієнтуючись на високі професійні успіхи й перемоги.

Науково-методичним джерелом і програмним координатором цих якісних змін стають саме викладачі вищої освіти, які актуалізують необхідність організації педагогічного супроводу становлення професіоналізму майбутніх вихователів. Виходячи з цих позицій, вважаємо, що квінтесенцією у забезпеченні якості освіти має той факт, яким чином побудовано й організовано навчальний процес, наскільки застосовувана організаційна структура навчання відповідає іï цілям, змісту, насамперед, потребам і тих, кого навчають, і тим, хто навчає.

Досить впливовим аргументом на користь впровадження в систему вищої освіти є технологія концентрованого навчання - особлива технологія організації навчального процесу, за якої увага викладачів зосереджується на більш глибокому вивченні кожної дисципліни за рахунок об’єднання занять, скорочення кількості дисциплін, які вивчаються паралельно упродовж навчального дня, тижня та більш крупних одиниць навчання (Г. Ібрагімов). Сутнісними ознаками такої технології є: подолання поліпредметності 
THEORETICAL FOUNDATIONS OF THE FUNCTIONING OF EDUCATION. WAYS TO

IMPROVE THE EFFECTIVENESS OF EDUCATIONAL ACTIVITIES

навчального дня або тижня; разова тривалість вивчення дисципліни або іï окремого модуля; неперервність процесу пізнання та його цілісність; укрупнення змісту та форм організації навчального процесу; інтенсифікація педагогічного процесу по кожній дисципліні [116, с. 15].

Таке бачення навчання майбутніх педагогів дошкільної освіти зумовлене низкою переваг запропонованої технології перед існуючими, по-перше, нейрофізіологічною основою $є$ закон домінанти або домінантний механізм роботи мозку, який забезпечує природну потребу в інтелектуальній активності; nо-друге, психофізіологічним базисом слугують закономірності динаміки працездатності особистості; по-трете, можливістю за мінімально можливий навчальний час забезпечити ефективне засвоєння максимально можливого матеріалу (потужна активізація пізнавальної діяльності); по-четверте, глибоке занурення (зосередження зусиль) до певної дисципліни (або модуля), спрямоване на цілісність педагогічного процесу. На нашу думку, такі теоретичні основи (нейрофізіологічні, психофізіологічні, психологічні, дидактичні) концентрованого навчання $€$ рушійними силами адаптації післядипломної педагогічної освіти до нових умов інтенсивного розвитку взагалі, й оновлення всієї системи безперервного розвитку педагогічних кадрів, зокрема.

3 огляду на те, що в умовах сьогодення система дошкільної освіти перейшла на новий етап розвитку - оновлення нормативної бази, формування й розвиток мережі ЗДО, які забезпечують гнучкість та розмаїття наданих послуг: міні-садки, групи короткочасного утримання, дошкільні навчальні заклади санаторного типу (оздоровчі), сімейні дошкільні навчальні заклади, ігрові центри, лекотеки та ін. - всі ці зміни передбачають активну участь вихователів у відборі методів та прийомів роботи 3 дітьми, розробці та адаптації змісту відповідно до особливостей конкретного дитячого колективу, врешті-решт наявність професійної мобільності.

На нашу думку, особливе місце займає позиція В. Кременя, який акцентує увагу на тому, що «людина інноваційного мислення, інноваційного типу культури, здатної до інноваційного типу діяльності - лише така людина може 
бути конкурентоспроможною, такі люди можуть скласти мобільне суспільство, мобільну націю. Тому формування інноваційної людини - нагальне завдання освіти» $[117$, с. 16$]$.

У зв'язку з цим слід відзначити важливість та актуальність думки В. Андрущенка стосовно того, що «чим вищий рівень розвитку соціальнопрофесійної мобільності педагогів, тим більш інтенсивно вони залучені в інноваційний процес, оскільки новації і мобільність в сучасних освітніх закладах - це два чинники, взаємопов'язаних і взаємовпливаючих один на одного. При цьому соціально-професійну мобільність можна розглядати як засіб, спосіб і результат освоєння новацій педагогом, що свідомо включається в інноваційну педагогічну діяльність і фундаментально підготовлений до здійснення цього процесу. Це об'єктивно посилює вимоги до якості професійної підготовки на етапі навчання, де, власне, і розкривається інноваційний потенціал особистості педагога як «суб'єктивне джерело зародження інновацій» у професійній діяльності, як «особливість стану індивідуальної свідомості педагога, його відкритість до сприйняття нового, незалежність від стереотипів та шаблонів» [118, с. 61].

Отже, педагогічний вплив та його концепції мають велике значення у формуванні майбутнього конкурентноспроможного, сучасного, професійного вихователя закладу дошкільної освіти. 
DOI 10.46299/ISG.2021.MONO.PED.II-131-138

\section{5 Професійна підготовка майбутніх педагогів до інноваційної діяльності в інклюзивних умовах закладів дошкільної освіти}

Орієнтація українського суспільства на демократичні принципи, реорганізація системи освіти на забезпечення рівних можливостей для здобуття освіти всіх без винятку громадян, зумовлюють необхідність впровадження нових прогресивних концепцій, запровадження в освітній процес сучасних педагогічних технологій, нового ставлення до формування професійних знань, умінь та навичок випускників закладів вищої освіти. Відповідно до Закону України «Про вищу освіту» перед викладачами університетів, які готують фахівців 3 напряму підготовки «Дошкільна освіта», «Спеціальна освіта (Логопедія)», «Початкова освіта», постає цілий ряд нових викликів, які потребують негайної реалізації [119].

Проблема підготовки фахівців дошкільної освіти висвітлена у працях провідних вчених (А. Богуш, Н. Гавриш. І. Дичківської, К. Крутій , Ю. Рібцун, Т. Поніманської та інших), спеціальної освіти (В. Бондаря, В. Синьова, А. Колупеєвої, А. Шевцова, М. Шеремети та ін.) [120].

Відповідні зміни щодо забезпечення інклюзивної освіти, на сьогодні, введено в законодавчі та нормативно-правові документи, що стосуються дошкільної, загальної середньої та вищої ланок освіти. «Інклюзивне навчання» це система освітніх послуг, гарантованих державою, як визначено в Законі «Про освіту», що базується на принципі недискримінації, врахуванні багатоманітностей людини, ефективному залученні та включені до освітнього процесу всіх його учасників». «Інклюзивне освітнє середовище»- сукупність умов, способів і засобів їх реалізації для спільного навчання, виховання та розвитку здобувачів освіти з урахуванням їхніх потреб та можливостей [121].

Інклюзивна освіта в закладах дошкільної освіти - педагогічна інновація, що знаходиться на стадії впровадження, а тому має немало протиріч. По-перше, це професійна непідготовленість педагогів дошкільних груп до роботи з дітьми 3 особливими освітніми потребами (відсутні знання). По-друге, академічна 
THEORETICAL FOUNDATIONS OF THE FUNCTIONING OF EDUCATION. WAYS TO IMPROVE THE EFFECTIVENESS OF EDUCATIONAL ACTIVITIES

перевантаженість дошкільних навчальних програм, які досить важко адаптувати до потреб дитини з вадами у розвитку. Скорочення змісту навчального матеріалу може полягати у модифікації навчального плану або освітніх цілей для конкретної дитини, внесенні змін до навчальних завдань, визначенні обсягу знань, які їй необхідно засвоїти. По-третє, архітектурна непристосованість споруд. Деякі особливості облаштування фізичного середовища зумовлені особливими потребами дітей (фізичними, психологічними), тому перш ніж відкривати інклюзивні групи, керівник навчального закладу повинен у контексті організації освітнього середовища чітко визначити (згідно статті 2 Конвенції ООН про права осіб з інвалідністю), основні принципи універсального дизайну: рівноправне використання; гнучкість користування; сприйняття інформації 3 урахуванням різних сенсорних можливостей; припустимість помилок; низький рівень фізичних зусиль; наявність необхідного розміру i простору [122]. По-четверте, необхідне доопрацювання нормативно-правої бази, є потреба додаткового фінансування інклюзивних закладів освіти, чітке регулювання системи методичного забезпечення інклюзивної освіти дітей дошкільного віку.

Позитивний вплив інклюзивної освіти демонструє досвід європейських країн. Вчені доводять, що діти, які мають нормативний розвиток, навчаються сприймати відмінності між людьми як нормальне явище, шанувати людську гідність, бути відповідальними за інших, уважними до потреб оточуючих. Залучення до масових навчальних закладів дітей 3 особливими потребами вимагає від усіх учасників цього процесу певного перегляду традиційних поглядів щодо мети, функцій, організації роботи закладу. Проте, до найактуальніших проблем успішної реалізації інклюзивного навчання належить питання професійної підготовки майбутніх педагогів до роботи в нових умовах закладу дошкільної освіти.

3 огляду на вище зазначене, на сьогодні є актуальною проблема підготовки майбутніх педагогів до інноваційної професійної діяльності в інклюзивних умовах закладів дошкільної освіти. 
THEORETICAL FOUNDATIONS OF THE FUNCTIONING OF EDUCATION. WAYS TO IMPROVE THE EFFECTIVENESS OF EDUCATIONAL ACTIVITIES

Особливої уваги заслуговує проблема підготовки вихователів дошкільних груп до роботи в умовах інклюзивної освіти, оскільки функції вихователя значно розширюються. Як зазначає Ю. Рібцун, в умовах логопедичної групи чи спеціального закладу дошкільної освіти, крім загальноосвітніх заходів, передбачених масовою програмою навчального закладу, повинен виконуватись цілий ряд специфічних корекційних завдань, спрямованих насамперед на усунення первинного мовленнєвого дефекту та вторинних психофізіологічних нашарувань. Водночас слід пам’ятати, що корекційно-виховний напрямок занять у логопедичній групі є першочерговим, а загальноосвітній - другорядним. На відміну від масового ЗДО, вихователь логопедичних груп приділяє значну увагу мовленнєвій роботі [120]. Тобто, крім основних (навчальної, виховної, розвивальної), вихователь в умовах інклюзивної групи повинен виконувати такі функції:

- просвітницьку (інформування громадськості про особливості інклюзивного навчання);

- $\quad$ рефлексивну (уміння розробляти показники для аналізу корекційно педагогічного процесу й пошуку шляхів його корегування);

- інноваційну(використання інноваційних технологій в роботі 3 дітьми 3 особливими потребами).

Для виконання цих функцій, вихователь дошкільних груп має володіти знаннями $з$ фахових дисциплін, методиками корекційної роботи 3 дітьмилогопатами та здоровими дітьми. Навчальна програма закладу вищої освіти повинна передбачувати для фахівців 3 дошкільної освіти уміння і навички складання індивідуальної програми розвитку для дитини з особливими освітніми потребами. Як зазначає А. Колупаєва, основна мета загальноосвітнього навчального закладу, в якому впроваджується інклюзивне навчання, - надання індивідуально-орієнтованої педагогічної, психологічної та соціальної допомоги дітям, що мають особливі освітні потреби [123]. Відповідно, в освітні навчальні програми спеціальності 012 «Дошкільна освіта» має бути включений блок «Особливості створення індивідуальної програми розвитку для дітей 3 
THEORETICAL FOUNDATIONS OF THE FUNCTIONING OF EDUCATION. WAYS TO IMPROVE THE EFFECTIVENESS OF EDUCATIONAL ACTIVITIES

особливими освітніми потребами». Індивідуальну програму розвитку створюють на основі навчальної програми яка затверджена навчальним закладом освіти i має такі розділи: загальні дані про дитину, особливості психофізичного розвитку, термін на який складається програма; студенти повинні вміти, залежно від складності порушень розвитку вивчати можливості та потреби дитини. За висновками фахівців інформаційно - ресурсного центру вихователі повинні узагальнити інформацію щодо впливу порушень розвитку дитини на її здатність до навчання та мати уяву про додаткові послуги педагогів, та інших фахівців, які необхідні дитині для засвоєння навчальної програми. Зміни до навчального змісту програми стосуються як його змісту, так і складності навчального завдання і ця нова функція вихователя повинна бути сформована під час аудиторних, практичних занять у закладі вищої освіти. У випадку, коли дитина переїжджає в інший район, новий педагог повинен отримати IНП і дізнатися, що саме необхідно для навчання й розвитку вихованця. Ознайомившись 3 IНП, батьки повинні розуміти: чому їхня дитина потребує особливого навчання; хто буде проводити навчання; де відбуватиметься навчання; тривалість навчання; програма оцінювання; скільки часу їхня дитина проводитиме в спеціальному навчальному закладі; які заходи здійснюватимуться для дитини, наприклад, професійна та фізична терапія, надання порад, консультацій, перевезення.

Виконуючи професійні функції вихователь має дотримуватись принципів роботи в інклюзивних групах. Серед таких принципів: індивідуалізації та диференціації (вихователь має знаходити підхід до кожної дитини, враховуючи ii особливість та працюючи за індивідуальною програмою розвитку, диференціювати завдання для дітей відповідної вікової групи); принцип єдності сенсорного, комунікативного, фізичного розвитку (у відповідності до потреб дитини); підтримка самостійної активності дитини (вихователі мають надавати дітям час на вільні ігри, діяльність, підтримувати дитину у ініціативі активності); міждисциплінарного підходу (освіта дитини з психофізичним рушенням вимагає комплексного, міждисциплінарного підходу до визначення впровадження методів і засобів іiі виховання, навчання і розвитку); принцип співпраці 3 
THEORETICAL FOUNDATIONS OF THE FUNCTIONING OF EDUCATION. WAYS TO IMPROVE THE EFFECTIVENESS OF EDUCATIONAL ACTIVITIES

родиною (тільки у спільній діяльності закладу дошкільної освіти з батьками діток може бути ефективний результат); принцип варіативності в організації процесів навчання і виховання (закладу дошкільної освіти і вихователю має надаватись право у виборі навчальної програми за якою працювати, форм i методів організації освітнього процесу).

Важлива складова успішного функціонування інклюзивної системи освіти - командний підхід. Однак, практика спільного викладання ще не стала загальноприйнятою в системі надання вищої освіти в Україні. Тому, вважаємо за необхідне введення теми: «Форми спільного викладання» в дисципліну «Дошкільна педагогіка», де розкрити особливості командної освітньої роботи в інклюзивній групі; диференційованого викладання (робота 3 великою та малою навчальними групами); паралельне викладання (навчальний матеріал однаковий, а методи навчання можуть бути різними). Наукові дослідження (Н. Дятленко, Н. Софій, О. Мартинчук, Ю. Найда) визнають співпрацю як найбільш корисний i доступний ресурс, який є в розпорядженні педагогів системи загальної освіти. Посаду асистента вчителя, вихователя введено в українське законодавство та відображено в ряді нормативно - правових документів [124]. Робота з асистентом вихователя потребує вміння вихователя використовувати практику спільного проведення навчальних занять, навички спільного планування та обговорення освітнього процесу. Очевидно, що система професійної підготовки майбутніх фахівців дошкільної освіти, яка проводиться у закладах вищої освіти повинна відреагувати на виклики сьогодення і внести відповідні зміни у освітні та робочі програми дисциплін [125].

Під час підготовки майбутніх вихователів у закладі вищої освіти має бути передбачена навчальна і виробнича практика у різних типах закладів дошкільної освіти. Викладачі-керівники практик мають знайомити майбутніх педагогів 3 можливими умовами подальшої професійної педагогічної діяльності в інклюзивних групах закладів дошкільної освіти. Така робота має включати попередньо надані теоретичні знання студентам, які згодом вони зможуть реалізувати на практиці. Тільки через занурення майбутніх педагогів в освітній 
THEORETICAL FOUNDATIONS OF THE FUNCTIONING OF EDUCATION. WAYS TO

IMPROVE THE EFFECTIVENESS OF EDUCATIONAL ACTIVITIES

процес закладу дошкільної освіти, студент зможе відчути різницю діяльності вихователя у звичайній та інклюзивній групі. Вихователі які вже із студентських років отримували знання про роботу з дітьми з особливими потребами зможуть у практичній діяльності допомогти дитині 3 особливими потребами, а не нашкодити їй. На сьогодні за останніми дослідженнями та опитуваннями вихователів закладів дошкільної освіти, результати свідчать про те що педагоги не готові до роботи з дітьми з особливими потребами, за думкою вихователів їм не вистачає теоретичних знань, практичних вмінь та навичок, психологічної готовності працювати у групі де багато діток, але водночас тримати у полі зору дітей з особливими освітніми потребами.

Відповідно до положення Про команду психолого - педагогічного супроводу дитини з особливими освітніми потребами в закладі загальної та дошкільної освіти, затвердженого наказом МОН України від 08. 06. 2018p. за № 609, потребує особливої уваги вивчення майбутніми фахівцями методики складання, змісту, форми та послідовності засвоєння дитиною дошкільного віку з ООП, компонентів освітньої програми з метою реалізації іiі індивідуальної освітньої траєкторії [126]. У зв’язку з наявністю такої навчальної дисципліни як «Логопедія», передбачено опанування студентами закономірностей формування мовлення, принципів аналізу мовленнєвих порушень, оволодіння методами та прийомами діагностики, корекції вад мовлення у дітей, однак, мало уваги приділяється практичній діяльності вихователів закладів дошкільної освіти. Так, інклюзивно-ресурсні центри які проводять комплексну оцінку 3 метою визначення особливих освітніх потреб дитини, в тому числі коефіцієнта іï інтелекту, розроблення рекомендацій щодо освітньої програми, надання психолого-педагогічних та корекційно-розвиткових послуг відповідно до потенційних можливостей дитини, а спеціалісти закладів дошкільної освіти не завжди кваліфіковано можуть їх використовувати. Педагогічна пропаганда психолого-педагогічних та корекційно-розвиткових послуг дітям з особливими освітніми потребами, які надають ІРЦ теж іноді відсутні в арсеналі навчально - виховної роботи закладу дошкільної освіти. 
THEORETICAL FOUNDATIONS OF THE FUNCTIONING OF EDUCATION. WAYS TO IMPROVE THE EFFECTIVENESS OF EDUCATIONAL ACTIVITIES

В командах психолого-педагогічного супроводу дитини 3 особливими освітніми потребами у закладах дошкільної освіти, а також психолого- педагогічних комісіях спеціальних закладів загальної середньої освіти приймають участь педагогічні працівники інклюзивно-ресурсного центру 3 метою моніторингу динаміки розвитку дитини не рідше, ніж двічі на рік. Особливостям співпраці вихователів з різними фахівцями необхідно приділити більше уваги, оскільки здійснення спільного викладання позитивно впливатиме на якість освітнього процесу в інклюзивній групі [127, с. 10].

Залучення батьків дітей 3 особливими освітнім потребами до педагогічного процесу має свою специфіку. Дуже важливою та незвичною для педагогів є участь батьків у роботі команди психолого - педагогічного супроводу кожної дитини 3 особливими освітніми потребами. Необхідно педагогам інклюзивних груп навчитися активно залучати батьків до освітнього процесу на етапі оцінювання рівня розвитку дитини, планування іï освітньої траєкторії, участі у різних навчальних видах діяльності. Однак, перш за все, їх потрібно навчити давати об'єктивну оцінку навчальним знання, вмінням та навичкам своєї дитини з урахуванням іiі освітніх потреб. Одним із відповідальних завдань, які постають перед батьками на цьому етапі $є$ створення індивідуальної програми навчання та виховання дитини на основі їі актуального рівня розвитку, з метою визначення освітніх цілей і навчальних завдань, для здійснення необхідних змін в освітньому процесі та забезпечення додаткових потреб дитини. Завдання закладу вищої освіти полягає у виборі форм, методів, нових педагогічних технологій навчання майбутніх спеціалістів роботі в нових умовах інклюзивної освіти. Батьки мають право отримувати інформацію про освітній процес, про місію навчального закладу, додаткові можливості та послуги. Педагоги повинні вміти регулярно та вчасно надавати батькам дітей 3 особливими освітніми потребами інформацію щодо прогресу в розвитку дитини та його навчальній діяльності. Батьківська спільнота повинна розуміти значення закладу дошкільної освіти для дитини, сприймати вихователів як об’єктів педагогічного колективу які допоможуть дитині у їі розвитку [129]. 
Отже, одним із пріоритетних завдань державної політики є створення умов для розвитку сучасної системи інклюзивної освіти в Україні. Залучення до масових навчальних закладів освіти дітей з особливими освітніми потребами вимагає від усіх учасників цього процесу перегляду традиційних поглядів на мету, завдання, функції, організацію роботи педагогічного колективу в умовах сьогодення. Професійна підготовка майбутніх педагогів в умовах закладу вищої освіти повинна враховувати таку важливу складову успішного функціонування інклюзивної системи освіти - командний підхід. Завдання - розкрити особливості командної навчально-виховної роботи в інклюзивній групі: диференційованого викладання, паралельного викладання та ін. Наукові дослідження визнають також співпрацю як найбільш корисний і доступний ресурс, тому посаду асистента вчителя, вихователя введено в українське законодавство та потребує відпрацювання система співпраці 3 додатковими фахівцями. Робочі програми відповідних дисциплін закладу вищої освіти мають передбачувати включення для фахівців з дошкільної освіти формування умінь і навичок складання індивідуальної програми розвитку для дитини з особливими освітніми потребами. Активна участь батьків в освітньому процесі є однією 3 важливих передумов інклюзивної освіти. 
DOI 10.46299/ISG.2021.MONO.PED.II-139-147

\section{6 Християнська педагогіка - основа сімейного виховання дитини}

Аннотація. Православна сім'я - це структура, що має суворо вертикальну ієрархію. Главою сім'ї є чоловік, дружина залежить від чоловіка, а діти - від батьків. Головне завдання батьків - виховати християнина на основі взаємної любові та поваги один до одного, бачачи в дитині образ Божий.

Ключові слова: Християнська педагогіка, сімя, Закон Божий, християнське виховання, особистість, духовне життя.

Актуальність. Сім'я́ (Родина) — соціальна група, яка складається з людей, які зазвичай перебувають у шлюбі, їхніх дітей (власних або прийомних) та інших осіб, поєднаних родинними зв'язками з подружжям, кровних родичів, і здійснює свою життєдіяльність на основі спільного економічного, побутового, моральнопсихологічного укладу, взаємної відповідальності, виховання дітей [130, с. 3]. Сукупність різноманітних етнографічних, історичних даних та соціальна статистика свідчать про те, що людська сім'я є інститутом соціальним, а не біологічно зумовленим. Жодна світова релігія не відводить настільки важливе місце сім'ї в системі віровчення, як Християнство. Можна визначити саме християнство як релігію сім'ї та сімейних відносин.

Основний зміст. Сім'я функціонує на основі спільного побуту, економічного, морально-психологічного укладу, виховання дітей, взаємної відповідальності. Вона забезпечує соціалізацію людини, самореалізацію особистості, захист від проблем, сприяє формуванню особистості з усталеною поведінкою. Християнство створення сім'ї освячує в Таїнстві Шлюбу (Вінчання), одному з семи Таїнств Православної Церкви. Так високо шанується нею шлюб. Сам Господь Ісус Христос Своє служіння людству почав дивом на шлюбному бенкеті в Кані Галілейській (Ів. 2: 1-11). Апостол Павел вказує на три сутності людини: тіло, душу і дух (1 Сол 5, 23). Освячений Церквою шлюб об'єднує всі три складники людського єства. Сучасне православне богослов'я i, зокрема, протоієрей Іоанн Мейєндорф, так визначає сутність шлюбу і його роль у становленні нової людини: 
THEORETICAL FOUNDATIONS OF THE FUNCTIONING OF EDUCATION. WAYS TO IMPROVE THE EFFECTIVENESS OF EDUCATIONAL ACTIVITIES

«Християнин покликаний, вже в цьому світі, мати досвід нового життя, стати громадянином Царства; і це можливо для нього в шлюбі. Отже, шлюб перестає бути тільки задоволенням тимчасових природних спонукань ... Шлюб - це унікальний союз двох особистостей у любові, двох осіб, які можуть перевершити свою власну людську природу і бути з'єднаними не тільки «один з одним», але й «у Христі» [130].

У Священному Писанні шлюб є виявом граничної радості, граничної повноти, торжества радості і любові [134]. У чому сенс шлюбу, якою має бути сім'я за християнським поданням? Єдина плоть, яку становить подружжя, повинна, природно, мати одну голову. Розумно, якщо ця глава - чоловік. Чоловік, як сказано в Біблії, створений раніше жінки, створений як самостійна особа, жінка ж сотворена як помічниця йому: «Недобре бути чоловікові одному, створимо йому помічника, відповідного йому» (Бут. 2, 18), - читаємо у Святому Писанні. Жінка ніяк не нижче чоловіка гідністю, але вона інша. Вперше проявивши самостійність, послухавши спокусника-змія, перша жінка здійснила і перший гріх. Сва порушила Господню заповідь не їсти «плодів дерева пізнання добра і зла, що в середині раю» (Бут. 3, 3). Окрім того, вона схилила до гріха і чоловіка: «Взяла плодів його і їла, i разом дала теж чоловікові своєму, і він їв" (Бут. 3, 6). Тим накликала прокляття на землю. За цей проступок Господь покарав іï, а в іï особі і всіх жінок, життя яких передбачає тепер вічний послух чоловікові. На цьому послухові дружини i грунтується домашній світ. У православ'ї послух зовсім не означає рабство. Дружина - це перший помічник чоловіка, учасник сімейної ради [134].

Шлюбний союз християн, в істинному розумінні своєму, представляє не тільки отримання статусу чоловіка і дружини, але і внутрішнє єднання їх душ для взаємного морального вдосконалення і порятунку душі.

«Чуєте це мужі, навчитеся дружини», - говорить Іоанн Златоуст, вказавши на приклад святого життя Авраама і Сари. «Всі станемо наслідувати праведному: дружині чоловік нехай буде найдорожчим, i чоловікові дружина нехай буде найпривітнішою. Дружина повинна бути однодумцем зі своїм чоловіком; на цьому стверджується благий устрій всього світу. Дивись: світ складається 3 міст, міста - 3 
THEORETICAL FOUNDATIONS OF THE FUNCTIONING OF EDUCATION. WAYS TO IMPROVE THE EFFECTIVENESS OF EDUCATIONAL ACTIVITIES

родин, сімейства - з чоловіків і дружин. Отже, коли виникнуть сварки між мужами i дружинами, перевернуться міста, а потім і весь світ повинен наповнитися заворушеннями і суперечками» [134]. Християнське богослов'я шлюбу стверджує, що ієрархічне улаштування сім'ї заповідано Богом. Чоловік у сім'ї може бути тільки главою. Батько є духовним главою сім'ї, ï опорою і захистом. У збереженні ієрархії, коли дружина повинна бути за чоловіком, як за кам'яною стіною, а чоловік - вдома 3 дружиною, як у раю, і полягає порятунок один одного.

Обов'язок чоловіка - любити свою дружину. I не тільки любити, але піклуватися про неї, «живити і гріти», а, крім того, чоловік відповідає за дружину перед Господом, тому що, вступаючи в шлюб, він зобов'язується дбати і про її душі, щоб представити їі Господу як жінку, котра «не має плями чи вади, чи чогось подібного, але щоб вона була свята й непорочна» (Еф. 5, 27). Про взаємини чоловіка і дружини апостол Павло говорить: «Дружини, своїм чоловікам будьте покірні в усьому, як Господу» (Еф. 5,22). А також «жінка нехай боїться мужа свого» (Еф. 5,33), звичайно, «боїться» треба розуміти не в житейському звичайному сенсі страху, а в релігійному: «боятися» скривдити, образити, зробити неприємне чоловікові. Основою християнської сім'ї є чоловік і дружина, пов'язані перед Богом для вічності обітницями взаємної любові та спільності всього життя, служінням Богові. Разом із дітьми та іншими членами сім'ї вони утворюють домашню Церкву, присвячену тим святим, імена яких носять члени сім'ї. Коли у шлюбі з'являються діти, чоловік i дружина змінюються, перетворюючись на батька i матір. У християнському шлюбі для дітей духовні узи батьків є дуже важливими. Адже чоловік не тільки чоловік, а й батько, тобто той, без кого й не могло бути материнства. Дітям потрібна любов не тільки матері, а й батька, якого мама ніколи замінити не може. Для кожного зі своїх членів родина є школою любові як постійної готовності віддавати себе іншим, піклуватися про них, оберігати їх. На основі взаємної любові подружжя народжується батьківська любов, відповідна любов дітей до батьків, бабусь, дідусів, братів і сестер. Радість і горе в духовно здоровій родині стають загальними: всі події сімейного життя об'єднують, підсилюють і поглиблюють почуття взаємної любові. 
Наш сучасник, вчений і священик Гліб Каледа у своїй книзі, «Домашня Церква», говорить про те, що «чернецтво корисно для тих, хто багатий любов'ю, а звичайна людина навчається любові в шлюбі» [133]. У православній традиції сімейне життя розуміється як «шлях до Спасіння», сходження по якому пов'язане 3 несенням «хреста» повсякденних обов'язків, взаємних турбот, співпраці, розуміння і згоди. Особлива роль родини - «домашньої Церкви» у християнській культурі (Рим. 16, 4; Флм. 1, 2) - полягає у виконанні споконвічної функції духовно-моральному релігійному вихованні дітей. За вченням Церкви, «дітородження» (йдеться не тільки про народження, а й виховання дітей) $\epsilon$ спаситильне для батьків. Діти сприймаються не як випадкове придбання, а як дар Божий, який батьки покликані берегти i «примножувати», допомагаючи розкрити в дитині усі сили і таланти. «Основним і найголовнішим завданням християнської сім'ї, - вважає Е. А. Морозова, - $є$ не тільки просто виховати дітей, але й неодмінно виростити їх як справжніх чад Церкви Христової, врятувати їхні душі для вічного життя. Кінцева мета виховання - формування гармонії тіла, душі і духу 3 провідною роллю духу» [135]. У вихованні дітей сім'я не може бути замінена ніяким іншим соціальним інститутом, йй належить виняткова роль у становленні дитячої особистості. У сімейному спілкуванні людина вчиться долати свій гріховний егоїзм, в родині дізнається, «що таке добре і що таке погано». У сім'ї народжується почуття живої спадкоємності поколінь, відчуття причетності до історії свого народу, минулого, сьогодення та майбутнього своєї Батьківщини.

Філософ І. А. Ільїн як православна віруюча людина, вважав, що «перемінені духовно люди перетворять своєю дією світ». Система його педагогічних поглядів така: на перших порах життя дитини зміцнення його волі і сил душі, прищеплення релігійної та громадянської відповідальності через приклади батька і матері, a потім, у дорослому житті, перенесення накопиченого в зовнішню площину соціальної і господарської активності [132]. Тільки сім'я може виховати сім'янина. За мудрим словом I. А. Ільїна, добра родина дарує людині «два священних першообрази, у живому ставленні до яких зростає його душа і міцніє його дух: прототип чистої матері, що несе любов, милість і захист; - першообраз благого 
THEORETICAL FOUNDATIONS OF THE FUNCTIONING OF EDUCATION. WAYS TO

IMPROVE THE EFFECTIVENESS OF EDUCATIONAL ACTIVITIES

батька, котрий дарує можливість насититися, справедливість і розуміння» [132]. Ці батьківські образи філософ називає джерелами духовної любові і духовної віри людини.

Власну точку зору щодо виховання пропонує протоієрей Василій Зеньковський. Ним створено особливе вчення про духовне життя в дитинстві, започатковано дослідження вікової динаміки релігійного почуття і відмінностей у типах релігійності в дітей (щоправда, докладної і завершеної типології Зеньковському досягти не вдалося). У цьому ж контексті розглядає автор і вплив сім'ї, яка тісно пов'язана 3 процесом духовного становлення індивідуальності дитини [131].

Письменник, богослов, учений Н. Є. Пєстов пише про такі умови успіху в справі виховання, як наполеглива праця батьків над дитиною, самовіддана любов, робота над словами, порядок життя, турбота про чистоту душі дитяти, освіту дитини і його трудові навички. Найголовнішими факторами духовного виховання Пєстов називає таїнства, молитву, піст, благочестивий приклад батьків, духовне середовище, духовне читання, освячення обстановки [136]. Відомий педагог К. Д. Ушинський каже: «нехристиянських педагогіка $є$ річ немислима - безголова потвора і діяльність без мети» [138].

Вчення православ'я цікаве тим, що воно не дає рецептів, воно ці рецепти рішуче застосовує, до того ж до самого вихователя. Воно, на думку А. Б. Рогозянського, «ставить людину в такий стан і дає йому таке розуміння речей, у якому будуть зроблені найправильніші, наймудріші та благі рішення і дії» [137].

Спробуємо виділити деякі принципи і завдання православного виховання, що грунтуються на десяти Заповідях, сформульованих у Біблії, і $є$ основою не тільки православ'я, а й європейської культури.

1. Головне завдання батьків - виховання християнина (тобто, необхідно навчити дітей жити за заповідями Божими).

2. Основа виховання - приклад доброчесного життя самих батьків (дотримання батьками заповідей Божих). 
3. Виховання грунтується на прояві істинної любові («Возлюби ближнього твого, як самого себе» (Мф. 22, 37-39).

4. Шанування батьків і слухняність їм (як виконання п'ятої заповіді).

Розглянемо тепер принципи і завдання православного виховання більш докладно.

1. Головне завдання батьків - виховання християнина.

Протопресвітер В. В. Зеньковський вважає, що «головна тема сімейного виховання - виховання релігійне. Сім'я за своєю структурою є нескінченним джерелом релігійних сил. Саме сімейне життя - це ніби святиня, наше ставлення до батьків є єдиним, вічним, неповторним». Тобто найголовніша задача батьків виховання християнина [131]. В основі християнського виховання лежить християнське життя сім'ї - від батька і матері. Тобто виховання дітей - це створення умов, у яких би народилося, процвітало, множилося духовне життя дитини.

2. Основа виховання - приклад доброчесного життя самих батьків.

Виховання доброї вдачі дитини, розвиток ії здатності до доброчинного життя завжди визначалися способом життя матері і батька, тим, наскільки самі батьки могли показати їй добрий приклад. Без прикладу і навчання в добрі дитина втрачає здатність формуватися як особистість. Про це пишуть святі отці і пастирі Церкви: Святитель Василій Великий: «Якщо хочеш виховувати інших, виховай спочатку самого себе в Богові»; Святитель Ігнатій Брянчанінов звертається до матері маленької дівчинки: «Знай, що паче всіх твоїх настанов словами життя твоє буде найсильнішою настановою для дочки»; Священик Олександр Сльчанінов: «Для виховання дітей найважливіше, щоб вони бачили своїх батьків, які живуть великим внутрішнім життям» [136].

Важливо підкреслити, що досвід сімейних взаємовідносин відіграє для дитини важливу роль не тільки у формуванні його особистості та життєвого сценарію, тобто набору типових схем поведінки і відносин з іншими людьми. Він також $є$ найважливішим фундаментом, на якому дитина формує і будує своє сприйняття Бога і спілкування з Ним.

3. Виховання грунтується на прояві істинної любові. 
THEORETICAL FOUNDATIONS OF THE FUNCTIONING OF EDUCATION. WAYS TO

IMPROVE THE EFFECTIVENESS OF EDUCATIONAL ACTIVITIES

Духовне життя в любові повинно виявлятися в сімейному побуті настільки повно, наскільки це можливо. Кожен член сім'ї живе для блага іншого, несучи «тягарі один одного» і виконуючи таким чином «закон Христовий» (Гал. 6, 2). У сім'ї має панувати милосердя, прощення і взаємне збагачення, а також всі можливі прояви справжньої любові: «Любов довготерпить, любов милосердствує, не заздрить, любов не величається, не вихваляється, не поводиться нечемно, не шукає свого, не дратується, не мислить зла, не радіє неправді, але тішиться правдою, усе зносить, вірить у все, сподівається всього, усе терпить» (1 Кор. 13, 4-7). Православ'я завжди несло розвинене духовне розуміння любові. Любов - як традиційна для української культури цінність - це те, що протилежне егоїзму. А в релігійному сенсі - це життя за заповідями, за Свангелієм, наслідування Христа. Св. Іоанн Златоуст говорить про «одностайність» подружжя як важливого складника сімейного життя: «Любов така, що ті, хто люблять, є вже не двоє, а одна людина, і цього не може зробити ніхто, крім любові» [140]. Любов об’єднуює, а гріх розділяє. Усе християнське віровчення може бути цілком зрозуміле як заклик, щоб ми любили один одного (1 Ів. 3,11$)$, пізнали любов як першооснову справжніх цінностей. I тільки на основі такої любові може будуватися виховання в християнській сім'ї.

4. Шанування батьків і слухняність їм.

Закон слухняності пронизує всю християнську сімейну структуру: діти рятуються через шанування батьків, дружина - через послух чоловікові, а чоловік через послух Богові. Ще в Старому Завіті в Синайському законодавстві першою заповіддю про любов до людини була заповідь про шанування батьків. За це людині Господом обіцялися усілякі блага і довголітнє життя. Апостол Павел вчить: «Діти, слухайтеся своїх батьків у Господі, бо цього вимагає справедливий Господь. Шануй свого батька та матір: так буде тобі благо і будеш на землі довголітній» (Еф. 6, 1-3). «Хто кляне свого батька та матір свою, погасне світильник йому серед темряви» (Прип. 30, 11). «Діти, будьте слухняні в усьому батькам, бо це угодно Господу» (Кол. 3,20). У слухняності проявляються й інші важливі риси, такі як довіра, шанування батьків і повага до старших, совісність, правдивість, добра послужливість та ін. Шанування батьків, слухняність їм сприймаються дітьми як 
THEORETICAL FOUNDATIONS OF THE FUNCTIONING OF EDUCATION. WAYS TO

IMPROVE THE EFFECTIVENESS OF EDUCATIONAL ACTIVITIES

Божа заповідь і необхідна умова благополучного росту духовного та дорослішання. Християнська слухняність є прояв смирення і лагідності. Смирення і слухняність невіддільні одне від одного. Батьки повинні з самого дитинства вселяти дітям, що, не підкоряючись батькам, вони грішать проти Самого Бога i накликають цим на себе Його гнів, тимчасовий і вічний [139].

Якщо дитина не слухається батьків, то вони можуть і навіть зобов'язані покарати іiі. (Слово «покарати» церковнослов'янською мовою означає напоумляти, навчати, вдосконалити). 3 точки зору християнської педагогіки тільки те погано, що гріховно перед Богом. Карати треба тільки за те, що заслуговує на покарання в очах Божих, що становить гріх перед Богом. «Дитя тільки тоді заслуговує покарання, коли воно свідомо і самовільно порушило закон Божий, коли воно з власної волі зробило що-небудь заборонене заповіддю Божою або Церквою», - пише Г. І. Шиманський [139].

Без покарань не можна обійтися, але карати повинна любов. Головною підставою покарання повинна бути любов, а єдиною його метою - виправлення дитини. Звідси випливає, що покаранню слід бути батьківським і воно ніколи не повинно переходити в жорстокість, особливо не повинно звершуватися в гніві, бо гнів людини, за висловом Слова Божого, не творить правди Божої (Як. 1,20). Заклик апостола Павла до батьків не дратувати дітей, щоб вони не сумували (Кол. 3, 21), найкраще відбиває християнський погляд на покарання: як тільки діти починають дратуватися і сумувати від заборон і покарань, строгість стає не тільки педагогічно невиправдана, але й шкідлива. «Погано ламати дитину, - кажуть досвідчені педагоги, - але ще небезпечніше його постійно гнути». Тиск особливо відбивається на релігійному почутті. За прикладом матері і батька «діти в цьому випадку сприймають Бога не люблячим i турботливим Небесним Батьком, але авторитарним і самоуправним владикою, і серце їх закривається для благодаті», вважає А. Б. Вул [139]. Але погляд християнства в той же час оптимістичний: гріх не є властивістю душі, не таврує людини на все його життя. Розрізнити гріх від грішника - одна 3 фундаментальних основ виховання. «Одне сказати: «він розгнівався», а інше - :«він гнівливий і вимовити вирок про все його життя», - так 
вчить про це преподобний Авва Дорофей. Тільки розрізнивши в кому-небудь образ Божий, над яким гріх чинить насильство, можна по-справжньому співчувати i бажати допомогти ближньому [139].

Лад сім'ї, побудованої на релігійних засадах та християнських цінностях, має традиційний сімейний уклад, що включає в себе п'ять компонентів:

1. звичаї (усталені, звичні форми поведінки);

2. традиції (перехідний з покоління в покоління спосіб передачі ціннінозначущого змісту культури, життя сім'ї);

3. відносини: сердечні відчування і настрої;

4. правила (образ думок, норми поведінки, звичаї, звички) доброго і благочестивого життя;

5. розпорядок (встановлений порядок дня, тижня, року); у вітчизняній православній культурі цей розпорядок визначався ладом благочестивого життя християнина [139].

Висновки. Отже, християнська сім'я - це структура, що має суворо вертикальну ієрархію. Главою сім'ї є чоловік, дружина залежить від чоловіка, а діти - від батьків. Головне завдання батьків - виховати християнина на основі взаємної любові та поваги один до одного, бачачи в дитині образ Божий. Основним виховним методом $\epsilon$ приклад благочестивого життя батьків. Підставою i фундаментом морального виховання дитини має бути послух і шанування батьків. Якщо ми ставимо завдання з'ясувати особливості сімейного виховання в сімї, заснованій на православній церковній традиції, то логічніше всього звернутися до вивчення сімей так званих воцерковлених людей. Вони більше, ніж інші, занурені в життя православної Церкви через такі його інститути як Церква, духівництво, церковний переказ (мається на увазі - регулярне відвідування храму, участь у таїнствах Церкви, духовне окормлення у священика). Важливо і те, що ці люди орієнтовані на практичну реалізацію положень православної віри і євангельських заповідей. 
THEORETICAL FOUNDATIONS OF THE FUNCTIONING OF EDUCATION. WAYS TO IMPROVE THE EFFECTIVENESS OF EDUCATIONAL ACTIVITIES

DOI 10.46299/ISG.2021.MONO.PED.II-148-153

\section{7 Розвиток професійної компетентності педагогічних працівників закладів дошкільної освіти засобами мультимедійних технологій (на прикладі фінляндії, швеції, норвегії, данії)}

В умовах інформаційних процесів вагомого значення для української педагогічної науки i практики набуває вивчення зарубіжного досвіду використання мультимедійних технологій в освіті, що $є$ особливо актуальним для розв’язання проблем розвитку професійної компетентності педагогічних працівників закладів дошкільної освіти, що забезпечуватимуть конкурентноспроможнього, активного та компетентного фахівця, здатного до постійного мобільного розвитку власної професійної, зокрема IКТ компетентності.

Науковий інтерес викликають праці вчених про сучасний досвід підготовки вчителя у Швеції (Н. Кошарна); зміст і напрями професійної підготовки фахівців у Данії (О. Леонтьєва, О. Матвієнко); формування системи вищої освіти у контексті Болонського процесу в Норвегії (В.Семілетко, В. Стинська); реформування, модернізацію освітньої системи у західноєвропейських державах (О. Карпенко, П. Кряжева, Г. Поберезська, А.Ржевська).

За висновками PISA, ефективність освітньої системи Фінляндії потребує усебічного іï вивчення та запозичення як найкращого досвіду [141]. Стратегічним ідеалом фінського суспільства $\epsilon$ постійне нагромадження «капіталу знань» - від раннього дитинства й аж до найвищих наукових ступенів і навчання дорослих» [142].

Унікальність фінської системи полягає у широкому використанні мультимедійних засобів та інформаційних мереж у тісному взаємозв'язку 3 педагогічною підготовкою спеціалістів дошкільної освіти. Дані науковців виділяють цифрові навчальні ресурси (Digital Learning Resources), відкрите та дистанційне навчання (Open and Distance Learning), систему управління навчанням (Learning Management Systems); навчальні платформи (Pedanet, Moodle, Optima, Its learning, Claned) [143, c. 4]. 
THEORETICAL FOUNDATIONS OF THE FUNCTIONING OF EDUCATION. WAYS TO

IMPROVE THE EFFECTIVENESS OF EDUCATIONAL ACTIVITIES

Науковець К. Котун, досліджуючи питання розробки компетентнісних моделей Фінляндії, виділяє низку комунікативних технологій, таких як система управління WebCT (інструмент, який надає можливість створювати професійні он-лайн курси та підготовку друкованих матеріалів для покращення таких курсів); платформа Moodle (система управління курсами, тобто електронне навчання, також відома як система управління навчанням або віртуальне навчальне середовище; вільний, але розповсюджений за універсальною загальною ліцензією (GNU General Public License); веб-додатки, що надають можливість створювати сайти для онлайн-навчання; використання двосторонньої аудіо/відео телеконференцій та інші [145]. Зокрема використовуються ІКТ-базовані інтерактивні канали, такі як: електронна пошта, чати, Фейсбук, Вікілайф та інш. Навчання здійснюється через технологію Web 2.0: Вікі (веб-сайт, що дозволяє користувачам змінювати самостійно зміст сторінок через браузер, використовуючи спрощену і зручнішу, порівняно 3 HTML, вікі-розмітку тексту), Netvibes (персональний робочий стіл); різноманітні блоги та інші. На використання нових брендів вказує інтерактивна дошка (Interactive Whiteboard) Clever-board, AKTIV-board, SMART-Board та інші [146, c. 7].

Серед останніх проектів можна виділити: «Багатовимірне навчальне середовище», «Чисте покоління» (Net Generation), «Відповідальність в ІКТ» (Responses to ICT), «Особисте навчальне середовище» (Personal Learning Environments), «Неперервна педагогічна підготовка» (Continuing Teacher Training), «Електронне навчання» (E-Learning), «Педагогіка в ІКТ» (Pedagogy of ICT in General), «Багатовимірне навчальне середовище» (Multidimensional Learning Environments) Найбільш оптимальним $є$ портал «Opeka» (http://oppika.fi/). Даний онлайн-інструмент забезпечує зворотній зв'язок для педагога; аналіз ситуації у вигляді звіту та рекомендації про те, як далі розвивати використання IКТ в освітньому процесі; підтримку щодо складання плану використання IKT; можливість відслідковувати та оцінювати результати подальшого розвитку[148]. 
THEORETICAL FOUNDATIONS OF THE FUNCTIONING OF EDUCATION. WAYS TO

IMPROVE THE EFFECTIVENESS OF EDUCATIONAL ACTIVITIES

За рейтингом країн світу за рівнем розвитку IКТ технологій (індекс розвитку IKT в країнах світу - ICT Development Index) Норвегія входить в першу десятку (VIII - Норвегія (індекс 8,47) [149].

Так, програма «еNorge» (електронна Норвегія) репрезентує стратегію розвитку освіти через впровадження найновітніших інформаційнокомунікаційних технологій, реалізацію синергетичних потенціалів особистості до самоусвідомлення, самовдосконалення й саморозвитку (принцип «постійного навчання»), формування впевненості особистості, яке свідчить про сформованість інформаційного суспільства [150].

Норвезька програма становлення й переходу до інформаційного суспільства «Краще використання інформаційної технології у Норвегії» акцентує, що на тому, що «Дистанційна освіта повинна бути пристосована до необхідності індивідів набувати знання й навички з використання інформаційних технологій» [151].

На необхідність кардинальних змін в освіті, зокрема й дошкільній, указує національний проект Норвегії «Неперервна освіта в секторі дошкільного виховання - огляд попиту i пропозицій» («Etter - og videreutdanning i barnehagesektoren - kartlegging av tilbud og etterspørsel»). Актуалізуються компетентності, що забезпечують життєвий успіх людини у напрямку інформатизації. Зазначено потребу використання в освітньому процесі нових інформаційних та комунікаційних технологій, що дозволяють збільшити швидкість сприйняття, розуміння та глибину засвоєння великих масивів знань. Найпопулярнішими серед них є вітчизняне віртуальне навчальне середовище «ClassFrontier», зарубіжні - BHC «Luvit», «It's Learning», «First Class», «Karb», «WebCT», «BlackBoard» i «Learning Space», «Top Class», «Team Wave», «Response» [152].

Цікавим є підхід до порушеної проблеми в Данї, де до сучасних ініціатив Уряду, у сфері професійної освіти, віднесено підвищення рівня мультимедійної компетентності педагогів дошкільної освіти. Чинна модель неперервної 
THEORETICAL FOUNDATIONS OF THE FUNCTIONING OF EDUCATION. WAYS TO

IMPROVE THE EFFECTIVENESS OF EDUCATIONAL ACTIVITIES

професійної освіти в Данії свідчить про наявність інноваційних підходів в управлінні та організації цісї системи [153].

Проекти "Playful computer writing", "Writing to read" підкреслюють важливість надання дітям дошкільного віку доступу до ІКТ. Особливою новацією є використання ігрових методів навчання 3 комп’ютером для дітей 6 років.

Дошкільна освіта Швеції розглядається як перший самодостатній елемент системи неперервної освіти.

За П. Хенуолом, більшість шведських батьків виступають проти впровадження ІКТ в практику дошкільної освіти, мотивуючи це негативним впливом засобів ІКТ на дітей дошкільного віку. Тому застосування IКТ в практиці багатьох дошкільних закладів Швеції залишається все ще явищем новим. Але швидкий розвиток IКТ, концепція неперервного навчання, забезпеченість дошкільних закладів засобами ІКТ (персональні та планшетні комп'ютери, інтерактивні дошки) спонукають до реформування освітнього процесу відповідно до інтеграції діяльнісного, особистісно орієнтованого та компетентнісного підходів [154].

Шведська національна навчальна програма для дітей дошкільного віку серед пріоритетів називає сприяння розвитку професійної компетентності педагогічних працівників, що забезпечує ефективне використання IКТ в дошкільній освіті [155].

Чинна програма Швеції «IКТ в системі освіти» визначає неперервну педагогічну освіту як трансформуючий чинник, що суттєво впливає на розвиток нової системи освіти в умовах інформаційного суспільства. Увагу приділено заходам, спрямованим на розвиток ІКТ компетентності фахівців дошкільної освіти: проведення курсів підвищення кваліфікації побудованих за принципами мультимедійного навчання і занять з оволодіння цифровою компетентністю; надання після закінчення навчання відповідного сертифікованого документа; адаптування навчальних курсів відповідно до розвитку ІКТ у навчальному середовищі освітнього закладу; розробка мережних (on-line) курсів для реалізації 
THEORETICAL FOUNDATIONS OF THE FUNCTIONING OF EDUCATION. WAYS TO IMPROVE THE EFFECTIVENESS OF EDUCATIONAL ACTIVITIES

концепції навчання протягом життя; покращення координації між науководослідними інституціями у сфері застосування IКТ [156]. На державному рівні моделювання неперервної освіти на основі застосування IКT у педагогічній діяльності та самонавчанні, здійснюється за такими формами як: навчання на виробництві (in-service training) та професійна підготовка на базі університетів (pre-service training). Важливою є однакова статусність усіх видів освіти.

За дослідженнями I. Капустіної, результатом розвитку ІКТкомпетентності шведського педагога $\epsilon$ : мотиваційна компетентність (здатність до подолання психологічного бар’єру при освоєнні IКТ, потреба, прагнення до IКТ знань, ідентифікація власної особистості як «Я - комунікат»); технологічна, «цџифрова» компетентність (уміння користуватися програмами: текстові процесори (word processors), дизайн презентацій (presentation designer), табличні процесори (spreadsheets), бази данних (databases), навчальне програмне забезпечення (computer aided instruction software), засоби розробки сайтів (web page development tools), пошукові системи (search engines), електронний поштовий клієнт (e-mail), списки обговорення і групи новин (discussion lists and newsgroups), чати і форуми (chat and forum), електронні енциклопедіï, атласи (electronic encyclopedia or atlas), браузери (browsers), мультимедійні засоби (instructional films); рефлексивно-педагогічна компетентність (мережна педагогічна взаємодія: міжособистісна, особистісно-технологічна, особистісноінформаційна).

У контексті дослідження розвитку професійної компетентності педагогів засобами мультимедіа, зокрема світового досвіду, $\epsilon$ діяльність центру неперервної освіти (ENCELL (livslangt larande) на базі університету м. Йончопінг. У числі засобів навчального програмного забезпечення використовуються як системи, що розроблені науковцями цього університету (PING PONG, PIM - «Personal Information Manager»; система «Ladok» або «Ladok Novau») так і зарубіжне програмне забезпечення («Levitz», «Mentor», «Telia Instant Education», «Maestro», «FirstClass», «Comenious online», «Lecando», «Librix», «Marratech» i «WebCat»). У системі неперервної освіти поряд із 
THEORETICAL FOUNDATIONS OF THE FUNCTIONING OF EDUCATION. WAYS TO

IMPROVE THE EFFECTIVENESS OF EDUCATIONAL ACTIVITIES

використання CD-ROM та Веб-сайтів 3 готовим змістом передбачено ебібліотеки (Jonkoping University Library), електронні енциклопедіï, атласи (electronic encyclopedia or atlas), мультимедійні засоби (instructional films) [157].

Таким чином, проведення порівняльного досвіду є прикладом успішного використання мультимедійних технологій, що сприяють розвитку професійної компетентності педагогів дошкільної освіти. Перспективи подальших розвідок вбачаємо у моделюванні процесу розвитку професійної компетентності педагогічних працівників дошкільних закладів в системі післядипломної освіти засобами мультимедійних технологій, з урахуванням досвіду зарубіжних країн. 


\section{SECTION 3. HISTORY}

DOI 10.46299/ISG.2021.MONO.PED.II-154-164

\section{1 Особенности формирования централизованной системы образования в Российской империи в первой трети XIX ст.}

В начале XIX ст. в Российской империи произошла смена образовательной парадигмы, характерной чертой которой явилось создание централизованной системы управления образованием всех уровней в стране. Первые попытки, направленные на усиление роли государства в управлении образованием в России, предпринимались еще основанной в 1782 г. Комиссией об учреждении народных училищ, но ее деятельность распространялась на часть учебных заведений страны. Придя к власти в марте 1801 г., молодой император Александр I взялся за подготовку ряда реформ, наиболее результативными из которых оказались реформы административного управления и образования. Вопрос о путях развития образования обсуждался в Негласном комитете, объединявшим молодых друзей императора (В. Кочубей, Н. Новосильцев, П. Строганов, А. Чарторыйский). Исследователь истории Министерства народного просвещения С. В. Рождественский отмечал, что с особой остротой этот вопрос был поставлен перед реформаторами в декабре 1801 г., когда Александр предложил комитету рассмотреть письмо, полученное от его бывшего воспитателя, швейцарского просветителя и государственного деятеля Ф. Лагарпа[158]. В письме, в частности, выдвигалась идея создания централизованного органа управления образованием в стране, что нашло поддержку в кругу молодых друзей. В русле административной реформы 8 сентября 1802 г. был издан манифест об учреждении министерств, на основании которого создавалось и Министерство народного просвещения. Оно самостоятельно действовало с 1802 по 1817 гг., затем с 1824 по 1917 гг., а образовавшаяся в его работе лакуна связана с созданием двуединого министерства - Министерства духовных дел и народного просвещения, в котором оно было представлено в форме особого департамента. Первым министром просвещения стал выходец из украинской казацкой старшины 
THEORETICAL FOUNDATIONS OF THE FUNCTIONING OF EDUCATION. WAYS TO IMPROVE THE EFFECTIVENESS OF EDUCATIONAL ACTIVITIES

П. В. Завадовский, который сразу же инициировал обсуждение вопроса о необходимости реформы в образовательной сфере и назревших в ней новациях.

В процессе подготовки реформы структура управления образованием и некоторые другие элементы были заимствованы из опыта польской Эдукационной комиссии и плана французского просветителя Никола Кондорсе, которые правительство приспособило к российским условиям. Первым в Европе ведомством общегосударственного руководства образованием являлась Эдукационная комиссия (Комиссия национальной эдукации) - руководящий орган системы образования в 1773-1794 гг. Речи Посполитой. Эдукационная комиссия в процессе реформирования системы начального, среднего и высшего образования разделила территорию страны на 10 учебных округов. Рычаги управления образованием находились в руках комиссии, что приближает ее деятельность к появившимся несколько позже министерствам образования.

Не меньший интерес представлял для подготовки реформы в России французский проект организации образования, предусматривавший создание государственной системы школ, который был направлен в апреле 1793 г. в Законодательное собрание Франции ученым, философом, одним из лидеров жирондистов эпохи французской революции конца XVIII ст. Жаном Антуаном Никола Кондорсе (1743-1794). Он разделил образовательные учреждения на пять ступеней: 1) первоначальные школы, 2) школы второй ступени, 3 ) институты, 4) лицеи, 5) Национальное собрание наук и искусства (структура, осуществляющая организацию и управление образованием в стране). Проект не был реализован во Франции, но его основные идеи широко использовались в ряде европейских государств, вступивших на путь формирования национальных систем образования. Уровень общественного интереса к развитию образования и степень участия в нем государственных структур определили основное направление этого процесса, который в каждой стране имел специфические черты. При этом общим для всех было расширение участия государства в деле распространения образования. 
THEORETICAL FOUNDATIONS OF THE FUNCTIONING OF EDUCATION. WAYS TO IMPROVE THE EFFECTIVENESS OF EDUCATIONAL ACTIVITIES

Главными положениями российской реформы стали заимствованные из рассмотренных документов идеи о формировании единой многоступенчатой образовательной системы, создании централизованного управления образованием и разделении страны на особые территориальные единицы учебные округа. 23 января 1803 г. увидели свет «Предварительные правила народного просвещения», которые на этом этапе стали государственной образовательной доктриной. На следующий день, 24 января 1803 г., вышли два важных указа. Одним из них была оформлена четырехступенчатая система образования: приходские училища-уездные училища-гимназии- университеты, что позволило развернуть в стране формирование массива государственных высших, средних и начальных учебных заведений. В Российской империи, кроме Московского, создавались 5 новых университетов: Виленский, Дерптский, Казанский, Харьковский, Главный педагогический институт в Санкт-Петербурге (с 1819 г. - университет).

Согласно второму указу «Об учреждении учебных округов с назначением для каждого отдельных губерний» вся территория страны была разделена по количеству университетов на 6 административных единиц, которые стали именоваться Московским, Санкт-Петербургским, Виленским, Дерптским, Казанским и Харьковским учебными округами. На них возлагалась задача реализации образовательной реформы. Каждый учебный округ возглавлял попечитель. Однако функции попечителей в документах 1803 г. были сформулированы расплывчато. В первой трети XIX ст. попечители не имели распорядительной власти и выступали связующим звеном между министерством, университетом и училищным комитетом (органом, создававшимся при университете под руководством ректора, состоявшим из нескольких избранных профессоров). В рамках Министерства народного просвещения заметная роль принадлежала Главному правлению училищ (18021863), являвшемуся коллегиальным органом, в состав которого входили попечители учебных округов и назначаемые академики. Оно занималось составлением и рассмотрением учебных планов университетов, средних и 
THEORETICAL FOUNDATIONS OF THE FUNCTIONING OF EDUCATION. WAYS TO IMPROVE THE EFFECTIVENESS OF EDUCATIONAL ACTIVITIES

низших учебных заведений, ведало назначением и перемещением педагогического персонала, управляло материальной базой учебных заведений.

5 ноября 1804 г. вышел «Устав университетов и гимназий», где окончательно была определена структура системы образования. В процессе образовательной реформы 1803-1804 гг. была разработана сбалансированная система управления по схеме: университетская корпорация-директор гимназиисмотритель уездного училища-начальник приходского училища.

В период формирования новой образовательной системы наиболее подготовленной к преобразованиям оказалась научная общественность основанного еще в 1755 г. Московского университета. Созданный на его базе Московский учебный округ включал территорию 10 центральных губерний. Первым попечителем округа стал М. Н. Муравьев (1803-1807), способствовавший формированию корпуса отечественной профессуры в университете, инициировавший создание при нем в 1804 г. Общества истории и древностей. Однако и в Московском округе распространение сети учебных заведений проходило неравномерно. Если гимназии в губернских городах основывались достаточно быстро, то численность уездных и приходских училищ в течение первой трети XIX в. оставалась неудовлетворительной. Над решением этой проблемы работал следующий попечитель - сын последнего гетмана Украины А. К. Разумовский (1807-1810) и его преемники.

Центральным учебным заведением Дерптского учебного округа стал основанный в 1802 г. Дерптский университет, где преподавание велось на немецком языке. В состав округа входили: Курляндская, Рижская, Дерптская и Эстляндская губернии. Попечителями округа в первой трети XIX в. были: писатель Ф. Клингер (1803-1817), генерал от инфантерии К. Ливен (1817-1828), генерал от кавалерии М. Пален (1828-1835). Несмотря на то, что большинство из них были военными и придерживались консервативных взглядов, в целом они позитивно относились к распространению науки и образования в округе. Постепенно крепла научная база Дерптского университета, где в 1832-1833 гг. работали 26 ординарных профессоров, 1 - экстраординарный, 12 преподавателей 
иностранных языков и учителей искусств[159]. Согласно отчету попечителя К. А. Ливена за 1825 г. постепенно росло число учебных заведений в губерниях округа. Так, в Курляндии в отчетном году насчитывалось 249 училищ (4272 ученика), 345 частных школ и пансионов (2195 учащихся)[160]. В 1837 г. на Дерптский учебный округ было распространено «Положение об учебных округах» 1835 года.

Значительные особенности имел Виленский учебный округ, в состав которого входили 8 губерний: Виленская, Витебская, Волынская, Гродненская, Минская, Могилевская, некоторое время Подольская и Киевская, которые в конце 10-х гг. были переведены в Харьковский учебный округ. В 1807 г. под контроль Виленского округа были переданы учебные заведения присоединенной к Российской империи Белостокской области. Ведущим учебным заведением округа стал основанный на базе Главной Виленской школы в 1803 г. Виленский университет, где дисциплины преподавались на польском языке. Структура университета и деятельность училищ округа регламентировалась специальным уставом от 18 мая 1803 года. Во главе Виленского учебного округа стояли члены Негласного комитета Александровской поры А. Чарторыйский (1803-1823) и Н. Новосильцев (1823-1831). Польский князь А. Чарторыйский способствовал развитию учебных заведений в округе, поддерживая их польскую направленность, что стало очевидным в связи с раскрытием в 1823 г. тайных польских обществ, в которых заметную роль играла студенческая молодежь. Их деятельность привела к отставке А. Чарторыйского. На должность попечителя был назначен Н. Новосильцев (1823-1831). Если в начале царствования Александр I сочувственно относился к свободолюбию поляков, то в конце правления он полностью отказался от подобных взглядов, что, в свою очередь, потребовало изменения политики в сфере образования, которая реализовалась в учебном округе. Отныне ее целью стало формирование у местного населения лояльного отношения к Российской империи.

Попечитель Н. Новосильцев разработал проект реформирования учебных заведений, который 1 сентября 1825 г. был введен в действие. Суть проекта 
THEORETICAL FOUNDATIONS OF THE FUNCTIONING OF EDUCATION. WAYS TO

IMPROVE THE EFFECTIVENESS OF EDUCATIONAL ACTIVITIES

Н. Новосильцева заключалась в выведении всех типов школ из подчинения католическому и униатскому духовенству и расширении светского образования. Его реализация проходила в период, когда к власти после смерти Александра I пришел его брат Николай I, требовавший максимальной централизации всех сфер общественной жизни, в том числе и образования. В ходе реформы в 1828 г. произошла реорганизация начального и среднего звеньев образования в округе. В округе 1832 г. насчитывалось 91 училище, в которых обучалось 6654 человек[161]. Попечитель был наделен широкими полномочиями в борьбе с инакомыслием в регионе. Однако попытки, предпринимаемые им с целью остановить студенческое движение, не имели успеха. В польском восстании 1830-1831 гг. принимали участие многие студенты и преподаватели Виленского университета и других учебных заведений округа. Н. Новосильцев был среди душителей польского восстания, в результате которого Виленский университет был закрыт, а учебный округ в 1832 г. ликвидирован. Учебные заведения округа перешли под контроль Харьковского и созданного в 1829 г. Белорусского округа. Лишь в 1850 г. Виленский учебный округ был вновь восстановлен.

В Санкт-Петербургский учебный округ входили Петербургская, Архангельская, Вологодская, Новгородская, Псковская и Олонецкая губернии. Первым попечителем округа был назначен член Негласного комитета Н. Н. Новосильцев (1803-1810). Позднее им руководили С. Уваров (1810-1821), Д. Рунич (1821-1826), К. Бороздин (1826-1833). Сначала на территории округа не было университета. Это обусловливалось наличием в столице нескольких высших учебных заведений и материальными трудностями в связи с образованием университетов в регионах. Во времена попечительства C. С. Уварова был подготовлен проект преобразования Главного педагогического института в университет, реализованный в 1819 г. В годы попечительства К. Бороздина в Петербургском учебном округе действовало 7 гимназий, 47 средних училищ, 73 приходских и волостных, 81 частный пансион[162]. 
THEORETICAL FOUNDATIONS OF THE FUNCTIONING OF EDUCATION. WAYS TO

IMPROVE THE EFFECTIVENESS OF EDUCATIONAL ACTIVITIES

В Казанский учебный округ первоначально входили Вятская, Казанская, Нижегородская, Пермская, Пензенская, Саратовская, Симбирская, Оренбургская, Тамбовская, Тобольская и Иркутская губернии, а также периодически Астраханская и Кавказская область. После увеличения общего числа учебных округов в стране Казанский округ в начале 30-х гг. сохранил контроль над 8 губерниями. Системообразующим элементом всего учебновоспитательного процесса в округе был основанный в 1804 г. Казанский университет. Попечителями округа в первой трети XIX в. были ученыйастроном, академик С. Я. Румовский (1803-1812), сенатор Н. А. Салтыков (18121818), поэт и государственный деятель, предлагавший строить народное образование на православных началах М. Л. Магницкий (1819-1826), почетный член Российской Академии наук Н. Н. Мусин-Пушкин (1827-1845).

Получив статус учебно-окружного города, Казань превратилась в культурно-просветительский центр. Округ объединил большие территории, на которых действовали Главное народное училище, 1 гимназия, 11 уездных, 7 приходских училищ, а также 1 женский пансион. В 1833 г. число училищ в округе выросло до 118, в них обучались 7625 человек[163]. Руководители округа проводили ревизии учебных заведений, в процессе которых выявляли в их работе не только достоинства, но и недостатки. В частности, Н. Н. МусинПушкин утверждал: «Уездные училища в значительной степени еще далеко стоят от указанной им цели»[164], что определяло дальнейшие направления деятельности попечителей в округе.

Систематически менялся состав Харьковского учебного округа. На рубеже 20-30-х гг. XIX ст. в него входили 9 губерний, 3 области и земли Донских и Черноморских казаков. В первой трети XIX ст. Харьковский учебный округ возглавляли: С. О. Потоцкий (1803-1817), 3. Я. Корнеев [Карнеев] (1817-1822), Е. В. Карнеев (1822-1825), А. А. Перовский (1825-1830), В. И. Филатов (18301834). Центральным учреждением округа стал основанный в 1805 г. Харьковский университет. Первый попечитель округа пригласил в университет иностранных профессоров, которые совместно с отечественными заложили 
THEORETICAL FOUNDATIONS OF THE FUNCTIONING OF EDUCATION. WAYS TO IMPROVE THE EFFECTIVENESS OF EDUCATIONAL ACTIVITIES

основы новой образовательной традиции. Преподаватели и выпускники университета внесли свой вклад в развитие украинской журналистики, начав издание содержательных газет, журналов и альманахов. В губерниях округа в начале 30-х гг. действовали 2 гимназии, 13 уездных, 51 приходское и 97 народных училищ, 29 мужских и женских пансионов[165].

На рубеже 20-30-х гг. XIX в. были сформированы еще четыре учебных округа. Их основание было связано с деятельностью ставшего в 1828 г. министром народного просвещения К.А. Ливена. Он имел опыт работы в должности попечителя Дерптского учебного округа и считал, что в связи с ростом количества учебных заведений в губерниях страны возникла необходимость дробления старых учебных округов и основания новых. Однако количество университетов на конец 20-х гг. XIX в. не изменилось. И все же министр выступил с предложением основать Белорусский учебный округ, где предполагалось открыть в Орше высшее училище или лицей (правда, данный проект тогда не был реализован).

Следует отметить, что вошедшие в состав Российской империи белорусские земли, воспринимались российским правительством неодинаково. Так, Витебская и Могилевская губернии рассматривались как «возвращенные от Польши», а остальные территории - как «присоединенные от Польши». Такая дифференциация обусловила различную тактику правительства в отношении этих земель и их населения. Для управления учебными заведениями Витебской и Могилевской губерний, изъятых из состава Санкт-Петербургского учебного округа, в 1829 г. был утвержден отдельный попечитель, в том же году возник Белорусский учебный округ. Первым попечителем округа стал известный математик Г. И. Карташевский (1829-1835), который большое внимание уделял развитию начального образования и распространению женских учебных заведений в округе. В 1832 г. в систему управления Белорусским учебным округом вошел Временный училищный комитет, находившийся в Вильно. Он не имел распорядительной власти и руководил только текущей деятельностью учебных заведений. $\mathrm{C}$ ликвидацией Виленского учебного округа 
THEORETICAL FOUNDATIONS OF THE FUNCTIONING OF EDUCATION. WAYS TO

IMPROVE THE EFFECTIVENESS OF EDUCATIONAL ACTIVITIES

подведомственные ему училища Виленской, Гродненской губерний и Белостокской области перешли в ведение Белорусского округа. В 1836 г. на Белорусский учебный округ было распространено общероссийское «Положение об учебных округах».

Основывая Белорусский учебный округ, К. А. Ливен одновременно выступил с предложением о создании учебного округа в Новороссийском крае, мотивируя необходимость этого шага слишком большой территорией, которая контролировалась Харьковским округом. Важным аргументом министра также стал многонациональный и поликонфессиональный состав региона. К тому же, в 1817 г. в Одессе был основан Ришельевский лицей, вскоре получивший статус главного учебного заведения региона, что также служило аргументом для создания на юге учебного округа, формирование которого осуществлялось поэтапно. Первым шагом стало решение Николая I Ришельевский лицей сделать независимым от Харьковского университета, подчинив ему все городские учебные заведения. Приказом от 30 июля 1830 г. был основан Одесский учебный округ, которому подчинялись исключительно учебные заведения Одессы, где в то время функционировали: Ришельевский лицей, 1 девичье народное училище, 1 греческое коммерческое училище, 4 мужских и 4 женских пансиона и 1 еврейское училище[166]. Во главе учебного округа был поставлен директор одесских училищ Н.Ф. Покровский (1830-1836). Осенью начался процесс расширения территории Одесского учебного округа.

В ноябре 1830 г. в состав округа вошла Бессарабская область. В ней тогда действовало 6 уездных, 1 приходское и 1 греческое училище и 30 частных школ. В следующем году был проведен новый раздел губерний уже с учетом Одесского на 7 учебных округов. В декабре 1832 г. Одесскому учебному округу были подчинены учебные заведения Херсонской и Таврической губерний, а в конце мая 1833 г. территория округа увеличилась присоединением Екатеринославской губернии.

В 1832 г. был основан Киевский учебный округ, в который вошли Киевская, Подольская, Волынская и Черниговская губернии. Первым попечителем округа 
THEORETICAL FOUNDATIONS OF THE FUNCTIONING OF EDUCATION. WAYS TO

IMPROVE THE EFFECTIVENESS OF EDUCATIONAL ACTIVITIES

стал Е. Ф. фон Брадке (1832-1838). В составе округа на момент его основания работали 32 училища, в которых обучались 3515 детей[167]. В это время уже было озвучено предложение об открытии университета в Киеве, что подтверждало право региона на учреждение Киевского учебного округа. После основания в Киеве университета св. Владимира в 1834 г. на него, как и на другие университеты, было возложено руководство всеми учебными заведениями округа. Для этого совет университета выбирал на два года трех профессоров, под председательством ректора, которые составляли училищный комитет, действовавший до мая 1836 г., когда окончательно на этой территории вошло в силу новое Положение об учебных округах.

Характерной чертой Положения об учебных округах, утвержденного 25 июня 1835 года стало существенное расширение полномочий попечителей. Из ведения университетов изымались средние учебные заведения, управление ими полностью сосредоточилось в руках попечителей учебных округов. Им дано право выбирать директоров гимназий и утверждать в должности инспектора и учителей. При каждом попечителе создавался попечительский совет, в который входили помощник попечителя, окружные инспектора, директора учебных заведений, а порой (по приглашению) профессора университетов. Компетенции совета подлежали учебно-методические вопросы и административные дела[168].

Таким образом, одной из особенностей создания централизованной системы образования в Российской империи первой трети XIX в. было ее поэтапное становление. В исследуемый период можно выделить три этапа трансформации образовательной системы в стране. На первом этапе (1803-1828) было создано Министерство народного просвещения и 6 учебных округов, основанных вокруг университетов и руководимых попечителями. Разработана и введена четырехступенчатая система образования. Роль попечителей на этом этапе была еще слабой.

С конца 20-х годов XIX в. начался следующий этап, отличительной чертой которого стало увеличение численности учебных округов, создававшихся даже там, где не было университетов: Белорусский, Одесский, Киевский учебные 
THEORETICAL FOUNDATIONS OF THE FUNCTIONING OF EDUCATION. WAYS TO

IMPROVE THE EFFECTIVENESS OF EDUCATIONAL ACTIVITIES

округа (1829-1834). Третий этап был подготовлен принятым в 1835 г. новым положением об учебных округах, которое существенно повысило статус попечителей и упрочило централизацию в системе российского образования. В ходе реформы к концу первой трети XIX в. удалось увеличить количество учебных заведений в стране, хотя первоначальная цель - создать в каждом губернском городе гимназию, а каждом уездном городе - уездное училище не была выполнена. 
THEORETICAL FOUNDATIONS OF THE FUNCTIONING OF EDUCATION. WAYS TO

IMPROVE THE EFFECTIVENESS OF EDUCATIONAL ACTIVITIES

\section{SECTION 4. INNOVATION IN EDUCATION}

DOI 10.46299/ISG.2021.MONO.PED.II-165-187

\section{1 Инновационные аспекты профессиональной деятельности педагога}

Современные социально-экономические преобразования в России, ориентирование на гуманистические и демократические принципы во всех сферах человеческой деятельности обусловили необходимость внедрения инновационных процессов. Под этим в образовании понимают внедрение инноваций для улучшения учебного процесса. Под инновациями в образовании также понимают и нововведения, т.е. продукты освоения и внедрения инноваций, при этом процедура их разработки рассматривается как условия инновации, но не включается в ее состав. Нововведения имеют место при внедрении в практику достижений науки, при использовании передового педагогического опыта. При этом нововведения - это новое состояние учебновоспитательной практики, формирующейся благодаря осмыслению и реализации инноваций.

Во второй половине 90-х годов XX ст. были созданы условия для целенаправленной разработки проблем образовательной инноватики (Поляков С.Д., 1993). Как считает С.Д. Поляков, чтобы разобраться, в сущности, в действительном содержании и механизмах реализации новых педагогических систем, технологий, методик, вошедших в образовательное пространство, целесообразно обратиться к понятиям: инновация нововведения, инновационный процесс, инновационная деятельность, педагогическое творчество, учитель инновационной ориентации, инновационный эксперимент (Поляков С.Д., 1993).

Разделяя позиции ученых, в данном исследовании мы остановились на таком определении инноваций - это комплексный, целенаправленный процесс создания, расширения и использования нововведений, цель которых удовлетворение потребностей и интересов людей новыми способами, ведущими к определенным качественным изменениям системы и способов 
THEORETICAL FOUNDATIONS OF THE FUNCTIONING OF EDUCATION. WAYS TO

IMPROVE THE EFFECTIVENESS OF EDUCATIONAL ACTIVITIES

обеспечения ее эффективности, стабильности и жизнеспособности. Инновационный процесс связан с переходом в качественно иное состояние, с ревизией устаревших норм и положений, ролей, а часто и их пересмотром. Развитие (конкретизацию) данного подхода находим в работах В. И. Загвязинского (Загвязинский В.И., 1999). На его взгляд, новое в образовании - это не только еще не использованные идеи, подходы, методы, технологии, но это и тот комплекс элементов или отдельные элементы педагогического процесса, несущие в себе прогрессивное начало, позволяющее в изменяющихся условиях и ситуациях достаточно эффективно решать задания развития личности и образования. Для решения заданий исследования, на наш взгляд, имеет значение мысль о связи инноваций как с развитием общества, системы образования, так и преподавателей - специалистов образовательной среды. Поэтому в исследовательском поиске мы приняли как начальное положение идею В. И. Загвязинского, считающего, что инновационные педагогические процессы отвечают прогрессивным тенденциям развития личности преподавателя как субъекта профессиональной деятельности. Несколько по-иному рассматривается развитие системы образования и профессионализма преподавателя, что в свою очередь служит основанием для развития профессионального сознания преподавателя (Загвязинский В.И., 1999).

Анализируя подходы к изучению инноваций в образовании, нами разработана структура компонентов инновационной деятельности преподавателей (рис. 1). 


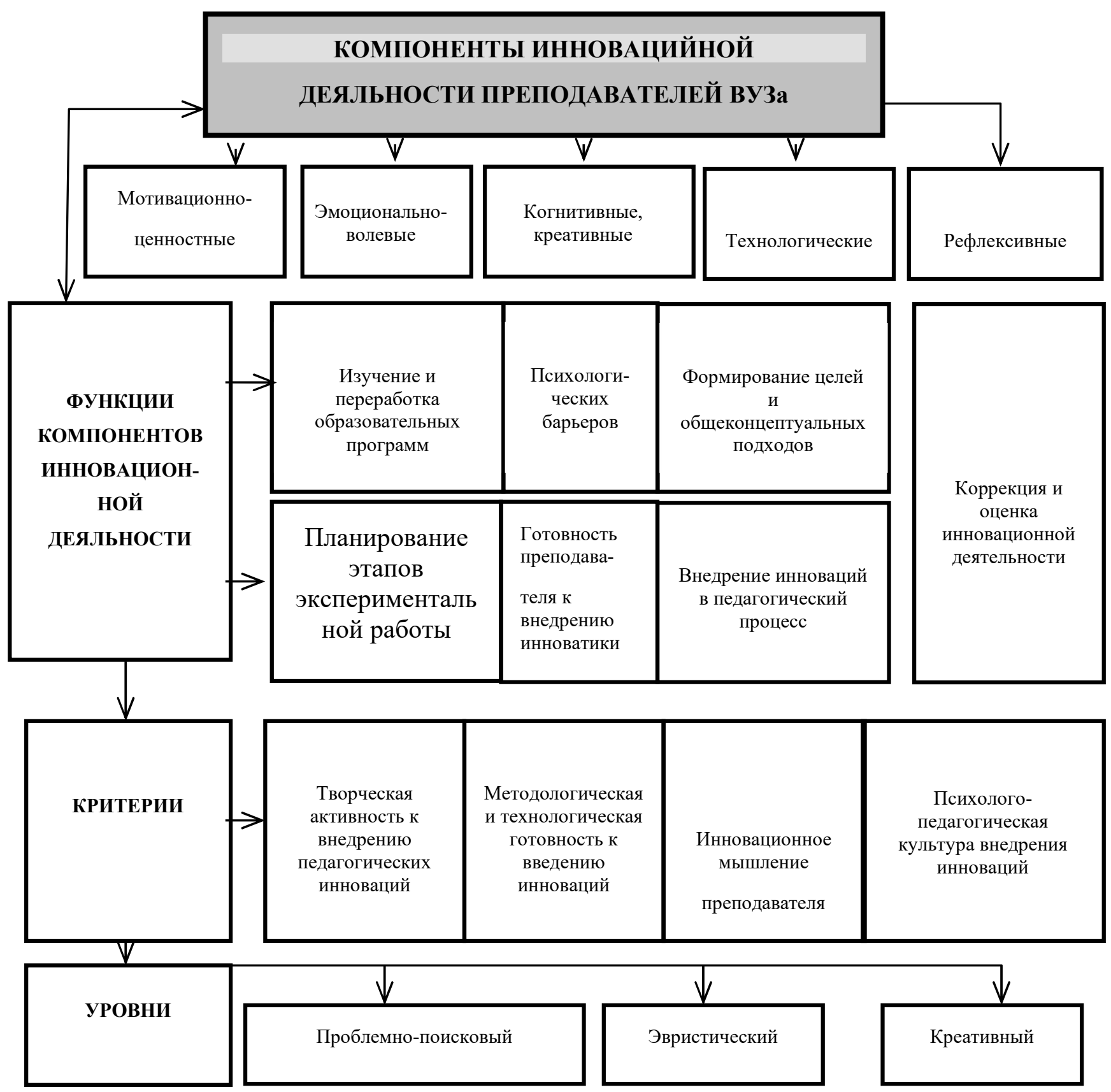

Рис. 1. Структура компонентов инновационной деятельности преподавателя высшей школы

С точки зрения управления, стихийные и целенаправленные инновации, по мнению В. И. Загвязинского, делятся на четыре подтипа: научный контрольные функции выполняют научные организации; научноадминистративный - контроль осуществляют они же при поддержке органов управления образованием; административно-научный - контроль и управление осуществляют органы управления, опираясь на науку; политико- 
THEORETICAL FOUNDATIONS OF THE FUNCTIONING OF EDUCATION. WAYS TO

IMPROVE THE EFFECTIVENESS OF EDUCATIONAL ACTIVITIES

административный - контрольные функции берут на себя административные органы (Загвязинский В.И., 1999).

Современный этап развития инновационных процессов в образовании характеризуется тенденцией к ликвидации разрыва между процессами их восприятия, адекватной оценке освоения и применения их на практике, а также к преодолению противоречия между стихийностью этих процессов и возможностью сознательного управления ими (Berg Carin and Vlasctanu Lazar, 1991). Сказанное позволяет выдвинуть предположение, что источником развития профессионализма преподавателя, влияющим также на развитие его профессионального сознания, являются инновационные образовательные процессы. Для доказательства этого предположения необходимо рассмотреть позицию преподавателя в инновационных процессах, поскольку создание нового в профессиональной деятельности преподавателя имеет свои особенности и связано, в том числе, с самобытностью личности преподавателя, его профессиональным сознанием, с особенностями учебного процесса. Инновации в образовании отличаются от других систем тем, что «объект» влияния инноваций, предмет их деятельности - это развивающаяся живая личность, имеющая неповторимое «Я». Инновации существенно отличаются одна от другой по влиянию на человека, отношением к ним субъекта, они выполняют разные функции в разных социальных процессах. Категории субъекта, объекта, субъект-субъектных отношений являются общеметодологическим основанием для анализа механизма развития инновационных отношений.

А.И. Пригожин отмечает, что главная характеристика субъекта инноваций, т.е. понимание своей личностной инициативы как субъективно возможной и ощущение общественно принятого собственного существования. Автор представляет субъективность как единство целеположений и целесовершения в одной личности (Пригожин А.И., 1985). Преподаватель как субъект инновационной деятельности и ее организатор вступает с другими членами педагогического сотоварищества в процесс создания, использования и расширения инноваций, он обсуждает содержание нововведения и те возможные 
THEORETICAL FOUNDATIONS OF THE FUNCTIONING OF EDUCATION. WAYS TO IMPROVE THE EFFECTIVENESS OF EDUCATIONAL ACTIVITIES

в самосознании, привычках, традициях изменения. Инновации обуславливают преобразования в профессиональном сознании, начинающиеся с принятия человеком требований, поставленных перед ним условиями жизни и современным обществом, с осознания новых, возникающих в обществе отношений, а также изменений, происходящих в нем самом. С иной стороны происходят изменения в характере и содержании требований, которые человек сам предъявляет к жизни, к обществу. В случае несовпадения выдвигаемых обществом к человеку требований, а также ожидаемых от него результатов с требованиями, адресованными человеком обществу, неминуемо возникают конфликты, как во взаимоотношениях человека с внешним миром, так и внутреличностные. Эти конфликты служат основанием несоответствия новым условиям и требованиям, основанием для реальных изменений в мышлении в индивидуальном сознании. Человек оказывается перед необходимостью переоценки своих требований к жизни, изменения взгляда на вещи и на самого себя (Пригожин А.И., 1985). Инновационная деятельность во многом определяется успешностью вхождения в особую культурную среду. Как отмечает А. И. Пригожин, исходя из идеи, что вхождение в новую культуру сопровождается неприятными чувствами (утрата друзей и статуса, дискомфорт при осознании различий между культурами), путаницей в ценностных ориентациях и собственно личностной идентичностью, вводит термин «культурный шок». Его симптомы могут проявляться через отсутствие уверенности в себе, тревожности, раздражительности, бессоннице, депрессии. Чаще всего «культурный шок» ассоциируется с негативными последствиями. И лишь немногие обращают внимание на его позитивную сторону, когда первичный дискомфорт сменяется принятием новых ценностей, моделей поведения, ведущих, в конце концов, к саморазвитию и личностному росту (Пригожин А.И., 1985).

Процесс инновационной деятельности преподавателя высшей школы складывается с двух взаимодополняющих частей. Первая строится через изменения мотивационных отношений путем подражания и заражения 
THEORETICAL FOUNDATIONS OF THE FUNCTIONING OF EDUCATION. WAYS TO IMPROVE THE EFFECTIVENESS OF EDUCATIONAL ACTIVITIES

инноватикой. Она определяет отношение к инновациям и переживание событий, связанных с их внедрением. Вторая часть получает информацию через направленное, осознанное инновационное обучение, поддерживаемое самой структурой нашего общества (Сластенин В.А, 1997).

Вся относящаяся к инновации информация связана с определенной системой ценностей и барьеров. В науке психологические барьеры понимаются как внутренние преграды (нежелания, боязнь, неуверенность), мешающие человеку успешно выполнять определенные действия. Каждый человек во взаимодействии с внешней информацией выбирает только ту, которая может быть усвоена, не ломая и не внося существенного расстройства в его душевную жизнь. Но охрана сложившихся о мире представлений мешает творческому процессу, обращенному к пониманию нового (Радугин А.А., 1996).

Через отсутствие завершенной теории управления инновационной деятельностью профессорско-преподавательского состава высшего учебного заведения становится необходимым установление новых связей между теоретическими положениями и современной практикой в образовании и возникает потребность в разработке прогностических моделей управления инновационной деятельностью профессорско-преподавательского состава высшего учебного заведения.

Особенности профессиональной деятельности преподавателей высшей школы проявляются в социальной деятельности, направленной на передачу знаний, накопленной человечеством культуры, профессионального опыта и подготовке к выполнению определенных социальных потребностей общества. Н. В. Кузьмина выделила в структуре профессиональной деятельности преподавателей три взаимосвязанных компонента: конструктивный, организаторский и коммуникативный (Кузьмина Н.В., 1993).

А.И. Щербаков (Щербаков А.И., 1967) относит конструктивный, организаторский и исследовательский компоненты к общетрудовым. Но он конкретизирует функцию преподавателя на этапе реализации учебного процесса, представив организаторский компонент как единство информационной, 
THEORETICAL FOUNDATIONS OF THE FUNCTIONING OF EDUCATION. WAYS TO IMPROVE THE EFFECTIVENESS OF EDUCATIONAL ACTIVITIES

развивающей, ориентационной и мобилизационной функций. Особенно следует обратить внимание на научно-исследовательскую функцию преподавателя, хотя она отнесена автором к общетрудовым. Реализация научно-исследовательской функции требует от преподавателя научного подхода к овладению умениями эвристического поиска и методами научного исследования, в том числе анализу собственного опыта и опыта других коллег. Конструктивный компонент профессиональной деятельности преподавателя может быть представлен как внутренне взаимосвязанная аналитическая, прогностическая и проектная функции. Все компоненты или функциональные виды деятельности проявляются в работе преподавателя любой специальности. Одним из наиболее важных требований, выдвигаемых профессией преподавателю, является четкость социальной и профессиональной позиций. Позиция преподавателя - это система тех интеллектуальных, волевых и эмоционально-оценочных отношений к миру, являющихся источником его активности. Она определяется, с одной стороны, теми требованиями, ожиданиями и возможностями, выдвигаемыми и предоставляемые ему обществом, а с другой - действуют внутренние, личностные источники активности - влечения, переживания, мотивы и цели преподавателя, его ценностные ориентации, мировоззрение, идеалы. В позиции преподавателя проявляется его личность, характер социальной ориентации, тип гражданского поведения. Социальная позиция преподавателя возрастает в системе взглядов, убеждений и ценностных ориентаций (Щербаков А.И., 1967).

Беря во внимание отмеченное, можно сделать вывод, что профессионалом следует считать преподавателя высшей щколы, овладевшего нормами профессиональной деятельности, профессионального общения и реализующего их на высоком уровне, достигая профессионального мастерства, придерживаясь профессиональной этики, ориентируясь на профессиональные ценностные ориентации; развивающего и изменяющего свою личность и индивидуальность средствами профессии; стремящегося и умеющего вызвать интерес общества к результатам своей деятельности, способствующего повышению авторитета и престижа своей профессии в обществе, гибко учитывающего новые запросы 
THEORETICAL FOUNDATIONS OF THE FUNCTIONING OF EDUCATION. WAYS TO IMPROVE THE EFFECTIVENESS OF EDUCATIONAL ACTIVITIES

общества к нему. Становление названных качеств профессионала проходит ряд этапов. Главное - это качественные, поддающиеся изменения профессионализма на отдельных этапах, которые можно изучать, формировать и шлифовать в себе и в другом человеке.

Профессиональная деятельность человека включает ряд функций и обязанностей, требующих от специалиста наличия соответственных качеств, определяемых как профессионально важные качества личности. Под профессионально важными качествами преподавателя следует понимать индивидуальные качества, влияющие на эффективность профессиональной деятельности и успешность ее освоения.

В ряде исследований есть несколько подходов к выделению определенных свойств личности, характеризирующих ее как профессионала, как субъекта профессиональной деятельности (Кузьмина Н.В., 1992; Кузьмина Н.В., 1993; Сластенин В.А., 1997).

В табл. 1 показано профессионально обусловленную структуру личности преподавателя: профессиональная мотивация; профессиональная компетентность; профессионально важные качества личности специалиста; социально-психологические компоненты деятельности, профессионально обусловленные компоненты деятельности.

\section{Таблица 1.}

Профессионально обусловленная структура деятельности личности педагога

\begin{tabular}{|c|c|c|c|}
\hline $\begin{array}{c}\text { СТРУКТУРН } \\
\text { ЫЕ } \\
\text { КОМПОНЕНТЫ } \\
\text { ДЕЯТЕЛЬНОСТИ }\end{array}$ & \multicolumn{3}{|c|}{ СОДЕРЖАНИЕ СТРУКТУРНЫХ КОМПОНЕНТОВ } \\
ДЕЯТЕЛЬНОСТИ \\
\hline $\begin{array}{c}\text { Личностные } \\
\text { компоненты в } \\
\text { профессиональной } \\
\text { деятельности }\end{array}$ & $\begin{array}{c}\text { Пная мотивация и } \\
\text { направленность } \\
\text { преподавателя, } \\
\text { идеалы, убеждения, } \\
\text { профессиональное } \\
\text { сознание }\end{array}$ & $\begin{array}{c}\text { Профессионал } \\
\text { ьная } \\
\text { компетентнос } \\
\text { ть }\end{array}$ & $\begin{array}{c}\text { Профессионал } \\
\text { ьно важные } \\
\text { психологические } \\
\text { качества личности }\end{array}$ \\
& & & \\
& & & \\
\hline
\end{tabular}


THEORETICAL FOUNDATIONS OF THE FUNCTIONING OF EDUCATION. WAYS TO IMPROVE THE EFFECTIVENESS OF EDUCATIONAL ACTIVITIES

\begin{tabular}{|c|c|c|c|}
\hline $\begin{array}{c}\text { Социально- } \\
\text { психологические } \\
\text { компоненты } \\
\text { деятельности }\end{array}$ & $\begin{array}{c}\text { Социально- } \\
\text { профессиональные } \\
\text { интересы: готовность } \\
\text { ко взаимодействию, } \\
\text { социальная } \\
\text { ответственность, } \\
\text { отношения, } \\
\text { установки }\end{array}$ & $\begin{array}{c}\text { Психологичес } \\
\text { кая культура, } \\
\text { познавательные, } \\
\text { коммуникативные, } \\
\text { эмоционально- } \\
\text { волевые качества }\end{array}$ & $\begin{array}{c}\text { Типологическ } \\
\text { ие, } \\
\text { характерологические } \\
\text {, интеллектуальные, } \\
\text { эмоционально- } \\
\text { волевые, социально- } \\
\text { профессиональный } \\
\text { интеллект }\end{array}$ \\
\hline $\begin{array}{r}\text { Профессиона } \\
\text { льно обусловленные } \\
\text { компоненты } \\
\text { деятельности }\end{array}$ & $\begin{array}{l}\text { Направленнос } \\
\text { ть на } \\
\text { профессиональные } \\
\text { успехи, достижения } \\
\text { и профессиональный } \\
\text { рост, надежность и } \\
\text { т.п. }\end{array}$ & $\begin{array}{r}\text { Научная } \\
\text { компетентность, } \\
\text { персональная } \\
\text { компетентность: } \\
\text { знания, умения, } \\
\text { навыки; } \\
\text { квалификация, } \\
\text { специальная } \\
\text { практическая } \\
\text { компетентность }\end{array}$ & $\begin{array}{c}\text { Профессионал } \\
\text { ьная } \\
\text { самостоятельность, } \\
\text { креативность, } \\
\text { аналитичность, } \\
\text { наблюдательность, } \\
\text { профессиональная } \\
\text { мобильность, } \\
\text { самоконтроль, } \\
\text { умения и } \\
\text { способность } \\
\text { планировать }\end{array}$ \\
\hline
\end{tabular}

Специфической особенностью профессиональной деятельности преподавателей есть то, что их решения практически никогда не лежат на поверхности. Они часто требуют напряженного мышления, анализа различных показателей, условий и обстоятельств. Кроме того, то, на что направлено поиск, не представлено в четких формулировках: оно вырабатывается на основании интуиции, прогноза, творческой и научной работы преподавателей. Решение взаимосвязанного ряда профессиональных заданий очень тяжело поддается алгоритмизации. Если же алгоритм уже существует, использование его разными преподавателями может дать разные результаты. Это объясняется тем, что творчество преподавателей постоянно связано с инновационным поиском решения профессиональных заданий.

Освоение преподавателем существенных характеристик квалификации в практической деятельности способствует развитию новых качеств его личности - профессионализма (опираясь на анализ исследований, можно дать такое рабочее определение). Профессионализм представляет собой интегративные свойства личности преподавателя, отображающие уникальную для каждого преподавателя взаимосвязь и содержательное наполнение компонентов, входящих в состав рассматриваемых свойств - профессиональной 
THEORETICAL FOUNDATIONS OF THE FUNCTIONING OF EDUCATION. WAYS TO IMPROVE THE EFFECTIVENESS OF EDUCATIONAL ACTIVITIES

компетентности, моральности, инициативы и мастерства, позволяющих количественно и качественно охарактеризовать самобытную индивидуальность педагога, опираясь на которую можно определить пути повышения конкурентоспособности преподавателя на современном рынке образовательных услуг (рис. 2).

ПРОФЕССИОНАЛЬНАЯ КОМПЕТЕНТНОСТЬ

Компетенции: методическая, организационная, психологическая, рефлексивноисследовательская, коммуникативная, акмеологическая

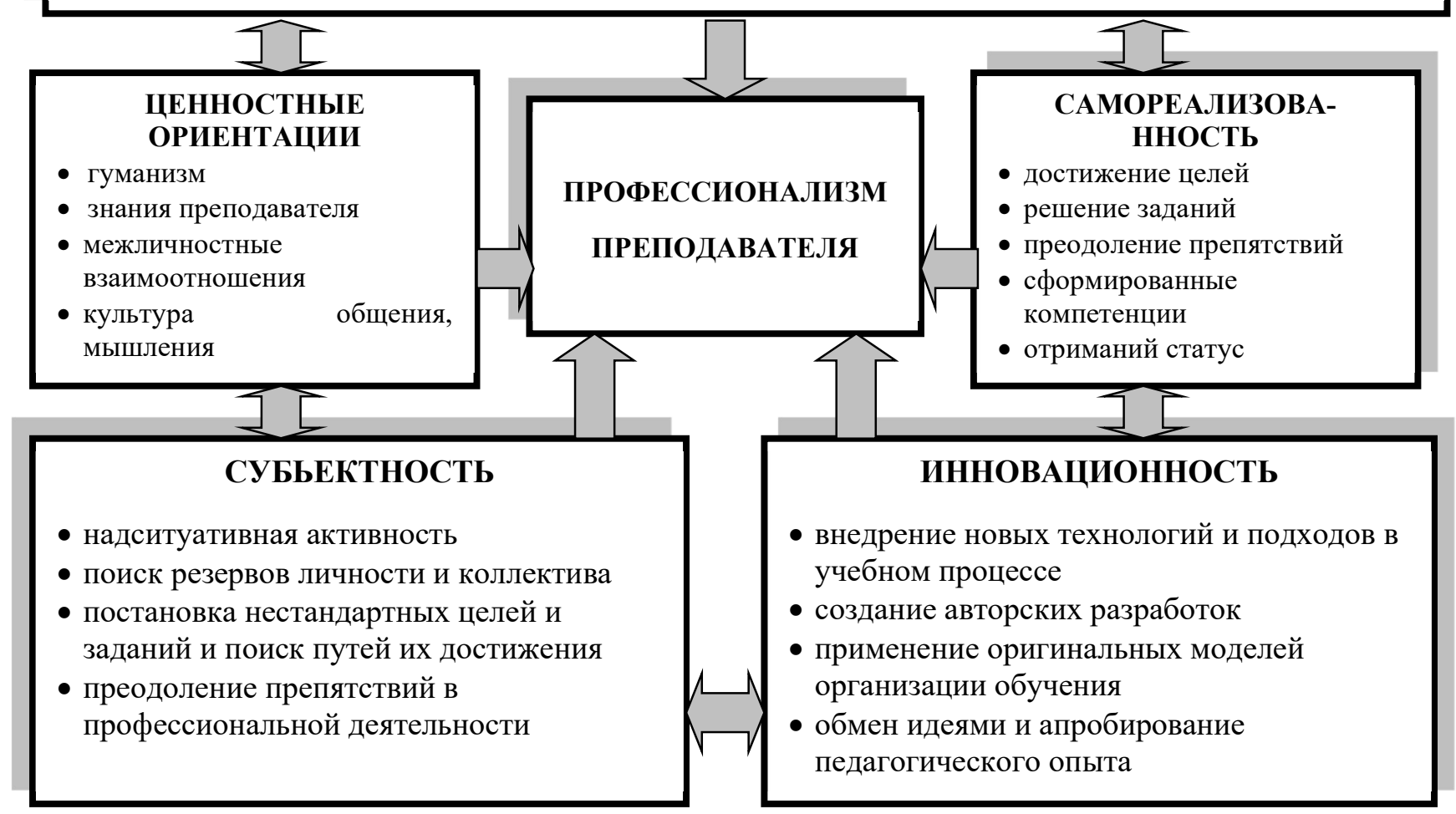

Рис. 2. Функциональная структура профессионализма преподавателя высшей школы

Основной функциональной единицей, при помощи которой определяются все свойства профессиональной деятельности преподавателей, есть педагогическое действие как единство целей и содержания. Педагогическое действие преподавателя вначале выступает в форме познавательного задания. Опираясь на имеющиеся знания, преподаватель теоретически сопоставляет средства, предмет и предполагаемый результат своего действия. Познавательное задание, будучи решенным преподавателем, психологически, потом переходит в форму практического преобразующего акта. При этом проявляется некоторое 
THEORETICAL FOUNDATIONS OF THE FUNCTIONING OF EDUCATION. WAYS TO IMPROVE THE EFFECTIVENESS OF EDUCATIONAL ACTIVITIES

несоответствие между способами и объектами педагогического влияния, что сказывается на результатах действий преподавателя. В связи с этим формы практического акта вновь переходят в форму познавательного задания, условия которого становятся более полными. Таким образом, профессиональная деятельность преподавателя по своей природе является не что иное, как процесс решения множества заданий разных типов, классов и уровней (Лифинцева Н.И, 1999).

В психологической деятельности преподавателя высшей школы большое значение играет психологическая культура, прослеживаемая во всех основных ипостасях педагогического взаимодействия в образовательной среде: личность, субъект, индивидуальность; имеет иерархическое многоуровневое строение и многокомпонентный состав; позволяет выявлять особенности восприятия другого субъекта, глубину его понимания адекватности знаний о нем, характер переживаний, связанных с другим человеком, а также воспитывать умения общаться и продуктивно работать над общим делом (рис. 3).

\section{КУЛЬТУРА ЛИЧНОСТИ ПЕДАГОГА}

Духовность. Сознательность. Деятельность. Поведение. Общение.

ПСИХОЛОГО-ПЕДАГОГИЧЕСКОЕ МАСТЕРСТВО:

отражает качественную определенность, указывающую на наличие профессионально-личностной уникальности преподавателя

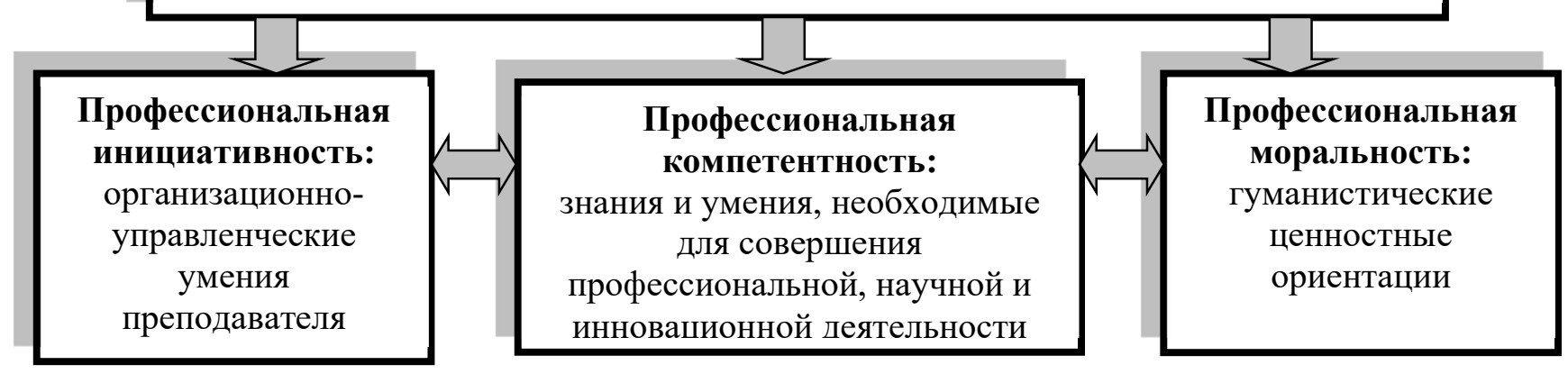

Рис. 3. Психологическая структура профессионализма преподавателя высшей школы

Зрелая психологическая культура преподавателя является наиболее гармоничным психологическим образованием формирования профессионализма педагога (Турянская В.Э., 2008). Психологическая культура выступает 
THEORETICAL FOUNDATIONS OF THE FUNCTIONING OF EDUCATION. WAYS TO

IMPROVE THE EFFECTIVENESS OF EDUCATIONAL ACTIVITIES

социально-психологическим механизмом продуктивной профессиональной деятельности в образовательной среде, является условием полноценного и успешного взаимодействия с окружающими людьми и социальной культурой, детерминантом психологического здоровья человека, показателем качества любой человеческой деятельности, в том числе образовательной и профессиональной.

Когнитивный компонент: система научных психологических знаний о человеке и социальном взаимодействии людей, система адекватных представлений о своем внутреннем психологическом мире и индивидуальных качествах, развитой интеллект, креативность, склонность к социальному творчеству.

Рефлексивно-перцептивный компонент:

наблюдательность, внимательность к человеку, психологическое проникновение, умение адекватно воспринимать самого себя и других людей (конгруэнтность), прогностические умения, способность к идентификации.

Эмоционально-аффективный компонент: внимательность к человеку, развитая эмпатия и умение сопереживать, богатство и действенность переживаний, эмоциональная стабильность, внимательность, уважительность, великодушие, милосердие, чувство собственного достоинства, чувство юмора.

Волевой компонент: способность противостоять внешнему давлению, способность сдерживать негативные эмоции, влияния и сильные переживания, способность не допускать срывов деятельности при значительных психических и физических нагрузках, самоконтроль, выдержка, настойчивость в утверждении моральных ценностей и отстаивании моральных принципов, надежность.

В образовательной среде психологическая культура личности выступает как единство знаний, отношений воспитания, переживаний и жизненного опыта. Рассматривая психологическую культуру в общетеоретическом плане в рамках системного подхода, В. Э. Турянская (Турянская В.Э., 2008) определила ее как многомерное психологическое образование, выделила ее компоненты: знание социального взаимодействия, регулятивный и коммуникативный 
(системообразующий); ценностно-мотивационный, выступающий стержнем, интегрирующим в этой системе; когнитивный, эмоционально-аффективный, рефлексивно-перцептивный, волевой (рис. 4).

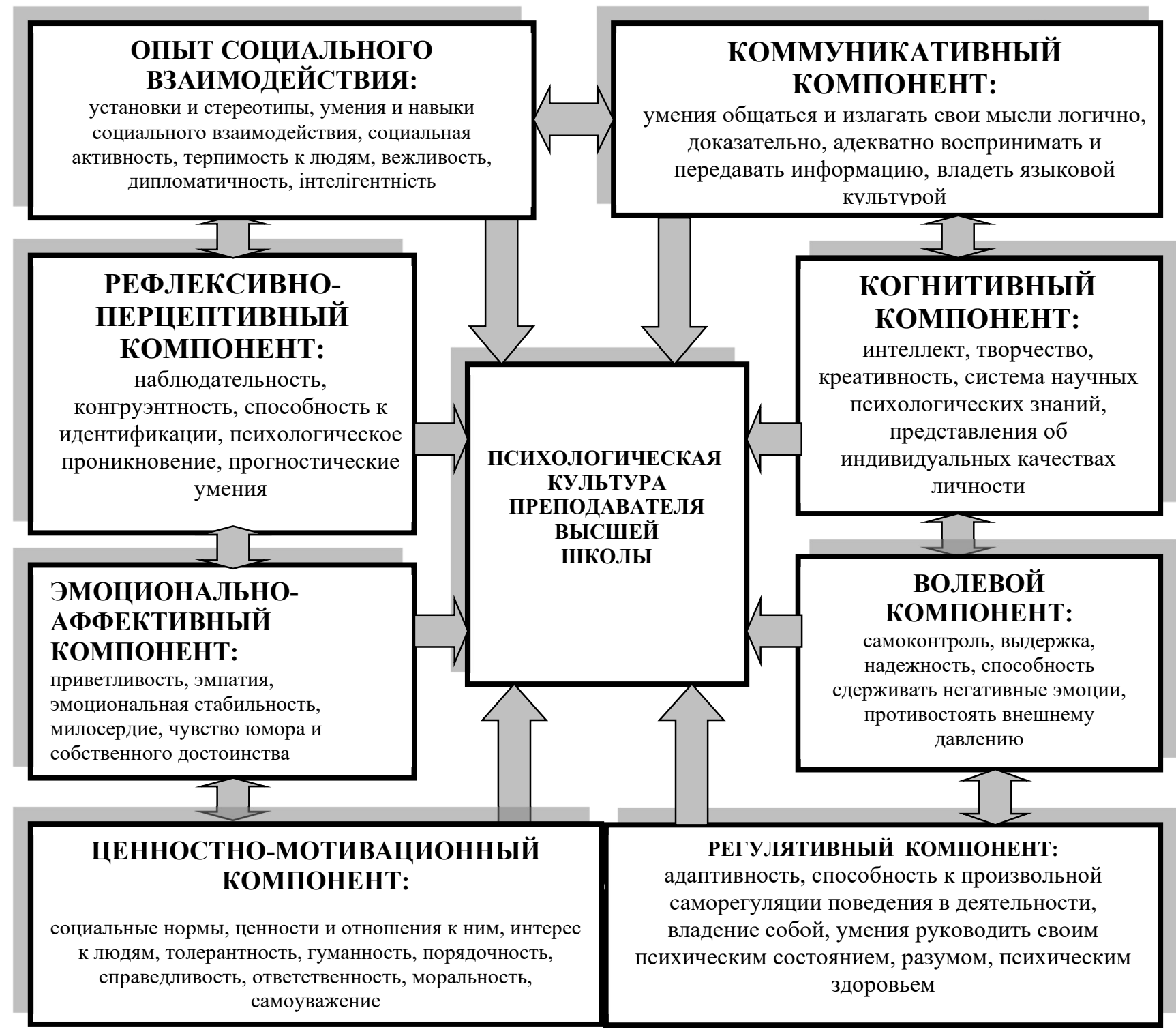

Рис. 4. Основные компоненты психологической культуры личности преподавателя высшей школы

Коммуникативный компонент: умение общаться с разными людьми, адекватно воспринимать и передавать информацию, умение строить и излагать свои мысли логично, доказательно и понятно, языковая культура.

Регулятивный компонент: адаптивность, совестливость, моральная саморегуляция, способность к произвольной саморегуляции поведения в деятельности, обладание собой, умение руководить своим психологическим состоянием, разумом, психическим здоровьем. 
THEORETICAL FOUNDATIONS OF THE FUNCTIONING OF EDUCATION. WAYS TO IMPROVE THE EFFECTIVENESS OF EDUCATIONAL ACTIVITIES

Опыт социального взаимодействия: установки и стереотипы культурного поведения, развитые умения и навыки социального взаимодействия, социальная активность, терпимость к людям, уважительность, дипломатичность, старательность, внутреннее достоинство, интеллигентность.

Ценностно-мотивационный компонент: социальные нормы, ценности, интерес к людям, личностные потребности, толерантность, гуманность, порядочность, справедливость, ответственность, моральное самоуважение.

В целостном процессе профессионального становления личности Э. Ф. Зеер (Зеер Э.Ф., 2000) выделяет семь стадий. Переход от одной стадии профессионального становления к другой означает изменение социальной ситуации развития, изменение содержания ведущей деятельности, освоение или присвоение новой социальной роли профессионального поведения, и, конечно же, перестройку личности (табл. 2). Все эти изменения не могут не вызывать психического напряжения личности. Переход от одной стадии к другой порождает субъективные и объективные трудности, межличностные и внутриличностные конфликты. Можно утверждать, что изменение стадий инициирует нормативные кризисы профессионального становления личности. Деятельность педагога совершается в системах «человека - общество», «человек - человек», «человек - группа» и относится к категории сложных динамических систем, выдвигающих высокие требования к психическим функциям субъекта.

Таблица 2

Стадии профессионального становления личности (за Э. Ф. Зеером )

\begin{tabular}{|r|c|c|}
\hline \multirow{2}{*}{ o. } & СТАДИЯ & ОСНОВНЫЕ ПСИХОЛОГИЧЕСКИЕ \\
& НОВООБРАЗОВАНИЯ \\
\hline 1 & $\begin{array}{c}\text { Аморфная } \\
\text { оптация } \\
\text { (0-12 лет) }\end{array}$ & $\begin{array}{c}\text { Профессионально сориентированные } \\
\text { интересы и наклонности }\end{array}$ \\
\hline $\mathbf{2}$ & Оптация & Профессиональные намерения, выбор пути \\
& $\mathbf{( 1 2 - 1 6 ~ л е т ) ~}$ & $\begin{array}{c}\text { профессионального образования и } \\
\text { профессиональной подготовки, учебно- } \\
\text { профессиональное самоопределение }\end{array}$ \\
\hline 3 & Профессиональная & Профессиональная подготовленность, \\
& подготовка (16-23 лет) & $\begin{array}{c}\text { профессиональное самоопределение, готовность к } \\
\text { самостоятельному труду }\end{array}$ \\
\hline
\end{tabular}


THEORETICAL FOUNDATIONS OF THE FUNCTIONING OF EDUCATION. WAYS TO IMPROVE THE EFFECTIVENESS OF EDUCATIONAL ACTIVITIES

\begin{tabular}{|c|c|c|}
\hline 4 & $\begin{array}{l}\text { Профессиональная } \\
\text { адаптация } \\
(18-25 \text { лет }) \\
\end{array}$ & $\begin{array}{l}\text { Освоение новой социальной роли, опыта, } \\
\text { самостоятельного выполнения профессиональной } \\
\text { деятельности, профессионально важные качества }\end{array}$ \\
\hline 5 & $\begin{array}{c}\text { Первичная } \\
\text { профессионализация } \\
\text { (25-35 лет) }\end{array}$ & $\begin{array}{c}\text { Профессиональная позиция, интегративные } \\
\text { профессионально значимые констелляции, } \\
\text { индивидуальный стиль деятельности. } \\
\text { Квалифицированный труд }\end{array}$ \\
\hline 6 & $\begin{array}{c}\text { Вторичная } \\
\text { профессионализация } \\
\text { (35-45 лет) }\end{array}$ & $\begin{array}{c}\text { Профессиональный менталитет, } \\
\text { идентификация с профессиональным } \\
\text { сотовариществом, профессиональная мобильность, } \\
\text { корпоративность, гибкий стиль деятельности, } \\
\text { высококвалифицированная деятельность }\end{array}$ \\
\hline 7 & $\begin{array}{l}\text { Профессиональное } \\
\text { мастерство } \\
\text { (выше } 45 \text { лет) }\end{array}$ & $\begin{array}{c}\text { Творческая профессиональная деятельность, } \\
\text { подвижные интеграционные психологические } \\
\text { новообразования, самопроектирование своей } \\
\text { деятельности и карьеры, вершина (акме) } \\
\text { профессионального развития }\end{array}$ \\
\hline
\end{tabular}

Ряд исследователей считают, что рост профессионализма возможен при условии существования акмеологической и социально-культурной среды, в которой развитие профессионализма является ценностью, традицией, требованием, реальностью и идеалом. В развитой профессиональной среде типичным является активное межличностное сотрудничество, выступающее важным условием интенсивного информационного обмена и профессионального развития (Деркач А.А., 2004; Лифинцева Н.И., 2000). Целостное познание формирвания профессионализма преподавателя предполагает выделение системы его детерминант, обстоятельств, которые, будучи тесно связанными, могут выполнять опосредующие функции следствия, внешних и внутренних показателей, условий, предпосылок и звеньев, движение и изменение которых необходимы для развития профессионализма педагога, выступающего в роли важного детерминанта (Ломов Б.Ф., 1981; Ломов Б.Ф., 1984), параметра порядка (Пригожин А.И., 1985), определяющего и обеспечивающего возможности перехода на новый уровень развития.

В профессиональной деятельности педагога психологическим аспектам не всегда уделяется надлежащее внимание. В основном учитываются такие показатели, как опыт работы, место в служебной иерархии, статистические показатели выполнения профессиональной деятельности. Такая практика работы часто приводит к низкой эффективности в развитии профессиональной 
THEORETICAL FOUNDATIONS OF THE FUNCTIONING OF EDUCATION. WAYS TO

IMPROVE THE EFFECTIVENESS OF EDUCATIONAL ACTIVITIES

мотивации преподавателя, формальному выполнению служебных обязательств, негативным проявлениям в межличностных отношениях, фактам профессиональной деформации.

Психологический анализ профессиональной деятельности преподавателя служит основанием для решения ряда таких научно-практических заданий, как реконструкция существующих и проектирование новых видов профессионального труда преподавателя, возникающих в связи с новыми потребностями общества, новыми видами социально-экономических отношений в образовании. Для изучения содержания и структуры профессиональной деятельности педагога мы использовали метод профессиографии. Данный метод имеет научное, информационное и практическое значение, помогая понять функциональную структуру профессиональной деятельности педагогов, позволяет дать адекватную оценку, наметить пути коррекции, организовать эффективную систему обучения и профессионального совершенствования (Поляков С.Д., 1993).

Деятельность преподавателя связана с высокими психологическими нагрузками, поскольку она проистекает в нестандартных, постоянно изменяющихся, напряженных ситуациях, связана с решением важных государственных заданий, ответственностью за эффективное обучение и подготовку студентов.

Надежность деятельности педагога возможна только при наличии высокой профессиональной компетентности, когда способность к самостоятельному и сознательному выполнению конкретных заданий объединяется с профессионально важными качествами его личности.

Детерминанты развития профессионализма преподавателя высшей школы предполагают психологические условия и показатели, которые можно назвать акмеологическими, поскольку они являются обстоятельствами, влияющими на достижение высшего уровня профессионализма педагога. К этим условиям принадлежат: социальный госзаказ на профессионалов-педагогов высокой квалификации; ситуации профессионально-личностного развития. Нами 
THEORETICAL FOUNDATIONS OF THE FUNCTIONING OF EDUCATION. WAYS TO

IMPROVE THE EFFECTIVENESS OF EDUCATIONAL ACTIVITIES

выделены детерминанты формирования профессионализма педагогов высшей школы (рис. 5).

Показатели: научная

деятельность, обучение;

творчество; креативность;

профессиональная активность;

навыки управления

организацией учебного

процесса
Условия: социальный госзаказ на профессионаловпреподавателей высокой квалификации; система повышения квалификации преподавателей; научноисследовательская деятельность, профессиональноличностное развитие; поиск личностных резервов, усовершенствование профессионально-важных качеств

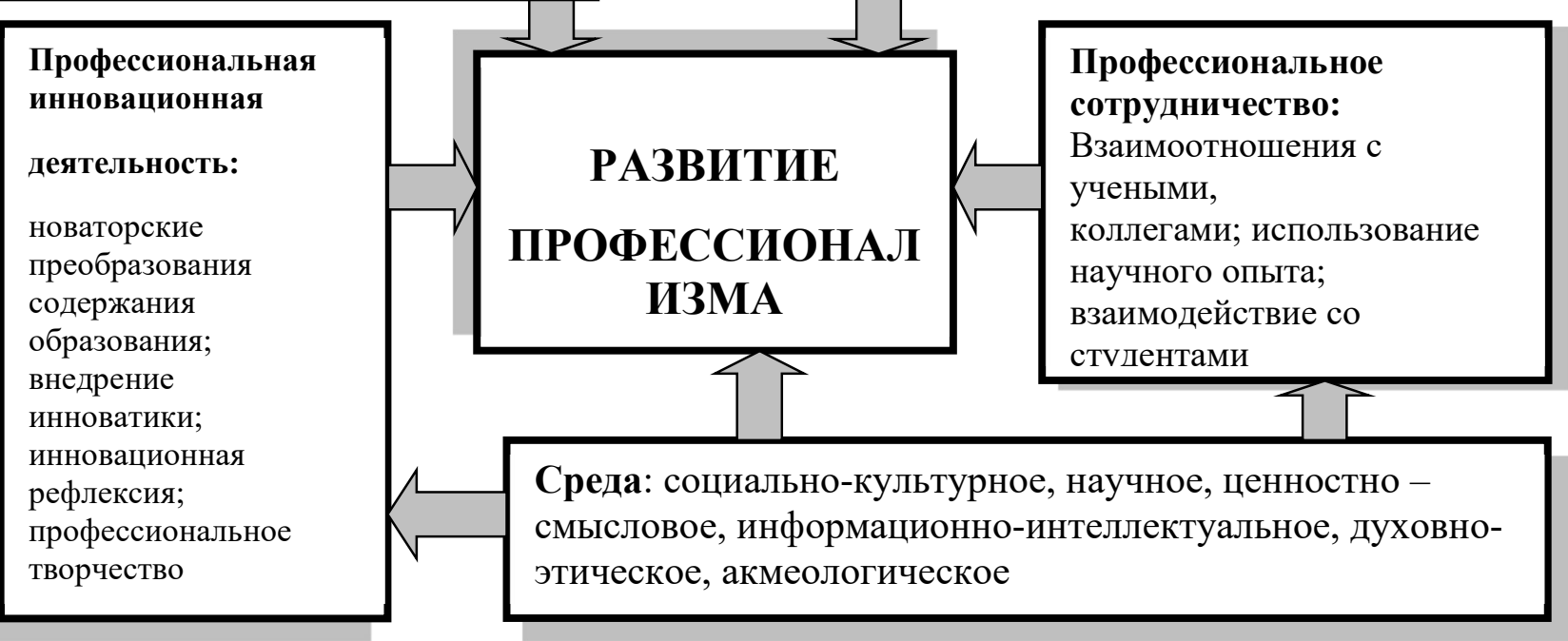

Рис. 5. Детерминанты развития профессионализма преподавателей высшей школы

А.И. Щербаков считает, что в психологической структуре личности педагога должны быть выделены общественные качества, этичнопсихологические, социально-перцептивные, индивидуально-психологические особенности, практические умения и навыки (Щербаков А.И., 1967). Содержание профессиональной готовности педагогов, показанное в психограмме, отражает параметры личности и психологические характеристики их профессиональной деятельности. Накопленный опыт построения психограммы преподавателя позволяет профессиональные требования к преподавателю объединить во взаимосвязанные и дополняющие один одного комплексы: общественные качества; определяющие специфику профессии преподавателя качества; специальные теоретические, практические и научные знания, умения и навыки по предмету и специальности (Кваша В.П., 1994). 
THEORETICAL FOUNDATIONS OF THE FUNCTIONING OF EDUCATION. WAYS TO

IMPROVE THE EFFECTIVENESS OF EDUCATIONAL ACTIVITIES

Проведенные нами исследования показывают, что профессиональная деятельность преподавателя высшей школы требует следующих личностных, профессиональных, социальных, психологических качеств и педагогических способностей, включенных нами в психограмму:

- профессиональная мотивация: профессиональные интересы, ценностные ориентации, установки, профессиональная направленность;

- профессиональная компетентность: методическая, психологическая, коммуникативная, акмеологическая, рефлексивно-исследовательская и организационная, профессиональные умения и навыки;

- профессиональная целенаправленность: постановка профессиональных заданий, прогнозирование результатов, отбор методов обучения, психологическая грамотность;

- когнитивные качества: профессиональные знания; аналитичность, критичность, гибкость, креативность, инновационность мышления; развитые память, воображение, наблюдательность; устойчивое внимание; активная интеллектуальная деятельность, научно-педагогическая эрудиция, научный поиск, научно-исследовательская деятельность;

- коммуникативные качества: культура общения, активность, уверенность, ассертивность, толерантность, вербальная тактичность, выразительность языка и речи, открытость, суггестия, этика поведения, педагогическая интуиция;

- организационно-управленческие качества: лидерство, конструктивность деятельности; планирование, моделирование учебного процесса и инновационных технологий; владение педагогической техникой;

- эмоционально-волевые качества: эмпатия, оптимизм, эмоциональноволевая устойчивость, уважительность, стрессоустойчивость, адекватность поведения, выдержка, самообладание, твердость характера;

- морально-этические качества: идеалы, ценности, гуманность, профессиональная этика, мораль, принципиальность, убеждения, направленность, уровень требований, патриотизм, авторитет, имидж, 
THEORETICAL FOUNDATIONS OF THE FUNCTIONING OF EDUCATION. WAYS TO IMPROVE THE EFFECTIVENESS OF EDUCATIONAL ACTIVITIES

гражданская активность, оптимизм; высокий уровень ответственности общей и психологической культуры;

- регулятивные качества: осознание цели, процесса и результата деятельности, уровни психологической грамотности, компетентности саморегуляции, самоконтроля, самообразования, самоусовершенствования;

- индивидуально-психологические особенности: типологичные (активность, динамичность уравновешенность); характерологические (дисциплинированность, честность, адекватное восприятие студента как личности); проектирование целей обучения и прогнозирование путей профессионального становления будущего педагога; духовно-воспитательное влияние на академическую группу и личность студента, позитивная Яконцепция; способности: общие, специальные, педагогические, дидактические, коммуникативные, перцептивные, научно-исследовательские, инновационные.

Указанная модель (рис. 6) отражает специфику деятельности преподавателя и необходимые для выполнения его профессиональных обязанностей профессионально важные личностные качества.

В овладении преподавателем стратегиями обновления и преобразования профессиональной деятельности решающее значение имеет такой компонент профессионализма, как инновационность. Он характеризует динамику роста овладения преподавателем инновациями, как через формы индивидуальных открытий, так и через расширение внедрения инноваций в профессиональную деятельность. Это, безусловно, предполагает выявление конкретных критериев профессионализма преподавателя, при помощи которых должны возникать связи между всеми его компонентами (Лифинцева Н.И, 2000).

На рис. 6 приведена разработанная нами модель (психограмма) профессиональной деятельности преподавателей высшей школы. 


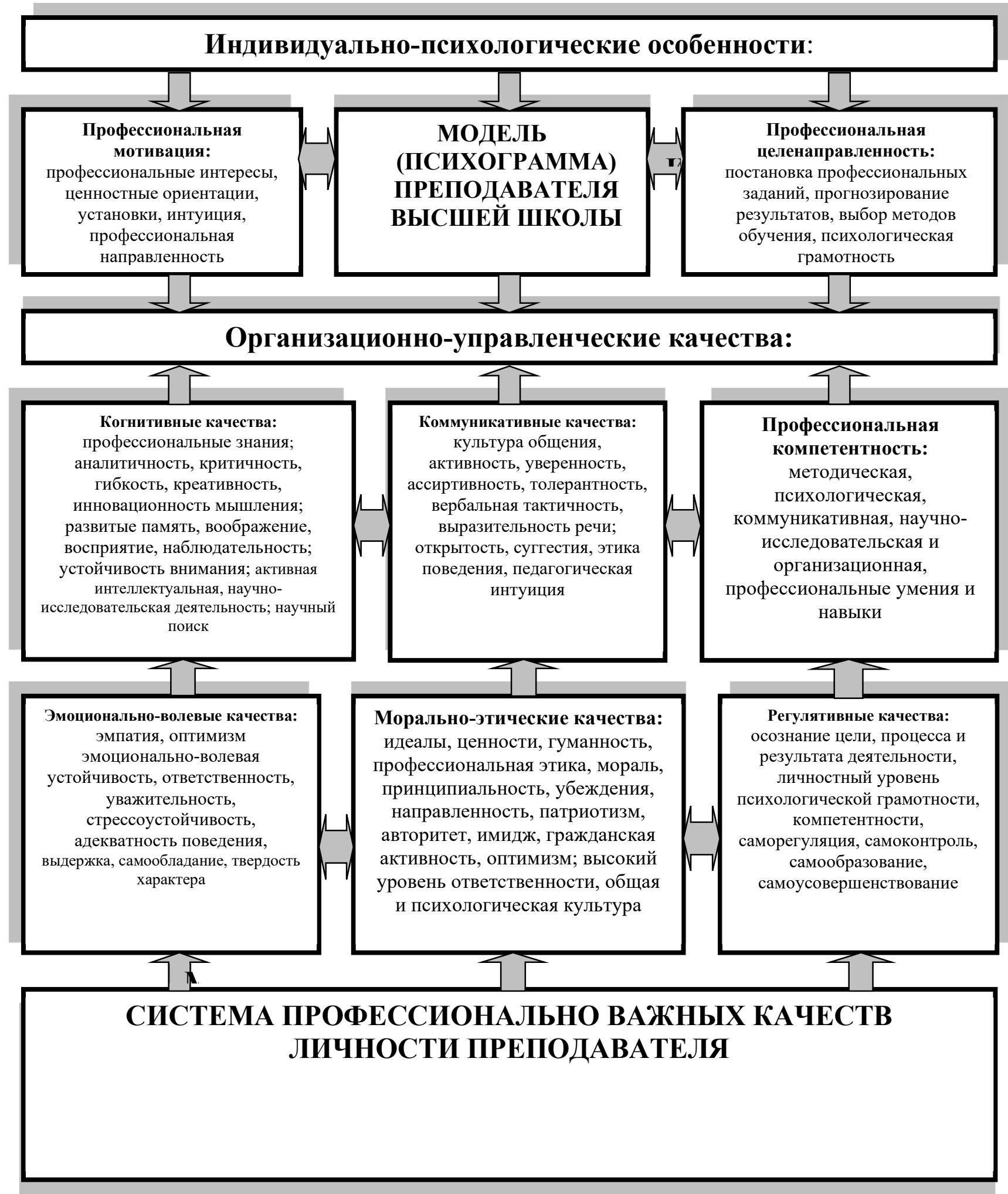

Рис. 6. Функциональная модель (психограмма) профессиональной деятельности преподавателя высшей школы 


\section{THEORETICAL FOUNDATIONS OF THE FUNCTIONING OF EDUCATION. WAYS TO IMPROVE THE EFFECTIVENESS OF EDUCATIONAL ACTIVITIES}

Можно предположить, что эффективность инновационной деятельности преподавателей повысится за счет учета разнообразия психологопедагогических инноваций; теоретико-методологических представлений о природе и сущности инновационных процессов, включающих разные по содержанию этапы: инновационный психолого-педагогический поиск, психолого-педагогическая экспертиза, аттестация, усвоение обновленной образовательной практики на основе использования инноваций.

Оценка эффективности управления инновационной деятельностью профессорско-преподавательского состава вуза приведена в табл. 3.

Таблица 3. Характеристика функций управления инновационной деятельностью профессорско-преподавательского состава ВУЗа

\begin{tabular}{|c|c|}
\hline $\begin{array}{r}\text { Функции } \\
\text { управленческой } \\
\text { деятельности }\end{array}$ & $\begin{array}{l}\text { Характеристика показателей эффективности управления } \\
\text { инновационной деятельность в образовании }\end{array}$ \\
\hline $\begin{array}{l}\text { Мотивацио } \\
\text { нно-целевая }\end{array}$ & $\begin{array}{l}\text { 1. Целевая направленность функцинирования образовательной системы и } \\
\text { управленческой деятельности: ориентированные на развитие личности обучаемого и } \\
\text { преподавателя; учет их интересов и потребностей; сформулированы стратегические и } \\
\text { тактические задания управления инновационной деятельностью преподавателей; } \\
\text { конкретные цели, обеспечивающие функционирование образовательной системы в } \\
\text { режиме развития. } \\
2 \text { Осуществляется ориентация на весь спектр профессиональных } \\
\text { потребностей вузов и работающих в них преподавателей (вовлечение в творческую } \\
\text { деятельность, повышение квалификации, повышение социально-профессионального } \\
\text { статуса через категориальную аттестацию, обмен опытом, изучение отечественного и } \\
\text { зарубежного опыта). } \\
\text { 3. Проведение стимулирующих форм контроля (творческие отчеты, } \\
\text { аттестация вузов). Выпуск психолого-педагогических бюллетеней, знакомящих } \\
\text { преподавателей с результатами стимулирования инновационной деятельности. } \\
4 . \text { Постоянное поощрение преподавателей, достигших высокого уровня } \\
\text { результатов в инновационном образовательном процессе. }\end{array}$ \\
\hline $\begin{array}{r}\text { Функции } \\
\text { управленческой } \\
\text { деятельности } \\
\end{array}$ & $\begin{array}{l}\text { Характеристика показателей эффективности управления } \\
\text { инновационной деятельностью в образовании }\end{array}$ \\
\hline $\begin{array}{r}\text { Планово- } \\
\text { прогностическая }\end{array}$ & $\begin{array}{l}\text { 1. Планирование деятельности преподавателей вуза на основе } \\
\text { разработанной концепции инновационного развития образования. } \\
2 . \text { Концепция инновационного развития образования ориентирована на } \\
\text { практику и содержит реальные ближние, средние и дальнейшие прогнозы } \\
\text { деятельности преподавателей и их развития. } \\
3 . \text { Прогнозирование инновационной деятельности преподавателей } \\
\text { осуществлется путем проектирования на основе программно-целевого подхода и } \\
\text { анализа состояния образовательного процесса вуза. }\end{array}$ \\
\hline
\end{tabular}




\begin{tabular}{|c|c|}
\hline $\begin{array}{l}\text { Информаци } \\
\text { онно- } \\
\text { аналитическая }\end{array}$ & $\begin{array}{l}1 . \text { Осуществлется оперативный сбор информации и используются } \\
\text { методы, адекватные целям и заданиям развития образования. Создается банк данных } \\
\text { по всем направлениям развития образования. } \\
2 . \quad \text { Содержание информации должно объективно отражать состояние } \\
\text { образования, результаты образовательного процесса; выделение показателей и } \\
\text { психолого-педагогических условий, позволяющих оценить инновационную } \\
\text { деятельность преподавателей вуза } \\
3 . \\
\text { Цели анализа ориентированы на выявление динамики психолого- } \\
\text { педагогических инновационных процессов, анализ которых носит системный характер } \\
\text { и позволяет обнаружить основные причинно-наследственные с вязи. } \\
4 . \quad \text { Информационные потоки обеспечивают принятие правильного } \\
\text { управленческого решения. }\end{array}$ \\
\hline $\begin{array}{r}\text { Opı } \\
\text { ионн } \\
\text { исполните }\end{array}$ & $\begin{array}{l}\text { 1. Организационные структуры вуза должна быть гибкими и } \\
\text { адаптированными к изменяющимся в образовании психолого-педагогическим } \\
\text { условиям. } \\
\text { 2. В организации деятельности функциональных и проектных структур } \\
\text { используется координация целей и содержания инновационной деятельности } \\
\text { профессорско-преподавательского состава. } \\
\text { 3. Формирование организационных отношений в управлении как по } \\
\text { вертикали, так и по горизонтали. } \\
\text { 4. Выполнение нормативных требований высших организаций всеми } \\
\text { структурами вуза. }\end{array}$ \\
\hline $\begin{array}{r}\text { Контрольн } \\
\text { о-диагностическая }\end{array}$ & $\begin{array}{lll}\text { 1.Создание системы } & \text { диагностического сопровождения } & \text { образовательных } \\
\text { программ на основе научно обоснованных параметров. } & \\
2 . \quad \text { Систематический } & \text { контроль } \quad \text { за инновационной } & \text { деятельностью } \\
\text { преподавателей вуза и его адекватность целям управления. } & \\
\text { 3. Оперативность и гибкость контроля. Стимулирующий характер контроля. }\end{array}$ \\
\hline $\begin{array}{r}\text { Коррекцио } \\
\text { нно-регулятивная }\end{array}$ & $\begin{array}{lll}\text { 1. Определение иерархично } & \text { взаимосвязанных зон коррекции социально- } \\
\text { психологических особенностей } & \text { функционирования } & \text { органов } \\
\text { инновационными процессами и инновационной деятельностью преподавателей вуза. }\end{array}$ \\
\hline
\end{tabular}

Реализация таких подходов, на наш взгляд, будет способствовать оптимизации функционирования инновационных процессов в системе образования и всех ее составных элементов, а также созданию социальнопсихологических условий, благоприятных для повышения профессионализма педагогов высшей школы и развитию их профессионального сознания.

Такой подход не является застывшей, замкнутой системой. Её организация, формирование и апробирование, безусловно, обусловят возникновение новых проблем, требующих ее коррекции, усовершенствования, отказа от одних ее элементов и введения новых. Эта система открыта и предполагает динамичное развитие образования. Таким образом, развитие системы образования вызывает потребность и в развитии управления инновационной деятельностью профессорско-преподавательского состава вуза, предполагая как обогащение традиционных функций управления новыми проектами, так и создание социально-психологических условий, 
THEORETICAL FOUNDATIONS OF THE FUNCTIONING OF EDUCATION. WAYS TO

IMPROVE THE EFFECTIVENESS OF EDUCATIONAL ACTIVITIES

способствующих развитию профессионализма преподавателей высшей школы в инновационной деятельности.

\section{Выводы.}

Динамичность развития общества диктует необходимость опережающего развития образования и системы управления им, обуславливая своевременность разработки прогностических моделей управления инновационными процессами в образовании.

Проведенные исследования показывают, что профессиональная деятельность преподавателя высшей школы требует ряда таких личностных, профессиональных, социальных, индивидуально-психологических качеств, как: профессиональная мотивация, профессиональные интересы, ценностные ориентации установки, профессиональная направленность; профессиональная целенаправленность, профессиональная компетентность (методическая, психологическая, коммуникативная, акмеологическая, рефлексивноисследовательская и организационная, профессиональные умения и навыки); морально-этические качества (мировоззрение, идеалы ценности, гуманность, профессиональная этика, мораль, принципиальность, убеждения, нацеленность, уровень стремлений, авторитет, имидж, гражданская активность, оптимизм; высокий уровень ответственности общей и психологической культуры); организационно-конструктивные качества (лидерство, конструктивность деятельности; планирование, моделирование учебного процесса и инновационных технологий; владение педагогической техникой).

В практике современной педагогической деятельности широко используются новые технологии взаимодействия в системе индивидуальность личность - социум (общество). Только конкретная деятельность преподавателей, их творчество, основанное на принципах креативности, способна влиять на их инновационную деятельность. 
THEORETICAL FOUNDATIONS OF THE FUNCTIONING OF EDUCATION. WAYS TO IMPROVE THE EFFECTIVENESS OF EDUCATIONAL ACTIVITIES

DOI 10.46299/ISG.2021.MONO.PED.II-188-208

\section{2 Розвиток емоційного інтелекту студентів у навчальному процесі}

На сучасному етапі розвитку України зростають вимоги до системи освіти, якості підготовки професіоналів і рівня сформованості їх професійно-значимих характеристик, які значною мірою закладаються на етапі професійної підготовки в віщій школі. Досліджувана нами проблема обумовлена, необхідністю пошуку прогресивної концепції навчання студентів - майбутніх фахівців. Вивчення феномену емоційного інтелекту затребуване практикою професійної підготовки, що потребує конкретних даних про емоційно-інтелектуальний розвиток студентів у навчальному процесі, а також про взаємообумовлені якісні зміни в їх особистості. У зв'язку з цим виявлення умов і чинників, що детермінують розвиток емоційного інтелекту майбутнього фахівця, дозволить управляти цим процесом, проектувати і доцільно впливати на цей розвиток.

У кінці 90-х років все частіше висловлюється думка, що для успішної реалізації особистості в суспільстві найважливіше мати розвинені здібності ефективної взаємодії з навколишніми людьми, уміння особистості орієнтуватися в соціальних ситуаціях, правильно визначати особові особливості і емоційні стани інших людей, вибирати адекватні способи спілкування 3 ними i реалізовувати усе це в процесі взаємодії. Це потребує поглиблення розробок в області соціального інтелекту i його провідного компонента - емоційного інтелекту (Орме Г., 2003).

Проблема емоційного інтелекту викликала великий інтерес у дослідників 3 моменту публікації книги Деніела Гоулмана "Емоційний інтелект". 3'явилися дослідження, в яких наводяться порівняльні характеристики академічного, практичного, соціального і емоційного інтелекту, а також їх структурні складові. Д. Гоулман під емоційним інтелектом розуміє "такі здібності особистості, як самомотивація і стійкість до розчарувань, контроль над емоційними спалахами і уміння відмовитися від задоволень, регулювання настрою і уміння не давати переживанням заглушати здатність думати, співпереживати i сподіватися" (Гоулман Д., 2009). 
THEORETICAL FOUNDATIONS OF THE FUNCTIONING OF EDUCATION. WAYS TO IMPROVE THE EFFECTIVENESS OF EDUCATIONAL ACTIVITIES

У ряді сучасних теорій, емоція розглядається як особливий тип знання. Відповідно до цього підходу до розуміння емоцій висувається поняття "Емоційний інтелект", який визначається, як здатність діяти 3 внутрішнім середовищем своїх почуттів і бажань (Андрєєва I.Н., 2006); здатність розуміти стосунки особистості, що репрезентуються в емоціях, і управляти емоційною сферою на основі інтелектуального аналізу і синтезу (Юркевич В.С., 2005); сукупність емоційних і соціальних здібностей особистості, які роблять вплив на загальну здатність справлятися з вимогами і тиском соціуму (Bar-On R., 2000).

Г.Г. Гарскова звертає увагу, що емоційний інтелект це "здатність розуміти стосунки особистості, що репрезентуються в емоціях, і управляти емоційною сферою на основі інтелектуального аналізу і синтезу" (Гарскова Г.Г., 2013). «Емоційний інтелект - це сукупність ментальних здібностей до розуміння власних емоцій і емоцій інших людей і до управління емоційною сферою» визначає I.Н. Андрєєва (Андрєєва I.Н., 2004).

На думку М.А. Манойлової емоційний інтелект - це "здатність людини до усвідомлення, прийняття і регуляції емоційних станів і почуттів інших людей і себе самого" (Манойлова М. А., 2004).

Дослідник Гоулман Д, відмічає, що високий рівень розвитку емоційного інтелекту сприяє успішності в різних сферах життя людей - таких, як освіта, психологія, юриспруденція, медицина; а низький - пов'язаний $з$ соціальною дезадаптацією: афективними розладами (передусім депресією і тривогою), а також різними формами поведінки особистості (Гоулман Д., 2011).

I.Н. Андрєєва відмічає кореляцію емоційного інтелекту 3 певними життєвими успіхами і розглядає передумови розвитку емоційного інтелекту, гендерні відмінності у вираженості компонентів емоційного інтелекту, а також можливості розвитку емоційного інтелекту в процесі психологічного тренінгу (Андрєєва I.H., 2007).

М.А. Манойлова вивчала розвиток емоційного інтелекту педагогів і довела можливість розвитку емоційного інтелекту шляхом спеціально організованого навчання. Вона провела аналіз різних підходів до формування емоційного 
THEORETICAL FOUNDATIONS OF THE FUNCTIONING OF EDUCATION. WAYS TO

IMPROVE THE EFFECTIVENESS OF EDUCATIONAL ACTIVITIES

інтелекту і здібностей, що входять до його складу і встановила ефективність використання тренінгу в розвитку емоційного інтелекту. На ії думку потрібна розробка наукової основи для проведення дослідження умов і методів розвитку емоційного інтелекту (Манойлова М. А., 2004).

Як стверджує В.С. Юркевич посилаючись на власні дослідження і роботи інших авторів, у 95\% інтелектуально обдарованих дітей відзначається недостатність емоційного інтелекту. Вона особливо підкреслює, що у цих дітей спостерігаються яскраво виражена інфантильність в емоційному відношенні, понижений інтерес до діяльності, не пов'язаної з отриманням знань, труднощі спілкування з однолітками (Юркевич В.С., 2005).

Незважаючи на існуючі дослідження проблема розвитку емоційного інтелекту вимагає подальшого вивчення, у зв'язку 3 наявністю спірних i невирішених питань: немає єдиного розуміння поняття і концепції емоційного інтелекту, його природи, психологічної суті, закономірностей і умов розвитку, що вимагає глибшого і різнобічного його вивчення. Отже, потрібний системний аналіз наукового знання про емоційний інтелект, що включає узагальнення теоретико-методологічних підходів до його дослідження, розробку структурнофункціональної моделі; виявлення рівнів і критеріїв його сформованості і визначення найбільш суттєвих умов, що впливають на його розвиток, необхідних для успішної інтеграції особистості в соціальне оточення.

Соціально-економічні і політичні умови розвитку суспільства, актуалізують проблему розвитку особово-професійних якостей студентів, у тому числі, їх емоційного інтелекту (Корнілова Т.В., Кондратчик А.Л., 1993)

Андрєєва I.Н., звернула увагу на те, що "Інтелект - це здатність вирішувати проблеми незапрограмованим (творчим) чином". Вона відмічає, що "це здатність особистості діяти доцільно, думати раціонально і діяти ефективно відносно оточення" (Андрєєва I.Н., 2007).

Дослідник Люсін Д.В., розглядає інтелект як запоруку успіху людини і враховує, що саме здатність особистості адаптуватися до свого оточення найбільш важлива особливість їі інтелекту, оскільки ніякий інтелектуальний 
THEORETICAL FOUNDATIONS OF THE FUNCTIONING OF EDUCATION. WAYS TO

IMPROVE THE EFFECTIVENESS OF EDUCATIONAL ACTIVITIES

механізм принципово не може бути реалізований без системи особової оцінки значущості сприйманого і результатів власної поведінки. Він відмічає, що усвідомлення цілей і бажань людини, бачення реальної дійсності і адекватне реагування на неї і системне мислення - усе це грані інтелекту, розумових здібностей особистості, не пов'язаних з логічним мисленням (Люсін Д.В., 2004).

Відкриття того, що інтелект - це не лише знання, отримані в результаті освіти, належить гарвардському дослідникові Говарду Гарднеру, який виявив різносторонність інтелекту і описав його. Згідно теорії Г. Гарднера інтелект розуміється як множинний конструкт і існує декілька різних інтелектів: лінгвістичний, що проявляється при читанні, слуханні, усній і письмовій мові; логіко-математичний, використовуваний при логічному мисленні і рішенні математичних завдань; просторовий використовуваний при контакті з фізичним оточенням; музичний, використовуваний при співі і сприйнятті музики; тілеснокінестетичний, реалізовується в спорті і в танцях; міжособистісний, такий, що проявляється при взаємодії з іншими людьми і внутрішньоособистісний, пов'язаний з високим рівнем розвитку знань про себе і саморозуміння. Останні два види інтелекту і складають емоційний інтелект, який не менш важливий в житті чим логіко-математичний (Гарднер Г., 2007).

I.Н. Андрєєва, в своїх дослідженнях стверджує, що емоційний інтелект (EQ) - це здатність усвідомлювати емоції, досягати і генерувати їх так, щоб сприяти мисленню, розумінню емоцій і того, що вони означають $\mathrm{i}$, відповідно управляти ними так, щоб сприяти своєму емоційному і інтелектуальному зростанню (Андрєєва І.Н., 2004). На відміну від звичного усім розуміння інтелекту (IQ), емоційний інтелект є здатністю правильно тлумачити обстановку і робити на неї вплив, інтуїтивно уловлювати те, чого хочуть і чого потребують інші люди, знати їх сильні і слабкі сторони, не піддаватися стресу і бути привабливим (Андрєєва І.Н., 2006).

Одно з визначень емоційного інтелекту, сформульоване Дж. Мейєром, Д. Карузо і П. Селовеем, звучить як «Здатність глибокого досягнення, оцінки і вираження емоцій; здатність розуміння емоцій і емоційних знань; а також 
THEORETICAL FOUNDATIONS OF THE FUNCTIONING OF EDUCATION. WAYS TO IMPROVE THE EFFECTIVENESS OF EDUCATIONAL ACTIVITIES

здатність управління емоціями, яка сприяє емоційному i інтелектуальному зростанню особистості». На їх думку "Людське мислення не обмежується розсудливою калькуляцією. Хоча взаємозв'язки емоцій i iнтелекту дуже різноманітні, лише деякі з них роблять нас по-справжньому розумніше. I цю досить обмежену сферу взаємного перетину i впливу можна визначити як емоційний інтелект" (Mayer J.D., Caruso D., Salovey P., 1999).

Огляд англо-американських джерел показав, що в обговоренні проблем підготовки студентів, майбутніх фахівців, все частіше звучить поняття емоційного інтелекту (EQ). Становлення студента, майбутнього професіонала розглядається сьогодні на основі розвитку ряду його психологічних якостей, серед яких емоційний інтелект розвиває емоційну компетентність і повагу до інших, в той же час, студенти як суб'єкти професійної діяльності не завжди розрізняють раціональні і емоційні компоненти в оцінюванні ситуацій i 3 розвитком їх професіоналізму зв'язується роль емоційного інтелекту у вдосконаленні навичок професійного спілкування (Montgomery J. E., 2008).

Дослідники Р. Стернберг, Б.Форсайт і Дж.Хедланд, підкреслювали роль емоційного інтелекту в процесі саморозвитку, як процесу інтеграції потреб індивіда $з$ вимогами суспільства. На їх думку проблема становлення особистості є ключовою в гуманістичній психології. Соціалізація розуміється як процес, за допомогою якого індивід придбає знання, цінності, соціальні навички і соціальну чутливість, які дозволяють йому інтегруватися в суспільство і поводитися там адаптивне, але для того, щоб інтегруватися в таке складне суспільство як нинішнє, кожному індивідові потрібний саме емоційний інтелект (Стернберг Р., Форсайт Б., Хедланд Дж., 2002).

Теорія, яку пропонують Дж. Мейєр, Д. Карузо і П. Селовей, зв'язує емоційний інтелект з особовими чинниками, такими як теплота і чуйність. Вони визначають поняття емоційного інтелекту як здатність усвідомлювати сенс емоцій і використовувати ці знання, щоб з'ясовувати причини виникнення проблем і вирішувати ці проблеми. На їх думку, емоційний інтелект обумовлює 
THEORETICAL FOUNDATIONS OF THE FUNCTIONING OF EDUCATION. WAYS TO

IMPROVE THE EFFECTIVENESS OF EDUCATIONAL ACTIVITIES

наявність різних здібностей, які задіяні в адаптивній обробці емоційної інформації. Автори зв'язують емоційний інтелект з наступними здібностями:

- уміння точно оцінювати вираження емоцій, як самого індивіда, так і людей, що оточують його;

- когнітивна асиміляція емоційного досвіду;

- розпізнавання, розуміння і осмислення емоцій;

- адаптивна регуляція емоцій індивіда і навколишніх людей. Ці автори запропонували декілька механізмів, що означають емоційний інтелект, що припускає його зв'язок з розумовими здібностями:

- емоції пов'язані з процесом мислення;

- певні емоції можуть збільшувати продуктивність процесу мислення i направляти увагу на рішення конкретних завдань;

- ефективне регулювання емоцій може співвідноситися i 3 такими здібностями, як співпереживання і відвертість;

- дослідження нездатності оцінювати і виражати емоції припускають можливу відсутність взаємозв'язку між областями мозку, які забезпечують єдність мислення і емоцій (Mayer J.D., Caruso D., Salovey P., 1999).

За визначенням П. Селовея М. Брекета і Дж. Мейєра, емоційний інтелект особистості це група ментальних здібностей, які сприяють усвідомленню i розумінню власних емоцій і емоцій оточення. Вони виділяють чотири головних складових емоційного інтелекту - самосвідомість, самоконтроль, емпатія, навички стосунків (Salovey P., Brackett M., Mayer J.D., 2004).

У сучасній психології виділяється декілька провідних теорій вивчення емоційного інтелекту: теорія емоційно-інтелектуальних здібностей (Mayer J.D., Caruso D., Salovey P., 1999); теорія емоційної компетентності (Гоулмен Д., 2009); некогнітивна теорія емоційного інтелекту (Bar-On R., 2000); двокомпонентна теорія емоційного інтелекту (Люсін Д.В., 2004). Змістовною характеристикою емоційного інтелекту, яка об'єднує перераховані теорії, є сукупність здібностей до розуміння і управління власними емоціями, розуміння і управління емоціями інших людей. Аналіз теоретичних переконань вищезгаданих авторів дозволяє 
THEORETICAL FOUNDATIONS OF THE FUNCTIONING OF EDUCATION. WAYS TO IMPROVE THE EFFECTIVENESS OF EDUCATIONAL ACTIVITIES

визначити емоційний інтелект як сукупність емоційно-когнітивних здібностей до соціально-психологічної адаптації особистості. Усі структурні компоненти емоційного інтелекту взаємозв'язані, i їх тісна взаємозалежність сприяє ефективній міжособистісній взаємодії.

Різноманітність моделей емоційного інтелекту, викликала необхідність в їх класифікації. Найбільшою мірою заслуговують на увагу дві спроби такого роду. Дж. Мейєр, Д. Карузо і П. Селовей, запропонували розрізняти моделі здібностей і змішані моделі. До першого типу відносяться моделі, що трактують емоційний інтелект як когнітивну здатність, а до другого типу - моделі, що трактують емоційний інтелект як поєднання когнітивних здібностей i особистісних характеристик (Mayer J.D., Caruso D., Salovey P., 1999).

Дослідники Р. Дж. Стернберг, Дж. Б. Форсайт, провели дещо інше розрізнення, яке вони вважають ширшим: емоційний інтелект як здатність i емоційний інтелект як риса. Вони стверджують, що характер моделі визначається не стільки теорією, скільки використовуваними методами виміру конструкта. Емоційний інтелект як риса пов'язаний 3 оцінкою стійкості поведінки в різних ситуаціях, тому для його виміру можуть застосовуватися опитувальники. Емоційний інтелект як здатність відноситься до традиційної психології інтелекту, тому для його виміру найбільш адекватні завдання, подібні до завдань інтелектуальних тестів (Стернберг Р., Форсайт Б., 2002).

Нині найбільш описані наступні моделі емоційного інтелекту: - модель здібностей емоційного інтелекту; - змішана модель; - модель характерних рис емоційного інтелекту.

Модель здібностей. Концепція емоційного інтелекту П. Селовея, М. Брекета і Дж. Мейєра, намагається визначити емоційний інтелект у межах стандартних критеріїв інтелекту. Первинне визначення ними було переглянуто як: "Здатність розрізняти емоції, інтегрувати емоції для сприяння мисленню, розуміти емоції i регулювати емоції для стимулювання особистісного зростання". На їх думку модель здібностей дозволяє бачити в емоціях корисне джерело інформації, яке допомагає індивідові осмислити і зорієнтуватися в 
THEORETICAL FOUNDATIONS OF THE FUNCTIONING OF EDUCATION. WAYS TO

IMPROVE THE EFFECTIVENESS OF EDUCATIONAL ACTIVITIES

соціальному середовищі. Модель припускає, що індивіди розрізняються у своїх здібностях обробляти інформацію емоційної природи, і у своїх здібностях додатка емоційних процесів до пізнання світу. Ці здібності проявляються в конкретних актах поведінки. Згідно цієї моделі, емоційний інтелект включає чотири типи здібностей:

1. Розрізнення емоцій - здатність виявити і розшифрувати емоції по особах, картинках, голосах і культурних артефактах, включаючи здатність розпізнати власні емоції. Розрізнення емоцій є базовим аспектом емоційного інтелекту, оскільки робить можливою подальшу обробку емоційної інформації.

2. Використання емоцій - здатність сполучення емоцій з різними видами пізнавальної діяльності, такими як роздум і рішення проблем. Емоційно інтелектуальна людина може отримати максимальну вигоду від зміни власного настрою для отримання найкращого поєднання з виконуваними завданнями.

3. Розуміння емоцій - здатність осмислити емоційну мову і розібратися в складних взаємовідносинах між емоціями. Наприклад, розуміння емоцій включає здатність бути чутливим до щонайтонших змін між емоціями, і здатність розпізнати і описати, як емоції змінювалися в часі.

4. Управління емоціями - здатність регулювати власні емоції і інших людей. Емоційно інтелектуальна людина, може опанувати емоції і направити їх на досягнення намічених цілей (Salovey P., Brackett M., Mayer J.D., 2004).

Модель емоційних компетенцій, представлена Дениелом Гоулманом, фокусується на емоційному інтелекті як на широкому списку компетенцій і навичок, які ведуть до розвитку лідерського потенціалу і містить чотири головних конструкта емоційного інтелекту:

1. Самоусвідомлення - здатність прочитати власні емоції і визначити їх вплив на ухвалення рішень.

2. Управління собою - включає контроль над власними емоціями i імпульсами і пристосування до обставин, що змінюються.

3. Соціальна обізнаність - здатність сприймати, розуміти і реагувати на емоції інших людей, знаходячись в соціальному оточенні. 
THEORETICAL FOUNDATIONS OF THE FUNCTIONING OF EDUCATION. WAYS TO

IMPROVE THE EFFECTIVENESS OF EDUCATIONAL ACTIVITIES

4. Управління стосунками - здатність надихати, впливати i розвивати інших, управляючи конфліктами (Гоулман Д., 2011).

Дослідник включає деякий набір емоційних компетенцій до складу кожного 3 конструктів емоційного інтелекту. Він відмічає, що емоційні компетенції - це не природжені якості, а швидше придбані здібності, над якими треба працювати і які можуть бути розвинені для отримання видатних здібностей (Гоулман Д., 2011).

Рувен Бар-Он пропонує визначати емоційний інтелект як усі некогнітивні здібності, що дають людині можливість успішно справлятися 3 різними життєвими ситуаціями. Він виділяє п'ять сфер, в кожній з яких відмічає найбільш специфічні навички, що ведуть до досягнення успіху:

1. Пізнання власної особистості (обізнаність про власні емоції, упевненість в собі, самоповага, самореалізація, незалежність);

2. Навички міжособистісного спілкування (міжособистісні взаємовідносини, соціальна відповідальність, співпереживання);

3. Здатність до адаптації (рішення проблем, оцінка реальності, пристосовність);

4. Управління стресовими ситуаціями (стійкість до стресу, імпульсивність, контроль);

5. Переважаючий настрій (щастя, оптимізм) (Bar-On R., 2000).

Дослідник Рувен Бар-Он розробив опитувальник для виміру емоційного інтелекту, EQ, який складається з 133 тверджень і з 15 шкал, що відповідають вищепереліченим субкомпонентам. Він вважає, що емоційний інтелект людини розвивається з часом i може бути поліпшений за допомогою тренінгів, програмування і терапії. Його теорія висуває гіпотезу про те, що люди з рівнем EQ вище за середній, зазвичай успішніше справляються з тиском довкілля, а недолік емоційного інтелекту може означати складнощі в досягненні успіху в життя і виникненні емоційних проблем. Проблеми в невмінні справлятися 3 власним оточенням, на думку Бар-Он, найбільш поширені серед тих людей, яким бракує навичок оцінки реальності, рішення проблем, стресостійкості і контролю 
THEORETICAL FOUNDATIONS OF THE FUNCTIONING OF EDUCATION. WAYS TO

IMPROVE THE EFFECTIVENESS OF EDUCATIONAL ACTIVITIES

над власними імпульсами. Він вважає, що емоційний інтелект і когнітивний інтелект роблять рівний вклад в загальний інтелект особистості, який $\epsilon$ індикатором успішності людини в житті (Bar-On R., 2000)

Дослідник Д.В. Люсін пропонує розглядати емоційний інтелект як здібності до розуміння своїх і чужих емоцій і управлінню ними. При цьому він підкреслює, що здатність до розуміння і здатність до управління емоціями можуть бути спрямовані і на власні емоції, і на емоції інших людей. Таким чином, автор пропонує розглядати два варіанти емоційного інтелекту "внутрішньоособистісний" i "міжособистісний". Обидва варіанти, за його твердженням, припускають актуалізацію різних когнітивних процесів і навичок особистості Модель емоційного інтелекту, запропонована Д.В. Люсіним, включає три елементи: когнітивні здібності - швидкість і точність переробки емоційної інформації; уявлення про емоції, як про цінності, як про важливе джерело інформації про себе самого і про інших людей; особливості емоційності - емоційна стійкість, емоційна чутливість (Люсін Д.В., 2004).

Юркевич В.С., запропонував концептуальну відмінність між моделлю здібностей і моделлю характерних рис емоційного інтелекту. Він відмічає, що характерні риси емоційного інтелекту це констеляція уявлень про власну емоційну сферу, розташована в глибинних шарах психіки, для яких характерні риси емоційного інтелекту які мають відношення до того, що саме людина думає про власні емоційні здібності. Це визначення дослідником емоційного інтелекту включає поведінкові диспозиції і уявлення про власні здібності, оцінювані через самозвіт. Він відмічає, що характерні риси емоційного інтелекту повинні досліджуватися у рамках структури особистості і альтернативною назвою того ж конструкта може бути здатність до самореалізації як емоційна характерна риса особистості. На його думку модель характерних рис емоційного інтелекту об'єднує моделі Гоулмана і Бар-Он і перекладає розгляд поняття емоційного інтелекту на більш високий рівень. Він відмічає, що розгляд $\mathrm{EQ}$ як особистісних рис веде до формування конструкта, що лежить за межами таксономії людських когнітивних здібностей і є дуже важливою особливістю, оскільки вона полегшує 
THEORETICAL FOUNDATIONS OF THE FUNCTIONING OF EDUCATION. WAYS TO

IMPROVE THE EFFECTIVENESS OF EDUCATIONAL ACTIVITIES

практичне застосування, як самого конструкта, так і сформульованих теорій (Юркевич В.С., 2005).

Аналізуючи підходи до підготовки студентів вищої школи, майбутніх фахівців слід відмітити:

- високі темпи розвитку вищої освіти і повільне оновлення змісту підготовки майбутніх фахівців;

- недостатню розробленість науково-педагогічних основ формування емоційного інтелекту і необхідність його формування у студентів в процесі професійної підготовки;

- необхідність розвитку емоційного інтелекту у студентів як особовопрофесійної якості;

- потрібність суспільства в кваліфікованих фахівцях здатних розвивати у студентів емоційний інтелект у навчальному процесі.

Розвиток емоційного інтелекту у студентів вищої школи найуспішніше можна здійснювати в тренінгових групах. Якщо IQ мало міняється в зрілому віці, то EQ, в основі якого лежить досвід управління собою і оточенням, може i повинен зростати. На думку авторів (Бар-Он Р., Гоулман Д., Майєр Д.), найбільш оптимальним засобом розвитку емоційного інтелекту $є$ участь студентів в тренінгових заняттях. Бар-Он пропонує проводити тренінгові зайняття на протязі тривалого часу. Він вважає, що це дасть можливість не просто розвинути необхідні компоненти емоційного інтелекту, але і закріпити отримані зміни в поведінці людини (Bar-On R., 2000). Гарднер Г., стверджує, що будь-яка людина здатна вчитися і розвивати рівень свого емоційного інтелекту за допомогою постійної практики (Гарднер Г., 2007). У зв'язку з цими дослідженнями Вачков I.В., виділив наступні переваги психокорекційної роботи в групах:

- груповий досвід протидіє відчуженню, допомагає рішенню міжособистісних проблем;

- група відбиває суспільство в мініатюрі, робить очевидними такі приховані чинники, як тиск партнерів, соціальний вплив і конформізм; 
THEORETICAL FOUNDATIONS OF THE FUNCTIONING OF EDUCATION. WAYS TO

IMPROVE THE EFFECTIVENESS OF EDUCATIONAL ACTIVITIES

- можливість отримання зворотного зв'язку i підтримки від людей 3 схожими проблемами;

- в групі людина може навчатися новим умінням, експериментувати 3 різними стилями стосунків серед рівних партнерів;

- і усе це в атмосфері доброзичливості, прийняття і підтримки;

- в групі учасники можуть ідентифікувати себе з іншими, "зіграти" роль іншої людини для кращого розуміння його і себе i для знайомства 3 новими ефективними способами поведінки;

- взаємодія в групі створює напругу, яка допомагає прояснити психологічні проблеми кожного;

- група полегшує процеси саморозкриття, самодослідження і самопізнання (Вачков I.B., 2001).

Розвиток емоційного інтелекту, як складної інтеграційної освіти, що забезпечує усвідомлення, розуміння i регуляцію власних емоцій i емоцій оточення, буде ефективним при реалізації моделі розвитку емоційного інтелекту, що враховує структуру емоційного інтелекту і включає: цільовий блок; форми організації учбового процесу; методи розвитку емоційного інтелекту; етапи розвитку емоційного інтелекту; прогнозований результат і програму розвитку емоційного інтелекту, важливою частиною якої $\epsilon$ групове зайняття 3 використанням активних методів соціально-психологічного навчання (АСПН) (Слепкова B.I., 1997).

Активне соціально-психологічне навчання (АСПН) студентів є психологопедагогічною формою розвитку емоційного інтелекту і вдосконалення умінь i навичок взаємодії в суспільстві, здійснюваної в умовах групової навчальнотренувальної діяльності. На взаємодію студентів в навчальній групі впливає модель їх відносин в соціумі. АСПН нами застосовувалось для формування у студентів специфічних емоційних, комунікативних, когнітивних та поведінкових умінь, 3 метою підвищення емоційного інтелекту, комунікативної та психологічної компетентності. Активне навчання спрямоване на самостійне 
оволодіння студентом знаннями та вміннями використовувати досвід розвитку емоційного інтелекту.

В нашому дослідженні ми навчали студентів, професійно вірно та ситуативно обумовлено вступати в спілкування, прогнозувати емоційні реакції партнерів зі спілкування на власні дії, психологічно настроюватися на емоційний тон співрозмовників, емоційне настроюватися на ситуацію спілкування, психологічно «пристроюватись» до співрозмовника, адекватно ситуації вибирати жести, пози, ритм своєї поведінки - це лише деякі аспекти, рішення яких дозволить студентам ефективно навчатися і працювати використовуючи навички емоційного інтелекту. Розробляючи проблему розвитку емоційного інтелекту студентів ми вважаємо що іі можна вирішити не тільки просвітою та підвищенням загальної культури, але й спеціальними заняттями розвитку емоційного інтелекту i в першу чергу, професійно спрямованими. Нами розроблена психологічна модель розвитку емоційного інтелекту студентів, яка представлена на мал. 1. 
THEORETICAL FOUNDATIONS OF THE FUNCTIONING OF EDUCATION. WAYS TO IMPROVE THE EFFECTIVENESS OF EDUCATIONAL ACTIVITIES

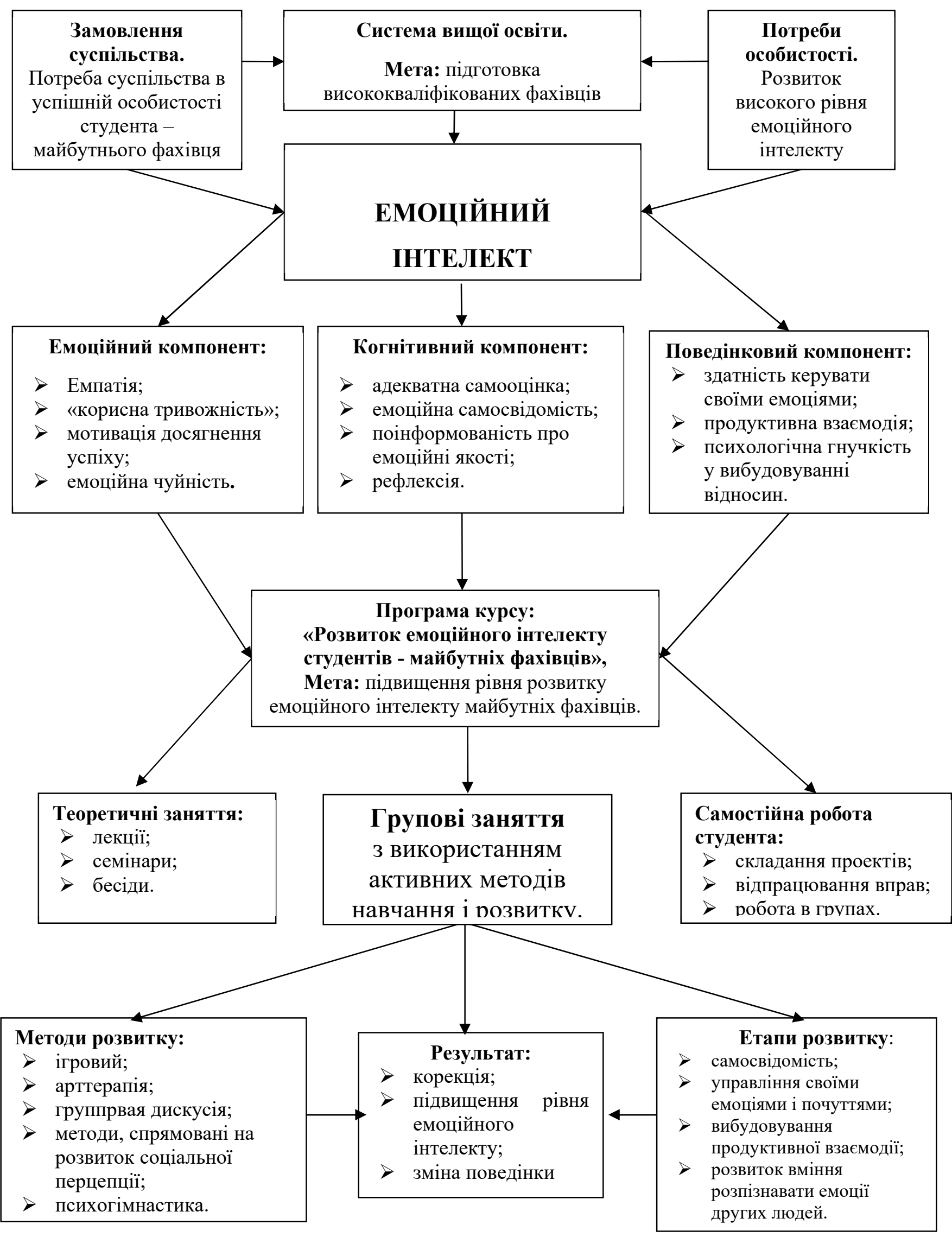

Мал. 1. Психологічна модель розвитку емоційного інтелекту студентів.

Нами застосовано комплекс теоретичних методів і прийомів: теоретикометодологічний аналіз, осмислення, порівняння й узагальнення основних 
THEORETICAL FOUNDATIONS OF THE FUNCTIONING OF EDUCATION. WAYS TO IMPROVE THE EFFECTIVENESS OF EDUCATIONAL ACTIVITIES

положень наукових джерел, що відповідають темі та меті дослідження. При реалізації програми використовувались наступні методи: дискусія, інтерв'ювання, міні-лекції, круглі столи, тематичні дискусії, творча діяльність (проект), ділові ігри, рольові та імітаційні ігри, відеоконференції.

На заняттях ми наділяли увагу важливим елементам навчання навичкам емоційного інтелекту студентів, професійним прийомам взаємодії, та труднощам, які зустрічаються в процесі міжособистісних контактів.

Застосування методів активного соціально-психологічного навчання (АСПН) у ВШ дозволяє учасникам розвинути навички спілкування і взаємодії в малій групі, сформувати ціннісно-орієнтаційну єдність групи; навчити гнучкій зміні соціальних ролей залежно від ситуації, прийняттю моральних норм і правил спільної діяльності, розвинути навички аналізу і самоаналізу в процесі групової рефлексії. Активне соціально-психологічне навчання в системі "Викладач група" сприяє нестандартним стосункам в організації освітнього процесу, формуванню мотиваційної готовності до міжособистісної взаємодії в учбових і професійних ситуаціях (Вачков I.В., 2011).

В дослідженні нами розроблена корекційно-розвиваюча програма "Розвиток емоційного інтелекту студентів - майбутніх фахівців" у групах активного соціально-психологічного навчання, яка мала наступні завдання:

1. Виявлення рівня емоційного інтелекту членів групи;

2. Збагачення учасників групи знаннями про сутність емоційного інтелекту, його характеристики та ефективність міжособистісної взаємодії;

3. Навчання елементам емоційного інтелекту, та розвиток навичок самоконтролю і емпатійних відносин у взаємодій з іншими;

4. Допомога в адекватному самооцінюванні, самоаналізу i саморефлексії;

5. Розвиток емоційної зрілості та чуттєвого сприйняття іншого;

6. Зняття негативних установок до інших;

7. Розвиток загальної комунікативної толерантності, спостережливості та здібностей до емоційного інтелекту. 
THEORETICAL FOUNDATIONS OF THE FUNCTIONING OF EDUCATION. WAYS TO

IMPROVE THE EFFECTIVENESS OF EDUCATIONAL ACTIVITIES

Згідно з завданням роздробленої нами програми, ми досягали мети перспективними і діяльнісними засобами впливу на студентів - майбутніх фахівців, їх емоційні, комунікативні здібності та комунікативну компетентність. В дослідженні ми прагнули до розвитку у студентів навичок самопізнання, самоаналізу, самореалізації, підвищення моральних принципів взаємодії та позитивного ставлення до інших, що дозволило більш ефективно розвивати емоційній інтелект членів групи. Важливу роль в розвитку емоційного інтелекту має участь студентів у тренінгових заняттях, виконанні спеціальних вправ та психологічних ігор. Найбільший інтерес студенти проявили при виконанні таких вправ: «Емоційне слухання», «Усмішка», «Асоціації», «Свій стиль», «Відвертість», «Стійкість», «Емоції і злість», «Приємні спогади», «Скульптура», «Очі. Погляд», «Жести. Поза», «Настрій», «Візуалізація», «Подарунки», «Сімейний альбом». Згідно 3 програмою розвитку емоційного інтелекту студентів для них приводились такі тренінгові заняття: «Розвиток емоційного інтелекту», «Особистісне зростання», «Емоційна стійкість», «Позитивне самовиховання та впевнена поведінка». На тренінгових заняттях використовувались такі психологічні ігри: «Корабельна аварія», «Твоє обличчя», «Пошук скарбів», «Хто я?», «Два королівства», «Перестановка ролей» (Вачков I.В., 2007; Грецов А., Бедарева Т., 2008; Манойлова М.А., 2004; Рамендік Д. М., 2018; Семенова С. М., 2002; Слепкова B.I., 1997).

Застосування активного соціально-психологічного навчання (АСПН) дозволило студентам, учасникам групи розвинути емоційний інтелект, навички спілкування і взаємодії в групі: сформувати ціннісно-орієнтаційну єдність групи; навчитися гнучкій зміні соціальних ролей в залежності від ситуації; прийняттю моральних норм і правил спільної діяльності; розвинути навички аналізу i самоаналізу в процесі групової рефлексії. АСПН в системі «викладач - група» сприяє нестандартному відношенню до організації освітнього процесу, формуванню мотиваційної готовності до міжособистісної взаємодії в навчальних і професійних ситуаціях. 
THEORETICAL FOUNDATIONS OF THE FUNCTIONING OF EDUCATION. WAYS TO

IMPROVE THE EFFECTIVENESS OF EDUCATIONAL ACTIVITIES

Відповідно до корекційно-розвиваючої програми "Розвиток емоційного інтелекту студентів - майбутніх фахівців" в групах активного соціальнопсихологічного навчання (АСПН), підібрано комплекс методів для проведення занять, які відповідають поставленій перед нами меті. Згідно з програмою проводилась групова практична робота. Специфіка даної програми в тому, що вона має спрямованість на зміну поведінки, на розвиток емоційного інтелекту, емоційно-вольових, когнітивних якостей особистості. В основі продуктивного, якісного проходження програми лежить співпраця, цілеспрямованість діяльності і щирість у вираженні своїх думок, а також, активність студента і його творче, дослідницьке ставлення до занять. Застосовуваний комплекс методів формувався за зростанням рівня складності завдань. Ефективність застосованої програми проявлялась у підвищенні рівня емоційного інтелекту майбутніх фахівців, що фіксується за допомогою застосування психодіагностичних методик, і об'єктивної реєстрації змін їх особистості. За масштабу розв'язаних завдань оптимізації розвитку емоційного інтелекту майбутнього фахівця, надання емоційної підтримки та інформації про позитивні аспекти проходження програми підводило студентів до розуміння його бажання участі в проекті, та обговорювались їх очікування від програми та організації занять. Підібрані нами методики орієнтовані на відпрацювання вербального і невербального спілкування, перцептивних навичок, сприйняття і уявлення, встановлення взаєморозуміння, розуміння себе, вивчення основ психофізіогноміки, відпрацювання комунікативних навичок та навичок емоційного інтелекту.

Дослідження розвитку емоційного інтелекту у студентів проводилося нами на базі Горлівського інституту іноземних мов «Донбаський державний педагогічний університет» (35 студентів) та «Уманського державного педагогічного університету імені Павла Тичини» (21 студент). У дослідженні взяли участь 56 студентів.

Дослідження проходило протягом ряду етапів:

- психодіагностика рівня емоційного інтелекту у студентів 3 використанням наступних методик: "Методика дослідження соціального 
THEORETICAL FOUNDATIONS OF THE FUNCTIONING OF EDUCATION. WAYS TO

IMPROVE THE EFFECTIVENESS OF EDUCATIONAL ACTIVITIES

інтелекту" Дж. Гілфорда і М. Саллівена, опитувальник «Емоційний інтелект» Д. В. Люсіна (Михайлова Е.С., 2006; Люсин Д.В., 2009; Вачков I.В., 2007);

- впровадження корекційно-розвиваючої програми "Розвиток емоційного інтелекту студентів - майбутніх фахівців" в групах активного соціальнопсихологічного навчання (АСПН);

- виявлення рівня розвитку емоційного інтелекту у студентів та ефективності розробленої програми активного соціально-психологічного навчання "Розвиток емоційного інтелекту студентів - майбутніх фахівців" в групах (АСПН).

На першому етапі дослідження використовувалась методика Дж. Гілфорда і М. Саллівена дослідження соціального інтелекту. Основне призначення даної методики - діагностування когнітивної складової комунікативної компетентності людини. Обрана методика визначає рівень "соціального інтелекту". Соціальний інтелект - це інтегральна інтелектуальна здатність, що визначає успішність спілкування і соціальної адаптації, яка об'єднує і регулює пізнавальні процеси, пов'язані 3 відображенням соціальних об'єктів (людини як партнера по спілкуванню або групи людей). До процесів, що його утворюють, відносяться соціальна чутливість, соціальна перцепція, соціальна пам'ять і соціальне мислення.

Стимульний матеріал складається з тестових зошитів (субтестів).

Субтест № 1 «історії із завершеннями». Основне призначення - діагностика здатності передбачати наслідки поведінки людей в певній ситуації, передбачати те, що відбудеться в подальшому.

Субтест № 2 «групи експресії». Основне призначення - діагностика здатності до логічного узагальнення, виділення загальних істотних ознак в різних невербальних реакціях людини.

Субтест № 3 «вербальна експресія». Основне призначення - діагностика здатності розуміти зміну значення подібних вербальних реакцій людини в залежності від контексту ситуації яка їх викликала. 
THEORETICAL FOUNDATIONS OF THE FUNCTIONING OF EDUCATION. WAYS TO

IMPROVE THE EFFECTIVENESS OF EDUCATIONAL ACTIVITIES

Субтест № 4 «історії з доповненням». Основне призначення - діагностика здатності розуміти логіку розвитку ситуацій взаємодії і значення поведінки людей в цих ситуаціях (Михайлова Е.С., 2006).

Ми вважаємо правомірним використання даної методики, тому що вона вимірює виділені нами компетенції емоційного інтелекту: визначення наявності емоційного переживання в іншої людини; ідентифікація емоцій інших людей; розуміння причин, які викликали емоцію; розуміння наслідків, до яких веде та чи інша емоція; фасилітація мислення внаслідок підбору більш підходящої для ситуації емоції.

В дослідженні використовувався опитувальник «Емоційний інтелект» (Емін) розроблений Люсіним Д. В., в якому виділяється 4 шкали: міжособистісний інтелект (MEI), внутрішньоособистісний інтелект (BEI), розуміння емоцій (РЕ), управління емоціями (УЕ).

Шкала MEI - діагностує здатність особистості до розуміння емоцій інших людей, а також управління емоціями інших людей.

Шкала BEI - діагностує здатність до розуміння власних емоцій, а також управління ними.

Шкала РЕ - дозволяє виміряти здатність до розуміння своїх емоцій, а також емоцій інших людей.

Шкала УЕ - діагностує здатність до управління своїми емоціями, а також емоціями інших людей (Люсин Д.В., 2009).

На першому етапі дослідження, були отримані наступні результати: у 37,5\% студентів було діагностовано середній рівень розвитку емоційного інтелекту, у 13,75\% - високий і у 48,75 - низький.

Після проведення корекційно-розвиваючої програми були отримані наступні результати: низький рівень показали - 17.5 \% студентів; середній рівень - 58.3\%; високий - $24.2 \%$.

Відбулося значне підвищення середніх і високих показників розвитку емоційного інтелекту студентів і знизились низькі показники. Активне соціально психологічне навчання студентів в групах (АСПН), 3 використанням 
THEORETICAL FOUNDATIONS OF THE FUNCTIONING OF EDUCATION. WAYS TO

IMPROVE THE EFFECTIVENESS OF EDUCATIONAL ACTIVITIES

корекційно-розвиваючої програми "Розвиток емоційного інтелекту студентів майбутніх фахівців" показало свою ефективність, але потребує іi удосконалення, для використання на другій ступені розвитку емоційного інтелекту у студентів, що надає змогу студентам з низьким та середнім рівнями розвитку емоційного інтелекту покращити свої результати.

Аналіз навчальної діяльності студентів показав, що для того, щоб успішно виконувати свою роботу, майбутній фахівець повинен мати добрі спеціальні професійні здібності, до яких відносяться ті здібності, що впливають на його успішну професійну діяльність. Емоційний інтелект є важливим елементом цілісної системи успішної професійної діяльність майбутніх фахівців.

Таким чином, впливаючи методами соціально-психологічного навчання (АСПН), стимулюючи розвиток емоційного інтелекту за допомогою програми "Розвиток емоційного інтелекту студентів - майбутніх фахівців", організовуючи роботу в групах, можна сформувати установки на управління емоціями.

\section{Висновки.}

1. Емоційний інтелект (EQ) розуміється як здатність усвідомлювати емоції, досягати і генерувати їх так, щоб сприяти розумінню емоцій і управляти ними, сприяючи своєму емоційному i інтелектуальному зростанню. Емоційний інтелект пов'язаний із здібностями, які означають: точність оцінки і вираження емоцій, як самого індивіда, так і людей, що оточують його; когнітивну асиміляцію емоційного досвіду; розпізнавання, розуміння і осмислення емоцій. Емоційний інтелект - стійка ментальна здатність, частина великого класу ментальних здібностей.

2. Конструкт емоційного інтелекту можна також представити як сукупність емоційно-когнітивних здібностей до соціально-психологічної адаптації особистості.

3. Ефективність роботи в групах активного соціально-психологічного навчання (АСПН) із студентами висока, оскільки сам по собі юнацький вік припускає рухливість, пластичність і сенсітівность емоційної і інтелектуальної 
сфер особистості. Робота в групах АСПН спрямована на позитивні зміни в розвитку емоційного інтелекту у студентів.

4. Розвинений емоційний інтелект майбутніх фахівців є важливою умовою життєвого успіху, задоволеності і упевненості в професійній діяльності.

5. Існує потреба в подальшому дослідженні феномену емоційного інтелекту, його структури, шляхів його розвитку, що відкриє реальну можливість оптимізації взаємовідносин через глибше усвідомлення емоційних станів, що виникають в професійній діяльності майбутніх фахівців. 
DOI 10.46299/ISG.2021.MONO.PED.II-209-254

\section{3 Трансформація педагогічної освіти в XXI столітті}

\subsubsection{1. Професійна педагогічна освіта в XXI столітті: проблеми, виклики, перспективи}

Сучасна система професійної освіти України характеризується динамічним оновленням освітнього простору. Стрімкий розвиток інноваційних педагогічних технологій, оновлення матеріально-технічної бази, застосування кращих актуальних практик зумовлює запровадження компетентнісної парадигми в практику діяльності закладів професійно-педагогічної освіти. В таких умовах змінюються вимоги до працівників закладів освіти, актуалізується потреба розвитку їхніх фахових компетентностей.

Реформування системи професійної педагогічної освіти регламентоване законами України «Про освіту» (2017), «Про вищу освіту» (2014), «Концепції розвитку освіти України на період 2015-2025 роки» (2014), «Концепції «Нова українська школа» (2016), «Концепції розвитку педагогічної освіти» (2018), «Концепція розвитку неперервної педагогічної освіти» (2013), «Національній стратегії розвитку освіти в Україні на 2012-2021 роки» (2012), «Стратегії сталого розвитку України до 2030 р.» (2017).

На початку XXI століття $є$ все більш зрозумілим, що необхідна кардинальна реформа наявної системи освіти, котра вже давно не відповідає новим умовам існування людства. Створення нової системи освіти для миру, що здатна підготувати населення до життя в нових умовах постіндустріальної (інформаційної) цивілізації, - одна 3 найважливіших і актуальних проблем сучасного суспільства. Більше того, це єдина надія на подолання глобальної кризи сучасної цивілізації, на створення необхідних умов для виживання та подальшого безпечного й усталеного розвитку людства.

Проте, ця думка ще недостатньо усвідомлена. Свідоцтвом цього $є$ недостатня увага, що приділяється нині проблемам освіти з боку урядів багатьох країн світової спільноти, в тому числі й України. Мізерні обсяги фінансування, що виділяються нині для системи освіти, ніякою мірою не відповідають ні 
THEORETICAL FOUNDATIONS OF THE FUNCTIONING OF EDUCATION. WAYS TO IMPROVE THE EFFECTIVENESS OF EDUCATIONAL ACTIVITIES

масштабам, ні стратегічній важливості цієї проблеми, іiі значенню для нашого найближчого та віддаленого майбутнього.

Усе сказане вище повною мірою можна віднести до професійної педагогічної освіти як складника освіти в цілому. Професійна педагогічна освіта має довготривалу історію. Як показав аналіз літератури, різні аспекти філософії професійної педагогічної освіти висвітлено в працях В.Андрущенка, Г.Васяновича, І.Зязюна, В.Кременя, В.Лутая та ін., дидактики вищої професійної освіти - А.Алексюка, В.Аніщенко, М.Артюшиної, С.Архангельського, Ю.Бабанського, В.Бондаря, С.Гончаренка, О.Матюшкіна, П.Підкасистого, Д.Чернілевського, О.Щербак та інші. Концептуальні засади підготовки майбутніх фахівців-педагогів розглянуто в працях С.Батишева, О.Гребенюка, О.Дубасенюк, А.Кирсанова, А.Лігоцького, Л.Лук’янової, Н.Ничкало, В.Радкевич, С.Сисоєвої, І.Смірнова, Ф.Шльосека. Проблеми порівняльної професійної педагогіки досліджували Н.Абашкіна, Н.Бідюк, М.Лещенко, В.Кудін, Н.Ничкало, Л.Пуховська, О.Сухомлинська та ін.

Отже, професійно-педагогічна освіта призначена для виконання спеціального, лише їй властивого соціального замовлення. Як соціальний інститут освіта покликана створювати необхідні умови, що забезпечують усім членам суспільства можливість на основі кваліфікованої діяльності брати реальну участь у створенні і національного, і власного добробуту. Разом із економічними задачами вона має впливати на вирішення багатьох інших проблем морального, соціального та політичного характеру. В педагогічному контексті їі соціальне призначення полягає в тому, щоб інтегрувати загальний стан людини з їі професійною самореалізацією.

Усе це не лише філософські, а й доволі прагматичні питання, що продиктовані самим життям і настирливо вимагають відповіді. Спроба знайти на ці питання достатньо обгрунтовані відповіді та їх коротко аргументувати й $\epsilon$ головною метою цього параграфу.

Як відомо, наприкінці XX століття професійна освіта перетворилася на один iз найважливіших соціальних інститутів суспільства. Сама категорія 
THEORETICAL FOUNDATIONS OF THE FUNCTIONING OF EDUCATION. WAYS TO IMPROVE THE EFFECTIVENESS OF EDUCATIONAL ACTIVITIES

«професійна освіта» набула доволі складної структури. Вона одночасно відображає систему установ, що забезпечують і надають кваліфіковані освітні послуги - це заклади вищої освіти, училища і коледжі, науково-дослідні інститути, методичні служби, видавництва, органи управління та ін.), результат оволодіння професією з присвоєнням відповідної кваліфікації, а також сам процес або технології навчання. Складність категорії «професійно-педагогічна освіта» визначається ще й тим, що вона охоплює значну кількість і різноманіття видів діяльності людини, котрі складають сукупну суспільну працю, яка в міру розвитку науково-технічного прогресу набуває більш складного, комплексного та наукоємнісного характеру. Професійна компетентність людей $є$ нині вирішальною передумовою виробництва високоякісних товарів i надання сучасних послуг. Високий рівень професійної освіти є нині вирішальним фактором стимулювання економічного та суспільного розвитку та забезпечення конкурентоздатності економіки в міжнародному вимірі інформаційного суспільства.

Аналізуючи сучасні тенденції, можна зробити висновок, що в майбутньому серед фахівців усіх рівнів буде значний запит на фундаментальну та методологічну професійну підготовку в полі певної професії, а також, що виходить за межі професії, ключові кваліфікації (компетентності), котрі не застарівають і є основою набуття спеціальних знань і вмінь в процесі неперервної освіти. Іншими словами, в стратегії розвитку професійної освіти необхідним $\epsilon$ курс на його генералізацію, котра в процесі професійної діяльності людини в міру необхідності може перетворитися в спеціалізацію.

Створення перспективної системи освіти, зокрема педагогічної освіти, здатної підготувати людей до життя в зовсім нових умова постіндустріальної цивілізації, - одна 3 найбільш важливих і актуальних проблем сучасного суспільства. Це єдина надія на подолання глобальної кризи нинішньої цивілізації, на створення необхідних умов для виживання та подальшого безпечного розвитку людства. Проблема взаємодії людини 3 новим інформаційним середовищем особливо гостро постала наприкінці ХХ століття. 
THEORETICAL FOUNDATIONS OF THE FUNCTIONING OF EDUCATION. WAYS TO

IMPROVE THE EFFECTIVENESS OF EDUCATIONAL ACTIVITIES

Вона була вперше зумовлена все більш швидко зростаючими потоками інформації, що обрушились на людей в сучасному світі, і викликали в них почуття дискомфорту та психологічного перевантаження.

Ми констатували, що глобальний процес формування нового високоавтоматизованого інформаційного середовища суспільства створює безпрецедентні можливості для розвитку людини, більш ефективного розв'язання ii багатьох професійних, економічних, соціальних і побутових проблем. Однак, використовувати ці можливості зможуть лише ті члени суспільства, які будуть володіти необхідними компетенціями, тобто знаннями та вміннями орієнтуватися в новому інформаційному просторі та використовувати його можливості.

Виникає питання: в чому саме полягають проблеми нинішньої системи освіти й якою ми бачимо перспективну систему освіти для того, щоб забезпечити не тільки добробут кожної нації, а й подальший сталий розвиток людства?

На основі результатів досліджень науковців багатьох країн [224, с. 10, с. 24, с. 25] уважаємо, що найважливішими стратегічними планами майбутньої системи освіти є такі:

- фундаменталізація освіти, що має найкращим чином підвищити іiі якість;

- випереджувальний характер усієї системи освіти, iї спрямованість на проблеми постіндустріальної цивілізації, розвиток творчих здібностей людини;

- суттєво більша доступність системи освіти для людей за рахунок використання методів дистанційного навчання та самоосвіти на основі сучасних інформаційних і комунікаційних технологій.

Отже, фундаменталізація освіти, зокрема професійної, педагогічної передбачає все більшу орієнтацію на вивчення фундаментальних законів природи, суспільства, техніки, а також природи та призначення самої людини. Саме це має дозволити людям самостійно находити й обирати відповідальні рішення в умовах невизначеності, в критичних і стресових ситуаціях, а також у тих випадках, коли людина зустрічається 3 новими, досить складними 
THEORETICAL FOUNDATIONS OF THE FUNCTIONING OF EDUCATION. WAYS TO

IMPROVE THE EFFECTIVENESS OF EDUCATIONAL ACTIVITIES

природними i соціальними явищами. Наукові знання та високі моральні принципи є в цих випадках єдиною надійною опорою.

Термін «фундаменталізація» в подальшому розуміємо як суттєве підвищення якості освіти та рівня освіченості людей, які їі одержують, за рахунок відповідної зміни дисциплін, що вивчаються, і методології реалізації освітнього процесу.

Для досягнення цілей фундаменталізації освіти вважаємо за необхідне таке:

1. Перемістити фокус уваги викладачів і здобувачів освіти 3 проблеми вивчення прагматичних знань на проблеми розвитку загальної культури людини на основі пізнання найкращих досягнень цивілізації, а також на формування в неї наукових форм системного мислення.

2. Змінити зміст і методологію освітнього процесу таким чином, щоб крім вивчення історії розвитку культури і суспільства, та процесу формування сучасної науки, що безумовно необхідні для загального розвитку кожної людини, значна частина часу приділялася виробленню сучасних уявлень про цілісний зміст системи наук, перспективи їі подальшого розвитку.

Інакше кажучи, акцент має бути зроблений на вивченні найбільш фундаментальних законів природи і суспільства в їх сучасному розумінні. 3 цією метою уявляється доцільним уже нині розробити і ввести в систему освіти низку нових освітніх дисциплін, що узагальнюють останні досягнення фундаментальних наук у таких областях наукового знання, як синергетика, глобалістика, ноосферологія, теоретична і соціальна інформатика, геополітика i безпека, інформаційна безпека тощо.

Мова у цих випадках йде не просто про збільшення кількості дисциплін, що вивчаються, а про формування принципово нових фундаментальних освітніх курсів для системи орієнтованих на формування цілісних сучасних уявлень про наукову картину світу та здатності виходити на системний рівень його пізнання.

Нині уявляється виключно важливим надати новим фахівцям належні екологічні знання. Якісна загальна екологічна освіта дозволяє не лише 
THEORETICAL FOUNDATIONS OF THE FUNCTIONING OF EDUCATION. WAYS TO

IMPROVE THE EFFECTIVENESS OF EDUCATIONAL ACTIVITIES

сформувати у випускників закладів вищої освіти (ЗВО) нові світоглядні установки, необхідні людям у XXI столітті, а й також більш ефективно використовувати необхідні професійні знання та практичний досвід (компетенції) із різноманітних сфер соціальної практики для спільного вирішення багатьох екологічних проблем сучасності.

Ми також уважаємо, що в перспективній системі фундаментальної освіти, насамперед, у педагогічній, мають домінувати інформаційні компоненти. Справа в тому, що випускники ЗВО жити і працювати будуть в інформаційному суспільстві, де пріоритетну роль грають фундаментальні знання, про інформаційні процеси в природі та суспільстві та нові інформаційні, в тому числі інформаційно-комунікаційні технології.

Вельми важливим і перспективним напрямом розвитку сучасної освіти $є$ широке впровадження дистанційного навчання та самоосвіти на основі використання нових i перспективних інформаційних та інформаційнокомунікаційних технологій, засобів віддаленого доступу до розподілених баз даних і знань науково-технічної та навчально-методичної інформації.

Розвиток дистанційної освіти і навчання на відстані є нині особливо важливим [220, с. 4, с. 20]. Створення ефективних форм і систем дистанційного навчання в країнах 3 чималою територією не тільки суттєво підвищує доступність якісної освіти для значної частини населення, а й, що дуже важливо в умовах інклюзивного навчання сприяє вирішенню проблем освіти для людей 3 обмеженою рухомістю, а також тим людям, які 3 певних причин не можуть навчатися очно.

Ми вважаємо, що дистанційна освіта як нова форма навчання не є ні модернізацією, ні тим більше аналогом заочного навчання, котре поки ніхто не відміняв і яке має власну нішу в системі неперервної освіти. Різниця цих форм навчання полягає в такому:

1. Ключовим словом дистанційного навчання $\epsilon$ інтерактивність постійна систематична взаємодія викладача та студентів і студентів між собою в навчальному процесі. У заочному навчанні інтерактивність епізодична. 
THEORETICAL FOUNDATIONS OF THE FUNCTIONING OF EDUCATION. WAYS TO IMPROVE THE EFFECTIVENESS OF EDUCATIONAL ACTIVITIES

2. Засоби реалізації всіх компонентів системи дистанційного навчання здійснюють специфічний вплив на кожний із компонентів системи навчання, зумовлюючи їх відбір, структуризацію, організацію. Курс дистанційного навчання та курс заочного навчання відрізняються один від іншого принципово, організацією навчального матеріалу, його структурою, способом взаємодії викладача та студентів, організацією інформаційно-освітнього середовища навчального процесу. Методи і форми навчання також різняться принципово під впливом використовуваних інтернет-технологій. Вони вбудовані в освітній процес і становлять його невід'ємну частину.

3. Система управління пізнавальною активністю студентів також зумовлена специфікою використовуваних послуг Інтернет [239].

Успіх дистанційної освіти і навчання багато в чому залежить від викладачів дистанційного навчання та вчителів, їхнього професіоналізму. Очевидним є той факт, що перспективою широкого впровадження дистанційної освіти в практику загальноосвітньої, професійної (професійно-технічної), фахової передищої та вищої школи вже зараз є важливим завданням підготовки, насамперед, студентів педагогічних та інженерно-педагогічних 3ВО не тільки для очної, а й дистанційної форми навчання.

Отже, перспективна система професійно-педагогічної освіти має враховувати головні виклики XXI століття та пов'язані з ними найважливіші проблеми людини в сучасному та майбутньому інформаційно-технологічному суспільстві. Вона має стати головним засобом для формування нової свідомості людей і нової культури суспільства, котрі необхідні для подолання глобальної кризи сучасної цивілізації та іï подальшого безпечного й усталеного розвитку.

Отже, головними напрямами переходу до нової освітньої концепції, що має стати основою необхідної для умов XXI-го століття перспективної системи освіти є такі:

- фундаменталізація освіти на всіх іiі рівнях;

- реалізація концепції випереджувальної освіти, орієнтованої на умови існування людини в інформаційному суспільстві; 
THEORETICAL FOUNDATIONS OF THE FUNCTIONING OF EDUCATION. WAYS TO IMPROVE THE EFFECTIVENESS OF EDUCATIONAL ACTIVITIES

- широке впровадження методів і форм інноваційної та розвивальної освіти на основі використання сучасних інформаційних технологій;

- підвищення доступності якісної освіти шляхом розвитку системи дистанційного навчання і засобів інформаційної підтримки освітнього процесу сучасними IKT [229].

Активне формування інформаційно-цифрового освітнього простору України та інших країн створює для людини не тільки нові можливості, а й нові проблеми, що пов’язані з їі адаптацією до цього середовища, та породжує нові форми соціальної нерівності. Розширення інформаційно-цифрового простору і підвищення його доступності для широких верств населення повинне дозволити знизити гостроту цих проблем.

У всіх ланках перспективної системи професійної освіти має приділятися підвищена увага проблемам соціального використання інформації як нового ресурсу розвитку суспільства і перспективним IКT, що є каталізатором цього розвитку.

\subsubsection{2. Розвиток сучасної педагогічної освіти: деякі проблеми і шляхи їх вирішення}

Діяльність закладів вищої освіти нині проходить в умовах непростих викликів, що постали перед країною. Насамперед, це пандемія COVID-19, тотальна цифровізація суспільного життя, прискорена пандемією коронавірусу, посилення конкуренції ЗВО в умовах інноваційного типу процесу, проблеми стійкого розвитку та ін. Це робить ще більш актуальним зміцнення єдності української нації, здатної ефективно протистояти негараздам, увійти в річище стійкого соціально-економічного розвитку, реалізації конституційних норм, щодо європейської та євроатлантичної інтеграції. Пошук відповідей на ці питання та інші виклики вимагають подальшого розвитку науки, зокрема педагогічної освіти, їх ролі в людському житті, розвитку кожної людини.

У період розроблення в Україні нової парадигми педагогічної освіти, що визначає їі розвиток на період до 2027 року, важливо проаналізувати актуальний стан системи підготовки педагогічних кадрів, виявити й охарактеризувати деякі 
THEORETICAL FOUNDATIONS OF THE FUNCTIONING OF EDUCATION. WAYS TO IMPROVE THE EFFECTIVENESS OF EDUCATIONAL ACTIVITIES

бар’єри, перепони, що перешкоджають подальшому стійкому розвитку розглядуваної системи.

Метою дослідження, результати якого представлені в цьому параграфі, є з’ясування бар'єрів розвитку педагогічної освіти в Україні, пов’язаних з ї університетизацією, і визначення обгрунтованих шляхів їх подолання. Одержані результати можна використати в процесі розроблення навчальних планів педагогічних і класичних університетів.

Емпіричну базу дослідження склали: факти, одержані в процесі порівняльного аналізу навчальних планів закладів вищої освіти, що забезпечують професійну підготовку педагогічних кадрів; результати проведених під керівництвом авторів у 2019/2021 навчальному році опитування молодих учителів закладів загальної середньої освіти Вінниці й Вінницької області; відомості, одержані в процесі спостереження й аналізу уроків, що проводились студентами-практикантами Навчально-наукового інституту педагогіки, психології, підготовки фахівців вищої кваліфікації та факультету математики, фізики та технологій Вінницького державного педагогічного університету імені Михайла Коцюбинського.

Одержані факти піддавались в подальшому аналізу в контексті тенденції розвитку педагогічної освіти в Україні та Свропейських країнах, результатом чого $\epsilon$ моделювання науково-обгрунтованих шляхів подолання недоліків університетизації педагогічної освіти.

Результати роботи свідчать про те, що проблеми молодого вчителя фіксуються на методологічному та технологічному рівнях. Методологічний рівень характеризується світоглядним вакуумом, нездатністю опертися на педагогічну антропологію та герменевтику в процесі створення умов розвитку підростаючого покоління, орієнтацією на рольову, а не на концептуальну поведінку. Технологічний рівень характеризується неготовністю забезпечувати здобувачам можливість вільного та відповідального вибору, необізнаність у володінні методами організації навчання в співпраці 3 демократичними 
THEORETICAL FOUNDATIONS OF THE FUNCTIONING OF EDUCATION. WAYS TO

IMPROVE THE EFFECTIVENESS OF EDUCATIONAL ACTIVITIES

процедурами прийняття рішень, невмінням перефразовувати індиферентне для студента середовище в оптимальний простір його розвитку.

Причини, що склались в розглядуваній ситуації, різноманітні. Одна з них - наслідки університетизації педагогічної освіти. За першу чверть XXI століття кількість педагогічних 3ВО, в яких підготовка вчителів є основним завданням, значно скоротилась. Низка педагогічних інститутів (Житомирський, Волинський, Ніжинський, Кам'янець-Подільський, Глухівський та ін.) свого часу були реорганізовані в класичні університети, Київський, Вінницький, Дрогобицький, Уманський, Тернопільський, Чернігівський та ін. - у педагогічні університети. Університетизація вищої педагогічної освіти позначилась на посиленні фундаментальної наукової підготовки фахівців освіти і послабленні професійної психолого-педагогічної підготовки. Це відзначають багато фахівців педагогічних університетів.

Так, за останнє десятиліття загальна кількість навчальних годин на різних факультетах українських педагогічних університетів $\mathrm{i}$ педагогічних спеціальностях класичних університетів збільшилась майже вдвічі, в той час, як кількість навчальних годин 3 педагогіки, психології, методики викладання предмету - лише зменшувалася. Фактично кількість годин на вивчення психолого-педагогічних дисциплін майбутніми вчителями значно скоротилась. Відповідно строки вивчення педагогічних дисциплін скоротилися 3 трьох до одного року п’яти місяців. На багатьох факультетах і спеціальностях вивчення психолого-педагогічних дисциплін завершується в п’ятому семестрі. Кількість годин, що відводяться на методику викладання предмета, суттєво відрізняється на різних спеціальностях, не дивлячись на те, що всім присвоюється однакова кваліфікація «Учитель».

У педагогічних ЗВО переважає надмірна теоретизація курсів, що вивчаються 3 відривом від реальних процесів, котрі відбуваються в загальноосвітній школі. Так, наприклад, із загального обсягу годин $з$ педагогіки (220 год) i психології (160 год.) на різних факультетах педагогічних університетів і педагогічних спеціальностей лекційні години складають більше 
THEORETICAL FOUNDATIONS OF THE FUNCTIONING OF EDUCATION. WAYS TO

IMPROVE THE EFFECTIVENESS OF EDUCATIONAL ACTIVITIES

половини освітнього часу, в той час, як на лабораторні заняття відводиться в середньому лише 6 годин.

Уяву про це надає порівняльна таблиця, котру ми склали за архівними даними, включивши розподіл навчальних годин з педагогічних дисциплін з 2000 по 2020 рр. (таблиця 1).

\section{Таблиця 1}

\section{Розподіл годин з педагогічних дисциплін}

\begin{tabular}{|c|c|c|c|c|c|c|c|c|c|c|}
\hline Педагогічні & \multicolumn{2}{|c|}{$2000 p$} & \multicolumn{2}{|c|}{$2005 p$} & \multicolumn{2}{|c|}{$2010 p$} & \multicolumn{2}{|c|}{$2015 p$} & \multicolumn{2}{|c|}{$2020 \mathrm{p}$} \\
\hline Заг. к-сть год. & $\begin{array}{c}\text { Заг. } \\
\text { к-сть } \\
\text { год. }\end{array}$ & $\begin{array}{l}\text { К-сть } \\
\text { ауд. } \\
\text { год }\end{array}$ & $\begin{array}{c}\text { Заг. } \\
\text { к- } \\
\text { сть } \\
\text { год }\end{array}$ & $\begin{array}{l}\text { К- } \\
\text { сть } \\
\text { ауд. } \\
\text { год }\end{array}$ & $\begin{array}{c}\text { Заг. } \\
\text { к- } \\
\text { сть } \\
\text { год }\end{array}$ & $\begin{array}{c}\text { К-сть } \\
\text { ауд. } \\
\text { год }\end{array}$ & $\begin{array}{c}\text { Заг. } \\
\text { к- } \\
\text { сть } \\
\text { год }\end{array}$ & $\begin{array}{c}\text { К-сть } \\
\text { ауд. } \\
\text { год }\end{array}$ & $\begin{array}{c}\text { Заг. } \\
\text { к- } \\
\text { сть } \\
\text { год }\end{array}$ & $\begin{array}{c}\text { К-сть } \\
\text { ауд. } \\
\text { Год }\end{array}$ \\
\hline Педагогіка & 108 & 72 & 108 & 72 & 108 & 72 & 90 & 28 & 90 & 28 \\
\hline $\begin{array}{l}\text { Методика } \\
\text { роботи }\end{array}$ & 72 & 36 & 72 & 36 & 72 & 36 & 60 & 28 & 60 & 28 \\
\hline $\begin{array}{l}\text { Основи педагогічної } \\
\text { майстерності } \\
\text { (каф. педагогіки) }\end{array}$ & 54 & 40 & 54 & 36 & 54 & 28 & 90 & 22 & 90 & 22 \\
\hline $\begin{array}{l}\text { Основи педагогічної } \\
\text { майстерності } \\
\text { (фахова каф.) }\end{array}$ & 108 & 64 & - & - & 90 & 44 & & 20 & & 20 \\
\hline $\begin{array}{l}\text { Спецкурс } \\
\text { психолого-педагог. } \\
\text { дисциплін }\end{array}$ & 42 & & 42 & - & - & - & - & - & - & - \\
\hline Історія педагогіки & 54 & 36 & 54 & 36 & 54 & 26 & 60 & 28 & 60 & 28 \\
\hline $\begin{array}{l}\text { Пропедевтична } \\
\text { практика }\end{array}$ & 72 & 32 & 72 & 32 & 72 & 32 & 60 & 16 & 60 & 16 \\
\hline $\begin{array}{l}\text { Інструктивно- } \\
\text { методична практика }\end{array}$ & 36 & 36 & 36 & 36 & 36 & 36 & 30 & 16 & 30 & 16 \\
\hline Позашкільна практика & 144 & & 108 & & 108 & & 90 & 8 & 90 & 8 \\
\hline Педагогічна практика & 216 & 1 & 216 & 1 & 216 & $\begin{array}{l}\text { 1год. } \\
\text { на } \\
\text { одног } \\
\text { о } \\
\text { студ. }\end{array}$ & 180 & 0,5 & 180 & $\begin{array}{l}0,5 \text { год. } \\
\text { на } \\
\text { одного } \\
\text { студ. }\end{array}$ \\
\hline
\end{tabular}

Нами було проаналізовані навчальні плани підготовки спеціалістів, нині бакалаврів різних педагогічних спеціальностей з присвоєнням кваліфікації: вчитель української мови, вчитель історії, вчитель хімії, біології щодо відведених годин на вивчення педагогічних дисциплін і педагогічної практики й 
THEORETICAL FOUNDATIONS OF THE FUNCTIONING OF EDUCATION. WAYS TO

IMPROVE THE EFFECTIVENESS OF EDUCATIONAL ACTIVITIES

узагальнено дані за 2000 p, 2005 p, 2010 p, 2015 p, 2020 p. Варто зазначити, що впродовж цього періоду спостерігається тенденція щодо зменшення кількості годин з окреслених дисциплін. Так, якщо з 2000 року по 2005 рік на вивчення «Педагогіки» було відведено 108 год. із них 72 год. - лекції, практичні, лабораторні, що становить $66,7 \%$ від загальної кількості годин, то в навчальних планах 2015, 2020 рр. кількість годин відповідно зменшено (загальна кількість 90 год, і лише 28 год. - лекції, практичні лабораторні заняття, що становить 31,1\% від усього обсягу).

Зменшено кількість годин на таку навчальну дисципліну в педагогічному ЗВО як «Основи педагогічної майстерності». У 2000 р. за навчальним планом на цю навчальну дисципліну виділялися години кафедрі педагогіки та фаховій кафедрі. Проте кількість годин зменшено із 162 год., що передбачено навчальним планом 2000 р. до 90 год - 2020 р. Відповідно, кількість годин, відведених на лекції, практичні, лабораторні заняття зменшено із 104 год. до 44 год.

У навчальному плані 2000 року на різні види практики виділено 468 год, тоді як у навчальних планах 2015, 2020 років зазначений обсяг зменшено на 108 год.

Зменшення кількості годин на вивчення педагогічних дисциплін і практики у педагогічному ЗВО негативно впливає на якість підготовки майбутнього вчителя. I, як наслідок, у школах непоодинокі випадки виникнення ситуацій в яких учителі окремих предметів виявляють професійну незрілість, некомпетентність, низький рівень моральної культури тощо. Адже упускаються 3 поля зору майбутнього фахівця обговорення ключових питань сучасної дидактики, теорії виховання, розвитку, соціалізації і виховання особистості, освітнього менеджменту, що $\epsilon$ підгрунтям у формуванні його загальнопедагогічної компетентності. Робота педагога $з$ особистістю дитини, вплив на їі розум, почуття є складною справою і потребує величезних зусиль, спеціальних знань, умінь, відповідних особистісних характеристик, що мають формуватися під час навчання у педагогічних ЗВО. 
THEORETICAL FOUNDATIONS OF THE FUNCTIONING OF EDUCATION. WAYS TO

IMPROVE THE EFFECTIVENESS OF EDUCATIONAL ACTIVITIES

Для порівняння: в 1985 році в загальному обсязі годин з педагогіки (200 год.) 28 годин відводилось на лабораторні заняття, 18 - на практичні. У порівнянні з 1985 р. кількість годин, що відводяться на теоретичну підготовку 3 психолого-педагогічних дисциплін, невпинно зростає, на відміну від практичної. Це негативно відображається на формуванні в студентів професійної мотивації, умінь та навичок, педагогічних компетенцій.

У подальші роки значно знизилась кількість годин на організацію педагогічної практики студентів. Це виявляється в скороченні іiі термінів, формальному керівництві, відсутності постійного моніторингу процесу i результатів роботи студентів-практикантів. У більшості університетів активна психолого-педагогічна практика студентів починається, переважно, на третьому курсі в літніх оздоровчих таборах (зауважимо, що в більшості класичних університетів іїі взагалі немає). Відсутність педагогічної практики на першому та другому курсах навчання в університеті призводить до того, що студенти із значним запізненням починають уявляти ситуацію в сучасній реформованій школі, особливостях нинішнього покоління школярів.

За останні десять-п'ятнадцять років кількість тижнів, що відводиться на всі види педагогічної практики студентів, скоротилась, в середньому на 7, в той час, як вимоги до змісту практики залишилися без змін. Це призводить до формалізму в іii організації, значно ускладнює ознайомлення студентів 3 реаліями педагогічної професії, негативно впливає на мотивацію педагогічної діяльності і готовність до її компетентної реалізації. У чинних навчальних планах на всі види практики відводиться від 8 до 17\% навчального часу. В той час, коли навчальний план підготовки вчителів початкової школи Франції, наприклад, включає 10001200 годин теорії і 500 годин шкільної практики (тобто 50\% навчального часу). У низці країн (Німеччина, Франція, США та ін.) два останніх роки навчання в педагогічному ЗВО присвячені спеціалізації, тобто педагогічній практиці як учителя-стажера, а також заняттям у системі дидактичного семінару безпосередньо в школі під керівництвом досвідчених шкільних учителів. 
THEORETICAL FOUNDATIONS OF THE FUNCTIONING OF EDUCATION. WAYS TO

IMPROVE THE EFFECTIVENESS OF EDUCATIONAL ACTIVITIES

Недоліки університетизації вищої освіти в Україні - не поодиноке явище в історії світової освітньої практики. В країнах Західної Європи цей феномен був зафіксований в 60-х pp. XX ст., і вже наприкінці 70-х років стали очевидними перші ознаки кризи університетської підготовки фахівців освітньої та соціальної галузі. Традиційний академізм університетів призвів до того, що виробнича практика або зовсім не включалась в програму професійної підготовки педагогів, або займала в ній незначне місце, хоча всі університети вимагали від студентів самостійного набуття практичного досвіду.

У результаті випускники університетів виявилися неготовими до здійснення педагогічної діяльності з низки показників: не усвідомлювали місію педагогічної професії в розвитку особистості та культури, ототожнювали предмет, що викладали, з його дисципліною; не забезпечували умов для вияву самобутності окремого учня, його індивідуальності; недостатньо оволоділи професійно-комунікативними компетентностями; не розуміли дитячої психології, актуальних потреб учнів, не могли створити позитивний емоційний фон навчання й організувати продуктивну педагогічну взаємодію. Іншими словами, зміщення акценту на дисциплінарну підготовку майбутнього вчителя в ущерб професійно-педагогічній складовій залишає випускників університетів, навіть і педагогічних університетів, мотиваційно, особистістно, методологічно і технічно не готовими керувати природними механізмами саморозвитку підростаючого покоління.

Крім того, статистичні відомості, надані провідними інформаційними центрами з проблем вищої освіти США, Великої Британії, Німеччини, Франції свідчать про те, що університетизація вищої педагогічної освіти блокує успішну самореалізацію особистості в процесі професійної діяльності, відображає помітне зростання невдоволення вчителів своєю професією, відмову від педагогічної сфери і масовий перехід в інші галузі професійної активності.

Шляхи подолання зазначених недоречностей університетизації педагогічної освіти, на наш погляд, мають бути пов'язаними з відновленням його культуротворчої функції, інтеграцією фундаментального знання зі способами 
THEORETICAL FOUNDATIONS OF THE FUNCTIONING OF EDUCATION. WAYS TO

IMPROVE THE EFFECTIVENESS OF EDUCATIONAL ACTIVITIES

самореалізації особистості в професійній діяльності, посиленням методологічного і технологічного аспектів реалізації фундаментальних знань в педагогічному процесі.

Фундаменталізація педагогічної освіти - вимога часу. Школі не потрібні вчителі філології, які пишуть на дошці з помилками, або вчителі історії, котрі плутаються в датах і подіях, мають обмежений кругозір. Але школі не потрібні й вчителі, які не можуть в доступній формі донести думку до учня, не можуть його зрозуміти, поважливо поставитись до його проблеми, надати допомогу в його вирішенні.

Основний шлях подолання кризи університетизації педагогічної освіти в теорії та практиці зарубіжної та вітчизняної педагогіки вищої школи пов’язують з посиленням практико-орієнтованості університетської підготовки педагога, що виявляється як на рівні структурування змісту освіти, так і на рівні організації педагогічного процесу (яскравий приклад «дуальна форма» організації педагогічного процесу), котру треба всіляко підтримувати.

Що можемо запропонувати для університетів у цьому аспекті:

1. Коригування навчальних планів: приведення у відповідність співвідношення фундаментального (загальноосвітніх і спеціальних предметів) i професійного (психолого-педагогічного) блоків змісту педагогічної освіти; встановлення оптимального балансу між дисциплінами теоретичного i практичного циклів у психолого-педагогічній компоненті змісту освіти; збільшення кількості практичних, лабораторних занять і самостійної роботи студентів відповідно до лекційних занять; посилення варіативного компоненту змісту педагогічної освіти, що забезпечує професіоналізацію особистості у відповідності з індивідуальним навчанням запитом і на різних рівнях складності.

2. Поступове введення багатопрофільної спеціалізації через модульну систему педагогічної підготовки студентів на елективній основі. Максимальне розширення тематики курсів із педагогічних спеціальностей i їх викладання у вигляді незалежних один від іншого модулів. При цьому групи студентів мають формуватися за їхнім індивідуальним вибором. Така система дозволяє 
THEORETICAL FOUNDATIONS OF THE FUNCTIONING OF EDUCATION. WAYS TO

IMPROVE THE EFFECTIVENESS OF EDUCATIONAL ACTIVITIES

індивідуалізувати професійну підготовку майбутнього вчителя, підготувати вчителів для різних типів шкіл, фахівців у галузі освіти для роботи з дітьми різних вікових категорій, які мають особливості психічного та фізичного розвитку (робота з обдарованими дітьми, педагогічна підтримка невстигаючих, робота з учнями з низьким соціальним статусом тощо).

3. Посилення в змісті психолого-педагогічних дисциплін праксеологічного компоненту, що має бути представлений процедурним знанням ефективної педагогічної діяльності. Забезпечення професійної спрямованості навчальних дисциплін, що викладаються для здобувачів освіти на педагогічних спеціальностях.

4. Орієнтація навчальних програм і самостійної роботи студентів на формування метакогнітивних здібностей, що дозволяють самостійно працювати зі знаннями, здобувати й опрацьовувати інформацію, безперервно забезпечувати своє професійне зростання.

Аналогічні пропозиції для вдосконалення педагогічного процесу:

1. В організації освітнього процесу в ЗВО було б доречно надати пріоритет активним формам і методам навчання, сучасним освітнім технологіям у тому числі цифровим IKT, інтерактивним технологіям тощо; формувати навички роботи в співробітництві, вміння продуктивної міжособистісної взаємодії засобами технологій інтерактивного, кооперативного, проєктного та інших видів навчання. В змісті технологічної (методичної) підготовки провідними мають стати проєктна та експертна форми і методи засвоєння педагогічної культури. Обов’язковим елементом атестації здобувача освіти за рік має бути мікровикладання (як групове, так й індивідуальне).

2. Удосконалення змісту й організації всіх видів практик, докорінно якісне реформування цього виду професійної підготовки педагога й надання йому значущості на рівні державного іспиту, а також експериментальну базу, для виконання курсових і дипломних проектів. Збільшення навчального часу на проведення педагогічної практики в різних іï формах 3 першого курсу по випускний (форма поодиноких відвідувань, серійна практика - виокремлення 
THEORETICAL FOUNDATIONS OF THE FUNCTIONING OF EDUCATION. WAYS TO IMPROVE THE EFFECTIVENESS OF EDUCATIONAL ACTIVITIES

одного дня для проходження практики кожного тижня, блочна практика - до 1416 тижнів), поступовий перехід на дуальну форму навчання.

Доцільно проаналізувати можливість виокремлення спеціального часу на адаптацію молодого фахівця як педагога-стажера або помічника вчителя від 1 до 3 років. Професійна адаптація вчителя, як і лікаря, в світовому освітньому просторі здійснюється в різних формах: у Великій Британії - випробувальний рік; в США - менторінг; в Японії - наставництво і т.д. Загальна оцінка 3 педагогічної підготовки фахівців освіти має виставлятися за результатами екзамену з педагогічної практики і державного іспиту з педагогіки.

3. Убачаємо за необхідне введення тьюторської системи в новому форматі. Тьютор відслідковує професійне зростання прикріпленого до нього студента, проводить з ним індивідуальні консультації і заняття, допомагає скласти особистісно орієнтовану програму дій, активізує його пізнавальну активність в галузях професійно-педагогічного знання, що відповідає індивідуальним інтересам і здібностям. Успішність такого досвіду також підтверджена провідними університетами світу.

Отже, передумовою визначення шляхів розвитку педагогічної освіти є виявлення недоліків університетизації педагогічної освіти як основної тенденції модернізації системи підготовки педагогічних кадрів в Україні. Ці недоліки становлять бар'єри, позитивна функція яких полягає в мобілізації зусиль суб’єктів на їх подолання за умови адекватного осмислення i розуміння складності та суперечності ситуації. Здійснені дослідження дозволили констатувати незбалансованість теоретичної і практичної підготовки педагогічних кадрів в університеті, що відбивається на реальній готовності випускників до роботи в сучасній школі. Шляхи подолання кризи університетизації педагогічної освіти вбачаємо не в обмеженні фундаменталізації, а в посиленні методологічної і технологічної складової реалізації фундаментальних знань в педагогічному процесі. Це дозволяє досягти практико-орієнтованості університетської підготовки вчителів за рахунок модернізації змісту освіти і процесу його засвоєння на всіх ступенях і рівнях. 
THEORETICAL FOUNDATIONS OF THE FUNCTIONING OF EDUCATION. WAYS TO

IMPROVE THE EFFECTIVENESS OF EDUCATIONAL ACTIVITIES

\subsubsection{3. Роль інтеграції змісту навчання в підготовці вчителя}

3 погляду на закономірності розвитку сучасної педагогічної науки є всі підстави констатувати факт все більшого прояву в ній інтеграційних процесів. Це знаходить відображення у тому, що все більш тісно зливаються дидактика i психологія мислення, педагогічна психологія, соціологія і педагогіка в цілому. В дидактиці для визначення закономірностей навчання дослідники все частіше стали використовувати поняття і теоретичні передумови кібернетики та соціології; понятійний апарат дидактики поповнюється за рахунок понять 3 теорії інформації, теорії систем, теорії оптимізації, нейрокібернетики, біокібернетики, евристики, семіотики.

Ідея синтезу психолого-педагогічних знань як умови формування цілісної теорії навчання можу бути реалізована в тому випадку, коли буде знайдено відповідну системоутворюючу основу. Така основа повинна мати свою ієрархію інтеграції в дидактиці і обгрунтування на трьох рівнях:

- методологічному (філософія дидактики), тобто інтеграція на рівні законів, закономірностей і принципів розвитку особистості;

- дидактичному, тобто інтеграція на рівні ідей, закономірностей i принципів організації навчання;

- прикладному - інтеграція змісту конкретних навчальних предметів, способів і методів навчання та виховання тощо.

Інтеграційні процеси в освіті нині відбуваються переважно на прикладному рівні. В цьому випадку інтеграція як педагогічна категорія становить цілеспрямоване об'єднання, синтез певних навчальних дисциплін у самостійні системи цільового призначення, спрямовані на забезпечення цілісності знань та умінь студентів.

У вдосконаленні підготовки майбутніх учителів до праці в нових умовах важлива роль належить теоретичному обгрунтуванню і практичному втіленню ідей інтеграції науки і техніки, освіти і виробництва, пошукам на цій основі нового змісту навчання студентів у вищих закладах освіти, а також змісту педагогічної діяльності викладачів. 
THEORETICAL FOUNDATIONS OF THE FUNCTIONING OF EDUCATION. WAYS TO

IMPROVE THE EFFECTIVENESS OF EDUCATIONAL ACTIVITIES

Не викликає сумніву той факт, що в комплексі проблем, які постали нині перед системою вищої педагогічної освіти України, завдання оновлення змісту освіти посідає чільне місце. Саме в змісті освіти знаходять відображення ті складові елементи людської культури, котрі суспільство і заклади освіти пропонують новим поколінням. Наявні навчальні плани і програми, підручники i навчальні посібники різко контрастують 3 тими новими умовами, до яких рухається наше суспільство, і тому потребують оперативної заміни. При цьому недостатньо, як це робиться, лише деполітизувати програми і підручники, або запровадити нові курси і дисципліни - економіки, екології, IКТ і т.д.

Примітною особливістю методологічної свідомості нашого часу $є$ розуміння всі більшої інтеграції наукового знання. Інтеграція, як відомо, поняття загальнонаукове. Тому під час аналізу факторів і механізмів, зумовлюючих розвиток сучасного знання, все більше усвідомлюється та обставина, що повнота картини не може бути досягнута шляхом вивчення лише однієї з груп факторів. Увагу дослідників привертають соціокультурні фактори, що впливають на формування нових наукових напрямів, на введення нових наукових ідей. Скажімо, системотехніка, проблема штучного інтелекту, обчислювальна техніка, інженерна психологія, технічна естетика, праксеологія, генна інженерія та інші напрями наукового пошуку не могли б сформуватися, якщо б у системі сучасного наукового знання не відбувалися б деякі інтегративні процеси, що народжують ці новоутворення.

Вивчення результативних сторін впливу сучасної науки на техніку i технічні знання пов’язане, насамперед, 3 аналізом певних характеристик, 3 поширенням використання досягнень фізики, кібернетики, біології та інших фундаментальних наук, ідеї і методи яких виступають як основа, передумова формування теоретичного знання в різних галузях.

У працях сучасних філософів підкреслюється, що інтеграція докорінно змінила зміст і структуру наукового знання, інтелектуально-концептуальні можливості окремих наук. Важливою особливістю інтеграції є те, що завдяки їй 
THEORETICAL FOUNDATIONS OF THE FUNCTIONING OF EDUCATION. WAYS TO

IMPROVE THE EFFECTIVENESS OF EDUCATIONAL ACTIVITIES

підвищується успішність та інформаційна ємність знання, рівень його узагальненості і комплексності, ущільненості та організованості.

Відповідно до цього загальними закономірностями інтеграції сучасного наукового знання виступають такі:

- діалектична єдність інтеграції та диференціації, що складають дві взаємопроникаючі сторони у розвитку наукового пізнання;

- перевага інтегративної тенденції перед диференціацією;

- ріст ступеня складності інтеграції науки в зв’язку з ускладненням їі предмета, структури і функцій;

- збільшення швидкості i потужності інтеграційних процесів відповідно до експотенційного зростання головних компонентів науки;

- нерівномірність процесу інтеграції, пов’язана зі зміною конкретних інтегруючих факторів, зміною лідерства в науці і зумовлена в підсумку потребами практики;

- зростання прогресивної частки тенденцій у рухові наукового знання до єдності, в розвитку науково-технічного і соціального прогресу [234, с.56].

3 точки зору нашого дослідження трансформації освіти особливий інтерес має інтеграція фундаментальних природничонаукових і технічних знань. Раніше дуже чітко помітна границя між фундаментальними і прикладними технічними знаннями є все більше розмитою, що приводить до виникнення систем знань, які все частіше називають фундаментальними технічними науками (наприклад, інженерна фізика). Це визначає відповідні революційні зміни в будові центральної ланки самої технічної науки, іï теорії, в царині технічних наук зростає необхідність у базових науках. Підвищується фундаментальність власне технічних наук.

Підсилення зв’язку природничих i технічних наук, яке зумовлює доцільність і можливість інтеграції загальнонаукових і технічних дисциплін у вищій педагогічній школі, пов’язане зі зміною погляду на об'єкт технічного знання як на штучні матеріальні утворення. Все частіше у структуру деяких сучасних технічних об’єктів включені процеси природничонаукового характеру. 
THEORETICAL FOUNDATIONS OF THE FUNCTIONING OF EDUCATION. WAYS TO

IMPROVE THE EFFECTIVENESS OF EDUCATIONAL ACTIVITIES

Наростаючі тенденції до інтеграції наукового знання зумовлюють необхідність докорінних змін у свідомості людей, в характері їхньої діяльності і, відповідно, у підготовці сучасних фахівців. Одним із шляхів удосконалення такої підготовки, безумовно, має бути дидактична інтеграція.

Проблема інтеграції навчальних дисциплін тісно пов'язана 3 наявними дослідженнями міжпредметних зав'язків, які інтенсивно розвивались в останній час, особливо в рамках системи загальної середньої освіти і професійнотехнічної освіти.

Відомо, що міжпредметні зв’язки є певним відображенням у змістові і методах навчання об'єктивно наявних зав'язків між науками і взаємозв'язків, які об’єктивно існують у природі і пізнаються різними науками. В той самий час необхідно пам'ятати, що це не буквальне відбиття міжнаукових зв'язків, що міжпредметні зв’язки виконують певні дидактичні функції, вони є дидактичною умовою підвищення наукового рівня знань студентів, умовою вдосконалення всього освітнього процесу.

Безперечно, що інтеграція навчальних дисциплін має будуватися на своїх принципах. У загальному випадку логічну структуру дидактичної інтеграції наукової здійснюють три основних елементи: база, завдання і знаряддя. Базою при цьому буде кооперуюча дисципліна, завданням - вихідна проблема, що формується в рамках базової дисципліни, знаряддям - теоретичний і технічний інструментарій базової дисципліни, що бере участь у кооперації.

У зв’язку з цим виокремлені три рівні дидактичної інтеграції.

Перший рівень - це асиміляція інструментарія (теоретичного або технічного) базової науки з тією, що бере участь в інтеграції; кожна з них має при цьому свій науковий суверенітет у навчальному процесі. Цей тип міжпредметної інтеграції знаходить зараз втілення в понятті міжпредметних зв'язків.

Другий рівень дидактичної інтеграції має знайти втілення у синтезі взаємодіючих наук на основі однієї з них (базової), який, у свою чергу, може бути як частковим, так і повним (дисциплінарним). При цьому кожна з наук зберігає 
THEORETICAL FOUNDATIONS OF THE FUNCTIONING OF EDUCATION. WAYS TO

IMPROVE THE EFFECTIVENESS OF EDUCATIONAL ACTIVITIES

свій предмет, свої концептуальні основи, тобто свій науковий статус. До суттєвих особливостей дидактичної інтеграції на рівні синтезу необхідно віднести те, що вона не повинна бути ні простим злиттям інформації взаємодіючих наук, ні їхньою механічною сумою, ні поглинанням одних наук іншими. Їхній механізм не можна уявити у вигляді простого механічного переносу інформації з одного курсу в інший. Це положення природно має місце стосовно до інтеграції природничо наукових і технічних дисциплін. У результаті їх інтеграції звичайно повинна змінюватись методика викладу матеріалу, причому, насамперед, у бік збільшення проблемності його подання.

Нарешті, третій рівень дидактичної інтеграції, так званий рівень цілісності, завершується формуванням нової навчальної дисципліни, що носить інтегративний характер і має свій власний предмет вивчення.

Якщо певний рівень міжпредметної взаємодії находить досить широке використання у практиці навчання, то взаємодії другого та третього рівнів ще тільки зароджуються і розвиваються.

Між тим, наші дослідження дали можливість констатувати, що між предметами одного циклу дисциплін (наприклад, між природничонауковими або технічними дисциплінами) значною мірою доцільна інтеграція на рівні міжпредметних зв’язків або на рівні цілісності (про це свідчить наявність, наприклад у навчальних планах підготовки учителя технологій, до прикладу інтегрованих курсів, як «Машинознавство» та «Основи виробництва»).

Наші наукові розвідки були спрямовані на можливості інтегрування змісту фундаментальних дисциплін і предметів загальнотехнічного та спеціального циклів. Зокрема, розробляється питання інтеграції змісту такої дисципліни, як фізика 3 дисциплінами, що визначають професійну підготовку майбутнього педагога - вчителя технологій: електротехніка, гідравліка, теплотехніка, теорія машин і механізмів, деталі машин, різання матеріалів, опір матеріалів тощо.

Розроблено авторську навчальну програму курсу «Загальна фізика», в якій враховані ідеї інтеграції. Створення і реалізація такої програми висуває низку методичних проблем, найбільш складною 3 яких $є$ проблема створення 
THEORETICAL FOUNDATIONS OF THE FUNCTIONING OF EDUCATION. WAYS TO

IMPROVE THE EFFECTIVENESS OF EDUCATIONAL ACTIVITIES

відповідних посібників для студентів. Для цього необхідно без застосування складного математичного апарату викласти основні ідеї курсу, їх фізичну сутність, методи та інструменти дослідження, основні результати. При цьому розкрити органічний перехід від теорії до практичного використання фізичних досліджень.

Виникає запитання: a навіщо здійснювати інтеграцію навчальних дисциплін у педагогічному закладі вищої освіти? Студенту важливо оволодіти однією дисципліною, а тут збирають цілу низку предметів, складність яких зростає з курсу до курсу. Тут не треба забувати про їхню майбутню педагогічну діяльність у закладі загальної середньої освіти або закладі професійно-технічної освіти (ЗПТО). Шкільне навчання поступово переходить до викладання на інтегрованій основі.

Джерелами дидактичного синтезу навчальних предметів у школі або в закладі ПТО можуть виступати об'єкти і предмети навколишнього світу, що вивчаються у межах навчальних дисциплін. Виходячи 3 цього, можна допустити, що в середній школі можуть бути інтегровані навчальні предмети, покликані знайомити учнів $з$ такими галузями знань:

- суспільство і суспільні відносини (історія всесвітня, історія України, історія рідного краю, суспільствознавство і правові відносини, народознавство, основи економічних знань);

- природа та її основні закономірності (фізика, астрономія, хімія, біологія, екологія);

- природознавство й основи виробництва (фізика, електротехніка, хімія, матеріалознавство, техніка й технологія сучасного виробництва, агрономія, тваринництво);

- логічні й алгоритмічні процедури (математика, інформатика й обчислювальна техніка, основи кібернетики).

На основі реалізації інтеграційних зв’язків між навчальними предметами загальноосвітньої школи не лише на якісно новому рівні вирішуються питання навчання, виховання та розвитку, оптимального констрюювання змісту освіти, 
THEORETICAL FOUNDATIONS OF THE FUNCTIONING OF EDUCATION. WAYS TO

IMPROVE THE EFFECTIVENESS OF EDUCATIONAL ACTIVITIES

але також закладається фундамент для комплексного бачення школярами складних проблем дійсності.

Інтегровані курси сприяють видаленню другорядного матеріалу, зайвої деталізації і конкретизації, виокремленню головного, працюючого на освіченість, на формування світоглядної картини буття і діяльності людей. Разом 3 тим, вони мають властивість вкладеності (ієрархічності) простих понять в більш загальні, що дозволяє їх досить легко добудовувати, наприклад, від пропедевтичних (базовий компонент) до спеціальних (професійне навчання, поглиблення, задоволення індивідуальних пізнавальних потреб). Ось чому інтеграційні зв’язки і тенденції варто вважати важливою умовою і результатом комплексного підходу до навчання, виховання та розвитку школярів.

Проблема інтеграції навчання цікавить не тільки вчених-педагогів, а й досить широке коло практичних працівників освіти. Показовими щодо цього є організація та проведення інтегрованих занять. Вибір навчальних питань для вивчення на інтегрованих уроках необмежений (наприклад, «Як виникло життя на Землі» - біологія, фізика, історія; «Походження людини» - біологія, історія; «Важливість періодичного закону Д.І,Менделєєва для науки і діалектики» хімія, суспільствознавство; «Проценти і пропорції» - математика, хімія). Варіанти інтегрованих уроків можуть бути досить різноманітними: біологіяісторія, історія-географія, фізика-біологія-географія, природознавство-трудове навчання (технологіi)-література тощо.

Отже, теоретична розробка проблеми вже йде. Це стосується, насамперед, навчальних планів. Як відомо, навчальний план визначає номенклатуру дисциплін, послідовність їх вивчення, час, що відводиться на кожний предмет, форми контролю (заліки, екзамени) тощо. В навчальному плані реалізуються принципи дидактики, такі як науковість (за номенклатурою навчальних дисциплін), доступність (у плані відповідності навчального матеріалу пізнавальним можливостям тих, хто навчається), системність і наступність (в плані реалізації міжпредметних зв’язків). 
THEORETICAL FOUNDATIONS OF THE FUNCTIONING OF EDUCATION. WAYS TO

IMPROVE THE EFFECTIVENESS OF EDUCATIONAL ACTIVITIES

Як вже зазначалось, навчальні плани 3ВО, шкіл, закладів профтехосвіти, коледжів, грішать багатопредметністю, тут є багато дисциплін, на вивчення яких відводиться мізерна кількість годин (в тиждень 1-2 години). Такий стан справ $є$ ненормальним. І ось 3 яких причин.

Є труднощі з організацією освітнього процесу. За тиждень, що проходить від одного заняття до іншого, учні забувають матеріал, що вивчався. Якщо 1-2 уроки випадуть з якихось причин (свята або хвороба викладача), то розрив збільшиться до 2-3 тижнів. Якщо вчитель веде в даному класі або групі лише один предмет, він фізично не в силах вивчити учнів - то про яку ж якість навчання може йти мова?

Важко здійснити контроль знань та їх об’єктивну оцінку. Це, в свою чергу, викликає відповідне ставлення учнів до навчального предмета, який вони розглядають як другорядний або третьорядний. Без належного контролю, що реалізує зворотний зв'язок учнів і викладача, якісне навчання неможливе. В предметах з малою кількістю годин цю елементарну вимогу до навчального процесу виконати неможливо.

Серйозну трудність становить підготовка викладача, вчителя-фахівця 3 такої навчальної дисципліни. Його неможливо забезпечити повним навантаженням, тому він повинен набирати години на іншому багатогодинному предметі: для чого має спеціалізуватись на головному (в смислі навчального навантаження) предметі, приділяти все менше уваги предмету з малою кількістю годин. До того ж, у педагогічних навчальних закладах не готують викладачів для викладання предметів, на які навчальні плани виділяють малу кількість годин. У результаті ці дисципліни викладають, як правило, люди, які в процесі навчання у ЗВО зовсім не вивчали цю науку або в кращому випадку прослухали невеликий курс, проте не одержали належної методичної підготовки в галузі дисципліни, що викладається. Рівень викладання і якості знань будуть низькими, а ті цілі i завдання, що ставлять в процесі введення цих дисциплін у навчальний план, фактично не реалізуються. 
THEORETICAL FOUNDATIONS OF THE FUNCTIONING OF EDUCATION. WAYS TO

IMPROVE THE EFFECTIVENESS OF EDUCATIONAL ACTIVITIES

Який же вихід і зазначених ситуацій? Скажімо, в змістовому аспекті навчальних дисциплін?

Ми вважаємо, що вихід є: полягає в ліквідації багатопредметності за рахунок інтеграції споріднених навчальних предметів. Такі предмети вже є. Багаторічний досвід нагромаджено, наприклад, у коледжах (фізика і астрономія, фізика з основами електротехніки), який зараз переноситься у школи та ЗПТО.

Створюються крупні навчальні предмети із значною кількістю годин, шо вирішує проблему навантаження викладачів. Полегшується їхня підготовка до викладання такого інтегрованого навчального предмета, його формування як підготовленого фахівця. Міжпредметні зв'язки перетворюються у внутрішньо предметні, що розв’язуються у більшості випадків автоматично, оскільки відпадає проблема синхронізації навчального матеріалу двох незалежних предметів у часі. В процесі реалізації інтеграції зростає темп викладання навчального матеріалу (до 4-6 годин на тиждень), що концентрує увагу учнів та стимулює їх пізнавальну діяльність. Знімається проблема ставлення учнів до «дрібних», «другорядних» предметів, суттєво полегшується система контролю (в тому числі тести, контрольні роботи, заліки та екзамени), оскільки всі розділи інтегрованих курсів рівноправні i однаково значущі. Інтеграція сприяє формуванню наукової картини світу.

Отже, інтеграція споріднених навчальних дисциплін $є$ достатньо перспективним засобом удосконалення навчальних планів і всієї системи освіти.

Іноді проти такого підходу заперечують, виходячи з положення про те, що кожній конкретній науці має відповідати навчальний предмет, що розвязує свої специфічні завдання.

Але ж будь-яка класифікація наук має сенс лише на даному історичному відрізку часу і змінюється в процесі розвитку людського знання. Як слушно зазначив відомий американський фізик, лауреат Нобелівської премії Р.Фейнман, «науки разделены не естественным путем, а лишь из соображений удобства. Природа вовсе не заинтересована в подобном разделении, и многие интересные 
явления лежат именно на стыке разных областей науки» (Цитується за книгою «Фейнмановский лекции по физике». - М., «Мир», 1977. - Т.3. - С.154).

Не випадково, що в результаті виникла низка «прикордонних» наук, про які йшла мова вище. Фізики, спеціалісти в галузі елементарних частинок, астрономи, які вивчають процеси еволюції Всесвіту, працюють спільно в одних інститутах і лабораторіях, використовують одні і ті самі методи і теорії, i розрізнити - хто з них фізик, скажімо, а хто астроном - можна лише заглянувши в їхні дипломи. Також паралельно і спільно працюють фізики, хіміки і біологи, розв'язуючи спільне завдання будови живої речовини, проблему спадковості тощо. Таким чином, інтеграція наук, часто раніше віддалених одна від іншої, стимулює і інтеграцію навчальних предметів.

Отже, немає і не може бути ізоморфної відповідності номенклатури наук і номенклатури навчальних предметів. Наявність тих чи інших предметів у навчальному планові визначається цілями та завданнями цілісної системи освіти, тобто чисто педагогічними міркуваннями. Саме вони настирливо диктують необхідність інтеграції споріднених навчальних предметів з метою оптимізації навчального плану і тим самим - системи освіти і процесу навчання.

Коли ж можлива інтеграція навчальних предметів? На нашу думку, вона передбачає виконання таких умов:

1) під час вивчення суміжних дисциплін розглядаються однакові або достатньо близькі об’ єкти (так звана «об’єктна інтеграція»);

2) під час навчання учнів різним дисциплінам використовуються однакові або близькі методи пізнання (дослідження) («дослідницька інтеграція»);

3) засвоєння знань із загальноосвітніх і спеціальних дисциплін засновано на одних і тих самих теоріях або закономірностях («теоретична інтеграція»);

4) у процесі навчання здобувачів освіти учнів різним предметам і в процесі виробничої підготовки використовуються однакові прийоми діяльності («діяльнісна інтеграція») [220].

Однак, інтеграцію споріднених дисциплін іноді проводять як антиінтеграцію, при цьому один предмет розчиняється в іншому. 
THEORETICAL FOUNDATIONS OF THE FUNCTIONING OF EDUCATION. WAYS TO

IMPROVE THE EFFECTIVENESS OF EDUCATIONAL ACTIVITIES

Треба пам’ятати, що інтеграція навчальних предметів - далеко не механічна діяльність, а інтегрований навчальний предмет не є просто сумою окремих навчальних курсів. Цей процес потребує суттєвої переробки змісту і структури навчальних предметів, посилення у них спільних ідей і теоретичних концепцій.

Як уже зазначалось, теоретична розробка цих проблем розпочалася. Однак практичні працівники закладів освіти, не чекаючи завершення теоретичних пошуків, самі розробляють шляхи і способи вивчення взаємопов'язаних дисциплін на основі споріднення й єдності.

Наші тривалі теоретичні й експериментальні дослідження показали, що запровадження інтегрованих курсів в освітньому процесі відкриває перед здобувачами освіти можливості оволодівати узагальненими, сукупними знаннями, спроможними звільнити їх від однобічного розвитку і прискорити розширення їхнього світогляду.

На завершення цього параграфу сформулюємо деякі висновки:

1. Інтеграція навчальних дисциплін дозволяє уникнути багатопредметності i виключити 3 навчального плану предмети 3 малою кількістю годин, ефективність яких дуже низька.

2. Інтеграція предметів можлива, коли є певні умови: спорідненість наук, відповідно до інтегрованих навчальних предметів, співпадання або близькість об’єкта вивчення, наявність спільних закономірностей і спільних теоретичних концепцій, використання однакових прийомів діяльності.

3. Можливі різні форми інтеграції: повне злиття навчального матеріалу в одному курсі (приклади - хімія та матеріалознавство, фізика та електротехніка тощо); злиття більшої частини навчального матеріалу 3 відокремленням специфічних глав (фізика та астрономія, електротехніка та радіотехніка, електротехніка та спецпредмет тощо); побудова автономних блоків 3 самостійними програмами або розділами загальної програми, самостійними підручниками та методиками. Такі блоки можуть бути розрахованими на певний період навчального року. Ця форма інтеграції, очевидно, буде позитивною для 
THEORETICAL FOUNDATIONS OF THE FUNCTIONING OF EDUCATION. WAYS TO IMPROVE THE EFFECTIVENESS OF EDUCATIONAL ACTIVITIES

таких інтегрованих курсів, як трудове навчання (технології, включаючи креслення), історія та людина і суспільствознавство (включаючи основи правових знань), математика 3 основами інформатики та обчислювальної техніки.

4. Підготовка вчителів у педагогічних 3 ВО має бути адекватною номенклатурі інтегрованих предметів в навчальних планах закладів освіти.

\subsubsection{4. Формування в майбутніх педагогів навичок дослідницької}

\section{діяльності}

У Вінницькому державному педагогічному університеті імені Михайла Коцюбинського впродовж понад 15 років здійснюється підготовка майбутніх педагогів професійного навчання зі спеціальності 015 Професійна освіта (галузь 01 - Освіта/Педагогіка за спеціалізацією «Комп’ютерні технології в навчанні й управлінні», пізніше «Комп’ютерні технології», нині «Цифрові технології». Роль комп'ютерних або цифрових технологій у сучасному суспільстві важко переоцінити. Тому сучасна економічна ситуація в країні, що базується на оновленні економіки, інформатизації суспільства, цифровізації всіх сторін життя кожної людини, передбачає іншу за своїм характером систему професійної освіти, де першочергове місце в підготовці кадрів відіграють запити суспільства, вимоги ринку праці до результатів підготовки відповідних фахівців. Діалог освіти, сфери праці та суспільства закладає основу для підвищення вимог до підготовки педагога професійного навчання, який здатен творчо підходити до розв’язання складних задач навчання, виховання та розвитку кваліфікованих робітників і спеціалістів фахової передвищої освіти в умовах переходу від індустріальної економіки до економіки знань.

Рівень кваліфікації, необхідний для виконання трудових функцій педагога професійного навчання, передбачає одержання відповідної педагогічної освіти і додаткової освіти за допомогою професійних компетенцій. Рівні бакалаврату та магістратури спеціальності «Професійна освіта» (за галузями знань) характеризуються багатовекторним характером підготовки 3 педагогічної та галузевої спрямованості відповідно до галузевого стандарту спеціальності 
THEORETICAL FOUNDATIONS OF THE FUNCTIONING OF EDUCATION. WAYS TO IMPROVE THE EFFECTIVENESS OF EDUCATIONAL ACTIVITIES

(затверджений 21.11.2019 р., наказ МОН України №1460) та Національної рамки кваліфікацій (наказ МОН України №1341 від 23.11.2011 р. зі змінами від 25.06 .2020 р.), що враховують педагогічну та галузеву спрямованість, варіативність освітніх траєкторій здобувачів освіти в залежності від напрямів, профілів підготовки та їхньої базової кваліфікації.

Аналіз довідників нових і перспективних професій, затребуваних на ринкові праці, а також провідних спеціальностей, опублікованих відповідними міністерствами низки європейських країн засвідчив, що лідируючі місця займають інноваційні технологічні фахівці, що задає нові орієнтири в підготовці педагогів професійного навчання (за галузями знань).

Найзатребуванішими нині $є$ не просто висококваліфіковані фахівці за відповідними галузями, а такі, які здатні самостійно орієнтуватися в потоці інформації, котра змінюється, вміють порівнювати, аналізувати, узагальнювати, знаходити найкращі варіанти вирішення проблемних ситуацій у відповідній галузі, а також здатні навчити всьому своїх учнів і студентів. Отже, педагог професійного навчання за дослідницькою діяльністю виконує дві головні функції: дослідницьку функцію спеціаліста галузі та педагогічну функцію навчання дослідницькій діяльності студентів.

Вітчизняними та закордонними науковцями представлені різноманітні погляди 3 питань підготовки здобувачів вищої освіти до дослідницької діяльності, що відображені у відповідних наукових працях. Феномен дослідницької діяльності та визначення шляхів формування навичок у підготовці до неї досліджені в працях Г.Альтшулера, Р.Гуревича Е.Кулика, М.Донченка, П.Лузана, Н.Ничкало, Л.Лукянової, В.Радкевич, О.Микитюка, В.Гриньової, О.Щербак, Т.Щербаня та багатьох інших.

Зацікавленість навчанням дослідницької та науково-технічної діяльності студентів існує досить тривалий час. Ще в XIX ст. німецький педагог Адольф Дістерверг писав: «... без стремління до наукової роботи той, хто навчається, попадає до влади трьох демонів: механічності, рутинності, банальності. Він деревеніє, кам'яніє, опускається» [220, с.151]. У рамках реформи тодішньої 
THEORETICAL FOUNDATIONS OF THE FUNCTIONING OF EDUCATION. WAYS TO IMPROVE THE EFFECTIVENESS OF EDUCATIONAL ACTIVITIES

освітньої системи Вільгельм фон Гумбольдт сформулював принципово нові цілі, такі як «... навчити студентів самостійно мислити, ознайомити їх 3 освітніми принципами та методами наукового дослідження». Звідси випливає, що «без опертя на цей фундамент пізнавальна наукова діяльність не може перетворитися в істинно інтелектуальну освіту й стати плідною для розуму» [220, с.151-152].

Організація науково-дослідної діяльності в зарубіжних країнах реалізується нині в різних формах, скажімо, преміювання студентів, які беруть участь у наукових дослідженнях (Ірландія); створення нового університету «Denmark's Paedagogiske Universitat» для аспірантів, які займаються дослідженнями в галузі освіти (Данія); серйозні інвестиції (12 млн фунтів стерлінгів кожні три роки) для стипендій за кращі практичні дослідження i програми професійно-педагогічного розвитку (Велика Британія); розвиток освітніх закладів професійно-педагогічної підготовки (Скандинавські країни Фінляндія та Швеція); збільшення фінансування наукових досліджень у педагогічній освіті з боку держави (Бельгія та ін). Кількість подібних прикладів можна збільшити. В цілому європейський освітній простір нині характеризується тенденцією зростання кількості студентів, котрі бажають продовжити навчання в аспірантурі та займатися науково-дослідною діяльністю [241].

Подальше підвищення результатів підготовки педагогів професійного навчання до дослідницької діяльності грунтується не лише на оволодінні практичними навичками та знаннями педагогічного змісту. Проблема підготовки має бути спрямованою на активне використання процесів обговорення мислення, дискусії та інших видів дослідницьких дій майбутнього педагога професійного навчання.

Методологія наших досліджень базується на філософських і педагогічних парадигмах, що розвивають сутнісні та змістові характеристики поняття «дослідницька діяльність», а також на ідеях компетентнісного підходу до проблеми формування дослідницьких компетенцій.

Аналіз проблеми підготовки педагога професійного навчання (за галузями) в цілому та виокремлення в ній формування дослідницької функції майбутнього 
THEORETICAL FOUNDATIONS OF THE FUNCTIONING OF EDUCATION. WAYS TO IMPROVE THE EFFECTIVENESS OF EDUCATIONAL ACTIVITIES

педагога професійного навчання демонструє, що дослідницька функція в педагогічній діяльності пов’язана 3 вивченням професійних потреб самих здобувачів, необхідністю побудови педагогічної системи підготовки педагогів професійного навчання, вивченням суперечностей між бажаним та реальним рівнем продуктивності рішень управлінських, педагогічних та освітніх задач професійної діяльності педагога професійного навчання, розглядом факторів продуктивності галузевих дослідницьких матеріалів за всіма навчальними планами, аналізом способів відбору, корекції й удосконалення навчальних матеріалів майбутньої професійної діяльності педагога професійного навчання. Згідно 3 твердженнями знаного педагога в галузі професійної підготовки Н. Кузьміної, дослідницька функція педагога представлена як гностична та включає в себе такі складові: аналіз педагогічних ситуацій; формування педагогічних задач; набуття нових знань; аналіз процесу розв’язування задач i результатів їх вирішення; співставлення поставленого дослідницького завдання 3 реально існуючим [240, с.20].

О.Микитюк відзначає залежність рівня професіоналізму педагога від наявності у нього дослідницької позиції та сформованості дослідницьких умінь [241, с.12]. Педагог може досконало володіти «готовим» матеріалом, що накопичено в педагогічній теорії та практиці, але, якщо ці знання не переплавляються у власному досвіді та не генеруються в «особисте знання», якщо в нього не сформувалася звичка постійного пошуку на основі вже наявних знань свого психолого-педагогічного шляху, йому загрожує небезпека зупинитись у своєму розвитку.

Формування дослідницьких знань, умінь i навичок (компетенцій) випускника є одним із головних результатів засвоєння освітньої (освітньонаукової) програми, що здійснюється комплексно. Педагог професійного навчання одержує особливу системну освіту, що складається 3 трьох інтегрованих компонентів. Це психолого-педагогічна, галузева підготовка i підготовка згідно з робітничою професією. Діяльність педагога професійного 
THEORETICAL FOUNDATIONS OF THE FUNCTIONING OF EDUCATION. WAYS TO

IMPROVE THE EFFECTIVENESS OF EDUCATIONAL ACTIVITIES

навчання є поліфункціональною і передбачає інтеграцію загальнопедагогічних i галузевих знань, вмінь, навичок і компетенцій.

Про формування дослідницьких компетенцій йде мова i в стандартах професійної (професійно-технічної) освіти. Зокрема, про такі: здатність здобувачів освіти оперувати науковими категоріями дослідження; здатність добирати та застосовувати теоретичні і емпіричні методи дослідження; здатність розробляти педагогічні інновації для реалізації основних ідей дослідження; здатність проводити педагогічний експеримент та узагальнювати результати педагогічного дослідження [224].

Одні компетенції формуються через засвоєння кількох елементів освітньої програми, інші - в межах одного, але спеціально побудованого елемента освітньої програми - освітнього модуля (це стосується, в першу чергу, дисциплін професійного циклу). Деякі компетенції, що мають «наскрізний» характер, формуються впродовж усієї освітньої програми через спеціальні освітні технології та види навчальної діяльності. Таким чином, процес формування дослідницьких компетенцій може відбуватися в двох напрямах: поява нових або підвищення рівня вже набутих здобувачами компетенцій того чи іншого виду. Це, в свою чергу, означає, що необхідно встановити рівні формування компетенцій.

Співвідношення професійних стандартів, державних освітніх стандартів і рівнів кваліфікації, згідно з Національною рамкою кваліфікацій, вимагає в процесі вибору змісту підготовки педагога професійного навчання виконання професійних дослідницьких функцій під час виокремлення таких рівнів:

1) низький, що дозволяє випускнику програми (ступеня, модуля) застосовувати дослідницькі знання, вміння та навички під час виконання повсякденної професійної діяльності в своїй галузі;

2) середній, що визначає здатність педагога брати на себе психологопедагогічну відповідальність за підготовку здобувачів до дослідницької діяльності, застосовувати іï під час виконання простих завдань, формувати у здобувачів більш широкі мотиваційні здатності і особисту відповідальність за 
THEORETICAL FOUNDATIONS OF THE FUNCTIONING OF EDUCATION. WAYS TO IMPROVE THE EFFECTIVENESS OF EDUCATIONAL ACTIVITIES

прийняття рішення стосовно того, яким чином може розв’язуватися дослідницьке завдання в різних наукових та технологічних виробництвах;

3) високий, що демонструє педагогічну систему педагога з формування у здобувачів освіти самостійності та відповідальності під час керування діяльністю і в процесі визначення того, яким чином наявні у них компетенції (результати навчання) можуть бути використані в конкретній ситуації. Це передбачає наявність здатності будувати власну стратегію їх застосування не лише в конкретній ситуації, а й упродовж тривалого періоду, а також уміння будувати схеми, що дозволяють оцінювати як реальні, так і майбутні зміни (передбачення, прогнозування тощо).

Так, низький рівень дослідницької компетенції майбутнього педагога професійного навчання можна розглядати як діяльність, що спрямована на задоволення його лише пізнавальних (когнітивних) потреб (галузева підготовка).

Середній рівень дослідницької компетенції майбутнього педагога професійного навчання полягає в орієнтовано-дослідницькій, інтелектуальнотворчій і пізнавальній діяльності (психолого-педагогічна підготовка).

Високий рівень дослідницької компетенції майбутнього педагога професійного навчання, на наш погляд, полягає в розгляді дослідницької діяльності управління підготовкою (менеджмент підготовки).

Дослідницька діяльність студентів $є$ складовою частиною освітнього процесу і науково-технічної творчості, що виконується в позаурочний час. Так, у навчальному процесі здобувачі виконують такі завдання, лабораторні роботи, курсові та дипломні роботи, що містять у собі елементи наукових досліджень; під час педагогічної практики (навчально-ознайомчої, навчально-виробничої) виконують завдання, що носять конкретні, нетипові завдання дослідницького характеру; вивчають теоретичні основи, методику, постановку, організацію та виконання досліджень, планування й організацію та виконання досліджень, планування й організацію наукового експерименту, обробку одержаних даних. Останнім часом значна увага під час навчальних занять приділяється участі в 
THEORETICAL FOUNDATIONS OF THE FUNCTIONING OF EDUCATION. WAYS TO

IMPROVE THE EFFECTIVENESS OF EDUCATIONAL ACTIVITIES

квестах, блогах, блог-квестах, розв'язанні проблемних ситуацій, створенні презентацій, написанні ессе тощо.

Дослідницька діяльність здобувачів освіти, що виконується в позаурочний час, організується у формах роботи в студентських наукових гуртках, проблемних групах, у роботах, передбачених індивідуальними планами науковопедагогічних працівників, докторантів, аспірантів, скажімо, спільне написання статей, розробка комп’ютерних програм тощо.

Крім того, студенти магістратури останнім часом включаються до складу творчих колективів, які виконують наукові дослідження в рамках вітчизняних або міжнародних проєктів, грантів, науково-дослідних робіт за замовленням Міністерства освіти і науки України, інших установ й організацій.

Незмінною $є$ участь майбутніх педагогів професійного навчання за спеціальністю 015 «Професійна освіта» в студентських олімпіадах, конкурсах, студентських наукових доповідей, де вони демонструють свої вміння та навички розв’язувати завдання, складати комп’ютерні програми, писати анотації та реферати з використаної літератури. Невичерпні можливості в цих випадках їм надає Інтернет. За останні три роки студенти спеціальності 015 «Професійна освіта (комп’ютерні технологіï)» тричі посіли призові місця в конкурсі студентських наукових робіт 3 інформаційно-комунікаційних технологій в освіті, з них два - перше, одне - третє.

Останніми роками, в зв’язку 3 поширенням гостровірусної інфекції коронавірусу, пандемією COVID-19, збільшилось число науково-практичних конференцій і вебінарів, у яких беруть участь студенти. Тут вони в режимі онлайн можуть поділитися 3 колегами та викладачами інших закладів вищої освіти результатами своєї роботи, дізнатися про нові дослідження, прослухати вебінари провідних закладів освіти, Інститутів НАПН України і вчених щодо можливостей, котрі надає режим онлайн і змішаний формат навчаня в закладах освіти різних рівнів і типів.

Закордонний досвід (Австрія, Бельгія, Німеччина та інші країни) свідчить, що підготовку майбутніх педагогів професійного навчання в закладах освіти, в 
THEORETICAL FOUNDATIONS OF THE FUNCTIONING OF EDUCATION. WAYS TO

IMPROVE THE EFFECTIVENESS OF EDUCATIONAL ACTIVITIES

тому числі для виконання дослідницьких функцій бажано здійснювати за допомогою дуальної освіти. Дуальна освіта - вид професійної освіти, під час якого практична частина підготовки відбувається на робочому місці, а теоретична частина - на базі освітнього закладу. Система дуальної освіти має передбачати спільне фінансування програм підготовки фахівців під конкретне робоче місце комерційними підприємствами та регіональними органами влади. Траєкторія реалізації дослідницької функції педагога професійного навчання містить такі етапи: навчально-ознайомча практика на робочому місці в закладі професійної (професійно-технічної) освіти (ЗП(ПТО)); теоретичний (у закладі вищої освіти); навчально-виробнича практика в ЗП (ПТО); проєктно-дослідна діяльність у закладі вищої освіти; теоретично-рефлексивний етап в стінах 3ВО.

Напрацьовані впродовж майже 20 років положення щодо підготовки здобувачів освіти до формування навичок дослідницької діяльності успішно використовують на кафедрі інноваційних та інформаційних технологій в освіті. За цей час кафедра, що мала досить бідний науково-педагогічний потенціал, перетворилася в потужний підрозділ, в якому працюють один дійсний член (академік) НАПН України, один дійсний член (академік) НАПН України за сумісництвом, два доктори наук, чотири професори, понад десять кандидатів наук, доцентів. Всі готують зі студентів молодих учених, які переважно опікуються проблемами професійно-технічної освіти. Дослідження проводяться на базі кращих професійних закладів освіти Вінниці і Вінницької області, а також закладів фахової передвищої професійної освіти (ДПТНЗ «Вінницьке міжрегіональне вище професійне училище», Вище професійне училище №11 м.Вінниці, Вище художнє професійно-технічне училище №15 м.Вінниці, технічний і транспортний коледжі), де майбутні педагоги професійного навчання проходять також і педагогічну практику.

Кафедра інноваційних та інформаційних технологій в освіті Вінницького державного педагогічного університету імені Михайла Коцюбинського нині має 100\% викладачів з науковим ступенями та званнями. 
THEORETICAL FOUNDATIONS OF THE FUNCTIONING OF EDUCATION. WAYS TO

IMPROVE THE EFFECTIVENESS OF EDUCATIONAL ACTIVITIES

Випускники-магістри та навчально-допоміжний склад через аспірантуру університету готуються та захищають дисертації на здобуття вищої освіти «доктор філософії» (спеціальність 015 - професійна освіта за галуззю знань «Освіта (педагогічні науки)». Усі наведені факти свідчать про те, що робота 3 формування в майбутніх педагогів професійного навчання навичок дослідницької діяльності має гідні результати.

Не всі проблеми підготовки педагогів професійного навчання вирішені. Ми констатували відсутність узгодженості і наступності освітнього та освітньонаукового стандарту вищої освіти за напрямом «Професійна освіта (за галузями)», відповідно, і основних навчальних програм педагогічного профілю галузевим стандартам (у тому числі Державному стандарту України). Також наявні серйозні суперечності в самому розумінні компетенцій. Ринок праці та представники системи освіти по-різному трактують це поняття. Викладачі говорять про компетенції, розуміючи при цьому потенціал здобувачів освіти, виходячи зі знань, вмінь, навичок, що можна одержати, вивчивши визначені навчальні дисципліни. Ринок праці в особі роботодавців під компетенціями розуміє можливість особи ефективно виконувати професійні функції. Цей підхід заснований на дослідженні й описі поведінки, що сприяє найкращому виконанню роботи і застосовується дослідниками і консультантами, які спеціалізуються в галузі ефективного управління.

Наявні суперечності в підходах до компетенцій в галузі освіти і ринку праці можуть призвести до загрози того, що система вітчизняної освіти збереже відданість пропозиціям студентів, а не набуття ними компетенцій в розумінні практики. Іншими словами, компетентнісний підхід може носити лише формальний характер, що в результаті може посилити дисбаланс між ринками освіти та праці.

Отже, поєднання галузей освіти та праці в діяльності педагога професійного навчання характеризується багаторівневим характером підготовки за педагогічною та галузевою спрямованістю у відповідності до професійних стандартів, що враховують педагогічну та галузеву спрямованість, варіативність 
THEORETICAL FOUNDATIONS OF THE FUNCTIONING OF EDUCATION. WAYS TO

IMPROVE THE EFFECTIVENESS OF EDUCATIONAL ACTIVITIES

освітніх траєкторій, котрі залежать від напряму підготовки, профілю, базової кваліфікації здобувачів. Розроблена система рівнів змісту дослідницьких функцій педагогів професійного навчання (низький, середній, високий) може бути також використана під час планування, організації і контроля за якістю освітнього процесу.

\subsubsection{5. Вплив цифровізації суспільства на розвиток сучасної освіти}

У середині ХХ століття не існувало концепції так званого онлайн-навчання й про цифровізацію навчання не було й мови. В той час у всьому світі був розповсюджений традиційний спосіб навчання, коли учні та студенти, ходять в конкретні установи (школи, коледжі, заклади вищої освіти) й одержують знання від своїх педагогів. Останні, до речі, працювали також як соціальні працівники, й вони не лише навчали здобувачів освіти, а й здійснювали виховну і соціальну роботу для більш якісної підготовки до викликів того часу.

Нині, як і на інші галузі, на освітній сегмент серйозно вплинула пандемія коронавірусу. За даними ЮНЕСКО, в березні 2020 р. в 165 країнах світу були закриті заклади освіти, в результаті чого постраждало понад 1,5 млрд дітей i молоді. До цих пір є значна невизначеність відносно того, коли навчальні заклади будуть знову працювати в звичайному режимі. На щастя, нині $є$ множина безкоштовних і простих у використанні інструментів цифрового зв’язку, що дозволяють використовувати різноманітні рішення для дистанційної освіти.

Сучасні науковці стверджують, що цифровізація стосується всіх галузей економіки i ті, хто переконаний, що консервативної сфери освіти вона не торкнеться, глибоко помиляються. Багато педагогів у той самий час до цих пір уважають, що цифровізація не більше, ніж чергова «модна тема», що пройде, тоді як «вічні цінності» освіти як самого стабільного суспільного інституту залишаться минулими. Зокрема, це пов’язане з тим, що цифрова епоха потребує не лише нових умінь від випускників шкіл і закладів вищої освіти, а й іншого підходу до організації самого навчання.

Мета цього параграфу полягає у дослідженні впливу цифровізації суспільства на розвиток сучасної освіти. 
THEORETICAL FOUNDATIONS OF THE FUNCTIONING OF EDUCATION. WAYS TO

IMPROVE THE EFFECTIVENESS OF EDUCATIONAL ACTIVITIES

Суть цифрової трансформації навчання в тому, щоб ефективно та гнучко використовувати новітні технології для переходу до персоналізованого й орієнтованого на результат освітнього процесу. Відомо, що цифровізація - це один із способів зробити освіту однаково якісною для всіх. 3 «цифрою» легше та швидше сформувати персоналізований підхід до здобувачів освіти, легше впровадити диференційоване навчання, що враховує потреби кожного.

Цифровізація освіти впродовж останніх десяти років сприймалася як привабливе, але ризиковане майбутнє, що вже є подекути справжнім; але це майбутнє, здавалося, все ще можна пригальмувати і відкласти на завтра. Навіть Масові Відкриті Освітні Курси (МВОК), так звана революція, створена платформою Coursera, сприймалася як глобальний експеримент, що в різних формах і 3 різними результатами відтворювався окремими країнами та університетами, але не став повсюдною практикою. Цифрова онлайн-освіта розглядалася як важлива і в цілому прогресивна форма навчання, що, тим не менш, лише доповнює і оживляє аналогові формати. Загроза пандемії COVID-19 стала перевіркою на міцність усієї системи освіти. Перехід до дистанційних форм навчання виявився раптовим і вимушеним для всіх рівнів освіти і для всіх учасників освітнього процесу незалежно від ступеня їхньої технічної готовності, рівня цифрової грамотності та бажання. Якщо говорити мовою методології соціологічних досліджень, весь світ перебуває нині в ситуації одного 3 наймасштабніших в історії квазіекспериментів щодо різкої трансформації умов праці і зайнятості, в тому числі і в системі освіти.

Для розуміння готовності системи освіти до переходу на дистанційні рейки навчання необхідні знання про те, наскільки ця система була готова до таких змін.

Ми в дистанційному режимі хотіли зафіксувати і проаналізувати проникнення цифрових технологій у процес навчання студентів і обговорили різні аспекти цифровізації освіти з понад 60 викладачами і адміністраторами провідних українських 3ВО, коли ніщо ще не віщувало цифрової бурі на ринку праці і у вищій освіті. Отже, вже тоді було зібрано унікальний масив первинних даних, що 
THEORETICAL FOUNDATIONS OF THE FUNCTIONING OF EDUCATION. WAYS TO

IMPROVE THE EFFECTIVENESS OF EDUCATIONAL ACTIVITIES

дозволило зафіксувати ставлення українських педагогів до цифровізації навчання напередодні форсмажорних обставин переходу до нього, що дало розуміння ступеня готовності, очікувань і ризиків розвитку освіти в Україні.

Використання цифрових технологій нині стало невідємною частиною сучасної освіти, і вивчення цього процесу викликає все більший інтерес у академічної спільноти, і практиків, і управлінців. Рідкісний захід, присвячений питанням викладання в ЗВО, до прикладу, залишає цю тему неохопленою.

За всіх сильних і слабких сторонах цифрових освітніх технологій $99 \%$ викладачів, опитаних Міжнародною асоціацією університетів, визнають їх необхідними для поліпшення якості вищої освіти. Нові технологічні явища, скажімо, машинне навчання, штучний інтелект, блокчейн, чат-боти, великі бази даних та ін. на порозі пандемії оцінювалися представниками академічної спільноти як драйвери змін на краще, хоча кожний четвертий визнавав, що ЗВО не зовсім підготовлені до такого майбутнього, а 39\% опитаних готові до нього лише деякою мірою.

Як і будь-які інші новації, цифрові технології стикаються з низкою бар'єрів на шляху активного впровадження в освітній процес. У емпіричних дослідженнях установлені деякі чинники, що сприяють прийняттю і використанню викладачами у своїй педагогічній діяльності цих технологій. Це:

1) чинники, пов'язані з самою цифровою технологією (унікальність та інноваційність, надійність, корисність і простота, спрощення розумових процесів і планування, забезпечення економії часу);

2) чинники, пов'язані з організацією застосування цифрових технологій (підтримка з боку ЗВО і достатня обізнаність його керівництва в питаннях політики щодо використання цих технологій, застосування їх колегами, технічна підтримка, повноцінні програми навчання роботі 3 інформаційнокомунікаційними засобами);

3) чинники, пов'язані з самими викладачами, які впроваджують цифрові технології (вміння використовувати ресурси і легкість їх освоєння, віра в 
THEORETICAL FOUNDATIONS OF THE FUNCTIONING OF EDUCATION. WAYS TO

IMPROVE THE EFFECTIVENESS OF EDUCATIONAL ACTIVITIES

поліпшення якості навчання, відповідність технології тієї філософії викладання, якою володіє цей педагог).

Сучасні науковці, зокрема А. Мюльдер [241] приділяють особливу увагу значенню цифровізації для майбутнього університету як спільноти, котра часто дискутує про вищу освіту. Він бачить можливу перевагу університету в конкурентній гонці за бажаючими навчатися в соціальному просторі, що пропонує такий ЗВО. Адже університет - це не тільки місце, куди студенти приходять для оволодіння професією, а й місце, де вони заводять друзів, формують соціальні мережі і навіть знаходять майбутніх партнерів. До цього можна додати, що і саме знання акумулюється не лише в аудиторіях, а й у особистій взаємодії між здобувачами освіти, викладачами i дослідниками у позанавчальний час. Цифровізація радикально змінила уявлення про спільність завдяки соціальним мережам, проте А.Мюльдер закликає бачити в цій тенденції не загрозу для університету, а можливість згуртувати студентів, об'єднати за схожими академічними інтересами, налагодити зв'язок між випускниками і працедавцями, а також знайти для студентів, які зазнають труднощі з проходженням курсу, осіб, готових їм допомогти.

Упродовж історії свого існування університети розглядаються переважно як інтелектуальні середовища і спільноти вчених, а не як робочі місця. Викладачі університетів більше наголошували на своїй високій місії, ніж говорили про працю, про себе як про громадян науки, а не як про найманих працівників. Нині університети стають всі більш цифровізованими і віртуалізованими, що істотно впливає на академічну працю, перш за все, в силу розмивання особистого i робочого персонального просторів і часу, зростання технологізованого контролю над академічною працею. Крім того, масовізація вищої освіти, неоліберальний поворот у соціальній політиці і революція медіатехнологій зрушили системи управління сучасною вищою освітою в сторону нових моделей з їх прагненням до зниження витрат i гонкою за гнучкістю i можливостями персоніфікувати контроль. Можна сказати, що кількісне зростання використання нових освітніх технологій привело до нової реальності «цифрового університету». При цьому 
THEORETICAL FOUNDATIONS OF THE FUNCTIONING OF EDUCATION. WAYS TO

IMPROVE THE EFFECTIVENESS OF EDUCATIONAL ACTIVITIES

відбувається взаємопроникнення аналогових освітніх технологій і технологій цифрових: другі повністю не витискують перші, а перші - вже не можуть існувати незалежно одна від іншої.

Ключові проблеми розвитку та впровадження цифрових, інформаційнокомунікаційних технологій навчання розроблені українськими вченими (В.Биков, А.Гуржій, Р.Гуревич, М.Жалдак, В.Заболотний, Л.Лупаренко, В.Осадчий, О.Пінчук, Ю.Триус, А.Яцишин та ін.). Серед таких проблем науковці називають:

- розвиток штучного інтелекту, «машинне навчання», нейромережі;

- забезпечення мобільності ІКТ-діяльності користувачів у мобільному просторі, подальший розвиток мобільно орієнтованих засобів і ІКТ доступу, до електронних даних;

- широке запровадження технологій блокчейн, чат-бот і криптовалют;

- розвиток технології хмарних обчислень та віртуалізації, корпоративних, загальнодоступних і гібридних IКТ інфраструктур, а також запровадження технологій хмарних обчислень;

- розвиток телемедицини;

- розроблення нових функцій доповненої реальності і доступність обладнання для віртуальної реальності;

- широке запровадження чат-ботів і віртуальних помічників накопичення та опрацювання значних обсягів цифрових даних, формування та використання електронних інформаційних баз і систем, зокрема, електронних бібліотек і наукометричних баз даних.

Перелік таких проблем можна продовжити.

Результати наявних досліджень про вплив цифрових технологій на навчання неоднозначні. В цілому, певні чинники, скажімо викладачі, попередні знання або новизна конкретного цифрового середовища, надають більший вплив на результати навчання, ніж використання цифрових технологій як таких. Однією 3 причин висновків про вплив цифрових медіа в аналогічних дослідженнях може бути те, що вони дуже неоднорідні щодо вимірів і застосовуваних ними 
THEORETICAL FOUNDATIONS OF THE FUNCTIONING OF EDUCATION. WAYS TO

IMPROVE THE EFFECTIVENESS OF EDUCATIONAL ACTIVITIES

параметрів навчання. Тому в таких дослідженнях узагальнені загальні вимірювання змінних, що відображають результати навчання в наявних емпіричних дослідженнях. Це сприяє знаходженню спільної мови між дослідниками для опису ефективності шляхом загального розуміння різноманітних результатів навчання. Конкретна теоретична точка зору, котру дослідники і практики застосовують для навчання 3 використанням цифрових засобів масової інформації, може вплинути на те, як вони проєктують освітні онлайн-середовища, як вони використовують відповідні змінні і як вони вимірюють результати навчання.

Досвід свідчить, що у цифровій освіті здобувачі рідко відвідують освітні установи і всю роботу виконують вдома. Педагоги також дають їм завдання, що розв'язуються достатньо легко і відправляються через різні додатки або електронною поштою. Зараз онлайн-навчання поширюється всім світом і дає здобувачам освіти ще один сучасний досвід навчання за допомогою мобільних телефонів і комп’ютерів.

Методи навчання у вищій освіті за останні 20 років сильно змінилися. В той час, як одні освітні установи все ще залишаються прихильниками старої і традиційної освіти, інші установи використовують різні сучасні технології та сучасне системне обладнання. Також інформаційні технології неймовірно розширили змістову ресурсну базу даних. Тепер не потрібно ходити в шкільну університетську або міську бібліотеку, оскільки є такі пошукові системи, як Google, величезні цифрові енциклопедії, як Wikipedia, платформи відеоуроків i інструкціï, як Zoom, Google meet, Skipe, YouTube та ін. Студенти також можуть навчатися за допомогою цих джерел, і немає суттєвої необхідності відвідувати заклади вищої освіти. Онлайн-освіта створила безліч нових курсів і відкрила доступ до університетів дистанційно, тому частина студентів, скажімо за кордоном, до прикладу в Німеччині, зареєструвалися в академічних установах тільки через такі курси. 
Розробляються нові методи навчання, а місце традиційної освіти займають цифрові комунікації та інформаційні технології. Така величезна різноманітність нової інформації і технологій збільшила доступність освіти для решти світу.

Цифрові технології вносять багато змін у систему освіти. Вони допомагають вчителям і викладачам скоротити паперову роботу, всі вправи і звіти здобувачів освіти переносяться на комп’ютери, ноутбуки, і в цифровому світі не потрібні друковані копії, а всі роботи і оцінки завжди можуть бути надані в друкованому вигляді за запитом. Ці технології дозволили студентам працювати у віртуальних групах, де вони обговорюють свої проєкти з колегами за допомогою багатьох додатків, таких як Google Classroom, Zoom, Google Meet i т. д. На думку деяких учених, згодом може відпасти необхідність проводити лекції в офлайн режимі. Форма цифрового формату поліпшить онлайн-лекції, і кожний студент одержить свої матеріали з Інтернету.

В умовах загальнонаціональних заходів самоізоляції школи і університети залежать від методів онлайн-навчання, щоб забезпечити неперервність освіти. Багато закладів освіти використовують наявні програми, проводять заняття через Google Hangouts або Zoom, а також відправляють інтерактивні робочі листи i відеоуроки для навчання.

Цифрові освітні системи вносять гідний вклад у навчання. Серед адміністрацій соціальних мереж Facebook нині $\epsilon$ найвідомішими завдяки тематичному спілкуванню зі знайомими $\mathrm{i}$ незнайомими людьми. Вплив використання Facebook на студентів дуже ефективний. Машинне навчання змушує студентів знаходити корисні дані для вирішення проблеми. Онлайннапрями в соціальних мережах залучають велику кількість учасників i використовуються як методи для самих різноманітних заходів.

Цифрова освіта вже поширюється через соціальні мережі. Процедури цифрового навчання - це нові методи, що демонструють використання інновацій з метою поліпшення характеру освіти і залучення учнів до процедури навчання. $€$ значна кількість цифрових технологій, включаючи проблемне навчання, проєктне 
THEORETICAL FOUNDATIONS OF THE FUNCTIONING OF EDUCATION. WAYS TO IMPROVE THE EFFECTIVENESS OF EDUCATIONAL ACTIVITIES

навчання, цифрові історії, онлайн середовища навчання, інтегровані в технології стратегії навчання, розвивальні ігри та автентичне навчання.

Хоча нині інтернет-навчання $\epsilon$ найбільш сприятливим механізмом здійснення освітньої діяльності, в зв’язку 3 тимчасовим припиненням функціонування традиційних освітніх установ, воно висвітлило деяку нерівність у системі освіти. Певна частина здобувачів освіти не вчиться. Деякі заклади освіти використовують найпростіші інтернет-додатки на зразок Viber, WhatsApp i електронну пошту для зв’язків зі здобувачами освіти.

На що треба звернути увагу в умовах самоізоляції:

1) здоров'я викладачів, студентів і учнів. Необхідно розуміти, що проста заміна контактних годин онлайн-лекціями і семінарами може позначитися на здоров'ї учасників освітнього процесу, якщо не буде балансу активної діяльності і діяльності в мережі Інтернет.

2) емоційне здоров'я учасників освітнього процесу. Новини про поширення i вплив коронавірусу, захворювання, смерті людей можуть бути тривожним i дезорієнтуючим фактором для учасників освітнього процесу.

3) доступ до пристроїв. Здобувачі освіти частіше мають доступ до смартфонів, ніж до ноутбуків. У зв'язку з цим є суттєва різниця в можливостях серед студентів або учнів: хтось може повноцінно користуватися всім функціоналом онлайн-платформ, а хтось - бути лише спостерігачем і слухачем.

Очевидно, що необхідно шукати рішення і альтернативні ресурси для подолання такої нерівності на рівні держави.

4) управління доступом до IT-інфраструктури. В деяких місцях може виникнути проблема одночасного підключення всіх учнів або студентів, і варто також контролювати доступ до IT-інфраструктури, щоб забезпечити гарний доступ для всіх. Ця проблема актуальна для українського простору, де багато важкодоступних і віддалених населених пунктів, що не мають мережних комунікацій.

Підводячи підсумки, наголосимо, що цифровізація освіти - процес настільки необхідний, як і неминучий. Але при переході до цифрового навчання 
THEORETICAL FOUNDATIONS OF THE FUNCTIONING OF EDUCATION. WAYS TO

IMPROVE THE EFFECTIVENESS OF EDUCATIONAL ACTIVITIES

дуже важливо зберегти наявне «аналогове» багатство, що складає фундамент класичної системи освіти. Випускникам освітніх закладів у подальшому знадобляться не лише цифрові компетенції, а й фундаментальні знання та навички критичного мислення, оскільки в житті не все буде «онлайн».

Що стосується подальших досліджень у цій сфері, то зусилля варто спрямовувати на таке:

1. Створення, тестування та впровадження навчально-методичних матеріалів із застосуванням технологій машинного навчання, штучного інтелекту та ін.

2. Розвиток онлайн-навчання. Поступова відмова від паперових носіїв інформації.

3. Розроблення нових систем управління навчанням $(\mathrm{CУH})$. У дистанційній освіті СУН - це програми щодо адміністрування та контролю за навчальними курсами. Такі додатки забезпечують рівний i вільний доступ здобувачів освіти до знань, а також гнучкість навчання.

4. Обов'язкове підвищення ключових компетенцій і компетентності педагогів у сфері цифрових технологій.

Усе вище висловлене дає можливість безумовно стверджувати, що цифровізація як сучасний феномен у розвитку суспільства здійснює суттєвий вплив на педагогічні аспекти традиційної освіти. 


\subsection{English as a lingua franca in business contexts: teaching language strategies}

The English language is growing, and its dominance has been demonstrated in social and commercial communications as well as academics in the entire globe. A concise indicator of this is the international periodical publications in the 1990s, more than $75 \%$ and $90 \%$ respectively of social and natural science were published in English while $98 \%$ and $83 \%$ were published in German. Currently, Chemistry and Physics disciplines are using English as their working language. Regarding business, English is gaining dominance since almost $85 \%$ of international organizations use English as their official language. Moreover, regions such as Asia and Pacific conduct approximately $90 \%$ of their proceedings in English. Internationally, English is used as the default language in international e-commerce. Globally, the English language is used by $1 / 3$ of the total number of online users' i.e. 536 million out of 1.7 billion users. As a result, almost $91 \%$ employers in international companies reported that English is highly relevant to their performance. $89 \%$ of the employees said that they would prefer employing employees who are in a better position in communicating English up to certain levels. Despite the controversy and the criticism that has come as a result of English dominance over other languages, it is much clear that English is the most common and widely shared language in international relations and it is not likely to be replaced by any other language soon.

Nowadays many linguists believe that English is the fastest spreading language in human history because of technology and media. So the scale and scope and rapidity with which English is spreading is unprecedented and staggering.

The market for English Language Teaching (ELT) might seem reasonably mature and competitive. Most people speaking English today are not communicating with native English speakers from the USA, the UK or Australia. They are communicating with other non-native English speakers.

The 'average' English speaker in 2016 is someone from Tokyo pitching to someone in Beijing. Or someone in Sao Paulo doing business with someone in Warsaw. In fact, a pivotal study into 'Business English as a lingua franca' (BELF) 
concluded that English is now perceived as a neutral, equal alternative as it is usually neither party's mother tongue. In short, it is no longer 'owned' by any specific nation.

English has not become the global 'lingua franca' as a result of colonialism or soft power initiatives. It has been chosen by billions of people around the globe as the most effective and established method of communicating across borders. It has been coopted as the language of ambition, of personal advancement and career progression.

Many organizations, and governments, have already recognized, that there is a clear correlation between mobility, affluence, innovation and English proficiency.

Organizations that effectively marry language strategy with their global talent management process gain a leg up on the competition, say HBR's Tsedal Neeley and Robert Steven Kaplan.

As a result, companies are beginning to accept that they need more than just education and learning programs; they need a 'Strategy for Language' that is separate from other aspects of the educational agenda. And that strategy, more often than not, has English as a central component.

Anne Kankaanranta and Leena Louhiala-Salminen, from the Aalto University School of Business in Finland, have proposed a model called Global Communicative Competence (see figure below) as a framework for language strategy. This framework consists of three layers: multicultural competence, competence in English as a Business Lingua Franca and the communicator's business 'know how.'

Methods of teaching BELF, according to this framework, would assume a shared "core" of the English language, but focus as well on interactional skills, rapport building, and the ability to ask for and provide clarifications. Crucially, this means that ALL employees, including native English speakers, would need to participate in order for it to be a success. So, it is enlighten in figure 1 . 


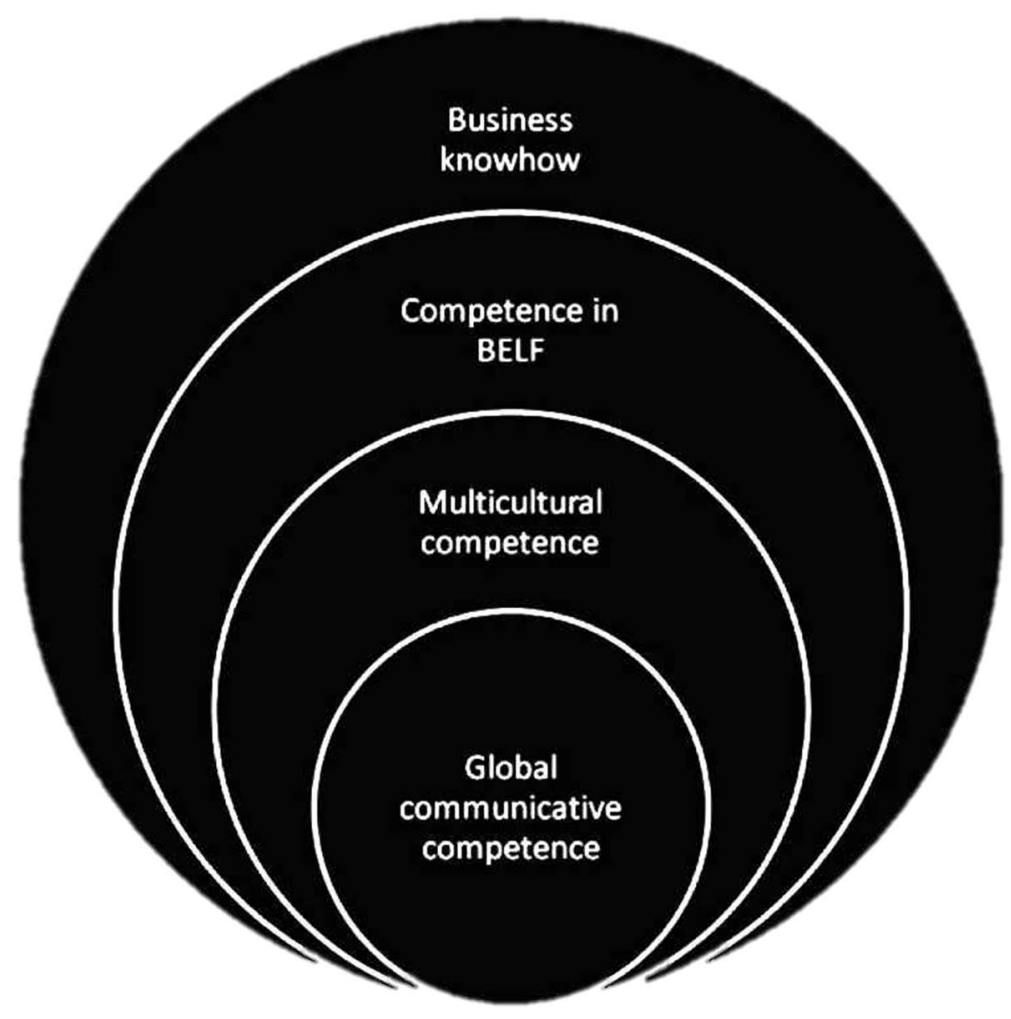

Figure 1. Methods of teaching BELF

As an initiative designed to confer competitive advantage at the organizational level, BELF is most effective when championed by the CEO. The most celebrated example is Hiroshi Mikitani, the CEO of Japanese retail giant Rakuten. He has been an outspoken evangelist for the adoption of BELF internally, often in the face of outrage and condemnation from the business community elsewhere in Japan.

Why have companies chosen to adopt BELF?

When two individuals with different native-tongues meet, there is a need for a shared language of some form to make discourse possible. Individual interpreters can be employed at the most senior levels in business and government but this is not a scaleable solution for large groups or organizations.

International initiatives to establish a lingua franca by mandate (either an existing language or an invented one such as Esperanto) have been resisted for reasons of sovereignty and a desire to preserve cultural independence. Recent adoption of 
BELF, on the other hand, has been 'bottom up': less about individual mandate and more an acknowledgement of established practices on the ground.

\section{Tsedal Neeley lists 3 overarching needs behind adoption of BELF:}

Pressure from competitors - Multinational companies need to interact with clients, suppliers and business partners, and those that ignore the need for a language strategy "are essentially limiting their growth opportunities to the markets where their language is spoken." This, in turn, gives their competitors an edge.

Globalization of resources - Neeley references the term "Tower of Babel" to illustrate what can happen if an employee in France needs input from a colleague in Brazil. "Better language comprehension gives employees more firsthand information, which is vital to good decision-making."

International mergers \& acquisitions - Mergers or acquisitions get increasingly more complicated if there's a language barrier; "nuances are easily lost, even in simple email exchanges." Neeley also notes that English made things easier for Hoechst's and Rhône-Poulenc's 1998 merger. Newly formed Aventis' choice of English, rather than one of the new company's two native tongues, helped it to "avoid playing favorites."

Rakuten's Hiroshi Mikitani has written extensively about his rationale for adopting BELF. The reasons he has highlighted are:

Talent - a lack of English proficiency limits Japanese companies from pursuing global talent and retaining non-Japanese staff.

Knowledge ecosystem - Mikitani uses this term to refer to the ease with which employees can exchange information, skills and know-how to better engage with customers, clients and business partners outside Japan. A lingua franca underpins this capability.

Time - A lot of time is saved when everyone in a company worldwide can communicate quickly, easily, without the need for translation. The need for this grows every day as the speed of business accelerates.

Cost saving - translation is a big cost for Japanese companies. A lingua franca would reduce this cost substantially over time. 
Innovation - language barriers hinder innovation, a lingua franca facilitates it. Not just in terms of direct communication but in terms of people's awareness of different cultural approaches and ideas. "English is not just a practical way of doing business, but involves a turn outward to search for new ways of thinking about doing business."

Additional reasons include:

Contracts - contracts between companies that do not share a common language are, more often than not, drafted in English. Furthermore, international tenders require applicants to submit their offer in English or to submit an English version.

What are the shortcomings of BELF?

There are many, although they are mainly issues of execution. Mikitani believes strongly that 'English-nisation' has been a success at Rakuten but acknowledges that the implementation was too severe and employees, at first, were not given adequate support.

Tsedal Neeley believes the decision to adopt a lingua franca must be balanced with the need to speak local languages and adapt to local cultures. Decision makers often mistake language skills for business experience and domain expertise so must be cautious about how they hire and promote staff.

What do companies need to support BELF programs?

Traditional teaching methods and technologies have failed to keep up with the specific application of English within the corporate environment and the need of BELF programs.

There exists a large and growing opportunity to meet the need the corporate market has for new products and services that support internal change management programs aimed at establishing BELF.

These products need to recognize and cater to senior managers and business leaders, many who already possess a solid grasp of the basics of English, but have little experience of 'business communication' or the skills to convey issues of strategy or organizational culture effectively.

A comparison of how the two outlooks differ is summarized in the table below. 
Table 1. The results of language strategies

\begin{tabular}{lll}
\hline Criterion & EFL & BELF \\
\hline $\begin{array}{l}\text { Successful interactions } \\
\text { require }\end{array}$ & NS-like language skills & $\begin{array}{l}\text { business communication skills and } \\
\text { strategic skills }\end{array}$ \\
$\begin{array}{l}\text { The speaker/writer aims to } \\
\text { NNSs are seen as }\end{array}$ & $\begin{array}{l}\text { emulate NS discourse } \\
\text { get the job done \& create rapport }\end{array}$ \\
Main source of problems & inadequate language skills & $\begin{array}{l}\text { inadequate business } \\
\text { communication skills }\end{array}$ \\
"Culture" & national cultures of NSs & $\begin{array}{l}\text { business community cultures and } \\
\text { individual cultural backgrounds }\end{array}$ \\
& & nobody - and everybody \\
\hline
\end{tabular}

There is also an even greater number of companies who do not have a language strategy. In these organizations, uncontrolled multilingualism tends to lead to a chaotic and inefficient work environment. They present an opportunity to raise awareness of the need for BELF or to at least understand the rationale for its non-adoption.

BELF, as distinct from EFL (English as a foreign language) requires new pedagogical methods and tools. These methods need to take into account the specific requirements of BELF and move away from the purist dogma of 'traditional' EFL.

It has been observed that there is a very real danger that native English speakers, especially those who never mastered another language, risk missing out on business opportunities - whether in the form of contracts, idea development, job opportunities and the like - due to a basic lack of understanding of what international English communication entails. What makes BELF so appealing is that everyone needs to learn it, including 'native' English speakers, meaning the addressable market is significantly larger than has been assumed. All users of BELF need to take time to understand the specific nuances and techniques necessary to communicate effectively across borders. 
DOI 10.46299/ISG.2021.MONO.PED.II-261-267

\subsection{Problems and prospects of online education in higher educational institutions}

Distance learning involves the interaction of real subjects of education in a virtual environment using special means of communication. The specificity of the interaction environment and the peculiarities of the organization of educational information in the absence of direct contact between the student and the teacher determine the psychological and pedagogical features of distance learning.

This theme is very topical nowadays. And many scientists have already studied the topic: Berg, Gary, Stygalov Yu. M., Bayeva L. V. and many more. It brought lot's of challenges and opportunities. It proved to be ineffective when trying to apply the offline means of teaching to on-line education. Our goal is to derive the best and most productive ways of education.

Educational process is very versatile and thus needs to be seen from different positions:

1. Lecture;

2. Seminar;

3. Practise;

We can define some of the common disadvantages, brought by distance learning, and the main and most harmful is, of course, deprival of psychological connection between the teacher and the student, because of transparent wall of internet connection. Contingently we call it "a phone conversation" factor.

"A phone conversation" factor's idea lies upon the fact that people feel it easy to refuse when speaking on the phone rather than in private face to face conversation. It happens because of different perception.

When speaking about distance learning, we should take into account that it goes not only about technical means of rendering information. As the whole learning process is NOT about simply delivering some processed the most useful information. For this purpose we could use videos or audios. It goes, above of all, about perception. 
And the perception of material by the students, provided by a lecturer depends on how students perceive the lecturer. Because, the degree of a student's involvement into educational process depends on the authority of the teacher.

Though, "in many respects, the creation of electronic culture is a new type of creativity, it cannot be attributed only to the material or spiritual sphere, since it has features of both. Having created a "second nature" - the world of things, man, in fact, gave birth to a third nature - the world of virtual phenomena, which is a kind of synthesis of the world of consciousness and modern high information technologies. Just as the invention of the microscope or telescope opened up new worlds for researchers, the invention of IT technologies opened up a new life world for users, in which the problems of space, time, language, human restrictions on social status and physical parameters were largely removed" as states Bayeva Liudmila Vladimirovna.[253] The statement to our opinion is a very controversial one or at list to fold. The authority of the teacher is vitally important for learning process. As it involves such needed factors as: inspiration and aspiration. Which are largely ensue from the factor of authority.

The forced work of universities remotely in the context of the pandemic (COVID-19) has generated a lot of discussion about the benefits of the new form of education. The first results were summed up and reports were presented, the materials of which showed that the main goal of online education - the prevention of the spread of infection, - has been achieved. Against this background, proposals and publications have appeared substantiating the effectiveness of the massive introduction of distance learning, including in higher education. However, the assessment of such training by the population and students in publications and in social networks was predominantly negative and showed that the number of emerging problems exceeds the possible benefits of the new educational technology. Based on the analysis of the materials of publications and personal experience of teaching online, the potential benefits and problems of distance learning in higher education are considered. It is proposed to consider the effects separately for the suppliers of new technology (government, universities) and consumers (students, teachers, society). It is substantiated that the 
massive introduction of online education allows not only to reduce the negative consequences of epidemics, but also to reduce budgetary funding for universities, optimize the age composition of teachers, and reduce the cost of maintaining educational buildings. However, there will be a leveling / averaging of the quality of education, and responsibility for the quality of training will shift from the state/universities to students. The critical shortcomings of online education are the low degree of readiness of the digital infrastructure, the lack of a mechanism for identifying and monitoring the work of students, information security problems, and the lack of trust in such training of the population. The massive use of online education creates a number of risks for the country, the most critical of which is the destruction of the higher education system and a drop in the effectiveness of personnel training. The consequences of this risk realization are not compensated by any possible budget savings [254].

We can never underestimate the real need in increasing the literacy of population all over the globe, but to our opinion the most vicious thing that is about to happen is the dramatic downturn in the level of education if the approaches for distant education (that not deliberately turned out to be the today's reality for many teachers and students) will remain just the same.

According to the "livejournal" internet source the results of the poll shows that majority of people are against distant education and are for live communication in class education. The results of the poll, where 526 people were questioned about their attitude towards distant education, proved to be negative and are depicted in the figure № 1. given bellow. 


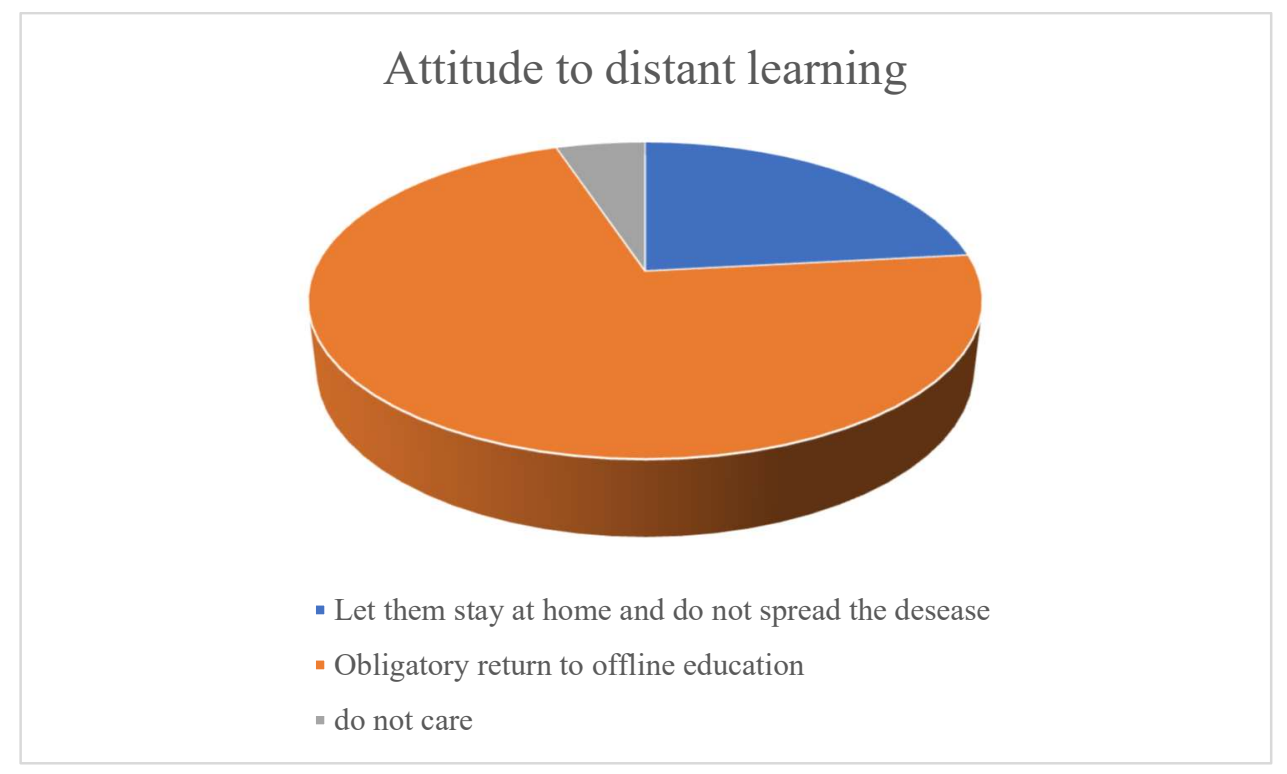

Figure 1. Attitude to distant learning.

$23,38 \%$ consider that distant education is acceptable under pandemic conditions. $71,86 \%$ think it is of vital importance to get back to normal in class education. $5,13 \%$ stayed indifferent.[258]

In accordance with another source, where 5000 people were asked, the results are approximately the same.

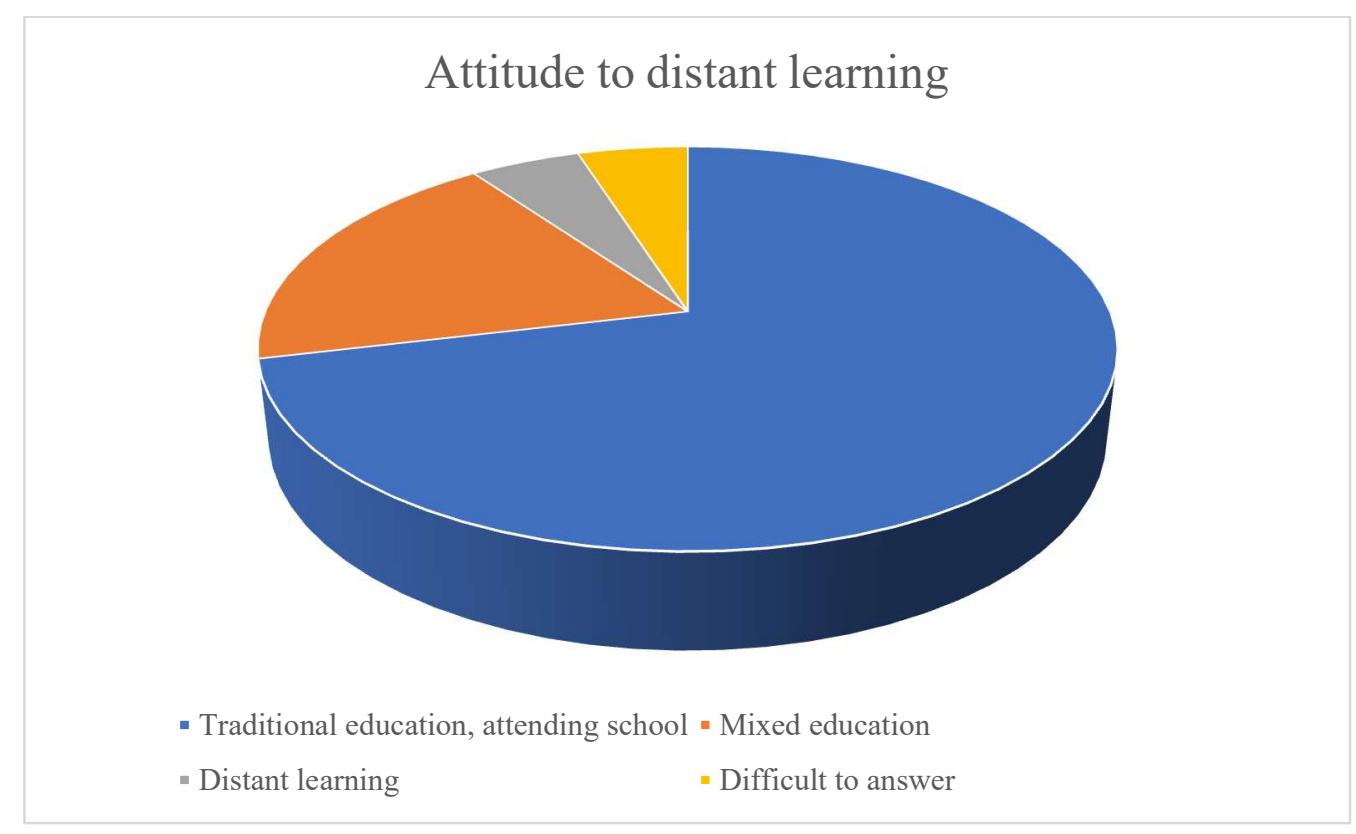

Figure 2. Attitude to distant learning.

Taking into account the data obtained within this poll we can conclude, that there is a clear understanding that traditional education is irreplaceable. 
$72 \%$ of people, who took part in the poll are sharply against distant learning. $19 \%$ consider it to be possible to accept mixed version of education. $5 \%$ have nothing against distant learning. 5\% consider it to be difficult to answer. [259]

The approaches that work for offline education (at least not all of them) are suitable and efficient for a distant form of education, to say nothing of those obsolete methods still used in the study rooms as those that are considered to belong to classical or old school methods. And the most ridiculous thing about what is happening in one of the most important spheres of human beings`activity is when advances technologies are being tried to be drown onto those methods to represent the ensuing transformation as a new and effective way of education. But the matter of fact is that the result of described above actions is some kind of disability.

We cannot escape mentioning some sort of discrimination that occurs against those participants of educational process, who simply do not possess corresponding equipment that would meet the requirement and be able to eliminate lags and going downs of the system.

According to the statistics given in electronic source "The correspondent" $68 \%$ of questioned people consider themselves to be poor. [259]

We cannot omit mentioning that education is not simply a process, but first of all, the process aimed to obtain measured results. So, if would be totally hypocritic to talk exclusively how convenient or inconvenient, affordable or difficult to afford this or that type of learning is. What is the most important and worth discussing is the result of common work for both the ones, who deliver education to students and from student.

In this respect we would like to present you another statistical data obtained by In accordance with the results of the polls, conducted by this source, where 5000 people were asked $66 \%$ people think the results of education worsened, and the knowledge obtained by students are poor; $18 \%$ think, that there in no difference in result between distant and off-line learning; 8\% HOPE for improvement. "Hope" is the key word that depicts how ridiculous is the situation, where for every participant of this process it is obvious that distant learning proved to be invalid.

Schematically you can see the result in the figure №3 bellow: 


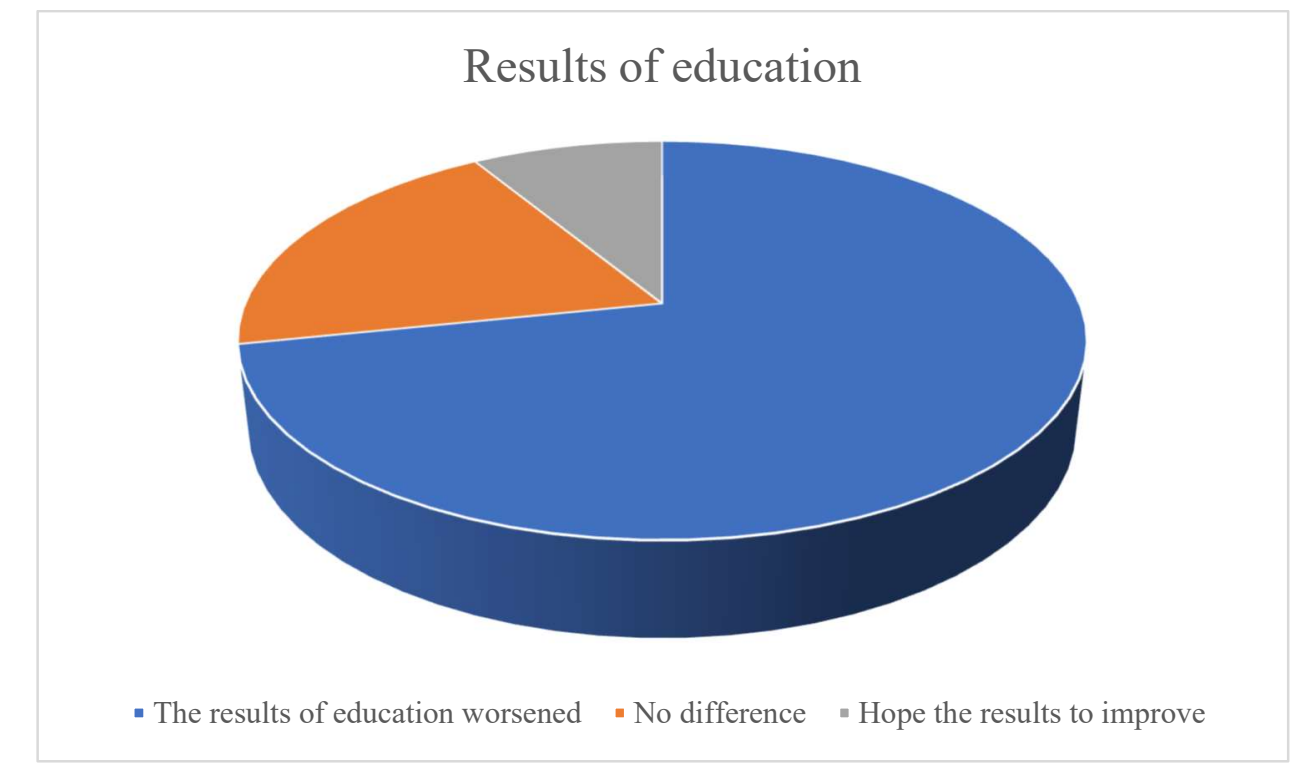

Figure 2. Results of distant learning.

Considering all this, we can summarize, that educational process under such conditions will give and already giving poor results in terms of residual students` knowledge.

All above said gives as the real picture of the state of affairs in the sphere of distant education as it is currently.

Among all the disadvantages of distance learning the most vicious and notorious is the tearing apart of the connection between the master (teacher) and the student. The authority, aspiration to knowledge and inspiration for achievement has been deprived from both sides through the depriving of that sacral connection. Which is a sly plan of making a whole generation of "people of one button".

Fortunately, those who realize what is going on find the way to restore the connection and adjust to the given conditions by changing the approach using the technologies for good and new methods of teaching are being developed, they take into account the experiences of the best result giving approaches and invent new ones.

And those are NOT tests! Tests cannot be used for teaching. Tests are one of the worst type of students ' check and cannot be represented as main form of revision. It deprived from students creativity skills and ability to express thought. Which can in not such a distant prospective give rise to ignorance and ignorance can give rise to destructions in all possible ways of its manifestations. 
In general, as shown by the results of an express survey of the Federal Institute for the Development of Education of the Russian Presidential Academy of National Economy and Public Administration, conducted at the beginning of the new academic year, about a third of students are pessimistic, panic, or indifferent about the upcoming study due to the threat of going to distant education.

The study involved 2,778 respondents from 38 constituent entities of the Russian Federation, $46 \%$ of the respondents clearly stated that they would like to study only in full-time format, since online education does not allow you to effectively engage in training [255]. 
DOI 10.46299/ISG.2021.MONO.PED.II-268-279

\subsection{Identification of PhD students' subject specific and generic competences and their integration in EAP syllabus}

Abstract. The aim of the paper is to provide an analysis of the most important subject specific and generic competences needed within a framework of EAP Syllabus for a successful implementation in the further PhDs students' academic and professional life. Although some attempts have been made to address the issue, the previous investigations were not focused on EAP-related competences. From the quantitative and comparative analyses, there were identified basic competences. The pre-course and post-course surveys were carried out to compare the PhDs' expectations with competences developed and implemented in real life situations. The study shows that $\mathrm{PhDs}$ are able to generate competences needed for the course, analyse them and assess own achievements in the process of learning.

Key words: Doctoral education, EAP, competences, $\mathrm{PhD}$ students, survey

\subsubsection{Introduction}

Almost a year ago, in September 2020, the Ministry of Education and Science of Ukraine posted a draft of 'Strategy for the Development of Higher Education of Ukraine for 2021-2031' (Ministry of Education and Science of Ukraine Project) on its official website, the document was prepared pursuant to the Order of the President of Ukraine №210/2020 “On the Improvement of Higher Education in Ukraine”. There has been an increased recognition that more attention needs to be paid to the level of development of science as a determining factor for the progress of Ukrainian society. This necessitates the priority of the PhDs support creating conditions for the realization of their intellectual potential in science and technology, ensuring Ukrainian $\mathrm{PhD}$ students will be able to use national and world scientific achievements to meet academic, social, economic, cultural and other needs. Although the indicators of how to assess one or another competence were not properly developed and described, in particular the indicators which can value the competences developed in the framework of teaching English for Academic Purposes (EAP). 
The European Union regards the competences development as one of the main direction for supporting economies with skilled workforce, for this purpose the opportunities should be given to university graduates to master those skills and enter the labour market with dignity. The PhDs with their skills, knowledge and expertise are considered to be on the top of the University graduates pyramid and represent the 'brain' and great potential for both national and global societies.

The Tuning project's approach makes a distinction between generic competencies (GC) and subject specific ones (SSC), although it is accepted that key outcomes of university curricula will be subject-related competences. Tuning project's survey demonstrated that employers, graduates and academic staff agreed on generic competences, from a range offered in a questionnaire, which are the more relevant ones, although they differed slightly the importance of some of them.

Presently, the importance of the generic competences is widely understood, but understanding of the concept alone is insufficient. The heart of the problem lies in the implications a competence-based approach has for teaching and learning, i.e. the University teachers should investigate and implement the appropriate teaching methods, develop learning activities to foster competences in terms of knowledge, understanding and skills, and create the measurable ways of competencies assessment.

In general, many studies, research reports, surveys highlighted a problem the University graduates face with, in particular a skill shortage after graduating from universities (Jorre de St Jorre \& Oliver, 2018; Matthews and Mercer-Mapstone, 2016; Hill at al., 2018; Bogle, Dron, Eggermont and Willem van Henten, 2010). However, fewer publications focused on competences actually developed and implemented in major disciplines, especially at the doctoral level.

Barthélémy Durette (2014) presented the results of a survey on PhDs competencies conducted on $2794 \mathrm{PhDs}$ who graduated from universities in France and determine the 'core' competencies of doctorate holders, i.e. the competencies that have the same probability of being developed through the $\mathrm{PhD}$ irrespectively of the discipline, the date of graduation and other factors. This analysis provides a sound basis to define the outcomes of doctoral education in France in terms of competencies. 
Amor \& Serrano Rodríguez (2019) compared generic competences of different groups: students, teaching staff and the groups comprising graduates. The obtained results demonstrate that certain competences from the Instrumental Competences, i.e. competence in a foreign language and technological competency, are perceived to be less developed.

In fact, the $\mathrm{PhDs}$ curricula are still focused on teaching traditional scientific skills rather than paying attention to generic competences in particular of those ones which can be developed in the frameworks of English for Academic Purposes (EAP) course.

Definition of the term 'generic competence'. In the Tuning Project, which was the driving force behind the curricular reforms in Higher Education in Europe, there was given a definition of both specific and generic competences:

Competences are obtained or developed during the process of learning by the student/learner. In other words competences represent a dynamic combination of knowledge, understanding, skills and abilities. Fostering competences is the object of educational programmes. Competences will be formed in various course units and assessed at different stages.

Competences can be distinguished in subject specific and generic ones. Although Tuning acknowledges to the full the importance of building-up and developing subject specific knowledge and skills as the basis for university degree programmes, it has highlighted the fact that time and attention should also be devoted to the development of generic competences or transferable skills. This last component is becoming more and more relevant for preparing students well for their future role in society in terms of employability and citizenship.

Zabalza (2011) suggested the inclusion of generic competences to all university educational itineraries, although it was mentioned that they might at first appear to have nothing in common with being educated in a particular discipline, but in the upshot generic competences prove to be tremendously valuable for the integral education and imply great relevance for professionals.

Presently Tuning distinguishes three types of generic competences (Tuning Educational Structures in Europe, Competences): 
Instrumental competences: cognitive abilities, methodological abilities, technological abilities and linguistic abilities.

Interpersonal competences: individual abilities like social skills (social interaction and co-operation).

Systemic competences: abilities and skills concerning whole systems (combination of understanding, sensibility and knowledge; prior acquisition of instrumental and interpersonal competences required).

The aim of this research is: (1) to enhance understanding of indispensable $\mathrm{PhDs}$ ' competences in the framework of EAP learning and teaching at University's Doctorate level; (2) to indicate EAP areas for competences development with further implementation into EAP Syllabus.

\subsubsection{Methods of the study}

The present article analyses the data collected from PhDs specializing in Natural, Exact Sciences and Humanities in Odesa I.I. Mechnikov National University between 2017 and 2021. The participants of the study were the first- and second-year Doctorial candidates studying EAP course amounting 180 hours. Two different methods were used to collect and analyse the data received the surveys. In the first stage, as the precourse activity $\mathrm{PhDs}$ were offered to point out those EAP-related and generic competences which they reckon as the most valuable and should be developed throughout the EAP course. Prior the completing the questionnaire, PhDs were explained the difference between specific and generic competences, there was welcomed team working and sharing ideas with peers, although no competences were declared in the questionnaire in advance.

The questionnaire consisted of two questions:

Question 1: Will you, please, enumerate specific competences you would like to develop during EAP course. The competences should be expressed in the prioritized, bullet-point way, in quantity from 3 to 5.

Question 2: Will you, please, enumerate generic competences you would like to develop during EAP course. The competences should be expressed in the prioritized, bullet-point way, in quantity from 3 to 5. 
Quantitative and qualitative analyses were used to process the resulting 27 competences, group them into two main categories: subject specific (i.e. EAP-related) and generic competences where the latter ones were also subdivided into Instrumental, Interpersonal and Systemic in accordance with Tuning basic types taking into consideration the PhDs' possibility of describing the similar competences in synonymic way. Then the PhDs' questionnaires were analysed by counting the frequencies of competence mentions and setting up the order of their priority (see Table $1)$.

In the second stage of the analysis, after collecting and processing the data of the first survey, the research participants were provided with the second questionnaire where the competences of both categories were listed in full compliance with EAP Syllabus. Following this, Doctorial candidates were asked to rank them starting with the most important ones towards the less important (see Table 2, Pre-course survey).

Finally, post-course survey was carried out to investigate the participants' opinion on the quality of competences development within EAP course and the most important aspect - their real-life implementation within the period of participants' studying and writing a $\mathrm{PhD}$ thesis (see Table 3, Post-course survey, column 3).

\subsubsection{Results}

The results of the research are presented in Tables 1,2 and 3. Then two bar charts were built to compare of PhDs' preferences with existing competences stated in EAP Syllabus (Fig. 1 and Fig. 2). The bar chart (Fig. 2) also illustrates the factual realization of competences in real-life situations, the participants' positive responses were presented by crosshatching bar in percentage.

Table 1 shows that the most frequently cited category is SSC 'Good written and oral communication in academic English', it was mentioned by $46.3 \%$ of $\mathrm{PhDs}$. Second position is occupied by the SSC 'Writing scientific papers in English' (24\%). Generic competences 'Ability to perceive and process a great deal of information' and 'Ability to understand and analyse the innovations in the specific field' were mentioned in the third and fourth positions respectively. Finally, the abilities in "Networking and effective cooperation with peers, teachers, scientific supervisors' and 'Knowledge 
about papers submission to international editions' are declared by $\mathrm{PhDs}$ as necessary for development GC competences. It can be observed from Table 1 that four GCs constitute the majority among six top competences generated by $\mathrm{PhDs}$.

Table 1.

SSC and GC: Rating of importance from PhDs' point of view

\begin{tabular}{|c|c|c|}
\hline № & $\begin{array}{l}\text { EAP-related competences generated by PhDs } \\
\text { (in pre-course survey) }\end{array}$ & $\begin{array}{c}\text { Position } \\
\text { in the rating }\end{array}$ \\
\hline 1. & Good written and oral communication in academic English. & 1 \\
\hline 2. & Useful and frequent language in academic texts. & 12 \\
\hline 3. & Diagrams description. & 19 \\
\hline 4. & The structure of scientific paper for international journals. & 24 \\
\hline 5. & Correct pronunciation of formulae. & 15 \\
\hline 6. & Correct formulation of definitions. & 25 \\
\hline 7. & $\begin{array}{l}\text { Understanding complex grammar and vocabulary structures in } \\
\text { scientific papers. }\end{array}$ & 27 \\
\hline 8. & Writing scientific papers in English. & 2 \\
\hline 9. & Reading and understanding information on professional sites. & 8 \\
\hline 10. & Speaking at the conferences. & 10 \\
\hline \multicolumn{3}{|c|}{ Generic competences generated by PhDs } \\
\hline \multicolumn{3}{|c|}{ Instrumental competences: } \\
\hline 11. & Presentation skills. & 7 \\
\hline 12. & $\begin{array}{l}\text { Ability to understand and analyse the innovations in the specific } \\
\text { field. }\end{array}$ & 4 \\
\hline 13. & Ability to perceive and process a great deal of information. & 3 \\
\hline 14. & Knowledge about papers submission to international editions. & 6 \\
\hline 15. & Ability to search needed information quickly. & 22 \\
\hline \multicolumn{3}{|c|}{ Interpersonal competences: } \\
\hline 16. & Motivation to study Academic English. & 26 \\
\hline 17. & Team working in class. & 11 \\
\hline 18. & $\begin{array}{l}\text { Networking and effective cooperation with peers, teachers, } \\
\text { scientific supervisors. }\end{array}$ & 5 \\
\hline 19. & Ability to perceive constructive feedback. & 14 \\
\hline 20. & Ability to learn from own and peers' mistakes. & 23 \\
\hline 21. & Academic honesty. & 17 \\
\hline
\end{tabular}


Continuation of Table 1

\begin{tabular}{|c|l|c|}
\hline \multicolumn{2}{|c|}{ Systemic competences: } \\
\hline 22. & Independent scientific work. & 21 \\
\hline 23. & Time management. & 18 \\
\hline 24. & Thinking and working effectively. & 20 \\
\hline 25. & Self-evaluation. & 13 \\
\hline 26. & Constant improvement. & 16 \\
\hline 27. & Bringing new ideas in the field. & 9 \\
\hline
\end{tabular}

Table 2 and Table 3 illustrate how PhDs assess the importance of both SSCs and GCs presented in EAP Syllabus at the beginning of the course (1-st column) and the level of these competences development in the framework of their EAP course (2-nd column). The 3-rd column demonstrates the participants' feedback on whether they managed to implement the obtained competences in real-life situations for the two-year period of the EAP study.

Table 2.

Percentage distribution of PhDs' responses as to the importance of specific competences designated in competence-based EAP Syllabus

\begin{tabular}{|l|c|c|c|}
\hline \multirow{2}{*}{$\begin{array}{c}\text { Subject Specific competences of the Syllabus } \\
\text { 'English for Academic Purposes' }\end{array}$} & $\begin{array}{c}\text { Pre-course } \\
\text { survey }\end{array}$ & \multicolumn{2}{|c|}{$\begin{array}{c}\text { Post-course } \\
\text { survey }\end{array}$} \\
\cline { 2 - 5 } & $\begin{array}{c}\text { Importance } \\
\text { of } \\
\text { (\%) } \\
\text { (\%) }\end{array}$ & $\begin{array}{c}\text { Development } \\
\text { within EAP } \\
\text { course } \\
\text { (ranking } \\
\text { scale } \\
\text { from 0 to 5)* }\end{array}$ & $\begin{array}{c}\text { Implementation } \\
\text { in real-life } \\
\text { academic/ } \\
\text { professional } \\
\text { situations } \\
\text { (yes/no) }\end{array}$ \\
\cline { 2 - 5 } $\begin{array}{l}\text { SSC-1. Ability to use academic and } \\
\text { professional English terminology in the } \\
\text { research area. }\end{array}$ & $41.5 \%$ & $89.2 \%(5)$ & $86 \%$ (yes) \\
& & $10.8 \%(3)$ & $14 \%$ (no) \\
\hline $\begin{array}{l}\text { SSC-2. Ability to collect data for research, } \\
\text { systematize and interpret them in English. }\end{array}$ & $38.1 \%$ & $62.1 \%(5)$ & $67 \%$ (yes) \\
\end{tabular}


Continuation of Table 2

\begin{tabular}{|l|c|c|c|}
\hline $\begin{array}{l}\text { SSC-3. Ability to write academic texts of } \\
\text { different genres, taking into account the } \\
\text { purpose and addressee of the message } \\
\text { according to the generally accepted } \\
\text { conventions for academic writing, using the } \\
\text { necessary language resources and means of } \\
\text { logical communication. }\end{array}$ & $\begin{array}{c}72 \%(4) \\
18 \%(3)\end{array}$ & $\begin{array}{c}72 \% \text { (yes) } \\
28 \% \text { (no) }\end{array}$ \\
\hline $\begin{array}{l}\text { SSC-4. Ability to create a Power Point } \\
\text { presentation and present it in concordance } \\
\text { with academic communication requirements. }\end{array}$ & $43.1 \%$ & $71.1 \%(4)$ & $87 \%$ (yes) \\
& & $29.9 \%(3)$ & $13 \%$ (no) \\
\hline $\begin{array}{l}\text { SSC-5. Ability to use techniques of } \\
\text { paraphrasing and summarizing information } \\
\text { from different sources. }\end{array}$ & $15.3 \%$ & $69 \%$ (4) & $66 \%$ (yes) \\
\hline $\begin{array}{l}\text { SSC-6. Ability to identify and apply different } \\
\text { citation styles, compile a list of sources used } \\
\text { in accordance with academic convention. }\end{array}$ & $9.6 \%$ & $17.3 \%(3)$ & $34 \%$ (no) \\
\hline $\begin{array}{l}\text { SSC-7. Ability to linguo-creativity in the } \\
\text { field of science and innovation. }\end{array}$ & $0.8 \%$ & $25.3 \%(2)$ & $4 \%$ (yes) \\
& & $74.7 \%(1)$ & $96 \%$ (no) \\
\hline
\end{tabular}

It should be noticed that both EAP-related and generic competences were not separated in the survey intentionally the participants of research were offered to point out the most significant competences they would like to develop in the course. Although, subsequently the SSCs and GCs were categorized during analyses. 
Table 3.

Percentage distribution of PhDs' responses as to the importance of GCs designated in competence-based EAP Syllabus

\begin{tabular}{|c|c|c|c|}
\hline \multirow{3}{*}{$\begin{array}{l}\text { Generic competences of the Syllabus 'English } \\
\text { for Academic Purposes' }\end{array}$} & $\begin{array}{c}\text { Pre-course } \\
\text { survey }\end{array}$ & \multicolumn{2}{|c|}{$\begin{array}{l}\text { Post-course } \\
\text { survey }\end{array}$} \\
\hline & \begin{tabular}{|c|}
$\begin{array}{c}\text { Importance } \\
\text { of } \\
\text { competence } \\
(\%)\end{array}$ \\
$\%$
\end{tabular} & $\begin{array}{c}\text { Development } \\
\text { within EAP } \\
\text { course } \\
\text { (ranking } \\
\text { scale } \\
\text { from 0 to 5)* }\end{array}$ & $\begin{array}{l}\text { Implementation } \\
\text { in real-life } \\
\text { academic/ } \\
\text { professional } \\
\text { situations } \\
\text { (yes/no) }\end{array}$ \\
\hline & 1 & 2 & 3 \\
\hline $\begin{array}{l}\text { GC-1. Ability to think abstractly and } \\
\text { critically, generate new ideas in English in } \\
\text { the process of writing a dissertation, } \\
\text { scientific papers, reports. }\end{array}$ & $21.2 \%$ & $\begin{array}{l}30.3 \%(4) \\
44.8 \%(3) \\
24.9 \%(2)\end{array}$ & $\begin{array}{l}58 \% \text { (yes) } \\
42 \% \text { (no) }\end{array}$ \\
\hline $\begin{array}{l}\text { GC-2. Ability to search, systematize and } \\
\text { critically analyse information from various } \\
\text { English-language sources. }\end{array}$ & $22.9 \%$ & $\begin{array}{l}12.4 \%(5) \\
56.5 \%(4) \\
31,1 \%(3)\end{array}$ & $\begin{array}{l}21 \% \text { (yes) } \\
79 \% \text { (no) }\end{array}$ \\
\hline $\begin{array}{l}\text { GC-3. Ability to plan and carry out research } \\
\text { based on a systematic scientific worldview } \\
\text { with the use of modern ICT. }\end{array}$ & $7.8 \%$ & $\begin{array}{l}52 \%(3) \\
48 \%(1)\end{array}$ & $\begin{array}{l}52 \% \text { (yes) } \\
48 \% \text { (no) }\end{array}$ \\
\hline $\begin{array}{l}\text { GC-4. Ability to network with the scientific } \\
\text { community in accordance with the specifics } \\
\text { of the specialism in order to present and } \\
\text { discuss the results of PhD's scientific work } \\
\text { in written and oral forms. }\end{array}$ & $39.4 \%$ & $\begin{array}{l}5.8 \%(5) \\
6.9 \%(4) \\
67 \%(3) \\
20.3 \%(2)\end{array}$ & $\begin{array}{l}24 \% \text { (yes) } \\
76 \% \text { (no) }\end{array}$ \\
\hline $\begin{array}{l}\text { GC-5. Awareness of the scientific ethics } \\
\text { and compliance with academic ethical } \\
\text { requirements. }\end{array}$ & $3.1 \%$ & $\begin{array}{c}67 \%(4) \\
30.2 \%(2) \\
2.2 \%(1)\end{array}$ & $\begin{array}{l}68 \% \text { (yes) } \\
32 \% \text { (no) }\end{array}$ \\
\hline $\begin{array}{l}\text { GC-6. Ability to work and upgrade own } \\
\text { skills in online environment using modern } \\
\text { educational platforms. }\end{array}$ & $11.3 \%$ & \begin{tabular}{c|}
$69 \%(4)$ \\
$17.3 \%(2)$ \\
$13.7 \%(1)$
\end{tabular} & $\begin{array}{l}56 \% \text { (yes) } \\
44 \% \text { (no) }\end{array}$ \\
\hline $\begin{array}{l}\text { GC-7. The ability to learn and work } \\
\text { independently; to learn throughout life. }\end{array}$ & $14.6 \%$ & $\begin{array}{l}15.2 \%(4) \\
84.8 \%(3)\end{array}$ & $\begin{array}{l}98.7 \% \text { (yes) } \\
1.3 \% \text { (no) }\end{array}$ \\
\hline $\begin{array}{l}\text { GC-8. Ability to self-assess and peer-assess } \\
\text { the work of colleagues. }\end{array}$ & $6.9 \%$ & \begin{tabular}{l|}
$2.4 \%(5)$ \\
$65.8 \%(4)$ \\
$31.8 \%(1)$
\end{tabular} & $\begin{array}{l}87 \% \text { (yes) } \\
13 \% \text { (no) }\end{array}$ \\
\hline
\end{tabular}

*Ranking scale indicators: 0 - none; 1 - weak; 2 - satisfactory; 3 - considerable; 4 - strong; 5 - excellent. 
An evaluation of the data from Table 1 allowed us to build a competence rating. It can be seen from Fig. 1 that the first two positions are occupied by EAP-related competences, although, the participants highlighted the importance of generic competences giving next four positions to them.

SSC: Good written and oral communication in academic English.

SSC: The structure of scientific paper for international journals.

GC: Ability to perceive and process a great deal of information.

GC: Ability to understand and analyse the innovations in the specific field.

GC: Networking and effective cooperation with peers, teachers, scientific supervisors.

GC: Presentation skills

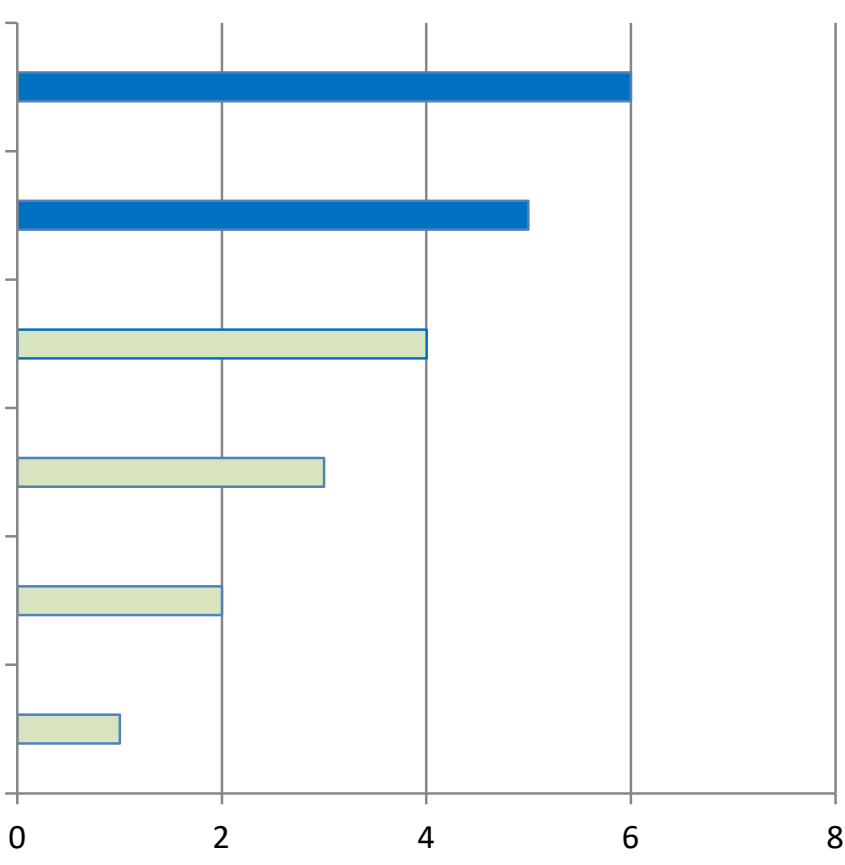
GC - Generic Competence

- SSC - Subject Specific Competence

Figure 1. Top EAP-course competences generated by $\mathrm{PhDs}$ in pre-course survey.

The bar chart (Fig.2) presents the top six competences which are in demand, in $\mathrm{PhD}$ students' judgement. On the other hand, the chart illustrates the comparison between the competences from EAP Syllabus and their practical application in $\mathrm{PhD}$ students' scientific and academic activities.

The comparative analysis of the state of the art shows that EAP-related competences were underestimated by $\mathrm{PhD}$ students at the beginning of EAP study, although the post-course survey demonstrates that the mentioned above competences were successfully developed and actualized by Doctoral students within academic or professional events.

As shown in Fig.2, the PhDs do not only admit the necessity of GCs development since they have included three GCs on the list of prioritized ones in Doctoral curriculum, it is also vital that Doctorate students realise the value of GCs, as they seem to be more motivated to develop them. Such GCs as 'GC-4: Ability to network with 
the scientific community in accordance with the specifics of the specialism in order to present and discuss the results of PhD's scientific work in written and oral forms', 'GC2: Ability to search, systematize and critically analyse information from various English-language sources', 'Ability to think abstractly and critically, generate new ideas in English in the process of writing a dissertation, scientific papers, reports'.

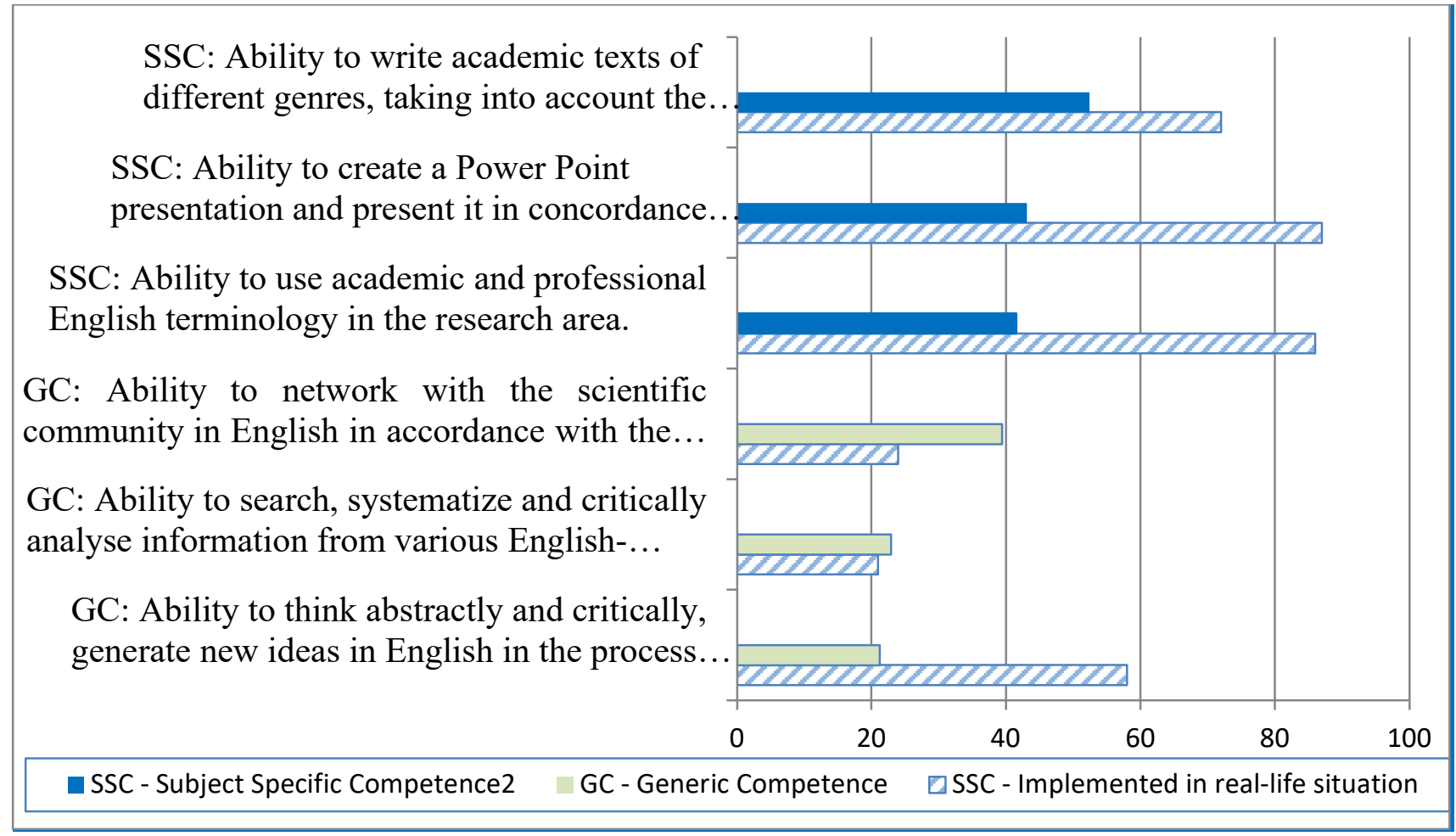

Figure 2. Top SSC and GC competences elicited by PhDs from EAP Syllabus and their real-life implementation.

\section{Conclusion}

This study aimed to develop a greater understanding of both SSCs and GSs which should be developed in the framework of EAP Syllabus for the purpose of assuring profound outcomes in Doctoral training.

Basing on a PhDs' pre-course and post-course surveys, we found that $\mathrm{PhD}$ students are sufficiently aware of the competences which are in demand and require developing. We also identified the most important EAP-related and generic competences offered by EAP Syllabus and generated by PhD students through open-ended questions. It was proposed to include all competences generated by Doctoral students in the EAP Syllabus. On the basis of the research presented it can be recommended to include generic competences in the Doctorial curriculum irrelatively to specialisms of the $\mathrm{PhD}$ 
students. Undoubtedly, the doctoral education cannot be reduced to a list of competences developed by EAP, though we consider them to be an efficient practical tool to help $\mathrm{PhDs}$ in assessing their doctoral experience in international environment. 


\subsection{Distance learning in the process of teaching English for law students: optimistic or skeptical challenges}

Nowadays one of the most oft-used terms during the pandemic in the sphere of education, learning and teaching is distance learning. The COVID-19 pandemic has triggered such new ways of learning and teaching students in the universities and educational establishments. Law students are not the exception. That's why it is very actual to analyze problems, difficulties, advantages and disadvantages in order to have some positive or negative experience to share.

All around the world, educational institutions are looking toward online learning platforms to continue with the process of educating students. The new normal now is a transformed concept of education with online learning at the core of this transformation. Today, digital learning has emerged as a necessary resource for students and schools all over the world. For many educational institutions, this is an entirely new way of education that they have had to adopt. Online learning is now applicable not just to learn academics but it also extends to learning extracurricular activities for students as well. In recent months, the demand for online learning has risen significantly, and it will continue doing so in the future [271].

In the review of Doug Valentine University of Oklahome [272], we can trace the history of distance learning and the way the term has been defined in the past and how it is currently defined in the literature. The term can be used to describe any of a number of instructional situations. Although it is thought of as a new term, distance learning has been around for well over 100 years. One of the earlier forms of distance learning was done through correspondence courses started in Europe. This stayed the primary means of distance learning until the middle of this century when instructional radio and television became more popular (Imel, 1996). As technology has changed, so has the definition of distance learning. Videotaped lectures have been a standard in university and professional courses for the last two decades (Moore \& Lockee, 1998). Audiotapes and lessons sent through the mail have been used in correspondence courses to teach subjects such as foreign language for quite some time (Teaster \& Blieszner, 1999). 
Today, the Internet and compressed video have taken distance learning in new directions, allowing distance learning to occur in real time. Live video instruction is the most popular and fastest growing delivery mode in the United States (Ostendorf, 1997) [272].

Merriam Webster defines distance learning as, "a method of study where teachers and students do not meet in a classroom but use the Internet, e-mail, mail, etc., to have classes" [273].

There have been many definitions put forward in modern literature. Greenberg (1998) defines contemporary distance learning as "a planned teaching/learning experience that uses a wide spectrum of technologies to reach learners at a distance and is designed to encourage learner interaction and certification of learning" (pg. 36). Teaster and Blieszner (1999) say the term distance learning has been applied to many instructional methods: however, its primary distinction is that the teacher and the learner are separate in space and possibly time" (pg. 741). Desmond Keegan (1995) gives the most thorough definition. He says that distance education and training result from the technological separation of teacher and learner which frees the student from the necessity of traveling to "a fixed place, at a fixed time, to meet a fixed person, in order to be trained" (pg. 7). From these definitions we can see that the student and teacher are separated by space, but not necessarily by time. This would include compressed video, which is delivered in real time. As stated earlier, this type of live video instruction is the fastest growing means of distance learning today [272].

Referring to different definitions and explanations of the term distance learning, online learning, digital learning we fully agree with the thoughts that distance learning is basically a way of disseminating knowledge, where the educators and students are separated in distance or time or even both. Distance learning does not include any inperson interaction with an instructor or study peers. Students study at home on their own, and the learning is more individual and varies on speed and timeline according to each individual student and their availability. 
Distance learning actually relies on the educational tools of online learning, and that is probably why there is some confusion between the two. It is possible to study with online distance learning as well.

Online learning is when teachers or students use educational tools which are accessible on the internet as well. This means that students can also use online tools while they are physically in a classroom with their teachers. Online learning can be used anywhere and anytime, so teachers may have students using them as tools in class or for preparation and assignments at home. Online learning tools are often used to create blended learning environments in the classroom. This helps keep students engaged in the class and in the material.

Online learning also helps teachers save preparation time before class. With the help of online educational tools, teachers can spend more time grading papers, giving one-on-one attention to students, and maybe even getting some free time for themselves in their busy work schedule.

Undoubtedly, distance learning offers wide variety of opportunities to students to attain higher education, but it is not all about benefits and advantages indeed. The distance mode of education offers students the flexibility to decide, what they want to learn, when they want to learn, at what pace they want to learn and what they would like to learn. It is understood and well researched that not all students tend to learn via same technique of open learning and there is no particular technique that facilitate learning in everyone. There are several factors that affect student's capacity to study. Applied learning, interaction, prior knowledge, analytical skills and motivations are some of the factors [274].

As with most teaching English methods, online learning also has its own set of positives and negatives. Decoding and understanding these positives and negatives will help institutes in creating strategies for more efficient delivery of the classes, ensuring an uninterrupted learning journey for the students. 
Expressing opinions and probabilities, using our own experience of English Language in professional use teaching at Law Department of Lesya Ukrainka Volyn National University we define such advantages and of distance learning.

1. Efficiency. Online learning offers teachers an efficient way to deliver lessons to students. Online learning has a number of tools such as videos, PDFs, podcasts, and teachers can use all these tools as part of their lesson plans. By extending the lesson plan beyond traditional textbooks to include online resources, teachers are able to become more efficient educators.

2. Accessibility Of Time And Place. Another advantage of online education is that it allows students to attend classes from any location of their choice. It also allows schools to reach out to a more extensive network of students, instead of being restricted by geographical boundaries. Additionally, online lectures can be recorded, archived, and shared for future reference. This allows students to access the learning material at a time of their comfort.

3. Affordability. Another advantage of online learning is reduced financial costs. Online education is far more affordable as compared to physical learning. This is because online learning eliminates the cost points of student transportation, student meals, and most importantly, real estate. Additionally, all the course or study materials are available online, thus creating a paperless learning environment which is more affordable, while also being beneficial to the environment.

4. Improved Student Attendance. Since online classes can be taken from home or location of choice, there are fewer chances of students missing out on lessons.

In other words we can study anywhere, anytime, any place. Distance learning is student centered. Access to Resources is great one. Today students have access to resources and materials that may be physically located anywhere in the world. An instructor can compile a resource section online with links to scholarly articles, institutions, and other materials relevant to the course topic for students to access for research, extension, or in depth analysis of course content material. Teaching is becoming more and more creative, we, teachers seek new forms and methods of teaching and presenting material. 
Besides, we have resulted from our own online learning experience some disadvantages. The first one, and is the most useful in our point of view that we teachers, and our students have no physical interaction. When the physical interaction between teachers and students is missing, then students tend to lose personal interaction with their educators and thereby the mental buildup of students may get hampered. Most of the students prefer to learn when their educators are physically present in the classroom. So, for such students distance learning would not be beneficial indeed.

It goes without saying, distance learning is less motivational. In distance learning, students are not required to attain classroom in person. They are isolated and hence they don't get same sort of interaction with other fellow colleagues in the course. Besides, the educators will also not be able to interact with the student directly; therefore they can't motivate the students as they do in classroom. In traditional way of learning, the students get the opportunity to thrive in an environment. In distance mode of learning, all these motivational factors are not present and can be unfavorable for many students.

Distance learning doesn't help in developing oral skills and social interaction, most of the distance learning courses don't facilitate oral communication, unless the program is synchronous learning event, where the students are asked to participate by using some communication techniques. This idea concerns such courses as English in Professional Use (Law), Academic Writing, Legal Writing.

Another difficulty we face in the process of teaching English that distance is the requirement of sound technical skills; this includes good typing skills to excel in distance learning setup. Distance learning also includes some hidden cost, like maintenance and purchasing of computer and other equipments to succeed in the learning process. Another key challenge of online classes is internet connectivity. While internet penetration has grown in leaps and bounds over the past few years, in smaller cities and towns, remoted villages a consistent connection with decent speed is a problem. Without a consistent internet connection for students or teachers, there can be a lack of continuity in learning for the student. 
For many students and teachers as well, one of the biggest challenges of online learning is the struggle with focusing on the screen for long periods of time. With online learning, there is also a greater chance for students to be easily distracted by social media or other sites. Therefore, it is imperative for the teachers to keep their online classes crisp, engaging, and interactive to help students stay focused on the lesson.

Students can learn a lot from being in the company of their group mates. However, in an online class, there are minimal physical interactions between students and teachers. This often results in a sense of isolation for the students. In this situation, it is imperative that the school allow for other forms of communication between the students, peers, and teachers. This can include online messages, emails and video conferencing that will allow for face-to-face interaction and reduce the sense of isolation.

In order to successfully participate in an online classes, students must be well organized, self-motivated, and possess a high degree of time management skills in order to keep up with the pace of the course.

We fully agree with above mentioned author of great research on distance learning of Doug Valentine University of Oklahome [272], towards instructor concerns. It is underlined that Instructors worry about putting their course materials online because once there, the knowledge and course design skill in that material is out of their possession. This puts the administration in a position to hire less skilled, and cheaper, workers to deliver the technologically prepackaged course (Noble, 1998 cited in Dibiase, 2000). Instructors are not always convinced that administration is behind distance learning. The rewards are not always there for the good distance-learning instructor. The increased amount of time necessary to adequately prepare for distance learning takes away from the activities they will be evaluated on, such as grant writing and publishing. Many of the instructors concerns are valid and should be addressed by administration as distance learning becomes more common, as is predicted to happen [272]. 
If to speak about distance learning process at our university, Faculty of Law, we try to combine all kinds of online courses. For instance, Conference classes, which allow students and teachers to meet up for class in real time, whether in a group or oneon-one with an instructor. Using the phone or video chatting, such as Skype, Viber students and teachers can engage in live lessons despite distance.

Correspondence courses which consist of students engaging in class material via mail or email. Students receive material and assignments through mail, and they send completed assignments back through the same method. These courses are reflected in Google Classroom Platform or our university platform Office 365.

Hybrid courses which combine traditional classroom settings with online learning at home. This can mean that students learn individually at home and meet up for inperson instructions or lectures at certain intervals during the course. The amount of athome learning and in-class learning varies for each hybrid course.

Being involved in a collaborative learning process is an important part of forming the foundation of a learning community. When this is not encouraged, participation is generally low and dialog is absent (Palloff \& Pratt, 2000). Students also need the attention of the instructors. This may be truer in a distance situation than in a traditional classroom. In a situation where eye contact and proximity are limited, students cannot be disciplined nor affirmed by eye contact and body language (McKnight, 2000). Students may also have a difficult time reading the reactions of the remote location class members many experts now contend that [272].

As for me, I prefer to work with students in the classroom, to feel them, to feel their mood, to communicate, to have real feedback. But it was and is not very easy to combine all these types of work with future lawyers because of the peculiarities of law specialty.

All educators approach this new paradigm with varying degrees of enthusiasm and concern. Are you optimistic or skeptical about Online Learning? Are you interested in knowing how delivering courses online can improve your teaching and offer unprecedented learning opportunities for your students, or do you want to know what you will be up against as you plan and deliver your classes online? It is important to 
consider both the pros and cons of online learning so you can be better prepared to face the challenge of working in this new environment as well as embrace the new opportunities that it has to offer.

Now when we have a rundown of the distance learning definition, and the different kinds that are available, you can decide whether it's a right fit for you and your life. Many students find distance learning to be a fulfilling and practical way to receive quality education, without needing to attend a traditional university.

But nonetheless, virtual learning still serves as major convenience and efficiency in delivering content with no physical constraints, especially nowadays, in a time of global crisis. We teachers, are really facing that challenge and we are to carry out an important task for the university, community, country, which deserves to be praised and which can bring about innovation in schools like never before. 
DOI 10.46299/ISG.2021.MONO.PED.II-288-306

\section{8 Діалого-культурологічний проект освіти: вітчизняна локальність в глобальному контексті}

Сучасна освіта як феномен поліфонічної культури в Україні становить єдність загальносвітового та національного начал. 3 одного боку, етнокультурна ідентифікація українського народу відбувається нині в контексті входження України в глобальний «інтердискурсивний дискурс» інформаційного суспільства з притаманною йому тенденцією до діалогу культур. 3 іншого боку, виклики міжкультурної освіти в Україні відчуваються особливо гостро, зважаючи на полікультурність національного життя, історично складену внаслідок прикордонного геополітичного положення нашої держави між Сходом і Заходом. Маргінальним культурам притаманне суперечливе поєднання аскези й містики, відкритості й закритості, космополітизму й етнографізму, ксенофобії і хворобливого плазування перед іноземним - протилежні умонастрої, що однаковою мірою походять від невміння вести справжній діалог. Більш того: українська полікультурність, зрештою, зводиться до світоглядного дуалізму відкритого чи прихованого протистояння традиціоналістських впливів на Сході і Півдні та неоліберальних впливів на Заході. Просторова модель даного протистояння надає йому додаткової духовної напруги і сприяє формуванню свого роду «міфологічної географії» «своїх» $\mathrm{i}$ «чужих», «космосу» $\mathrm{i}$ «хаосу», «правильного світу» та «світу навиворіт», який залишається свого роду Чужим, монстром, «річчю в собі», джерелом табу, страхів і забобонів.

На специфіку духовного життя в Україні впливає також світоглядна ситуація, утворена у пострадянському просторі. Ідеологічна ніша, що «оголилася» внаслідок відмови від радянської ідеології, потребує свого заповнення, що провокує інтенсивні світоглядні експерименти. Їх учасниками $\epsilon$ представники різних поглядів і культур: від православної консервативної до католицької і постмодерної, що однаковою мірою номінують утворений вакуум у символічній структуру соціуму. На цьому тлі активізується освітня діяльність, яка у контексті парадигми універсальної етики та етики Іншого, філософії діалогу та гуманістичної педагогіки та на підставі конституційного принципу 
THEORETICAL FOUNDATIONS OF THE FUNCTIONING OF EDUCATION. WAYS TO

IMPROVE THE EFFECTIVENESS OF EDUCATIONAL ACTIVITIES

свободи совісті повинна виконувати миротворчу функцію щодо конфлікту східних і західних інтенцій через феноменологічний дискурс неупередженої академічної науки.

На наш погляд, зазначені вище опозиції східного і західного начал $є$ умовними і штучними. Їх необхідно подолати заради запобігання численних релігійних, політичних та світоглядних конфліктів. Питання полягає у тому, якими є конкретні механізми, програми освіти, які допомогли б «вилікувати» чи, принаймні, «притлумити» найбільш больові зони та базові травми нашої культури. Таким, на нашу думку, постає розроблений нами авторський кейс діалого-культурологічний проект навчання. Прикметник «діалогокультурологічний» складається із двох компонентів: «діалогічний» ma «культурологічний». Це вказує на апеляцію пропонованого концептуального підходу одразу до двох проблемних сфер: до філософії діалогу як до парадигми гуманітарного знання та до культурології як до інтегративної гуманітарної науки. Стосовно культурології філософія діалогу виконую функцію одного із провідних іiі методологічних напрямів, який передбачає інтерпретацію культури як буття Іншого, простору багатовимірної взаємодії культур. Відтак, маємо справу з філософією діалогу як культурологічною проблемою, переломленою крізь освітню «призму».

У даній роботі ми на підставі власних культурологічних досліджень, методологічно зорієнтованих на історизм, феноменологію, герменевтику та діалогістику, та на основі багаторічної педагогічної практики зробимо спробу визначити теоретично-методологічні засади та змістові складові діалогокультурологічного проекту навчання у межах сучасної вищзої та середньої освіти в Украӥні. Задля реалізації поставленої мети розглянемо наступні питання:

1. Аналіз основних проблем та провідних тенденцій розвитку освіти в сучасній Україні та у світі на прикладі виокремлення домінуючих світогляднометодологічних підходів до викладання і навчання гуманітарних знань (дані підходи класифіковані нами як «модерні» та «постмодерні»). 
THEORETICAL FOUNDATIONS OF THE FUNCTIONING OF EDUCATION. WAYS TO IMPROVE THE EFFECTIVENESS OF EDUCATIONAL ACTIVITIES

2. Розкриття конц̧епціiі діалого-культурологічного проекту як компромісного шляху у протистоянні наявних освітніх підходів (через уведення категорій «активної толерантності» та філософії діалогу як філософії Третього);

3. Окреслення перспектив практичного впровадження діалогокультурологічного проекту навчання в сучасну систему національної освіти (через окреслення ідеальної моделі освіченої людини у межах пропонованого проекту; виокремлення основних позицій методологічної та методичної новизни проекту та надання практичних рекомендацій на прикладі викладання авторських академічних курсів).

3 певними застереженнями можемо говорити про кризовий (або наближений до такого) стан освітнього прочесу в Україні. Головною причиною кризи є проблема методологічного зяяння у семіосфері освіти, яке дедалі поглиблюється завдяки відсутності в теоретичному та ментальному полі виховання відповідних духові епохи (i водночас не кон'юнктурних) концептуальних засад інтерпретації навчального матеріалу (або ж навіть відсутності самого усвідомлення необхідності вироблення таких знань i упровадження в навчально-виховний процес).

У науковому контексті сучасні методологічні засади викладання гуманістики постають як вияви відповідних теоретичних позицій (традиціоналізм, лібералізм, історизм, марксизм, екзистенціалізм, психоаналіз, феноменологія, герменевтика тощо). Якщо подивитися на ці методології чисто із світоглядної точки зору, можна редукувати їх багатоманітність до смислової опозиції двох найвпливовіших на сьогодні ціннісно-смислових установок, активно обговорюваних на форумах у Давосі та Порту-Алегрі. Мова йде про установки модерну $i$ постмодерну, які фіксують дві протилежні моделі філософування та, ширше, культурної екзистенції суб’єкта: їх дихотомію можна репрезентувати у формі опозицій універсалізм (модерн) - партикуляризм (постмодерн), або: фундаменталізм - релятивізм, ессенцііалізм екзистенцуіалізм [1, с. 311$]$. 
THEORETICAL FOUNDATIONS OF THE FUNCTIONING OF EDUCATION. WAYS TO IMPROVE THE EFFECTIVENESS OF EDUCATIONAL ACTIVITIES

Головна феноменологічна відмінність універсалізму (до якого тяжіють класичний лібералізм, персоналізм, екзистенціалізм, фрейдомарксизм, етика діалогу) від партикуляризму (до якого схильні неолібералізм i мультикультуралізм, традиціоналізм, консерватизм) полягає у спробі (для модерну) або утриманні (для постмодерну) від розв’язання фундаментальних проблем сутнісних основ явищ,, або метанаррацій, наприклад, питання про буття Абсолюту, сенс людського існування, єдність людства, наявність чи відсутність універсалій культури як спільних загальних витоків культурно-історичного процесу тощо. Якщо модерн тяжіє до позитивного розв'язання трансцендентальних проблем, виявляючи тим самим схильність до «проникнення у сутність», позитивної онтології, у версіях сакральної метафізики або світської (ідеалістичної чи матеріалістичної) діалектики, до виявлення причин явищ і тотального узагальнення законів їх розвитку та функціонування, то постмодерн як механізм ритуального самовідтворення модерну в умовах його кризи, з притаманним для нього іронічним прагненням до ковзання поверхнею (ризомою), звільняється від будь-яких метафізичних апеляцій, спрямовуючи свої деконструкції буття на іманентні категорії гри, випадку, ситуативності, плюральності, сліду, знаку, «мему», медіа-вірусу.

Наведений нами дискурс філософської дискусії складає світоглядне тло розвитку сучасної освіти в Україні. Серед тенденцій цього розвитку можемо виділити модерні (універсалістські) та постмодерні (партикуляристські), які формують відповідні концептуальні підходи до навчання. Модерні підходи тяжіють до апріорних метафізичних оціночних установок при визначенні культури. Дана категорія інтерпретується як онтологічне поняття, спрямоване на пошук самототожності, метафізичної ідентичності, сутності, самості, пам'яті, безперервності, походження, цүілісності існування, його витоків у вигляді універсалій та архетипів; розкриваються також проблеми сакрального досвіду у світській культурі, проблеми також Абсолюту, надприродного, Бога, постнаукової метафізики, істини. Причому істинність чи хибність розглядаються тут не як суто гносеологічні, а як буттєві категорії. На грунті позитивної онтології 
THEORETICAL FOUNDATIONS OF THE FUNCTIONING OF EDUCATION. WAYS TO IMPROVE THE EFFECTIVENESS OF EDUCATIONAL ACTIVITIES

освіта зближається з представниками богословсько-теологічного та атеїстичного напрямів, які однаковою мірою абсолютизують базовий характер духовного чи матеріального начал у якості антиномії. На рівні середньої шкільної освіти буттєва присутність богословсько-теологічного та світського підходів викликає дискусію про запровадження у школи, відповідно, або курсу релігійної етики, або курсу світської (академічної) етики. Перший варіант ускладнюється конфесійним розмаїттям нашої держави, а другий - погрожує перетворенню нейтрального «просвітницького» духу навчання у відверту атеїстичну пропаганду в стилі радянських стереотипів.

Постмодерний або близький до нього спосіб подолання тупикової ситуації пропонує феноменологічна школа, яка, спираючись на традиційний прийом ероhе Е. Гуссерля пропонує відмовитися від будь-яких оціночних суджень щодо метанаррацій, зупинитися, утриматися, подібно до Будди в стані золотого мовчання, від постановки і розв’язання метафізичних проблем, обмежившись сферою описового неупередженого розгляду інтенціональної спрямованості свідомості на предмет. Так, антиномічні кантівські запитання про Бога, добро, істину, красу, справедливість, рівність, ієрархію, свободу замінюються на дескриптивні практики окреслення того, як ми їх сприймаємо. На феноменологічний позиціях Україні часто стоять представники молодшого покоління освітніх діячів. Абстрагуючись від постановки невластивих для компетенції науки завдань, обмежуючись характеристикою конкретної багатоманітності культурного досвіду, феноменологи змінюють рух наукової думки 3 індуктивного на дедуктивний, 3 абстрактного на конкретний, iз загального на спеціалізований, з теоретичного на прикладний. Незважаючи на величезну роль феноменології у розвитку «чистої», «нейтральної», гуманістики, яке може запобігти численним конфліктам на грунті премордіального, представники феноменологічного напряму нерідко піддаються звинуваченням 3 боку своїх класичних академічних опонентів у позбавленні науки та навчання «світоглядної глибини», редукуванні його до еклектичного, фактографічного, ілюстративного, констатаційного підходу, що, таким чином, не тільки не сприяє 
THEORETICAL FOUNDATIONS OF THE FUNCTIONING OF EDUCATION. WAYS TO IMPROVE THE EFFECTIVENESS OF EDUCATIONAL ACTIVITIES

діалогу культур, але й унеможливлює його, оскільки спустошує комунікацію, редукуючи іiі до ввічливої, «люб'язної» бесіди по законах пасивної толерантності, позбавляє спілкування глибинних, екзистенційних смислів, взаємопроникнення яких складає справжню суть діалогу як взаємного руху Логосів.

Одним iз найбільш важливих аспектів протистояння модерного та постмодерного типів навчання є славнозвісна дискусія про універсалї, яка має ще середньовічні витоки. Чи існують поняття, цінності, які можна охарактеризувати як загальнолюдські? Чи, можливо, кожній із культурних традицій притаманний свій набір універсалій? У контексті даної дилеми модерн, орієнтуючись на «платонівсько-кантівський канон», позитивно відповідає на це запитання: так існують, і на цій підставі можна здійснити світовий синтез культур. Крайні вияви універсалізму тягнуть за собою небезпеку стандартизації, уніфікації, масовізації, центрації, тобто зосередження навколо єдиної панівної культури (європоцентризм, соціоцентризм, логоцентризм, «фалологоцентризм»), відносно якої інші культурні традиції піддаються ієрархічному лінійно-еволюційному ранжуванню на «модернізовані» та «відсталі», утворюючи матрицю прогресу, що більше нагадує глобалістичну колонізацію.

Постмодерн, на противагу, модерну, дотримується партикуляризму i оголошує установку на одиничне й особливе в кожній із множинних культур. Так, антикантіанець і постструктураліст Р. Рорті, представник нового прагматизму, стверджував, що «немає нічого в глибині кожного з нас, ніякої загальнолюдської природи, ніякої притаманної людству солідарності, яку можна було б використати для морального посилання» [275, с. 311]. Відповідно, універсалістська ідея синтезу розцінюється з боку східних культур як прихована реалізація західного (християнського) імпульсу через штучний пошук прозахідних елементів в абсолютно інших культурах світу. Фундаменталістський вибух на Сході довів неможливість такого синтезу, i наукова громадськість спрямувала свою думку в бік деконструктивістського 
THEORETICAL FOUNDATIONS OF THE FUNCTIONING OF EDUCATION. WAYS TO IMPROVE THE EFFECTIVENESS OF EDUCATIONAL ACTIVITIES

загострення відмінностей, вираженого у відомому афоризмі Р. Кіплінга про Захід і Схід, яким ніколи не зійтися [276].

Наслідки такого відношення - не менш (якщо не більш) болючі, ніж тотальна уніфікація. Надмірний релятивізм призводить відчуження, втрати цінностей, краху переконань, розчинення «Я» в Іншому, дистанціювання атомарних індивідів, нівеляції їх самості, тенозофобії та реваншизму. Толерантність у межах пасивного релятивізму завжди носить характер негативної, індиферентної толерантності, перверзивної лояльності, що спричинює кризу етнічної, культурної, релігійної ідентичності.

У результаті гуманітарна думка опиняється перед уявним бінарним вибором між двома крайнощами однієї сутності, а освіта як піi дзеркало коливається між тяжінням до чистої метафізики аксіологічної одержимості буттям або до іронічної феноменології руйнації його структури, коливаючись від статики до динаміки, від синтагми до парадигми, від синхронії до діахронії, від структури до історії. Від цих суперечок (часто - номінальних) страждає найбільшою мірою молодь, представники якої, виховані у сім’ях з різними світоглядними орієнтаціями, опиняються поруч у межах одного навчального колективу. Автор даної статті нерідко відчуває неминучі складності при читанні лекцій 3 культурологічних дисциплін, побоюючись, 3 одного боку» своєю універсалістичною «традиційністю» образити переконання постмодерних ліберальних іроніків, а 3 іншого боку, своїм релятивізмом (доля якого феноменологічно необхідна науці та освіті для підтримки належного рівня критицизму) образити консерваторів та аксіологів. Необхідно пам’ятати, що у реальній живій практиці культурного переживання буття молодь нерідко виявляється мудрішою за своїх наставників. Через безпосередні симпатії і прихильності, через імпровізаційне щирого спілкування нею інтуїтивно прокладаються ті шляхи, які передвіщають новий тип освіти і навчання.

Конфлікт універсалістичного та партикуляристського підходів в гуманітарному дискурсі інтуїтивно підводить нас до думки про певну «третю альтернативу», - не модерну i не посмодерну, але альтермодерну, - яка 
THEORETICAL FOUNDATIONS OF THE FUNCTIONING OF EDUCATION. WAYS TO IMPROVE THE EFFECTIVENESS OF EDUCATIONAL ACTIVITIES

пропонувала б «золотий серединний шлях» розв’язання проблеми. Яким чином зберегти відчуття єдності людства, яке сприяє міжнародному миру, і при цьому не стандартизувати своє існування? Як сприйняти ідею культурної множинності і при цьому не розчинитися у ній, не втратити власної ідентичності? Яким чином «обійти» болючі та інтимні питання особистих ціннісних переконань і при цьому не позбавити навчання екзістенційно глибини, не перетворити його на сухий ілюстраційний та конституційний опис фактів, коли викладач, втрачаючи духовну мужність артикуляції позиції, стає абстрактною «цифрою», віртуальним придатком, сервісом вічного карантину почуттів? Виникає асоціація 3 розумінням «золотої середини» у коанах дзен, коли остання не є консенсус (рікою між берегами), а є радикальним розривом з обома полюсами ілюзорного вибору (відсутністю берегів).

Такою сучасною «відсутністю берегів» постає, на нашу думку, діалогокультурологічний проект освіти. Головною конщептуальною засадою даного проекту є ідея активної толерантності. Щоб краще пояснити іiі сутність, звернемося до методологічних розробок сучасної герменевтичної критики. Для цього будемо застосовувати означники для двох виявів толерантності: «nacuвна» та «активна». В основу даного поділу кладеться ідея любові як універсальної духовної активності - поваги до Іншого, що виражається в здатності жертовно діяти заради нього (а не просто «терпіти» його присутність). У межах активної (дієвої) та пасивної (бездіяльної) толерантності по-різному розв'язується питання принц̧иповості як основи автентичності. Справжня, активна, жертовна толерантність не тільки не суперечить принциповості, але, навпаки, сприяє іiі розвитку. Активна толерантність не змішує саме переконання з агресією переконання: вона може протестувати проти ортодоксальності, але не торкатися принциповості. Бути толерантним за таких умов означає сповідувати власні переконання, але при цььому не нав'язувати їх Іншому. Відмінності між мною та Іншим не перебільиуються, але й не применшуються: вони втрачають своє абсолютне деструктивне значенням перед обличчям того спільного, щзо нас поєднує, - універсальної етики реальної любові. 
THEORETICAL FOUNDATIONS OF THE FUNCTIONING OF EDUCATION. WAYS TO

IMPROVE THE EFFECTIVENESS OF EDUCATIONAL ACTIVITIES

Утриматися на хиткій межі між активною та пасивною толерантністю надзвичайно важко. Активній толерантності постійно загрожує небезпека виродження $\quad$ у толерантність пасивну. Усвідомлення плюральності і релятивності думок може призвести до деградації щирої жертовної поваги у легковажно-зневажливу лояльність, поверховість, дистанційовану індиферентність щодо Іншого i, зрештою, безпринцинність. Небезпека такої деградації криється у формально-логічному підході до розв'язання проблеми: визнання за Іншим свободи мати і висловлювати власні переконання означає або поблажливо-зневажливе, снобістське визнання його права на помилку (виходячи 3 апріорної передумови, що мої переконання - «істинні», а переконання Іншого - «хибні»), або визнання його права на істину, але, якщо ми визнаємо, що Інший - правий, то ми можемо припустити, що помиляємося ми, виходячи з іманентно притаманної для європейської культури аристотелівської логіки опозицій. Підключення сюди східної релятивної логіки (у дусі силогізмів «А $\epsilon \mathrm{B} »-« \mathrm{~A}$ не $\epsilon \mathrm{B} »,-« \mathrm{~A} \epsilon \mathrm{B}$ і не $\epsilon$ В одночасно») створює враження, що правi-yci, що «істин» - багато, що вони є відносними і контекстними (залежними від конкретних умов «вживання», а відтак - однобічними i, якщо взяти кожну із них окремо, недосконалими, оскільки Захід, на відміну від Сходу сприймає релятивізм як шлях до порожнечі, зяяння, а Схід наповнює порожнечу онтологічним змістом непізнаваної сутності - шуньяти). 3 цього приводу згадаємо міркування П. Рікера щодо «корозії» толерантності, метаморфози іiі гуманістичної сутності в егоїстичну установку, відповідно до якої «все варте й ніщо не варте того, щоб зобов'язувати нас» [277, с. 325].

Відтак, плюральність (хаотична множинність) породжує плюралізм (легалізацію множинності у нормативний принцип), який, у свою чергу, призводить до культурного релятивізму (усвідомлення відносності множинного) $i$ нісілізму (заперечення множинного і відносного). Звідси - ціла низка релятивних станів атомарного суб'єкта постмодерну: відчуження" самотність, абсурд, онтологічна нудьга", криза метафізичної ідентичності, травма, зяяння. Розмивається архетипний образ Істини як Цілого і Єдиного. 
THEORETICAL FOUNDATIONS OF THE FUNCTIONING OF EDUCATION. WAYS TO IMPROVE THE EFFECTIVENESS OF EDUCATIONAL ACTIVITIES

Яким чином подолати кризову ситуацію? Необхідно певним чином поєднати сприйняття і переживання багатоманітності культурних позицій 3 відчуттям їх внутрішньої єдності, усвідомлення наявності багатьох точок зору й одночасне прагнення до правди Цілого. Для цього потрібно представити ці точки зору як конкретні (однаково досконалі, але й однаково обмежені) вияви єдиної істини у різних її варіаціях та версіях, що відображають їі різні грані і при цьому тільки через взаємодію (діалог) можуть дати повну і цілісну картину дійсності. Отже, потрібно знайти спільний базис культурних протистоянь, який перетворює їх на альтернативні, але все ж таки часткові інтерпретації загального, виносячи за дужки руйнівні відмінності, але зберігаючи екзистенційно важливі самобутність і оригінальність кожного. Цим базисом, власне, і постає філософія діалогу як філософія Третього - Закону, мета-позиції, «Другого Іншого», тексту, посередника між Автором і Читачем, духу, про який говорив М. М. Бахтін [278, c. 293].

Третій - це спільний суддя учасників суперечки, який відіграє роль єдиної точки опори у плюральному протистоянні. Саме Третій окреслює межі толерантності, накладає ліміт на інерцію розгортання релятивізму. Третій сприяє формуванню активної толерантності на основі пасивної або попереджає iii деградацію, утримуючи їі в активному стані, не дозволяючи альтруїстичному переживанню світу перерости в індиферентну лояльність. Третій дозволяє повернутися до ідеалу абсолютних цінностей, групуючи навколо їх «вісі» взаємодію численних трактовок. Тим самим Третій запобігає кризі ідентичності і відіграє ключову роль у формуванні методологічних засад науки, культури, освіти та, зокрема, діалого-культурологічного проекту освіти. Зрештою, уся філософія діалогу у сучасному дискурсі може бути прочитана як філософія Третього між «Я» та Іншим, що перетворює їх на нерозривне і незілляне «Ми».

Водночас існує архетипічний бар’єр у спілкуванні, який заважає появі Третього. Очевидна потреба в Іншому стикається 3 життєстійкістю етнічних архетипів, ядро яких складає міфологічний поділ Всесвіту на дві нерівні за цінністю і якістю сфери: «вищу», яка асоціюється із свойми як носіями 
THEORETICAL FOUNDATIONS OF THE FUNCTIONING OF EDUCATION. WAYS TO IMPROVE THE EFFECTIVENESS OF EDUCATIONAL ACTIVITIES

культурних цінностей, та «нижчу», де мешкають чужі як «дикуни» і «варвари». Звідси - комплекси ксенофобії, реваншизму, расизму, моноетніцизму тощо. Культура етноцетричного типу спирається на розширене знання власних цінностей, яке, грунтуючись на емоційно-чуттєвій сфері, затьмарює для неї інші культури, формує їх образи відповідно до своїх фантазмів, страхів, забобонів та редукційних стереотипів - вульгаризованих зведень усієї внутрішньої багатоманітності і суперечливості кожної культурної традиції до певних крайніх, видимих переважно профанній аудиторії, знаково-символічних форм, панівних непроникних означників, що уявляються їй джерелом небезпеки, хаосу, агресії.

Як це не парадоксально, Третій відкривається у момент, коли напруження між культурами досягає апогею, і непроникна «гладкість» їх символічних форм дає тріщину, загрожує розірватися під впливом короткого семітичного змикання, коли крізь символічні означники прориваються реальність і роздирає «шви» між означниками та означуваними. Поява Третього є до певної міри неминучою. Вона випливає із пізнання людиною Чужого, але пізнання особливого, яке можливе лише за рахунок герменевтичної інтерпретації його внутрішнього світу як тексту, щзо піддається дешифровці, де|кодуванню, деконструкиї. Конфліктна ситуація, яка виникає між учасниками діалогу, тільки збільшує глибину проникнення в Іншого. Адже в умовах «Виклику»у міжкультурний континуум виходять гени-архетипи культури, які чекають на свою «Відповідь». Виникає суперечлива ситуація ідентифікацію 3 Тінню: діалог культур найефективніше відбувається в умовах протистояння свідомостей їх носїв, коли суб'єктивні ставлення не можуть зупинити процес об'єктивних запозичень. Свідомість-текст Іншого лежить перед своїм інтерпретатором, який повинен, використовуючи ресурси асоціативної пам'яті i творчої уяви проникнути через емпатію та співпереживання у цей текст та зрозуміти його прихований смисл - настільки, наскільки допускає цього сам Автор тексту i навіть і більше - зрозуміти як Реальне. Для цього потрібно уміти ставити себе на місце Іншого, тобто - вступити в процесі рефлексї у внутрішній діалог. Таке уміння особливо важливим постає для людей творчих професій (митців, 
письменників, педагогів), у яких діалог, спілкування, комунікація, порівняння себе з Іншим - читачем, глядачем, слухачем, учнем - постає основою фахової діяльності. Ще О. Мандельштам наголошував, що поет повинен прориватися до «провіденщійного співбесідника», який є невід’ємною передумовою творчого самовираження автора: «Немає лірики без діалога. - пише О. Мандельштам. - А єдине, що штовхає нас в обійми співбесідника, - це бажання здивуватися своїм власним словам, полонитися їх новизною і неочікуваністю» [5, с. 174]: немає без діалогу і педагогіки, бо за суттю вона теж є поезією спілкування.

Так народжується спільна «дитина» у діалозі «Я» та Іншого - Третій, який трансформує Хаос Чужинця на Космос, Ворога - на Друга, - хай і незбагненного, але нагально необхідного для «мого» внутрішнього виживання. Третій одомашнює Чужого, надає йому знайомих культурних рис Іншого і Ближнього, робить його зрозуміліше, відкриває його як зворотну сторону «Я», яке завдяки усвідомленню нестачі Іншого осягає і власну травму. Завдяки діалектиці Третього Чужий перетворюється на Іншого, а Інший - на Ближнього. Функціональні повноваження Третього можна розділити по двох основних напрямах: соиіально-комунікативний та морально-етичний.. Перший стосується плюралістичного характеру суспільства, мультикультурної ситуації, у якій відбувається діалог культур. Образ Третього допомагає віднайти спільну нормативну точку опори за умов наявності множинних шляхів розвитку окремих культур. Другий напрям акцентує увагу на морально-етичному фокусі діалогу, який стягує воєдино його численні лінії перетину. Мова йде про ціннісне опосередкування діалогічного прочесу. Третій відіграє роль морально-етичного критерію, який сприяє розмежуванню конструктивних і деструктивних виявів культурної активності, виключаючи з поля діалогу вульгарні редукції культур. Відтак процес соціокультурної інтеграції у діалозі культур поєднується із процесом моральної селекиї.

Конщепт Третього - цілком педагогічний, діалогічний, етичний та культурологічний. Адже Третій - це, у першу, чергу, «універсалії культури»загальнокультурні інваріанти, що піддаються безлічі історичних та регіональних 
THEORETICAL FOUNDATIONS OF THE FUNCTIONING OF EDUCATION. WAYS TO IMPROVE THE EFFECTIVENESS OF EDUCATIONAL ACTIVITIES

інтерпретацій. Культурологія ж є інтегративною наукою про смисли культури, виражені у відповідних текстах, а педагогіка є способом виховання учня через культуру, вона має високий культурологічний потенціал, будучи формою здійснення трансляції культурної пам’яті. У цьому контексті концепт Третього та діалог як «взаємопроникнення смислів» за посередництва символічної іпостасі Третього постає спільною предметною основою культурології, педагогіки, філософії діалогу та етики Іншого одночасно.

Універсальні смисли культури потрібно сприймати як апріорну данicmb, оскільки наявність або відсутність їх не верифікується через позитивістські методи. У межах критичного бачення можемо говорити лише про умовні риси універсалій. Дані смисли є: екзистениійними, оскільки сягають глибинних духовних основ людського буття в його інтимно-трансцендентальному вимірі. Вони є трансперсональними (одухотвореними, але не особистісними), оскільки поєднують інтимну сингулярність 3 універсальністю людства; інтеркультурними (полегшують процес спілкування між культурами); кроскультурними («перетинають» культурні кордони) i водночас транскультурними (трансцендентними стосовно частковостей культурного простору і водночас іманентно притаманними внутрішньому світові кожного суб’єкту даного простору, - отож, можемо стверджувати їх транскультурність як «інтракультурність»). Найбільші труднощі полягають у спробі науково конкретизувати зміст універсальних смислів, буття яких виходить за межі раціоналістичного дискурсу. Хаос і космос, життя і смерть, чоловіче і жіноче, добро i зло, любов і ненависть, краса і потворність, істина i хиба, свобода i відповідальність, тривога і мужність, самотність і соборність, благо і шкода- ось неповний перелік «ликів» Третього.

В етиці поняттю універсалій відповідає категорія «загальнолюдські цุінності» як значущі для людства категорії високої моральні вартості. На рівні гносеології Третій - це Істина при багатоманітності пізнавальних підходів до неї. На рівні теологічного підходу Третій - це Бог при багатоманітності духовних шляхів до нього. У мистецьких діалогах Третій складає правду Цілого, яка, 
THEORETICAL FOUNDATIONS OF THE FUNCTIONING OF EDUCATION. WAYS TO IMPROVE THE EFFECTIVENESS OF EDUCATIONAL ACTIVITIES

будучи невисловленою, у формі невербального підтексту плаває у паузах між репліками (пригадаємо «принщ̧ип айсбергу» - прихованого змісту твору - в постулатах Е. Хемінгуея, Е.Р.М. Ремарка, А.П. Чехова, М. Цвєтаєвої, М. Басьо). Наявність «Третього» формує головний результат діалогу - почуття активної толерантності як універсальної духовної якості людини, яка через переживання своєї спільності 3 Іншим здатна до допомоги йому як Ближньому i до усвідомленого злиття двох нестач - своєї та Іншого - в любові.

Коли ми звертаємося до прикладних кейсів діалого-культурологічного проекту навчання, у першу чергу, постає запитання: що $є$ його кінцевим продуктом? Яким є ідеал освіченої людини в контексті діалогу культур? Збагнути його сутність видається надзвичайно важливим, адже цей новий тип релігійної особистості, як «Велике напередодні», є і досі уявним проектом, алгоритмом, розгортання якого кардинальним чином позначиться на долі культур. Чи буде ця людина майбутнього постмодерною «надлюдиною» у дусі Ф. Ніцше чи М. Фуко чи «вищою людиною» модерну, як того М. Гайдеггер та Ю. Габермас? Наразі можемо судити лише про окремі абриси світогляду діалого-культурологічної особистості. Очевидно, що це повинна бути особистість, що володіє здатністю віднаходити Третього у міжкультурному спілкуванні. Основою ï світогляду повинна стати культура діалогу (діалогічна свідомість) - відкритість світові різноманітних духовно-емоційних, ментальних, цивілізаційних, етнічних, конфесійних традицій, які пронизують внутрішній світ «людини культури» у якості їі інтеріорних складових та синхронно взаємодіють у ньому. Така людина повинна бути готова до емпатійного пізнання Іншого, поваги до нього, турботи про нього, відповідальності за нього і співпраці з ним на основі щирої, альтруїстичної зацікавленості чужими культурами, які стають органічною складовою іï власної самості, не відтинаючи при цьому сутнісно необхідні умови їі власної екзистенції. Традиційний партикуляризм у поліфонії культур за принципом матрьошки вкладається в модерний універсалізм єдності людства як поля міжкультурного діалогу. Діалог є формулою єдності у багатоманітності, погодження універсалізму з партикуляризмом. 
THEORETICAL FOUNDATIONS OF THE FUNCTIONING OF EDUCATION. WAYS TO IMPROVE THE EFFECTIVENESS OF EDUCATIONAL ACTIVITIES

Можемо говорити про три головні компетениії діалогічної свідомості нашого вихованця: культурологічна освіченість, сочіальна комунікативність $i$ активну толерантність. Перша риса - культурологічна освіченість - відбиває інформаційну евристичну компетенцію людини, iї обізнаність із фактом існування Чужого, не схожого на мене. Друга риса - соиіальна комунікативність - засвідчує уміння вступати у взаємодію з Чужим як з Іншим (дивним, але не ворожим сусідом). Третя риса - активна толерантність - вищий етап еволюції діалогічної свідомості до рівня любові - пов’язана із універсальною моральнодуховною компетенцією людини, іiі здатністю жертовно ставитися до Іншого як до Ближнього - у первинному, біблійному сенсі цього слова (співзвучну думку у контексті релігієзнавства висловлює бельгійський дослідник Б. Роббен, класифікуючи релігійну освіту на «мульти-, інтер- та інтрарелігійний» iї типи $[280$, c. 5-6]).

Різноманітні освітні технології в Україні мають великий досвід формування такої людини. Так, наприклад, в окремих навчальних закладах упроваджувалися методи «иколи діалогу культур» (експериментальної програми В. Біблера, яку застосовували Г. Балл, А. Волинець, В. Литовський, В. Возняк та інші); школи «особистісно орієнтованого навчання» («педагогічної майстерності» I. Зязюна). Водночас зазначені експериментальні майданчики, стосувалися, в основному, загальної середньої освіти, і наразі - їх недостатньо для формування високої комунікативної культури учня у плюральному соціумі. Нові методологічні та методичні кейси пропонованого нами діалогокультурологічного проекту навчання $€$ спробою заповнення зазначеного педагогічного вакууму та виявляються у таких позиціях: а) культурологічний підхід до філософії діалогу; б) проекція культурології діалогу на освіту; в) урахування негативних наслідків міжкультурного діалогу (криза ідентичності) та вироблення шляхів їх подолання (концепт Третього в діалозі); г) забезпечення спадковості діалогічного навчання у межах вищої та середньої освіти.

Перший кейс діалого-культурологічного проекту освіти: діалогічна гра. Даний проект грунтується на поєднанні філософії діалогу та культурологї через 
THEORETICAL FOUNDATIONS OF THE FUNCTIONING OF EDUCATION. WAYS TO IMPROVE THE EFFECTIVENESS OF EDUCATIONAL ACTIVITIES

семантичну трактовку діалогу культур як взаємодї̈ смислів. Якщо діалогічна філософія складає методологічний світоглядний аспект нашого проекту, то культурологічне знання складає його внутрішній навчальний зміст. У контексті діалого-культурологічного підходу вихованець перестає бути просто учнем чи студентом: він перетворюється у Творияя та Iнтерпретатора Тексту Культури, активного учасника смислових процесів, які відбуваються всередині іiі життєсвіту та всередині індивідуального духовного світу учня або студента.

Відтак, першоджерела, оригінальні тексти культури (а не лише тексти критики, коментарі другого, третього і т.д. порядків) стають живим змістом культурологічної освіти, а герменевтична інтерпретація як процедура діалогу із методу культурологічного дослідження перетворюються у метод навчання i виховання. Мова йде не тільки про різні типи уроків, лекцій та семінарських занять, але й про діалогічні заняття: наприклад, автор цього дослідження регулярно проводить із студентами студії-діалоги у формі рольової гри, темою якої є диспут «героїв» різних культур з приводу універсалій («сенс людського буття», «образ людини» тощо). Під час такої культурологічної гри студенти через інтерпретацію оригінального тексту культури «переймаються» світом обраної ними традиції і навчають мистецтву полеміки з іншими точками зору.

Другий кейс діалого-культурологічного проекту освіти: зближення сакрального та секулярного світоглядів. Даний проект має специфічну спрямованість на освіту як на простір діалогу релігійних та світських традицій. Ідея діалогу культур репрезентується через ідею взаємодї сакральних смислів даних культур, взятих у їх світському культурологічному розумінні $і$ навпаки: світські тексти інтерпретуються як приховано релігійні. Така кореляція дозволяє глибше осягнути архетипи культури, оскільки найбільш глибинні діалогічні «дотики» культур відбуваються саме у межах релігії. Крім того, синтез культурології, педагогіки, етики та релігієзнавства у межах даного проекту відповідає пріоритетним тенденціям до інтегращії гуманітарних наук, результатом якої є виникнення нових галузей знання, які складають основу відповідних університетських спеціальних курсів. Результатом нашої спроби 
THEORETICAL FOUNDATIONS OF THE FUNCTIONING OF EDUCATION. WAYS TO IMPROVE THE EFFECTIVENESS OF EDUCATIONAL ACTIVITIES

застосування культурологічної методології в релігієзнавстві та релігієзнавчого матеріалу в культурології є розроблені автором спеціальні курси для студентів спеціальностей «Культурологія» та «Релігієзнавство»: «Культура стародавніх цุивілізацій», «Типологія культур Сходу», «Культура і релігія», «Культурологічні проблеми релігійно-філософської думки», «Філософія Іншого та етика діалогу». Особливо важливим, з огляду на наш проект, є курс «Філософрія Іншого та етика діалогу», оскільки він вводить студентів одразу у теоретичний, етичний, ментальний, релігійний та культурологічний контекст парадигми Іншого i Третього), забезпечуючи базову світоглядну підготовку на активну толерантність. Цей курс допомагає вихованцю в умовах релятивізму та плюралізму подолати тіньовий «виворот» діалогу - втрату культурної ідентичності за допомогою залучення універсальної етики. Ключову роль у цьому відіграє концепт Третього як ключова категорія філософії діалогу, яка стає головною концептуальною засадою освітнього процесу.

Третій кейс діалого-культурологічного проекту освіти: спадковість освіти. Пропонований проект сприяє не лише діалогу культур, але й становленню продуктивної взаємодії середньої ma вищуої освіти через упровадження у загальноосвітніх школах адаптованих елементів зазначених академічних університетських курсів. На основі упровадження діалогокультурологічного проекту у вищій школі нами розроблено та затверджено МОН України оригінальний авторський інтегрований експериментальний факультативний курс “Розмаїття релігій $i$ культур світу”, що нині впроваджується в навчально-виховний процес в окремих середніх загальноосвітніх навчальних закладах. Курс призначений для учнів 1-12 класів та спроектований як альтернативний курсам секулярної та релігійної етики [7]. Мета курсу - компаративний аналіз різних типів культур на підставі спільних изінностей (універсалій): індо-буддійської, японо-буддійської, даоськоконфуціанської, арабо-мусульманської, християнської. У змісті курсу цей аналіз репрезентований як своєрідна співбесіда-перекличка різних голосів культури 3 універсальних проблем людства. 
THEORETICAL FOUNDATIONS OF THE FUNCTIONING OF EDUCATION. WAYS TO

IMPROVE THE EFFECTIVENESS OF EDUCATIONAL ACTIVITIES

Таким чином, діалог з Іншим, який веде учень або студент, завершується діалогом дорослої людини зі світом. Водночас у самому використанні дієслова «завершувати» щодо діалогу відчувається відверта итучність: справжній діалог ніколи не можна завериити - його можна лише перервати. Перервати після закінчення школи, щоб наразі розпочати знову у зрілому віці життя, занурюючись у глибини ціннісних спектрів Чужинця, який став Другом. Власне, саме така здатність визначає тип людини XXI ст. на межі модерну та постмодерну і виховується через евристичні, соиіально-комунікативні та морально-духовні компетенциї поступової еволюції свідомості вихованця від Чужсго через Іншого до Ближнього, від мови ненависті через мову активної толерантності до мови любові й солідарності.

Діалого-культурологічний проект навчання - це педагогічна розмова у стилі «нон-стоп» на грунті синтезу філософії, етики та культурологї в освіті, розмова, подібна до сократівського діалогу, де «любов до мудрості» (Philia Sophia) поста' як рух до горизонту істини, яка одночасно пізнавана та непізнавана, близька та далека, передує діалогу і наслідує його, творить суб'єкта як подія і твориться ним в історії культури. Можливо, це буде видаватися утопією, але, пригадаймо «Вірую, тому що абсурдно» Квінта Тертуліана - цю геніальну формулу глибинної «справжності», практично повторену в слогані студентів Сорбонни 1968 року: «Будьте реалістами, вимагайте неможливого». діалог є механізмом радикального розриву з прагматикою панівних означників. Його результатом постає одночасно нове і старе відкриття, оскільки традиція є інновацією за умов іiі нового переживання, а інновація - традицією за умов іiі номінації старими іменами. Людина відкриває у своєму індивідуальному мікрокосмі увесь макрокосм думок і почуттів людства і при цьому не втрачає власної ідентичності, тому що відчуває «свою-чужу» цілісність і самототожність.

Реалізуючи людство, така людина реалізує себе, і навпаки: реалізуючи себе, реалізує людство. «Возлюби ближнього свого», переломлене крізь кантівський категоричний моральний імператив і загартоване у постмодерних 
THEORETICAL FOUNDATIONS OF THE FUNCTIONING OF EDUCATION. WAYS TO

IMPROVE THE EFFECTIVENESS OF EDUCATIONAL ACTIVITIES

інтелектуальних битвах, - таким є остаточний девіз діалого-культурологічного проекту освіти. Щоб зрозуміти Іншого, потрібно залищатися Собою, - щзоб зрозуміти Себе, треба в самому собі стати Іншим. Можна заперечити: ідея діалогу, дійсно, не є новою, але просто відкладеною людством на полицю майбутнього пильною старою книгою, але «витіснене повертається». Воно повертається у новій інтерпретації Іншого через Третього, поєднуючи сакральний досвід традиції з універсальною етикою, а культурологічну гру - 3 онтологічною істиною.. 
THEORETICAL FOUNDATIONS OF THE FUNCTIONING OF EDUCATION. WAYS TO

IMPROVE THE EFFECTIVENESS OF EDUCATIONAL ACTIVITIES

DOI 10.46299/ISG.2021.MONO.PED.II-307-313

\section{9 Тайм-менеджмент та його роль в системі дистанційного навчання закладу освіти}

Навчання в закладах освіти - один із найважливіших періодів життя сучасної молодої людини, особистісного росту і становлення їі як фахівця. В більшості навчальних закладів здобувачі освіти не володіють необхідними для навчання i життя методами i навичками самоорганізації. Організація навчального процесу є проблемою, від вирішення якої залежить успішність у навчанні та подальшій кар’єрі майбутнього фахівця. Вирішення поставленого завдання потребує розроблення та впровадження нових шляхів успішної адаптації до змінених соціальних умов і нової діяльності. Все це вимагає від учасників навчального процесу значної мобілізації власних можливостей для успішного входу в нове оточення і якісно інший ритм життєдіяльності. В процесі адаптації до соціальних змін у молоді, що навчається, відбувається формування стійких механізмів комунікативної взаємодії із середовищем. Головним помічником в організації навчального процесу його може стати таймменеджмент - окремий напрям менеджменту, спрямований саме на вирішення проблем організації часу та встановлення пріоритетів при його використанні. Тайм-менеджмент допомагає визначити, що є головним і потребує організації, планування, а що - другорядним, допомагає контролювати власний час, розпоряджатися ним. Недостатня увага до тимчасової організації розумової праці завдає серйозної шкоди здоров’ю і негативно позначається на навчальних досягненнях здобувачів освіти.

Нещодавня доктрина розвитку освіти в Україні підкреслила необхідність рівного доступу до якісної освіти для усіх громадян. Основною вимогою сучасної якісної освіти є застосування електронних та інтернет-орієнтованих засобів у навчанні. Проблема дистанційного навчання в українській освіті набула широкого вивчення, проте зі швидкою зміною вимог до сучасних технологій навчання $€$ нестача повної інформації про вплив мотиваційних факторів на успішність дистанційного навчання. Закон України «Про освіту» наголошує на 
THEORETICAL FOUNDATIONS OF THE FUNCTIONING OF EDUCATION. WAYS TO IMPROVE THE EFFECTIVENESS OF EDUCATIONAL ACTIVITIES

інформаційному забезпеченні освітнього процесу навчального закладу, як стандарту освітньої діяльності [282]. У цьому вимірі виникає питання збереження мотивації учасників освітнього процесу при дистанційному навчанні 3 метою отримання якісного результату. Тайм-менеджмент в закладах освіти здійснювався структурованою вертикаллю - фахівцями 3 відповідними посадовими зобов'язаннями та навиками. 3 переходом до дистанційної форми навчання, доводиться перелаштовувати і цю вертикаль, з метою збільшення автономії всіх учасників навчального процесу. Але така автономія дає і негативні наслідки, зокрема розпорошення уваги між навчальним контентом та багаточисленним інструментарієм дистанційного навчання.

Одним з пріоритетних напрямів програми модернізації загальноосвітньої та вищої школи визнане дистанційне навчання. В сучасних умовах існує потреба отримання вищої освіти дистанційно, що викликано необхідністю навчатися без відриву від виробництва, отримання освіти людьми 3 обмеженими можливостями та тими, що перебувають за кордоном тощо. Таку можливість надає дистанційне навчання, яке здійснюється завдяки інформаційно-освітнім технологіям і системам комунікації [283]. Дистанційна форма навчання має ряд беззаперечних переваг. Наприклад, здобувач вищої освіти може навчатися у зручний для нього час, звичному оточення та у відносно автономному темпі. Варто врахувати також і нижчу вартість такого навчання, оскільки відпадає потреба в оренді та утриманні приміщень, оплаті значної кількості персоналу, та економію часу [284].

Проте, система дистанційного навчання має і недоліки. При тривалому дистанційному навчанні здобувач освіти перестає правильно формулювати свої думки, висловлюватись та проводити дискусійне обговорення. Разом з тим, така форма навчання потребує свідомого і вмотивованого підходу до отримання освіти. Можливість навчатися у зручний час може перетворитися не на систематичне навчання, а на постійну прокрастинацію цього виду діяльності. Саме тому дистанційна форма потребує особливої самоорганізованості та вміння 
THEORETICAL FOUNDATIONS OF THE FUNCTIONING OF EDUCATION. WAYS TO

IMPROVE THE EFFECTIVENESS OF EDUCATIONAL ACTIVITIES

розрахувати свій час. I наразі, актуальним в самоорганізації постає таймменеджмент.

В повсякденному житті кожна людина стикається із проблемою розподілу свого часу. Розуміння того, що таке тайм-менеджмент та якими є його принципи, дозволяє не лише досягати цілей з мінімальними зусиллями, а й у потрібні терміни [285].

Тайм-менеджмент - це раціональний розподіл годин в добі так, щоб і все встигнути, і спати повноцінні 7-8 годин, і бути ефективним, i залишатися здоровим. Це управління часом. Це така навичка, яку варто «прокачувати» постійно.

В управлінні часом можна визначити такі процеси:

- Аналіз.

- Моделювання стратегій, враховуючи проведений аналіз.

- Цілепокладання: постановка мети або визначення ключового напрямку розвитку. Визначення та формулювання мети (цілей).

- Планування і розстановка пріоритетів. Розробка плану досягнення поставлених цілей і виділення пріоритетних (першочергових) завдань для виконання.

- Реалізація - конкретні кроки та дії відповідно до наміченого плану і порядку досягнення мети.

- Контроль за досягненням мети, виконанням планів, підведення підсумків за результатами проведеної роботи.

Міфи про «Тайм-менеджмент»:

- Міф 1. Тайм-менеджмент — це розпланувати день похвилинно.

- Міф 2. Є універсальні поради з управління часом, які підходять усім.

- Міф 3. Тайм-менеджмент не для творчих людей.

Розвіюючи ці міфи, потрібно чітко розуміти якою $є$ кінцева мета, а відповідно - виділити головні завдання. У цьому доречно буде звернутися по допомогу до піраміди Франкліна (Рис. 1). 


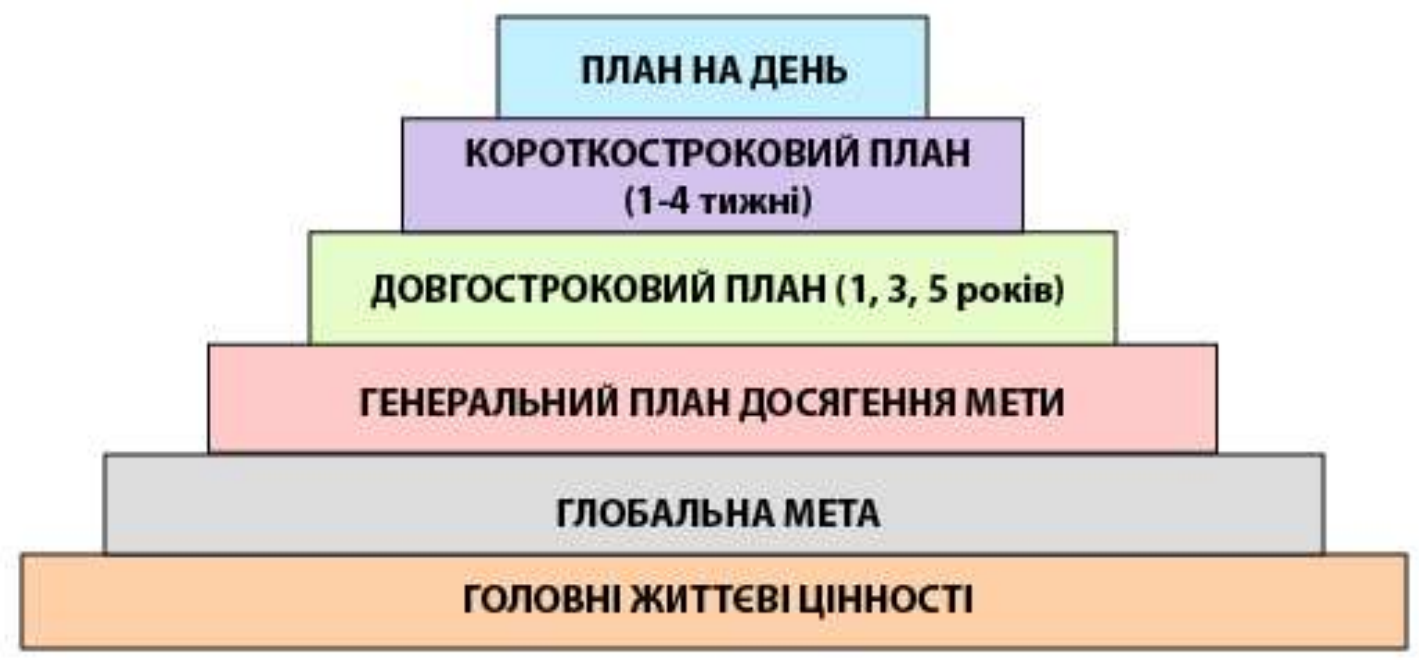

Рис. 1. Піраміда Франкліна

Піраміда Франкліна (ії також називають пірамідою ефективності) - це комплексна система постановки і досягнення цілей, яка розрахована на все життя. Відмінність піраміди Франкліна від інших методик у тому, що вона планує не тільки час, але і зайнятість, шляхи досягнення глобальної мети.

Ця техніка «спрямована в майбутнє» - визначає те, що повинно бути зроблено, а не концентрується на перегляді поточної діяльності, щоб організувати іï ефективніше. Наразі лише 1\% людей можуть точно сказати, чого вони хочуть досягти в житті. Але Франклін ще в юності склав план досягнень і намагався його виконувати. Суть полягала в наступному: глобальне завдання розбивалося на більш дрібні, а ті, в свою чергу, ще на дрібніші. Це - основна ідея піраміди Франкліна [286].

Заповнювати їі потрібно знизу вгору. Так ви сформулюєте глобальні цілі, виходячи з життєвих цінностей. Генеральний план - виходячи з глобальної мети і так далі. I так серед щоденних завдань легко буде виділити ті, які потрібні для досягнення ваших цілей. Вони і стануть пріоритетними.

Якщо застосувати піраміду Франкліна у системі дистанційного навчання, то можна виокремити наступне:

- Перелік навчальних предметів. Здобувачу освіти важливо знати повний перелік навчальних предметів, що вивчатимуться протягом певного періоду (наприклад, року). 
- Кожен предмет важливий, кожному предмету відповідна кількість годин. Кожен предмет повинен містити перелік тем та загальну кількість годин на іï вивчення.

- Кожна година (урок, заняття) значима і використати ії треба максимально ефективно (план уроку, заняття).

3 метою економії часу та зменшення ефекту «розпорошування уваги» було б доцільно прийняти в закладі освіти:

- Чіткі правила роботи он-лайн (одні для всіх).

- «Єдину точку входу» - інструментів для здійснення дистанційного навчання дуже багато, але всі учасники навчального процесу мають знати звідки починається кожен навчальній день (урок).

- Визначення платформ для ведення дистанційного навчання (з урахуванням побажань викладачів та здобувачів освіти).

Однією з головних навичок для здобувачів освіти є «вміння вчитись», саме ця навичка виходить на перший план в дистанційному навчанні. I для його успішного опанування пропонується «Дорожня карта» для того, хто навчається:

1. Структура навчального процесу (загальний об'єм).

2. Навчальний план (план курсу).

3. Чіткий розклад (кількість занять, тривалість, платформа, тип заняття).

4. Домашнє завдання, правила та рекомендації щодо його виконання.

5. Оцінювання домашнього завдання.

6. Самооцінка

У системі дистанційного навчання для кожного домашнього завдання необхідні чіткі рекомендаційні поради, можливо із написанням відповідних інструкцій, щодо їх виконання. Такий чіткий план дозволить здобувачу освіти зосередитися на виконанні завдання, а не витрачати час на «здогадування» «Що», «Де» i «Як» виконувати.

Прикладом такої чіткої інструкції можуть бути наступні вимоги/рекомендації:

1. Відкрити файл ... 
2. Вирішити, розв'язати ...

3. Доповнити завдання (відповідь) авторським рішенням...

4. Приєднати файл....

5. Здійснити самооцінку в табелі просування...

В процесі дистанційного навчання важливим $є$ контроль знань. Для закріплення навчального матеріалу та контролю знань бажано використовувати тестові завдання різних типів:

- тренувальні тести - безліч спроб надання відповідей, миттєве отримання оцінки, можливість бачити правильні відповіді;

- підсумкові тести - контроль знань з однієї спроби надання відповіді, миттєве отримання оцінки.

Цікавим і корисним для застосування тайм-менеджменту у дистанційному навчанні може бути матриця Ейзенхауера.

Матриця Ейзенхауера - це відмінна модель для розстановки пріоритетів. За iï допомоги можна виділити найважливіші завдання, відсіявши все зайве. Сенс цієї моделі полягає у швидкому розсортуванні списку справ, навіть якщо їх багато. Зовні все виглядає гранично просто - дивимося на список завдань і по кожному відповідаємо собі на два питання: 1) Це важливо? - Так / ні; 2) Це терміново? - Так / ні (Рис. 2).

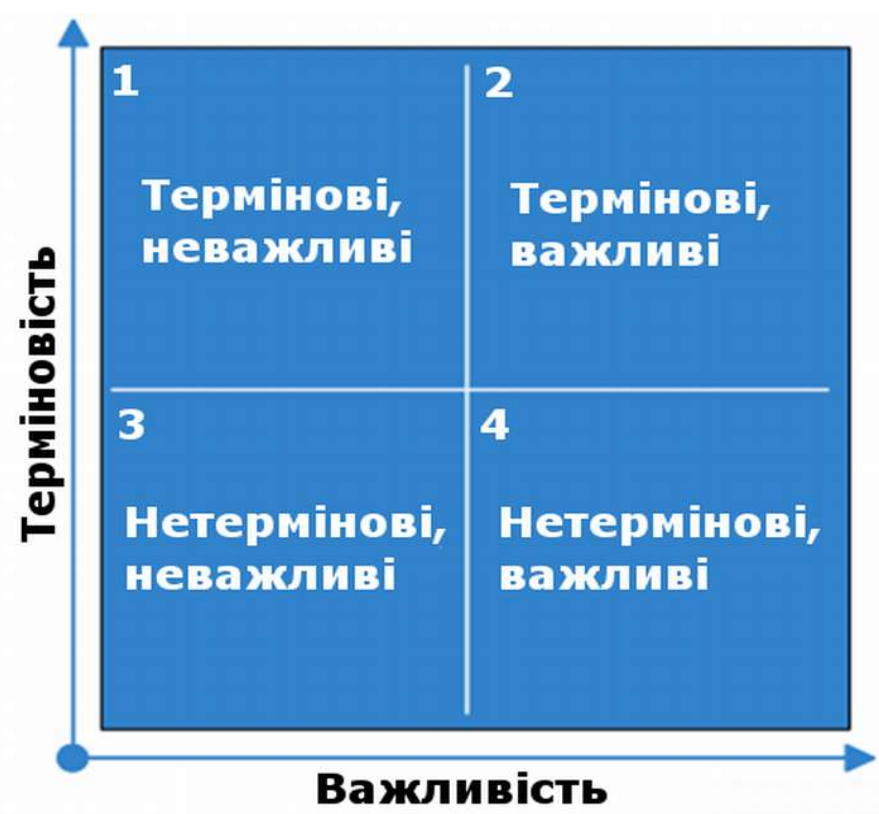

Рис. 2. Матриця Ейзенхауера 
Сенс матриці Ейзенхауера полягає в оцінці конкретного завдання по параметрам важливості / терміновості і сортуванні списку справ за цим принципом. 3 якою метою це використовується на практиці? Тут є два варіанти:

- Планування. Дуже часто людина орієнтується в першу чергу на дедлайни завдання, забуваючи оцінити їх необхідність. Даний метод допоможе зосередити свої сили на тих речах, які дійсно будуть наближати до поставленої мети.

- Оцінка особистої ефективності. Якщо в кінці тижня або місяця заносити в таблицю виконані завдання, то таким чином можна проаналізувати своє вміння розставляти пріоритети. I зрозумівши, які помилки були допущені, - більш конструктивно спланувати свої справи на наступний відрізок часу [287].

Одним із найважливіших завдань будь-якого закладу освіти при використанні системи дистанційного навчання, є дії, спрямовані на швидку й успішну адаптацію до такої форми навчання, ефективне формування соціальних відносин, освоєння нової ролі як викладачами, так і здобувачами освіти.

На ефективність адаптації учасників навчального процесу до дистанційного навчання у закладах освіти впливає такий фактор, як вміння керувати своїм часом. I тут в нагоді буде трактування сутності поняття «тайм-менеджмент» на основі піраміди Франкліна та матриці Ейзенхауера. Бо, саме використання таймменеджменту - це крок до покращення продуктивності навчання, який надає можливість ефективно спланувати свій розпорядок дня, тижня i процесу навчання в цілому. Недотримання планів і невиконання поставленої мети призводить до постійної нестачі часу, зниження мотивації i, як наслідок, негативного результату процесу навчання. 
THEORETICAL FOUNDATIONS OF THE FUNCTIONING OF EDUCATION. WAYS TO IMPROVE THE EFFECTIVENESS OF EDUCATIONAL ACTIVITIES

DOI 10.46299/ISG.2021.MONO.PED.II-314-325

\subsection{0 Концепция применения средств информационно- коммуникационных технологий в обучении физике}

Введение. В настоящее время в Казахстане происходят серьезные преобразования в сфере информатизации общества, перехода на информационно-коммуникационные технологии, автоматизированное, высокотехнологичное производство. Информатизация общества предполагает повсеместное внедрение информационных и коммуникационных технологий практически во все сферы жизни и деятельности человека. Он трансформирует все структуры общества и влияет на систему образования.

Информатизация образования должна выходить за рамки информатизации других сфер общественной деятельности, потому что именно здесь начинают формироваться социальные, психологические, общекультурные, профессиональные предпосылки информатизации всего общества. Однако остается еще много нерешенных вопросов.

C начала и до наших дней основную ношу информатизации несут школьные учителя и преподаватели вузов «на своих плечах». Некоторые университеты ушли здесь далеко вперед, а другие сильно отстают. Это свидетельствует о несоответствии фактического и необходимого уровня действий учителей по использованию информационно-коммуникационных технологий в образовательном процессе.

\subsection{1. Психолого-педагогические основы информатизации} физического образования

Психолого-педагогические исследования, выполненные в русле психологической теории деятельности человека и теории учебной деятельности, показывают, что наиболее, оптимальной с возрастной точки зрения следует считать трёхступенчатую модель использования информационной техники в физическом образовании [288].

Первый этап - младшая школа: развитие элементарной компьютерной грамотности и информационной культуры. 
THEORETICAL FOUNDATIONS OF THE FUNCTIONING OF EDUCATION. WAYS TO IMPROVE THE EFFECTIVENESS OF EDUCATIONAL ACTIVITIES

Второй этап - общеобразовательная школа: освоение новых областей знаний по принципу - совместно с учителем и сверстниками, построение и описание школьных дисциплин. Компьютер в этом возрасте можно использовать как многофункциональный инструмент для редактирования текстов, проведения лабораторных экспериментов, мастер-классов, разработки совместных проектов и т. д.

Третий этап - старшая и высшая школа: благодаря широкому знанию всех областей профессиональной деятельности человека, c помощью компьютерного моделирования студенты учатся строить и управлять важнейшими производственными процессами и социальной деятельностью людей. На этом этапе используются информационные инструменты для развития навыков самообразования и переподготовки.

Информатизация физического образования является одной из форм интенсивного проникновения современных человеко-машинных систем во все сферы общественной жизни. Согласно теории таких систем [289] их ведущим компонентом является человеческая деятельность, а машинный компонент выступает как орудийное средство её эффективной реализации. Человеческая деятельность имеет много разных видов и форм, генетически исходной основой которых является трудовая деятельность.

Использование компьютерных технологий позволило создать обучающие машины типа тренажера, реализующие процесс выполнения упражнений и проверки усвоения знаний и умений по различным предметам, в том числе по физике. Но при этом механизированы не столько операции обучающего действия обучающегося, который овладевает знаниями и умениями, сколько некоторые операции учебной работы (что, конечно, важно само по себе). В результате при ознакомлении студентов с новыми областями знаний и организации учебной деятельности такие системы не преодолели, а, наоборот, обострили противоречия, присущие традиционному безмашинному обучению. 
THEORETICAL FOUNDATIONS OF THE FUNCTIONING OF EDUCATION. WAYS TO IMPROVE THE EFFECTIVENESS OF EDUCATIONAL ACTIVITIES

Применение средств информационно-коммуникационных технологий в учебном процессе является не только предпосылкой совершенствования обучения, но и потенциальным источником негативных последствий. В частности, использование компьютера может послужить причиной распада целостной системы "учитель-класс" на отдельные элементы типа "учениккомпьютер" контролируемые преподавателем. Поэтому специальной задачей проектирования информационно-коммуникационных технологий обучения является поиск способов организации учебного процесса.

Как считает психолог Рубцов В.В. [289] целостность организации учебного процесса является необходимым условием для разработки человекомашинных систем образовательного назначения. По его мнению, она может быть достигнута за счёт трёх основных аспектов:

- управления познавательной активностью отдельных школьников;

- управления учебной деятельностью как системой "учитель-компьютерученик";

- управления взаимодействиями и сотрудничеством учителя и учащихся, самих учащихся.

Первая группа требований связана с выбором и характером рекомендованного к усвоению материала, что определяет предметносодержательную основу создаваемой учебной среды. Выполнение этих требований обеспечит единство психологической основы того или иного учебного предмета или его раздела и тех учебных действий и операций, с помощью которых учащиеся смогут успешно идентифицировать происхождение теоретически обобщенных знаний.

Вторая группа требований касается оперативного обеспечения учебных действий обучающихся, а также режимов обмена действиями между пользователем и машиной.

Третья группа относится к организационной поддержке учебной среды, которая состоит из конфигурации системы и списка способов взаимодействия 
THEORETICAL FOUNDATIONS OF THE FUNCTIONING OF EDUCATION. WAYS TO IMPROVE THE EFFECTIVENESS OF EDUCATIONAL ACTIVITIES

преподавателей и учеников. (Более подробно требования описаны в [289]).

Успешное достижение педагогических целей при использовании информационно-коммуникационных технологий возможно в условиях функционирования информационно-образовательной среды, под которой понимается совокупность условий, способствующих возникновению и развитию процессов информационно-образовательного взаимодействия между студента (ов), преподавателя и средств информационных технологий, а также формирования познавательной деятельности студента при условии, что компоненты среды (различные виды учебного, демонстрационного оборудования, сопряженные с компьютерными технологиями, программным обеспечением и системами), учебно-наглядные пособия и др.) наполнены предметным содержанием определенного учебного курса. [290].

Информационно-учебная среда включает средства и технологии сбора, накопления, передачи, обработки и распределения учебной информации, средства представления знаний, обеспечивая связь и функционирование организационных стРуктур педагогической деятельности.

Цель информационно-обучающей среды: выявление, раскрытие и развитие способностей личности и потенциала творческой инициативы: создание условий для самостоятельного извлечения знаний и их качественного усвоения, обеспечение автоматизации процесса обработки результатов обучения, в том числе результатов. успеваемости в обучении; компенсирующие негативные последствия общения студента средствами информационных и коммуникационных технологий.

Реализация процесса информатизации физического образования возможна при наличии развитой учебно-информационной базы. Для создания такой базы, отмечает Роберт И.В. [290], должны быть решены комплексные проблемы:

- производство-комплектов учебной вычислительной техники, отвечающих техническим, психолого-педагогическим и эргономическим 
THEORETICAL FOUNDATIONS OF THE FUNCTIONING OF EDUCATION. WAYS TO

IMPROVE THE EFFECTIVENESS OF EDUCATIONAL ACTIVITIES

требованиям;

- создание системы сервисного обслуживания технических и программных средств;

- создание лабораторий предназначенных для проведения учебных экспериментально-исследовательских работ, с использованием средств информационных технологий;

- создание распределённой системы государственных и локальных баз данных и баз знаний учебного назначения;

- создание телекоммуникационной сети учебного назначения регионального и межгосударственного масштабов;

- интеграция ведомственных, территориальных и других вычислительных систем учебного назначения в единую Государственную информационно-вычислительную сеть, ориентированную на использование в системе образования.

Результатом педагогического воздействия является раскрытие и развитие потенциала личности, их совершенствование; развитие умения самостоятельно приобретать знания и открывать изученные закономерности; развитие способности принимать решения в изменяющихся внешних условиях.

Реализация возможностей информационно-коммуникационных технологий в образовании создает предпосылки для формирования информационной культуры образовательной деятельности, повышает мотивацию обучения за счет возможности самостоятельного выбора форм и методов обучения. А использование учебного оборудования, функционирующего на базе средств информационно-коммуникационных технологий, обеспечивающего проведение экспериментальноисследовательской деятельности при изучений процессов, протекающих в реальном мире, или изучение поведения моделей этих процессов создают предпосылки для раскрытия и самораскрытия творческих возможностей и способностей индивида, что, в свою очередь, приводит к развитию аналитика- 
THEORETICAL FOUNDATIONS OF THE FUNCTIONING OF EDUCATION. WAYS TO

IMPROVE THE EFFECTIVENESS OF EDUCATIONAL ACTIVITIES

синтетических видов мышления. Это является основой интенсификации процесса развития личности обучаемого.

Таким образом, в связи с информатизацией образования изменяется парадигма педагогической науки (система основных научных теорий и методов педагогической науки, по образу которых организуется исследовательская деятельность и практика ученых-педагогов, направленная на разработку стратегии отбора содержания и организационных форм, методов обучения и воспитания [291].

В основе концепции лежат следующие требования для создания и дальнейшего использования информационных и коммуникационных технологий в обучении физике: 1. Современные требования к организации учебного процесса; 2. Создание условий для усиления самостоятельной работы студентов; 3. Выполнение принципа непрерывности; 4. Внедрение современной науки и техники; 5. Обеспечение современной научной организации преподавателей и студентов; 6. Унификация информационных и коммуникационных технологий в обучении физике; 7. Выполнение принципа гуманизации.

Стержнем концепции явилась блочная модель автоматизированного комплекса обучения физике, набор блоков (базовых, дополнительных, традиционных и организационных приемов), обеспечивающих плавный переход от традиционных методов обучения физике к использованию информационно-коммуникационных технологий.

Концепция учитывает возможность использования информационнокоммуникационных технологий в контексте дифференциации и индивидуализации обучения (см. схему, рис.1). 


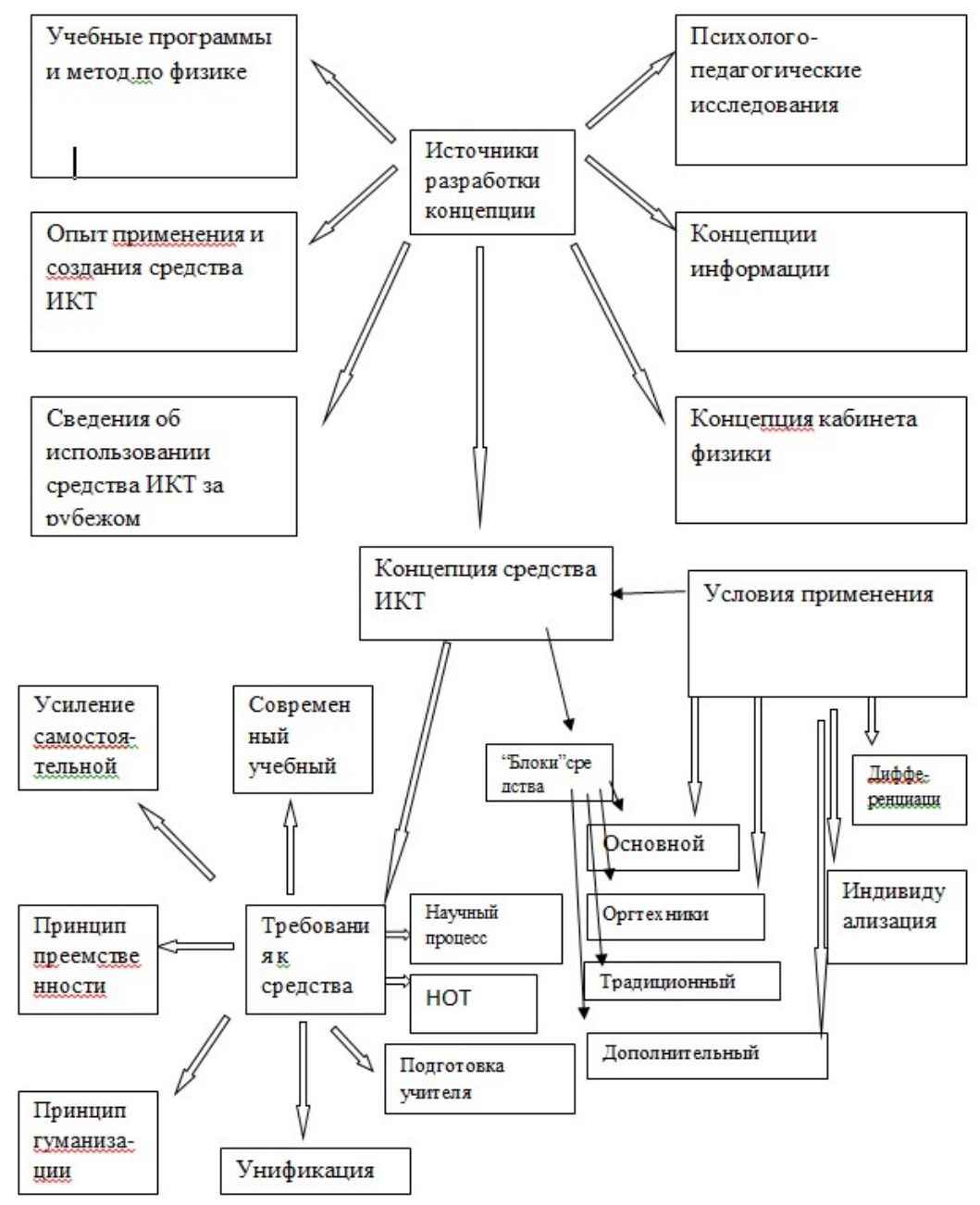

Рис.1 Блок-схема концепции применения средств новых информационных технологий обучения физике

\subsection{2 Дидактические возможности средств информационно-} коммуникационных технологий в физическом образовании

Учебники всегда использовались, чтобы стимулировать интерес к предмету, улучшить наглядность и сосредоточить внимание ученика на самом важном или сложном учебном материале.

К традиционным средствам обучения относятся учебники, макеты, таблицы, модели, учебные пособия, лабораторное оборудование и многое другое. Эти средства были выделены на интерпретацию нового материала, средства утверждения и повторения, а также средства контроля. Использование всех этих инструментов в процессе обучения в той или иной степени повлияло на мотивацию, академические достижения и интеллектуальное развитие 
THEORETICAL FOUNDATIONS OF THE FUNCTIONING OF EDUCATION. WAYS TO

IMPROVE THE EFFECTIVENESS OF EDUCATIONAL ACTIVITIES

студентов, но ни один из этих инструментов не имел особых дидактических возможностей с использованием информационно-коммуникационных технологий.

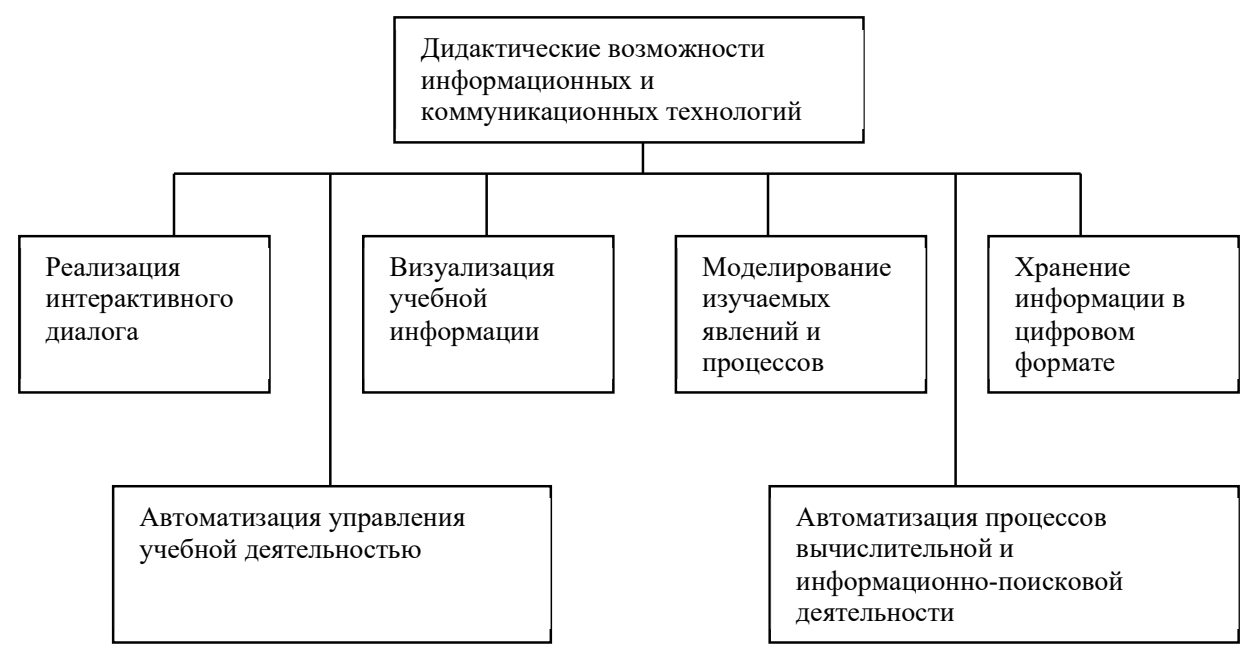

Рис.2. Дидактические возможности средств информационно-коммуникационных технологий

Перечислим наиболее важные дидактические возможности средств информационно-коммуникационных технологий (рис.2).

1. Реализация интерактивного диалога обеспечивается мгновенной обратной связью между пользователем и инструментами ИКТ. Интерактивность на английском языке означает взаимодействие, взаимодействие, влияние друг на друга. Интерактивность диалога позволяет студенту активно взаимодействовать с системой, каждый его запрос вызывает реакцию системы, и, наоборот, реплика последней требует ответа пользователя.

2. Визуализация учебной информации об исследуемом объекте предполагает визуальное статическое представление исследуемого объекта и (или) его компонентов на экране компьютера, перемещение любого процесса или его модели на глубину экрана, более детального рассмотрения изучаемого объекта, стенда или агрегата. Некоторые программы предлагают процессы, протекающие в микро- и макромирах, а также процессы, которые невозможно изучить с помощью учебных лабораторных стендов. Возможна графическая интерпретация исследуемой выборки. 
THEORETICAL FOUNDATIONS OF THE FUNCTIONING OF EDUCATION. WAYS TO

IMPROVE THE EFFECTIVENESS OF EDUCATIONAL ACTIVITIES

3. Моделирование реальных или виртуальных процессов и явлений, моделирование лабораторных стендов, агрегатов и машин, интерпретация информации об изучаемых или исследуемых объектах в виде таблиц, графиков (например, моделирование процессов и явлений при высоких или низких температурах в космосе; создание предметной виртуальной среды для тренинга при подготовке к будущей профессиональной деятельности).

4. Хранение в цифровом формате больших объемов информации с возможностью удобного доступа, воспроизведения, передачи на любые расстояния; автоматизация служб сбора, накопления, хранения, обработки и поиска информации.

5. Автоматизация процессов вычислительной деятельности, а также обработки результатов учебного эксперимента (в том числе масштабе реального времени) реализуется с помощью специальных лабораторных стендов на базе микропроцессорной техники, программно-аппаратных комплексов, снабженных датчиками, сопрягаемыми с ПЭВМ, что позволяет выводить на экран компьютера полученные в ходе эксперимента данные и производить статистическую обработку, строить графики, таблицы, диаграммы.

6. Автоматизация управления образовательной деятельностью и контроль результатов обучения, тренировки, тестирования; автоматизация информационных сервисов и информационного взаимодействия участников образовательного процесса в локальных и глобальных компьютерных сетях с целью улучшения управления учебным процессом в вузе.

В современных программных разработках, предназначенных для образования, уже реализуются в той или иной степени перечисленные ранее уникальные дидактические возможности средств ИКТ. Это позволяет повышать эффективность обучения прежде всего за счет усиления наглядности демонстрации учебного материала, индивидуализации и дифференциации процесса обучения, обеспечения объективности контроля, оценки знаний, умений и навыков [5]. 
THEORETICAL FOUNDATIONS OF THE FUNCTIONING OF EDUCATION. WAYS TO

IMPROVE THE EFFECTIVENESS OF EDUCATIONAL ACTIVITIES

Появление новых научных теорий и техническое развитие существующих оказывало определенное влияние на способы представления информации, используемой в педагогике. В настоящее время наиболее интересным можно считать создание единой среды мультимедиа, включающей в себя различные виды представления информации, порожденные появлением компьютеров [6].

Есть разные определения мультимедиа. Для нас мультимедиа - это интерактивная среда, которая позволяет получать и обрабатывать информацию в виде потоков, включая текст, графику, звук, видео и системы связи.

В понятие мультимедиа технологий на современном этапе зачастую включают совокупность средств управления и программных продуктов, предназначенных для работы со сгенерированными компьютером иллюзиями временно подменяющими окружающую нас действительность.

Виртуальная реальность похожа на имитацию физической реальности. В виртуальной реальности вместе с окружающим пространством вы видите виртуальный образ, который меняется по мере вашего движения. Создание виртуальной реальности основано на использовании имитационного моделирования, теории дистанционного управления, техники взаимодействия человека с машиной. Технология виртуальной реальности используется в управлении производственными процессами и в индустрии развлечений при создании сложных спецэффектов.

Использование преподавателем мультимедийного компьютера для контроля усвоения материала.

В то же время существует ряд проблем, возникающих при использовании обучающе-контролирующих программ в процессе обучения.

Во-первых, автоматическое управление возможно с помощью достаточно простой и однозначной формы стандарта. Для сложных физических структур создание единственно правильного стандарта становится более сложным, и чем сложнее изучаемое физическое явление, тем менее однозначно можно дать единственно правильный стандарт. При вводе речи автоматический контроль вообще становится очень проблематичным, так как спонтанную устную и 
THEORETICAL FOUNDATIONS OF THE FUNCTIONING OF EDUCATION. WAYS TO IMPROVE THE EFFECTIVENESS OF EDUCATIONAL ACTIVITIES

письменную речь вообще нельзя сравнивать с каким-то единым правильным эталоном. Невозможно предугадать словесную реакцию школьника на ситуацию, возникающую в процессе обучения, даже самый нестандартный ответ на вопрос не может быть абсолютно правильным с точки зрения физических законов.

Во-вторых, если ответ ученика не соответствует стандарту, очень важно правильно диагностировать причину ошибки. Ошибка может быть основана на плохом понимании нового материала, незнании ранее пройденного материала или чисто психологических причинах, например, невнимательности. Теоретической причиной ошибки могут быть объяснения учащегося на другом языке по сравнению с языком учебника, сходство изучаемой конструкции с любой другой и, наконец, просто структурная сложность изучаемой конструкции. Кроме того, возможны описки, опечатки и случайные нажатия кнопок. Очевидно, что в каждом конкретном случае эффект управления будет разным. В простейших случаях возникающие ошибки можно спрогнозировать и учесть при составлении программы обучения и контроля, в более сложных случаях необходима индивидуально ориентированная аналитическая работа учителя.

В-третьих, компьютерные упражнения следует использовать только там, где они действительно методически оправданы. Работа в компьютерном классе должна быть тесно связана с предыдущей и последующей работой в классе. Недопустимо использовать компьютер как простейшее средство, чтобы чем-то занять учеников. При использовании компьютера в качестве учебного пособия нужно уделять особое внимание предварительной подготовке учителей к уроку.

Заключение. Названные проблемы не кажутся нам непреодолимым препятствием для использования компьютера, чтобы облегчить работу учителя. Учитывая нынешний интерес к созданию и использованию обучающих программ, можно с уверенностью сказать, что эти проблемы могут быть успешно решены в ближайшем будущем. 
Таким образом, компьютер должен помочь учителю избавиться от рутинной монотонной работы и превратить управление в творческую составляющую управления учебным процессом. Анализируя приведенное выше совершенствование методики преподавания физики, связанное с внедрением информационно-коммуникационных технологий в образовательный процесс, можно сделать вывод, что оно должно идти по пути определения структуры методики обучения, фактически обеспечиваемой в образовательном процессе, усиление его практической направленности, индивидуализации и дифференциации. 
DOI 10.46299/ISG.2021.MONO.PED.II-326-336

\subsection{1 Веб-квести як основа творчої самостійної роботи студентів медичних і біологічних спеціальностей $з$ мікробіології, вірусології, імунології}

Одним із векторів державної політики в освітній галузі є розвиток системи вищої освіти, підвищення якості процесу викладання і забезпечення його ефективності. Сучасна організація освітнього процесу потребує пошуку нових методів удосконалення системи вищої освіти. Особливу увагу на даному етапі реформування освіти приділяють самостійній роботі $(\mathrm{CP})$, яка органічно поєднує аудиторну і позааудиторну роботу студентів. Цей напрям навчальної діяльності може здійснюватися як під керівництвом викладача, так i без його безпосередньої участі [294,295,298]. Натепер методичне забезпечення самостійної роботи є ще недосконалим і потребує залучення дієвих заходів. У цьому контексті актуальним є використання різних видів навчально-методичного забезпечення при усвідомленому засвоєнні теоретичних питань та організація низки заходів для ефективного опанування студентами практичних навичок і вмінь 3 мікробіології, вірусології та імунології при підготовці до визначених тем позааудиторної роботи.

Метод веб- квестів як одна 3 форм навчання, доповнюючи інші педагогічні технології, будується з урахуванням індивідуальних якостей, навчає працювати в колективі, породжує нові ідеї, навчає застосовувати засвоєні знання на практиці при вивченні мікробіології, вірусології, імунології та інших дисциплін, а згодом і в майбутній професійній діяльності. Якщо проект колективний, студенти набувають ще i певних комунікативних навичок, вчаться працювати в команді.

Концепція веб-квесту було розроблена викладачами університету СанДієго Берні Доджем і Томом Марчем у 1995р. Б. Джодж пояснив цю технологію як «орієнтовну діяльність, де практично вся інформація береться 3 мережі інтернет» [294,312,313]. 
THEORETICAL FOUNDATIONS OF THE FUNCTIONING OF EDUCATION. WAYS TO IMPROVE THE EFFECTIVENESS OF EDUCATIONAL ACTIVITIES

На сьогодні ця технологія використовується як найбільш продуктивний спосіб використання інтернету в освітньому процесі. У педагогічній науці існують різні позиції щодо визначення змістового наповнення поняття «веб квест». У класичному розумінні веб-квест (webquest) - це проблемне завдання 3 елементами рольової гри, для виконання якого використовуються інтернетресурси. Як зазначає В. Шмідт, «веб-квести - це мініпроекти, засновані на пошуку інформації в інтернеті» [295, 313, 314]. Т. Кузнєцова розглядає квест як приклад організації інтерактивного освітнього середовища. I. Сокол зазначає, що сучасна квест-технологія допомагає студенту знаходити необхідну інформацію, піддавати іiі аналізу, систематизувати, вирішувати поставлені завдання, розвивати пізнавальну діяльність та формувати ключову компетентність.

Веб-квест - це сайт в інтернеті, з яким працюють студенти та викладачі, виконуючи ту чи іншу навчальну задачу. Розрізняють два типи веб-квестів: для короткочасної (поглиблення знань та їх інтеграція, розраховані на декілька занять) та тривалої роботи (поглиблення і перетворення знань учнів, розраховані на тривалий термін - може бути, на семестр або навчальний рік). Особливістю освітніх веб-квестів є те, що частина або вся інформація для самостійної або групової роботи студентів з ним знаходиться на різних вебсайтах. Крім того, результатом роботи 3 веб-квестом $\epsilon$ публікація робіт студентів у вигляді веб-сторінок і веб-сайтів (локально або в Інтернет). Технологія веб-квест дозволяє формуватися наступним компетенціям:

- використання інтернет-технологій для вирішення професійних завдань (в т.ч. для пошуку необхідної інформації, оформлення результатів роботи у вигляді комп'ютерних презентацій, баз даних);

- самонавчання і самоорганізація;

- робота в команді (планування, розподіл функцій, взаємодопомога, взаємоконтроль);

- вміння знаходити кілька способів рішень проблемної ситуації, визначати 
THEORETICAL FOUNDATIONS OF THE FUNCTIONING OF EDUCATION. WAYS TO

IMPROVE THE EFFECTIVENESS OF EDUCATIONAL ACTIVITIES

найбільш раціональний варіант, обгрунтовувати свій вибір;

- навики публічних виступів (обов'язково проведення передзахисту та захисту проектів з виступами авторів, з питаннями, дискусіями).

Переваги веб-квестів такі, як: а) мотивація студентів до вивчення нового матеріалу; б) організація роботи у формі цілеспрямованого дослідження, необмеженого за часом; в) активізація самостійної індивідуальної діяльності студентів, якою вони самі керують. Незважаючи на назву самостійна робота, важливу роль відіграє викладач як наставник або консультант. При іiі організації із застосуванням інформаційно-компютерних технологій з вебквестами спочатку необхідно визначити проблемне завдання (на прикладі конкретного хворого), потім продумати передбачуваний результат (наслідки захворювання), далі визначитися з указаним переліком джерел інформації (спеціальною літературою), продумати процес діяльності (лабораторної діагностики, лікування) і вже на завершальному етапі презентувати результати пошукової діяльності. У всьому цьому викладач допомагає і спрямовує майбутнього спеціаліста. Так, на одному занятті студентів можна розділити на дві підгрупи по 5 осіб і дати завдання спільно лабораторно дослідити (бактеріологічні, серологічні методи) конкретного хворого. На наступному занятті кожна підгрупа надає результати своєї пошукової, дослідницької та лікувально-діагностичної діяльності у вигляді Power-Point презентації [296]. .

Веб-квест - це поєднання теорії та практики, постановка певного розумового завдання і практичне його виконання.

Суть методу досить повно розкриває Є.С. Полат: « Цей метод передбачає певну сукупність навчально-пізнавальних прийомів, що дозволяють вирішити певну проблему під час самостійних дій з обов'язковою презентацією результатів» [297]. Як зазначає О. Рибіна: «Це педагогічна технологія, орієнтована не на інтеграцію фактичних знань, а на їх використання і здобуття нових (іноді і шляхом самоосвіти)». Більшість дослідників схильні розглядати метод веб-квестів як технологічну діяльність 
THEORETICAL FOUNDATIONS OF THE FUNCTIONING OF EDUCATION. WAYS TO IMPROVE THE EFFECTIVENESS OF EDUCATIONAL ACTIVITIES

[298]. Технологія проектування передбачає розв'язання суб'єктом навчання або їх групою проблеми, в результаті чого вони отримують певну суму знань.

Основний принцип методу веб-квестів - це опора на інтереси сьогодення, що повинно бути вихідним принципом навчання. Для педагога це пошук балансу між академічними і прагматичними знаннями, уміннями, навичками та конгнітивними перевагами [299].

Аналіз літератури свідчить, що цей метод сприяє розвитку ініціативи, самостійності, умінню планувати свою діяльність, враховує інтереси суб'єкта навчання, розвиває свідоме ставлення до діяльності, передбачає досягнення дидактичної мети через детальне розв'язання проблеми, яка повинна завершитись цілком реальним практичним результатом. Виконання роботи розраховується на певний проміжок часу, протягом якого здійснюватиметься самостійна, індивідуальна, парна та групова робота.

Основними ознаками веб-квестної діяльності студентів є: самостійність (самостійний вибір шляху розв'язання проблеми); креативність (пошук оптимального шляху розв'язання проблеми, яка активізує творчий та інтелектуальний потенціал); технологічність (організація діяльності, відповідає етапам створення проекту); конгнітивність (дає можливість розкрити пізнавальний потенціал і спрямувати освітній рух до реалізації пізнавальних потреб); практична спрямованість (проект призводить до конкретних результатів, які можуть бути втілені у життя); інтегрованість змісту (проект передбачає синтез знань та способів діяльності); самоорганізація (сприяє трансформації функцій зовнішнього управління освітньюю діяльністю студента, що забезпечує самоорганізацію діяльності та необхідний рівень ефективності процесу навчання). Аналіз літератури доводить перспективність застосування методу веб-квестів 3 метою формування знань 3 мікробіології, вірусології, імунології студентів медичних і біологічних спеціальностей.

Так як, одним з важливих завдань сучасної освіти $€$ навчити студента самостійно здобувати і поповнювати знання [300], то важлива особливість 
самостійної роботи полягає в тому, що дає можливість студентам створювати та реалізовувати власні освітні ідеї та задуми [301].

Освітні веб-квести у вищій школі містять не тільки навчальний компонент, який пов'язаний із здобуттям знань, умінь i навичок, але i забезпечує можливість самореалізації і професійної підготовки, це засіб організації самостійної роботи, яка перетворює різну інформацію в систему знань, в результаті якої особистість розвивається, а також самовизначається в своїй діяльності. Вони передбачають спільну роботу викладача і студента. Реалізація його вимагає самостійності, творчості та пізнавальної активності.

На основі аналізу літературних джерел [299,300,301,302] розроблено модель організації самостійної роботи студентів, яку використано нами у експерименті (рис. 1).

Запропонована модель спирається на діяльнісно-компетентнісний та особистісно-орієнтований підходи до навчання [302,303,311], передбачає визнання студентів активними учасниками цього методу. 


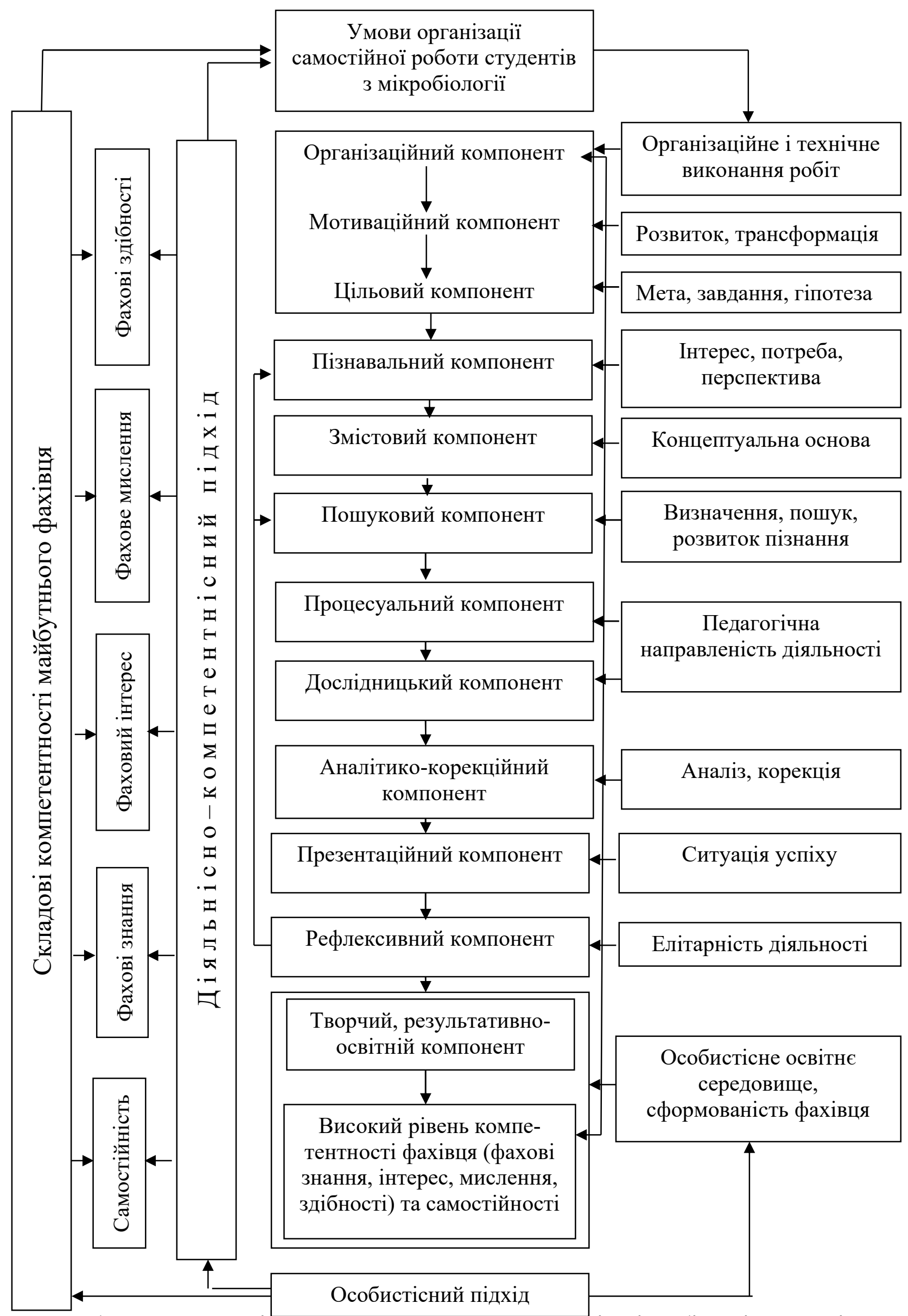

Рис. 1. Модель організації самостійної роботи студентів мікробіологічного змісту 
Створюючи модель ми керувались трактуванням моделі як спрощеного опису педагогічного явища або процесу як системи, який розкриває найбільш суттєві властивості і відносини [304,305]. Цінністю моделі є те, що студенти працюючи, не задовольнялися готовими знаннями, а самостійно їх набували i використовували при цьому різноманітні джерела інформації, критично оцінювали їх та обирали особисті шляхи досягнення мети, до якої прагнули. Формується самостійна робота внаслідок актуалізації таких складових, як мотив, мета, інтереси, потреби, діяльність, результат, які є основою моделі.

При організації та проведенні занять 3 використанням дидактичних можливостей моделі, нами здійснювалась координація та консультування, а студенти були активними суб'єктами навчання. Особливістю даної моделі є узагальненість, системність і прогностичність. Використання ії базувалось на логіці формування самостійної роботи, а саме появі мотивів самостійної роботи. Мотив - це сила, яка приводить студента до визначення мети та ії втілення [306,307].

Реалізація пізнавальних потреб при роботі над презентаціями сприяла забезпеченню розвитку особистості студента, сприйняттю знань як цінності, що визначає готовність їх після закінчення вузу до роботи у різних галузях медицини. Дані якісної характеристики самостійної роботи залежать від усвідомлення студентами значимості виконуваного проекту. Вони $є$ взаємопов'язаними і зумовлюють логіку формування та розвитку самостійної роботи.

Компоненти, які становили основу моделі i визначали ii функції: організаційний, мотиваційний, цільовий, пізнавальний, змістовий, пошуковий, процесуальний, дослідницький, аналітико-корекційний, презентаційний, рефлексивний, творчий, результативно-освітній. До структури моделі входили результат і зворотний зв'язок рефлексивного та пізнавального та пошукового компонентів. Через цей зв'язок можна оцінювати стан виконання самостійної роботи, вносили корективи або поверталися назад. Основні функції компонентів моделі: 
1. Організаційний компонент моделі визначав умови організації самостійної роботи, застосування форм, методів та конкретних прийомів іiі організації, їх структурування 3 врахуванням знань та пізнавальних можливостей, а також спрямовував студентів на організацію самостійної роботи.

2. Мотиваційний компонент моделі сприяв розвитку та трансформації мотивів самостійної роботи під час виконання проектів. Чим важче завдання виконання проекту, тим вищою була внутрішня мотивація, що дозволила студенту почуватись більш компетентним. Мотив стимулював визначення мети.

3. Цільовий компонент включав конкретизацію мети на основі мотивів та завдань і потреб проекту, гіпотези, вибір джерел інформації, критеріїв оцінювання проекту, визначення його структури, терміну реалізації етапів та форми презентації. Цільовий компонент мав інтегруюче значення для реалізації моделі на всіх етапах проекту.

4. Пізнавальний компонент $є$ вибірковою спрямованістю самостійної роботи, тенденцією, потребою особистості займатися науковою діяльністю. Трансформується під час виконання проектів у пізнавально-творчий, теоретичний та теоретично-конструктивний (творчий).

5. Змістовий компонент включав всі етапи створення та виконання проекту, що підлягали самостійній роботі. Представлений фактичним матеріалом, знаннями, ідеями, відомостями.

6. Пошуковий компонент визначав пізнавальні інтереси, потреби, внутрішній стимул і глибину у характері самостійної роботи та зумовлював активність в оволодінні знаннями [307,308,309,310].

7. Процесуальний компонент включав: форми організації самостійної роботи (аудиторні заняття, позааудиторні заняття, заняття в гуртку), методи (словесні, наочні, практичні), методичні прийоми (організаційні, логічні, технічні), в межах яких здійснюється формування та самостійне здобуття знань студентів-медиків 3 мікробіології спеціальностей «Лікувальна справа», «Біологія» і «Фармація». 
8. Дослідницький компонент визначав якість і результативність самостійної роботи, забезпечував розвиток пізнавальної активності. Дослідницька діяльність $є$ найбільш важливою при виконанні проектів, так як у процесі створювався пізнавальний шлях студента, відбувалось формування системи знань, досвіду пізнання, культури експериментування, виникав інтерес до науки, встановлювався зв'язок між складовими змісту проекту.

9. Аналітико-корекційний компонент передбачав обдумування, аналіз отриманих результатів, їх корекцію, обговорення та перевірку гіпотези, підготовку і формулювання висновків підсумкового подання результатів роботи. Аналітико-корекційний компонент забезпечував суб'єктивну позицію щодо змісту і процесу отримання знань.

10. Презентаційний компонент передбачав презентацію проекту, яка сприяє набуттю навичок подання результатів своєї роботи. Форми презентації: доповіді, реферати, буклети, газети, мініпідручники, довідники, таблиці, згортки, конференції, відеофільми, журнали, представлення матеріалів в мережі Інтернет i т. д. При цьому оцінювали компетентність, майстерність представити опанований зміст проекту, оригінальність i творчість. Презентаційний компонент виконував такі функції, як контроль, самоконтроль та оцінювання якості виконаного проекту.

11. Рефлексивний компонент полягав в усвідомленні якості виконаної роботи над проектом, виникненні нових думок щодо вибору наступної теми освітньої роботи. Рефлексія - це критична самосвідомість, джерело внутрішнього досвіду, засіб самопізнання і необхідний інструмент мислення. Під час рефлексії відбувався самоаналіз індивідуальних проектів, що допомагало студенту усвідомити свою індивідуальність, успіхи в даній діяльності, недоліки та помилки.

12. Творчий, результативно-освітній компонент в роботі над проектом полягав в тому, що формувався фахівець, складовими компетентностями якого були фахові знання, інтерес до вивчення дисципліни, дослідницькі уміння і навички, фахові здібності та мислення, відбувався розвиток творчої особистості, 
яка набувала самостійності, змінювались іï пізнавальні інтереси та потреби, збільшувалась сила внутрішніх мотивів. Даний компонент відповідав формуванню знань, на якому проходив контроль та аналіз результатів творчої діяльності студентів. Використання проектної діяльності сприяло самовиявленню, самореалізації, самовизначенню, побудові системи знань на основі опрацьованого, зростанню мотивації, розвитку пошукових та творчих здібностей, відповідальності, співробітництва.

При формуванні знань студентів ми розробили i використали в експериментальному навчанні різні презентаційні проекти, зокрема: «Клітинні механізми регулювання імунної реактивності організму на різні бактеріальні антигени», «Профілактика i лікування нозокоміальних інфекцій та їх перспективи», «Бактеріологічна діагностика хелікобактеріальної інфекції та ії ефективність», «Бактерії-коменсали мукозних оболонок для профілактики і терапії нозокоміальних інфекцій людини», «СНІД - чума ХХІ століття», «Віруси та вакцини», «Антибіотики та їх вплив на організм людини», «Імунна система та аномалії імунної відповіді». В окремих випадках до виконання веб-квестів залучались і співробітники кафедри.

Узагальнивши результати досліджень, можна зробити висновок, що використання методу веб-квестів є важливим засобом організації самостійної роботи суб’єктів навчання. Вміння педагога ефективно організувати та впроваджувати проектну діяльність в навчальний процес $є$ показником високого рівня його професійної компетентності. Метод веб-квестів належить до прогресивних освітніх технологій XXI століття і є важливим педагогічним засобом формування компетенцій особистості. Оскільки, метод поєднує в собі групову самостійну дослідну і комунікативну діяльність, ми передбачили, що його застосування відповідно до компонентів самостійної пізнавальної діяльності, може підвищити рівень сформованості знань студентів, їх творчих умінь, розвинути вміння опрацьовувати різні інформаційні джерела, сприятиме формуванню позитивної мотивації, дасть можливість остаточно самовизначитись у спеціалізації на відповідних кафедрах. 
Отже, особливість веб-квесту як засобу навчання полягає у реалізації освітніх завдань через ігрову діяльність; використанні сучасних технічних засобів навчання, які сприяють самовираженню студента; цілеспрямованому мотивуванні емоційної та інтелектуальної активності; пошуковому характеру навчальної діяльності; розвитку інформаційної та медіа грамотності, вчить використовувати інформаційний простір інтернет-мережі для розширення репертуару своєї майбутньої професійної діяльності. 
DOI 10.46299/ISG.2021.MONO.PED.II-337-343

\subsection{2 Викладання гуманітарних дисщиплін у технічних закладах вищої освіти України}

У XXI столітті, коли відбувається перехід до інформаційно розвиненого суспільства, вища освіта набуває особливого значення для розвитку всього людства. Головним завданням кожного вищого навчального закладу, у тому числі і аграрного, є навчання і виховання молодої особистості, яка зможе самостійно вирішувати складні професійні, політичні, економічні, соціальні, культурні та інші проблеми, які з'являються у сучасному суспільстві.

«Педагогіка нас вчить, що спочатку треба поставити завдання, мати певну практику, певні результати. Згодом ми повинні проаналізувати ці результати, просто їх перевірити, з’ясувати що саме вдалося, а що не вдалося. I лише на цій основі пропонувати студентству нові навчальні курси, або приймати якісь глобальні рішення щодо змін у системі освіти. На жаль, усі ми вже звикли працювати у дещо іншій площині, коли спочатку приймаються рішення, а потім педагогічні колективи змушені працювати «під ці рішення»»» [315, с. 24].

Вища освіта в Україні в умовах сьогодення (проблеми в соціальноекономічній сфері, нестабільна політична ситуація, освітянська рерфома, війна на сході України та карантин в умовах пандемії COVID-19) вимагає від викладачів гуманітарнрх дисциплін для модернізації технічної освіти впровадження інноваційних методів викладання.

Відповідно до Закону України «Про інноваційну діяльність», інновації це новостворені і вдосконалені конкурентоздатні технології, продукція або послуги, a також організаційно-технічні рішення виробничого, адміністративного, комерційного або іншого характеру, що істотно покращують структуру та якість виробництва і соціальної сфери [2, ст.1].

Становлення та розвиток нових технологій і методів у сучасній вищій освіті актуальні, тому є потреба у викладацьких кадрах, які б змогли забезпечити інноваційний підхід до реалізації цих тенденцій під час навчально-виховного процессу. Викладачі отримали можливість створювати і втілювати власні новітні 
методики [317, с. 48]. Але слід зазначити, в умовах реформування системи вищої освіти, зменшення набору студентів, запровадження ЗНО для випускників коледжів та бакалаврів, виникає певна конкуренція між викладачами фахових та суспільно-гуманітарних дисциплін. Усі ці зміни активізували потребу оновлення і вдосконалення освітнього середовища ВНЗ. В Національній доктрині розвитку освіти зазначено, що в Україні повинен забезпечуватися прискорений, випереджальний інноваційний розвиток освіти шляхом оновлення змісту освіти та організації навчально-виховного процесу відповідно до демократичних цінностей, ринкових засад економіки, сучасних науковотехнічних досягнень [318].

Актуальність матеріалу обумовлюється тим, що в умовах модернізації суспільства, глобалізації світу, входження вітчизняної системи освіти у загальносвітовий простір та тими викликами, що стоять перед Україною, без запровадження інноваційних технологій у закладах вищої аграрної освіти та збереження гуманітарних дисциплін, побудова громадянського супільства у нашій державі буде занадто важкою. Оскільки саме суспільно-гуманітарні науки формують особистість студента відповідно до сучасних і реальних вимог нашого суспільства, розвивають його логічне, історико-філософське мислення, навчають політичному і соціально-економічному аналізу процесів, які відбуваються, та розкривають особливості розвитку нашого різномаїтнього світу.

Метою роботи є спроба визначити характерні особливості засобів, форм i методів навчання за допомою інноваційних технологій на прикладі роботи кафедри суспільно гуманітарних наук Таврійського державного агротехнологічного університетету імені Дмитра Моторного, розкрити специфіку їх використання в інтерактивному середовищі вишів України.

Терміни «традиційне навчання» та «інноваційне навчання» запропоновані групою вчених у доповіді Римському клубу (1978), який звернув увагу світової наукової громадськості на неадекватність принципів традиційного навчання

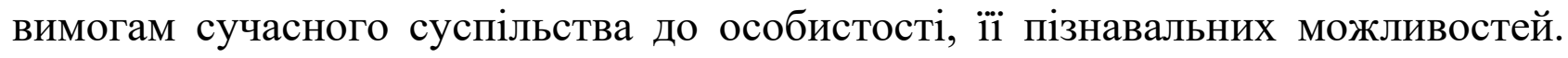
Інноваційне навчання орієнтоване на формування готовності особистості до 
динамічних змін у соціумі за рахунок розвитку здібностей до творчості, різноманітних форм мислення, а також здатності до співробітництва з іншими людьми. Головними недоліками традиційної системи освіти є породжені нею невміння і небажання дітей вчитися, несформованість цілісного ставлення до власного розвитку та освіти. Подолання кризи сучасної освіти можливе завдяки формування принципово нової системи освіти [319, с.28].

Інновація освіти - цілеспрямований процес часткових змін, що ведуть до модифікації мети, змісту, методів, форм навчання й виховання, адаптації процесу навчання до нових вимог. Інновації у вищій школі передбачають: вивчення, узагальнення та поширення кращого вітчизняного, європейського та світового досвіду в цій сфері; організація і проведення конференцій, семінарів, круглих столів, тренінгових курсів 3 інноваційних методик викладання гуманітарних дисциплін у аграрному ВНЗ; застосуванні кредитно-модульної системи організації навчального процесу з рейтинговою оцінкою знань студентів. Це $є$ запорукою підвищення якості навчання та стимулювання самостійної роботи студенів [320, с. 35].

Для більш результативного навчання виправдане застосування принципу наочності разом з викладанням матеріалів леції за допомогою комп'ютера, проектора, інтерактивної дошки, телевізорів $з$ великою діогоналлю тощо. Таким чином викладач оптимізує та урізномаїтнює процесс гуманітарних дисциплін.

Але існують перепони пов'язані із застосуванням інноваційних технологій, які мають об’єктивний та суб’єктивний характер. До першого типу віносяться: недостатність правового забезпечення або часті зміни у змісті навчального процесу; неготовність викладачів перейти на нові форми і методи викладання; відсутність організаційних осередків інновацій; матеріальнотехнічні проблеми. До другого типу: - пасивність викладача у використанні нових технологій, через постійну зміну «правил гри».

Викладач вважається готовий до інноваційної діяльності за таких умов: внутрішньо визнав значимість змін; він готовий до розв'язання нестардатних 
ситуацій у навчальному процесі; ситуація в колективі та установі сприятливі до запровадження інновацій та підримує викладача-новатора.

На сьогодні педагогічна наука розрізняє кілька видив традиційних технологій: предметно орієнтована (головна мета навчання - засвоєння матеріалу); особисто орієнтована (від студента, головне не засвоєння матеріалу, а розвиток його особистості); партнерська (викладач дбає як за засвоєння навчального матеріалу, так і за розвиток особистості студента).

Але криза освіти у сучасному світі викликали до життя нові освітні технології, пов'язані 3 неможливістю опанувати існуючий обсяг знань, зростанням вимог до професійних навичок, що виявляє великі проблеми у передачі знань традиційнми формами навчанн. Новою технологією організації навчального процесу є технологія ситуаційного навчання (кейс-метод). Його сутність можуть ілюструвати наступні положення. По-перше, мета навчання відрізняється від класичної схеми - навчити, дати єдино «правильні», раз і назавжди визначені знання, вміння та навички. Навчальний процес орієнтований на усвідомлення не єдиної, а багатьох істин. У технічному ЗВО кейс-метод можна застосувати для вивчення дисциплін, істина в яких плюралістична: у філософії, педагогіці, психології, історії тощо. По-друге, кейс-методу, на відміну від традиційних технологій, властивий демократичний характер процесу одержання знань. Студент є рівноправним із іншими учасниками обговорення проблеми, у тому числі з викладачем [321, с.100]. Головним у навчанні $є$ не оволодіння готовими знаннями, а їх вироблення в процесі співтворчості студента й викладача.

Але, на жаль, в Україні через значні соціально-економічні проблеми застосування цієї технології поки неможливе. Традиційні форми організації навчального процессу дають нам такі показники за умов пассивного навчання (лекція - 5\%, читання - 10\%), а найбільші - активного та інтерактивного (дискусійні групи - 50\%, практика через дію - 75\%, навчання інших чи негайне застосування - 90\%) [322, с.101]. Це, безперечно, середньостатистичні дані, і в конкретних випадках результати можуть бути дещо іншими, але в середньому 
таку закономірність може простежити кожен педагог. В даний час немає чіткого поділу між активними та інтерактивними методами навчання, одні і ті ж методи можуть ставитися різними експертами і до активних, і до інтерактивних [323].

Сучасною формою активних методів навчання виступають інтерактивні методи навчання. Інтерактивні методи навчання пов'язані з більш тісною взаємодією студентів не тільки з викладачем, але і між собою. Викладач виконує роль організатора, помічника, створюючи новий формат проведення занять.

Кафедра суспільн-гуманітарних наук була створена 26 серпня 2015 року шляхом обєднання кафедр українознавства та філософії і соціології. (Наказ №374-ОД від 26.08.15). Сьогодні кафедра налічує 13 співробітників, серед яких 2 професори, 1 доктор політичних наук, 1 ддоктор філологічних наук 10 кандидатів наук: історичних, філологічних, педагогічних, філософських, соціологічних; 4 ст.викладача та 2 старших лаборанта. Очолює кафедру кандидат філологічних наук, доцент Максимець Оксана Миколаївна.

Специфікою кафедри є викладання широкого спектру дисциплін для студентів усіх факультетів університету: «Історія України та історія української культури», «Історія науки і техніки», «Українська мова за професійним спрямуванням», «Культура наукової мови», «Психологія», «Політологія», «Соціологія», «Етика та естетика», «Інтелектуальна власність», «Філософські проблеми наукового пізнання», «Філософія науки та інноваційного розвитку», «Психологія і педагогіка в вищій школі», «Педагогіка».

Викладачі кафедри навчальну роботу спрямовують на активізацію інтелектуально-духовного потенціалу молоді, вдосконалення iї мовної культури, поглиблення знань з україністики, філософії, правознавства, психології та педагогіки, використовуючи сучасні методи та прийоми викладання. Важливе значення серед різних форм проведення занять завжди мала і має лекція. До числа найбільш часто використовуваних інтерактивних лекцій можна віднести: проблемну лекцію, лекцію-провокацію, лекціювізуалізацію, лекцію прес-конференцію, лекцію-бесіду і лекцію-дискусію. При 
навчанні студентів не можна повністю відмовитися від класичних лекцій, необхідно поступово доповнювати їх нетрадиційними формами, вносити в них інноваційні елементи, орієнтуючись на студентську аудиторію.

Останнім часом серед викладачів кафедри СГН популярності набувають інтерактивні лекційні та практичні заняття. В ході таких занять у студентів формуються вміння формулювання своєї позиції, постановки і рішення задач, відстоювання своєї точки зору, навички проведення дискусії. Найпопулярнішими серед викладачів при проведенні інтерактивних занять є такі методи: навчальна дискусія, «мозковий штурм», «круглий стіл», ділова гра які застосовуються на заняттях 3 історичних, філософських, психологічних та філологічних дисциплін.

Ще одним іноваційним методом організації навчальної діяльності викладачів кафедри є використання дистанційної освіти, яка забезпечує доставку інформації в інтерактивному режимі за допомогою використання інформаційнокомунікаційних технологій (система Moodle) від викладачів до студентів. Дистанційне навчання зробило справжню революцію в освітньому та інформаційному процесах. Онлайн-курси різних дисциплін кафедри СГН доступні кожному студенту, який має доступ до мережі Інтернет та навчального порталу ТДАТУ. Портал наповнений різноманітними пропозиціями онлайнкурсів, тому студенту лишається тільки обрати курс собі відповідно навчального плану свого курсу та спеціальності. Особливо актуальним стало використання дистанційної освіти під час карантину в умовах пандемії COVID-19.

Метою самостійної роботи є закріплення знань, формування умінь i навичок, розширення інтересу до дослідницької діяльності, підвищення рівня підготовки студента. в сучасних умовах великого значення набуває використання інтерактивних форм самостійної роботи студентів. Наприклад, завдання для самостійної роботи студентів можуть бути спрямовані на підготовку презентацій з окремих проблемних питань дисциплін кафедри, робота з базою тестів для навчання і для контролю знань, Провідні фахівці кафедри, маючи на меті залучити студентів до цілеспрямованої наукової 
діяльності, керують роботою наукових студентських гуртків, учасники яких оволодівають необхідними навичками дослідницької роботи.

Одним із пріоритетів діяльності кафедри $є$ виховна робота. Адже утвердження української національної ідеї і розбудова на іiї основі нашої держави вимагає висококваліфікованих спеціалістів, з високими моральними якостями, розвиненими почуттями патріотизму, громадянської та національної гідності, активної життєвої позиції в процесі державотворення. Підготовка таких спеціалістів здійснюється на основі вимог державної концепції національного виховання та концепції виховання, розробленої в університеті, 3 урахуванням етнічних, соціальних і духовних особливостей студентського колективу. Зусилля викладачів кафедри спрямовуються на те, щоб кожна лекція, практичне чи семінарське заняття мали виховну спрямованість, а виховання студентів проводилося не лише на основі розгляду тих чи інших тем, питань, прикладів та фактів, але й особистісної оцінки різних проблем.

Отже, використання інноваційних методик у навчальному процесі ВН3, зокрема при вивчення гуманітарних дисциплін, створює умови для ефективної самореалізації особистості майбутнього фахівця аграрного профілю. Значною мірою це залежить від педагогічної майстерності викладача гуманітарних дисциплін, від прояву його майстерності, бажання оволодівати сучасними освітніми технологіями та готовності студента до цих інновацій і в навчальновиховному процесі. 
DOI 10.46299/ISG.2021.MONO.PED.II-344-358

\subsection{3 Поняття перевернутого класу. Перевернуте навчання як інноваційний педагогічний підхід Flipped Class}

Досліджено теоретичні та практичні питання моделі змішаного навчання перевернутий клас, підкреслена роль цього виду освіти, як основної форми майбутнього навчання, наведені докази ефективності інновації навчального процесу.

\section{Вступ}

Передумови до виникнення моделі Flipped Class виникли в системі вищої освіти XX-го століття як інноваційний педагогічний підхід.

ВНЗ практикували виконання лабораторних занять студентами за матеріалами лекції з теорії, ще не прочитаної їм. Графік здачі виконаних практичних робіт не передбачав відтермінування. Студентам доводилося самостійно засвоювати теорію як в процесі підготовки до виконання лабораторних робіт, так і в процесі їі захисту.

Ця методика сприяла об'єктивно кращому засвоєнню матеріалу. Під час його викладу в аудиторії завжди були студенти, які вже частково засвоїли цей матеріал і могли надати допомогу іншим або уточнити в ході лекції незрозуміле, тим самим спрямовуючи викладача на шлях більш докладного викладу «вузьких» питань предмета.

Акцент на самостійному засвоєнні предмета - це основний принцип моделі перевернутого класу (Flipped Class). Виділити його в окремий, інноваційний, напрямок навчання допоміг розвиток інформаційних технологій.

Ідею зміни парадигми навчально-класної форми, вперше запропонувала викладач коледжу Елісон Кінг. Вона виклала в статті досвід щодо зміни ролі вчителя «мудреця за кафедрою» на гіда з навчального матеріалу.

Перший практичний експеримент в 1997-му році 3 упровадження перевернутого навчання провів викладач Гарвардського Університету, що 
випустив книгу «Peer instruction: Керівництво користувача» вже 3 детальним звітом і результатами інноваційного навчання.

Автор - професор Ерік Мазур довів, що викладач може значно збільшити частку самоосвіти в засвоєнні студентами навчальних матеріалів, сконцентрувавшись на порадах щодо правильного підбору літератури, групової взаємодопомоги, дозування підказок і роз'яснень педагога.

Практична реалізація моделі Flipped Class почалася з настанням XXI століття. Роботу з викладачем замінювали відео-лекціями потокового мовлення або підбором і подачею навчального матеріалу за допомогою програмного забезпечення, як це було зроблено в Сідарвільском університеті.

Популяризатором відео-навчання стала Академія Хана. В основу навчання був покладений авторський курс, створений Ханом Салманом для навчання родички. Він полягав у запису уроку на відео, яке публікувалося зі списком додаткових матеріалів і практичних прикладів. Матеріал був розбитий на блоки, щоб сприяти подоланню труднощів у засвоєнні матеріалу.

Повсюдне впровадження Flipped Class йшло разом із розвитком Інтернету i різних, пов'язаних з ним додатків, які відкрили еру соц. мереж - популяризаторів дистанційного он-лайн спілкування.

Внесок у розвиток віддаленої освіти за методиками перевернутого класу зробили викладачі Ко і Гесс, які надали порівняльні характеристики щодо ефективності навчання студентів за системою традиційних лекцій і трьох методик інноваційної подачі матеріалу:

• вебдоповнена лекція;

- самостійна робота студента над новим матеріалом за допомогою спеціалізованого ПЗ;

- робота в групах - самостійне вивчення матеріалу з пошуком відповідей, подальший обмін отриманими знаннями 3 групою в процесі оф-лайн / он-лайн навчання.

Офіційними засновниками перевернутого класу вважаються два вчителі хімії. Джонатан Бергманн став першим викладачем, який у класі на уроках 
змушував студентів робити домашнє завдання, а також пропонуючи їм виклад теоретичного матеріалу у вигляді відео-лекцій для роботи вдома. Підключився до нього Аарон Семс , який запропонував допомогу в режимі он-лайн для учнів, розширивши можливість використання додаткового матеріалу.

3 2012-го року обидва педагоги поставили собі за мету науковий поступ методу навчання Flipped Class. У 2016-му році вони відкрили міжнародний факультет глобального вивчення перевернутого навчання для пошуку й вироблення стандартів інноваційного спрямування педагогіки.

За перші 20 років XXI століття розвиток сучасних технологій відкрив перед викладачами широкі можливості перевернутого навчання. Соц. мережі й популярні додатки значно спрощують подачу теорії в режимі он-лайн, знижують вартість фінансових витрат на Flipped Class для школи і ВНЗ.

У школу приходять «підготовлені життям» учні, які з молодших років прагнуть отримати навички серфінгу в Інтернеті через різні он-лайн додатки, засвоюючи віртуальні ігри, перебуваючи в пошуку розважального контенту. Сучасне життя неможливе без гаджетів і персональних комп'ютерів, що оточують дитину і підключені до «Всесвітньої Павутини».

Паралельно викладачі можуть користуватися вже наявними в сфері освіти, 3 готовим програмним забезпеченням навчальними платформами. Комбінування різних форм навчання відкриває кожному учневі велику кількість варіантів викладу матеріалу.

Перевернутий клас розв'язує важливу й складну педагогічну проблему сприяє розкриттю і розвитку індивідуальних здібностей (талантів) учня або студента. Навчання в режимі он-лайн дозволяє сегментувати клас на різні групи з різною складністю подачі матеріалу.

3 метою активного залучення молоді до самостійного навчання пропонуємо проведення уроків для учнів з різних класів, групи яких синхронізовані за швидкістю і глибиною засвоєння предмета.

В он-лайн просторі функціонують групи 3 сильних і слабких учнів або студентів. Груповий розбір матеріалу може сприяти покращенню знань учнів 3 
більш низькими результатами. Після досягнення мети такі різно-сегментні групи можуть бути розформовані.

Виведення частини навчання в он-лайн має важливі соціальні функції адаптації навчального процесу для людей з особливими потребами або певними вимогами національної культури.

Відео-лекції і уроки можуть супроводжуватися титрами для людей з вадами слуху або форматуватися в текст зі шрифтом Брайля. Для учнів, що невпевнено володіють мовою, якою викладено предмет, можуть уповільнювати виклад, для них можуть робити численні повернення і повтори.

Якщо вивчення теорії побудовано інакше: за методом проектів чи он-лайн груп, - учні комунікують одне з одним, покращуючи свої навички спілкування, так би мовити, в «домашній обстановці».

\subsection{1. Перевернутий клас - базова форма теорії змішаного навчання}

Розвиток технологій в середині XX-го століття «підказав» педагогічній науці нову форму навчання. В якості експериментальних методик до традиційної навчально-класної системи стали додавати он-лайн заняття,

які проводилися без вчителя, якого замінюють віртуальним помічником або при повній його відсутності як додаткові заняття. Після численних апробацій ця методика стала впроваджуватися безпосередньо в навчальний процес.

Розподіл освіти на он-лайн і традиційну класно - урочну форми позначили терміном - змішане навчання (Blended learning).

Базовою формою Blended learning став перевернутий клас. Викладачі вносили в інтерактивну частину навчання теоретичний матеріал, записуючи лекції у форматі відео, що опрацьовувалися студентами самостійно. Це дозволяло приділити більше уваги розв'язанню практичних завдань і роз'ясненню незрозумілих для студентів питань.

Види занять - теорія вдома й практика в класі - стали початковим етапом змішаного навчання. Перевернутий клас відкрив перед педагогами модель диференційованої освіти. У рамках навчальної програми викладач самостійно 
підбирає методи подачі матеріалу, домагаючись максимального залучення студентів чи школярів до вивчення предмета.

Вивчена вдома теорія створює умови для проведення практичних занять у різних інноваційних формах, як-от: метод проектів, рецензування, математичні маніпуляції, лабораторні дослідження тощо, поєднуючи їх 3 традиційною освітою.

Під час навчання в класно-урочній системі учні змушені засвоювати інноваційні методи самостійно. Система ж Flipped Class дозволяє викладачеві миттєво реагувати й усувати проблеми впровадження нових форм навчання або коригувати освітній процес для кожного конкретного класу або групи.

\subsection{2. Інноваційні акценти Flipped Class}

Основні ідеї перевернутого класу - досягти повного залучення учня в освітній процес, стимулювати його на пошук додаткової інформації з предмета, а також сприяти комунікації з іншими учнями для навчання один у одного.

Перевертаючи навчання, викладач повинен вибудувати навчальний процес таким чином, щоб він розвивав самостійність і стимулював активність. Учень, студент або група повинні навчитися не тільки засвоювати теорію поза класом, а й розвивати навички самооцінювання.

Метою викладача є також формування позитивного ставлення до навчання. Цьому сприяє такий методичний прийом, як зарахування тільки тих результатів, що задовольняють учнів чи студентів. Отже, вони будуть опрацьовувати матеріал, доки не досягнуть необхідного порогу знань. Такий підхід до навчання дозволить створити “ атмосферу успіху“. Учень перестає

відчувати страхи й панікувати, натикаючись на незрозумілі місця і стає впевненим в індивідуальній допомозі викладача в класі.

Педагогу важливо зрозуміти, що перевернутий клас дає свободу координації навчання, перетворює вчителя в консультанта і модератора

пізнавально-дослідницької діяльності учнів. Базою для цієї роботи є відеолекції або будь-яка інша інтерактивна подача теорії. 
Flipped Class дозволяє розширити і доповнити теоретичний матеріал за допомогою різних навчальних платформ. Освітня програма виступає відправною точкою, що запускає поглиблений процес навчання.

Під час обговорення самостійно вивченого вдома змісту програми учні та студенти краще розуміють матеріал, що викликав у них труднощі. Спільна практична робота в класі допомагає закріпити отримані знання, акцентуючи увагу на прикладах, які пояснюють незрозумілу частину теорії.

Подальша робота в класі може будуватися за принципом диференціації. Розібраний на уроці матеріал закріплюється учнями у відповідному темпі й обсязі. Клас розбивається на групи, де різні за успішністю учні працюють над різними практичними завданнями.

Це дозволить індивідуалізувати освіту, створити незалежні моделі курсів, що перевищують загальні норми школи або ВНЗ.

\subsubsection{Flipped Class: особливості трансформації таксономії викладання,} основні проблеми практики застосування інноваційного навчання

Інноваційна модель навчання Flipped Class налічує менше 20-ти років практики застосування. Недостатній досвід апробації цісї моделі призводить до проблем іiі використання, а також недостатнього розуміння суті перевернутого навчання на рівні школи чи національної педагогічної науки.

Для ефективного впровадження змішаної освіти в масштабах країни, області або міста, села треба створити рівні чи схожі умови для поширення інтернет-освіти, реалізації загальноприйнятих стандартів і підвищення рівня підготовки кадрів.

Нині ще багато викладачів сприймають Flipped Class як досить просту форму освіти, в якій лише помінялися місцями домашні завдання і класна робота. Теорія вивчається вдома, практика проходить під наглядом викладача.

У дійсності перевернуте навчання змінюе основні принципи таксономії викладання, на яких воно було побудовано, починаючи з 1960-х років. Педагогів треба переорієнтувати на нову організацію навчання - теорія вдома, 
практика в класі чи в аудиторії, залучати вчителів до використання методу проектів, навчати розумінню і усвідомленню нової «піраміди» освіти, а також підготовчої, поетапної роботи, щоб «перевернути» клас.

\subsubsection{1. Таксономія освіти Бенджаміна Блума i Flipped Class}

У 1956 році Бенджамін Блум запропонував педагогічну модель навчання, що отримала пізніше назву - таксономія освіти. У процесі спільних досліджень педагогів, психологів, фахівців із тестування були вироблені чіткі критерії і послідовність освітніх цілей і оцінки.

Довгі роки послідовність подачі й засвоєння навчального матеріалу являла собою стандарт у вигляді піраміди, показаний на малюнку нижче: Мал.1

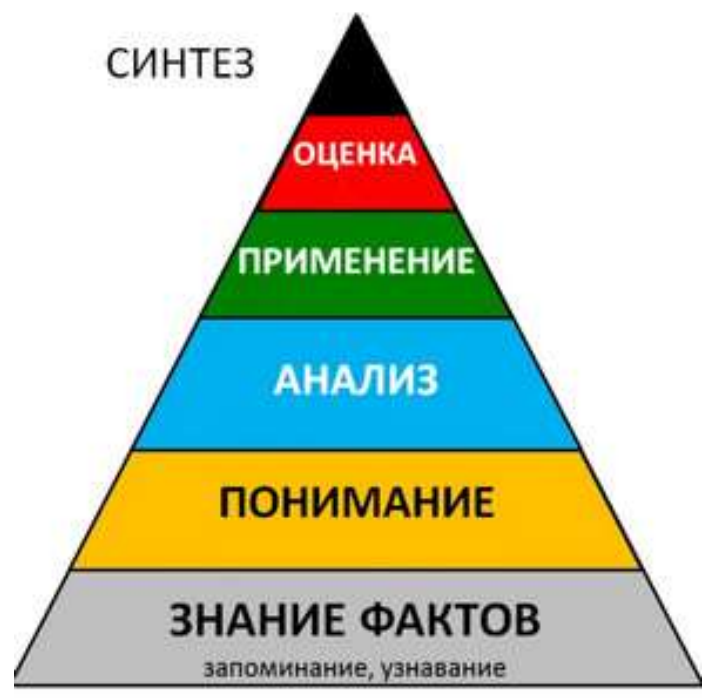

Малюнок 1. Синтез і його складові: оцінка, застосування, аналіз, розуміння, знання фактів (запам'ятовування, упізнавання)

Flipped Class в буквальному сенсі перевертає піраміду Блума, ставлячи процеси аналізу, розуміння, запам'ятовування і впізнавання основою класної роботи. Процес оцінювання й первинного застосування знань відноситься до позаурочної роботи. 
Викладачу відводиться роль коментатора незрозумілих місць, а традиційна подача нового матеріалу замінюється відео-лекціями, презентаціями, скрінкастами, проектами тощо.

Можливі такі форми організації навчальної діяльності: індивідуальна робота, практична, а також робота в міні-групах, уроки (екскурсії, дослідження, взаємонавчання). Комунікативно-інтелектуальні форми роботи: ігри (ділові, ролеві, квест), дискусії, круглі столи, диспути, конференції, уроки-змагання (вікторини, конкурси). Учням чи студентам важливо не тільки засвоїти матеріал, але й вміти «розв’язувати проблему, яка подає нові рішення».

Запропоновані форми освітньої діяльності для перевернутого класу зроблять навчання захоплюючим, цікавим і нестандартним; будуть сприяти спілкуванню і спонукатимуть мислити критично.

У свою чергу викладачі отримають нові інструменти автоматичного або алгоритмічного контролю знань учнів, способи індивідуальної чи групової комунікації.

Педагоги і школа зможуть виділити і відокремлено навчати високомотивованих і талановитих учнів, підвищивши в цілому якість подачі знань.

Цей процес у свою чергу змушує вчителя стати конструктором кейсів градації складності навчального матеріалу 3 предмета в рамках загальної освітньої програми.

Учень або студент засвоює тему самостійно, обираючи індивідуально швидкість опрацювання матеріалу й кількість часу на вивчення. У разі виникнення питання учень у першу чергу звертається до додаткового матеріалу, рекомендованого викладачем або знайденого в Інтернеті, чи користується порадою однокласника / одногрупника.

Педагог - остання інстанція, до якої може звернутися клас. Недоліки вивчення матеріалу вдома буде видно під час етапів аналізу та розуміння частин таксономії, що проробляються при перевернутому підході в класі. 
Завдяки такому оперативному контролю знань на уроці, у вивільнений від викладу нового матеріалу час викладач зможе виявити як індивідуальні, так i загально-групові проблемні місця в засвоєнні матеріалу.

Це в свою чергу вплине на синтез, створення нових знань, дозволить зібрати статистику й редагувати матеріал лекцій і зміст підручників або не змінюючи загальну структуру знань, доповнити проблемні місця посиланнями. Це досить просто реалізувати при електронному форматі лекцій і записаних відео-уроків, які використовуються в перевернутому навчанні.

\subsubsection{2. Проблеми процесу «перевертання» традиційного навчання}

На зараз немає єдиної, загальноприйнятої моделі перевернутого класу. Існуючі методики не можна назвати універсальними: он-лайн навчання або подача теорії в інтерактивному форматі вимагає певних навичок учня, студента, викладача.

Успішно реалізовані форми й інші програми, які теж не є універсальним засобом, через можливість мовної, програмної, соціальної несумісності.

Проте існує кілька універсальних порад, які допоможуть розв'язати проблему впровадження перевернутого навчання:

1.Використовувати гібрид ,тобто лекції і традиційні класні заняття перемежовувати 3 елементами групового «мозкового штурму», синтезу та аналізу для виявлення й подолання прогалин в ході навчання, а також для виявлення творчих здібностей учнів чи студентів.

Мозковий штурм - це приголомшлива техніка для генерації ідей, винайдення альтернативних варіантів та можливостей, виявлення фатальних вад та розробка творчих підходів.

Реалізація різних технік, на нашу думку, найбільш ефективна у групах 3 різним складом (сильні, 3 достатнім та середнім рівнем знань) для надання допомоги й проведення консультацій.

Упровадження гібридної діяльності також дозволяє студентам розвивати компетенції, , включаючи поєднання понять з різних предметів, творчості та 
критичного мислення. Очевидно, що спільна діяльність та задіяння інтелектуально-творчих регуляторів підвищують мотивацію до здобуття знань, більше, ніж звичайне навчання.

2. Пропонувати викладачам використовувати метод посилань - до початку уроку чи лекції учням надавати адреси доступу до майбутнього матеріалу, у вигляді мультимедійних файлів навчальних платформ. Хмарні ресурси, доступи по інвайт або «розшарювання» посилань є мотиваторами самостійної роботи учнів та студентів.

Інший варіант - лекції сторонніх освітніх ресурсів, де ті, хто навчається, можуть подивитися матеріал у викладі іншого викладача.

3. Упроваджувати “перевернуті оцінки" : учень або студент отримує оцінку за якість самостійної підготовки майбутнього матеріалу, а не за перевірку знань розглянутої в класі теорії.

Ми виявили, що ця комбінація мотивує в цілому процеси самонавчання учнів, розвиваючи такі компетентності, як креативність, робота в команді та усне спілкування.

Ухвалюючи рішення про впровадження навчання Flipped Class , педагог або колектив повинен усвідомлювати, наскільки зросте його завантаження в часі й методичному просторі. Обов'язково необхідний режим «пісочниці», де в тестовому варіанті створюються і запускаються інтерактивні матеріали, щоб виявити можливі проблеми в демонстрації, сприйнятті матеріалу учнями, організаційні питання.

Станом на зараз, враховуючи рівень життя в Україні, особливо важливо розуміти, що не всі учні й навіть студенти мають доступ до персональних комп'ютерів або ноутбуків. Вирішити цю проблему можна розробкою лекцій в мобільних додатках або мультимедійних формах, адаптованих для IOS i Android.

Для того щоб дізнатися про рівень забезпечення програмними засобами, необхідно проводити опитування, аби виявити он-лайн можливості засвоєння матеріалу. 3 етичних міркувань воно повинно проводиться в приватній, анонімній формі. 
Ще одна базова проблема перевернутого класу - невиконання домашнього завдання. Учень або студент буде приходити на урок або практику з нульовою теоретичною підготовкою.

Викладач зобов'язаний упровадити систему тестів і таймінгу, контролюючих реальний час роботи 3 матеріалом, а також процес його засвоєння. Якщо учень не досяг граничного рівня знань або має низький темп роботи, він продовжує самостійну роботу, щоб розібратися 3 теорією й вмотивовано працює над підвищенням темпу навчання.

\subsubsection{3. Ефективні форми подачі інтерактивного навчального} матеріалу

Основною формою подачі навчального матеріалу, як і раніше, вважаються лекції, що можуть бути доповнені відео-файлами, малюнками,схемами, тестами.

\subsubsection{1 Важливість і перевага відео-лекцій у змішаному навчанні}

На сьогодні існує безліч форматів відео й платформ для безкоштовного розповсюдження навчального матеріалу, що дозволяє задіяти будь-які пристрої, від персональних ПК і ноутбуків до смартфонів і планшетів. Освітній відеоматеріал може містити мега-посилання або фрагменти записів 3 інших навчальних ресурсів.

Школи та ВН3, що впроваджують інноваційну форму навчання перевернутий клас - і використовують для позакласної освіти файли презентацій, повинні врахувати наступні особливості відео-лекцій:

- Відео-фрагменти на 50\% перевершують презентації із запам'ятовування

- Відео йде на всіх пристроях, файли зі слайдами обмежені певними операційними системами

- При випуску лекцій у вигляді презентацій витрачається більше часу на переробку відео-файлів з інших навчальних платформ

Відеоматеріали уроків для позакласного самостійного або групового навчання вирішують три важливі завдання: 
- Вичерпний виклад теорії - учень або студент може вивчити урок або лекцію в стандартному обсязі або скористатися посиланнями на допоміжні матеріали, щоб отримати розгорнуті коментарі з теми

- Контроль ступеня розуміння викладеного матеріалу за допомогою інтерактивних тестів, вікторин он-лайн обговорення для самоперевірки або зворотнього зв'язку з викладачем

• Ігрова подача матеріалу - важлива для початкової та середньої школи

Відеоматеріали лекції повинні розбиватися на блоки по 5-12 хвилин, після яких учень або студент повинен пройти тестування.

\subsubsection{2 Особливості тестування в системі навчання методом} перевернутого класу

Тести визначають рівень знань кожного учня в класі як свідчення якості його домашньої роботи. Розробка питань покладена на викладача, але для опитування можна застосувати вже готові ресурси Google Docs або спеціально створені навчальні програми сайтів - Master-test.net, Learningapps.org або інші ресурси, створені на допомогу педагогові.

Тестування дозволяє мотивувати учнів шляхом розрахунку відносних оцінок знань на тлі загальної успішності класу. Крім того, кожне завершення теми можна завершити опитувальником у вигляді таблиць та питань щодо вивченого матеріалу для здійснення зворотнього зв'язку. Також викладач може заслухати пропозиції учнів або студентів для підвищеного інтересу до вивченого матеріалу.

Тестування й аналіз успішності може проходити не тільки індивідуально, але і в групах (для порівняння рівня їх успішності). Це дозволить учням i студентам ближче познайомитися один з одним, викладачеві - укрупнено оцінити можливості колективів, виділити сильних і слабких, диференціювати для зібраних груп різний рівень і швидкість подачі знань.

Сучасні сервіси Tricider.com або Triventy.com відкриють можливість постійного зв'язку з групами в режимі он-лайн, якщо освітній процес вимагатиме чергування уроків методом оф-лайн або он-лайн лекцій. Викладач зможе 
формулювати завдання на основі матеріалу освітніх платформ, отримувати зворотній зв'язок через їх використання, вести групу на правах адміністратора тощо.

\subsection{4. Перевернутий клас - передова форма освіти XXI століття}

У XXI столітті людство стоїть на порозі четвертої промислової революції. Вона виражається у фізичній кібернетизації всіх сфер діяльності людини, науки і виробництва.

Сьогоднішні школярі, завтрашні студенти, стануть свідками глобальних зрушень, які змінять до невпізнання: ринок праці, технологічні процеси, навколишнє середовище, політичні системи, людські взаємини, ідентичність і світогляд.

Промислова революція кидає прямий виклик педагогам, які повинні вміти розібратися в соціальних і інтелектуальних запитах і зрозуміти, яким вимогам повинен відповідати випускник школи або ВНЗ. Викладачі, гнучко змінюючи сучасний освітній процес, повинні ефективно відповісти на швидкі навколишні зміни, які привносить інформатизація і кібернетизація суспільства.

Вони привели до глобалізації та інваріантності освітнього процесу, де школа, ВНЗ або окремий викладач більше не є єдиним джерелом знань. Інтернет, соціальні мережі та зарубіжні інтелектуальні платформи активно використовуються в освітньому процесі.

Перед навчальними закладами, й освітою в цілому, стоїть завдання покращити рівень інтелектуальної спроможності випускників шкіл та вузів. Й орієнтуватися треба на новітні міжнародні тенденції в освіті.

Сучасний світ з малого віку залучає учнів в «хмари» соціальних мереж, ITплатформ, віртуальних ігор і додатків. Наукою доведено відносна небезпека технологій для дитячого і юнацького розвитку, але шкільна програма поки не має конкретно розроблених засобів етики і психології використання оточуючих інформаційних систем.

Змішане навчання на основі перевернутого класу ідеально підходить для вирішення завдань: 
• Першого знайомства принципів роботи з гаджетами, додатками, різними операційними системами

- Демонстрування методів правильної і безпечної роботи з IT-ресурсами

У процесі навчання учням треба пояснити, наскільки важливо застосовувати законні методи отримання інформації та роботи з нею, показувати на прикладах небезпеку залежності й різних фобій.

Педагоги повинні формувати необхідний мінімум навичок роботи в ITсередовищі, алгоритм засвоєння нових програм, принципів вибору додатків.

Ще одна важлива функція перевернутого класу - індивідуалізація освіти. Практика змішаного навчання в класі і он-лайн режимі дозволяє педагогу визначити швидкість засвоєння матеріалу кожним учнем і студентом. Це дає можливість диференціювати й індивідуалізувати подальшу подачу знань.

\section{Висновки}

Під змішане навчання підпадає кожен освітній процес, який передбачає отримання учнем інтегрованого досвіду навчання,чергування класних i позакласних занять. Останні проходять в електронному або он-лайн форматі, 3 частковим або повним викладацьким контролем.

Моделі перевернутого навчання змінили традиційну класну систему, модифікувавши роль педагога в координатора навчального процесу для класу в цілому, вибудували самоосвітню траєкторію для групового або індивідуального навчання, перетворили викладача на модератора освітнього он-лайн контенту.

Перехід на таке навчання зумовлений вимогами часу та особливостями дистанційної освіти, що затребувані соціальними й освітніми викликами.

Он-лайн чи оф-лайн освіта лише частково має технологічні проблеми, оскільки більшість учнівської та студентської молоді має доступ до Інтернету, мобільного зв'язку, володіє гаджетами і майже 100\% забезпечена смартфонами.

Завдання викладача - форматувати навчальний матеріал під Flipped Class, зібрати антологію вже існуючих за цим напрямком ресурсів і матеріалів. 
Правильний вибір допоміжних платформ для он-лайн подачі теорії поза класом або для лекційної аудиторії, а також готових методів контролю знань це той ресурс інноваційного навчання, що протистоїть традиційному.

Перевернуте навчання як форма змішаного навчання змінює основні принципи послідовності викладання, на яких воно було побудовано, починаючи з 1960-х років. Педагогів зорієнтовано на нові форми організації навчання .

Досягненням перевернутого навчання $€$ перевертання з ніг на голову самої послідовності дидактики.

У перевернутому класі учні вивчають матеріал вдома і виконують практичні завдання в класі. Це дозволяє вчителеві не тільки створювати цікаві заняття, а й допомагати учням усвідомити якість вивченої теорії.

Методика перевернутого класу надає педагогам час і засоби для аналізу того, який матеріал необхідно переглянути.

Загалом Flipped Class дає можливість учителеві організувати практичну i творчу діяльністю в класі, використовуючи сучасні технології і заохочуючи автономне навчання.

Школа, ВНЗ або окремий педагог може експериментувати з формами подачі знань у рамках курсу,надаючи перевагу активним нестандартним прийомам i методам роботи, одночасно створюючи рівні умови для всіх студентів, незалежно від їх культурних, фізичних, психологічних і освітніх можливостей. 
DOI 10.46299/ISG.2021.MONO.PED.II-359-365

\subsection{4 Досвід та перспективи викладання хімічних дисциплін в умовах дистанційного навчання}

За умови пандемії коронавірусу COVID-19 зручним та доступним способом отримання знань є дистанційна освіта. В 1997 року діяло близько 1000 навчальних закладів, що мали дистанційну форму навчання в 107 країнах світу i кількість осіб складала близько 50 млн. Кількість осіб, які отримали вищу освіту, використовуючи дистанційну форму навчанняв у 2000 року складала 90 млн, а у 2023 р. за прогнозами складатиме 120 млн осіб. У зв'язку з пандемією коронавірусу COVID-19 в Україні, як і в багатьох країнах світу, навчання студентів у нашому ВНЗ було переведено в онлайн-режим із застосуванням сучасних технологій дистанційного навчання [332,333].

Галузь вищої медичної (фармацевтичної) освіти була серед тих, що зазнала найбільшого впливу від пандемії [334-336], адже спілкування є необхідною умовою передачі знань та навичок від однієї людини до іншої [337]. Також, необхідно зазначити, що формування здобувачами освіти певних навичок можливе тільки за наявності спеціальних умов, зокрема спеціально обладнаних навчальних лабораторій та закладів охорони здоров'я, в яких реалізовано доступ студентів до пацієнтів тощо. Таким чином, співробітники закладів вищої освіти постали перед одним з найбільш серйозних викликів за всю новітню історію медичної та фармацевтичної освіти.

Отже метою роботи було узагальнення досвіду викладання хімічних дисциплін «Аналітична хімія» та «Фізична і колоїдна хімія» в умовах дистанційної форми освіти.

Аналітична хімія та фізична і колоїдна хімія відносяться до одних 3 найважливіших дисциплін, що вивчаються майбутніми фармацевтами в рамках їх природничо-наукової підготовки. Успішне засвоєння теоретичного матеріалу 3 цих хімічних дисциплін $є$ необхідною передумовою для вивчення таких навчальних дисциплін фармацевтичної підготовки як біохімія, фармацевтична хімія, фармакогнозія, токсикологічна хімія, фармакологія тощо. Додатково під 
час вивчення цих хімічних дисциплін у студентів формуються базові навички проведення експериментів за умови лабораторії. Важливість цих хімічних дисциплін для становлення майбутніх фахівців у галузі фармації студентам, що навчаються за спеціальністю «Фармація, промислова фармація» полягає ще і у тому, що названі дисципліни включено до структури іспиту «КРОК-1. Фармація». Як відомо до європейських стандартів освіти належать системний, контекстний, безперервний та компетентнісний підходи до якості освітянських процесів, що потребує облік усіх факторів, які впливають на навчальний процес. 3 метою забезпечення впровадження таких стандартів нами здійснюється методологічне i методичне обгрунтування i розробка організаційних технологічних підходів до методики викладання дисциплін.

3 початком карантинних обмежень в Дніпровському державному медичному університеті (ДДМУ) були затверджені єдині підходи до провадження навчальної роботи. Програмне забезпечення дозволяло організовувати відеоконференції, надавало можливість адресної видачи завдань та обліку відповідей студентів, планувати заняття у календарі, інтеграцію 3 іншими додатками тощо. Навчальний процес було реалізовано у синхронному режимі з повною візуалізацією навчального матеріалу.

Ефективність викладання хімічних дисциплін значною мірою залежить від якості візуалізації навчального матеріалу. Враховуючи зазначене доцільним $є$ використання в якості допоміжного програмного забезпечення редакторів хімічних формул та додатків, що дозволяють створювати тривимірні моделі молекул хімічних сполук. Демонстрація студентам моделей дозволяє значно полегшити пояснення такого матеріалу як геометрична та оптична ізомерія комплексних сполук, вплив просторової будови сполук на їх реакційну здатність та механізми хімічних перетворень.

Однією 3 основних проблем при викладанні хімічних дисциплін $є$ неможливість виконання студентами навчальних дослідів, що передбачені програмами дисциплін, які $є$ вкрай важливими для формування практичних навичок. Неможливість проведення лабораторних робіт частково було 
компенсовано демонстрацією студентам навчальних відеоматеріалів, в яких здобувачам вищої освіти представлено виконання досліду 3 детальним поясненням суті хімічних перетворень. Для покращення підготовки студентів провізорів нами складено крім програм з вищезазначених хімічних дисциплін, базу тестових завдань для підготовки до ліцензійних іспитів «Крок-1» в системі «moodle», для комп’ютнрних класів створені тестові завдання для контролю навчального матеріала по темам дисциплін, підсумкові тестові завдання за дисципліною за навчальний рік, комплексні тестові завдання за декількох дисциплін, надруковано вісім навчально-методичних посібників. Вагомий внесок у якісну підготовку студентів - провізорів вносять сучасні комп'ютерні технології - сайт кафедри, на якому розташовані: інформація про порядок навчального процесу, плани, методичні розробки лекцій, практичних занять, самостійної роботи, теми для індивідуальної роботи, рекомендована література для самопідготовки, лекції в системі «Google Meet» i багато іншого. Така інформація полегшує підготовку студентів.

Наразі франкомовні студенти теж засвоюють нову для них методику проведення лекційних та практичних занять - за допомогою онлайн-технологій. Проте, використання вищезазначеного сервісу у студентів-іноземців має певні особливості: вони потребують більше часу, а подекуди і детальних покрокових інструкцій для правильного виконання завдань, багато студентів не бажають самостійно здобувати знання, або вимагають від викладача спрощення завдань. У багатьох із них є проблеми із дотриманням розпорядку: вони не з'являються в мережі у час проведення занять, вимагають консультацій викладача у вечірній час чи у вихідні дні.

Враховуючи труднощі в засвоєнні франкомовними студентами навчального матеріалу, пов’язані з наявністю мовного бар’єра, недостатнім забезпеченням навчальною літературою, іноді низькою мотивацією до навчання студентів, недостатнім рівнем початкової підготовки на батьківщині, особливу увагу проведення занять для студентів-іноземців спрямовуємо на вдосконалення процесу отримання і засвоєння знань, формування практичних вмінь і навичок. 
Для вирішення цих проблем колективом кафедри створені комплекси навчально-методичного забезпечення самостійної i аудиторної роботи українською, російською, англійською та французькою мовами. Постійне оновлення вказаних комплексів із використанням найсучаснішого навчального матеріалу є шляхом до оптимізації та удосконалення роботи 3 іноземними громадянами.

Враховуючи недостатні знання хімічної термінології українською мовою для франкомовних студентів створені посібники на французькій мові, що є синхронними посібникам українською мовою.

Важливою формою організації навчального процесу є лекція, як процес забезпечення орієнтовної основи для подальшої навчальної діяльності студентів в ході практичних занять. Усі лекції щорічно оновлюємо сучасними досягненнями науки, методично вивірюємо, науково обгрунтовуємо для кращого розуміння та сприйняття. А для поліпшення сприйняття лекційного матеріалу іноземними студентами матеріал надаємо в стислій формі, розглядаємо конкретні, загальноприйняті питання та терміни та забезпечуємо консультації лектора, якщо студентам незрозуміло щось із наданого матеріалу. Для покращення засвоєння матеріалу активно використовуємо сучасні мультимедійні засоби, які дають змогу представити схеми, діаграми, таблиці, окремі тези, що є основою для подальшого вивчення фармацевтичних дисциплін в ході професійної підготовки іноземних громадян.

Перспективним напрямком розвитку навчального процесу для іноземних громадян може стати створення альбомів для практичних занять, які містять необхідний навчальний матеріал у вигляді відповідних схем, таблиць, ілюстрацій, що сприяє розвитку моторної і зорової пам'яті студентів, активізує пізнавальну діяльність, допомагає сформвати зацікавленість предметом. Цілком можливо, що дані видання допоможуть вирішити одну з основних проблем пов'язаних 3 протиріччям між об'ємом навчального матеріалу та часом проведення заняття, що є найбільш актуальним саме в групах іноземних студентів. 
Студенти - провізори активно беруть участь у науковій роботі кафедри, представляючи свої наукові роботи на Всеукраїнських та міжнародних студентських конференціях. Так, за останні три роки виступили 13 іноземних студентів -провізорів зі доповідями своєї наукової діяльності.

Побудова педагогічного процесу на основі прозорості оцінювання студентів - провізорів формує довірливе ставлення студента до викладача, стимулює процес більш наполегливого отримання знань. Менші можливості мати під рукою необхідну літературу надає важливість самостійної підготовці студента. На допомогу йому - організація самостійної роботи студента за допомогою підручників, методичних видань, розроблених кафедрою за складними, важкими для освоєння тем, робота в бібліотеці з електронними ресурсами, підручниками та періодичними фармацевтичними виданнями.

Оснащення кафедри комп'ютерними класами, повсюдний доступ мережі «інтернет» полегшує контроль за самостійною роботою студента, сприяє різноманітності їі форм і підвищує ефективність, робить можливою підготовку студентів до ліцензійних іспитів «Крок-1». Слід зазначити, що робота з базою тестових завдань «Крок-1» $є$ обов'язковою, що сприяє концентрації уваги студентів на ключові закономірності хімічних дисциплін, дозволяє перевірити свої знання, адаптує до майбутнього ліцензуванню в країнах світу, де вони, можливо, будуть працювати.

Ми намагаємося робити все для того, щоб наші студенти в повному обсязі придбали знання і оволоділи навичками та уміннями, необхідними в їх майбутній професії. Лекційні лабораторії оснащені мультимедійними системами для демонстрації навчальних фільмів та презентацій. Лабораторні роботи оснащені відповідною апаратурою, хімічними реагентами і посудом. Позиція керівництва ДДМУ полягає в тому, що якщо нам щось потрібно, то проблема вирішується в найкоротші терміни. Ставлення до студентів доброзичливе, але це не означає, що їм сходять з рук слабкі знання. Ми намагаємося донести інформацію до студентів так, щоб вони засвоїли тї, а не отримали хорошу оцінку тому, що заплатили гроші за навчання. 
Хімічна підготовка майбутніх провізорів $є$ основою формування основних трьох типів компетенцій (загальнокультурних, загально - професійних i професійних), тому треба враховувати місце і роль кожної хімічної дисципліни в системі підготовки провізорів. Наприклад, при вивченні аналітичної хімії звертаємо увагу на те, що ця дисципліна $€$ «містком» довузівської і вузівської етапів хімічної освіти, закладає основи хімічної освіти майбутніх провізорів, бере участь у формуванні хімічних компетенцій як основи загальнокультурних і професійних компетенцій, тому за своєю суттю вони являються професійно орієнтованими. При вивченні фізичної і колоїдної хімії звертаємо увагу на виконання цією дисципліною функції універсальної, інтегративної мови, що дозволяє описувати і вивчати хімічні об'єкти, процеси, методи аналізу.

Високий професійний рівень сучасного фахівця - провізора передбачає володіння хімічними, фізико - хімічними методами аналізу і навичками щодо їх використання. У процесі оволодіння знаннями 3 аналітичної, фізичної та колоїдної хімії закладається теоретична і методологічна база для вивчення фармацевтичних дисциплін, що і складає основу фундаментальної підготовки провізора.

Придбання необхідних хімічних знань, умінь, навичок, що трансформуються в комплекс хімічних компетенцій, як основи майбутнього професіоналізму, створення передумов формування особистісних якостей, які диктуються потребами майбутньої професії - ось, що важливо для підготовки студентів - провізорів до їх подальшої навчальної та професійної діяльності.

Як показали опитування студентів про причини їх неуспішності по деяким хімічним дисциплінам, поряд 3 об'єктивними труднощами їх засвоєння величезний вплив відіграє те, що студент часто погано уявляє собі місце і роль дисциплін у майбутній професійній діяльності.

Методичне забезпечення хімічних дисциплін для студентів - провізорів розроблено на основі компетентнісного підходу, модульності і послідовності викладання навчального матеріалу, що включає робочу програму, дидактичні та контролюючі матеріали і характеризується повнотою і доступністю інформації. 
Такий підхід визначає для студентів - провізорів кінцеві цілі освоєння хімічних дисциплін у вигляді хімічних компетенцій і напрямки їх досягнення (види, способи діяльності, в тому числі самостійної).

У методичних матеріалах до виконання лабораторних робіт значна увага приділяється профілізації викладання в плані ознайомлення студентів 3 фармакопейними методиками аналізу різних лікарських речовин. Кожна лабораторна робота виконується як індивідуальне навчально - дослідне завдання, що дозволяє найбільш об'єктивно оцінювати практичні навички студента провізора. Методичні рекомендації щодо організації самостійної роботи спрямовані на закріплення вміння пошуку, накопичення та обробки наукової інформації

Таким чином, підвищення якості підготовки фахівця неможливо без взаємозв'язку хімічних і фармацевтичних дисциплін, їх інтеграції в процесі навчально - пізнавальної та науково - дослідницької діяльності студентів, важливих для формування їх наукового світогляду і хіміко - фармацевтичної культури. Запорукою успішної реалізації концепції дистанційної освіти $є$ створення інформаційної бази кафедри та своєчасна допомога викладача студентам. Збільшення наочності та спрощена подача матеріалу у вигляді блоксхем сприятимуть не лише покращенню засвоєння матеріалу, а й допоможуть вирішити проблему, пов'язану з протиріччям між об'ємом навчального матеріалу та часом проведення заняття, а також стануть у нагоді при підготовці до підсумкового контролю та екзаменів, що дозволяє підвищити їх практичну значущість та вмотивованість студентів. 
DOI 10.46299/ISG.2021.MONO.PED.II-366-375

\subsection{5 Підготовка вчителів сврейської діаспори України до впровадження дистанційного навчання в початкову ланку}

Етнополітика сучасної України переживає сьогодні період становлення, іiі ключовим принципом $є$ забезпечення гармонійного співжиття всіх громадян України різних національностей, створення умов для їхнього етнокультурного розвитку. Серед багатьох завдань цього процесу слід виділити, як приоритетне, збереження етнічної ідентичності. Складовою частиною поліетнічного полікультурного простору України є культура єврейського народу. Шлях збереження національної культури в умовах життя у діаспорі - це передусім розвиток національної освіти. Самобутня історія, оригінальна система освіти i виховання молоді стали традиційно найважливішими компонентами культури євреїв України. Єврейська діаспора України має ретельно дбати про розвиток власної освіти, а держава повинна забезпечити умови для такого розвитку.

Серед єврейських національних навчальних закладів, які успішно функціонують у сучасній незалежній Україні, гідне місце займає ВНЗ «Міжнародний гуманітарно-педагогічний інститут «Бейт-Хана», що є закладом, який поєднує академічну підготовку здобувачів вищої освіти з практичними завданнями формування професійної компетентності майбутніх педагогів i психологів з урахуванням надбань і традицій національного українського та єврейського виховання, зі спрямуванням на задоволення потреб у забезпеченні вчителями систем формальної і неформальної єврейської освіти та працівниками організацій у структурі єврейських громад. Інститут проводить освітню діяльність за такими спеціальностями та ступенями: 012 Дошкільна освіта, 013 Початкова освіта за освітньо-кваліфікаційним рівнем молодшого спеціаліста; 012 Дошкільна освіта, 013 Початкова освіта, 053 Психологія за освітнім першим освітнім ступенем «бакалавр», спеціальностей 013 Початкова освіта та 053 Психологія за другим освітнім рівнем «магістр».

Запровадження карантину, спричиненого глобальною пандемією COVID-19, змусило системи освіти багатьох країн світу перейти на дистанційні форми навчання, зокрема і в Україні. Нажаль, система освіти, педагоги, батьки 
та учні переважно не були готові до цього, попри те, що «Положення про дистанційне навчання», в якому були визначені мета, зміст і шляхи його реалізації, було розроблено та затверджено МОН України ще у 2013 році.

Одним 3 найважливіших елементів дистанційної освіти є специфічне кадрове забезпечення, особливістю якого є якісно інші вимоги до викладача: від принципово нового рівня професійних і комп’ютерних знань та умінь до розуміння концептуальних положень й володіння дидактикою дистанційної підготовки. Дистанційне навчання, як результат еволюції системи освіти, активно увійшло до професійної підготовки педагогів, зокрема, вчителів початкових класів. Одним з найважливіших завдань сучасної початкової школи $\epsilon$ створення таких умов навчання учнів, що не тільки збагачують дітей знаннями, але і викликають потребу в пізнанні світу, сприяють збереженню та розвитку культури етнічних громад. Використання дистанційних технологій повинне бути додатковим поштовхом при розв'язанні цих проблем.

Наразі вкрай важливо було посилити роботу 3 формування готовності студентів до організації навчання в нових умовах та використання набутих навичок застосування дистанційних технологій у майбутній професійній діяльності, в тому числі, у закладах із єврейським етнонаціональним компонентом, чому і призвана слугувати дисципліна «Організація дистанційного навчання в початковій школі» для магістрів спеціальності 013 Початкова освіта у ВНЗ «Міжнародний гуманітарно-педагогічний інститут «Бейт-Хана». Вказана дисципліна має на меті підготовку магістрів до застосування в початковій ланці освіти дистанційних технологій навчання як нової форми організації освітнього процесу, що відбувається в основному за опосередкованої взаємодії віддалених один від одного учасників навчального процесу у спеціалізованому середовищі, яке функціонує на базі сучасних психолого-педагогічних та інформаційнокомунікаційних технологій.

Пропонована публікація знайомить 3 досвідом підготовки майбутніх учителів початкових класів до організації дистанційного навчально-виховного процесу з урахуванням єврейського етнонаціонального компоненту. 
Концепція розвитку педагогічної освіти заснована на збалансованому включенні в зміст підготовки вчителів фундаментальних, прикладних i методичних дисциплін, що визначають необхідний професійний рівень сучасного педагога. Ці вимоги було враховано при розробці авторського навчально-методичного комплексу дисципліни «Організація дистанційного навчання в початковій школі», що знайшло своє відображення в змісті матеріалу трьох послідовних блоків: теоретико-методологічного, програмнотехнологічного та предметно-методичного.

Зміст теоретико-методологічного блоку спрямований на формування у студентів розуміння сутності дистанційної освіти, ії нормативно-правової бази та понятійно-термінологічного апарату, дидактичних основ організації дистанційного навчання, вимог до кадрового забезпечення дистанційного освітнього процесу.

При ознайомленні 3 будь-якими фундаментальними теоретичними поняттями неможливо обійтись без розгляду їх витоків, історичних коренів, тож, насамперед слід проаналізувати передумови виникнення дистанційного навчання, історію його розвитку, поділену дослідниками на три етапи, виходячи з відсутності/наявності зворотного зв'язку чи його багатосторонності, який спирається на різні покоління засобів інформації, що обмежені певними проміжками часу. Далі пропонується дослідити нормативно-правове підгрунтя дистанційного навчання в Україні, зміст основних законодавчих та нормативноправових документів з їх прив'язкою до важливих етапів та подій інформатизації освіти. Сутність основних категорій дистанційного навчання багатогранна i різнопланова, відображає різноманітні підходи до його розуміння, що свідчить про стрімкий розвиток цієї галузі освітньої діяльності та намагання знайти оптимальне iii науково-методичне i технологічне наповнення. Тож, слід проаналізувати понятійно-термінологічний апарат дистанційної освіти, представлений як у концепціях, законах, постановах, положеннях, так i в наукових працях вчених-корифеїв цього напряму (В. Биков, М. Жалдак, В. Кремень, В. Кухаренко, В. Осадчий, С. Сисоєва, О. Спірін, А. Хуторськой, 
П. Вольф (P. Wolff), К. Сандерс (C. Saunders), Ч. Скотт (Ch. Scott), Ед Тіттел (E. Tittel) та ін.). Особливо детально розглядається зміст Положення про організацію дистанційного навчання у своєму навчальному закладі [338].

Вирішення складних проблем, що виникають у різних галузях людської діяльності, зокрема, в освіті, може бути ефективним лише за умови використання системного підходу, який вважається одним із провідних методологічних принципів дослідження в кожній галузі знань. Сучасна освіта являє собою складну систему, що об'єднує навчання і виховання, реалізує зміну парадигми навчання з традиційної інформаційної на розвиваючу самостійну пізнавальну. Дистанційна освіта реалізується через систему дистанційного навчання, яка $є$ частиною системи освіти України з нормативно-правовою базою, організаційно оформленою структурою, кадровим, системотехнічним, матеріально-технічним та фінансовим забезпеченням. Розгляд окремих видів забезпечення дистанційної освіти доцільно здійснювати на засадах академічної дидактики - характеристики базових складових дидактичної системи навчання (мети, змісту, методів, засобів, форм) з виділенням суттєвих специфічних рис.

Водночас удосконалення системи освіти залежить не лише від дослідження дидактичних особливостей упровадження сучасних дистанційних технологій в освітній процес та вивчення можливостей різних систем дистанційного навчання, а й від підготовки майбутніх фахівців до роботи в дистанційному інформаційно-освітньому середовищі, оскільки їх зміст та форма суттєво відрізняються від традиційної. У системі дистанційної освіти виділені 4 типи суб'єктів: здобувачі освіти (учні/студенти), тьютори (викладачі, наставники), організатори (для вирішення організаційних питань), адміністратори (для забезпечення стабільного функціонування технічного і спеціального програмного забезпечення, за допомогою якого здійснюється управління дистанційним навчальним процесом).

Для розуміння ролі тьютора в дистанційному навчанні особливо слід виділити соціально значуще i затребуване сьогоденням дисертаційне дослідження Катерини Осадчої «Теоретико-методологічні засади професійної 
підготовки майбутніх учителів до тьюторської діяльності», представлене на здобуття наукового ступеня доктора педагогічних наук у 2020 році [339]. У межах цієї актуальної роботи автором визначено зміст, мету, функції, завдання та методи тьюторської діяльності на основі аналізу вікових особливостей учнів 1-12 класів та провідного виду діяльності для кожного вікового етапу. Підкреслено, що в різних ланках 33СО тьюторська діяльність повинна бути спрямована на розробку й супровід індивідуальної освітньої програми, яка для учнів молодшого шкільного віку в основному спрямована на формування пізнавального інтересу та позитивної мотивації до навчання; для учнів середнього шкільного віку - на підтримку інтересу до навчання з орієнтацією на вибір групи предметів та допрофільну підготовку; для старшокласників - на професійне визначення. На основі такої диференціації виділено різні види тьюторства: залежно від функцій тьютора - тьютор-наставник, тьютор-куратор, тьютор-консультант, тьютор-керівник освітньої траєкторії, тьютор у міждисциплінарній освіті; від сфери здійснення тьюторської діяльності в початковій школі, в основній школі, в старшій школі, у вищій школі, в навчанні дорослих, в інклюзивному навчанні.

У програмно-технологічному блочі розглянуто можливості освітньої Інтернет-комунікації, використання Веб-технологій, послуг хмарних сервісів, спеціальних цифрових інструментів для дистанційного освітнього процесу.

Найперше слід активізувати знання магістрів з основ організації Інтернет, його найпоширеніших послуг (електронної пошти, телеконференцій, файлового сервісу, інтерактивного спілкування), перевірити навички володіння основними прийомами і способами дій, що найбільш властиві мережевим технологіям (навігації гіпертекстовими документами, використанню інформаційнопошукових систем) через виконання завдань, що потребують не тільки технологічних навичок, а й загальнопедагогічних та частковометодичних знань.

При розгляді хмарних технологій визначено їх сутність, як надання кінцевим користувачам віддаленого динамічного доступу до послуг, обчислювальних ресурсів і додатків (включаючи операційні системи та 
інфраструктуру) через Інтернет; рівні (надання програмного забезпечення у вигляді сервісу - SaaS (Software as a service), надання платформи в якості сервісу - PaaS (Platform as a service), надання інфраструктури в якості сервісу - IaaS (Infrastructure as a service)); покоління Веб сервісів та тенденцію розвитку сучасного освітнього середовища в напрямку використання хмаро орієнтованих платформ постачання сервісів і програмного забезпечення - хмаро орієнтованих навчальних середовищ (ХОНС).

На сьогоднішній день в україномовному сегменті мережі Інтернет найбільшою популярністю серед освітян користуються хмарні сервіси корпорації Google, що дозволяють організувати швидке впровадження хмарних технологій у навчально-виховний процес освітніх закладів (Gmail, Google Drive, Google Docs, Google Sheets, Google Slides, Google Forms, Google Meet тощо).

Окремий акцент було зроблено на використанні соціальних мереж, як загальних (Facebook, WhatsApp, Instagram, Twitter, Viber та ін.), так i спеціалізованих (освітніх та наукових). Серед останніх особливо корисними для педагогів є популярні освітні платформи - «Всеосвіта», «На урок», «Освіта», «Освіторія», «Педрада», які надають можливість участі в освітніх проектах, інтернет-конференціях, онлайн-семінарах, перегляду вебінарів, а ще отримання сертифікатів. Також було розглянуто платформи для організації дистанційного навчання, а саме: Zoom - як ресурс комунікаційного програмного забезпечення, який об'єднує відеоконференції, он-лайн зустрічі, чат і мобільну спільну роботу, а також зразки навчальних курсів на платформі Moodle у ВНЗ «Міжнародний гуманітарно-педагогічний інститут «Бейт-Хана».

Заплановано відпрацювання практичних навичок роботи 3 вікісередовищами, зокрема, з україномовною версією веб-енциклопедії Вікіпедія, 3 соціальними геосервісами, а особливо, з сервісами мультимедійних ресурсів засобами, які дозволяють безкоштовно зберігати, класифікувати, обмінюватися цифровими фотографіями, аудіо і відео записами, презентаціями (SlideShare, Flickr, Фотки (fotky.com.ua), Pinterest, Youtube). 
Значну увагу було приділено блогосфері освітян України, причому, як особистим блогам учителів початкової школи, так і суспільним (корпоративним) окремих навчальних закладів. Як приклад можна навести ресурс проекту неформальної освіти «Level Up by Smart J», що реалізується під егідою Федерації єврейських громад СНД, орієнтований саме на єврейські школи з метою підвищення їх ефективності шляхом інтенсифікації позакласного компонента, де в якості пілотних вибрано два напрямки - англійська мова та робототехніка.

У предметно-методичному блоиі здійснено аналіз змістовного, дидактичного та методичного забезпечення з урахуванням можливостей дистанційних форм навчання предметів початкової школи, особливо курсів 3 мов i літератур корінних народів і національних меншин та інших предметів гуманітарного циклу, пов'язаних 3 етнокультурним змістом освіти, зокрема предметів юдаїки. Організація дистанційного навчання не потребує додаткового розроблення і затвердження окремих освітніх програм за освітніми рівнями та навчальних програм із навчальних предметів, здійснюється відповідно до програми закладу освіти та має забезпечувати виконання суб'єктами дистанційного навчання державних стандартів освіти. Вчитель, як і раніше, зобов'язаний виконувати освітню програму для досягнення учнями передбачених результатів навчання, тобто надавати інформацію щодо обсягу та змісту навчального матеріалу, завдань на його закріплення, перевіряти й оцінювати їх та надавати відгуки на виконані завдання. Дистанційний освітній процес повинен реалізовуватися на основі навчальних планів, враховувати кількість годин та специфіку організації навчання різних дисциплін в різних формах: як у режимі онлайн, коли навчальні заходи і взаємодія з педагогом проводиться в режимі реального часу з використанням IКТ, так і в режимі офлайн, який забезпечує учням можливість освоєння навчального матеріалу в будь-який зручний для них час. Учитель, плануючи розклад за скорегованим календарно-тематичним плануванням, має розподілити навантаження, чергуючи навчання у формі відео-інструкцій, онлайн-уроків із завданнями у підручниках і посібниках для самостійного опрацювання. При цьому важливо пам'ятати, 
що за нормами ДСанПІНу час безперервної роботи з комп'ютером в учнів початкових класів не повинен перевищувати 15-20 хв.

У загальному вигляді систему управління змістом освіти можна представити наступним чином:

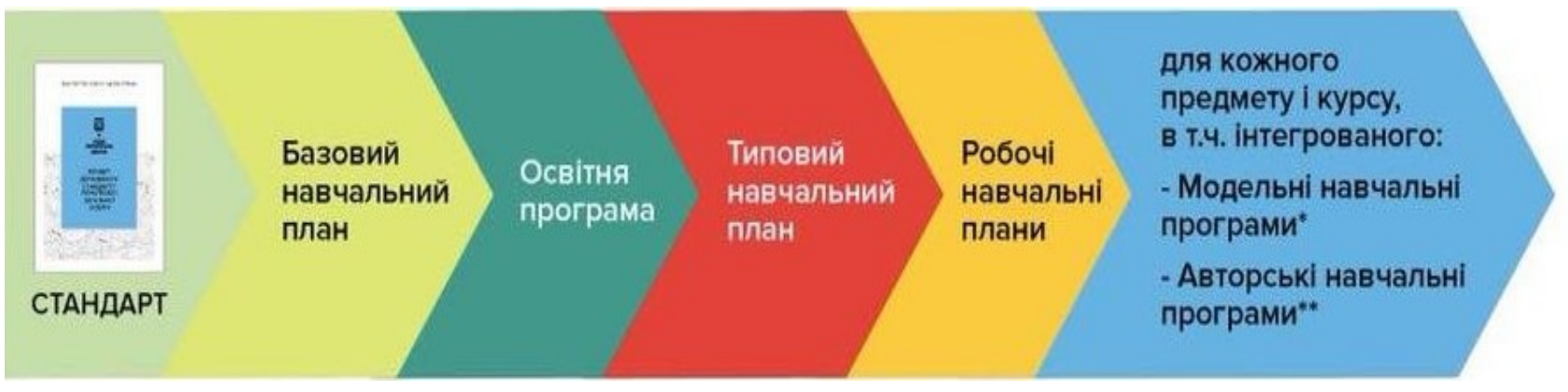

Нова реальність породжує запит на спеціальний науково-методичний супровід навчального процесу, який знайшов своє відображення в комплексах взаємопов'язаних між собою частин. Навчально-методичний комплект (НМК) це сукупність нормативних та навчально-методичних матеріалів на паперовій та/або в електронній формах, необхідних і достатніх для ефективного виконання школярами програми дисципліни, передбаченої навчальним планом. НМК, як сукупність навчальних видань різних видів i форм, містить: програмнометодичні видання (навчальні плани і програми); навчально-методичні видання (методичні вказівки і рекомендації); навчальні видання (підручники і посібники); допоміжні видання (робочі зошити, збірники задач і вправ, практикуми, збірники контролюючих матеріалів, електронні видання тощо). На прикладі змісту складових комплекту інтегрованого курсу «Я досліджую світ» було детально розглянуто забезпечення різних видів діяльності при дистанційній організації навчання в початковій школі зі вказівкою адрес їх електронних варіантів. Також магістрам було пропоновано цілий ряд інтернет-порталів, що 3 настанням карантину в Україні розміщували на своїх сторінках матеріали на допомогу вчителю про роботу шкіл у дистанційному форматі, серед яких сайти НУШ, Академії цифрового розвитку (АЦР), блоги порталів EdEra, НаУрок, Все освіта, а також ресурси обласних Інститутів післядипломної педагогічної освіти.

Окремо було підкреслено особливості підтримки різних видів діяльності здобувачів освіти при дистанційному навчанні - навчально-пізнавальної, 
контрольно-оцінювальної, аналіз дидактичних комплексів

організаційно-виховної.

Відповідно електронних ресурсів здійснювався за основними блоками матеріалів (інформаційно-змістовий, контрольнооцінювальний, розвивальний).

Крім загальної характеристики підходів до організації дистанційного навчання в початковій ланці освіти, практичні аспекти його реалізації розглядалися на прикладі функціонування шкіл із єврейським етнонаціональним компонентом, де студенти нашого закладу проходять різні види практик. Наголос ставився на особливостях навчання івриту в початковій школі. Програма з мови іврит розроблена Наталею Бакуліною з урахуванням вимог Державного стандарту початкової освіти, вікових особливостей розвитку та потреб учнів і забезпечує дітям з єврейських родин можливість повноцінно користуватися рідною мовою як засобом комунікації і пізнання, залучаючись до багатства єврейської культури [340]. Також у співавторстві 3 Іванною Фалесою було розроблено підручники з івриту з додатками (довідник і словник).

Невід’ємною частиною успішної організації процесу навчання івриту є контроль навчальної діяльності відповідно до основних цілей навчання з урахуванням інтересів і можливостей учнів молодших класів. Об'єктами контролю та оцінювання значаться мовні вміння 3 аудіювання, говоріння, читання, письма та сформованість певного кола знань про мову, мовні та правописні вміння, графічні навички письма. Було уточнено засоби діагностики комунікативних компетентностей 3 мови іврит, засоби оцінювання знань і умінь молодших школярів при дистанційному навчанні: спеціальні тестові завдання в Google-формах, вправи з картками в середовищі learningapps.org (https://learningapps.org/10943224, https://learningapps.org/14873045), аудіювання (https://www.youtube.com/watch?app=desktop\&v=u8VS3TRwlgY\&list=PL_0VYN1 GkfMgpS68avctgUFJxo5JxeTBG), творчі та ігрові завдання (https://play.makeit.app/play.html?code=468950), ситуативні діалоги при діалогічному мовленні (https://www.youtube.com/watch?v=UTIFRPD7XGo) тощо. 
Таким чином організоване дистанційне навчання сприяє якісному засвоєнню учнями навчального матеріалу, активному й самостійному виконанню завдань. Однак в умовах карантину не менш актуальною залишається і виховна робота, адже вона має такі важливі функції: профілактичну, ціннісноорієнтаційну, просвітницьку, формування особистісних якостей та гарних манер. Карантин не може стати перепоною для формування правильних цінностей та всебічного розвитку дітей, а також бути на заваді проведення заходів у дусі культури і традицій єврейського народу. Необхідно звернути увагу на такий вид організації роботи на уроках в початковій ланці як ранкові зустрічі, рутини, фізкультхвилинки, які у школах єврейської діаспори проводяться мовою іврит. Також 3 метою ознайомлення 3 національними традиціями, культурою дистанційно проводяться позашкільні заходи на честь національних свят: РошАшана, Йом Кіпур, Симхат Тора, Суккот, Ханука, Пурим, Песах, Лаг ба Омер, Шавуот.

Представлена авторська методика спирається на науково обгрунтовану теоретичну базу та підкріплена апробованими доцільними прикладами, проте потребує подальших наукових розвідок, технологічного удосконалення й методичного розроблення аспектів запровадження дистанційного навчання в систему єврейської освіти України, а запропоновані в даній публікації підходи та дібрані ресурси можуть слугувати практичними рекомендаціями для застосування в освітній практиці. 


\section{SECTION 5. SOCIAL PEDAGOGY}

DOI 10.46299/ISG.2021.MONO.PED.II-376-382

\subsection{Is pandemic the educational system collapse or an impact to optimize it?}

The pandemic has made adjustments to the plans of universities for the academic year. Everyone had to look around and find a way of their own existence.

On the one hand, in many countries, the measures taken, have affected the quality of teaching, the schedule of admission and, in general, the education accessibility. On the other hand, the pandemic turned out to be a strong incentive for optimizing the educational process, revising the university values and the organization of education in general.

The average characteristic of the system reaction as a whole should not hide the fact that a large part of the students were actually transferred to distance learning. The infrastructure and experience of digital technologies users in a number of universities turned out to be insufficient for an effective transition to a remote work format. This testifies to the accumulated some universities backlog from modern requirements in the management field and educational process organization [346]. Thus, the experience of recent months has shown the wide possibilities using formats and remote work technologies to solve not only traditional, but also new university tasks [347].

The main burden fell on the universities staff to ensure the transfer of all work processes to a remote mode. This was especially difficult, since this transition did not take place at the semester beginning, but in its middle (unlike in a number of other countries), which required courses restructuring on the fly [348]. An analysis of university practices shows that during the period of remote work, several modes of organizing educational activities have developed:

- asynchronous or part-time (students study the material at a convenient time, in accordance with the terms set by the teacher);

- synchronous (simultaneous participation in the lesson, for example, in the format of a webinar ); 
- mixed (combination of synchronous and asynchronous interaction, depending on the pedagogical tasks).

A meaningful analysis of these data showed that the teachers, were able to mobilize work under the new conditions, but the problem of the first weeks was the lack of work schedule awareness and the available resources. At the same time, the key deficit was not technological, but methodical, due to the fact that teachers do not possess modern methodological instruments for the high-quality organization of distance learning. The second survey, carried out two months later, showed that during this period $36 \%$ of teachers acquired the necessary competencies to conduct classes online, having completed the appropriate refresher courses [349]. At the same time, a significant part of the teachers felt social and psychological difficulties working from home. The teachers who worked in a synchronous mode noted the difficulties of retaining attention and involving students. It was among the specific methodological difficulties. Thus, $65 \%$ of teachers believe that conducting lectures in a distance format does not allow monitoring the students involvement in the educational process [345]. Many familiar formats have proven to be less effective than offline. For example, more than $70 \%$ fear an increase in the practice of dishonest behavior among students during exams, which are more difficult to control remotely. Teachers leading disciplines requiring laboratory or special equipment found themselves in a difficult situation. In the most cases, they did not receive methodological and technological support [341].

For some teachers, the distance format turned out to be more convenient both when planning their own working time and in terms of organizing training. Moreover, $15 \%$ of teachers believe that the education quality has improved significantly. However, almost $60 \%$ doubt the online learning quality and do not plan to continue active use of it after leaving self-isolation [345]. But the most educators agree that pandemic helped them to master new online learning tools and practices. Some teachers, held in the past few months, show that when analyzing the changed situation, the difficulties and opportunities that arise, first of all, discuss educational activities. But research and scientific work remained out of sight. This situation in many respects manifests the prevailing attitude towards research activity as secondary. 
At the same time, the proportion of teachers who see digital technologies as new opportunities to increase the quality education availability increased from $30 \%$ to $70 \%$ during their remote work. We can define the following groups with different attitude: - Teachers of disciplines that require a significant amount of practical, laboratory work, in the most cases did not have any serious substitute for teaching methods. They were engaged in methodological and organizational work, helped other teachers, on average about $5 \%$ of the total number of teachers. This group has largely opposed the use of the remote format and new technologies in the future.

- Teachers who actively used digital technologies (including online courses and resources) before the pandemic were able to quickly expand the use of familiar communication tools and create digital resources, learning management systems. Their share was about $25 \%$ (in leading universities - up to $40 \%$ ). This group generally supports the distance learning increased use and believes that the quality of training for a particular course online can be comparable to that of offline learning.

- Teachers familiar with digital technologies (including outside of professional activity), with searching for information on the Internet, with communication by email. They quickly mastered new tools, including synchronous learning, but this required significant efforts, about $40 \%$ (in leading universities - up to 50\%). This group is very "tired" of the work increased volume, of the quickly mastering new technologies difficulties. Basically, representatives of this group do not support a significant expansion of the open education, but they see in some cases the using communication technologies possibilities, educational management systems and the additional digital educational resources use.

- Teachers who during this period were unable to master new tools for organizing learning, teamwork and expanded digital resources use. They actually switched to distance learning, sending students control tasks and recommendations for materials study. Their share ranges from $5 \%$ to $30 \%$, depending on the university. For these teachers, the transition experience was traumatic, very difficult. They do not believe in the effectiveness of the distance format or in their ability to master new learning technologies. Thus, a significant part of teachers have certain negative attitudes 
towards online formats, which have practically not changed during their "remote" work [342].

It should be noted that distance learning brought with it a number of problems, among which the following can be distinguished:

- The methodological load and the intensity of educational work are to be increased. Only $12 \%$ of teachers believe that the distance format did not make the work more laborious.

- The teachers lack of readiness to use effectively digital technologies. More than $60 \%$ of teachers noted that even by the end of the work period in a distance format, they did not have sufficient competencies in the use of both university learning management systems and digital services in the field of students support and accompaniment with using messengers, social networks, services for collaborating with documents, etc. For an even larger group of teachers, methodological deficiencies in the design of classes are characteristic, which relate to the students involvement in activities during online classes, attention management, productive feedback organization, modern methods mastery of online assessment, midterm and final certification [343].

- The most active participants in virtual seminars are those students who are more confident and know more than others. Students who are not confident in their knowledge participate in discussions even less actively than usual.

In addition, distance learning does not work out constructively discussing topics: students can ask questions via chat, but chat is very distracting if you try to focus on what the speaker is saying. Often, because of the weak Internet, you have to turn off the video, and without video it is difficult to establish work contact: you don't even know if a student is listening or going about his business.

People are social creatures, so they learn better and assimilate information through ordinary communication, and not in front of a computer, which is an artificial environment. In any non-virtual classroom, a certain social environment is created where students want to communicate and be friends. They encourage each other to speak up. You cannot create such an environment on the Internet. 
Distant format is perceived as a total opposition to the traditional one according to the "black-and-white" principle. In a tough comparison, almost $90 \%$ of teachers prefer the traditional format in terms of the education quality, and $85 \%$ of them consider the traditional format to be more comfortable. At the same time, the proportion of teachers who see digital technologies as new opportunities to increase the availability of high-quality education increased from $30 \%$ to $70 \%$ during their work "remotely". For example, $41.2 \%$ of teachers believe that in the near future the teacher's freedom in choosing the methods and teaching techniques will increase [344].

When assessing the effectiveness of a new educational technology or learning model, it is tempting to compare the learning outcomes of learners using this technology with the learning outcomes of a traditional face-to-face learning model. However, such a comparative analysis, as a rule, does not provide substantiated statistically significant conclusions due to the fact that it requires:

- rigorous experimental design;

- content identical in content and different in format;

- the same control and measuring materials and conditions for the final certification;

a sufficiently large sample, randomly generated for each model (technology) of training;

- elimination of the influence of external factors on the experimental results, which reduce the validity of the experiment.

In addition, this analysis defines effectiveness as student achievement and does not consider other factors of success.

At the same time, success is not an absolute category, and can be measured based on the interests of different participants in the learning process.

For teachers, these are really student learning outcomes, and for students, in addition to academic performance, motivation and involvement in the learning process play an important role, which directly affect student achievement.

For the administration of the university, such indicators as the percentage of students who completed the course, reducing the workload of teachers and increasing 
their productivity, market coverage and the amount of attracted extra-budgetary funds come to the fore.

Evaluation of the effectiveness of online education or the use of distance learning technologies can be carried out through the prism of these target indicators, but such an assessment is appropriate in the context of a systematic transition to new models of the educational process.

In extreme conditions of a sharp reformatting of the educational process with limited internal and external resources, completely different assessment criteria come to the fore. They can be divided into 4 areas: assessment of the context (prerequisites) of changes, assessment of the feasibility and economic efficiency of changes, assessment of the processes of implementation of changes and results (products), direct and indirect.

In this regard, in order to assess the ongoing forced transition to distance learning, universities will have to answer the following questions:

What factors (social, institutional, administrative) determined the readiness of universities for the transition, the attitude of participants to changes and influenced the effectiveness of these changes?

Are there sufficient internal and external resources to make this transition? In particular, is the level of development of the IT infrastructure sufficient for technical support of changes? Do staff and teachers have the necessary competencies to carry out the assigned tasks? What stages of the transition process caused the greatest difficulty for the participants? What organizational mechanisms were failing? What are the results of the transition to distance learning for students, teachers, support staff? What is the reason for not achieving goals or negative feedback from participants? What problems need to be addressed to improve results?

Such an assessment is more focused on the analysis of prerequisites, needs, processes than on the assessment of results. And efficiency in this case is defined as the ratio of results and expended resources, taking into account the urgency of the tasks. 
Ultimately, it is much more important to draw conclusions from this "global experiment" and organize systematic work on mistakes in order to avoid these mistakes in the future.

Thus, based on the surveys conducted, the following conclusions can be drawn:

1. A massive retraining is needed, aimed not just at "passing the PC course", but at the introduction of new formats and technologies. Given the large heterogeneity of the university system, a special role in the new practices dissemination can be played by programs of intra-Ukrainian teachers mobility in order to increase their methodological competence.

2. It is necessary to create an encouragement and motivation system for teachers who are actively involved in the digital resources design use and practice. Such a system should ensure both the introduction of relevant indicators into the competitive selection procedures and a support system on the early mastering and using digital tools stages.

3. The radical nature of the transition "to full online" creates a negative background for the effective digital technologies introduction and new formats in the educational process. It is necessary to form rather specific and convincing ideas not about a complete traditional approaches and courses replacement, but about the such elements of digital technologies introduction that increase the existing quality and efficiency formats, facilitate the teachers work (primarily routine).

4. It is necessary to create incentive systems (grants) to support intra-university and inter-university communities of teachers, introducing innovative educational and digital practices. In many cases, the most "advanced" teachers have become the engine of universities rapid transition to the remote work format. The critical mass presence of such "innovators" is the most important factor in the successful universities adaptation to the changing conditions. 


\section{2 Соціально-педагогічний портрет неповнолітніх залучених до комерційного сексу}

Проституція як соціальне явище, властиве практично всім історичним формам громадської організації, виникло в найдавніші часи і зберігається до наших днів. Вона $є, з$ одного боку, загальновизнаним негативним соціальним феноменом, з іншого боку, надзвичайно прибутковим і легальним в багатьох країнах бізнесом. У світі існує величезний ринок секс-бізнесу, у тому числі дитячого, він приносить великі прибутки.

Особливе соціальне загострення це явище набуло у зв'язку з тим, що комерційний секс став одним із шляхів поширення СНІДу. Крім того, проституція «молодшає» - в сферу секс-бізнесу все активніше залучаються неповнолітні.

Визначень проституції існує багато. Термін «проституція» походить від лат. слова prostitutio, що означає осквернення, збезчещення, або prostituere виставляти привселюдно (Балакірєва О., Бондар Т., Сазонова Я., Сакович О., 2018; Протопопов А., Савельєва Н., 2009).

Проституцію можна визначити як надання сексуальних послуг за гроші (Гіденс Е., 1999). Крім того, проституція - це залучення до безладних статевих відносин інших осіб, окрім подружжя, в обмін на негайну оплату грошима чи іншими цінними речами (Мінц М., 2009); проституція - це здійснення статевих актів за винагороду; проституція - це надання жінкою свого тіла за винагороду особам, які шукають задоволення статевого бажання. На думку української науковиці І. Д. Звєрєвої, «проституція - це сфера знеособлених емоційно, позашлюбних, безладних, здійснюваних за плату статевих стосунків» (Звєрєва I., Безпалько О., Марченко С., 2004).

Дитяча проституція - проституція осіб віком до 18 років. У переважній більшості держав переслідується законодавством. Додатковий протокол до Конвенції про права дитини, що стосується торгівлі дітьми, дитячої проституції та дитячої порнографії, визначають дитячу проституцію як «практику, коли 
дитина використовується 3 метою отримання сексуальних послуг особами за винагороду або будь-яку іншу форму компенсації» (стаття 2b) (Факультативний протокол до Конвенції про права дитини щодо торгівлі дітьми, дитячої проституції і дитячої порнографії, 2000).

В Україні феномен проституції є недостатньо вивченим. Починаючи із 30х років ХХ ст., усі дослідження цієї проблеми у колишньому СРСР було припинено. Лише наприкінці 80-х років минулого століття проституцію було офіційно визнано соціальним явищем (Протопопов А., Савельєва Н., 2009).

На сучасному етапі розвитку суспільних наук при обговоренні даної тематики, крім терміну «проституція», все частіше використовується термін «сексуальний бізнес», «комерційний секс», тобто продаж сексуальних послуг, під якими мається на увазі не тільки наявність статевого акту, але і сексуально забарвлене спілкування, мастурбація тощо.

Згідно даних Українського інституту соціальних досліджень ім. О. Яременка, серед жінок, які займаються наданням сексуальних послуг в комерційних цілях, 11\% складали діти у віці від 12 до 15 років і 20\% - у віці від 16 до 17 років (Балакірєва О., Бондар Т., Галустян Ю., 2012).

Згідно 3 даними біоповедінкових досліджень цього ж Українського інституту соціальних досліджень ім. О. Яременка та ЮНІСЕФ (2013-2014 рр.) серед 123,5 тис. дітей, що належать до груп ризику, і дітей вулиці, кількість дівчат, які надають сексуальні послуги на комерційній основі, склала 5,5 тис., кількість хлопчиків-підлітків, які мали секс з чоловіками, склала 13 тис. (Балакірєва О., Бондар Т., Сазонова Я., Сакович О., 2018).

За оціночними даними соціологів, в 2011 році в Україні до комерційного сексу було залучено близько 110 тисяч жінок. За інформацією О. Балакірєвої, кожна шоста-сьома повія - неповнолітня.

Один 3 важливих питань дискусії навколо причин залучення до комерційного сексу та факторів, що сприяють цьому активно обговорюється роль перенесеного в дитинстві насильства. Численні дослідження показали, що психічні травми дитинства впливають на все подальше життя людини, 
формування характеру, психічне і фізичне здоров'я. Увагу дослідників все більше привертає феномен жорстокого поводження і домашнього насильства щодо дітей. Найбільш прихованим видом жорстокого поводження 3 дітьми $\epsilon$ сексуальне насильство, яке нерідко призводить до виникнення специфічних розладів.

Сексуальне насильство щодо дитини як форма домашнього насильства включає: будь-які діяння сексуального характеру, вчинені стосовно дитини незалежно від іiі згоди або в присутності дитини; примушування дитини до акту сексуального характеру з третьою особою; інші правопорушення проти статевої свободи чи статевої недоторканості особи, у тому числі вчинені стосовно дитини або в її присутності (п. 15 ч. 1 ст. 1 Закону України «Про запобігання та протидії домашньому насильству», 2017).

За офіційною статистикою у 2020 році 320 дітей в Україні зазнали сексуального насильства. На жаль, реальна кількість постраждалих у рази більша.

Згідно із дослідженнями Ради Європи кожна п’ята дитина в Україні стала жертвою різних форм сексуального насильства (від розбещення до згвалтування).

Поширеність сексуального насильства над дітьми в світі оцінюється близько $20 \%$ у дівчат і приблизно $8 \%$ у хлопців. За наявними даними найбільш високий рівень сексуального насильства над дітьми в Африці (близько 35\%), найнижчий в Свропі (9\%).

Дитячий фонд ООН (ЮНІСЕФ) представив результати дослідження «Комплексна оцінка масштабів продажу дітей, дитячої проституції та порнографії в Україні». Дослідження виявило, що основними групами дітей, які характеризуються підвищеним ризиком постраждати від дитячої проституції, порнографії та торгівлі дітьми є безпритульні, бездоглядні діти, з багатодітних, соціально-деструктивних, неповних, малозабезпечених сімей; діти віком від 13 років і старше. Опитування дітей 14-18 років виявило наступне: $11 \%$ показували своє голе тіло; 10,4\% дозволяли торкнутися до голих частин свого тіла (ощупати 
себе); 7,8\% займалися сексом за певну плату; 3,2\% погоджувалися сфотографуватися або знятися у фільмі в оголеному вигляд.

Також було показано, що серед дітей лише $34,4 \%$ опитаних мають обох батьків; впродовж останніх трьох місяців лише 11,7\% проживали 3 обома батьками, більшість дітей (58,4\%) описують свою сім'ю як дуже бідну, 31,8\% опитаних дітей ніде не навчаються. Основна причина, через яку вони не навчаються, є небажання вчитися, відсутність цікавості до навчання (40,5\%), 14,8\% дітей змушені замість навчання працювати, 11,2\% вважають, що краще працювати, ніж навчатися, 8,9\% батьки не дозволяють їм вчитися (Комерційна сексуальна експлуатація дітей і підлітків, 2011; Шиделко А., 2011).

Дівчата, що стоять на трасах, кільцевих дорогах та обслуговують водіївдалекобійників, отримують за секс-послугу 5 доларів. Крім дівчат, трапляються і хлопчики до 13 років, які також надають послуги водіям. Як причину роботи в проституції діти називають «бажання вижити», «мати гроші на якусь річ» та «необхідність допомагати батькам» (Швед О., 2005).

За даними досліджень, проведених Фондом Нічиї Діти в 2011 році, 24\% респондентів у віці 15-18 років заявили, що вони особисто знають принаймні одну людину, яка в минулому році була в контакті чи пов'язана сексуальними відносинами за гроші або інші подарунки (Комерційна сексуальна експлуатація дітей і підлітків, 2011).

Відповідно до інформації Українського інституту соціальних досліджень ім. О. Яременка та ЮНІСЕФ (2017-2018 рр.) серед 109 тис. дітей віком від 10 до 19 років включно, що належать до груп ризику, і дітей вулиці, кількість дівчат, які надають сексуальні послуги на комерційній основі, склала 5 тис., кількість хлопчиків-підлітків, які мали секс 3 чоловіками, склала 21,3 тис. Також показано, що у 2017 р. частка підлітків, які починають надавати сексуальні послуги за винагороду до досягнення 15 років, зменшується (у порівнянні з 2007 р.). Дещо зменшилась також й частка дівчат, які починають надавати сексуальні послуги за винагороду до досягнення повноліття (Балакірєва О., Бондар Т., Сазонова Я., Сакович О., 2018). 
Військовий конфлікт на Донбасі аналогічно посприяв поширенню такого явища. Відомі навіть випадки, коли дівчата пропонували секс в обмін на продукти харчування.

Крім того, в сучасній Україні проявилось таке явище як соціальне сирітство, коли батьки поїхали закордон на заробітки, покинувши своїх дітейпідлітків або самих, або на стареньких батьків. Ці діти зростають без батьківської уваги і вештаються вулицями тільки тому, що вдома нікого нема. На них легко впливати, чинити тиск через ще несформований характер (Тимків Н., 2019).

Спосіб життя неповнолітніх, які займаються проституцією, є достатньо безладний. Нерегулярність і неправильність харчування, хронічна втома, нервові перевантаження, насилля, вживання алкоголю, наркотиків та паління, інфекційні захворювання, мають руйнівний вплив на фізичне та психічне здоров'я підлітків. Такі діти $є$ потенційним джерелом інфекцій: венеричних захворювань, туберкульозу, гепатитів В і C, ВІЛ-інфекції тощо. Певна частина даної категорії дітей вживають алкоголь і наркотичні речовини з метою зниження тривожності, хвилювання, зняття депресивного стану і роздратованості, що, в свою чергу, породжує фізичну та психічну залежність з усіма наслідками (Протопопов А., Савельєва Н., 2009).

Поведінка дітей, що до комерційного сексу, принципово відрізняється від поведінки дорослих повій. До числа найбільш характерних відмінностей відносять наступні.

- Неусвідомленість своїх вчинків. На відміну від дорослих повій, які усвідомлено і цілеспрямовано ведуть антисоціальний спосіб життя для отримання доходу, у дітей в якості основних мотивів заняття проституцією виступають такі, як прагнення до самоствердження, цікавість, бажання виглядати дорослими.

- Отримання оплати за свою працю в різних формах. Якщо дорослі повії винагороду за свою працю отримують, як правило, виключно в грошовому вираженні, то з дітьми часто розраховуються речами, косметикою, спиртними напоями, вечерею в ресторані, сигаретами тощо. 
- Продаж свого тіла в будь-якому місці за бажанням статевого партнера. Дорослі повії зазвичай мають для надання сексуальних послуг певні умови (знімається постійна квартира, місця в готелях тощо), тоді як діти займаються проституцією переважно на вокзалах, в салонах автомобілів, підвалах, під'їздах, на горищах тощо.

- Споживання дитиною при наданні сексуальних послуг великих доз алкоголю або наркотичних речовин. Діти нерідко змушені пити зі своїм клієнтом якомога більше для того, щоб обпоїти останнього з метою пограбування.

- Заняття проституцією з вимушеною перервою, оскільки час від часу діти потрапляють, наприклад, в притулки або примусово повертаються до батьків.

- Залякування, шантажування підлітка можливим оприлюдненням щодо заняття проституцією перед групою однолітків, батьками або шкільним колективом у разі відмови займатися цим видом діяльності.

- Правовий нігілізм підлітків, який полягає в тому, що в число друзів підлітка, як правило, входять кримінальні елементи: спекулянти, валютники, наркомани, сутенери, але нікого 3 них вони не вважають злочинцями і не пов'язують себе з злочинним світом.

Особливості дитячої проституції полягають в тому, що в більшості випадків діти не усвідомлюють правильності своїх вчинків (Протопопов А., Савельєва Н., 2009).

Проституція неповнолітніх стала справжньою галуззю тіньової економіки, яка приносить великі прибутки організованим злочинним угрупованням. Розповсюдження й експлуатація дитячої порнографії - проблема світового рівня. Одним із сучасних засобів передачі продукції дитячої порнографії $\epsilon$ розповсюдження її каналами міжнародної комп'ютерної мережі Інтернет (Швед O., 2005).

Проведене нами дослідження щодо обізнаності сучасних підлітків щодо ризиків залучення до комерційного сексу вказує на те, що підлітки не розуміють, які існують ризики щодо залучення до комерційного сексу. Були опитані 644 особи, а саме, учні/учениці 8-9 класів. Наведемо деякі результати. 
Що стосується проблеми комерційного сексу, то ми поцікавилися у респондентів, чи знають вони, що таке комерційний секс. Більшість досліджуваних вважають, що комерційний секс - це проституція, секс за гроші, шлях отримання матеріальних благ, винагорода за матеріальні цінності. Багато респондентів зазначають, що комерційний секс робота, за яку потрібно достойно платити. Також, частина опитаних не знають або не розуміють, що означає дане поняття.

Важливим для нас було дізнатися думку дітей щодо чинників, через які діти та підлітки до 18 років вступають в сексуальні контакти за винагороду або будь-яку іншу форму компенсації (рис. 1). Аналіз відповідей респондентів показує, що більшість опитаних (301) вважають, що продають себе тому, що вони хочуть мати модний одяг, косметику, аксесуари, тобто вони допускають, що проституція може бути таким джерелом доходу, і що при певних обставинах надали б сексуальні послуги за винагороду в обмін на модний одяг, косметику, аксесуари. 300 осіб зазначили, що однією із причин може бути бажання справити враження на однолітків. Показово, що серед учнів/учениць велика кількість тих, хто вважає, що практикувати участь в сексуальній активності в обмін на плату через цікавість, бажання пережити пригоди та отримання задоволення від сексу (260 та 219 відповідно). 242 і 102 вказують на те, що до такого роду діяльності змушує тяжка життєва ситуація або примус з боку інших осіб, тобто вони розуміють, що сексуальне зловживання відносно дитини з боку дорослої особи за винагороду є неприпустимим. Зокрема, варіант відповіді «Не знаю/важко сказати» вибрали 104 юнаків/юнок. 
Не знаю/важко сказати 104

Тому, що вони хочуть отримувати задоволення від сексу

Тому, що їх примусили інші

Бажання справити враження на однолітків

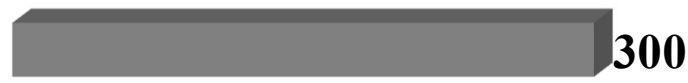

Цікавість, бажання пережити пригоди 260

Тому, що змушує їх тяжка життєва ситуація 242

Тому, що вони хочуть мати модний одяг, косметику, аксесуари

Рисунок 1. Чому, на твою думку, діти та підлітки до 18 років вступають у сексуальні контакти за винагороду або будь-яку іншу форму компенсації?

Аналізуючи відповіді респондентів на запитання: «В яких групах дітей та молоді існус великий ризик, що вони вступатимуть в статевий контакт за винагороду або будь-яку іншу форму компенсації?» (рис. 2), ми дійшли висновку, що переважна більшість учнів/учениць (600) вважають, що саме у дітей і підлітків з сімей у складних життєвих обставинах, сімей з проблемами (наприклад, алкоголь, наркотики, насильство) та 3 малозабезпечених сімей може існувати великий ризик, що вони вступатимуть в статевий контакт за винагороду або будь-яку іншу форму компенсації. На те, що у дітей та підлітків з сімей, де батьки не мають часу для своїх дітей і де батьки не говорять зі своїми дітьми про секс також є великий ризик, що вони вступатимуть в статевий контакт за винагороду або будь-яку іншу форму компенсації зазначили 238 і 183 опитаних відповідно. 183 підлітків відповіли, що люди, над якими було здійснене насильство, в тому числі сексуальне, в дитинстві можуть в подальшому надавати сексуальні послуги за винагороду, тобто сексуальні 
посягання вважаються причиною того, що діти в майбутньому будуть займаються проституцією.

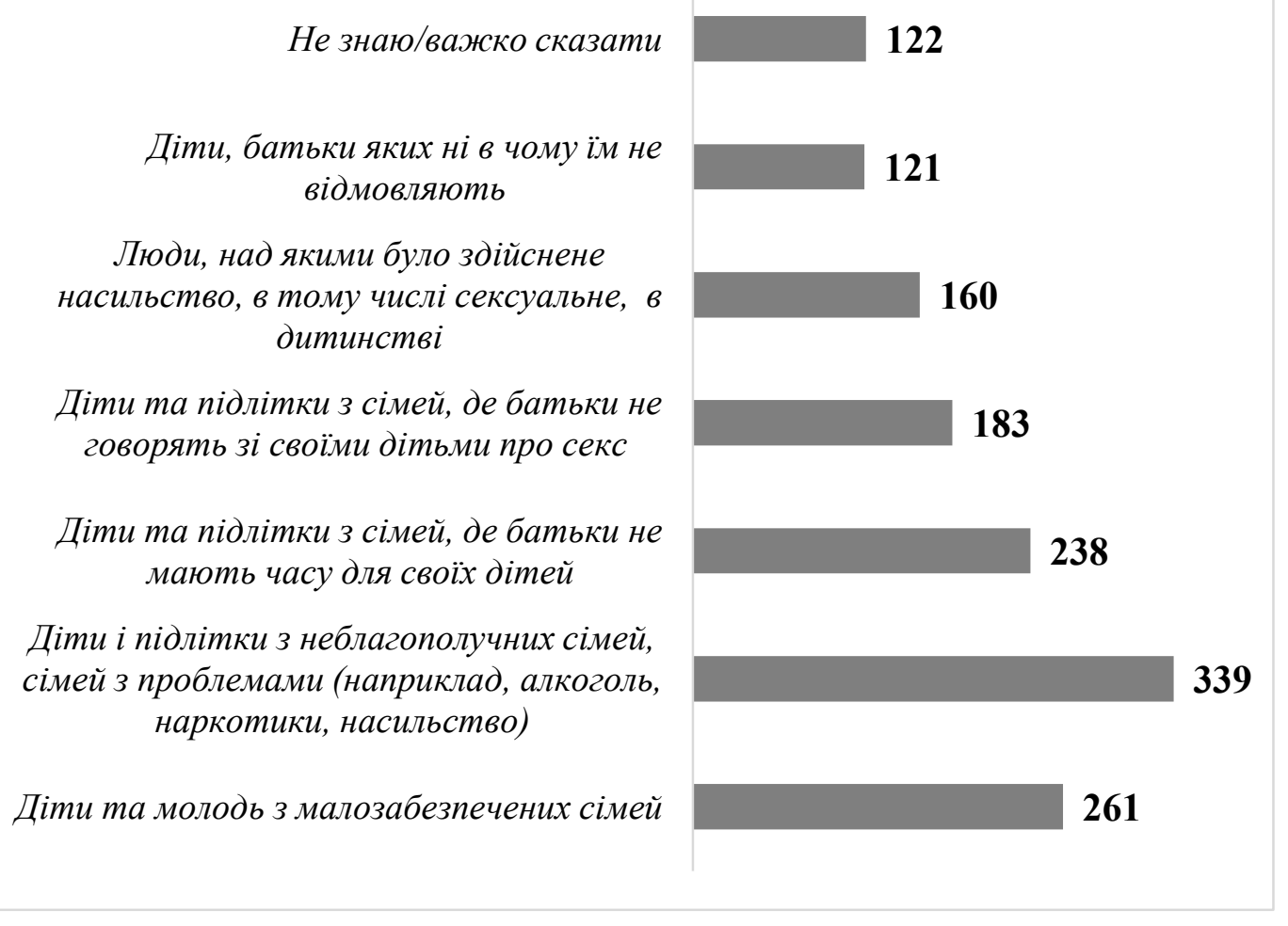

Рисунок 2. В яких групах дітей та молоді існує великий ризик, що вони вступатимуть в статевий контакт за винагороду або будь-яку іншу форму компенсації?

Наступний блок запитань стосувався позитивних і негативних моментів проблеми проституції (рис. 3, 4). Отримані дані показали, що до позитивних моментів комерційного сексу підлітки відносять задоволення сексуальної потреби людей, які живуть без партнера/партнерки, осіб з особливими потребами (424), зняття сексуальної напруги (180) та компенсація і доповнення до сексуальної активності (98). 161 учасник дослідження не знають, що відноситься до позитивних моментів проституції, тобто, вони засуджують такий вид діяльності. Негативним моментами, на думку, підлітків $\epsilon$ поширення інфекційних венеричних захворювань, ВІЛ/СНІДу (544), збільшення кількості абортів (380), зміна психіки в осіб, які займаються проституцією (239), втрата здатності до нормального шлюбу і материнства (221), поширення алкоголізму і наркоманії у зв'язку з високими емоційними стресами (181). 


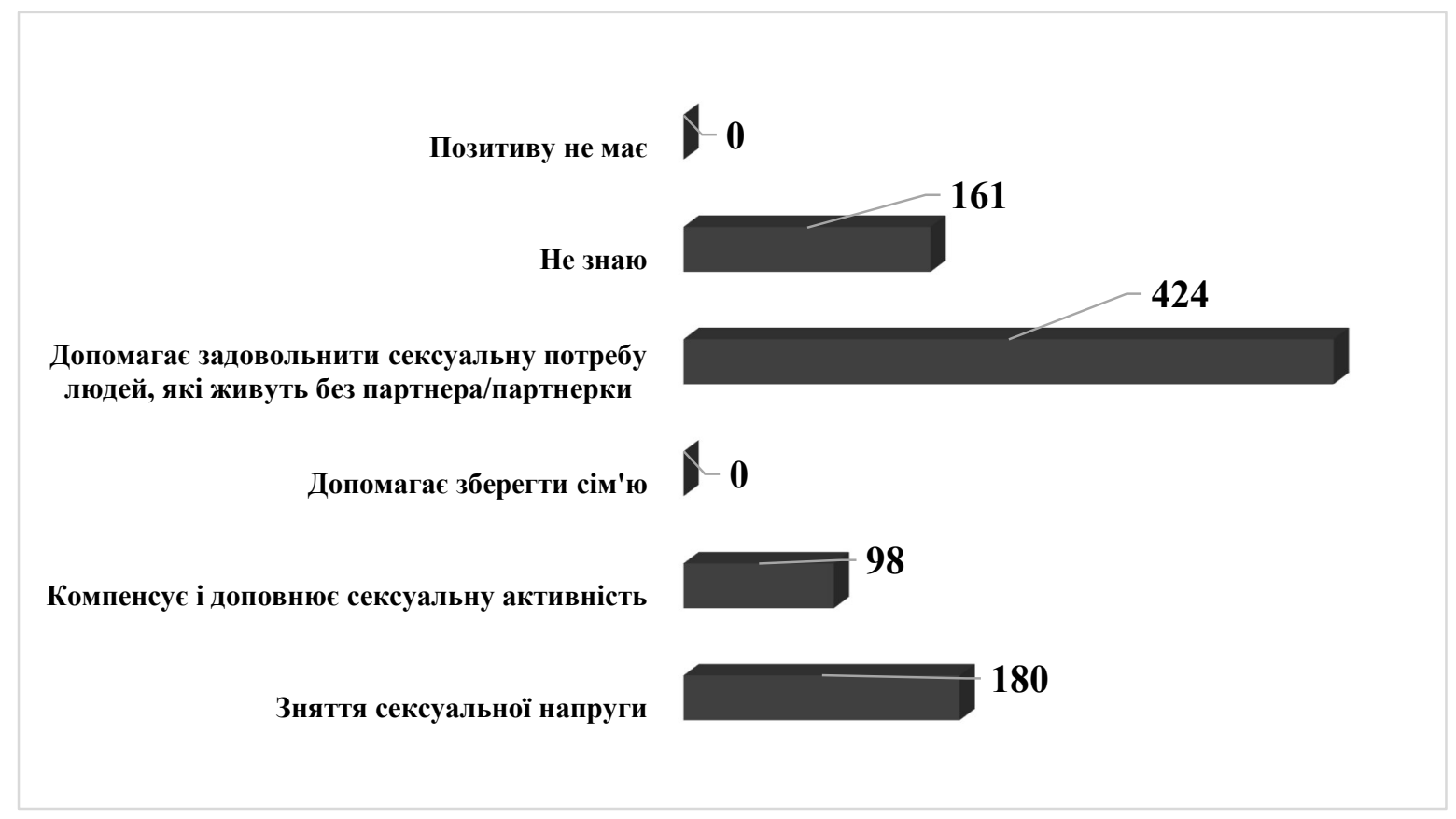

Рисунок 3. Позитивні моменти проституції

Негативних наслідків не мас

Не знаю

Збільшення кількості абортів

Поширення інфекційних венеричних захворювань, ВІЛ/СНІДу

Поширення алкоголізму і наркоманії, у зв' язку з високими емоційними стресами

Зміна психіки в осіб, які займаються проституцісю

Втрата здатності до нормального шлюбу i материнства

121 380
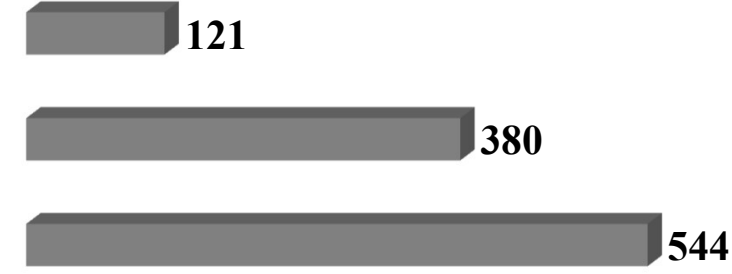

180

239

221

Рисунок 3. Негативні наслідки проституції

Отже, проаналізувавши отримані результати і узагальнивши дані, можна зробити висновок, що, на думку учнів/учениць, саме у дітей і підлітків з сімей у складних життєвих обставинах, сімей з проблемами (наприклад, алкоголь, наркотики, насильство) та з малозабезпечених сімей може існувати великий 
ризик, що вони вступатимуть в статевий контакт за винагороду або будь-яку іншу форму компенсації. Причинами, які, на думку, респондентів, можуть сприяти залученню підлітків до комерційного сексу є низький рівень доходів сім'ї , бідність, борги, нестача грошей, відсутність постійної роботи може спричинити залучення у сферу секс-бізнесу.

На жаль, в Україні надання секс-послуг дитиною старше 16 років (дитиною, яка досягла статевої зрілості) не є злочином. Проте міжнародні стандарти показують, що криміналізація купівлі секс-послуги від дитини може зменшити попит на дитячу проституцію, що відповідно зменшує пропозицію, i, як наслідок, кількість дітей-жертв сексуальної експлуатації. 


\section{3 Сучасні парадигми розуміння остракізації в освітньому середовищі}

У сучасних умовах педагоги й психологи все частіше звертаються до питань толерантності та протистояння агресії. Особливої актуальності набуває проблема остракізації в період проходження середнього й старшого шкільного періоду через їхню початкову кризовість, відсутність стабільності й почуття захищеності. Істотним для вивчення стає питання психологічної безпеки освітнього середовища та профілактики негативних явищ, передусім остракізації.

Важливість розуміння парадигмальних аспектів остракізму спричинена високим поширенням конфліктів серед учнів i підвищенням показників агресивної поведінки підлітків. У процесі навчання 29\% учасників освітянських колективів зіткнулися з вербальними проявами досліджуваного явища, 18\% - 3 глузуванням, 14\% - 3 криками з боку однокласників [368].

Поширюються тенденції чуток, примусу до дій проти власного бажання, несправедливі глузування, висміювання особливостей зовнішності. Також часто трапляються прояви німої агресії: ігнорування, уникання, виключення з групової взаємодії.

Остракізм у шкільному просторі може розглядатися як інстинктивна форма реагування на конфліктну ситуацію за недостатньо розвинених комунікативних навичок і саморегуляції [365]. Конфлікти - невід'ємна частина сучасного життя, їх виникнення закономірне й неминуче, оскільки спектр відмінностей у сучасному соціумі занадто широкий [367].

Тож на освітні організації лягає відповідальність за опрацювання та усунення проблеми соціального неприйняття, що дасть змогу зберегти психологічне здоров'я учнів і створити комфортне, розвивальне освітнє середовище, яке забезпечує високу якість освіти, духовного розвитку й виховання учнів, а також гарантує охорону та зміцнення фізичного, психологічного й соціального здоров'я учасників навчальних груп [374]. 
Вивчення особистісних характеристик учасників остракізації дає змогу стверджувати, що будь-який індивід, включений в освітні відносини, за збігу певних обставин може бути залучений до насильства. Остракізом, остракізатором або свідком виключення потенційно може стати кожен учень. Проте можна виокремити найбільш типові особистісні особливості, характерні для кривдників, потерпілих і свідків [370].

Як правило, особи, які остракізують, - це впевнені в собі особистості, схильні до домінування в групі й підпорядкування інших, морально і фізично сильні, емоційно імпульсивні; вони легко впадають у стан гніву й агресії, 3 низьким рівнем емпатії до своїх жертв [372].

Причиною такої поведінки може бути тривожність, зумовлена сімейним неблагополуччям, напруженими взаєминами 3 батьками, низьким рівнем навчальної успішності й заздрістю до більш успішних учасників 3 благополучних сімей, яка буде провокувати загрозу для статусу домінантних дітей і підлітків. Звернення до насильства (через приниження однолітків або молодших, а іноді й старших, учасників навчального процесу, утриманням усіх у страху) дає їм змогу підтвердити свій статус у класі або групі.

Особистісні особливості остракіза можуть проявлятися в таких характеристиках індивіда: дитина, яка 3 якихось причин змінила навчальний заклад або клас у середині року; особа, яка дуже відрізняється за будь-якими ознаками від інших учасників освітнього процесу.

L. Richman виокремлює такі чинники ризику [371]:

- Більш високий рівень тривожності, ніж в середньому в групі; брак впевненості, життєрадісності - такі особи нерідко здаються сумними;

- Низька самооцінка й негативне уявлення про себе. Учень може справляти враження того, хто не буде активно захищатися, коли на нього нападуть однолітки; не вміє адекватно реагувати на агресію, стає «легким» об'єктом нападок й остракізації; 
- $\quad$ Відсутність друзів у групі й труднощі у вибудовуванні й підтримці близьких взаємин 3 однолітками перешкоджають формуванню безпечних відносин у класі; така особа сприймається як закономірний об'єкт неприйняття;

- Для хлопчиків у певному віці стає важливою фізична сила. Індивід, що піддається остракізації, часто фізично слабший за своїх однолітків, що разом із його особливостями реагування знижує особистісні можливості протистояти нападкам з боку інших учасників колективу.

- Особливості зовнішності. Повнота, виразні недоліки зовнішності, непривабливість, поганий одяг та інші зовнішні ознаки, до яких легко причепитися, щоб почати дражнити дитину;

- Особливості поведінки. Особи, які погано навчаються, надмірно рухливі й неуважні, запальні (які не вміють керувати своєю агресією), які не вміють тримати дистанцію, з проявами, що дратують оточення та ін.;

- Об'єктами остракізму можуть стати учні, які належать до етнічної, національної або релігійної меншини [371];

- Нетрадиційна сексуальна орієнтація - універсальний фактор високого ризику цькування. Часто об'єктами остракізаторських проявів $є$ підлітки, поведінка яких виглядає недостатньо маскулінно.

- Підвищена тривожність щодо свого тіла («тілесна тривожність»): страх отримати травму, особа погано справляється 3 фізичними іграми, спортивними заняттями, будь-яким фізичним протистоянням або володіє поганою координацією (стосується переважно хлопчиків) [371].

- Жертвою остракізму може стати чутливий, тихий, замкнутий, пасивний, слухняний, сором'язливий учасник навчального простору, який легко й часто плаче, а також уникає прямої конфронтації у спілкуванні, відчуває труднощі із самоствердженням у групі однолітків.

Переживання остракізаторських проявів у середньому та старшому шкільному віці надзвичайно травматичне й, крім актуальних наслідків, значно 
впливає на подальшу життєдіяльність індивіда, насамперед на формування самооцінки, комунікативних можливостей, мотивацію до розвитку й досягнень.

C. Anderson, N. Carnagey виокремлюють такі актуальні наслідки існування явища остракізму в навчальному просторі [365]:

Афективні порушення: зниження настрою, депресивність, високий рівень тривоги, численні страхи, злість (велика кількість негативних емоцій);

$>\quad$ Соматичні порушення: порушення сну, апетиту, головні болі, болі в животі, порушення роботи шлунково-кишкового тракту, несподівані підвищення температури й т.д.;

$>$ Когнітивні порушення: нестійкість уваги, труднощі зосередження, порушення концентрації пам'яті тощо;

Порушення шкільної адаптації: зниження мотивації до навчання, пропуски школи, уроків, зниження успішності;

$>$ Поведінкові порушення: агресивність, втечі з дому, протестна поведінка;

$>$ Суїцидальні думки та спроби.

A. Hales до інших найбільш загальних наслідків остракізму зараховує: зниження самооцінки, порушення довіри до навколишнього світу, схильність до віктимності [369].

C. DeWall i S. Richman зауважують, що остракізація завдає істотної шкоди всім, хто до неї залучений. Остракізи не тільки страждають від проявів неприйняття, а й отримують психологічну травму, яка впливає на самооцінку особи й може здійснювати тривалий вплив на соціальну адаптацію. Зниження успішності, відмова відвідувати школу, аутоагресивна поведінка - найбільш часті наслідки виключення з освітнього середовища [367].

R. Shiffrin та W. Schneider вказують, що остракізатори частіше за інших учасників освітнього простору потрапляють у кримінальні ситуації, формують спотворене уявлення про соціальні взаємодії і дозвіл конфліктів [372]. 
Особи, які безпосередньо не беруть участь у процесі виключення індивіда 3 групи, переживають спектр негативних емоцій: страх бути на місці жертви, безсилля, негативне ставлення до навчального простору.

D. Abrams та M. Hogg, вивчаючи наслідки процесу остракізації для вчителів, звертають увагу на збільшення кількості негативних емоцій у спілкуванні з учнями, проблеми 3 дисципліною в навчальних колективах, зниження статусу серед учнів, почуття власної неспроможності й безсилля, ризик адміністративних стягнень. А в ситуації виходу явища остракізму 3-під контролю - фізичних пошкоджень та суїцидальної поведінки особи, конфліктів 3 батьками [363].

A. Bryman вказує, що недоброзичлива атмосфера, роз'єднаність між учасниками освітнього простору, зниження мотивації до навчання, недовіра до дорослих - це основні наслідки проявів неприйняття для освітнього середовища [366].

Вивчення наслідків поширення проблеми зумовлює потребу профілактики остракізму в освітньому закладі та мінімізації його найбільш небезпечних результатів. За H. Alroe та Е. Noe, представлено практичний досвід роботи 3 проблемою. Дослідники описують такі напрями психологічної профілактики [364]:

- створення умов недопущення явища (робота 3 педагогами, колективом учнів);

- $\quad$ швидке реагування та грамотне припинення стресового впливу на дитину (індивідуальна робота, кризова інтервенція);

- $\quad$ розвиток навичок стресостійкості, стратегій подолання труднощів (тренінги, лекції) [364].

Кожен 3 перерахованих вище напрямів має впроваджуватися у навчальному просторі за наступними принципами, створеними в освітній установі [364]:

$\checkmark$ наявність тепла, позитивного інтересу й залученості дорослих; створення твердих рамок і обмеження неприйнятної поведінки; 
$\checkmark$ дотримання послідовного застосування некаральних, нефізичних санкцій за неприйнятну поведінку й порушення правил;

$\checkmark$ наявність дорослих, які виступають у якості авторитетів і рольових моделей.

Головна мета профілактичних принципів - змінити структуру можливостей i нагород остракізаторської поведінки, результатом чого $\epsilon$ зменшення можливостей і нагород за остракізм.

Узагальнюючи світовий досвід програм профілактики соціального виключення в освітньому середовищі, можна виокремити три основні групи методів профілактики [365]:

1) методи, орієнтовані на конкретних дітей і підлітків;

2) методи, орієнтовані на сімейні взаємини;

3) методи, орієнтовані на найближче оточення дитини (мікросоціум).

Аналіз українського досвіду дає змогу сформулювати такі основні положення:

1. Напрями роботи на рівні навчального закладу:

a. діагностика психоемоційного середовища й мотиваційноосвітянська робота з адміністрацією;

b. програми формування сприятливого психологічного клімату в середині навчальних груп;

c. заходи, спрямовані на згуртування шкільної спільноти.

2. Напрями роботи з педагогічним колективом і батьками:

a. консультативно-освітня робота з педагогічним складом і батьками;

b. програми підвищення психолого-педагогічної компетентності дорослих (батьків, педагогів).

3. Напрями роботи з учнями:

a. консультативно-корекційна робота з дітьми, які зазнали виключення;

b. інформаційно-просвітницька робота з колективом учнів;

c. підвищення рівня комунікативної культури шкільних колективів;

d. профілактика й корекція відхилень в емоційній сфері підлітків; 
е. профілактика асоціальної поведінки школярів;

f. розвиток навичок стресостійкості, конструктивної поведінки в конфлікті та впевненої поведінки, навичок саморегуляції.

Період сьогодення характеризується поширенням технік групової роботи 3 дітьми. Оскільки більшість підлітків зазнає таких труднощів, як почуття самотності, відсутність друзів, складність встановлення контакту, відсутність впевненості у спілкуванні, варто розглядати проблему остракізації у контексті вирішення конфлікту ненасильницькими методами, й істотним завданням психолога стає навчання учнів навичок поведінки в конфлікті [366].

Важливим напрямом під час формування еталонів нормативної поведінки $€$ тренінгова форма роботи для досягнення довірливої атмосфери, де кожен може висловити свою думку, проявити себе, поділитися тим, що його турбує. Кожен учасник може бути впевнений, що він не зазнає глузувань, докорів або суперництва. Група допомагає остракізу та остракізатору по-іншому побачити себе, є джерелом підтримки [371]. Таким чином досягається емоційна відкритість і готовність до занять. У груповому просторі простіше, ніж в повсякденному житті, побачити свої звичні моделі поведінки, здобути нові навички, а потім поступово перенести новий досвід на освітнє середовище.

Метою профілактичних тренінгових заходів є:

1. створення умов для формування навичок конструктивної поведінки в конфлікті;

2. формування комунікативних навичок;

3. розвиток навичок емоційної саморегуляції.

На думку D. Waldeck та I. Tyndall, робота саме за цими напрямами важлива, щоб остракізована особистість змогла більш комфортно відчувати себе в колективі однолітків. Розвиток комунікативних навичок допомагає знизити тривожність у ситуаціях спілкування і подолати пов'язані з цим бар'єри, відчувати себе більш впевнено й вільно в ситуаціях спілкування. Велика увага приділяється розумінню емоцій, своїх і співрозмовника, способам вираження негативних емоцій соціально прийнятним чином [373]. 
Після здобутого досвіду групової роботи учасники відпрацьовують способи поведінки в конфліктній ситуації на прикладі рольових ігор та вправ.

Профілактичні заняття мають включати інформаційний блок і практичну частину, спрямовану на розвиток необхідних навичок і здобуття практичного досвіду. Теоретичний матеріал може подаватися у формі мінілекцій та групових дискусій. У практичній частині можна використовувати прийоми казкотерапії, ігротерапії, арт-терапії, поведінкової терапії, рольові ігри та вправи на зняття напруження і розвиток комунікативних навичок.

Важливим етапом у проведенні профілактики остракізму в навчальному середовищі є оцінка ефективності, яка виконується за допомогою контрольного психологічного обстеження поведінкових особливостей дітей, а також діагностичних методів: спостереження, бесіди з батьками.

У такий спосіб знижується ймовірність утворення остракізаторських тенденцій у просторі освіти: в остракізаторів зникає «необхідність» досягнення своїх інтересів через приниження інших, з'являються нові способи самореалізації; індивідам зі складнощами адаптації стає простіше проявити себе й отримати увагу однолітків. R. Gilman зауважує, що групова психологічна робота $є$ ефективною формою профілактики остракізму в навчальному просторі; хоч подібна робота $є$ незвичною для більшості учасників закладів освіти, багато учнів середньої та старшої школи розповідали, що спілкування в групі дуже відрізняється від спілкування у класі, воно більш щире й дає можливість побачити себе і товаришів по-новому [6]. 


\section{SECTION 6. THEORY, PRACTICE AND TEACHING METHODS}

DOI 10.46299/ISG.2021.MONO.PED.II-402-418

\subsection{Psychological features of students' fatigue at the stage of adaptation to study in higher education institutions (on the example of applicants for higher education speciality 016 special education)}

In the conditions of informatization of a society and modernization of system of education, transition of higher education to the European standards the problem of quality of professional training of future teachers acquires special value. Modern concepts of integration, socialization and personal development of people with special educational needs consider a special teacher as a leading entity that ensures the effectiveness of the correctional and developmental process and is ready for social interaction.

Solving problems to optimize different types of work involves a comprehensive study of functional states that arise in the process of work or study. The nature of the activity, as well as the features of its organization can be sources of formation of adverse functional states, such as stress, anxiety, fatigue, monotony and others. The development of these conditions can lead to reduced efficiency and quality of work, accidents and injuries, loss of physical and mental health of business entities. Therefore, knowledge of the specifics of the formation of functional states is the basis for the organization of correctional and preventive work aimed at improving employment.

Due to the intensification and optimization of educational activities, the need to absorb a large amount of information, as well as the uneven distribution of workload during the educational process, the problem of mental fatigue of students studying in higher education is becoming relevant. Active learning and cognitive activity of young people is a very complex process that takes place in the context of objectively existing contradictions, which include: the contradiction between the need to learn a significant amount of material and lack of time, between the gradual, long process of becoming a future specialist and the desire self-affirmation and self-expression, between the need to attend classes regularly and the inability to limit oneself to those educational services 
offered by a higher education institution. In addition, the methods and organization of higher education differ sharply from those used in general secondary education. They require a significant increase in independence in mastering educational material, the ability to plan their learning and free time. To resolve these contradictions, applicants for higher education make a lot of physical and mental effort. As a result, reduced efficiency and resistance to psycho-emotional stress, increased mental stress, increases the likelihood of mental fatigue, which reduces the ability of students to work, leads to deterioration of mental health.

1. Psychological features of adaptation to the educational process of students of higher education institutions.

Adaptation of students to higher education has its own characteristics. The entry of young people into the system of higher education, their acquisition of a new social status of higher education requires them to develop new ways of behavior that allow them to best meet their new status. This process of adaptation can take a long time, which can cause a person overstrain on both psychological and physiological levels, resulting in reduced student activity, and he can not only develop new behaviors, but also perform the usual types for him activities.

The specificity of the process of adaptation in higher education institutions is determined by the difference in teaching methods and its organization in secondary and higher schools, which creates a kind of negative effect - the didactic barrier. Freshmen do not get the various skills and abilities that are needed in higher education to successfully master the program. Adaptation to the new conditions requires a lot of effort, due to which there are significant differences in the activities and learning outcomes of general education and higher education. It is known that the process of adaptation to higher education is a rather complex, multifaceted phenomenon, which is completed by the end of the third year.

There are two aspects of social adaptation of students:

- professional adaptation, which means adaptation to the nature, content, conditions and organization of the educational process, the development of skills of independence in educational and scientific work; 
- socio-psychological adaptation - the adaptation of the individual to the group, the relationships in it, the development of their own style of behavior/

Professional adaptation is a prerequisite for active activity and a necessary condition for its effectiveness. This concludes the positive value of adaptation for the successful functioning of the individual (student) in a particular social role.

There are three forms of adaptation of freshmen to the conditions of the university:

- formal adaptation, which concerns the cognitive and informational adaptation of students to the new environment, to the structure of higher education, to the content of education in it, its requirements for their responsibilities;

- public adaptation, namely the process of internal integration (association) of groups of first-year students and the integration of the same groups with the student environment as a whole;

- didactic adaptation, which concerns the preparation of students for new forms and methods of educational work in higher education.

For successful adaptation, it is necessary to show an active position, which should be not only the teacher but also the student, namely there should be joint activities. The student must find and choose for themselves ways and means to achieve a particular educational goal, and the teacher - to create the conditions for this.

It is in the first year that the young person's attitude to learning, to future professional activity is formed, and the «active search for oneself» continues. Even those students who have excellent general secondary education, in the first year do not immediately find confidence in their abilities. The first failure sometimes leads to disappointment, loss of perspective, alienation and passivity.

It has been observed that the better a student understands why and why he may need knowledge for future work, the better he learns. The research results show that the level of higher education seeker's perception of the profession (adequate inadequate) is directly correlated with the level of his attitude to learning: the less the student knows about the profession, the lower his positive attitude to learning. 
Education in a higher education institution has a number of significant differences compared to school. Moreover, some school stereotypes of educational activities are not suitable for higher education and, in some cases, are an obstacle for it. In this case, the phenomenon of interference known in psychology is manifested, when previously acquired skills hinder the successful implementation of further activities and require some adjustment.

Let us define some stereotypes of cognitive activity of students formed in school, which complicate training in high school and need essential reorganization.

1. Students of the material being studied manifest these difficulties already in the process of perception and comprehension. In the institution of general secondary education, the main work with the comprehension of new knowledge takes place in the lesson under the guidance of the teacher using various methods that facilitate the learning process. Moreover, students' homework was mainly limited to repetition and memorization of the material.

A student, who has developed a stereotype of the mode of educational activity in the classroom, has to overcome it from the first days in college. This leads to the fact that most freshmen have poor logical operations to comprehend the material studied, and the educational process in the university is forced to rely heavily on the reproductive thinking of freshmen, which does not allow making optimal decisions in unusual situations and easily adapt to conditions. Assimilation of knowledge in them is reduced mainly to reading material from a textbook or lecture notes. At the same time, students try not so much to understand the material as to memorize it.

In this regard, the work on teaching students the technology of educational activities should include the disclosure of patterns and methods of perception and understanding of the studied material.

2. The influence of stereotypes of schooling is largely manifested in the organization of educational work on the repetition and consolidation of material. The school system is built in such a way that the explanation of the new material and its consolidation are combined into a single whole by the very structure of the lesson. In higher education, however, the synchronicity between the communication of new 
knowledge and their consolidation is largely absent. In addition, the presentation of material during lectures and its consolidation in practical or seminar classes are often separated by a long period. Therefore, in a higher education institution, the work of understanding and mastering the theoretical material taught in the lecture should be synchronized with the process of independent extracurricular work and accompanied by its deep understanding and self-control. The depth and strength of students' knowledge depends on how well this work is organized.

3. The specifics of higher education are largely due to the lack of systematic ongoing control over the quality of knowledge acquisition. In the institution of general secondary education, as is known, control over the educational work and assimilation of the research material is carried out at each lesson.

In universities, where there is no daily testing of knowledge, school graduates receive more freedom of action in this regard. There is a sharp change, or rather the destruction of those stereotypes of relations with teachers, which have developed over the years in high school.

Feeling quite free from pedagogical control, many freshmen replace regular work on knowledge acquisition with episodic, unsystematic classes, which leads to lag. You are tempted to do nothing or do everything on the last day. Such a system of educational work does not provide proper training for students.

4. It is extremely important for successful higher education to properly organize the independent work of students to expand and deepen their knowledge.

Classes in higher education, including lectures, are in relation to the process of learning only constitutive, indicative. The lecture plays the role of a factor that directs the independent creative activity of students, and it cannot be considered as the main source of knowledge. Students need to actively acquire knowledge in different ways: to work with a textbook, additional literature, scientific sources, etc. However, future students do not receive these skills at school. Additional literature studied by students consists of only a small number of primary sources. This may explain the inability of most graduates to work independently to deepen and expand their knowledge. Of course, it would be wrong to assume that a freshman is not ready for university. 
However, what he knows and can do is usually very little for successful university education. A freshman must be taught to learn - this is an indisputable truth.

Thus, professional adaptation in a higher education institution is a process of forming students' interest in the chosen profession, the desire to master it perfectly. Such adaptation involves mastering the full range of knowledge, skills and abilities in the profession, methodology and logic of science. Professional formation of a student is successfully carried out if it is based on the interest, inclinations and abilities of a young person to a certain profession.

Professional suitability for a particular activity is determined not only by the level of development of abilities, but also by a number of other personal characteristics and, above all, the nature of the motivational sphere - the content of motives, their focus and degree of activity.

Motivation in psychology means a set of factors that organize and guide human behavior. This is the process of determining behavior, activity, which may be due to internal (mental, physiological) and external (professional, social, economic, environmental) stimuli. Motivational processes are regulatory components of mental functioning, which give it an internal, subjective color. These processes are associated with the formation and implementation of motives (aspirations, actions to realize a need or a conscious internal motivation for activity) and have motivating functions.

Individual performance is directly and very clearly dependent on motivation. It can compensate for many shortcomings in the level of development of a number of professionally important qualities and in the organization of the production process, but the weak motivation is almost impossible to compensate and fill.

The level of motivation for activity depends on the nature of the subject's motivation, namely motivating a person to perform work tasks by activating his needwill sphere. Moral control, preferences, interests, inclinations, external situation, own possibilities, desires, conditions of achievement can act as motivators - psychological factors that in a specific motivational process determine a person's decision-making on this or that behavior, goals, consequences of their actions. 
The nature of motivation (specific motives and goals, direction, breadth and intensity) is determined by the peculiarities of the stages of professional development of the subject - the choice of profession, implementation of activities, professional reorientation and retraining.

The influence of motivation on the level of professional suitability is determined in the scientific literature. In practical psychology, it is considered in two aspects: first, in terms of measuring the effects of certain motives on the process of achieving the desired professional results and, secondly, from the standpoint of the regulatory function of motives (and motivators) in the formation of a given level of professional suitability.

All motivating sources of personal activity are united by the concept of motivational sphere, which includes the needs of the individual, his interests, aspirations, inclinations, beliefs, attitudes, ideals, intentions, as well as social roles, stereotypes, social norms, rules, life goals and values and, finally, worldviews in general.

Motivation of professional activity is specific in relation to the motivation of behavior in general. That is why in relation to the tasks of diagnosis and prediction of professional suitability, its formation is important to consider not only what needs motivate a person to perform a particular activity (meaningful theories of motivation), but also how the intention to perform (or not perform) a specific task quite specific purpose (procedural theories of motivation).

Learning motivation is a general name for processes, methods and means of motivating students to productive cognitive activity, to actively master the content of education. Figuratively speaking, the images of motivation are held in their hands together by teachers (learning motivation, their attitude to professional responsibilities) and students (learning motivation, internal, self-motivation).

The formation of motivation is not a simple growth of positive or increasing negative attitude towards the student, but the complication behind the structure of the motivational sphere, its motives and the emergence of new, more mature, sometimes contradictory relationships between them. Accordingly, in the analysis of motivation, 
we have a difficult task of determining not only the dominant motivator (motive), but also taking into account the entire structure of the motivational sphere of man. Motivational sphere or motivation in the broadest sense of the word from this point of view is understood as the core of personality, which is «pulled» such properties as orientation, values, attitudes, social expectations, harassment, emotions, volitional qualities and other socio-psychological characteristics. The concept of motivation in man includes all kinds of motivations: motives, needs, interests, aspirations, goals, inclinations, motivational attitudes or dispositions, ideals, etc.

Motivation is the main tool that will increase the level of students'interest in the educational process, will increase their personal scientific and creative potential. Insufficiently motivated student will not contribute to the development of their knowledge or the development of science itself.

The learning process is classified as a complex activity, so there are many motives for learning, and they cannot only be manifested separately in each person, but also merge into one, forming a complex motivational system.

Motivations of students in independent Ukraine have not been paid attention for a long time. In fact, in the 21 st century, this is one of the most effective ways to improve the learning process and the results of many years of seminars, lectures and sessions. Motives and motivation are the driving force of the process of learning and assimilation of information and material. Motivation is the main tool that will increase the level of students' interest in the educational process, will increase their personal scientific and creative potential.

Learning motives are classified by direction and content. Consider them in more detail:

- social (duty, responsibility, understanding of the importance of learning for society as a whole);

- cognitive (the desire to know more, to become an erudite person);

- professional and value (expanding opportunities to get a promising and interesting job); 
- aesthetic (learning comes from pleasure, reveals their hidden abilities and talents).

- communicative (the ability to expand their circle of communication by improving their intellectual level and new acquaintances),

- status-positional (aspiration through teaching or social activity is approved in society);

- traditional-historical (established stereotypes that have emerged in society and strengthened over time);

- utilitarian-cognitive (the desire to learn a particular subject and learn selfeducation);

- unconscious motives (based on a complete misunderstanding of the meaning of the information received and a complete lack of interest in the cognitive process).

These motives can merge to form a common motivation for learning. The initial idea of the superiority and action of certain motives for learning gives the student's attitude to learning.

There are several degrees of student involvement in the learning process:

1) Negative attitude to learning can be characterized by poverty and narrow motives. Here it is possible to explore a weak interest in success, focus on evaluation, inability to set goals, overcome difficulties, negative attitudes towards educational institutions, teachers.

2) Neutral (indifferent) attitude to learning: the characteristics are the same; it means the presence of abilities and opportunities to change the orientation to achieve positive results.

3) Positive attitude to learning: a gradual increase in motivation from unstable to deeply conscious, and therefore especially effective; the highest level is characterized by the stability of motives, their hierarchy, the ability to set long-term goals, to anticipate the consequences of their educational activities and behavior, to overcome obstacles to achieving the goal. In educational activities, there is a search for non-standard ways of solving educational problems, flexibility and mobility of ways of action, the transition to creative activity, increasing the share of self-education. The 
attitude of the applicant to higher education, the teacher characterizes the activity (learning, content development, etc.), which determines the degree (intensity, strength) of the «collision» of the student with the subject of his activity.

Thus, professional motivation plays an important role in the process of adaptation of higher education students to the conditions of higher education. All professional motives can be classified by levels and content, which indicates the difficulty and complexity of the issue. As mentioned, motivation is one of the most important, or even the only factors that can help a student overcome difficulties in adapting to learning, mastering professionally important knowledge, skills and abilities.

2. Psychological features of fatigue in the learning process.

Consider the main psychological factors of fatigue in educational activities. Immediately note that there are many classifications of such states. However, we do not intend to analyze these concepts.

Fatigue. A special kind of functional state of a person temporarily occurs under the influence of prolonged or intensive work and leads to a decrease in its effectiveness. Fatigue is manifested in a decrease in muscle strength and endurance, in the increase of energy expended when performing the same work, impaired coordination of movements, slowing down the speed of information processing, memory impairment, difficulty concentrating and switching attention, etc. The measure of fatigue is changes in quantitative and qualitative indicators of work, as well as physical functions during work or in response to special tests. A good way to prevent fatigue in any activity is to increase work motivation and physical fitness.

Fatigue. The subjective feeling of fatigue reflects the multiple changes in biochemical, physical and psycho-physiological functions that occur during prolonged or intense work. It makes you want to either stop it or reduce the load.

Fatigue. The peculiarity of the body as a whole or its individual parts to be prone to fatigue. The depth of fatigue at the same load depends on the degree of adaptation of a person to any activity and his training, physical and mental condition of the worker, levels of motivation and nervous and emotional stress. At physical work, training of 
any weight (intensity), and mental work fatigue the more, the lower level of the general physical working capacity.

Overfatigue. This is a pathological condition that develops in humans due to chronic physical or psychological stress, the clinical picture of which is determined by functional disorders in the central nervous system.

Nervous and emotional tension. A special condition that occurs in the process of work or communication, where the emotional component dominates, giving a high assessment of all or any elements of activity. Nervous and emotional stress is characterized by high CNS tone and increased activity of hormonal regulation.

Intellectual voltage - the voltage caused by frequent recourse to intelligent processes in the formation of the service plan, due to the high density of the flow of problematic service situations.

Sensory voltage - voltage caused by suboptimal conditions of sensory systems and arising in case of great difficulties and perceptions of the necessary information.

Physical stress - the stress of the body caused by increased load on the human musculoskeletal system.

Emotional stress - stress caused by conflict conditions, increased likelihood of an emergency, surprise or prolonged stress of other kinds.

Mental fatigue. Manifested by a decrease in the efficiency of intellectual work, weakening of attention (mainly, it is difficult for a person to concentrate), slowing down thinking.

Physical fatigue. It is expressed by disturbance of function of muscles: decrease in speed, force, accuracy, coordination and rhythmicity of movements, etc. Decreased efficiency.

Chronic fatigue. With constant fatigue (fatigue) there are pronounced dystrophic and destructive changes in part of the muscle fibers. One of the reasons for their appearance is hypoxia or impaired microcirculation of the musculoskeletal system.

Chronic fatigue, loss of muscle elasticity (hypertension, muscle imbalance, etc.), muscle pain, episodic muscle spasms are suggestive factors for injuries of the musculoskeletal system. 
Chronic fatigue in the tissues leads to under oxidation of metabolic products, which, in turn, leads to changes in the colloidal composition of tissues, circulatory disorders, manifested by hypersensitivity and muscle pain. In this phase of colloidal reactions, there are no domestic organic changes in the muscles and their return to normal is easy. It is necessary to apply cry massage, segmental massage, hydrotherapy and phonophoresis against the background of reduced physical activity, especially high-speed and speed-power.

Irrational use of physical activity (training) can lead to functional overload of tissues, and in the future, if training is carried out in the same mode, they will contribute to injuries and diseases.

The speed of fatigue depends on the specifics of work: it occurs much faster when performing work, which is accompanied by a monotonous posture, muscle tension, less tiring rhythmic movements. An important role in the emergence of fatigue is also played by a person's attitude to the work performed. It is well known that many people during the period of emotional stress for a long time do not have signs of fatigue and fatigue. Usually, when it is necessary to continue intensive work when fatigue occurs, a person expends additional strength and energy - changes in certain functions of the body (for example, physical labor increases respiration and heart rate, increased sweating, etc.). At the same time productivity decreases, and signs of fatigue amplify.

In the process of long and intense educational activity, there is a state of fatigue, as a normal reaction of the body to the work performed. Objectively, it characterizes the reduction of the body's ability to successfully continue it. Fatigue is accompanied by a subjective feeling - fatigue.

Fatigue - a mental phenomenon, an experience caused by fatigue. Fatigue can increase with job dissatisfaction, misunderstanding of its importance, failures in it. On the contrary, the successful completion of a work or some stage reduces the feeling of fatigue. Feelings of fatigue can be relieved by emotions, concentration and increased interest in work.

There are states of fatigue in which it is still possible to carry out mental work, but it no longer reveals the creative principles. A tired person can perform such work 
for a relatively long time. Then comes another period, accompanied by a feeling of tension, when the work requires willpower. Further continuation of work in this state leads to a feeling of dissatisfaction, often has a tinge of irritation.

When tired, the activity of the external senses or markedly increases, or weakens to the extreme; the power of memory decreases - what was learned shortly before disappears quickly. The onset of fatigue is not always manifested in the simultaneous weakening of all aspects of mental activity. In this regard, there is a local distinction between local and general fatigue. Thus, the decrease in efficiency in one type of educational work may be accompanied by the preservation of its effectiveness in another. For example, instead of doing computational operations, you can successfully read. However, there may be a state of general fatigue, which requires rest, sleep.

Thus, the main factor of fatigue while studying in a higher education institution is the educational activity itself. However, fatigue that occurs during it can be significantly complicated by additional factors that also cause fatigue (poor organization of life). In addition, it is necessary to take into account a number of factors that do not in themselves cause fatigue, but contribute to its occurrence (chronic diseases, poor physical development, irregular diet, etc.).

3. Emotional regulation of fatigue as a category of psychological analysis.

Peculiarities of human behavior, management of one's own emotions and understanding of other people's emotions depend on the level of development of emotional regulation, as well as its impact on interpersonal relationships.

As a direct expression of the needs of the subject, emotions are a regulator of his activity. They testify to the importance of a phenomenon for the individual and regulate the general direction and dynamics of its behavior in relation to the personal content of the situation, participate in goal setting and motivation to change the direction of activity, to change the person as a subject.

The main thing in emotional regulation is the regulation of emotions, their planning and direction. The regulatory function emphasizes the importance of emotions as an internal and external regulator. External emotional regulation is 
manifested in those emotions that are not generated directly by the activity, but are caused by any external to the activity factor.

Factors that negatively affect emotional regulation:

- constant stress;

- passive intrapsychic overcoming, such as self-blame;

- loss of control caused by a «critical situation» that does not solve the problem that has arisen, but satisfies the need to act urgently;

- strong negative emotions that need to be overcome immediately;

- large amounts of information being processed - the data obtained are limited, have insufficient appearance, according to which the phases of generation and reduction are not separated.

There are several factors influencing emotional regulation:

- evaluation processes, such as causal attribution;

- palliative methods - aimed at regulating emotions, focusing on the stabilization of the individual, his complacency;

- instrumental methods - aimed at changing and understanding the stressful event.

Thus, due to the intensification and optimization of educational activities, the need to absorb a large amount of information, as well as the uneven distribution of workload during the educational process, the problem of mental fatigue of students studying in higher education becomes relevant.

Active learning and cognitive activity of young people is a very complex process that takes place in the context of objectively existing contradictions, which include: the contradiction between the need to learn a significant amount of material and lack of time, between the gradual, long process of becoming a future specialist and the desire self-affirmation and self-expression, between the need to attend classes regularly and the impossibility to limit oneself to those educational services offered by a higher education institution. 
Fatigue is a human condition caused by work. Physical fatigue is facilitated by dynamic loads, such as long walks, running, and static loads - lifting weights, holding them, carrying.

Mental fatigue - is caused by the load on the senses (sight, hearing), severe stress and awareness of responsibility. Without fatigue there is no training, there is no adaptation of an organism to physical or mental activity. Fatigue stimulates the recovery process, expands the body's reserve capacity. Thus, fatigue plays not only a protective role, but also is important in improving the working mechanisms of the body.

The study of the conditions for improving the efficiency of human educational activity is one of the independent tasks of labor psychology. Among such conditions are the support of optimal performance based on the creation of optimal functional status. It is important to take measures to prevent and correct adverse functional conditions (fatigue, monotony, stress, etc.). This involves, firstly, the elimination of objective causes of their occurrence (drafting the optimal mode of work and rest, alternation of work activities, etc.), and secondly, the formation of human skills of regulation and management of their functional state (using a system of special training with in order to prepare for adverse situations, methods of neuromuscular relaxation, self-training).

If the work and rest regime is organized rationally, then productivity, efficiency and level of health in this area of production can be high. It should be borne in mind that the mode of work and rest is a very flexible tool that should be checked periodically - whether it gives the most beneficial effect or not. In the latter case, it must be modified.

Thus, increasing efficiency and accelerating the growth of productivity of educational activities should be associated with not only its facilitation, but also the ability of a person to enjoy the activity, to actively overcome fatigue, to include their reserves.

Emotional regulation is seen as ensuring the general direction and dynamics of behavior in relation to the personal content of the situation; as the ability to cope with 
their emotions by socially desirable means; as a process of increasing, maintaining and inhibiting emotional arousal.

Conclusion. Due to the intensification and optimization of educational activities, the need to absorb a large amount of information, as well as the uneven distribution of workload during the educational process, the problem of mental fatigue of students studying in higher education is becoming relevant.

Active learning and cognitive activity of young people is a very complex process that takes place in the context of objectively existing contradictions, which include: the contradiction between the need to learn a significant amount of material and lack of time, between the gradual, long process of becoming a future specialist and the desire self-affirmation and self-expression, between the need to attend classes regularly and the impossibility to limit oneself to those educational services offered by a higher education institution.

Fatigue is a human condition caused by work. Physical fatigue is facilitated by dynamic loads, such as long walks, running, and static loads - lifting weights, holding them, carrying.

Mental fatigue - is caused by the load on the senses (sight, hearing), severe stress and awareness of responsibility. Without fatigue there is no training, there is no adaptation of an organism to physical or mental activity. Fatigue stimulates the recovery process, expands the body's reserve capacity. Thus, fatigue plays not only a protective role, but also is important in improving the working mechanisms of the body.

The study of conditions for improving the effectiveness of human educational activities - one of the independent tasks of occupational psychology. Among such conditions are the support of optimal performance based on the creation of optimal functional status. It is important to take measures to prevent and correct adverse functional conditions (fatigue, monotony, stress, etc.). This means, firstly, the elimination of objective causes of their occurrence (drawing up the optimal mode of work and rest, alternation of work, etc.), and secondly, the formation of human skills of regulation and management of their functional state (using a system of special 
training to preparation for adverse situations, methods of neuromuscular relaxation, self-training).

If the work and rest regime is organized rationally, then productivity, efficiency and level of health in this area of production can be high. It should be borne in mind that the mode of work and rest is a very flexible tool that should be checked periodically - whether it gives the most beneficial effect or not. In the latter case, it must be modified.

Thus, increasing efficiency and accelerating the productivity of educational activities should be associated with not only its facilitation, but also the ability of the higher education student to enjoy the activity, actively overcome fatigue and include their reserves. 
DOI 10.46299/ISG.2021.MONO.PED.II-419-425

\section{2 Мовленнсва професійна підготовка студентів у системі філологічних дисциплін}

Професія педагога багатогранна та багатоаспектна. Провідне місце в підготовці вчителя початкових класів займає система філологічних дисциплін, як в іiі фундаментальній частині, так і у прикладних напрямах. Учитель початкової школи - носій мовленнєвої культури. Це аксіома класичної початкової школи. Особистість учителя, який формує майбутнє як вихователь, завжди знаходилася під пильним контролем суспільства, як цілеспрямованим, так і непрямим. Основоположні роботи з філософії педагогіки звертали увагу, перш за все, на здатність педагога пізнавати, розвиватися, бути зразком для наслідування, зокрема, у системі мовленнєвого спілкування.

Починаючи 3 давніх часів $\mathrm{i}$ до сьогоднішнього дня, робіт фундаментального характеру у цій галузі, як і окремих статей, нараховується багато [379- 382,386,387, 389-394].

У сучасному світі питання підготовки вчителя у сфері мовлення, мови та літератури викликане серйозними змінами в комунікативній сфері, розширенням поля опосередкованого спілкування, збільшенням контактів та зв'язків, завдяки посереднику у вигляді Інтернету, смартфону, тобто фактично специфічних машин. Всі ці нововведення потребують не тільки оволодіння новими формами мовлення, а й уміннями швидко переключатися з одного виду комунікації на інший, при цьому зберігаючи повноцінність вербального спілкування в рамках культури та загальноприйнятої норми.

Розглядаючи питання мовленнєвої підготовки вчителя-наставника потрібно зазначити, що основою його діяльності є учень, тому педагогічна думка минулого віддавала пріоритет формуванню мовлення учня, акцентуючи, що характер можливостей дитини та зміст його підготовки визначить зміст і характер діяльності вчителя.

У XX столітті питанню розвитку мовлення молодших школярів приділялося багато уваги. Тому, можна виділити два провідних напрямки. 3 
одного боку, пропонувалися серйозні вдосконалення перехідних педагогічних доробків, з іншого, розроблявся новий зміст, і визначалися його ефективні форми. До таких форм відноситься і розв’язання низки методичних проблем, які прямо стосуються професійної компетенції практикуючого вчителя. Ці доробки забезпечили стартові можливості досліджень XXI століття. Вони такі:

- Представлено комплекс фундаментальних посібників, які відображають позиції різних педагогічних шкіл для розв'язання задач методики викладання рідної мови: класичний, психолого-педагогічний, інноваційний варіанти. Створено базу здійснення на практиці варіативних розв'язань низки методичних проблем [383,384,385,388].

- Розмежовано знання, вміння та навички в галузі мови, мовлення та літератури, визначено обгрунтовані програмні мінімуми.

- Окреслено діапазон «зони найближчого розвитку» молодших школярів під час вивчення мови, мовлення та літератури.

- Розроблено прийоми, які спрощують оволодіння навичкою читання.

- Визначено систему граматичних та орфографічних правил для початкової школи, яка дозволяє забезпечити поступовий розвиток молодшого школяра.

- Дитяча книга визначена як навчальний матеріал у повному обсязі вимог процесу навчання.

- Представлено класифікацію систем вправ творчого характеру для молодшого школяра.

- Розроблено цілісну методичну систему взаємодії рідної та державної мови в процесі навчання.

- Визначено критерії та норми мовленнєвого, мовного та літературного розвитку молодшого школяра XX століття.

У кінці XX - початку XXI століття в практику введено наступні системи:

- Літературне читання як особливий напрямок у курсі читання та розвитку мовлення. 
- Дитяча риторики як навчальна мовленнєва діяльність у програмі рідної мови.

- Системи тестувань у предметній галузі рідної мови.

Неможливо стверджувати, що у вказаному переліку представлено повний обсяг досягнень методичного забезпечення процесу навчання XX - початку XXI століття, але, як показує ретроспективний аналіз наявних публікацій та реалій сучасного стану шкільної справи, проблема підготовки вчителя до вирішення представлених задач у вказаній галузі, до сих пір комплексно і у повному обсязі не визначена.

Університетська освіта повинна забезпечити на основі отримання комплексу знань, умінь та навичок оволодіння професійною мовленнєвою майстерністю, де традиційно виділяють три аспекти підготовки. До них відносяться:

- освоєння мовлення, мови та літератури з установкою на розширення знань, шляхом самонавчання та особистісного розвитку в цих галузях;

- оволодіння прийомами передачі знань засобами мовлення в повному обсязі, враховуючи елементи риторики як засобу свідомого управління мовленням;

- набуття навичок культури спілкування з учнями в процесі їх навчання, а також під час професійної діяльності з батьками та колегами.

Ці три напрямки підготовки студентів складають єдність базових знань, практики мовленнєвої діяльності, мистецтва впливу. Вони знаходяться у постійному розвитку, який пов'язаний $з$ розширенням діапазону вимог, які продиктовані аналізом стану професійної діяльності вчителя та технологічним розвитком суспільства.

Особливості сучасного життя вимагають розширення вимог до мовленнєвої підготовки вчителя, а саме: оволодіння електронними засобами комунікації, в основі якого є все теж слово, але в новій формі прояву. У цьому важливим є: освоєння нових реалій власне процесу взаємодії, як зі змістового, так і з технічного боку; загальна та професійна культура реалізації зв’язків між 
особами, які спілкуються; організація та здійснення процесу навчання в нових умовах. Останній фактор є найбільш складною стороною професійної діяльності педагога.

Стан мовлення сучасного вчителя вивчено недостатньо, але i y вітчизняних, і у зарубіжних публікаціях, де розглядаються ці питання, особливу увагу фіксують на грамотності мовлення - володіння нормами та виразністю мовлення як мистецтвом впливу. Можна, за непрямими чинниками, констатувати, що питання грамотності та виразності мовлення $\epsilon$ тими напрямами, де сучасному вчителю необхідна допомога. Цей висновок підтверджується дослідженнями, які проводилися в Лабораторії методичного забезпечення безперервної системної освіти «Школа-3ВО» Харківського національного педагогічного університету імені Г.С.Сковороди. Отримані результати спостережень системних замірів свідчать, що мовлення студентів, які вступають на факультет початкового навчання, характеризується як недостатнє. Базові мовленнєві уміння у $60 \%$ студентів недосконалі, вони спостерігаються не тільки у базовій - нормативній галузі (грамотність, мовленнєвий запас, читацький кругозір, культура мовлення), а і у виконавській діяльності (вимова, володіння інтонацією, специфічними прийомами спілкування в різних мовленнєвих ситуаціях). У процесі навчання студенти зазнають труднощів під час виразного читання 3 аркуша, декламації, написанні розгорнутих висловлювань, переказів, творів. Як правило, студенти мають нечітке уявлення про професійне мовлення, яке побудоване на розповіді, показі, поясненні, сценічному мовленні. Практично всі студенти не володіють риторичними уміннями та свідомою мовленнєвою поведінкою.

Мовленнєві компетентності студенти засвоюють під час вивчення провідних базових та спеціальних філологічних курсів. Характер сучасної університетської освіти зменшує аудиторний час до базового сегменту $\mathrm{i}$, як наслідок, звужує змістові рамки фундаментальних та методичних курсів. Формування компетентностей відноситься в пошукову область та самостійну діяльність, що проявляється у широкому введенні спеціальних курсів. У цій 
освітній конструкції спецкурси вводять студентів у сферу поглиблення професійних інтересів і беруть на себе навантаження сполучного компонента, виконуючи інтегруючу роль як в одній з предметних галузей, так і у системі предметного різноманіття. Спираючись на специфіку побудови навчального процесу, на кафедрі теорії і методики викладання філологічних дисциплін у дошкільній, початковій і спеціальній освіті ХНПУ імені Г.С.Сковороди в навчальний процес було додано комплекс спецкурсів філологічного напряму, які щорічно коректувалися та варіювалися. Використовуючи цю навчальну базу було поставлено та реалізовано задачу формування професійного мовлення вчителя через комплексну взаємодію, де координуючу роль грають спецкурси. Частковим проявом розв'язання поставленої задачі були:

- коректування теоретичних знань та вмінь базових курсів у бік їх практичної реалізації у шкільній справі;

- розробка системи спецкурсів, які б представили за можливістю ті напрями, які є провідними в усьому циклі підготовки;

- організація спеціальних практикумів, участь в яких забезпечила б контроль та самоконтроль рівня особистісного засвоєння програми навчання, дала б можливість виробити освітні критерії та норми;

- визначити та зафіксувати найбільш продуктивні форми навчальної роботи.

Найбільш продуктивними формами реалізації цього напрямку стали заняття, де провідними б були практика мовлення, мовленнєва поведінка.

- Організація інтенсивної мовленнєвої практики у раках проєкту «День у школі». Розробники: А.А.Ємець, О.М.Коваленко.

- Системне знайомство 3 різновидами професійного мовлення в рамках позааудиторної роботи: засвоєння особливостей сценічного мовлення та мовлення екскурсоводів, специфіки мовленнєвого співробітництва 3 читачаммолодшими школярами в умовах роботи дитячої бібліотеки, а також залучення до професійно направленої бесіди засобами обговорення зі спеціалістами (акторами, екскурсоводами, бібліотекарами), специфіки їх діяльності. Розробка, 
організація та реалізація: А.А.Смець, О.М.Коваленко, Ю.С.Дьякова, Г.В.Левандовська.

- Розробка та створення комплексних контрольних занять у формі тренінгу, які передбачають підготовчий - навчальний період, та заліковий у формі, яка дозволяє публічно продемонструвати досягнення в галузі колективної та індивідуальної творчості (концерт, спектакль, конкурс, читацька конференція, написання творчих робіт і т.д.). Розробка: О.В.Джежелей, А.А.Смець, О.М.Коваленко, здійснення та реалізація: Ю.С.Дьякова, Г.В.Левандовська.

У 2020/2021 навчальному році тренінг проходив у рамках дослідження за темою «Мовлення, мова, література у системі навчального процесу школа-3ВО». Формою заключної роботи стало написання твору за тематикою «Школа майбутнього та вчитель». Організація роботи передбачала, що під час вивчення всіх базових дисциплін та спецкурсів, де проводилася навчальна та позааудиторна робота співробітниками лабораторії, упродовж семестру, проводилося системне навчання предметного та творчого писемного мовлення, яка так, чи інакше, торкалася вказаної тематики. Розробка та реалізація проєкту: О.В.Джежелей, Ю.С.Дьякова, Г.В.Левандовська.

Апробовувалися наступні форми роботи: конспект, аналіз та вільний переказ літературного джерела; підготовка тез, доповідей, виступів; переказ літературного твору (письмовий та усний); письмові відповіді прагматичного та філософського характеру; вправи, які направлені на цілеспрямоване розширення словникового запасу; декламація творів класичної української та російської дитячої літератури; знайомство з матеріалами за темою на електронних носіях (міркування, які супроводжувалися демонстрацією фактів та об'єктів); занурення в історико-соціальний екскурс (вербальний і візуальний аспекти); написання міні-творів. Особливо, у рамках спецкурсу «Заняття з мовотворчості: риторика і виконавська майстерність» опрацьовувалася програма поєднання засвоєння методики проведення уроків з написання творів у початковій школі 3 практикою оволодіння написанням твору як формою творчої роботи студентів. 
Результати реалізація запропонованої програми показали достатній рівень ефективності, який дозволяє перейти до оформлення версії електронного посібника для забезпечення індивідуальної та групової роботи студентів, які спеціалізуються на запропонованому навчальному напрямку. 
DOI 10.46299/ISG.2021.MONO.PED.II-426-436

\subsection{Formation of prospective teacher professional motivation in the development of the new Ukrainian school}

The conceptual principles of implementing the state policy in the field of reforming secondary education "the new Ukrainian School" approved in 2016, reveals the strategic ways to reform Ukrainian secondary schools until 2029.

Among the nine key components required for the new school, the second position relates to a highly motivated teacher, who must be competitive, constantly working on their improvement, responsible, able to respond and adapt quickly to ongoing changes in the informational world, open and creative to perceive new ideas and ready to put them into practice and, what is more important, - capable of steady development of their soft and professional skills. "The Ukrainian school will be successful if it is joined by successful teachers. They - successful teachers and professionals - will resolve a multitude of issues regarding the quality of teaching, the volume of home assignments, communication with children and school administration. Children need a leader who can lead them forward, who likes their discipline, who teaches them professionally", says in Conceptual Principles of Secondary School Reform "The New Ukrainian School"

Obviously, it is a teacher who is motivated to pedagogical professionalism. That's why there is an urgent need to form strong incentives for professional motivation in prospective teachers who are able to become a true "agent of change" and change the third millennium school for the better.

The aim of this paper is to analyze the key incentives necessary to form the prospective teacher professional motivation in the development of the new Ukrainian school; reveal dominating incentives (extrinsic/intrinsic) in their professional motivation; consider the conditions necessary for developing sustainable incentives for the students' professional education.

While researching we have taken into account various scientific resources. Among the scholars who have investigated the problem of student motivation is (Georgiev, 2018); who has performed the motivational analysis in professional 
competences of prospective military officers (Luzan \& Zaitseva, 2013); has studied the students' cognitive activity in higher education institutions of economic sciences; S. Ihnatenko has investigated the development of students' motivation for their out-ofclass physical training (Ihnatenko, 2016); T. Klybanivska has analyzed the motivation as a determinant of students' educational activity in higher education institutions (Klybanivska, 2015); G. Kostyshyna has studied students' learning and cognitive activities in technical institutions (Kostyshyna, 2003); Luzan P. has considered students' academic activity in agricultural universities (Luzan, 2015); Patyk Yu. has researched future social workers motivational tendencies (Patyk, 2016); Silveistr A., Mokliuk M. have investigated the motivation in students' education as psychological and pedagogical problems (Silveistr \& Mokliuk, 2014); Y. Serbin has analyzed the personal adaptive potential of liberal arts students in the process of their adaptation to learning (Serbin, 2018).

Various aspects of forming strong motivation for learning activities, professional education, creative competency have been outlined by the following Ukrainian researchers: I. Halian (Halian, 2018), Y. Kaliuzhna (Kaliuzhna, 2016), A. Melnyk (Melnyk, 2017), L. Peretiatko (Peretiatko, 2016), V. Fritsiuk (Fritsiuk, 2016), V. Chernii (Chernii, 2017), S. Yalanska (Yalanska, 2017) and others.

Lynley H. Anderman, Valerie S. Leake have provided profound insights into the theory on motivation. Their findings cover three fundamental human needs - need for a sense of autonomy, need for fitting in, need for competence (Anderman \& Leake, 2005); Hamizan N., Zaid N. M. have investigated the enhancement of students motivation in learning through Blossoms video activity (Hamizan \& Zaid, 2014); Chan H., Wang X. have analyzed the connection between motivation for learning and learning outcomes between the students of technical colleges (Chan \& Wang, 2016);

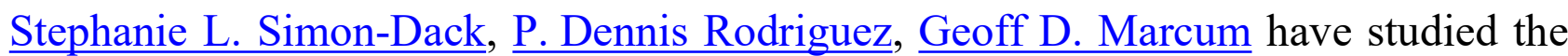
habits, motives, and strategies of college students with symptoms of ADHD (SimonDack, Rodriguez \& Marcum, 2016); Bruce W. Tuckman have revealed the links between motivational factors and self-regulatory behavior of college students (Tuckman, 2003); Stukalina Y. has described the specific features of modeling 
satisfaction and motivation of university students in integrated educational environment (Stukalina, 2016); Charikova I., Zhadanov V. have highlighted the role of a teacher in training a highly-qualified individual with intellectual, moral and spiritual values in a new paradigm of university education (Charikova \& Zhadanov, 2017); Plugina M. I., Sokolova I. Y., Gorbunkov V. Y., Znamenskaya S. V., Goman M. V. have outlined the role of innovative educational technologies (communicative, interactive, searching, informational, stimulant, entertaining, and others) in developing motivation for studying (Plugina, Sokolova, Gorbunkov, Znamenskaya \& Goman, 2016); Schlag B. has analyzed the links between studying and motivation (Schlag, 2013); Wagner R., Hinz A., Rausch A., Becker B. have specified the interrelation between learning and motivation (Wagner, Hinz, Rausch \& Becker, 2009); Öqvist A., Malmström M. have studied the influence of teacher leadership on the effectiveness of students' learning (Öqvist \& Malmström, 2018).

The overview of above-mentioned resources has proved that the problem of studying student incentives and motivation is relevant not only in Ukraine but internationally. The educators study its various aspects: both theoreticalmethodological and practice-oriented. Taking into account the educational reforms that have been implemented in Ukraine recently, we are to focus on studying the problem of forming prospective teacher motivation.

Nowadays, there is no unambiguous interpretation of the concept of "motivation". In this article, we use the definition given by of S. Rubinstein, who understands motivation as more or less adequately conscious incentives. (Rubinstein, 2002: 542). Consequently, the motivation can be defined as one of the most important components of the psychological structure of any activity, and which reveals the incentive nature of any action, behavior, human activity, and its essence. In learning, such motivation implies the incentives of initial cognitive activity, which is essential for ensuring its effectiveness. If a student learns without some cognitive interest, their motivation is to get a diploma, please their parents, or something else, and therefore, his knowledge might not be profound, which might result in having a non-motivated and indifferent teacher. 
Thus, under the motivations for the educational activity we understand the factors that impel a person to this activity, and determine human cognitive activity i.e. their ideas, goals, needs, interests, beliefs, social attitudes, feelings, etc. Student professional motivation emerges/develops in higher education institutions because the educational activity is closely connected with the professional and pedagogical activity. Therefore it is essential to talk about the motivations of the students' professional activity. By the latter, we mean everything that stimulates and directs them to study future disciplines.

The methods used in the research and full description of the experiment. Empirical study was conducted in Poltava V.G. Korolenko National Pedagogical University in March 2020. Second-year students (aged 18-19) of the Faculty of Philology and Journalism (full-time department) were selected to participate in a survey.

The research uses the following methodologies: 1) "Motivation for studying in pedagogical universities" (S.A Pakulina, S.M Ketko) (Ketko, Pakulina, 2011); 2) "Studying motivation for students' educational activity" (modification by A.A.Rean, V.A Yakunin)" (Methods for studying motivation of educational activity (modification by A.A Rean, V.A Yakunin, 2004).

Methods of studying students' motivations in pedagogical universities (S.A Pakulina, S.M.Ketko) offer students to fill in a table which divided into three blocks of motivations: 1) motivation to apply to university; 2) motivation to study at university; 3) professional motivation.

\begin{tabular}{|l|l|}
\hline \multicolumn{1}{|c|}{ Motivations } & Points \\
\hline \multicolumn{1}{|c|}{ I. What motivated you to choose this particular profession? } \\
\hline 1. Free education, low tuition fees & \\
\hline 2. Specialized secondary education & \\
\hline 3. Desire to obtain higher education & \\
\hline 4. Family tradition, parents wishes & \\
\hline 5. Friend's advice & \\
\hline 6. Higher education institution / faculty image and credibility & \\
\hline 7. Interest in teaching career & \\
\hline
\end{tabular}




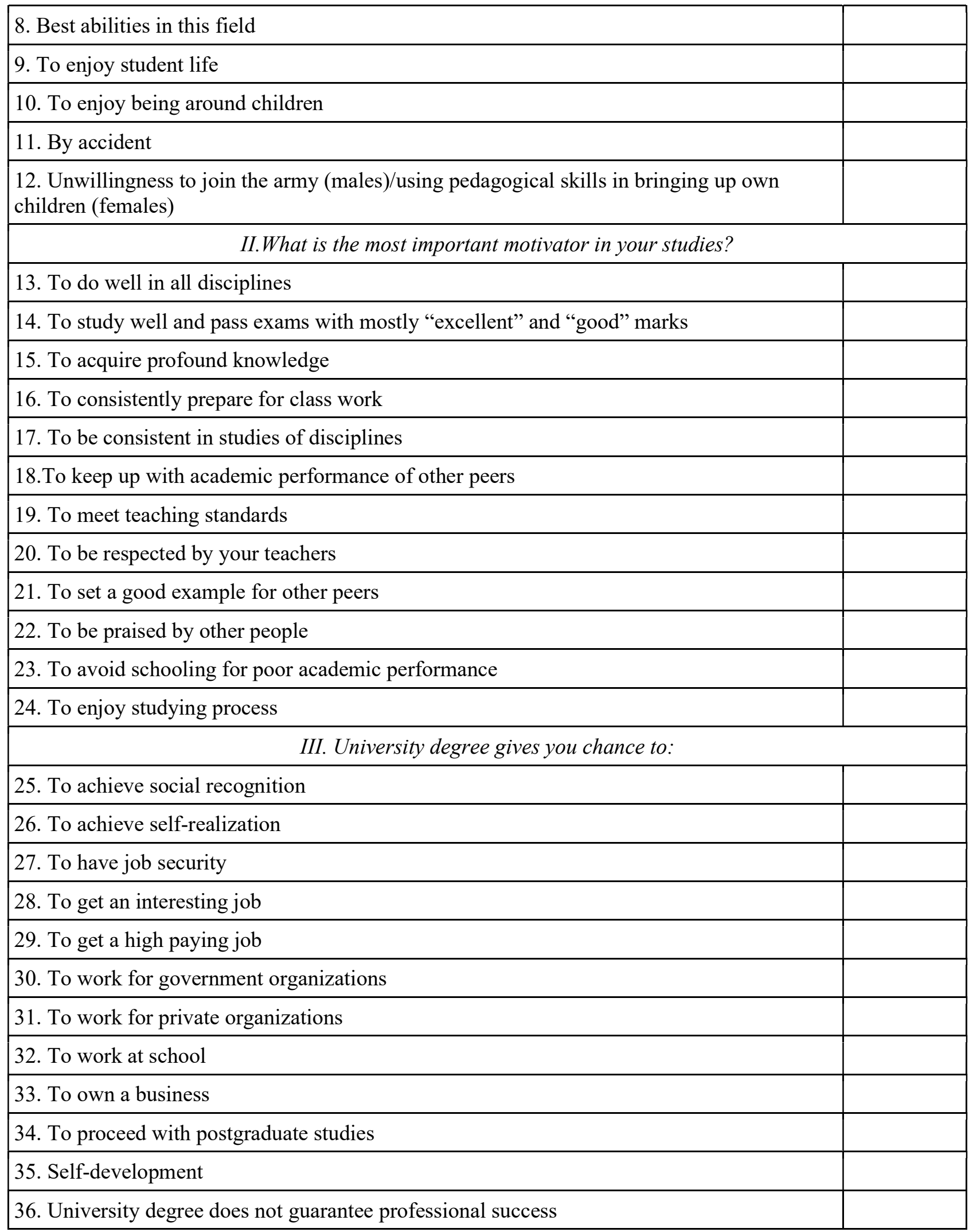

Students have to select the most important motivations to study in pedagogical university on a scale: 5 points - very significant, 3-4 - significant, 0-2 - not significant. Survey results analysis is given below.

The methodology for studying the motivation for studying activities (modification by A.A.Rean, V.A.Yakunin) was carried out in accordance with the first 
version, when students were given a list of motivations (the total number - 16), and they had to choose five most significant and tick them.

\section{List of motivations}

1. To be a high-qualified specialist

2. To get a university degree

3. To do well in all disciplines

4. To study well and pass exams with mostly "excellent" and "good" marks

5. To get a scholarship

6. To acquire profound knowledge

7. To be prepared for class work

8. To be consistent in studies of disciplines

9. To keep up with academic performance of your peers

10. To acquire the skills for successful career

11. To meet teaching standards

12. To be respected by teachers

13..To set a good example for other peers

14. To be praised by parents and other people

15. To avoid schooling for poor academic performance

16. To enjoy studying process

The survey results (Form 1) defined the frequency of motivations from among the most significant in this survey. On the basis of this, the rank of each motivation in the corresponding sample was determined.

\begin{tabular}{|l|}
\hline Motivation № in the list \\
\hline Quantity of motivations \\
\hline Frequency of the motivation \\
\hline Motivation rank \\
\hline
\end{tabular}

As mentioned above, there is no unambiguous concept of "motivation". In this article we use the definition given by of S. Rubinstein, who understands motivation as more or less adequately conscious incentive. (Rubinstein, 2002: 542). We consider motivation to be one of the most important components of psychological structure of 
any activity by means of which the motivation behind person's actions, their behavior and essence is revealed. In educational activity such incentives could be the motivation for educational and cognitive activity. Disclosing them is essential for ensuring their efficiency. If a student learns without cognitive interest, and his motivation is only to get a university degree or to please his/her parents or something else, he/she will never get profound knowledge. As a result - he/she will not become a motivated and interesting teacher.

Thus, under the motivation for educational activity we understand the factors that impel person to this activity, and determine human cognitive activity i.e. their ideals, goals, needs, interests, beliefs, social attitudes, feelings, etc. It is essential to talk about motivation of the student education activity because it is closely connected with professional and pedagogical activity and student motivation appears/develops in higher education institutions. By the latter we mean everything that stimulates and directs them to study disciplines.

The professional motivation for pedagogical university education activity implies the system of incentives that determines the specific student activities or behavior. These incentives may be extrinsic, outside the student's academic activity and having no direct connection with studying ("just to obtain knowledge" without any intentions to work in school, to keep up with fellow students, avoid schooling for poor academic performance, to get a scholarship, etc.), and intrinsic ones which are essential for the process of learning. They are strongly associated with studying professional skills (to develop their personality, cognitive interests, to pursue profound knowledge, to seek self-realization and professional development, etc.).

Results of methodology "Motivations for studying at pedagogical universities" (S.A. Pakulina, S.M.Ketko) are shown in tables 1,2,3; description of the methods on pages 6,7 of this article 
Table 1. Survey results on methodology "Motivations to study in pedagogical universities" (S.A. Pakulina, S.M. Ketko) (The first block of questions "What motivated you to choose this particular profession?"

\begin{tabular}{|l|l|l|l|l|l|l|l|l|l|l|l|l|l|l|l|}
\hline $\begin{array}{l}\text { No } \\
\text { ation }\end{array}$ & 1 & 2 & 3 & 4 & 5 & 6 & 7 & 8 & 9 & 10 & 11 & 12 & $\begin{array}{l}\text { Intrinsi } \\
\mathrm{c} \\
\text { motiva } \\
\text { tion } \\
\text { total } \\
\text { points } \\
\mathrm{c} \\
\text { motivat } \\
\text { ion total } \\
\text { points } \\
\text { by a } \\
\text { factor } \\
\text { of } 1.25\end{array}$ & $\begin{array}{l}\text { Extrin } \\
\text { sic } \\
\text { motiva } \\
\text { tion } \\
\text { total } \\
\text { points }\end{array}$ \\
\hline $\begin{array}{l}\text { Motiv } \\
\text { ation } \\
\text { total } \\
\text { points }\end{array}$ & 5 & 88 & $\begin{array}{l}25 \\
7\end{array}$ & 87 & 40 & 10 & 216 & 21 & 119 & 180 & 76 & 19 & 952 & $\mathbf{1 1 9 0}$ & $\mathbf{8 1 8}$ \\
\hline $\begin{array}{l}\text { Motiv } \\
\text { ation } \\
\text { rank }\end{array}$ & 4 & 9 & 1 & 10 & 12 & 8 & 2 & 3 & 7 & 6 & 11 & 5 & & & \\
\hline
\end{tabular}

Table 2. Survey results on methodology "Motivations for studying in pedagogical universities" S.A. Pakulina, S.M. Ketko) (The second block of questions "What is the most important thing in your studies?"

\begin{tabular}{|c|c|c|c|c|c|c|c|c|c|c|c|c|c|c|c|}
\hline $\begin{array}{l}\text { № } \\
\text { Motiv } \\
\text { ation }\end{array}$ & 13 & 14 & 15 & 16 & 17 & 18 & 19 & 20 & 21 & 22 & 23 & 24 & $\begin{array}{l}\text { Intrinsic } \\
\text { motivati } \\
\text { on total } \\
\text { points }\end{array}$ & $\begin{array}{l}\text { Intrinsic } \\
\text { motivati } \\
\text { on total } \\
\text { points } \\
\text { by a } \\
\text { factor of } \\
1.25\end{array}$ & $\begin{array}{l}\text { Extrin } \\
\text { sic } \\
\text { motiva } \\
\text { tion } \\
\text { total } \\
\text { points }\end{array}$ \\
\hline $\begin{array}{l}\text { Motiv } \\
\text { ation } \\
\text { total } \\
\text { points }\end{array}$ & $\begin{array}{l}20 \\
4\end{array}$ & $\begin{array}{l}22 \\
8\end{array}$ & $\begin{array}{l}24 \\
8\end{array}$ & $\begin{array}{l}18 \\
6\end{array}$ & $\begin{array}{l}20 \\
2\end{array}$ & $\begin{array}{l}18 \\
3\end{array}$ & 199 & $\begin{array}{l}19 \\
3\end{array}$ & $\begin{array}{l}15 \\
9\end{array}$ & $\begin{array}{l}15 \\
6\end{array}$ & $\begin{array}{l}11 \\
7\end{array}$ & $\begin{array}{l}21 \\
5\end{array}$ & 1081 & 1351 & 1209 \\
\hline $\begin{array}{l}\text { Motiv } \\
\text { ation } \\
\text { rank }\end{array}$ & 4 & 2 & 1 & 8 & 5 & 9 & 6 & 7 & 10 & 11 & 12 & 3 & & & \\
\hline
\end{tabular}

Table 3. Survey results on methodology "Motivations for studying in pedagogical universities" S.A. Pakulina, S.M. Ketko) (The third block of questions "University degree gives you a chance to..."

\begin{tabular}{|c|c|c|c|c|c|c|c|c|c|c|c|c|c|c|c|}
\hline $\begin{array}{l}\text { № } \\
\text { Motiv } \\
\text { ation }\end{array}$ & 25 & 26 & 27 & 28 & 29 & 30 & 31 & 32 & 33 & 34 & 35 & 36 & $\begin{array}{l}\text { Intrinsic } \\
\text { motivati } \\
\text { on total } \\
\text { points }\end{array}$ & $\begin{array}{l}\text { Intrins } \\
\text { ic } \\
\text { motiva } \\
\text { tion } \\
\text { total } \\
\text { points } \\
\text { by a } \\
\text { factor } \\
\text { of } 1.25\end{array}$ & $\begin{array}{l}\text { Extrinsi } \\
\text { c } \\
\text { motivati } \\
\text { on total } \\
\text { points }\end{array}$ \\
\hline $\begin{array}{l}\text { Motiv } \\
\text { ation } \\
\text { total } \\
\text { points }\end{array}$ & $\begin{array}{l}17 \\
9\end{array}$ & $\begin{array}{l}24 \\
9\end{array}$ & $\begin{array}{l}21 \\
8\end{array}$ & $\begin{array}{l}23 \\
4\end{array}$ & $\begin{array}{l}23 \\
1\end{array}$ & $\begin{array}{l}15 \\
9\end{array}$ & 200 & $\begin{array}{l}17 \\
2\end{array}$ & $\begin{array}{l}18 \\
1\end{array}$ & $\begin{array}{l}11 \\
7\end{array}$ & $\begin{array}{l}23 \\
0\end{array}$ & 87 & 986 & 1233 & 1271 \\
\hline $\begin{array}{l}\text { Motiv } \\
\text { ation } \\
\text { rank }\end{array}$ & 8 & 1 & 5 & 2 & 3 & 10 & 6 & 9 & 7 & 11 & 4 & 12 & & & \\
\hline
\end{tabular}


Results show that intrinsic motivations turn out to be dominant for students in their studies. According to the first block of questions "What motivated you to choose this particular profession?" the ratio of intrinsic/extrinsic motivations is $1190 / 818$ (Table 1) and is equal to 1.455; in the second block of the questions "What is the most important thing in your studies?" the intrinsic / extrinsic motivation ratio is 1351/1209 (Table 2) and is equal to 1,117; in the third block of questions "University degree gives you a chance to..." intrinsic / extrinsic motivation ratio is 1233/1271 (Table 3) and is equal to 0.969 . Fig. 1 shows that overall ratio of internal / external motivations is $3774 / 3298$ respectively, and equals 1.144 .

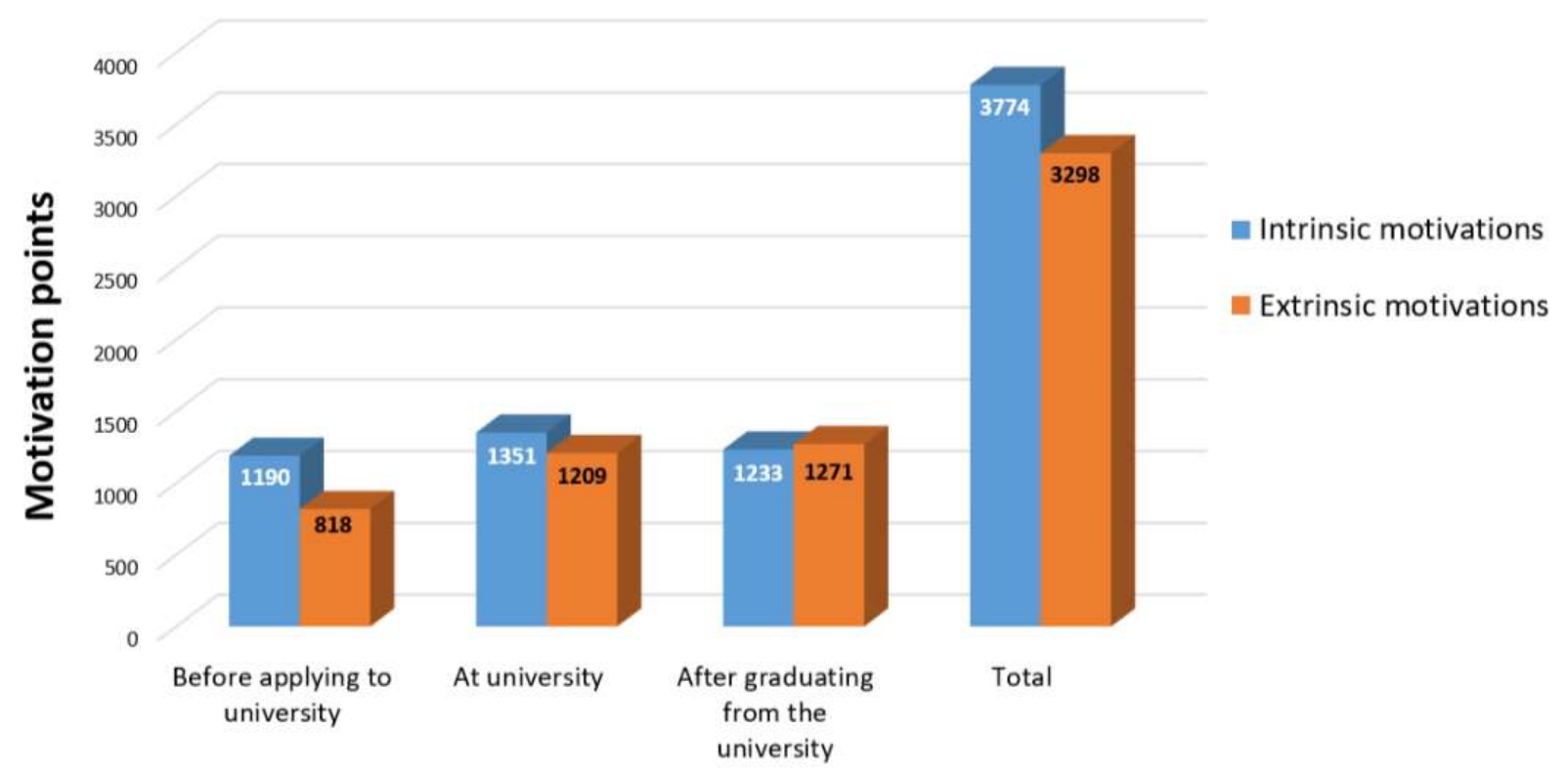

Motivation Periods

Figure 1.The overall ratio of intrinsic (by factor of 1.25) / extrinsic motivation based on the methodology "Motivations to study in pedagogical universities" (S.A.Pakulina, S.M.Ketko)

Survey results on individual motivations prove the key motivations that contribute to the choice of teaching career (first block of questions, page 6) are: first place - desire to obtain high education(257 points); second place - interest in teaching career(216 points); third place - great abilities in this field (211 points) (Table 1). The main reasons for learning (second block of questions, page 7) are: first place - to acquire profound knowledge (248 points); second place - to do well in studies and examinations, mostly "excellent" and "good" marks (228 points); third place - to enjoy 
studying process (215 points) (Table 2). The third block of questions "University degree gives you a chance to..." (page 7) results in the following: first place - to achieve self-realization (249 points); second place - get an interesting job (234 points); third place - to get a high paying job (231 points).

Thus, the main motivations for studying at pedagogical university were intrinsic ones (total points 3774). Students with intrinsic motivations have broad cognitive incentives, urge for self-education. They adapt effectively to university education, strive for improving the studying process, its content and organization, require nontraditional forms and methods of teaching, non-standard presentation of the material, highly qualified teachers who are always ready to cooperate. Extrinsic motivations to teach students (total points-3298) are characterized by low cognitive incentives, poor adaptation to education in university, weak creativity and the like.

The survey results on the motivations for studying activities (a modification by A.A. Rean, V.A. Yakunina) (description of methods is presented on pp. 7, 8) are summarized in Table 4. And according to the results first place is "to acquire skills for successful career" (83,64\%, 46 students); second place -"to be a highly-qualified specialist" (74,55\%, 41 students); third place - "to get a university degree" $(67,27 \%$, 37 students); forth place - "to acquire profound knowledge" (61,82\%, 34 students); fifth place - "to enjoy studying process" (49,09\%, 27 students).

Table 4. Results on methodology "Studying motivations for student learning activities" (modification by A.A. Rean and V.A. Yakunina)

\begin{tabular}{|l|l|l|l|l|l|}
\hline Motivation rank & 1 & 2 & 3 & 4 & 5 \\
\hline Quantity of motivation & 46 & 41 & 37 & 34 & 27 \\
\hline Motivation frequency \% & 83.64 & 74.55 & 67.27 & 61.82 & 49.09 \\
\hline Motivation № & 10 & 1 & 2 & 6 & 16 \\
\hline
\end{tabular}

Research results confirm that effectiveness and success of developing students' professional motivation depends on the maturity of their incentives. Intrinsic, professionally oriented motivations (high cognitive interest) should dominate the extrinsic ones (low cognitive interest). In order to achieve these results higher 
education institutions should organize purposeful, systematic work based on partnership and subject-to-subject interaction among the participants of studying process.

We found out that the following conditions are required for development of sustainable motivations for student professional activity:

$\checkmark$ procedural and informative: facilitation of educational activities; introduction of personally oriented learning; individualization of educational and professional activities; adhering to correct correlation of theoretical knowledge and practical skills; a variety of forms of individual and group work during psychological and pedagogical practice; application of the competence approach; humanization and democratization of education process; variety of forms and methods of students independent work; teacher's proficiency.

$\checkmark$ didactic and educational: giving students the possibility to choose disciplines and methods of study; avoiding stereotypic methods in conducting lessons, using problematic, interactive and scientific methods of teaching; standardizing of educational activity; structuring and prioritizing educational content; using principles of accessibility and didactics

$\checkmark$ psychological: holding sustainable interest in a chosen career; developing students' mental abilities, their awareness of intermediate and ultimate objectives of studying (close and long-term prospects), theoretical and practical significance of acquired knowledge, professional orientation of studying activity.

Prospects for further scientific research are to identify positive and negative impact on educational and cognitive activity of pedagogical university students; to explore the development of motivation for studying remotely; to research the specifics of forming motivation for studying and pursuing teaching career. 
DOI 10.46299/ISG.2021.MONO.PED.II-437-449

\subsection{Software package mathlab in linear algebra teaching}

Using of mathematics software packages is one of indicators of the professional learning level of university graduates in information computer technologies (ICT). The problems of linear algebra are easy to algorithmize. To increase the efficiency of students' professional competencies formation, it makes sense to talk about algorithms in the form they would be performed by a computer. The ICT use in linear algebra teaching is becoming relevant. The main types of educational software are electronic textbooks, mathematics software packages and monitoring software. Electronic textbooks are used at lectures. There are textbooks with built-in knowledge control tools. Some textbooks contain practical tasks. However, there is no educational virtual environment for practical tasks. Mathematics software packages Mathematica, Maple, MathCAD, Matlab are used at practical classes. They will automate arithmetic calculations and enable students to focus on the essence of method. In some mathematical packages, including Matlab, tools for the distance development of a Web application focused on complex calculations were developed.

Monitoring software diagnoses checks and evaluates the knowledge, abilities and skills of the student. The linear testing algorithm is the simplest. For each student, a test variant is generated in a random order from a task repository. At linear and randomized testing, all participants have test questions of the same complexity. For example, the Google Forms service is widely available; it allows randomizing responses and uploading data in Excel format.

The programming language Matlab was developed by Cleve Moler, the Dean of Computer Science Department of New Mexico University in the late 1970s (Wikipedia). John Little together with Cleve Moler and Steve Bangert rewrote Matlab in C programming language and founded The MathWorks. At the moment, Matlab is a high-level language and interactive environment for developing algorithms, calculations, visualization and data analysis. It was originally developed for control systems designing. Matlab has quickly gained popularity in many scientific and engineering areas. The Matlab package is effective in the educational process, in 
particular, linear algebra teaching. In 2004, the Ministry of Education and Science of Ukraine decided to implement it the senior classes and universities. According to the UNESCO ICT Competency System, teachers who have sufficient competencies in ICT using in their professional practice will be able to ensure a high level of educational quality and effectively promote the students' ICT competences development (Terms of use - CC BY SA).

The Matlab environment use in diploma theses and dissertations will increase the complexity and importance of research. It will significantly redistribute the workload of teachers from homework tasks assessment to network project management in the Matlab environment. For example, the Eindhoven Technical University in the Netherlands (Technische Universiteit Eindhoven), most parts of scientific and teaching equipment are designed by students and produced within the educational process. So, it saves funds for the purchase of laboratory equipment.

Matlab is one of the ICT student's educational tools. On May 16, 2019, the First International Scientific and Practical Conference "Matlab and Computer Computing in Education, Science and Engineering" were held at the Kyiv National Aviation University.

One of the key priorities of UNESCO in the education field is to assist UNESCO Member States in developing a strategy and implementing a policy for informatization of education: national education systems modernizing through the introduction of innovative models of management of educational institutions, as well as a strategy for solving problems of improving the quality of education using of modern ICT and advanced pedagogical methods into everyday teaching practice. The IT development and implementation in education is constantly being researched by scientists of international organizations: UNESCO, UN, European Union, Council of Europe and others. The works of S. Peipert, M. Reznik, E. Patarakin, E. Polat, A. Khutorsky, B. Yarmakhov, A. Yastrebtsev, V. Bykov, N. Zhaldak, N. Zgurovsky, V. Kukharenko, V. Lapinsky, N. Morze, A. Pilipchuk, S. Rakova, S. Semerikov, E. Slovak, A. Stryuk, M. Shishkina and other researchers are devoted to this issue. 
The purpose of paper is to present the capabilities of the Matlab package in linear algebra teaching using practical tasks.

Typical tasks of linear algebra are: finding a solution of linear equation systems, calculating the values of determinants and the matrix rank, finding a linear operator matrix, studying the roots of polynomials in one variable (Robert A Beezer, 2006). Linear algebra tasks are easy to algorithmize, but their implementation in the mathematical package Matlab is possible.

Let's consider matrices. Matrix elements are given in square brackets. Elements of one line are separated from each other by a space or comma. Lines are separated by a semicolon. To refer to a single matrix element, the matrix name and element indices in parentheses should be specified.

Basic operations with matrices:

- $\mathrm{A}+\mathrm{B}$ is addition of matrices $\mathrm{A}$ and $\mathrm{B}$ (operation is possible with the same order of the matrices).

- $\quad$ A - B is subtracting of matrices A and B (operation is possible with the same order of matrices).

- $\quad \mathrm{A} * \mathrm{~B}$ is production of matrices (an operation is possible when the number of columns of the matrix $\mathrm{A}$ is equal to the number of rows of the matrix $\mathrm{B}$. The operation is not commutative).

- $\quad \mathrm{A} *$ In the element wise multiplication of the matrices $\mathrm{A}$ and $\mathrm{B}$ of the same dimension.

- A. / B element wise division of the matrices A and B of the same dimension.

- $\quad \mathrm{A}^{\wedge} \mathrm{k}$ element wise raising of an array to $\mathrm{k}$ degree.

- A 'transposition of matrix A.

- $\quad \mathrm{A}^{\wedge}-1$ (or inv (A)) calculation of the inverse matrix $\mathrm{A}-1$ (the inverse matrix exists for square matrices whose determinant is nonzero).

- $\quad \operatorname{det}(\mathrm{A})$ calculating of the matrix A determinant.

- $\quad$ size (A) definition of the matrix A dimension.

- $\quad$ trace (A) the sum of the elements on the main diagonal. 
- $\quad \operatorname{sum}(\mathrm{A})$ the sum of the elements in each matrix A column.

- $\quad \operatorname{prod}(\mathrm{A})$ is the product of the elements in each column of the matrix A.

- $\quad \operatorname{diag}(\mathrm{A})$ the column vector of the elements of the matrix A main diagonal.

- $\quad$ sort (A) sorting of matrix A each column.

- $\quad \max (\mathrm{A})$ calculating the maximum in matrix A each column.

- $\quad \min (\mathrm{A})$ calculation of the minimum in matrix A each column.

- $\quad$ mean (A) calculation of the average value in matrix A each column.

- $\quad \operatorname{rot} 90(\mathrm{~A})$ rotation of matrix A to the left by 90.

- $\quad$ fliplr (A) flip of matrix A from left to right.

- $\quad$ flipud (A) flip of matrix A from top to bottom.

- $\quad A(n,:)=[]$ deletion of the row number $n$ from matrix A.

Let's consider the example. Matrices are given

$$
A=\left(\begin{array}{ccc}
-3 & 5 & 13 \\
11 & -5 & 7 \\
2 & -1 & -6
\end{array}\right), B=\left(\begin{array}{ccc}
2 & 9 & -8 \\
1 & -15 & 14 \\
4 & -12 & 3
\end{array}\right)
$$

Calculate

$\mathrm{A}+\mathrm{B}, \mathrm{A}-\mathrm{B}, \mathrm{A} \cdot \mathrm{B}, \mathrm{B} \cdot \mathrm{A},|\mathrm{A}|,|\mathrm{B}|, \mathrm{A}^{-1}, \mathrm{~B}^{-1}$. Set the matrix in the command window of the program

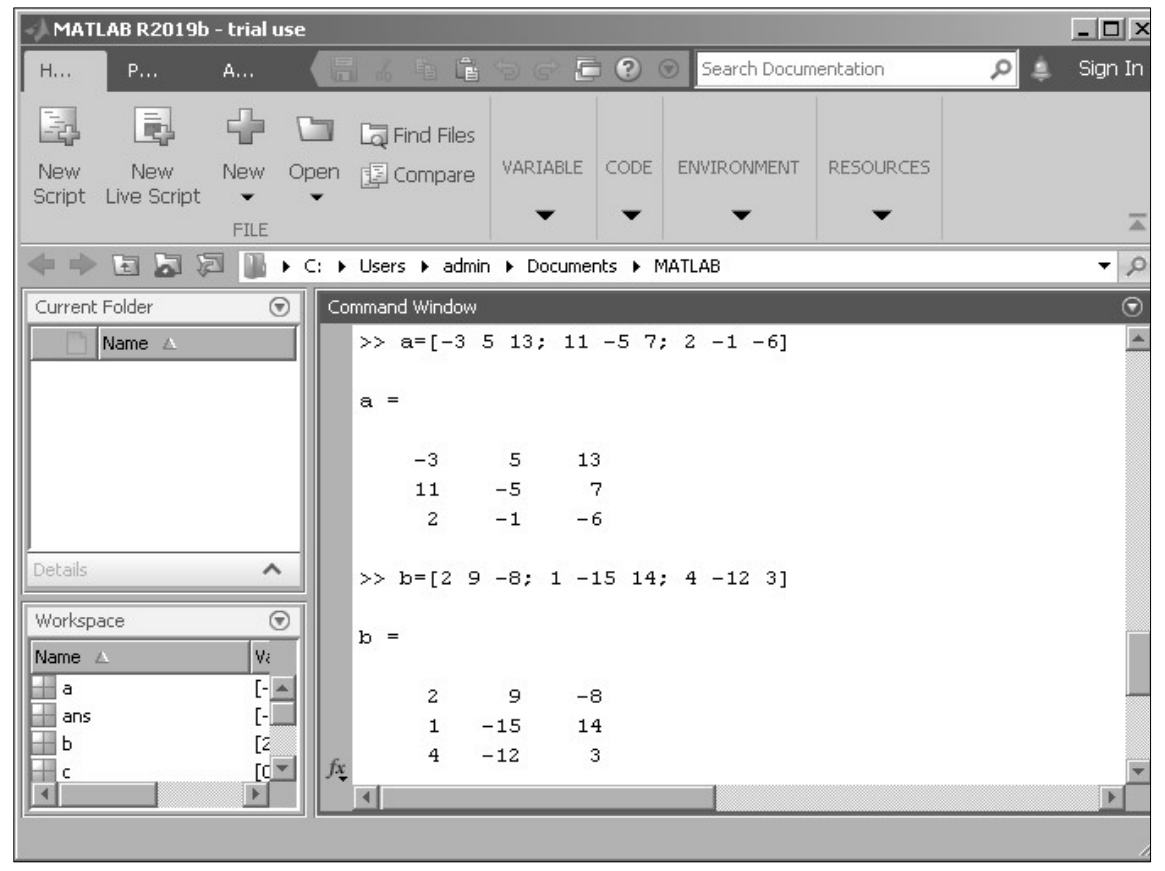

Figure 1. Initial data 


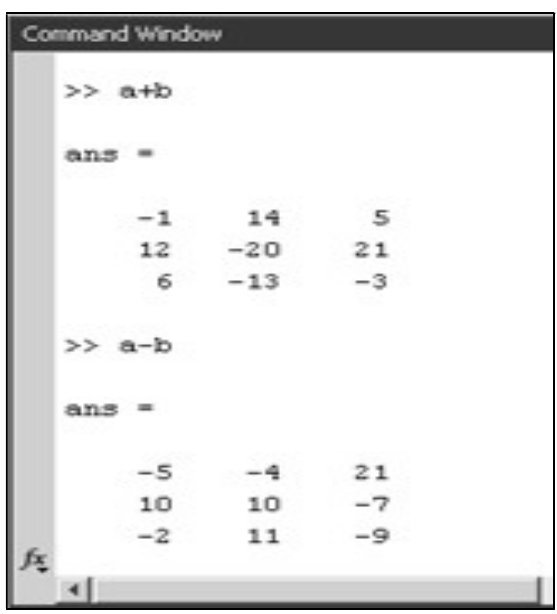

Figure 2. Sum and disparity result

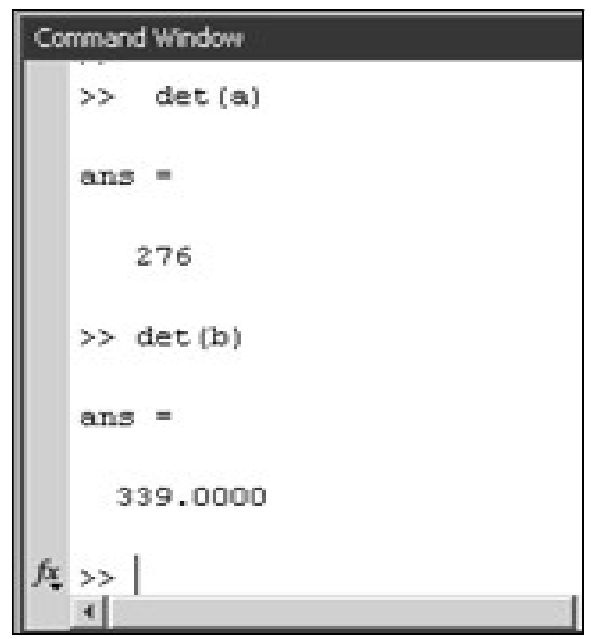

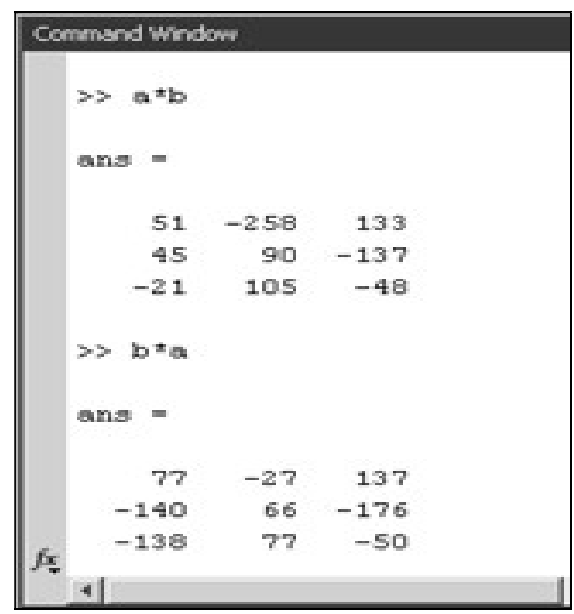

Figure 3. Multiplication result

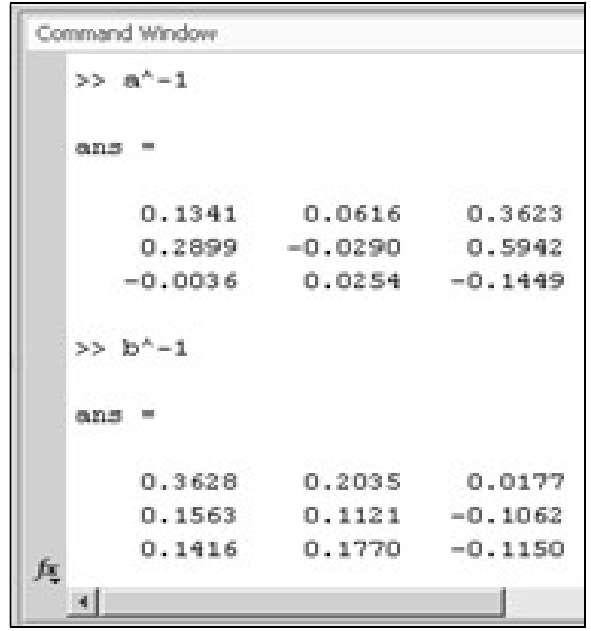

Figure 4. Result of finding the determinant Figure 5. Result of inverse matrix finding

In the example, the matrices are not shown. Operations are executable. Linear equation system. The system of linear equations is given:

$$
\left\{\begin{array}{c}
a_{11} x_{1}+a_{12} x_{2}+\cdots+a_{1 n} x_{n}=c_{1}, \\
a_{21} x_{1}+a_{22} x_{2}+\cdots+a_{2 n} x_{n}=c_{2}, \\
\cdots \\
a_{n 1} x_{1}+a_{n 2} x_{2}+\cdots+a_{n n} x_{n}=c_{n} .
\end{array}\right.
$$




$$
\begin{gathered}
\mathrm{A}=\left(\begin{array}{ccc}
a_{11} & \ldots & a_{1 n} \\
\ldots & \ldots & \ldots \\
a_{n 1} & \ldots & a_{n n}
\end{array}\right)-\text { the matrix of coefficients; } \\
C=\left(\begin{array}{c}
c_{1} \\
\ldots \\
c_{n}
\end{array}\right)-\text { column vector of free members; } \\
X=\left(\begin{array}{c}
x_{1} \\
\ldots \\
x_{n}
\end{array}\right)-\text { column vector of unknowns; }
\end{gathered}
$$

Given $|A| \neq 0$, the system has a single solution.

Example:

$$
A=\left(\begin{array}{ccc}
-3 & 5 & 13 \\
11 & -5 & 7 \\
2 & -1 & -6
\end{array}\right), \quad C=\left(\begin{array}{c}
46 \\
22 \\
-18
\end{array}\right)
$$

Let's consider three ways to solve a system of linear equations using Matlab.

Table 1. Ways to solve a system of linear equations using Matlab

\begin{tabular}{|c|c|}
\hline \multicolumn{2}{|c|}{ 1 way. Using the built-in function } \\
\hline Function linsolve(A,C) & $>\mathrm{X}=$ linsolve(A,C) \\
$\mathrm{X}=$ \\
1.0000 \\
1.0000 \\
1.0000 \\
\hline The matrix determinant A is & $>>$ det(A) \\
calculated & $\mathrm{X}$ X=A $\backslash \mathrm{B}$ \\
Vector X. & 1.0000 \\
& 1.0000 \\
& 1.0000 \\
\end{tabular}




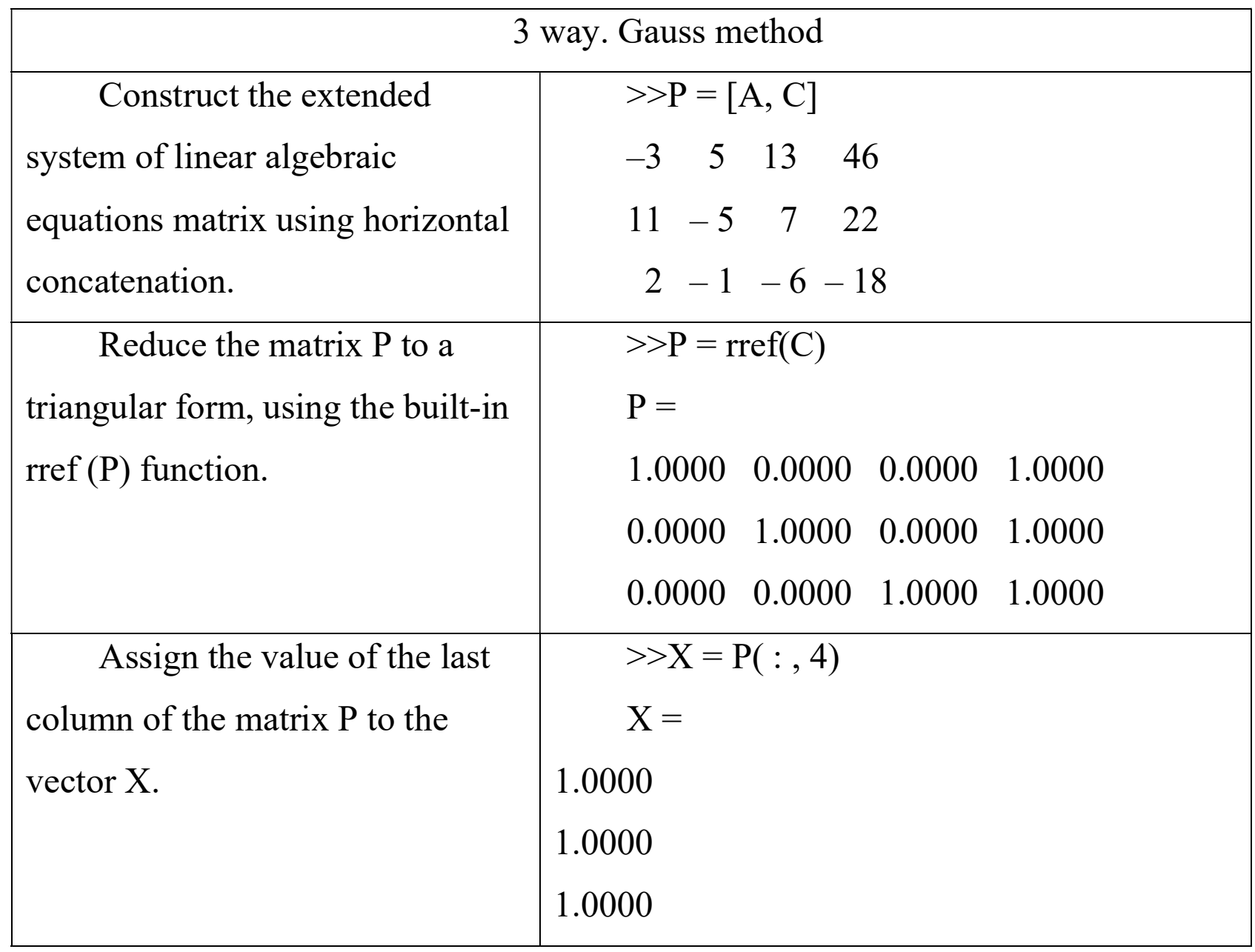

If the course of the solution is not important, then the command "alc" is used. To solve the system of linear equations by the Cramer method, it is necessary: to set the main matrix of coefficients for unknowns; set auxiliary matrices; calculate unknown systems of equations by dividing the determinant of the corresponding auxiliary matrix by the determinant of the main matrix.

To solve linear systems or nonlinear equations, Matlab has a special solve function. It is necessary: to determine symbolic variables, calculate unknowns by the formula $[\mathrm{x} 1, \mathrm{x} 2, \ldots]=$ solve ('equation1', 'equation2', ...), derive the found solution with a given accuracy using the vpa function (variable, number of characters).

The graphical method can be applied to systems of dimension 2 or 3 . It is necessary: to set symbolic variables, a function, design a function graph, add grid lines to the graph, use the graphic "magnifier" to scale the graph to achieve the required accuracy in determining the roots of the equation, the abscissas of the intersection points of the graph of the function are the roots of the equation. 
To study the system of linear equations for compatibility and finding the only solution, the script file can be developed:

disp ('System Compatibility Study')

disp (")\% display an empty string on the screen

disp ('Main matrix:')

$\mathrm{A}=$ [- 397399 407; 405-399 401; 396 -395 -400]

disp ('Number of equations:')

$\mathrm{n}=$ length $(\mathrm{A}(:, 1))$

disp ('Free member vector:')

$\mathrm{C}=[440$, c. 22 , c. -18$]$

disp ('Extended matrix:')

$\mathrm{AC}=[\mathrm{A} \mathrm{C}]$

disp ('Extended matrix rank:')

$\mathrm{rAB}=\operatorname{rank}(\mathrm{AC})$

disp ('Rank of the main matrix:')

$\mathrm{rA}=\operatorname{rank}(\mathrm{A})$

$\%$ Compatibility Check

$\%$ if $\mathrm{r}(\mathrm{AC})$ is not equal to $\mathrm{r}(\mathrm{A})$, then the system is incompatible if $\mathrm{rAC} \sim=\mathrm{rA}$

disp ('System is incompatible:')

$\%$ if $r(A C)=r(A)=n$, then the system has a unique solution

elseif $(\mathrm{rAC}==\mathrm{rA}) \&(\mathrm{rA}==\mathrm{n})$

disp ('The system has a single solution:')

$\mathrm{X}=$ linsolve $(\mathrm{A}, \mathrm{C})$

disp ('Check:')

$\mathrm{C}_{-}=\mathrm{A} * \mathrm{X}$

$\%$ if $r(A C)=r(A)<$ n, then the system has infinitely many solutions

else $(\mathrm{rAC}==\mathrm{rA}) \&(\mathrm{rA}<\mathrm{n})$

disp ('The system has infinitely many solutions:')

end 
There is the development of educational courses with automatic verification of homework, the integration of Matlab with modern and inexpensive equipment, a large number of learning video courses, documentation and many examples of code (Garrison, D and Vaughan, N., 2007). For example, Matlab Grader is a free teaching and learning environment based on Matlab. It designs the interactive learning courses, automatically evaluates students' work in real time, views the results of students completing individual tasks, compiles performance analysis for each student, establishes a weighted method for assessing of test tasks, uses libraries of reusable examples of courses and tasks, adapts courses for use outside the desktop for all users, integrates courses into the learning management system. To develop the interactive training courses, the teacher needs to create an account on www.mathworks.com. It should be linked to the university's license. After the registration, it becomes possible to develop a new course or use the available layouts and adapt them to the requirements. At a new learning course development, it is necessary:

- develop task's description.

- $\quad$ write the supporting decision.

- $\quad$ make a blank for students.

- $\quad$ write tests.

- $\quad$ check your decision.

It is necessary to add students to the course. Students are notified by email and receive a link to access the course. They should log in using their mathworks.com account password and email address. Matlab also has the ability to develop the interactive courses in the Live Editor. This application allows creating lectures, laboratory and practical works combined theoretical material, mathematical equations, program code and code execution results. Each block of the document can be launched independently and visualized code execution immediately after its execution.

274 first-year students of the Faculty of Physics, Mathematics and Informatics of Kherson State University took part in the pedagogical experiment on the introduction of MATLAB in the course «Linear Algebra». During experiment the following tasks were solved: study on formation of mathematical competence; 
disclosure of methodical features of teaching the course «Linear Algebra» with the use of ICT; introduction of the MATLAB software environment in the process of learning linear algebra; assessment of the effective use of the environment in the discipline teaching process.

At the theoretical stage, the curricula in the «Linear Algebra» discipline for specialties were analyzed. The possibility of linear algebra elements using in the studying process was examined. The methods for determining the effectiveness of experimental techniques were selected, as well as the forms of experiment conducting and results controls were established.

At this stage there was compiling of theoretical material that must correspond to the content of the curriculum, as well as the selection of problems in linear algebra for practical solutions that can be proposed during practical classes and which can be implemented using the MATLAB environment. During theoretical stage student surveys, individual interviews and pedagogical observation were used.

The formative stage of the experiment is characterized by the introduction of the MATLAB environment in the learning of elements of linear. Homogeneity and representativeness of experimental and control groups participated as respondents, regardless of their progress, interests, abilities etc. The homogeneity of the group was confirmed with the help of Student's t-test. The purpose of the formative experiment was to determine the effectiveness of MATLAB and to confirm or simplify the proposed hypothesis. The main task of the experiment was to evaluate the efficiency of student learning with the implementation of the experimental factor, i.e. the MATLAB environment, into the experimental group and without the introduction of the experimental factor in the control group. The experiment was conducted during study hours. In the experimental group students used the MATLAB environment during studying the elements of linear algebra in the general course «Linear Algebra», and students in the control group studied topics in linear algebra in the traditional mode of learning. Depending on the changes in the amount of hours, the distribution of practical and lecture classes may vary within the workload. Expected results of the 
experiment: as a result of using the MATLAB environment, the quality of learning the elements of linear algebra and the efficiency of learning increase.

At the final stage of the experiment, the results of the experimental research were processed and generalized, and conclusions were formulated. The impact of experimental learning was determined by the indicator of cognitive (knowledge) and activity (skill). Student's t-test was used to identify the differences in the levels of formation of mathematical competencies in linear algebra between the control and experimental groups. The study under hypothesis $\mathrm{H}_{0}$ considered the statement that the levels of formation of mathematical competencies in linear algebra in the samples differ slightly. The results testify that the null hypothesis is rejected with a risk of $\alpha=0.05$. Therefore, it can be claimed that with a reliability of 0.95 between the experimental and control groups there are significant differences in the levels of formation of mathematical competencies in linear algebra after the experiment.

The results of the test tasks and the final independent study are shown in diagrams 1,2, where the experimental group results are indicated in black.

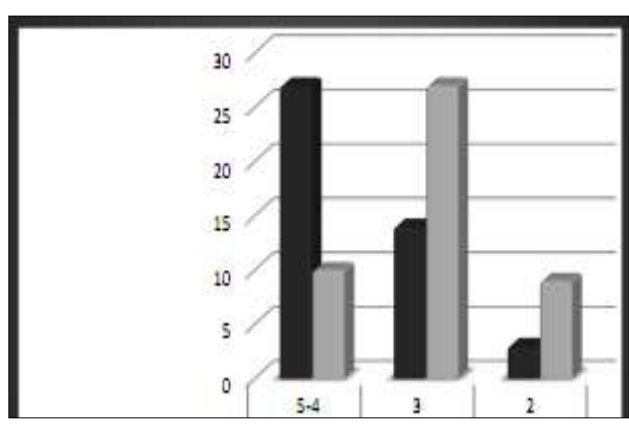

Figure 6. Results of cognitive component formation

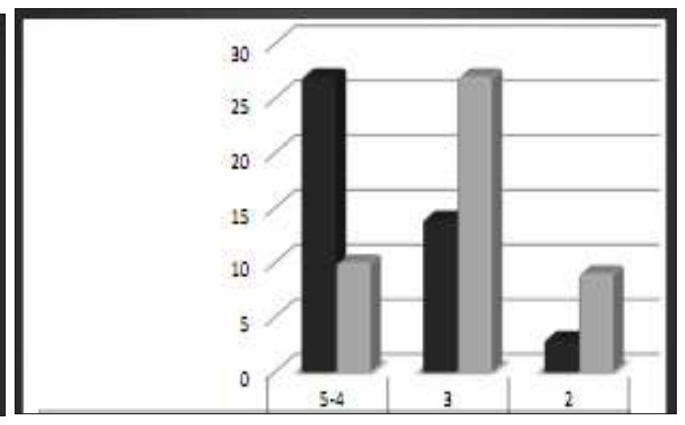

Figure 7. Results of activity component formation

The analysis of the results of the pedagogical experiment revealed and increase in the level of mathematical competencies in linear algebra in students of experimental groups because of the implementation of the MATLAB environment. The experiment showed that the students of the experimental group have a better understanding of the basic concepts of the linear algebra course, typical algorithms for solving problems; 
the ability to determine the most appropriate solutions; to model independent learning. It can be stated that the experimental learning of the linear algebra elements provides a higher level of mathematical competence of students.

The effectiveness of information and communication technologies use in teaching Mathematics in universities is achieved at the following conditions:

1. The availability and provision of positive motivation for learning, cognitive activity of students through the use of information and communication technologies.

2. Willingness and ability of students to master new knowledge, skills and abilities in the use of information technology in educational and future professional activities.

3. Organization of students' self-activity using electronic tutorials, including theoretical, practical, test and control material, guidelines for solving computeroriented problems.

4. Ensuring interactive cooperation in the learning process between students and teachers through information and communication technologies. Using IT for selforganization and self-monitoring of educational activities.

Introducing the capabilities of the Matlab package into the learning process allows improving the students' professional level and forming their interest in learning.

One of the significant advantages of the Matlab system is its integration into almost all areas of modern science and technology. Matlab is a global standard in higher education and research. The linear algebra teaching is based on the traditional presentation of the material. Matlab package application allows to increase the educational process efficiency and to form competencies necessary in future professional activities (Gilat, A., 2004).

Students are open to all kinds of technologies in Mathematics. This openness, together with the availability of high-tech tools, is changing the approach to linear algebra teaching.

Currently, in many educational institutions, the organizing forms of the educational process are being reformed and distance learning is being intensively introduced. It requires the development of electronic textbooks and practical works. 
So, the task of increasing the laboratory works efficiency by working only with a Web browser is actual. Tools for remote development have appeared in some mathematical packages, including Matlab. Web application development is a special feature of Matlab to use remote computing for solving tasks efficiency increasing. It greatly facilitates teachers' work and plays an important role in improving the effectiveness of educational organization tools and the distance learning introduction. In the following research, the question of online learning of linear algebra using Matlab will be studied. 
DOI 10.46299/ISG.2021.MONO.PED.II-450-457

\subsection{Features of studying the discipline "basis of ecology" by students of biotechnology}

The life of the average person today is filled with comfort. He travels long distances in a private car, plane or train, his diet consists of a variety of dishes, and his health is monitored by a whole army of doctors who make up a unified healthcare system. But this is only at first glance. In fact, each of us is constantly faced with serious risks that we may not even be aware of. We are talking about global environmental problems.

The ecological problems of the planet Earth are ecological crisis situations that are relevant for the entire planet, their solution is only possible with the participation of all mankind. I would like to immediately note that any environmental problems of the Earth are closely related to each other. We are talking about global problems of mankind, where the emergence of some leads to the emergence and aggravation of others.

There are so many environmental problems that cause excitement and disturb the soul, it is rather difficult to address everything. I want to focus and concentrate on seven, as well as motivate and inspire students to determine the degree and level of pollution, using not only highly sensitive instruments and analyzers, but also organoleptic methods that help find means and methods for solving environmental problems.

Global warming, the consequences of which are far from rosy (e.g., rising sea levels, declining agricultural production, fresh water shortages, greenhouse gases and other responses) have been worrying environmentalists and ordinary people around the world for several decades. There are some options that can help solve this problem, such as reducing carbon dioxide emissions and switching to carbon-free fuels, as well as developing a more economical fuel strategy, but these are not enough.

Overpopulation of the planet can lead to shortages of food, water and energy, as well as an increase in the number of diseases. Recently, new dangerous diseases caused by viruses and bacteria have appeared almost every year, for instance, COVID-19, the 
main and most global problem of our day. Endless epidemics, chronic diseases, social tensions and territorial conflicts over water sources torment people, forcing them to leave their homeland and go in search of a better life.

One environmental problem that leads to an increase in the flow of ultraviolet radiation to the Earth's surface is the depletion of the ozone layer. Steadily reducing the volume of ozone in the atmosphere, which serves to protect life on the planet from the harmful effects of ultraviolet rays. Increasingly, doctors are faced with serious sunrelated illnesses. The first ozone holes were discovered over the northern regions [Israel, 1984; Ecology of the city, 2000]. This fact is explained by artificial and natural reasons: flights of spaceships, satellites and jet planes, emissions of freons used in refrigeration units and air conditioners, shortage of ultraviolet radiation in winter. The percentage of ozone layer depletion over countries with a temperate climate has decreased by an average of $10 \%$, which negatively affects human health, there are problems with skin, eyesight and a number of others. Among other things, as a result of excessive ultraviolet radiation, significant damage is caused to agriculture [Environmental Protection, 1991].

The decline in biological diversity is another of the striking examples of intensive human activity; many species of animals and plants have disappeared from the face of the Earth. Unfortunately, this trend continues, and its main problems are considered to be the loss of habitat, overexploitation of biological resources, competition with biological species brought from other territories, and large-scale environmental pollution. There is a close correlation between all links of the biogeocenosis. In case of violation of one of the links of the biogeocenosis, the entire system is upset. The technogenic society has made amendments to the withering away of old and the emergence of new forms of living organisms. The natural duration of development of one species before human intervention is from one and a half to 2 million years. In this day and age, hundreds of thousands of species disappear annually, which results in a decrease in the area of population of animals, and this is a real ecological catastrophe.

It is sad to realize that about a third of the world's population suffers from a shortage of fresh water and at this time no active measures are being taken to preserve 
natural sources. Most cities around the world do not properly treat wastewater and this is one of the factors contributing to the pollution of rivers and lakes and other bodies of water. For several centuries, mankind has been using in industry toxic chemicals, heavy metals, chemical protection of cultures of biogeocenoses (pesticides). The laws of ecology testify and confirm that it is unrealistically difficult, or practically impossible, to restore and clean up an ecosystem subject to severe degradation due to pollution. Minimizing the release of harmful compounds, installing treatment facilities, monitoring and control will help assess the real situation and help protect the environment [Kobyakov et al., 2020]. For several years now, the scientific ecological community has been looking for technologies to solve such a problem as the pollution of the world's oceans with plastic waste. At the moment, five huge garbage islands have been discovered that drift in the waters of the Pacific, Atlantic and Indian oceans and pose huge risks to all their inhabitants. Some animals and fish mistake the microplastics for phytoplankton and consume them. Chicks of seabirds are attracted by larger plastic pieces of bright colors, young birds swallow them, condemning themselves to painful death. At the moment, no combination of technical and costeffective means to solve this situation has been developed. However, new concepts and ideas are constantly being researched by economists and scientists.

Deforestation is taking place at alarming speeds around the world. It is with good reason that forests are called the lungs of the planet, processing carbon dioxide, increasing the concentration of oxygen, which is necessary for the breathing of all life on the planet. In addition, deforestation leads to risks such as soil desertification and loss of biodiversity. It is extremely difficult to stop these processes, but it is necessary using integrated approaches and solving economic, social, and political problems.

Residents of megalopolises are especially concerned about the problem of air pollution. Huge volumes of exhaust gases, and industrial emissions envelop cities in a thick layer of smog, in which it sometimes becomes difficult to breathe. Hence, numerous health problems in adults and children. It is possible to clean the air from impurities through the reduction of road transport, the use of multistage purification 
systems at industrial enterprises, as well as through the widespread use of energysaving technologies.

Today, when the entire planet is under the influence of anthropogenic factors, significant changes are taking place in both living and inanimate nature. The improvement and harmonization of human relations with the environment is of great importance. We receive from nature everything we need for life, energy, food, various materials, emotional and aesthetic pleasure. Therefore, today, as never before, it is necessary not only to have a clear strategy for environmental protection and strengthen control over nature management, but also a well thought out system of environmental education and training. In modern conditions the problem of nature's relation to society is coming to the center of attention of the world community. The chaotic and incompetent use of natural resources has led to the emergence of a system of conflicting situations [Poleva, 2020]. Of course, most of them go deep into the history of mankind. However, the development of various industries and a lack of research and knowledge about the laws of nature have exacerbated the conflicting situation and given it a global character.

Achievements of mankind in various fields of science and technology will not be able to improve human life if they contradict the laws of nature. It is necessary to pay attention to the use of natural resources, taking into account and knowledge of the basic laws of ecology, and paying attention to the degree of anthropogenic pressure on ecosystems. Safe ecological development is one of the main tasks of humanity. New knowledge, forms of behavior, development and improvement of waste-free resourcesaving technologies will help to solve these problems. Due to the fact that ecology, under conditions of intensive practical use, has become an integral science, which has a direct connection with the natural sciences as well as with special disciplines, in different educational institutions its teaching is based on the specialization of students. Unfortunately, complementary practical work is not always available, although it is no secret that gaining practical experience increases understanding of classroom and laboratory knowledge. In my opinion, practical work helps not only to master the theoretical part of the subject and make sure that the laws of ecology really work, but 
also makes students look around, be aware of, and recognize signs, signals and "beacons" of nature, indicating the scale and seriousness of environmental pollution.

The goal of education of students of ecology requires them to understand the above-mentioned problems facing the environment. One area of concentration here at the Ukraine Agricultural University aimed at addressing some of the foreseeable food shortage problems, while keeping in focus the minimization of environmental damage, is the study of fisheries. Ensuring food security at the expense of resource, naturalclimatic and innovative potential is an important task of the current stage of development of fisheries. Currently, fisheries and aquaculture are receiving increasing attention, since these areas are important in the socio-economic development of various areas of the world and national economies, as well as sources of income, including from foreign exchange earnings, and to provide domestic markets with safe and highquality food [Bogeruk, 2011]. Fisheries are also a source of livelihood for millions of people around the world, and employment in the fisheries and aquaculture sectors has increased significantly over the past three decades, growing at an average annual rate of $3.6 \%$ since 1980. [FAO, 2014].

With the growth of the world's population, the demand for products from raw materials of water origin is increasing. However, the growth in catches of fishing is slowing down, as most of the important fishing areas have reached the limits of exploitation of their resource potential, and for many sites there is a critical state of stock in oceanic and inland waters. The quantity of fish caught has remained relatively stable since the mid-1980's within the range of 85-95 million tons. However, the efficiency of world fishing is steadily declining, and its average annual growth remains at the level of no more than 1.1 million tons [Zolotova, 2000].

In 2007, the US Food and Drug Administration published data that by 2030, if food consumption is maintained at today's level, the world's population will need an additional 40 million tons of fish per year. Natural reserves of aquatic biological resources will not be able to provide such a level of consumption. Moreover, the report of the International Council for the Exploitation of Marine Resources of the European Union states that if the current methods and volumes of fishing are not changed, then 
by 2050 the global fishing industry will cease to exist due to the lack of raw materials. Perhaps this may seem an overly pessimistic forecast, but it is grounded in real statistical evidence. As a result, the only source of increase in the volume of fish products and the most important component of the agro-industrial and fishery sectors of the economy is aquaculture, which provides the primary potential for increase in world fish production.

Aquaculture is human-controlled breeding and rearing of aquatic organisms in order to obtain valuable food, feed and technical products [Bogeruk, 2011]. At the moment, it is no less important for fisheries than for agriculture similar to the transition from hunting and gathering to agriculture and animal husbandry [Zolotova, 2000]. Modern artificial farming of fish and other aquatic animals and plants is based on the experience accumulated by mankind over many centuries and even millennia. It is generally accepted that the cultivation of aquatic organisms originated in China 3.5-4 thousand years ago [FAO, 2014]. However, despite the centuries-old traditions of fish farming in some countries, globally aquaculture is a young food industry that has experienced a period of rapid growth over the past 50 years [FAO, 2016]. The importance of aquaculture production in the world is constantly increasing, which is reflected in the materials of numerous meetings and forums of various international organizations, including the United Nations (UN) and the UN Food and Agriculture Organization (UN FAO) [Bogeruk, 2011].

Aquaculture is an integrated multifunctional sector of the fishery complex, which is currently expanding, becoming more diversified, dynamic, technically and technologically advanced. The global nature of the development of aquaculture inevitably entails an increase in cultivated areas and the number of farms of various types, a higher density of growing aquaculture objects, and widespread use of forage resources. The intensification and industrialization of aquaculture production leads to an increase in the volume of fish production, the restoration of the number of endangered or too-actively fished populations of aquatic biological resources, and provides positive socio-economic results. Governance and policy in global and national aquaculture are aimed at ensuring integrated multifunctional economic, social, 
environmental, legal and organizational development [Kozlov et al., 2004; Bogeruk, Lukanova, 2010]. The role and importance of aquaculture in the socio-economic development of different countries and regions of the world can vary and are determined by a diverse complex of reasons, among which an important place belongs to specially developed strategic documents that provide guidance for the production and marketing of aquaculture products [Bogeruk, 2011].

Saturation of the domestic fisheries market requires a significant increase in the volume of aquaculture production, which in turn is associated with a number of considerations, such as the provision of specialized feed, the occurrence of diseases of farmed objects, environmental complications, personnel training, and insufficient level of management. It is important for countries to develop domestic products and avoid importing products from other countries. Such work, first of all, is associated with the promotion of traditional products for any given country, which is possible only if it is safe and of high quality, environmentally friendly, and cost competitive. Developed strategic documents in the field of aquaculture to ensure these conditions should be built on an innovative basis using scientific and technological advances and modern management techniques [Bogeruk, 2011].

The curriculum of future specialists in aquatic biological resources and aquaculture should include the basic apparatus of concepts that help to strengthen ecological orientation and provide a competent approach in terms of environmental safety. The objectives of mastering the discipline "Fundamentals of Ecology" are: teaching the basics of research and development of modern biotechnological methods of the environment, and the formation of students' skills in applying biotechnology methods to protect the environment. The objectives of the discipline "Fundamentals of Ecology" for students specializing in aquatic biological resources and aquaculture are: the formation of knowledge about natural biological processes occurring in all natural ecosystems and the principles of their use, teaching the skills of laboratory work with biological objects, bringing the basic principles of organizing biological processes based on modern advances in science, and teaching theoretical and methodological foundations and practical skills in the use of modern methods of disposal of all types 
of pollution associated with human economic activity [Grinzhevsky, 2006; Kovalenko, 2014].

Teaching the discipline "Fundamentals of Ecology" for students of the specialty "Aquatic Bioresources and Aquaculture", in my opinion, should consist of three main aspects - methodological, didactic and applied. The main focus of environmental education in higher educational institutions should be the transition from informative demonstrative to interactive forms of education, which are achieved in lectures, laboratory, practical, and individual lessons. Production situations, modeling and forecasting methods, research assignments, seminars and discussions will help to unleash the creative potential of future specialists in the field of aquatic biological resources. In addition, the knowledge and skills gained in the multifaceted study of the discipline will help future specialists to act according to the situation, to look for nonstandard and non-traditional approaches to solving certain problems.

In order to solve the global issues of the millennium, the deterioration of the quality of drinking water, pollution of water bodies and air with products of various origins, a decrease in biodiversity, climate change, and a number of other environmental problems, the goal of the "Fundamentals of Ecology" discipline for future biotechnologists is to strengthen environmental education, science and culture. As you can see, the risks faced by our world are many. However, there is only one underlying reason for them, the consumer's attitude as a person toward the planet, its resources, other living beings inhabiting it and, moreover, to each other. None of the above problems can be solved in isolation. They can be solved only in a complex manner, provided that the vector of our consciousness changes towards the perception of the Earth as our common home, as a single living organism, of which we are all cells. 


\subsection{Sociocultural competences as essential components in teaching English}

The new social demands of modern society are focused on teaching foreign languages as a means of cross-cultural communication, the formation of a person ready for interethnic communication, and are reflected in the cultural policy of the Council of Europe and in the concepts of intercultural and sociolinguistic teaching of philological subjects. One of the priorities of English language teaching is the formation of students' sociolinguistic competence, which requires knowledge of national and cultural features of English-speaking countries, the norms of speech and non-speech behaviour of its speakers, and the ability to build their behaviour following these features and norms. Therefore, the purpose of the present study is to reveal the ways of forming students' sociolinguistic competence as a component of the process of teaching English, which is the key to effective cross-cultural communication.

Recent years have revealed a trend of increasing attention of scientists to the phenomenon of sociolinguistic competence as one of the indicators of a person's readiness for intercultural communication. The problem of the formation of sociolinguistic competence in the process of learning foreign languages is widely discussed, because the formation of sociolinguistic competences involves penetration into the culture, into the system of worldview and comprehension of the people. Since language and literature are forms of human mental activity, they cover all spheres of individual and social life, they constitute a part of human nature and reveal practical and theoretical activities of both an individual and a society [437]. The problem of the formation of sociolinguistic competence in the process of learning foreign languages has been dealt with by domestic and foreign linguists, namely by O. V. Ter-Minasova,
O. A. Kanibolotskaya,
G. V. Kolshansky,
T. V. Romanova,
O. D. Schweizer,

O. O. Pershukova, N. D. Galkova, E. Sapir, the research results of which were used in writing the present article.

The issue of acculturation is directly related to the teaching of English: the only and maximum purpose of teaching culture in connection with language and literature is the formation of a personality at the crossroads of cultures. In close connection with 
this problem, there is another set of methodological issues, namely the sociolinguistic aspect of teaching English. The social nature and essence of language should be understood as the unity of language and culture, the unity of language and society. Without a doubt, language and culture are interconnected. It is generally accepted that cultural processes affect language and language affects culture. If the influence of culture on language is obvious, then the influence of language on culture is not subject to ordinary observation. This problem was raised by W. von Humboldt, followed by E. Sapir and B. Wharf. But their hypothesis of linguistic relativity has not been conclusively proven by anyone. Other interesting opinions were expressed, for example, that certain types of culture determine certain language structures. However, these theories remained at the level of hypotheses.

George Peter M. [438, p. 124] defines the term culture as the set of values, customs, beliefs, and practices that constitute the way of life of a specific group, to start from a deeper knowledge. Likewise, the definition and etymology of this term by Terry Eagleton [439, p.58], indicates that the term culture has been created by the use of symbols. Etymologically this term is derived from the Latin word colere used to express "the tillage and use of the land" referring this meaning to cultivation, agriculture, cultivating the land. On the other hand, the Romans referred to the term cultura animi as the cultivation of the soul. The main thing that the term culture contributes is that values, customs, and practices constitute the way of life of every society. The term culture is more identified in this work with a special mention of languages, since this is an identity of society and even more so in learning a foreign language, considering that it varies from region to region. So, studying a language also implies learning that part of the values and customs that are part of the target language, and of a certain community, such is the case of the English language that contains a varied power and wide culture, of which we must be part when learning this language.

According to E. Sapir, "culture can be defined as what society does and thinks. Language is what people think. It is difficult to determine what special causal relationships can be expected between the selected inventory of experience (culture as a value choice of society) and the special technique by which society expresses its 
various experiences $[\ldots]$. The content of language is inextricably linked with the culture $[\ldots]$. Language through its vocabulary more or less accurately reflects the culture it does not serve; it is quite fair that the history of language and the history of culture develop in parallel [440, p. 171 - 172].

In academia, the teaching of culture has traditionally taken place separately from language and has often been restricted to the study of history, the political system, institutions, and folklore which constituted the Culture starting with a capital letter. Without considering cultural aspects as relevant to communication as presuppositions, misunderstandings, opinions and beliefs, and behaviour patterns (culture, starting with a lowercase letter) that openly determine communicative interaction within a given speech community.

The sociocultural component linked to language learning plays a central role in guaranteeing an effective communicative exchange. However, when introducing these contents in the classroom, the problem arises of what to teach at each level or how to do it without falling into stereotyping or clichés. In such a way that the information offered to the students is adapted to their training, their tastes, and interests and that it corresponds to the level of linguistic knowledge they possess, as well as that the cultural contents are contextualized and related to what the students already know. However, this process is not always straightforward. One of the examples that S. Pastor Cesteros cites regarding the relationship between language and culture is a reference to the speech acts: "the speech acts of some languages do not coincide with those of others, or they do not exist, or they develop differently" [441, p. 140]. This phenomenon has been widely studied in the Anglo-Saxon field, giving rise to a multitude of works on intercultural pragmatics that address how various speech acts are carried out such as complaining, expressing gratitude, apologizing, making requests, invitations, suggestions, taking the turn in the conversation, interrupt, etc. These contrastive studies referred to certain differences between the uses of English by representatives of Eastern and Western cultures, with a special emphasis on different pragmatics. 
Communicative speech competence consists of certain components: linguistic, sociolinguistic, and pragmatic. Each of these components includes, in particular, knowledge, skills, and abilities. Linguistic competencies include lexical, phonological, syntactic knowledge and skills, and other parameters of language as a system, regardless of the pragmatic functions of their implementation [442]. Sociolinguistic competence refers to the sociocultural conditions of language use. Due to the sensitivity to social conventions (rules of politeness, norms governing relations between generations, classes and social groups, linguistic codifications of some basic rituals in society), the sociolinguistic component permeates the entire process of communication between different cultures, even when its participants often are not aware of this impact.

Pragmatics deals with the textual conditions in which the linguistic events described by syntax and semantics take place; that is, according to M. López García, the use of the language in its context, as well as the extralinguistic aspects [443, p. 3839]. This discipline, in addition to being a theory of linguistic communication, studies how the speakers of a certain language interpret sentences within a context, that is, how they analyse the language in use since it is always contextualized. It is a discipline that is closely related to the teaching of foreign languages because it is important to convey to students that in each culture, in most cases, the speakers say not only what they mean but they also choose to say what is expected to be said. This is essential because linguistic expression is well codified by social norms that tell us how to behave appropriately in a group; obviously, the cultures of Ukraine and that of the UK or the United States are very different in this sense. Linguistic behaviour in the act of communication is one of the priorities since the existence of misunderstandings or misinterpretations within communication is more frequent in learning foreign languages than in communication in the native language. In the sense of the cultural and contextual aspects, the student needs to be aware of the fact that the behaviour of a speaker in each culture differs depending on the society. Therefore, it should be taken into account that if misinterpretations frequently occur in the mother tongue, yet are there more problems in the communication in the foreign language. For this reason, 
learning a foreign language is not just about acquiring skills of the correct and appropriate use of grammar and vocabulary, on the contrary, it goes beyond these aspects leading to the acquisition of different non-linguistic competences.

Pragmatic competencies are related to the functional use of linguistic means: the production of language functions, acts of speech, etc. They offer scripts or programs of an interactive exchange. They also deal with the skills of discourse, fusion, and coherence, identification of types and forms of texts, irony, and parody. For this component to function, it is essential to emphasize the importance of the interactions and cultural visions in which abilities are formed, even more than the value of the linguistic component.

Sociocultural competence (which includes sociolinguistic competence) involves expanding knowledge of sociocultural specifics of countries, improving the ability to build their language and non-verbal behaviour in accordance with this specificity, and taking into account the social status of communication partners, the ability to adequately understand and interpret. It is planned to expand the scope of linguistic and regional knowledge, skills, and abilities due to new topics and issues of language communication, taking into account the specifics of the educational profile: deepening knowledge about the country of the studied language, its culture, historical and modern realities, public figures, its place in the world community, culture, relations with other countries; expanding the amount of linguistic and cultural knowledge, skills, and abilities associated with the adequate use of language tools and rules of language and non-language behaviour in accordance with the sphere of communication, place, goals, social status of the interlocutor.

Sociolinguistic competences refer to the sociocultural conditions of the use of the language. Through its sensitivity to social conventions, the norms of courtesy, the norms that order relations between generations, sexes, classes, and social groups, the linguistic codification of certain fundamental rituals for the functioning of a community, the sociolinguistic component considerably affects the entire community by shaping the result of linguistic communication between representatives of different 
cultures, although the members involved in the action of communication may often not be aware of their influence.

Currently, the sociocultural component of learning is integrated into communicative competence, giving priority to the needs of the student when facing cultural difficulties that may arise in the daily life of a foreign country, or at the time of communication between Ukrainian students and native English speakers. The English language that is taught as a foreign language in countries other than the English-speaking ones may be lacking in cultural aspects because of high chances of impossibility, for example, to go to do internships in the countries where this language is official in order to soak up cultural knowledge. Neither is there a frequent special emphasis given to the teaching of the target culture, as it should be done together with the teaching of the target language. Thus, the formation of English-language communicative competence of students is impossible without achieving sociocultural competence, which includes regional and linguistic competence. Local lore competence provides students with knowledge of history, geography, economics, socio-political system, culture, life, traditions of Great Britain, USA, Canada, Australia, and other countries the official language of which is English. And linguistic competence is to develop speech and non-speech skills (facial expressions, gestures that accompany utterances) behaviour of native English speakers in certain communicative situations. This allows students to form a holistic system of ideas about the speech and national and cultural features of English-speaking countries and in this way to achieve full productivity in communication.

The separate view of linguistic competence as an integral part of the study of English is because the language itself as a means of communication tends to accumulate, store and reflect the facts and events of historical and cultural development of the native people of this language. These facts and phenomena are known, as a rule, to all members of a certain linguistic community, as they are assimilated by them in the process of education, training, etc. For example, the people of London are well aware of the meaning of the word the tube - London Underground transport system; the name of a street in London - Whitehall - can be used by the British people to mean 
the UK government. The main street of many cities in the UK is called the High Street; the abbreviation Oxbridge (Oxford + Cambridge) is often used. Americans are well aware that cheap consumer goods are sold in cent stores or Woolworth stores, and that sneakers are rubber-soled shoes or sport shoes. Australian English contains a large number of lexical items that are not used in the literary language, or have a special meaning. As a result, when students are introduced to such vocabulary additional sociolinguistic commentary is required. For example, durry - cigarette; pineapple - a fifty dollar note; spud - potato; manchester - household linen; OYO - on your own (flat or apartment); parcel - package; tea - evening meal; paddock - field, meadow. The word hotel gets the additional connotative meaning of "bar, pub" and is used instead of the normative English term $p u b$. In the Sydney area, the pejorative word brad is used to refer to immigrants from Southeast Asia. Abbreviations are common in the Australian national variant of English: ute - utility vehicle; cossie - swimming costume. Australians use the term rockmelon to refer to a variety of melon (the common scientific name is Cucumis melo cantalupensis), and in the province of Victoria, the word cantaloupe is used, which is also common to the American national variant of the English language. There are different lexical tokens to denote different varieties of dried grapes in the Australian variant, for example, sultanas, currants, the common hyperonym being raisins. Typical Australian realia, i.e., lexical units representing local realities, are didjeridu - a cylindrical musical instrument played by aboriginals; bat house - a house made of sun-dried bricks; boudy rat-marsupial devil, a small animal; brumby - a wild, untamed horse; costeen - a small pit in the upper layer of earth to access the gold-bearing formation; mallee - a species of Australian acacia; mulga - a species of eucalyptus. The above-mentioned realities reflect the specifics of a respective English-speaking society and national colour. Therefore, Anglicisms, Americanisms, Australianisms, etc. are lexical units that mean objects or phenomena that are characteristic of the British, American, Australian version of English. For example, the words ranch, prairie, drugstore are common in American English and express concepts of American society. 
Semantically, realities can be categorized into classes according to the lexical and semantic field they belong to. Geographical realities are related to physical geography and include the names of both natural and man-made objects, e.g.: Golden Gate Bridge, one of the largest bridges in the United States located in the San Francisco area; Underground Atlanta is a complex of shops, clubs, and restaurants; Fisherman's Wharf is a fishing spot, a stretch of the San Francisco Bay waterfront that is one of the landmarks of the city of San Francisco. On the other hand, ethnographic realities include words denoting the concepts of life, material and spiritual culture, religion, art, folklore, e.g.: Tooth fairy - a fantasy figure of early childhood in Western and Westerninfluenced cultures; the folklore states that when children lose one of their baby teeth, they should place it underneath their pillow or on their bedside table and the Tooth Fairy will visit while they sleep, replacing the lost tooth with a small payment; Easter bunny (also called the Easter Rabbit or Easter Hare) is a folkloric figure and symbol of Easter, depicted as a rabbit, sometimes dressed in clothes, bringing Easter eggs; Broadway is a famous street in New York City with theatres; sweatshirt is a type of sweater. Socio-political realities are a fairly broad category, which includes vocabulary to denote the administrative and territorial structure, bodies and holders of power, phenomena of socio-political life, e.g.: the Congress - the bicameral legislature of the federal government of the United States consisting of the House of Representatives and the Senate and located in Washington, DC, the Supreme Court of the United States the highest court in the federal judiciary of the United States of America; the Penitentiary - a correctional facility, a federal prison for convicted criminals.

To be effective in intercultural communication, these semantic divergences should be taken into account during communication, as neglect of this background knowledge leads to frustration of the communicative act. Such information refers to the background knowledge possessed by the inhabitants of a particular country, but in many cases, it is unknown to foreigners, which greatly complicates the communication process. Linguistic means of realization of background knowledge are the realia (nonequivalent lexical units, abbreviations, names of historical events and names of historical figures, names of phenomena of social and cultural life of the country) and 
background vocabulary (foreign vocabulary that differs in its lexical background from native language vocabulary). Thus, the literal translation of the name of London's Downing Street is not exhaustive, and in this case, an additional comment or explanation of the translator is needed: it is on Downing Street in London that the residence of the Prime Minister of the United Kingdom is located. The usual transliteration of the name of New York's Wallstreet (a symbol of business and financial America) in the absence of background knowledge does not convey any information.

As a result, it should be borne in mind that in the process of semantization of lexical units, both their lexical meanings and lexical background must be revealed. Therefore, the best way to semantize them is to comment in several ways: single, systemic, and comprehensive. A single comment explains the basic meaning of individual lexical units [444, c. 9]. For example, downtown is a business part of the city, or describing something located in the business part of the city; barbecue is meat and vegetables cooked on a grill over hot coals. The two lexical tokens have initially emerged in American English and induce associations with American culture, yet with time they have started being used in all other national variants of English and even more, have entered other languages representing typical US realia. The word barbecue is of Arawak (indigenous people inhabiting the Caribbean region) origin which went into English through Spanish barbacoa. Nevertheless, Australian English has developed an abbreviated form Barbie, the South African analogue is Braai (a term expressing emphasis on a family gathering, not so much on food prepared on a grill), and in the UK the usual form is truncated to $B B Q$. In light of the above, in these cases, a single comment is necessary for the communication to be effective.

A systemic commentary is used to semantize lexical items united by one common concept. This methodological technique is aimed at highlighting the general and specific features of the word that is semantized. For example, the name of the English holiday Pancake Day can be given next to Easter or Christmas, because the common concept for these words is "religious holidays": Pancake Day, also called Shrove 
Tuesday, is the traditional feast day before the start of Lent (the 40 days leading up to Easter) on Ash Wednesday.

A comprehensive commentary involves the semantization of thematic vocabulary. Thus, when studying the topic "Recreation and travel", the teacher ought to give a description of typical for the country types of recreation and travel, name favourite places for recreation and entertainment, identify the advantages and disadvantages of a particular mode of transport for travel and more. For better mastering of thematic vocabulary, such lexical units should be semantized at once together.

Cross-cultural communication, or also called intercultural communication, is an adequate mutual understanding of two participants in a communicative act belonging to different national cultures [446]. The desire for acquiring communicative competence as the end result of teaching a foreign language to students, regardless of their speciality, involves not only the possession of appropriate foreign language techniques (i.e., language competence of students) but also the acquisition of nonverbal information necessary for adequate communication and understanding. Therefore, the teaching of foreign languages at a stage when students have sufficient skills of reading, writing, listening and speaking, should be built as a study of the phenomenon of culture of the people who speak this language.

The formation of students' sociolinguistic competence as an essential component in the process of teaching English is the key to effective intercultural communication. An acquaintance of students with national and cultural features of the country whose language is studied helps to increase the educational role of foreign language teaching, as it allows to expand the horizons of students, to form and develop their interest in studying this subject, to raise their public consciousness. 


\subsection{The methodological potential of interactive approach in the context of teaching English in proficiency at the university education}

The use of interactive methods of learning is one of the topical issues of the methodology of teaching English as a foreign language. Having been to the USA at the Language Institute to train teaching English methodology the author would like to share the gained knowledge in it. As interactive training is a form of organization of cognitive activities, the aim of which is to create learning environments in which the student feels his success and confidence. It activates the creative activity of students, trains and develops their ability to think critically and objectively.

Having received the qualitative competence of university training students would easily be adapted to the situation in real life in order to become successful in their careers in modern society. Modern communication technologies have made possible access to a huge number of different types of information.

The formation of the English language competence during the students' study at the university is very important for them to acquire knowledge and skills which should ensure future specialists to be successful in the real society. The questions of the formation of the English language competence under the influence of globalization are reflected in the scientific works of many researchers and practitioners. Some of them are going to discuss in order to help teachers in solving the certain practical problems in the process of study students gain knowledge required by the labor market.

Changes in the modern world, as an objective tendency to cooperation in the methods and forms of functioning of all spheres of life, demonstrate to scientists new conditions and facts for the explanation of which new concepts are needed.

Modern approaches to education are associated with the challenges of its globalization, global universities and the global market for educational services. The globalization of education contributes to the standardization of teaching under the influence of modern social technologies and the emergence of global researched networks. The main factor that made influence on education is the economic ideology 
of globalization, which underlines the primary importance of the market, privatization and the reduction of the role of the public sector.

Increasing competition in the context of growing globalization brings to the system of education every time more serious requirements: 1) ensuring continuous training, retraining and professional development of personnel; 2) cost-effective use of it in the constantly changing conditions of the market economy; 3) need to give the future employee a broad education, including knowledge in the field of entrepreneurship, on crisis management, maneuverability in choosing the direction of production development, drawing up strategic plans and appropriate design of labor collectives; 4) teaching staff skills for the perception of new knowledge that will be needed to perform specific work in a competitive environment.

In the last current years many countries around the world have been reformed the national education systems, the content and direction of which is increasingly determined by globalization. The transformation of education into an important factor in the competitiveness of not only individual producers but also national economies as a whole requires a system of education of great flexibility, openness to change and the ability to respond adequately to them.

Nowadays the study of English has some difficulties. Exactly the use of information and communication technologies can greatly facilitate studying of the modern vocabulary of foreign language for future specialists. Considerable attention should be paid to the application multimedia technologies, which simultaneously use texts, graphics, video material, sound effects, animations - all this is a collection of audio and visual effects along with interactive software that affects emotional and conceptual spheres, contribute to a more effective assimilation of linguistic material. Combination of visual image, text and audio provides an opportunity for integrated development language skills for a student in a foreign language. This process has interactive character due to two-way communication: the ability to communicate with the computer, when the student and computer can ask questions and get answers to them. It is well known that the learning efficiency increases with the use of visual 
illustrations, and multimedia tools combine videos, audio materials, illustrations, tables, etc. on one CD or DVD. Thanks to this technologies educational systems of the new generation have emerged, which transform the process of learning in an exciting game. It should be noted that new information technologies do not stand in one place, they quickly develop, are refined. Internet resources that replaced audio materials, CD and DVD open up great opportunities for students studying English.

There are obvious advantages of using the Global Network. Internet creates the conditions for obtaining various information in any point of the globe: the national science material, to get acquainted with articles from newspapers and magazines, use virtual tours, on-line radio, 3D panoramas, Google maps, to read an interesting book, for example about the lives of residents of different countries of the world, and so on. This information is on our view is necessary for students not only for preparation for classes, but also for leisure activities, for personal and intellectual development.

On this site the frequency dictionary of the English language is presented. You can select the first thousand of the most frequently used words in the menu and study them. When you hover on a word or a black square next to it, a window with a translation into Russian and transcription pops up, and when you click on it you will hear the sound of the word. The only downside of this site is the lack of context so you learn only individual words, not the rules for their use. However, if you need to work on vocabulary and you prefer Russian-language sites this resource will suit you.

Among these technologies there are debates, discussions, round tables, conferences, role - playing. Their goal is the creation of additional conditions for the development of communicative competence of students, the formation of public speaking skills, the skills of dialogue and monologue speech of students in the course of discussions in a foreign language. During the discussion students develop their capacity for creative tasks. They learn to express themselves fluently, to manage their own emotions and to cooperate with other people.

Such a training allows to develop skills and abilities to use language as a communication tool. It is a leading principle of communicative orientation. The task of 
the teacher during the discussion is to guide and assist the process of information exchange by referring to the personal experience of participants in the discussion, to support and encourage their activity, to identify the variety of points of view.

Project activity is another effective interactive method of learning a foreign language. It must be emphasized that the creation of the project is a complex work. It is interesting for students who what to be real scientists, to gain experience in work with scientific literature, as well, as to learn the practical application of knowledge in the field of informational and computer technologies.

Creative project as a form of extracurricular activity on the subject is irreplaceable during the "round tables", newspaper competitions, is preparation for concerts and plays in a foreign language.

The following methods for interactive learning are used at the English lessons in our pharmaceutical university, the examples of which are given.

1. Introducing a "hook" - to begin a class with an interesting or controversial question that acts as a "warm-up". A "hook" is intended to capture the students" attention, to activate their sensory memory and refer to prior knowledge. By applying a "hook", the teacher manages to connect the students responses with the content of the lesson.

2. Using a misconception example - to incorrect assumptions, wrong applications and asking students to tell the problem with it.

3. Making students get information - instead of telling students what you think is important for them to know, it is relevant to first pose a question or a problem and get a student predict an answer.

4. Peer explanation - inviting students to discuss the key concepts with their peers, and then summarize them in 1-2 sentences.

5. One-minute summary: making students to pause, reflect and write one-minute summary of what they have learnt.

6. Introducing polls, quizzes and surveys. A simple way to check understanding of a topic to intersperse the class with interactive questions, to check on knowledge 
retention and understanding during a lesson, encourage greater number of participations to debate.

Expected learning outcomes: by the end of the lesson, students are expected to develop understanding of basic English vocabulary in different pharmaceutical career. Materials and resources: PP presentation, laptop and projection screen, videos on various pharmacy specialty. Introduction. Welcome words and lesson objectives. The "hook"discussing the picture at the slide. Questions to students on this slide.

Here is the following fragment of the lesson outline which features the main interactive learning strategies as described above.

\section{LESSON OUTLINE}

\section{Lesson topic: "PHARMACEUTICAL CARE"}

\section{Teacher's Name:}

Lesson: At the Chemist's

Total Time: 90 minutes

Date:

1. Lesson Objective: Students will be able to:

- Describe minor illness;

- To advise someone about a health problem;

- To buy medications in a drugstore;

- To describe and complain about health feeling.

\section{Functions:}

Explaining the drugstore vocabulary.

Giving descriptions of the drugstores (National \& American).

Describing and comparing differences and similarities of pharmaceutical care systems, showing the preferences. 


\section{Teaching Points:}

\section{Grammar:}

If I do ... (If I find ..., I'll ...)

If I did ... (If I found ..., I would ...)

If I were you, I would ...

I would ... if I were you.

\section{Vocabulary:}

Skin applications $\quad$ Analgesic Prescription

Poisonous drugs $\quad$ Cough mixtures Laxatives

Expectorants Antiseptics Hot-water bottles

Pills Drug cabinets Coloured labels

\section{Training Aids Needed:}

HO1(handsout) - list of the drug store vocabulary

$\mathrm{HO} 2, \mathrm{HO}, \mathrm{HO}, \mathrm{HO} 4, \mathrm{HO}$, and $\mathrm{HO}$ - practice exercises in reading (grammar, vocabulary), speaking, listening and writing skills.

- Video

\section{Part There}

a. Two Ss open the discussion with the Presentation (National \& American pharmaceutical care systems.)

b. Let the class compare differences and similarities of these health care systems, showing the preferences. Class/group work.

\section{Part four}

1. Break the Ss into 2 groups. 
Group A: Pharmacist.

Group B: Customer.

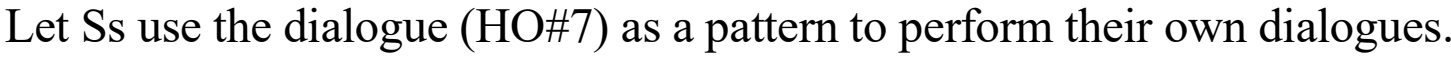

Have the Ss take the authentic drugs (T Hands them)

2. Have Ss practice the various drugstore activities with a partner. Ss write a composition on the following situations:

- If I were a health care Minister, I would do/change...

- If I were a drugstore owner I would...

- If I were a pharmacist

\section{Closing}

Summarize the high lights of the lesson.

$\mathrm{H} / \mathrm{w}$ :

- Practicing conditionals (If I were you...)

- Voc... Ex

- Finish and response a written composition

\section{Reserve activity}

Give 2 Supplementary tasks to do in class.

\section{Verification/Test}

Thus, the use of interactive teaching methods in extracurricular activities is one of the most effective ways to achieve the main goal of learning a foreign language in order to master the language without time of the lesson. Interactive method has a high potential and feasibility in educational process to disclose the most relevant methods of instruction and identify potential challenges which can be met while implementing this strategy during lessons. 
DOI 10.46299/ISG.2021.MONO.PED.II-475-482

\section{8 Критичне мислення та еко-творчий аудит як базис професійної інтерпретаційної діяльності у сфері дизайну}

Художньо-естетична інтерпретація - процес, який не функціонує при обмеженій свідомості та умовності пізнання. Формування розуміння у майбутніх дизайнерів аналітико-чуттєвого естетичного аналізу явищ, об'єктів та процесів натурального оточення - $є$ неоціненним в умовах глобальної комерціоналізації інтерпретаційних художніх здобутків, задля впливу на свідомість потенційного користувача. Орієнтуючись на науковий доробок С. Чирчика [451], О. Шикирінської [452], стосовно інтерпретаційної компетенції особистості, ми поділяємо їхню думку стосовно організації інтерпретаційного процесу на основі інтегративного та особисто-орієнтованого підходу до навчання, які забезпечать розвиток у майбутніх дизайнерів широкого світогляду, емоційного інтелекту та можливості до суб'єктивно-об'єктивних висновків. Проте, ми зосереджуємо свою увагу на впровадженні критичного та екологічного підходів до інтерпретаційної підготовки фахівця, які матимуть позитивний вплив на формування: реальних знань на навичок професіонального будування логічних ментальних шляхів, щодо виявлення причинно-наслідкових зв'язків, а також усвідомлення першопричин (прихованих істин та системи цінностей) у формуванні концептуального положення, його формоутворенні у тому чи іншому творі мистецтва; розуміння першочергового (стандартного та індивідуального) алгоритму роботи з проектним проблемним завданням у будьякій сфері дизайну. Окресленні аспекти, на нашу думку, під час інтерпретаційної діяльності та у іiі кінцевому результаті, сприятимуть отриманню нового об'єктивного знання та його грамотного художньо-естетичного формотворення. Такі інтерпретаційні здобутки відповідатимуть реаліям суспільно-культурного розвитку та надаватимуть відповіді на заплутані питання сьогодення.

Стосовно розуміння сутності самого поняття «критичне мислення», то в цілому, дослідники А. Арсеньєв, Б. Ананьєва, Д. Дьюї, М. Лімпман, П. Щедровський, Р. Пауль, та ін., стверджують, що воно походить від «наукового 
мислення» та відрізняється від останнього, цілеспрямованим застосуванням раніше отриманого об'єктивного знання задля вирішення професійних й життєвих проблем у бутті. Засновник концепції критичного мислення М. Лімпман, розумів процес навчання не тільки як записування різноманітної інформації на довготривалу або короткочасну пам'ять, а й в першу чергу «культивування мудрості», яка трактується як вічне прагнення до осягнення нових істин та передачі широкого систематизованого спектра знань, позбавлених навіть найменшого елемента ілюзії [453, с. 4]. Людина як особистість, на думку Б. Ананьєва, не може уособлювати лише продукт історичного процесу, іiі мета та сенс існування - брати активну участь у формуванні щасливої власної долі та розвитку навколишнього світу. Психофізіологічна активність людини по своїй природі базується на постійному критичному аналізі та самостійному осмисленні всіх спектрів буття (минулого, теперішнього та майбутнього) [454, с. 9]. Проте, дослідник А. Арсеньєв, ключовою проблемою в організації навчальновиховного та інтерпретаційного процесу на базі критичного підходу бачить у недостатній вмотивованості та усвідомленні майбутніми дизайнерами власних професійних перспектив, від опанування навичками здорового критицизму [454, c. 24]. На це, науковці Р. Пауль та П. Щедровський, прогнозуючи тенденції розвитку особистості в умовах інформаційного суспільства, виділяють два головні аспекти мотивування студентів, щодо актуальності розвитку критичного мислення:

I. Модернізація техніки вже замінилася на вдосконалення людини та іiі особистісних якостей, тому що саме особистість є головним виробником інформації - головного капіталу постмодерністської світової наукової спільноти. Гнучкість розуму та швидкість в інтерпретації фактичного матеріалу - $\epsilon$ «цінними акціями», які будуть тільки збільшувати свою собівартість незалежно від спадів і підйомів на ринку праці й послуг;

II. Занепад духовності в технократичному суспільстві, боротьба за творчу наукову спадщину та природні ресурси, не сприяє просуванню основ демократичної та гуманістичної думки в соціумі. Натомість, критичне мислення 
допомагає оцінити обставини тієї чи іншої ситуації (локальної чи глобальної), що склалася 3 позиції чистого розуму та духу, а не холодного прагматичного розрахунку. Саме на такій гармонійній у своїй логічності основі, будуються вільні цивілізації, вирішуються конфлікти, щодо перетину інтересів і формується цілісна особистість, яка є істинним взірцем своєї країни [453, с. 5].

Однак Д. Дьюї, застерігає від чисто механічної технології розвитку критичного мислення, оперуючи лише прагматичними потребами. Він зауважує, що виховання вільного та дисциплінованого розуму формується шляхом внутрішнього споглядання, розгляду, контролю та зміни людиною ходу власних думок. Щодо системотворчих компонентів процесу рефлексії, то сюди він відносить наступні: по-перше, стан невизначеності від постійних сумнівів свідомості між вибором кращого варіанту розвитку подій, а також об'єктивної неможливості заглянути в майбутнє для підтвердження чи спростування одного 3 варіантів тут у сьогоденні; по-друге, процес пошуку, дослідження та абстрагування від несуттєвих варіантів, які лише перешкоджають руху вільної думки для досягнення мети інтерпретаційної діяльності [454, с. 28].

На нашу думку, за своєю природою процеси критичного мислення та художньо-естетичної інтерпретації схожі між собою, тому що обидва припускають: нестандартність руху думки в процесі пізнання, без готового зразка для репродуктивного наслідування; перехід від початкових поверхневих оціночних суджень до багатофакторного аналізу (соціально-економічного, культурно-історичного, психологічного, художньо-естетичного) та варіативності думки, щодо виявлення логічних взаємозв'язків конструктивних елементів у загальній системі; оперування правдивою науковою інформацією, задля формування суб'єктивно-об'єктивних висновків та продукування нового знання; беззаперечне прийняття позиції існування істини у предметі обговорення (виходу із ситуації) та логічної стратегії планування щодо іiі знаходження; подолання первинного страху «чистого аркуша», оскільки початок думки починається 3 відмови від попередніх догматичних рішень; усвідомлення процесу пізнання у вигляді ментальної моделі ланцюга циклічних 
герменевтичних кіл, кожне з яких характеризується максимальним розглядом загального та часткового (цілісністю знання) й елементом невизначеності (відкритістю знання), який продукує новий цикл розуміння.

Ми погоджуємося з вищезазначеними дослідниками, щодо актуалізації на сповільненому темпі пізнання та обробки фактичного матеріалу у процесі інтерпретаційної діяльності. Операція критичного мислення ретельно намагається виявити всі наявні взаємозв'язки між причинно-наслідковими аспектами будь-якої проблеми. Тому невиправдані та стрімкі імпульси тільки зашкодять зв'язку між інтерпретатором та твором, який було утворено при первинному осягненні останнього, але потребує аргументації міцності своєї концептуальної конструкції завдяки дедукції, індукції та загальної узгодженості матеріалу. Це необхідно, оскільки цінність критичного мислення полягає в його цілеспрямованості відшукати єдине правильне рішення в конкретних умовах. У цьому разі його об'єктивність апріорі $є$ дотичною до принципу наступності та перспективності наукового знання, адже включає відкритість шляхів, щодо подальшої побудови гіпотез. Окреслене стосується, як до конкретної проблеми в одній області (в залежності від мінливості подразників навколишнього середовища), так і до розширення міжпредметного спектра взаємозв'язків до вельми віддалених дисциплін з урахуванням розгляду навіть незначної ланки (на перший погляд) в конструкті нової для розуміння системи. До означеного можна віднести й здатність до сприйняття та повторення ірраціональних шляхів побудова думки, сюрреалістичних i парадоксальних концепцій - пізнання протилежностей в автономності один від одного та цілісності (полярності).

3 огляду на те, що метою критичного мислення - $\epsilon$ знаходження першопричини всього сущого, безсумнівно, даний процес є неможливим без грунтовного впровадження до дизайн-освіти екологічного підходу. Сучасне технократичне суспільство характеризується наявністю великої інформаційної бази для швидкого осягнення навколишньої дійсності (Інтернет, 3MI та TV), проте віртуальність ніколи не замінить безпосереднього діалогу з природним проявом сущого, а не його відформатованою імітацією у різноманітних образах. 
Адже, якщо природа, при цілеспрямованому та усвідомленому діалозі, формує й розвиває інтелектуальні, творчі, духовні та фізичні здібності людини, як частини вищої цінності, - то будь-який образ, є лише монологічною базою даних, щодо живого аналогу. Так, молодий дослідник, за твердженням С. Сухомлинського, ніколи не повинен забувати та нехтувати «колискою дитячої думки» природи, яку він уособлював із взаємовідношенням матері та дитини під час та після вагітності, як єдиний органічний симбіоз, а не граничні полярності сущого та людини [455, с. 3]. Такий глибинний зв'язок частини та цілого вищого порядку, не може бути розірвано, як під час інтерпретаційної діяльності, так й у житті в цілому. Проте, на нашу думку, є фактори, які грунтовно його послаблюють, а саме:

- зовнішній фактор - нагромадження та забруднення свідомості людини деструктивними догматичними ціннісними системами, 3 метою формування психічно-неврівноваженого індивіда-фанатика, який ніколи не зможе стати цілісною творчою особистістю, адже його світосприйняття грунтується на абстрактних положеннях, а не власному аналітичному та емпіричному досвіді 3 експериментальної перевірки реальності;

- внутрішній усвідомлений фактор - егоїстичні наміри людини щодо «діалогу довіри» із сущим у процесі інтерпретаційної діяльності, 3 метою маніакального володіння природно-біологічними та матеріально-технічними ресурсами у власних меркантильних інтересах, задля розташування своєї персони не просто у центрі буття, а над усім сущим - уподібнення себе до творчого Абсолюту;

- внутрішній неусвідомлений фактор - патологія інтелектуального розвитку людини у наслідок психофізіологічних відхилень від народження (синдромальна та ідіопатична інвалідність). У такому разі органічний зв'язок із сущім не носить замкнутого характеру апріорі, однак й науково-дослідною роботою інтерпретаційна діяльність також не відзначається (хоча, можливі й винятки, наприклад П. Пінеда, Б. Кравчук). 
Окреслені негативні прояви відмежування особистості від природного джерела натхнення та різноманіття художньо-естетичних образів, не аби як впливає на рівень чистоти та яскравості творчої уяви.

Нам імпонує думка С. Рубінштейна, стосовно того, що відтворення митцем ментальних конструкцій з розуміння естетичного компонента завдяки можливостям власної уяви - рівноцінно вже впровадженню дизайн-виробу до навколишнього середовища й отримання суб'єктивно-об’єктивного зворотного зв'язку від атмосфери інформаційного поля навколо нього [456, с. 372]. Адже, ще з античної давнини відомо просту формулу «людина $є$ мікрокосмосом, такою ж мірою, як Всесвіт уособлює собою макрокосм». Психічний процес уяви зазнає гармонійного розвитку тільки, якщо першим етапом його становлення $\epsilon$ художньо-естетична інтерпретація природного формотворення Всесвіту - «екотворчий аудит». Проте, дивитися на природу у процесі дозвілля - ще не означає iï бачити. Епізодичність у спілкуванні з природою викликає коливання енергоінформаційних потоків «динамічної рівноваги» уваги, що призводить до незбалансованості уяви, та як наслідок, до безглуздості художнього образу від поверховості й пустоти естетико-семантичного наповнення частин та цілого у ньому. Природа, за словами К. Ушинського є «могутнім агентом у вихованні людини», адже тільки через неї відкривається натуральний духовний компас до «наближення горизонтів» між сущім та його інтерпретатором [457, с. 3]. Художньо-проектна діяльність повинна починатися зі споглядання й розуміння естетичного ідеалу сущого, у варіативній доцільності усього його інтерпретаційного природного здобутку. Саме слово «ідеал» або «ейдос» - це першообраз вищої цінності Бога, а таким є тільки «любов», як вища абсолютна істина й благо. Прекрасне у природі не містить канонічної та стереотипної «штучної ідеальності» з їі статичною геометричністю пропорційності елементів цілого. Навпаки, воно завжди невимушене у своїй динамічний, асиметричній граціозності натурального нескінченного ритму краси, знаходячись поза часовими обмеженнями моди та стилю. Грунтуючись на концепції «філософії серця» Г. Сковороди, додамо, що сформована ментальна співзвучність 
емоціаналізму та критицизму митця й природи, сприяє справжньому інтелектуальному та психологічному розкріпаченню усієї спектральності творчого потенціалу людини.

Саме тому уява дизайнера не може розвиватися тільки на художньоестетичній інтерпретації архетипів будь-якого виду мистецтва, який вже зображує аспект еко-творчого аудиту іншої людини. Тільки індивідуальний критичний досвід такої діалектики надасть можливість проектувати концепти навіть найсміливіших фантасмагоричних проектів футуристичного дизайну, однак завжди з елементом реальності стратегічного впровадження у просторовочасовій динаміці буття. Так, на нашу думку, каталізаторами свідомого інтерпретаційного процесу задля продуктивної реалізації імпульсів уяви завдяки еко-творчому аудиту, повинні бути наступні умови:

- привчання студентів до гігієни власного внутрішнього інфополя завдяки формуванню чистоти наукових інтересів (соціальний аспект) i позитивних особистісних помислів (індивідуальний аспект), задля гармонійного «наближення горизонтів» у «діалозі довіри» 3 твором мистецтва. Забрудненість свідомості стереотипами, сумнівами, негативізмом, показною емоційністю та чуйністю - $є$ не опрацьованими страхами інтерпретатора, щодо власної особистості. Основу останніх становлять комплекси, а передостанніх застарілі образи. Все це непотрібні психологічні та інтелектуальні «якоря», які не дозволяють людині повною мірою розкріпачитися у своїй природності та відчути, навіть первинне цілісне емоційне враження від твору мистецтва;

- підвищення екологічної свідомості студентів шляхом розроблення дизайн-виробів на базисі еко-тренду художньо-проектної діяльності: виготовлення продуктів з натуральних матеріалів шляхом збереження аспекту ручної обробки поверхні; модифікація справжнього хутра та шкіри тварин на штучні замінники високої ергономічної якості, й водночас, економічними за ціновою політикою ринку; актуалізація уваги на захисті довкілля, завдяки своєчасному усуненню деструктивних проявів інтерпретаційного доробку (сміття, нечистот, виражених руйнацій формотворення та збоїв у функціонуванні 
- шум, випромінювання, вібрації) протягом усієї динаміки його життєвого циклу; стратегічної можливості делікатної утилізації виробу з мінімальними екологічними збитками та багаторазового використання (перероблювання) матеріалів - безвідходне виробництво;

- впровадження до програми підготовки теоретичних та практичних завдань 3 художньо-естетичної інтерпретації природних мотивів (цілісних пейзажів, елементів флори та фауни), а також комбінаторних варіантів композиції творів з урахуванням: візуалізації емоційних вражень мінорного, мажорного та нейтрального характеру від споглядання природи без яких-небудь штучних додаткових подразників (традиційні та інноваційні ігрові, розвивальні та музичні пристрої); визначення пропорційного співвідношення природного та імітаційного аспектів у творах різних видів мистецтв; створення власного асоціативного візуального ряду до певних світлових й температурних умов пір року; створення творчих копій відомих творів мистецтва, які перероблені в іншій стилістиці 3 урахуванням трансформації перспективної плановості, зміни фонового акценту (небо/земля, природа/місто, закритий простір/відкритий простір, архаїчний/модерністський та навпаки) та інтерпретації художнього образу (неживе перетворити у живе, та навпаки);

Отже, як бачимо, у процесі підготовки майбутніх дизайнерів до професійної інтерпретаційної діяльності, високий рівень критичного мислення, $\epsilon$ необхідним компонентом. Адже, для побудови концептуального рішення проекту, фахівець повинен оперувати достатньо великою кількістю різноманітного матеріалу, утримувати та подовжувати вектори дуки, щодо кожного знання, задля побудови індивідуального багатоаспектного логічного ланцюга. Саме така логіка початкового конструкта дизайн-проекту відповідає сутності поняття «креативність». Також, інтерпретаційний процес неможливий без прийняття своєї природи, знаходження в стані гармонії зі світом, позитивної установки, щодо світлого майбутнього, квінтесенцією яких є логічність динаміки розвитку всього природного цілого. 


\section{9 Особливості моделювання художньо-виконавської техніки музиканта}

На сучасному етапі розвитку музичного мистецтва вагомості набувають процеси свідомого, системного формування художньо-виконавської техніки музиканта на грунті урахування індивідуально-психологічних рис особистості майбутнього артиста. Зважаючи на специфіку музичного мистецтва, формування виконавського процесу вимагає дослідження його діалектичної суті взаємозв'язку раціонального та ірраціонального. Таке розуміння становлення музиканта-фахівця спонукає до осмислення виконавського мистецтва як особистісно-фахового феномену та пошуку регулятивної (гнучкої) методики його формування. Центральною ланкою виконавської техніки є формування виконавських умінь музиканта, через які відбувається віддзеркалення особистісного у процесі виконання музичного твору. 3 іншого боку, через виконавські уміння музикант виявляє сутність, розкриває фабулу музичного твору. В самому понятті виконавської техніки музиканта сублімується індивідуальне та загальне, особистісне та соціальне, естетичне та вузько спеціалізоване. Власне виконавська техніка музиканта представляє суб’єктоб'єктний взаємозв'язок у процесі інтерпретації музичного твору $[458$, с. 2]. Отже, художньо-виконавська техніка $є$ поєднанням індивідуальноособистісного та фахово-спеціалізованого у процесі роботи над музичним твором, що вимагає напрацювання, розробки особистісно-фахової методики моделювання даного феномену, яка має враховувати, розвивати i удосконалювати індивідуально-особистісні якості музиканта-виконавця та специфіку його фахового становлення. Оскільки основним завданням музиканта-виконавця $\epsilon$ розкриття змісту музичного твору через доцільно дібрані технічні засоби виразності, важливим є здійснити диференціацію виконавської техніки інструменталіста, охарактеризувати кожен 3 видів виконавського уміння та визначити перспективні методи їх формування .

Проблемам якісного формування виконавської техніки музиканта присвячено велику кількість джерел, аналіз яких спонукає до визначення 
кардинальних напрямків розвитку даного феномену. Більшість науковцівмузикантів вбачають доцільність розвитку техніки музиканта-виконавця через вузькоспеціалізоване опанування технічними виконавськими прийомами [460]. Низка праць з методики опанування гри на інструменті пов’язується з процесом становлення музиканта-виконавця, грунтованого на аналізі фізіологічних та психологічних особливостей самої особистості музиканта [461]. На сучасному етапі розвитку художньо-виконавської техніки музиканта домінантності набувають креативно-регулятивні процеси формування професіоналізму через розвиток індивідуальних якостей та особистісних властивостей музиканта [ 462].

Мета статті полягає у розкритті сутності та структури художньовиконавської техніки музиканта, а також представленні інноваційної методики iii моделювання. Поставлена мета вимагає вирішення таких завдань: визначення сутності та структури художньо-виконавської техніки музиканта; здійснення характеристики пріоритетних методів моделювання художньо-виконавської техніки музиканта; дослідження специфіки формування художньо-виконавської техніки музиканта в процесі інтерпретації музичного твору.

У зв'язку, з цим у контексті фахової діяльності музиканта-виконавця домінантності набувають процеси застосування механізмів саморегуляції самопізнання, самоставлення та самокорекції. Саме розвиток музичновиконавських умінь на основі застосування методики саморегуляції в процесі опанування гри на інструменті сприяє постійному удосконаленню музичновиконавської діяльності і формує музичне виконавство як мистецтво [462].

Художньо-виконавська техніка музиканта є сукупністю засобів технічної виразності музиканта-інструменталіста, спрямованих на інтерпретацію змісту музичного твору. Виконавська інтерпретація представляє собою процес емоційно-інтелектуального осягнення музичного твору артистом, який здатний зрозуміти думку композитора, пережити та передати іiі слухачеві через індивідуальну систему технічних прийомів та музично-асоціативних образів. У 
зв’язку з цим, до структури виконавської техніки музиканта входять технічнодоцільні та художньо-інтерпретаційні уміння [463, с. 7].

До технічно-доцільних умінь відносимо технічні прийоми музикантаінструменталіста, сформовані на грунті усвідомленої взаємокоординації слухорухових та образно-рухових відчуттів. Все це складає процес розвитку сенсомоторики музиканта-інструменталіста. Наприклад, формування штрихової техніки інструменталіста, досягнення різнодинамічного звукоутворення на інструменті здійснюється на основі аналізу м’язового відчуття (стану) різноманітних рухових форм плеча, передпліччя, кисті та пальців у професійних рухах виконавця. Тобто, технічні прийоми музиканта-інструменталіста формуються через відчуття доцільного м'язового стану та через усвідомлення картини руху рук у надбанні технічних умінь. Отже, критерієм сформованості доцільного, якісного розвитку технічно-доцільних умінь музикантаінструменталіста є свідоме володіння та регуляція аналізом м'язового відчуття в процесі становлення технічних умінь, знання механіки та динаміки професійних рухів та усвідомлене їх застосування через регулятивні методи в процесі розвитку виконавської техніки музиканта.

Художньо-інтерпретаційні уміння можна трактувати як спосіб вимовлення музичної тканини твору, що інтерпретується, через відповідний добір технічно-доцільних прийомів інструменталіста. В основі побудови інтерпретації музичного твору є процес моделювання виконавської артикулящї. Виконавську артикуляцію можна розглядати як інструментальнотекстове вимовлення музичного твору засобами технічної виразності музиканта. Критерієм сформованості художньо-інтерпретаційних умінь $є$ свідоме володіння та регуляція темпоритмічною (агогічною), динамічною, тембральноштриховою та цезурною артикуляціями. Формування художньоінтерпретаційних умінь обумовлюється сформованістю технічно-доцільних умінь, оскільки інтерпретаційний процес музичного твору передбачає свідоме, регулятивне застосування системи засобів технічної виразності в роботі над розкриттям змісту музичного твору. Застосування того чи іншого виду 
виконавської артикуляції здійснюється виконавцем згідно його індивідуальної образно-асоціативної системи. Багатство, насиченість, неординарність, різноплановість, глибина даної індивідуальної системи спонукає до творчого застосування технічних прийомів, художньо обгрунтованих в процесі роботи над музичним твором.

Формування всіх видів виконавської артикуляції пов’язані з регулятивними механізмами, що свідомо поєднують у виконавському умінні слух, образ, рух для творення виконавського внутрішнього музичного образу. Крім цього, вся система артикуляції моделюється у полі інтерпретації музичного твору, згідно зі стилем та змістовним наповненням - фабулою музичного твору. Наприклад, у інструментальних барокових творах добір динамічної артикуляції, яка часто тут $€$ контрастною, грунтується на основі сенсомоторної саморегуляції м'язового відчуття у процесі звуковидобування у раптовому межуванні динаміки форте та піано. Ця контрастна динаміка у струнно-смичковій техніці кардинально відрізняється за принципом виконання у формах руху та м'язовому відчутті. Миттєва корекція, здатність до регуляції доцільних рухів та м'язових відчуттів $є$ основою еластичності, художності та естетичності динамічних відтінків у музикантів-інструменталістів.

Моделювання агогічної - темпоритмічної артикуляції у романтичному репертуарі, наприклад виконавця-струнника, вимагає тонкого володіння різноманітною швидкістю ведення смичка та відповідного натиску руки на нього. Темпові пришвидшення та заповільнення у грі на інструменті пов'язані 3 умінням використовувати різні м'язові стани - напруження та розслаблення, а також їх застосування у різних часово-темпових комбінаціях. Отже, свідоме напрацювання технічних умінь на грунті аналізу м'язового відчуття формує, в першу чергу, доцільний технічний прийом, а далі зумовлює його удосконалення чи трансформацію в процесі інтерпретації змісту музичного твору.

Важливим у процесі роботи над музичним твором є добір тембральноштрихової виконавської артикуляції. Цей вид артикуляції поєднує в собі застосування доцільних технічних прийомів виконавця-інструменталіста - 
звуковидобування, штрихів, аплікатури, вібрації відповідно до виконавських асоціативних образів, уяви та емоційного переживання змісту музичного твору. Тут особливої домінантності набувають процеси налагодження координації слуху, уяви та добору технічного прийому, в роботі над музичним твором, що власне $\epsilon$ основою формування художньо-інтерпретаційного уміння. Таким чином, дуже важливим у роботі над музичним твором $\epsilon$ формування індивідуального асоціативного образу, розвиток внутрішньої асоціативнообразної виконавської системи, яка в подальшому може видозмінюватися, регулюватися відповідно до асоціативно-образної системи фабули музичного твору.

Цезурна виконавська артикуляція $є$ системою розділових знаків у відтворенні музичного тексту, своєрідного показу розгортання - початку та закінчення музичної фрази, періоду, речення. Її можна вирізнити як контекстну ma підтекстову. Контекстна цүезурна артикуляція та, яка зображена композитором у нотному тексті і охоплює різноманітні позначки пауз, цезур, фермат. Підтекстова, або сюжетна артикуляція та, яка індивідуально відчитується, відтворюється виконавцем. Вона може збігатися або не збігатися 3 контекстною артикуляцією, тобто в різній мірі ( довгі фермати, короткі цезури) відтворюватися інструменталістом. У даному випадку це пов'язується зі змістовним розумінням виконавцем музичного твору, 3 індивідуальним способом фразування, зі специфічністю побудови архітектоніки виконання. Також сформованість даної артикулятивної системи пов'язується з контролем за диханням, як фізіологічної основи доцільного технічного прийому ( контроль дихання у процесі виконання різномантіних штрихів, вібрації тощо), так i художньої основи - показу тривалості, уривчастості дихання в залежності від характеру вимовлення музичної фрази, показу ( представлення) спаду чи кульмінації у частині твору.

Важливого значення у процесі формування художньо-виконавської техніки музиканта посідає формування сценічно-стабільного виконання твору музикантом як складової успішної презентації інтерпретації змісту музичної 
твору. Тут слід підкреслити, що виконання твору на сцені набуває стабільності за умови сформованої виконавської моделі інтерпретації. При сценічному виконанні необхідно слідкувати за - наперед продуманою виконавцем логікою розгортання переживань змісту музичного твору, та, згідно цього, контролювати якість виконання доцільно обраних технічних умінь.

У зв’язку з цим, важливого значення у становленні художньо-виконавської техніки музиканта набуває застосування методики моделювання програми саморегуляції виконавських умінь музиканта .

Методику саморегуляції музиканта-інструменталіста умовно можна розподілити на абстрактну ( загальну) - на грунті якої формуються технічнодоиільні виконавські уміння та предметну, що складає основу моделювання художньо-інтерпретачійних умінь.

Під абстрактною саморегуляцією розуміємо уміння музиканта-виконавця адаптувати власні технічні прийоми, згідно різноманітних завдань, не пов'язаних з інтерпретацією музичного твору. Серед основних таких завдань необхідно визначити основні.

В першу чергу, це здатність визначити, проаналізувати та відтворити найцінніший для виконавця технічний прийом гри. Визначити підгрунтя цінності даного технічного прийому - чи він найкраще технічно виходить у виконавця, чи має відповідну емоційно-образну характеристику, що консеквентна його особистісній духовно-ментальній сфері.

Далі, з'ясувати технічні відмінності виконання різноманітних форм технічний прийомів інструменталістів. Наприклад, з'ясувати відмінності виконання на інструменті штриха деташе - барокового, романтичного та декламаційного. Або штриха спіккато, який у виконавській техніці розрізняється за характеристиками як віртуозний так і драматичний прийом.

Важливим $є$ для виконавця вміти показати різноманітні інструментальні тембри, барви, колористику на інструменті та з'ясувати, проаналізувати їх взаємозв'язок, взаємозалежність з специфікою виконання технічних прийомів музиканта. Це зумовлює формування художньо-асоціативної техніки музиканта. 
Також до абстрактної саморегуляції можна віднести уміння регулювати добирати, комбінувати, творити засоби технічної виразності у відповідності до індивідуально-домінантної асоціативно-образної сфери музиканта-виконавця. Для цього застосовуються завдання, пов'язані 3 відтворенням у грі на інструменті власного найціннішого, улюбленого образу - природи, запаху квітки, найулюбленішого відчуття ( радість, сум...), найближчої людини. В даній ситуації опановується процес еластичної спрямованості власних технічних умінь на відтворення індивідуального уявного образу. Таким чином здійснюється інструментальна візуалізація образу .

Предметна або програмна саморегуляція - це, так звана, програмна саморегуляція виконавської техніки скрипаля у процесі інтерпретації музичного твору. Відмінність даної саморегуляції полягає в тому, що вона повинна бути конкретно спрямована на представлення власного професіоналізму виконавця в конкретно визначених композиції та драматургії музичного твору. Тобто, виконавська техніка має застосовуватися як система артикулятивних засобів, що розкриває інтонаційно-образну систему музичного твору. На грунті цього формується уміння саморегулювати суб'єктивне виконавське розуміння змісту та добирання інструментальної техніки в полі об’єктивного композиторськообразного континууму музичного твору.

Процес інтерпретації фабули музичного твору грунтується на предметній (програмній) музично-виконавській саморегуляції. В даному контексті необхідно застосовувати рефлексивні, креативні та корективні методи.

В основі рефлексивних методів лежить процес самопізнання як один із механізмів фахового самоусвідомлення. Даний процес грунтується на двох завданнях. Перше завдання полягає у визначенні виконавцем домінантного образу музичного твору, над яким ведеться робота та визначенні найбільш характеристичних композиторських прийомів його представлення. Це означає необхідність пізнання виконавцем композиційної та сюжетної ( драматургічної) форми музичного твору. Другим завданням рефлексивної методики $є$ процес визначення власного виконавського слухо-асоціативного образу музичного 
твору та індивідуальний підхід до його технічного, сенсомоторного відтворення.

Засадним у креативній методиці $є$ процес самопорівняння, творення самооцінки. Даний процес передбачає самоосмислення, самооцінку, самопорівняння доцільності власних слухо-асоціативних уявлень та засобів їх технічного відтворення в процесі роботи над музичним твором. Сутністю даної методики $€$ порівняння власного сприйняття твору з особливостями його композиторського представлення, з його стильовою специфікою. 3 цією метою, на першому етапі креативної методики пропонується застосовувати здійснення виконавсько-порівняльного аналізу твору різними еталонними виконавцями. На другому етапі виконавець здійснює самоосмислення, самопорівняння, самооцінку власного виконання даного твору 3 проаналізованими на першому етапі еталонними виконаннями. Здійснюється даний креативний самоаналіз на першому та на другому етапі на основі використання відповідних критеріїв: емоційність - ситуативна чи контекстна; технічність - абстрактна чи естетична (художня); виконавські новації - репродуктивні (наслідувальні) чи творчі.

Підгрунтям корективних методів $\epsilon$ уточнення, видозміна та програмування особистісно-виконавського уявлення, згідно 3 фабулою ( драматургією ) музичного твору, а також координація, добір відповідних засобів технічної виразності. Корекція образно-асоціативного уявлення віддзеркалюється на доборі засобів технічної виразності. Відбувається корекція - наближення виконавського домінантного асоціативного образу музичного твору до композиторського, а відповідно до корекції образної уяви коректується, видозмінюється сенсомоторне, асоціативно-технічне іiї представлення в межах індивідуальної фахової майстерності музиканта-виконавця. Даний процес не означає нівелювання індивідуального сприйняття домінантного композиторського образу музичного твору виконавцем. Він спонукає до пошуку різновидностей власного індивідуального, а не постійного збереження самостереотипу - індивідуальної стереотипності артиста. Тим самим, весь процес саморегуляції в загальному спрямований на пошук різноманітного 
індивідуального самовиявлення виконавця, до його творчої адаптації у процесі інтерпретації музичних творів різних стилів та авторів.

Даний процес не означає нівелювання індивідуального сприйняття домінантного композиторського образу музичного твору виконавцем. Він спонукає до пошуку різновидностей власного розуміння змісту музичного твору та його художньо-технічного представлення, що, у свою чергу, уможливлює трансформацію індивідуального виконавського стереотипу артиста. Тим самим, весь процес саморегуляції в загальному спрямований на пошук різноманітного індивідуального самовиявлення виконавця, до його творчої адаптації у процесі інтерпретації музичних творів різних стилів та авторів.

Застосування у процесі моделювання художньо-виконавської техніки музиканта механізмів саморегуляції, зумовлює сценічно стабільну демонстрацію усвідомленої, цілісної, системно сформованої виконавської інтерпретації на рівні інструментальної майстерності. Все це в підсумку спонукає до формування художньо-виконавської техніки музиканта як естетичного, мистецького феномену. 
DOI 10.46299/ISG.2021.MONO.PED.II-492-499

\subsection{0 Лекційне забезпечення навчального процесу на кафедрах факультету підвищення кваліфікації викладачів Національного Університету Охорони Здоров’я України Імені П.Л. Шупика}

Вступ. Досягнення сучасної медичної науки ставлять перед закладами вищої освіти цілу низку завдань, одним із яких $є$ збільшення кількості інформації, якою повинен оволодіти спеціаліст, чи лікар, який проходить навчання [465]. Без підвищення рівня фундаментальної підготовки наразі неможливо досягти головної мети перебудови медичної освіти - суттєвого покращання якості підготовки спеціалістів-медиків. Рівень викладання навчального матеріалу має забезпечити опанування слухачами закладів вищої освіти великого за обсягом інформації матеріалу за одиницю часу та іiі використання в процесі як навчання, так і в подальшій практичній діяльності.

Чільне місце у теоретичній підготовці лікарів в закладах вищої освіти посідає лекція. Нові тенденції, що намітились в реформуванні системи підготовки лікарів, обумовлюють необхідність впровадження в навчальний процес нових форм і методів навчання, які мають сприяти його інтенсифікації, стимулювати розумову діяльність студентів і лікарів-слухачів [466,467]. Сучасна лекція покликана озброїти слухачів знаннями методологічних основ певної клінічної дисципліни, ознайомити їх 3 основними етапами становлення i розвитку теоретичних концепцій, i, нарешті, тільки на лекції студент чи лікарслухач може сформулювати чітке уявлення про сучасний стан тієї чи іншої проблеми. 3 огляду на надзвичайно високий темп розвитку сучасної медичної науки, ні один із самих сучасних підручників, посібників чи монографія аналогічного завдання вирішити не зможуть. Не зможуть замінити лекцію навіть найкращим методологічним чином організовані семінарські чи практичні заняття.

Основна частина. Одною із основних форм організації систематичних навчальних занять при викладанні як клінічних, так і теоретичних дисциплін у закладах вищої освіти є лекція, як носій необхідної інформації з того чи іншого розділу відповідної дисципліни. Крім того, лекція $є$ незамінною для 
систематизації та структурування всього обсягу знань, отриманих слухачами 3 кожної конкретної навчальної дисципліни.

Згідно Вікіпедії (вільна енциклопедія) подано наступне визначення лекції: «лекція - це основна форма проведення навчальних занять, призначених для подальшого засвоєння теоретичного матеріалу».

Залежно від мети та форми або методів викладу навчального матеріалу лекції поділяються на вступні, навчальні, інформаційні, оглядові, проблемні, відкриті, підсумкові, комплексні, клінічні тощо.

Основною дидактичною метою лекції є забезпечення орієнтовної основи для засвоєння слухачами навчального матеріалу. Доцільно відмітити, що наявність певної частини самостійної роботи слухачів на сьогодні є вимогою до організації навчального процесу у вищій школі.

Кожна лекція виконує ряд функцій: інформаційну, стимулюючу, виховну, розвиваючу, методологічну, пояснювальну та сприяє активізації процесу мислення i уваги слухачів; створює умови для самостійного вивчення навчального матеріалу за підручниками, посібниками, керівництвами; формує мотивацію для роботи в пошукових мережах INTERNET.

Лекція повинна мати відповідну структуру і містити такі елементи як: вступ, у якому формулюється мотивація навчання, мета лекції та основні питання даної теми; виклад основного матеріалу; висновки, які надають можливість систематизувати навчальний матеріал і виділити основну ідею; відповіді на запитання слухачів та рекомендації щодо поглиблення самостійного вивчення теми.

Вузловими критеріями оцінки лекції є: зміст, методика, керівництво роботою слухачів, лекторські дані та результативність лекції. На ефективність лекції позитивно в пливають і деякі чинники довкілля (оптимальне освітлення, відсутність сторонніх звуків, чисте повітря аудиторії, зручні робочі місця, добра акустика, естетичне оформлення аудиторії тощо) та мистецтво лектора (відмінне знання предмету, бажання бути добрим лектором, культура мови, вміння логічно викладати свої думки, наполеглива праця з підготовки кожної лекції, практика і 
тренування, зовнішній вигляд, вміння налагодити контакт 3 аудиторією, педагогічний такт тощо). При підготовці до лекції лектору необхідно чітко визначити цілі і задачі лекції, дати назву у відповідності з навчальним планом і програмою предмета чи курсу, скласти план лекції, а потім конспект з вказівкою переліку літератури i необхідних цифрових даних, підготувати відповідні ілюстративні матеріали тощо.

При читанні лекції викладач зобов’язаний дотримуватись зовнішнього і внутрішнього регламенту занять (початок, кінець, розділи лекції), чіткої структури та виконання плану лекції, доступності та пояснення нових термінів і понять, виділення головних думок і висновків, підведення підсумків в кінці окремих питань та по всій лекції, використовувати технічні засоби навчання і ін. До читання кожного виду лекції необхідно підходити індивідуально, з творчою наснагою, оскільки лекції суттєво відрізняються між собою за метою, змістом та інформацією. Наприклад, вступна лекція знайомить слухачів з метою циклу (курсу), його місцем у системі навчальних дисциплін. Вступна лекція висуває та обгрунтовує основні методологічні позиції курсу, визначає предмет і методи дисципліни, що вивчається. Дуже важливим для вступної лекції $є$ зв’язок теоретичного матеріалу 3 практичними аспектами роботи лікаря. Під час вступної лекції викладач має можливість охарактеризувати підручник та навчальний посібник, які пропонуються для опрацювання; ознайомити слухачів 3 обов'язковою (рекомендованою) літературою. Таким чином, така лекція орієнтує лікарів на подальшу самостійну роботу та знайомить 3 методикою засвоєння циклу.

Тематична лекція - найбільш поширений вид лекції для вищої школи, у якій всебічно розкривається те чи інше питання, висвітлюються головні аспекти наукової проблеми, взаємозв’язок між різними розділами та темами курсу.

Оглядова лекція - передбачає систематичне узагальнення та аналіз головних проблем курсу. Як правило, аналіз має бути пов’язаний з практичною роботою слухачів. Таку лекцію рекомендується проводити у кінці вивчення декількох тем, оскільки вона є узагальнюючою. Але оглядова лекція може передбачати також 
загальне ознайомлення з навчальним матеріалом, який не планується для більш детального вивчення. Крім того, такі лекції дуже важливі для активізації самостійної роботи слухачів з метою опанування певних тем.

Квінтесенцією курсу є оглядово-повторювальна лекція, яка читається у кінці курсу та відображає всі положення, які складають науково-понятійну основу курсу.

Інформаційна лекція - надає головну інформацію з теми відповідно до навчального плану та програми.

Підсумкова (або заключна) лекція - завершує лекційний курс, систематизує одержані знання, підводить підсумки прочитаного курсу.

Слід зазначити, що у ВМНЗ післядипломної освіти крім вищенаведеної класифікації можуть використовуватись і інші види лекцій, які поділяють залежно від методів викладання навчального матеріалу.

Монолекція - $є$ начитуванням навчального матеріалу.

Проблемна лекиія - найбільш складний вид лекції, який вимагає від викладача глибокого володіння матеріалом, вміння створити проблемну ситуацію. При цьому теоретичний матеріал подається у вигляді проблемної задачі, що має певні протиріччя, які викриваються і розв'язуються разом зі слухачами.

Лекція-візуалізація. Така лекція є носієм усної інформації, перетвореної у візуальну форму. Можуть бути використані такі форми наочності, як: символічні (таблиці, схеми), образотворчі (фото, малюнки, слайди), натуральні (реактиви, препарати, апаратура і ін.). Загалом читання даної лекції - це розгорнутий коментар підготовлених візуальних матеріалів.

Клінічна лекція. Особливістю даного різновиду лекцій є іï структура. Проведення іiі потребує певної організації як навчального, так і лікувального процесу. Асистент лектора напередодні вивчає історії хвороб пацієнтів у базовому відділенні, вибирає, на його погляд, історію із класичним перебігом хвороби і готує коротку презентацію з даного клінічного випадку. Із згоди пацієнта можлива його демонстрація під час доповіді. Звертають увагу на 
патогномонічні прояви хвороби, за участю лектора проводять огляд хворого, акцентуючи увагу на певних симптомах. Аналізують дані лабораторних, інструментальних і спеціальних досліджень. Завершують презентацію формулюванням діагнозу згідно сучасної класифікації захворювання. Дана частина лекції не має перевищувати 15 хвилин. Далі лектор переходить до викладення етіології, патогенезу, клініки, класифікації, діагностики та лікування захворювання. Звертають особливу увагу на особливі клінічні варіанти його перебігу. Під час проведення клінічної лекції можливе інтерактивне опитування слухачів.

Майстер-клас - уроком це назвати примітивно. Після такого майстер-класу слухач сам зможе виконувати те чи інше.

Лекція - прес-конференціiя також достатньо складний вид лекції, що потребує від викладача високого професійного рівня, вміння швидко аналізувати та узагальнювати дані, які надходять. Під час такої лекції викладач називає іiі тему та просить слухачів надати письмові запитання з теми. Викладач впродовж 3 - 5 хвилин отримує питання стосовно змісту та починає лекцію. При цьому лекція не повинна виглядати як відповіді на запитання, а бути повноцінним текстом, в процесі викладання якого даються відповіді на запитання, що надійшли. Така лекція цікава тим, що вона надає можливість отримати зріз знань слухачів.

Лекція вдвох - цей вид лекції є розвитком проблемного викладання теми навчального курсу у формі діалогу двох викладачів. Але необхідно пам'ятати, що така лекція вимагає грунтовної підготовки викладачів для сумісного вирішення проблеми, вміння активізувати розмову з аудиторією. Необхідно, щоб слухачі були залучені до дискусії, задавали питання, наводили випадки із практичної діяльності, висловлювали власну думку. Важливою частиною лекції є відповіді на запитання слухачів.

Як правило, на цей елемент лекції відводиться мало часу, але нерідко питання після прочитаної лекції перетворюються в окремий вид роботи лектора. Виходячи з цього виділяють наступні активні форми лекцій: 
Лекиія-брифінг - складається 3 двох частин: короткого повідомлення лектора (до 20 хвилин) і відповідей на запитання слухачів (до 60 хвилин). Дуже важливим є зміст та форма повідомлення, тому викладач повинен ретельно підготуватись до нього. Принципова методична структура лекції-брифінгу: повідомлення лектора $\rightarrow$ запитання слухачів $\rightarrow$ відповіді лектора.

Лекиія-бесіда будується по-іншому. Якщо лекція-брифінг не передбачає виступів слухачів, а тільки запитання, то при цьому виді лекції допускаються виступи слухачів, викладення їх позиції, обмін досвідом т. ін. Таким чином, методична специфіка лекції-бесіди в тому, що викладач надає певну інформацію, ставить питання слухачам, щоб почути їх висловлювання, направляє діалог у потрібне русло.

Цікавим видом лекції є лекція-дисnуm. Вона також має короткий вступ на початку, а потім перетворюється у полемічну бесіду. Функції лектора передбачають організацію лекції таким чином, щоб виникали зіткнення думок, аналіз проблем, які розглядаються. Методична особливість лекції такого типу полягає в тому, що викладач повинен не тільки вміти вести бесіду, відповідати на запитання, але й мати навички організації диспуту та керування ним.

Існує ще один вид лекції - лекція-анкета. Викладач складає анкету опитувач з 20 - 25 питань за темою лекції. На початку лекції, отримавши анкету, слухачі під керівництвом лектора видаляють ті питання, які не викликають складностей. Питання, які залишились, ранжирують за ступенем складності, актуальності, тематикою, і таким чином складають план лекції. 3 методичної точки зору така лекція досить складна як на етапі підготовки, так і на етапі проведення. Від лектора вимагаються значні зусилля при складанні анкет, ерудованість, вміння аналітично мислити.

Практикується також бінарна лекиіiя чи лекиія-дует. Вона читається одночасно двома викладачами. Важливою умовою успішного проведення такої лекції є розподіл навчального матеріалу та попередня підготовка лекторів. Крім того, від викладачів вимагається вміння співпрацювати та імпровізувати. Не менш важливим є також глибока професійна підготовка викладачів. 
В лекційній практиці також описується ситуація під назвою «круглий стіл». В цьому випадку два або більше лектори розглядають одну загальну тему в одній аудиторії. Викладачі повинні і вести бесіду зі слухачами, і відповідати на їх питання. Вважається, що такий вид лекції максимально демократизує взаємовідносини лекторів та слухачів при обговоренні будь-якої проблеми.

У ряді випадків читаються також лекиійні спецкурси. Як правило, вони виходять за рамки навчальної програми, поглиблюють знання, отримані під час засвоєння програми. Завдяки лекційному спецкурсу слухачі знайомляться 3 певною науковою тематикою, науково-дослідною роботою кафедри тощо.

Висновки. У структурі всіх лекцій, що присвячені певній дисципліні чи вивченню певного курсу, для забезпечення підвищення якості навчального процесу, переважати мають лекції проблемного характеру, комплексні та клінічні лекції. Сучасна лекція має бути добре ілюстрованою, вона не повинна мати описовий характер. Для більшої інформативності мають використовуватися слайди, навчальні фільми, відеотехніка, а клінічні лекції мають ілюстроватися клінічними розборами і демонструванням тематичних хворих. Однак широке впровадження та використання технічних засобів навчання у навчальний процес не повинно замінювати живе слово педагога, применшувати значення особистості викладача-лектора. Сучасна підготовка висококваліфікованих лікарів передбачає оволодіння ними фундаментальними теоретичними знаннями, а також практичними вміннями та навичками. Професіоналізм викладача вищого начального медичного закладу, без сумніву, включає володіння предметом викладання та уміннями і навичками, що базуються на практичному досвіді. Саме професіоналізм лектора, як фахівця і як педагога, $\epsilon$ запорукою забезпечення підготовки висококваліфікованого та всебічно освіченого лікаря. Звичайно, з впровадженням дистанційного навчання, суттєво зміниться методологія проведення занять із слухачами, але живе слово лектора завжди буде залишатися запорукою розвитку клінічного та наукового мислення у слухачів. Лекція $є$ незамінним елементом у функції систематизації і структурі 
всього масиву знань з будь-якої дисципліни та служить головною ланкою дидактичного циклу навчання.

Проведення означених різновидів лекцій широко практикується у забезпеченні навчального процесу на кафедрах факультету підвищення кваліфікації викладачів Національного університету охорони здоров’я України імені П. Л. Шупика. 
DOI 10.46299/ISG.2021.MONO.PED.II-500-512

\subsection{1 Методика професійного навчання та економічна дидактика: тактика i стратегія формування професійної компетентності педагогів професійного навчання/фахівців з економіки}

Швидкість сучасного життя та зміни, що відбуваються у світі, обумовлюють постійну потребу суспільства у нових, актуальних знаннях, а також сучасних вміннях i навичках. Їх набуття можна пришвидшувати, якщо ефективно функціонує освітній простір, основу якого утворюють професійні педагоги, що здатні адекватно реагувати на світові виклики (наприклад, світова пандемія обумовила миттєве впровадження різних платформ дистанційного навчання, додаткових сервісів, і хоча до цього вони й використовувалися, але більше, як додатковий інструмент) та забезпечити підготовку фахівців, які б успішно реалізовували завдання своїх роботодавців у відповідних галузях. Успіх у професії має прямий зв'язок із професійною компетентністю особистості, але, крім професійних знань, умінь та навичок, важливими $є$ й особистісні риси, що $€$ компонентами соціальної компетентності. Отже, стратегічним завданням педагогів є визначення компонентів професійної та соціальної компетентностей та їх узгодження із запитами роботодавців щодо умінь і навичок майбутніх працівників.

Подібні запити репрезентуються на Всесвітньому економічному форумі у Давосі кожні п’ять роки на середньострокову перспективу. Дані щодо ТОП-10 ключових навичок сучасної успішної особистості, які б забезпечували ефективність іï професійної діяльності, виокремлені у 2010, 2015, 2020 роках [468], відображені на малюнку 1: 
Top 10 skills

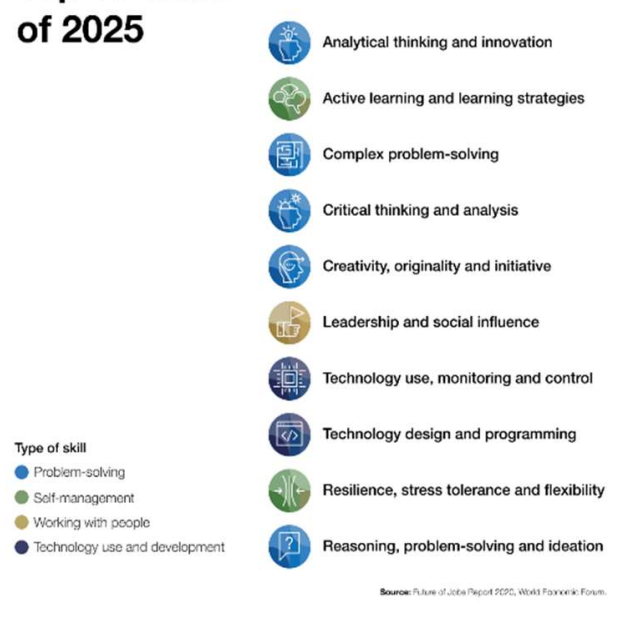

Top 10 skills
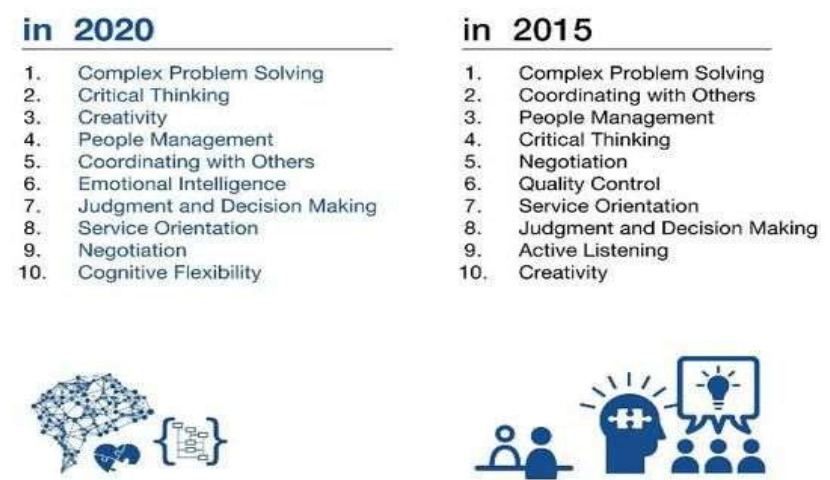

Малюнок 1. Порівняння ТОП-10 професійних навичок майбутнього у 2015, 2020 та 2025 роках

Порівнявши останні дані із навичками на 2015-2020 роки, бачимо, що відбулися суттєві зміни як змістовні, так й навіть у формі подачі та застосованій інфографіці:

1. вперше за 15 років серед пріоритетних навичок з’явилася здатність до активного навчання та використання стратегій навчання, що є позитивним сигналом для освітньої галузі в цілому, 3 одного боку, але й додатковою відповідальністю для педагогів, з іншого, оскільки вони мають імплементувати необхідні методи і прийоми, що спонукають до формування самоосвітніх навичок, у відповідні освітньо-професійні програми та конкретні навчальні дисципліни;

2. д додалися технологічні навички в аспектах їх використання у житті, a також й професійному напрямі (програмування), що обумовлено, у першу чергу, карантинними обмеженнями, спричиненими пандемією Covid-19, та необхідністю виконувати професійні обов’ язки у віддаленому доступі; крім того, це також вимагатиме зміни відповідного характеру у навчальних планах підготовки фахівців та набуття додаткових компетентностей педагогами; 
3. емоційний інтелект, що з'явився у ключових навичках 2020, наступного форуму замінений на витривалість, стресостійкість та гнучкість, які підкріплені лідерськими навичками та навичками соціального впливу; отож, у найближчій перспективі важливішими для будови успішної кар'єри замість вміння працювати у команді, співчувати, комунікувати, знову стануть індивідуальні психологічні характеристики особистості, пов'язані із працездатністю, особистою відповідальністю та вмінням швидко адаптуватися;

4. привалюючими навичками майбутнього (п'ять із десяти), як і у попередніх роках, залишаються навички щодо вирішення проблем, які пов'язані із специфікою мислення особистості, його рисами та характеристиками, що, в свою чергу, підтверджує актуальність дослідження; особисто авторка стовідсотково підтримує дану думку та активно впроваджує у власну викладацьку діяльність (про це мова буде йти згодом).

Думку учасників Всесвітнього економічного форуму підкріплюють дослідження експертів швейцарського банку UBS і консалтингової компанії PwC, які в доповіді Billionaires insights 2019 звернули увагу на те, що акції компаній, на чолі яких стоять мільярдери, ростуть майже вдвічі швидше за ринок в середньому, та пов'язали цю ситуацію з «ефектом мільярдера», появу якого автори доповіді пояснили трьома рисами характеру, властивими найбагатшим людям [469]:

$\checkmark \quad$ схильність приймати «розумні ризиковані рішення». «Коли мова заходить про те, щоб іти на ризики, підприємці-мільярдери проявляють оптимізм і фокусуються на ризиках, знаходячи розумні шляхи їх зниження», - зазначають дослідники.

зосередженість на бізнесі. Мільярдери постійно шукають навколо нові можливості.

висока стійкість, що зберігається мільярдерами, незважаючи на невдачі та перешкоди. 
У 2019-2021 рр. були проведені подібні дослідження щодо визначення ключових навичок успішного фахівця із відповідної спеціальності серед здобувачів освіти ДВНЗ «Київський національний економічний університет імені Вадима Гетьмана». Всього приймало участь 253 особи, які були об'єднані у три групи з врахуванням спеціальностей економічного, психологічного та подвійного педагогічно-економічного спрямування. На думку здобувачівмайбутніх економістів I-II курсів факультетів маркетингу та управління персоналом, соціології та психології 2020/2021 навчального року, критичне мислення $є$ найголовнішою навичкою для успішного фахівця економічного профілю (32,8\% опитаних); наступні дві якості (по 19\%) були готовність до ризику та стресостійкість; далі розташувалися цілеспрямованість (15\%), креативність (8,6\%), комунікабельність $(3,4 \%)$, наполегливість $(1,7 \%)$, інші.

Серед ключових навичок майбутнього успішного фахівця, на думку здобувачів освітньо-професійної програми «Економічна та соціальна психологія» 2019/2020 н.р., є, як і у попередньому випадку, критичність мислення (22\% опитаних), а далі розташувалися креативність (18\%), цілеспрямованість (15\%), комунікативність (15\%), наполегливість (10\%), стресостійкість (9\%), готовність до ризику (9\%), інші. Здобувачі наступного 2020/2021 навчального року цієї ж спеціальності виявилися не на стільки одностайними, запропонували нові навички та дещо змінили пріоритети: креативність (18\%), аналітичність (16\%), комунікативність (14\%), цілеспрямованість (11\%), готовність до ризику (9\%), стресостійкість (8\%), гнучкість (6\%), критичність (6\%), інноваційність (6\%), інші.

Опитування здобувачів освіти, що навчаються на спеціальності «Економічна та бізнес-освіта», а також тих, що отримують додатково педагогічну кваліфікацію, дало наступні результати: критичне мислення (24\%), комунікабельість (23\%), стресостійкість та готовність до ризику (по 15\%), стратегічність мислення (11\%), аналітичність (10\%), інші: серед яких були названі гнучкість, інноваційність, самомотивація, лідерські якості, організаційні якості, готовність до співпраці. 
Отже, думки здобувачів освіти цілком збігаються із експертними оцінками навичок майбутнього, основними з яких визнані певні характеристики мислення (більше 40\% незалежно від обраної освітньо-професійної програми). Слід зауважити, що здобувачі, які обрали фах економічного психолога, включили більш широкий перелік особистісних якостей. У випадку здобувачівекономістів, пріоритетність компонентів особистісного потенціалу підприємницької діяльності повністю співпадає з рисами «ефекту мільярдера». А здобувачам, що обрали подвійну спеціальність: педагог професійного навчання/фахівець 3 економіки, - вдалося гармонійно поєднати думки попередніх двох виділених груп опитуваних. Таким чином, ми отримали підтвердження, що підготовка фахівців економічного та міжпредметного (педагогічно-економічного, психолого-економічного) спрямувань повинна обов'язково формувати у процесі навчання характеристики економічного мислення, такі як креативність, критичність, аналітичність, прогностичність, інноваційність; та мотивувати до їх розвитку.

Наступим стратегічним завданням у системі підготовки фахівців $\epsilon$ визначення та апробація методів, прийомів та засобів, які дозволяли б сформувати протягом навчання у здобувачів освіти необхідні компоненти професійної та соціальної компетентностей, а також стимулювали б їх розвиток протягом всього життя. I це тісно пов'язано з третім стратегічним завдання, а саме: забезпечити ефективність процесу навчання дисциплінам, що входять до навчального плану підготовки фахівців певної спеціальності.

Визначені стратегічні завдання ми вирішуємо в процесі викладання навчальних дисциплін «Методика професійного навчання» для здобувачів освітньо-професійної програми «Економічна та бізнес-освіта» та «Економічна дидактика» для тих саме здобувачів, а також для тих, які обирають педагогічну кваліфікацію додатково.

В першу чергу, ми виходимо з того, що економічне мислення є різновидом професійного для здобувачів, що навчаються в економічному ВНЗ; по-друге, економічне мислення - це процес (і ми в цьому питанні згодні з когнітивними 
психологами), тому його можна вдосконалювати, тобто змінювати у напрямку підвищення продуктивності та ефективності мислення. 3 цією метою були обгрунтовані характеристики економічного мислення [470, с. 183], що співпадають в цілому із суспільною думкою:

$\checkmark$ аналітичність та наукова обтрунтованість - здатність до глибокого аналізу, точних узагальнень і висновків, критичних оцінок та ефективних рішень; дана риса наділяє людину баченням складного світу суспільного виробництва, дає змогу осягнути закони його розвитку $i$ механізми функціонування, основні зв'язки і залежності в економіці;

$\checkmark$ cистемність - забезпечення комплексного багатокомпонентного i багатоваріативного підходу до вирішення економічних проблем;

$\checkmark$ конструктивність - спрямованість на вирішення економічних завдань та забезпечення реальних і високих результатів економічної діяльності;

$\checkmark$ прогностичність - здатність передбачати наслідки прийнятих рішень у різних сферах суспільного життя, що забезпечується міжпредметним підходом до вирішення економічних ситуацій ;

$\checkmark$ зваженість - уміння дієво й результативно застосовувати теоретичні положення на практиці, правильно оцінювати, в тому числі критично, різноманітні економічні ситуації, можливі втрати та користь; і вчасно приймати необхідні всебічно обгрунтовані рішення;

$\checkmark$ діловитість - здатність енергійно та ефективно вирішувати проблеми, що виникають; уміння практично організувати певну справу, прагнення сумлінно виконувати свої обов'язки, доводити прийняті рішення до повного втілення у життя;

$\checkmark$ креативність - здатність генерувати нестандартні ідеї, бачити альтернативи, враховувати несподівані обставини, нові явища і процеси, зумовлені динамічністю економіки, НТП , рухливістю структури виробництва i потреб суспільства;

$\checkmark$ інноваційність - здатність втілювати нові оригінальні рішення у практику професійної діяльності. 
Розвиток зазначених вище характеристик може відбуватися на основі впливу на ментальні здібності особистості, що притаманні як правій, та і лівій півкулям головного мозку. Даний висновок зроблено на основі визначених специфічних можливостей півкуль головного мозку Р. Сперрі, а також дослідження Т. та Б. Бьюзен [471, с. 33-34, 520], Д. Халперн [472, с. 35] про модальність мислення. Саме тому, на початку навчання проводиться дослідження модальності мислення здобувачів за допомогою експрес-методики $[473$, с. 20$]$ та анкети Елвіна.

У 2020/2021 навчальному році у дослідженні брали участь 232 особи і були отримані наступні результати: традиційно за експрес-методикою ми отримали лівопівкульну домінантність, тобто привалювання логічного типу мислення (47,8\% опитаних), правопівкульна та збалансована модальність зустрічалися майже в однаковій кількості (25,1\% та 27,1\% відповідно). Як і в попередньому році [474, с. 111], більш грунтовне дослідження з використанням анкети Елвіна дало протилежні результати: домінуючими виявилися ментальні навички правої півкулі, тобто творчий тип мислення (48,8\% опитаних), домінування логічного типу мислення зафіксовано у 19,2\% здобувачів, та збалансована модальність зустрілася у $32,0 \%$ опитаних.

Порівняння результатів цього навчального року із даними попередніх років (див. малюнок 2) дає можливість стверджувати, що до системи економічної освіти (зокрема, до економічного університету, і це $є$ справедливим як для спеціальностей суто економічного профілю, так і психолого-педагогічного) вступають все більше здобувачів із домінантним творчим типом мислення, які добре вміють використовувати ментальні навички правої півкулі головного мозку. Таку динаміку можна пояснити, в першу чергу, заміною у КНЕУ в останні роки вступного випробування з математики історією, тобто більш гуманітарною спрямованістю абітурієнтів; та, до-друге, наслідками змін у шкільній підготовці майбутніх студентів, що обумовлені встановленим державою пріоритетом виховання всебічно розвиненої творчої особистості (до речі, цей тренд триває і в новій українській школі, але на базі компетентностей). 


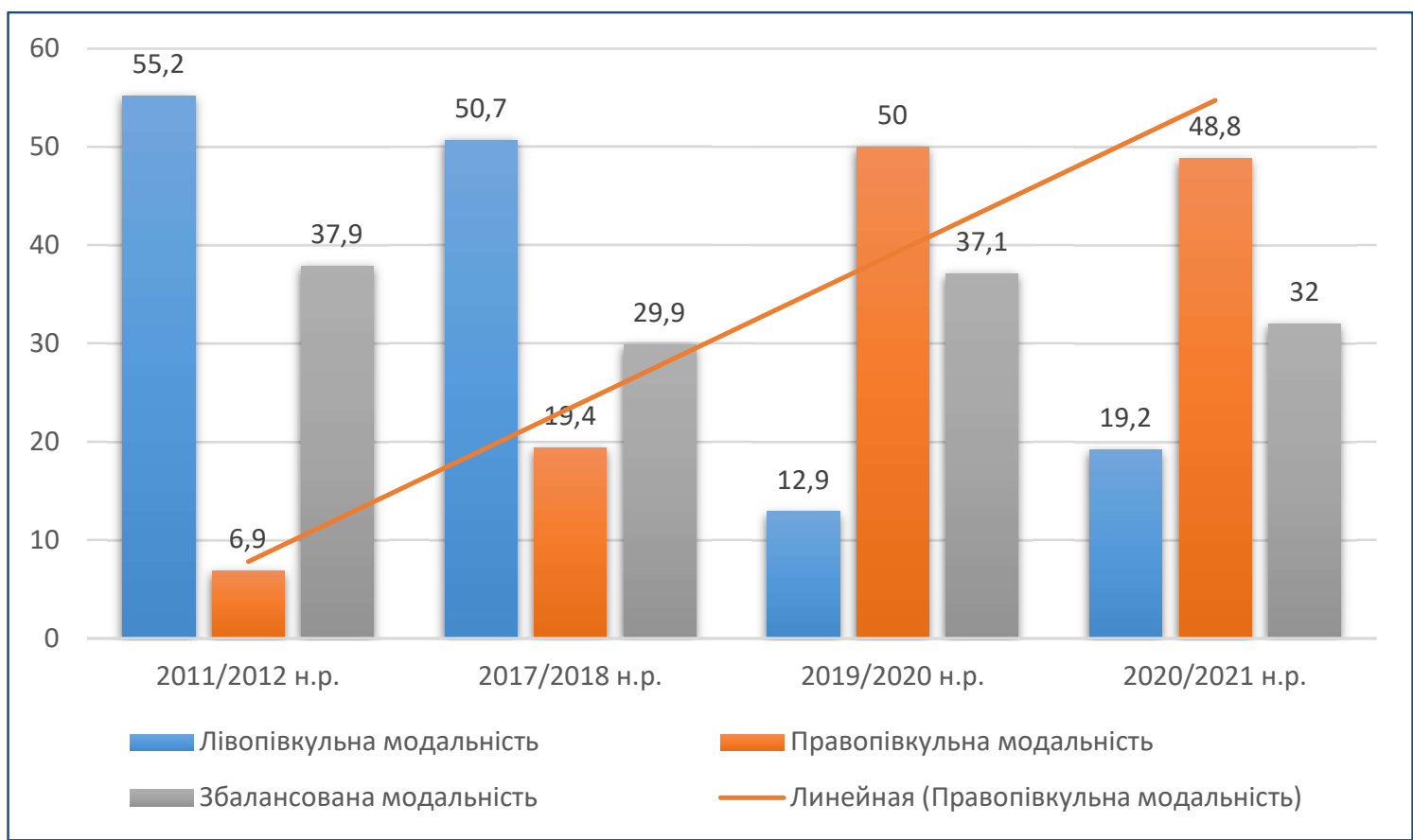

Малюнок 2. Порівняння результатів дослідження модальності мислення здобувачів освіти ДВНЗ «Київський національний економічний університет імені Вадима Гетьмана» 2011-2021 pp.

Не зважаючи на кардинально протилежні результати дослідження сформованості ментальних навичок півкуль головного мозку, показник збалансованої модальності протягом десятиліття залишається майже на одному рівні - приблизно 30\%, що дозволяє конкретизувати перше стратегічне завдання в аспекті необхідності забезпечення формування саме збалансованої модальності мислення здобувачів як здатності ефективно використовувати ментальні навички обох півкуль головного мозку, що вимагатиме змістовних змін у методичній діяльності викладачів у напрямі розробки, апробації та імплементації ефективного методичного інструментарію у практику викладання навчальних дисциплін.

Таким чином, тактично, враховуючи рівні сформованості ментальних навичок здобувачів, протягом 2019-2021 pр., крім методів активного навчання: дискусії, кейс-метод, розвивальні вправи, завдання різної складності, метод мозкового штурму, ігрові вправи, тренінги та проєкти, були запропоновані спеціально підібрані техніки і прийоми розвитку певного типу мислення, що 
були адаптовані авторкою до контенту навчальних дисциплін дидактикометодичного характеру [474, с. 112-113]:

$\checkmark$ для стимулювання розвитку логічного типу мислення - побудова ієрархій та послідовностей, «водна логіка» за Е. де Боно; елементи методик Е. де Боно, що стосуються підвищення продуктивності роботи мозку з фактичними даними, різного роду об’єктивною інформацією, наприклад, «6 капелюхів мислення» - у розділі прийомів мислення «у білому, чорному та жовтому капелюхах», або «6 пар взуття образу дії» - у розділі про «мислення та дії у сірих кросівках або коричневих черевиках»; створення конспект-схем (за методикою В.Ф. Шаталова);

$\checkmark$ для підтримки i стимулювання творчого мислення - методики нестандартного і творчого мислення за Е. де Боно, (наприклад, ефективний пошук альтернатив у процесі прийняття рішень, «латеральне мислення»), прийоми розвитку креативності мислення (наприклад, «бульбашки думок» М. Мікалко, «по-ідея» Е. де Боно, метод аналогій, випадкового слова та деякі інші);

для стимулювання розвитку збалансованої модальності та активізації застосування ментальних здібностей обох півкуль головного мозку - методика критичного мислення Д. Халперн та прийоми щодо розвитку критичного мислення інших авторів, наприклад оцінка стратегій роботи 3 партнером, методика розвитку радіантного мислення та створення інтелект-карт Т. та Б. Бьюзен, методики «шість капелюхів мислення» і «шість пар взуття образу дії» Е. де Боно, метод оцінки рішень «РМІ» та деякі інші.

Відповідні корективи довелося внести, враховуючи специфіку змішаного навчання поточного навчального року, тому більш активно використовувалися можливості платформи дистанційного навчання Moodle, cepвicy Zoom, за допомогою якого проводилися лекційні та частина практичних занять (особливо доречною була можливість створення окремих сесійних залів для виконання командних завдань), Telegram-канал для додаткових роз'яснень, рекомендацій та консультацій. 
Були запропоновані завдання більш аналітичного напряму, наприклад: дослідження ринку освітніх послуг України: суб'єкти, сегменти, ємкість; можливості співпраці академічних та корпоративних університетів (з участю у VIII Міжнародному бізнес-форумі «Наука-бізнес-освіта: стратегічне партнерство» 25.11.2020р., м. Київ). Також здобувачі виконували комплексне завдання «Ціна отримання кваліфікації «педагог професійного навчання» в українських ВНЗ». Їм пропонувалося проаналізувати дані щодо університетів в Україні, які здійснюють набір на спеціальність «Професійна освіта (Економіка)» та «Економічна та бізнес-освіта» (приклад наведений у таблиці 1).

Таблиця 1.

Ціна (контракт) та попит на отримання кваліфікації «педагог професійного навчання/фахівець з економіки» у 2020/2021 навчальному році

\begin{tabular}{|c|c|c|c|}
\hline Назва ВН3 & Спеціалізація & $\begin{array}{l}\text { Бакалаврат, } \\
\text { грн. на рік }\end{array}$ & $\begin{array}{c}\text { Кількість заяв / } \\
\text { Кількість } \\
\text { зарахованих } \\
\text { студентів }\end{array}$ \\
\hline $\begin{array}{l}\text { Національний педагогічний } \\
\text { університет імені } \\
\text { М.П.Драгоманова }\end{array}$ & $\begin{array}{c}\text { Професійна освіта } \\
\text { (Готельно- } \\
\text { ресторанна справа) }\end{array}$ & 14100 & $63 / 2$ \\
\hline $\begin{array}{l}\text { Національний педагогічний } \\
\text { університет імені } \\
\text { М.П.Драгоманова }\end{array}$ & $\begin{array}{l}\text { Професійна освіта } \\
\text { (Економіка) }\end{array}$ & 14100 & $20 / 0$ \\
\hline $\begin{array}{l}\text { Одеський національний } \\
\text { економічний університет }\end{array}$ & $\begin{array}{c}\text { Англійська мова в } \\
\text { економіці та бізнес- } \\
\text { освіті } \\
\end{array}$ & 18900 & $26 / 2$ \\
\hline $\begin{array}{l}\text { ДВНЗ «Київський національний } \\
\text { економічний університет ім. В. } \\
\text { Гетьмана» }\end{array}$ & $\begin{array}{l}\text { Економічна та } \\
\text { бізнес-освіта }\end{array}$ & 22800 & $100 / 11$ \\
\hline $\begin{array}{l}\text { Українська інженерно- } \\
\text { педагогічна академія }\end{array}$ & $\begin{array}{l}\text { Економічна та } \\
\text { бізнес-освіта }\end{array}$ & 14000 & $33 / 8$ \\
\hline $\begin{array}{l}\text { Чортківський навчально- } \\
\text { науковий інститут } \\
\text { підприємництва і бізнесу } \\
\text { Тернопільського національного } \\
\text { економічного університету }\end{array}$ & Професійна освіта & 17520 & $1 / 0$ \\
\hline $\begin{array}{l}\text { Мукачівський державний } \\
\text { університет }\end{array}$ & $\begin{array}{l}\text { Професійна освіта } \\
\text { (Економіка) }\end{array}$ & 13000 & $18 / 7$ \\
\hline $\begin{array}{l}\text { ДВНЗ "Херсонський державний } \\
\text { аграрний університет" }\end{array}$ & $\begin{array}{l}\text { Професійна освіта } \\
\text { (Економіка) }\end{array}$ & 12000 & $8 / 0$ \\
\hline
\end{tabular}


Необхідно було визначити: чому ціна отримання кваліфікації у різних закладах освіти $є$ різною?; з чого складається ціна отримання зазначеної кваліфікації; які фактори на це впливають та які з них є визначальними; запропонувати методику розрахунку собівартості надання освітніх послуг зі спеціальності «Професійна освіта», «Економічна та бізнес-освіта»; розробити елементи цінової політики університету; запропонувати шляхи стимулювання попиту абітурієнтів на дану спеціальність.

3 метою популяризації обраного фаху, підвищення практичної складової у підготовці здобувачів були проведені «workshop»и із залученням представника бізнесу - засновника та власника ТОВ «Свротелеком», доктора філософії у галузі державного управління, права П.Г. Булавіна, який також є активним учасником ринку корпоративної освіти. Крім того, здобувачі спеціальності «Економічна та бізнес-освіта» мали можливість (та скористалися нею) з метою забезпечення траєкторії індивідуального розвитку додатково обрати тренінг-курс «Розвиток економічного мислення», де під керівництвом авторки у тренінговому форматі формували й розвивали необхідні характеристики власного економічного мислення.

Протягом семестру аналізувалася динаміка прояву ментальних здібностей у власних портфоліо здобувачів та Контрольній таблиці розвитку економічного мислення, де фіксувалися результати виконання завдань, запропонованих для стимулювання ефективності та продуктивності останнього. Дієвість авторського підходу у визначенні методик, їх комбінації та вплив на риси економічного мислення підтверджується отриманими результатами, а також зростанням продуктивності інтелекту як здатності використовувати розум, щоб творчо відповідати на запитання та вирішувати практичні проблеми [475, с. 5]. В цілому, за начальний семестр відбулися суттєві покращення у роботі всіх десяти основних метальних навичках: числа, слова, логіка, переліки (списки), деталі (подробиці) - зафіксовано, що здобувачі почали більш точно формулювати визначення нових понять, встановлювати взаємозв'язки і підпорядкованість категорій та явищ, будувати послідовності, розраховувати показники 
економічної діяльності та прогнозувати вплив факторів зовнішнього та внутрішнього середовища; зображення, уява, колір, ритм, простір - здобувачі більш активно почали застосовувати кольори та ритм, навіть під час навчання іншим дисциплінам, впроваджувати візуалізації ідей i нових понять, застосовувати асоціативні зображення, системні (узагальнюючі) образи економічної та педагогічної діяльності, бізнес-процесів; продукувати більшу кількість ідей в процесі вирішення задач. До того ж, наприкінці навчання були зафіксовані позитивні зміни у рівні розвитку соціального інтелекту, дослідження якого проводилося за методикою Дж. Гілфорда $[473$, с. 100] (переважна більшість здобувачів показали середній та вище середнього рівні) та у рівні професійної спрямованості (визначався за методикою Т.Д. Дубовицької [473, c. 145]), де були отримані високі показники у 82,1\% респондентів. Така позитивна динаміка відобразилася і в успішності навчання здобувачів (показник склав 95,6\%), а частка найвищих оцінок «відмінно» А становила 28,8\%.

Отже, педагоги в сучасному освітньому просторі у рамках методичної діяльності здатні вирішувати окреслені стратегічні і тактичні завдання з метою формування професійної компетентності здобувачів освіти:

1. визначити компоненти професійної та соціальної компетентності здобувачів з кожної навчальної дисципліни (з врахуванням тенденцій світового ринку праці та запитів роботодавців);

2. відібрати, апробувати та імплементувати методичні інструменти (методи, форми, прийоми, техніки, засоби навчання) у навчальний процес 3 метою формування визначених компетентностей та їх подальшого розвитку протягом всього життя;

3. забезпечити ефективність навчання здобувачів з кожної навчальної дисципліни шляхом комбінації різних методичних інструментів.

Продукування системою освіти нових педагогів інноваційного типу, здатних не просто до самовдосконалення, а й на адаптацію нового до стану засвоєння іншими, дасть можливість суспільству адекватно відповідати на виклики майбутнього; скоротити час, необхідний на засвоєння нових знань, 
умінь і навичок; значно скоротити розрив між науковою фантастикою та реальністю. У дослідженні консалтингового агентства Capgemini освіта буде залишатися у ТОП-10 галузей, де працюватиме найбільша кількість мільйонерів, оскільки, у міру того як росте багатство, все більше людей прагнуть здобувати освіту, яка дозволяє підвищити багатство [476]. Саме педагогі здатні здійснювати суттєвий вплив на формування особистісного потенціалу майбутнього фахівця, центральним компонентом якого є навички мислення та комерційний інтелект - другої, на наш погляд, найважливішої інтегральної властивості особистості, особливо, коли її діяльність пов'язана з економікою. I якщо стратегічно жодних сумнівів не виникає, то тактично є неймовірно широке коло завдань, вирішення яких буде залежати від компетентності самого педагога, його особистих уподобань та віри в ефективність власної методичної системи. 


\subsection{2 Аксіологічні засади формування професійних оріснтирів майбутніх педагогів}

В сучасних умовах розвитку української вищої школи зростає актуальність дослідження потенціалу аксіологічного підходу у професійній орієнтації майбутніх педагогів. Ціннісний вакуум у ситуації соціально-економічної, культурної та освітньої кризи, вимагає наповнення змісту освіти аксіологічною основою, яка дозволить зберегти традиційні духовні цінності вітчизняної психологічної теорії та практики і ефективно використовувати їх в модернізації сучасної української педагогічної освіти.

Впровадження аксіологічного підходу у професійну підготовку майбутніх вчителів, пов'язано з тим, що, по-перше, саме в період навчання у ЗВО майбутній учитель удосконалює власну систему особистісних і професійних цінностей. По-друге, загальна спрямованість ціннісних орієнтацій майбутнього педагога переважною мірою зумовлює формування професійних знань та умінь щодо організації ним навчально-виховної взаємодії з учнями. По-третє, ціннісна проблематика в царині освіти має свою специфіку, що виявляється в іiі прикладному аспекті, оскільки для освітян виникає необхідність не тільки у визначенні провідних для педагогічної взаємодії цінностей, але й у пошуку ефективних засобів їх трансляції молодому поколінні.

У філософському вченні аксіологія тлумачиться як «наука про цінності, їх місці в структурі буття і ставленні до фактів реальності» [477, с.330]. Вперше аксіологічний підхід був використаний у психолого-педагогічній науці в кінці XIX століття і поклав початок вивченню ціннісного феномена людини. Вагомий внесок у розвиток аксіологічного підходу в психології внесли такі вчені як С.Л. Рубінштейн, Е.О. Помиткін, 3.С. Карпенко, І.А. Сікорський, М.В.Савчин, В.А. Сластенін і інші. Вченими даний підхід розглядається як філософськопсихологічна стратегія, що дозволяє реалізувати професійні аксіологічні орієнтації в системі освіти; формувати знання про загальнолюдські, педагогічні й професійні цінності та особистісні здатності, а також дає можливість 
майбутньому вчителю для особистісного і професійного розвитку. У свою чергу реалізація аксіологічного підходу у педагогічному процесі вищого навчального закладу освіти передбачає чітке визначення цінностей як підгрунтя його реалізації, як значимість для майбутніх професіоналів матеріальних, духовних, природних об'єктів, явищ, їх відповідність основним потребам суспільства i окремої особистості.

У студента, який отримує професію педагога, ставлення до професії тісно пов'язано з його особистісними уподобаннями, його безпосередніми емоційними реакціями на ті, чи інші особливості професії, професійні ситуації і взаємодії $з$ представниками професії. Саме тому, виходячи 3 системи особистіснопрофесійних ціннісних орієнтацій, в процесі первинної професіоналізації, не маючи ще практичного досвіду, формується ставлення до професії на емоційному рівні, а такі професійно важливі якості, як автентичність, самопізнання, безоцінність іншого, емпатія, толерантність усвідомлюються як цінності. Цінності $є$ основними детермінантами розвитку професійної спрямованості особистості, адже визнана цінність здатна мобілізувати знання та уміння на виконання найважливішої ціннісної функції - функції орієнтира поведінки і діяльності у відповідності до змісту професійної освіти.

Для формування професійних цінностей студента-педагога визначальною позицією, на нашу думку, буде не просто його особистісна система цінностей, а й ефективне використання цієї системи для розвитку професійно важливих якостей, тому що успішність діяльності педагога буде залежати багато в чому від того наскільки він зможе, орієнтуючись на власну систему цінностей, допомогти учневі зрозуміти наслідки вчинків для його власного житті і благополуччя близьких йому людей.

Низку переконливих аргументів знаходимо в працях М.Савчина, де прекрасно ілюстровано положення про неоціненну роль духовності в особистісно-професійному зростанні та життєдіяльності людини загалом, а також про ті негативні, катастрофічні наслідки, що їх спричиняє нехтування вищими цінностями, серед яких вірі у вищу ідею, вірі у Бога-творця належить 
неоціненна роль: «...сучасна цивілізація спотворила Божественний стан життя суспільства та конкретної людини, що призвело до страшних втрат: руйнування людських стосунків, спотворених уявлень про справедливість та свободу, поверховість життя, породила богоборчі прагнення. Морально-духовні цінності перестали бути головним змістом і внутрішнім рушієм активності людини, яка стала рабом речей, комфорту, прогресу, інформації, а відтак втрати автентичного сенсу життя...» [480, с. 440].

Особливої уваги та високої оцінки щодо ролі психологічної науки у сприянні духовному розвитку особистості, заслуговують праці Е.Помиткіна. Вчений наголошує: «Психологія духовного розвитку повинна взяти на себе значну частину функцій орієнтації людства на вищі ідеали, загальнолюдські цінності. Для цього бачиться необхідним теоретичне обгрунтування критеріїв духовності, психологічних закономірностей духовного розвитку, конкретизація духовних ідеалів і цінностей»[479, с.154 ]. У своєму баченні цього завдання дослідник виходить із державницьких позицій, із врахування актуальної потреби у духовному відродженні України.

Духовно досконала особистість не тільки усвідомлює вирішальне значення моральності у людських взаєминах, у розвитку суспільства на гуміністичних засадах, але й активно утверджує моральне начало у повсякденному житті - у ставленні до інших людей, до себе самої. Таким чином, суттєвою характеристикою професійного розвитку майбутнього педагога $є$ дієвість, конструктивно-перетворювальна сила ціннісних орієнтацій, якими вона володіє. Без такої дієвості можна говорити хіба що про певний рівень обізнаності людини 3 системою духовних цінностей. Зрозуміло, що така обізнаність $є$ вельми важливою, однак зовсім недостатньою умовою, щоб суттєво впливати на реальну поведінку, діяльність іншої людини. Тут має місце співвідношення між етичними знаннями та моральними переконаннями.

В. Франкл розглядав цінності як смислові універсалії, які узагальнюють досвід людства. На його думку, завдяки цінностям людина може зробити своє життя осмисленим. Він описав три класи цінностей: цінності творчості (праця); 
цінності переживання (любов) і цінності відносини (свідомо вироблена позиція в критичних життєвих обставинах, які неможливо змінити) [482].

Як бачимо, усі сучасні напрями психології вбачають основне покликання психологічної та педагогічної науки і практики, соціальної роботи в навчанні людей жити згідно з ідеалами гуманізму, змістовно і щасливо, щоб «кожен своїм шляхом дійшов того самого висновку, який узагальнено можна сформулювати так: провідним чинником гармонійного, піднесеного, натхненного, оптимістичного стану людини є іiі духовність - внутрішня, автентична віра, любов, надія, свобода» [478, с.285]. Тільки особистості з розвиненою духовністю та екзистенційною свободою і відповідальністю можуть утворити й утвердити гармонійні стосунки, конструктивну педагогічну взаємодію, розбудовувати в усіх вимірах українське прогресивне суспільство загалом.

Спираючись на вище наведені положення, можна стверджувати, що професійна діяльність $є$ одним 3 істотних факторів, що впливає на систему цінностей людини. Педагогічна діяльність включає всю сукупність конкретних педагогічних явищ, які поєднуються приналежністю до цілеспрямованого процесу формування особистості людини. Педагогічні явища (суб'єкти освітнього процесу, його зміст, засоби, форми і ін.) якісно відрізняються за змістом, визначеністю, що і зумовлює їх педагогічну цінність. 3 огляду на це, цінності педагогічної діяльності необхідно розглядати, як ті особливості, які дозволяють вчителю задовольняти свої матеріальні та духовні потреби та слугують орієнтиром для його особистісного та професійного розвитку, спрямованого на досягнення соціально значущих морально-духовних цілей.

До цінностей педагогічної діяльності, на нашу думку, слід віднести такі групи цінностей, які виявляються: утвердженні в професійному середовищі та міжособистісній взаємодії (соціальна значимість роботи вчителя, престиж професійної діяльності, визнання родичами та друзями, тощо); задоволенні потреби у спілкуванні (робота 3 дітьми, можливість спілкування $з$ цікавими людьми, обмін духовними цінностями); самовдосконаленні (можливість розвитку творчих здібностей, ознайомлення з духовною культурою, постійне 
поповнення своїх знань); самовираженні (творчий та різноманітний характер роботи вчителя, відповідність педагогічної діяльності інтересам та здібностям особистості тощо.

Говорячи про формування ціннісного ставлення до своєї майбутньої професії, можна послатися на думку В.А. Сластьоніна, який пише наступне: «Педагогічні цінності - це норми, що регулюють педагогічну діяльність та виступають як пізнавальна та ефективна система, яка служить сполучною ланкою між суспільним світоглядом у галузі освіти та діяльністю вчителя »[481, c.92].

Автор зазначає, що, «педагогічні цінності відрізняються рівнем свого існування, що може стати основою для їх класифікації» та виділяє наступні групи цінностей:

- Соціально-педагогічні цінності відображають природу і зміст тих цінностей, які функціонують у різних соціальних системах і з'являються в суспільній свідомості. Це сукупність ідей, уявлень, норм, правил, традицій, що регулюють діяльність суспільства у галузі освіти.

- Групові педагогічні цінності можуть бути представлені у формі ідей, концепцій, норм, що регулюють та спрямовують педагогічну діяльність у межах певних навчальних закладів. Сукупність таких значень має цілісний характер, відносну стабільність і повторюваність.

- особистісно-педагогічні цінності виступають як соціально-психологічні утворення, що відображають цілі, мотиви, ідеали, установки та інші ідеологічні характеристики особистості вчителя, представляючи систему його ціннісних орієнтацій [481]

Отже, педагогічна діяльність $є$ аксіологічна за своїм характером і повинна бути одухотворена моральним, гуманістичним сенсом.

Слід наголосити, що для виявлення ціннісних орієнтирів подальшого розвитку освіти необхідно систематизоване аксіологічне знання та створення педагогічно керованого науково-освітнього середовища, здорового психологічного клімату, ситуації успіху кожного студента, гармонізацію 
емоційного й інтелектуального факторів навчання, аксіологічної й особистісної спрямованості педагогічних знань, структурування їх у вигляді проблемної ситуації та розв'язання мисленнєвих задач на основі педагогічної взаємодії, співробітництва й співтворчості викладачів і студентів.

Формування особистості майбутнього майбутнього вчителя не обійдеться і без виховання у нього любові і шанобливого ставлення до своєї професії, почуття гордості за свій навчальний заклад, за обрану професію. Викладач в очах студента повинен виглядати цікавою особистістю, постійно невимушено демонструючи власну комунікабельність, товариськість, природність, ерудованість, професіоналізм, небайдужість до проблем студента і до власної педагогічної діяльності, в кожному сказаному слові якого повинна бути присутньою пристрасть і бажання навчити студента всьому, що він знає сам. Забезпечення етапності, систематичності та безперервності оволодіння майбутніми педагогами понятійним апаратом теорії наукових досліджень, особливо науковою етикою, досвідом практичної перетворювальної діяльності створює сприятливі умови для ціннісного саморозвитку студента, становлення його морального світогляду і засвоєння професійних цінностей.

На нашу думку, продуктивно i творчо буде працювати 3 молодим поколінням лише той учитель, який відчуватиме власну психологічну захищеність через співпричетність до унікального поля професійної культури, орієнтованої на аксіологічний підхід в системі освіти.

Якщо вести мову про психолого-педагогічні дисципліни, то тут актуалізація ціннісного потенціалу повинна реалізуватися через надання особистісного смислу отриманим знанням, через їхню проблематизацію, взаємодію педагогічної теорії й особистого досвіду студентів. Це формує позитивно-емоційне ставлення до цінностей обраної професії та педагогічної діяльності.

Зорієнтованість мети професійної освіти на формування особистіснопрофесійних цінностей дає можливість створення аксіологічної моделі 
формування ціннісних орієнтацій майбутнього вчителя, яка буде включати в себе наступні компоненти:

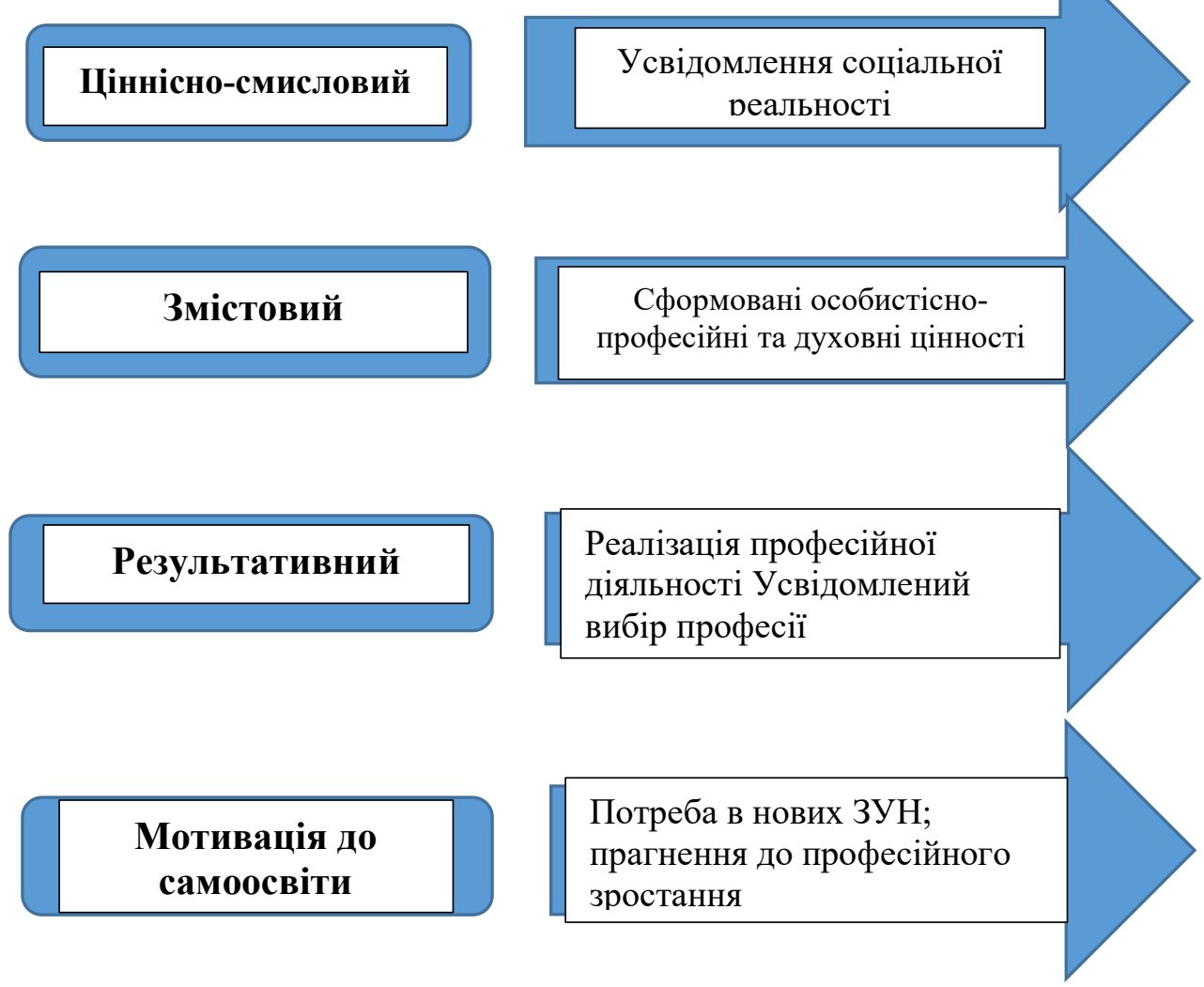

Рис 1. Аксіологічний еталон моделі майбутнього вчителя

Вказана модель випускника являє собою сукупність еталонних і реальних складових, що характеризують формування ціннісної ієрархії особистості на етапі професіоналізації й відображають взаємодію з соціокультурним, освітньопрофесійним середовищем.

Охарактеризуємо особливості формування кожного із компонентів визначеної аксіологічної моделі.

Будучи одним 3 центральних новоутворень особистості, ціннісні орієнтації, виражають свідоме ставлення студента-педагога до соціальної дійсності і визначають широку мотивацію іï поведінки, а також істотно впливають на всі сторони його дійсності.

Під час вивчення фахових дисциплін студент залучається до особливого ціннісного контексту - системи знань, уявлень, ставлень про взаємини дитини і 
дорослого, учня і вчителя, вихователя й вихованця. Саме тому, реалізація гуманістичного принципу аксіологічного підходу, в процесі професійнопедагогічної підготовки майбутнього вчителя, має бути спрямована на оволодіння здатності сприймати учня як цінність. Для цього майбутній вчитель повинен знати: вікові особливості фізичного, психофізіологічного, психологічного та особистісного розвитку дитини; рівень індивідуального розвитку та їх відповідність віковим нормам.

Засвоєння норм і правил поведінки професіонала, який у центрі діяльності бачить особистість дитини, має відбуватися через власну пізнавальну активність і творчість, через діяльність - знаково-символічну й предметну, імітаційну, ігрову, квазіпрофесійну. У цьому ціннісному вимірі студент, як індивід, що самовизначається й самореалізується, оволодіває власним реальним баченням аксіологічного змісту педагогічного знання, навчається робити моральноетичний вибір, прогнозувати результати власної діяльності, здійснювати систематичну рефлексію та самооцінку своєї аксіологічної позиції.

Ціннісно-змістовий компонент характеризується спрямованістю і змістом активності особистості, а також визначає загальний підхід людини до світу і до себе, надає сенс і напрямок особистісним позиціям, поведінці, вчинкам.

Змістова сторона спрямованості особистості майбутнього вчителя, становить основу іiї відносин, ядро мотивації, життєвої концепції і сенсу життя. Через ціннісні орієнтації виражається ставлення людини до навколишньої дійсності, формується здатність вірити, любити, творити добро, бути вільним та відповідальним, прагнення до самоактуалізації, самовдосконалення та самореалізації

Розвинені особистісно-професійні цінності виступають орієнтирами, на основі яких майбутній педагог, освоює і виконує свою професійну діяльність. Вони характеризуються ступенем домінування, ступенем усвідомленості і ступенем мінливості. Саме через спрямованість особистості, ії ціннісні орієнтації знаходять своє реальне відображення в діяльності людини і актуалізуються в формуванні професійних цінностей. 
Сформованість результативного компоненту забезпечить цілісність і стійкість особистості, утворюючи загальну спрямованість іiї інтересів і прагнень, певну ієрархію індивідуальних переваг, формування морально-духовного рівня розвитку особистості.

Вельми суттєвим моментом у цьому відношенні є мотивація праці: важливо, щоб людина ставилася до праці не лише як до засобу матеріального забезпечення, а й усвідомлювала та відчувала благородний вплив самого процесу праці на іiі психічний розвиток, на вдосконалення психічних функцій, на формування моральної свідомості та самосвідомості. Праця, яка усвідомлюється майбутнім педагогом найперше в іiі особистісному, аскіологічному сенсі, є невичерпним джерелом морально-духовного збагачення й моральної, особистісної та академічної зрілості. Саме академічна зрілість, яка виявляється у свідомості студентів, як інтегральна цінність, дозволяє усвідомлювати бажані цінності, які в підсумку складають основу професійних цінностей.

Отже, ціннісні орієнтації можна визначити як спрямованість суб'єкта на діяльність і певні цінності, які можуть бути сформовані вже в процесі цієї діяльності.

Професійна практична діяльність педагога є особливим видом соціальної активності, де узагальнені ідеї про цінність людини гранично конкретизуються і персоніфікуються в його словах і діях, спрямованих на іншу людину. Особистість, проявляє якості «актуалізатора», здатного найбільш успішно впоратися з завданням створення оптимістичного персоніфікованого образу іншої людини. Важливою якістю, якою повинен володіти майбутній педагог $\epsilon$ так званий деонтологічний менталітет, основу якого складають цінності, що визначають етичні мотиви i способи діяльності безвідносно до інституціалізованих стандартів.

Мотивація до самоосвіти - це той фактор, який сприяє розвитку професійної спрямованості, структурування своєї поведінки і діяльності відповідно до професійного змісту освіти. Саме тому, вчитель повинен прагнути до формування професійних, освітніх, комунікативних і загальнокультурних 
компетенцій, а основним пріоритетом освітньої діяльності повинно бути визнання фізичного, психічного, психологічного, соціального та моральногодуховного здоров'я особистості.

Тепер стає зрозумілим, що аксіологічний підхід дозволяє визначати стратегію і перспективи розвитку педагогічної вищої освіти, розкривати особистісний та морально-духовний потенціал і змістовне наповнення освіти на основі цінностей. В нашому дослідження важливим був опис контенту навчання майбутнього педагога на основі загальнолюдських та особистісних цінностей, який дозволить сформувати особистісно-професійні цінності студентів.

Впровадження аксіологічного підходу в зміст вищої професійної освіти дає можливість прояву нової спрямованості в освіті, скасовує підготовку «безликих» кваліфікованих кадрів, сприяє створенню результативності в загальному i професійному розвитку особистості майбутнього фахівця. На сьогодні, $є$ безперечним, що від змісту і характеру спрямованості особистості залежить вирішення соціальних, культурних та освітніх питань, а також безпеку людини i життєдіяльність суспільства в цілому.

Необхідність актуалізації аксіологічного підходу до формування змісту вищої професійної освіти в контексті модернізації обумовлено також потребою створення умов для формування єдиної гуманістичної системи цінностей як основи світогляду сучасних студентів, адже, професійних успіх багато в чому залежить від того, наскільки для студента цінною видається виконувана ним професійна діяльність.

Таким чином, опора на аксіологічний підхід в педагогічній теорії і практиці означає, що в сфері освіти все чіткіше фіксуються морально-духовні та загальнолюдські ціннісні пріоритети, а орієнтація професійної освіти спрямована на формування у студентів системи особистісних і професійних цінностей, які визначають їх ставлення до світу, до своєї діяльності, до самого себе як особистості та професіонала. 
DOI 10.46299/ISG.2021.MONO.PED.II-523-531

\subsection{3 Методичні засади використання фізико-технічних відкриттів в курсі медичної та біологічної фізики майбутніх лікарів}

Історичний розвиток медицини постійно і зростаючими темпами зазнає закономірного впливу базових фундаментальних природничих дисциплін. Безумовно, що основною серед фундаментальних наук є фізика, яка займає (з XVII ст. ) лідируючі позиції, а згодом біофізика та медична фізика (з XIX-XX ст. ), як прикладні розділи фізики, в яких фундаментальні закони та досягнення фізики застосовуються для пояснення процесів, що відбуваються у медико - біологічних системах, зокрема - людському організмі, з метою їх використання для вирішення практичних завдань медицини, перш за все, системи охорони здоров'я людини [483].

Варто зазначити, що завдячувати потрібно вченим фізикам, біологах, фізіологам, медикам, наукові відкриття яких, дали поштовх в розвитку медицини. Серед лауреатів Нобелівської премії в галузі медицини та фізіології є багато вчених фізиків - Арчібальд Хілл (1922рік, Англія) - за відкриття у галузі теплотворення м'язів, Георг Бекеші (1961рік, Угорщина) - за відкриття фізичних механізмів подразнення равликом, біофізик Моріс Вілкінс (1962рік, Англія) - за відкриття, що стосуються молекулярної структури нуклеїнових кислот та їх значення для передачі інформації у живій матерії, біофізик Алан Ходжкін (1963рік, Англія) - за відкриття іонних механізмів, що беруть участь у збудженні та гальмуванні. Макс Дельбрук (1969рік, США) - за відкриття механізмів реплікації і генетичної структури вірусів, Розалін Ялоу (1977рік, США) - за розвиток радіологічних методів визначення пептидних гормонів, А. М. Кормак (1979 рік, США) та Годрі Хаунсфілд (1979, Англія) - за розробку методів рентгенівської комп'ютерної томографії, Девід Хьюбелл (1981 рік, США) - за відкриття, пов’язані з обробкою інформації у зоровому аналізаторі. Пітер Менсфілд (2003 рік, Великобританія,) та хімік і біофізик Пол Лотербур (2003 рік, США) за дослідження в галузі магнітнорезонансної томографії [484].

3 іншого боку, існують беззаперечні історичні факти про те, що професором медицини Гілбертом ( XVII ст., Англія) були закладені основи магнітостатики, і в 
той же час лікарем Гальвані (XVII ст., Італія) закладений початок розвитку уявлень про електричні поля в біологічних системах, так звана «тваринна електрика», що в результаті призвело до створення електромагнітної теорії у працях фізиків Фарадея та Максвелла.

Професор медицини Даніель Бернуллі та математик Леонард Ейлер (середина XVII ст, Швейцарія) заклали основи гідродинаміки. Професор медицини Томас Юнг (початок ХІХст, Англія) розробив хвильову теорію світла, ввів поняття механічної енергії та модуля пружності, а професор медицини Жан Пуазейль та німецький фізик Готтгільф Гаген (середина ХІХст, Франція, Німеччина) описали закон руху рідини, що використовується для визначення в'язкості і швидкості руху в капілярних трубках. Лікар Юліус Роберт Майер, фізик Джеймс Джоуль та фізик і лікар Герман Гельмгольц в середіні XIX століття відкрили закон збереження енергії- універсальний закон перетворення енергії у живій природі. Це і $є$ відповідь на питання, а що ж медики зробили для розвитку фізики на початковому етапі iї становлення, і звісно ж всі вони достойні найвищої відзнаки і в галузі фізики, поєднання знань 3 фізики і медицини привели вчених до фундаментальних відкриттів.

Історично від початку елементарного фізичного дослідження в стародавній Греції, поняття «фізюс» означало дослідження природи і перші лікарі, які мали справу з природою здоров'я чи захворювання людини, також називали себе «фізюс» [485]. В ті часи не існувало істотної диференціації на фізиків і медиків (вчені одночасно були і лікарями і фізиками), що дало можливість стрімко розвиватись і фізичній і медичній науці паралельно, створюючи природничонаукові теорії на основі єдиних принципів існування та розвитку всього матеріального світу як для опису явищ неживої природи (неорганічного світу), так і живої природи (органічного світу).

Сьогодні, спостерігається все більша диференціація наук, і майбутній лікар, має можливість ознайомитись 3 фізико-технічними відкриттями вчених на двох рівнях: допрофесійної підготовки (ЗСО) та професійної підготовки (3ВО), що відповідає принципу неперервності освіти при підготовці фахівців медичної галузі. 
В допрофесійній підготовці учні 10-11 класів можуть обрати природничоматематичний напрям профільного навчання в середніх навчальних закладах (академічних ліцеях) Природничо-математичний напрям профільного навчання включає в себе такі навчальні профілі: фізико-математичний, хіміко - біологічний, хіміко - фізичний. Профільне навчання забезпечує створення оптимальних умов для виявлення задатків, нахилів і здібностей кожного учня, та створення умов відповідно до їхнього самовизначення та професійної орієнтації.

Обираючи один із навчальних профілів природничо-математичного напрямку, майбутнім фахівцям медичної галузі ми рекомендуємо обрати цикл курсів «Біологічна і медична фізика» (рекомендований МОН України, 2019 рік):

- Вступ до біофізики. Біомеханіка твердих тіл і рідин»,

- Фізичні основи гемодинаміки. Термодинаміка. Фізичні процеси в біомембранах.

- Електрика і магнетизм в медицині.

- Механічні коливання і хвилі. Акустика. Оптика. Елементи квантової біофізики і основи дозиметрії.

Цикл курсів передбачає поглиблення і розширення пізнавальних інтересів учнів, формування наукового світогляду учнів, ознайомлення 3 історією відкриттів та сучасними напрямками розвитку медичної та біологічної фізики, забезпечення прикладної і початкової професійної спеціалізації навчання.

На етапі професійної підготовки студенти 1 курсу вищих медичних закладів вивчають дисципліну «Медична та біологічна фізика», де передбачено вивчення явищ живої природи, які відбуваються на всіх іiі рівнях організації, починаючи від молекул і клітин та закінчуючи біосферою в цілому; механізмів дії зовнішніх полів на організм людини, які лежать в основі функціонування сучасної електронної медичної апаратури та визначають головні принципи їі роботи і використання [486 - 488]. Діючою програмою ( 2019 р.) передбачено вивчення наступних змістових модулів:

- Основи математичної обробки медико - біологічних даних

- Основи біологічної фізики 
- Електронна медична апаратура

- Основи медичної оптики та радіаційної медицини

У відповідності до закону України «Про вищу освіту» пріоритетним напрямком $\epsilon$ професійно-орієнтоване навчання, яке визначає компетентність як динамічну комбінацію знань, умінь і практичних навичок, способів мислення, професійних, світоглядних і громадянських якостей, морально-етичних цінностей, що формує здатність особи здійснювати професійну діяльність [489].

Для реалізації завдань професійно-орієнтованого навчання нами створена структурно - функціональна модель: «Методичні засади використання фізикотехнічних відкриттів у навчанні медичної та біологічної фізики майбутніх лікарів. В даній моделі (Рис. 1) запропоновані, на нашу думку, найбільш ефективні, дві сучасні технології навчання, які дозволяють розкрити питання фізико-технічних відкриттів та їх використання як у допрофесійній так і в професійній підготовці майбутніх лікарів. До них належать: кейс - метод та презентації наукових трендів.



Рис.1. Структурно-функціональна модель реалізації методичних засад використання фізико-технічних відкриттів у навчанні медичної та біологічної фізики майбутніх лікарів. 
Кейс метод (Case study- метод аналізу ситуацій ) є ефективним методом вивченні фундаментальних наук в медицині, зокрема в біологічній і медичній фізиці, яка може стати початковим етапом застосування методу аналізу ситуацій у навчанні майбутніх лікарів. Використання методу Case study на практичних заняттях за змістовими модулями «Основи біологічної фізики», «Електронна медична апаратура», «Основи медичної оптики та радіаційної медицини» дозволяє підвищити пізнавальний інтерес до дисципліни, сприяє розвитку дослідницьких, творчих навиків i набуття професійних компетенцій студентів-медиків. Особливою рисою методу є створення проблемної ситуації на основі фактів 3 реального наукового життя фізиків, що здійснили відомі відкриття в науці. Шлях до відкриття пов'язаний з науковою діяльністю не одного покоління вчених, де кожен робить свій внесок, не завжди оптимальний, але в повній мірі той, що прискорює відкриття. Case study в конкретних ситуаціях, які розроблені 3 фактичного матеріалу, саме занурення в історію відкриттів, розгляд конкретних ситуацій, які привели до відкриття, дає можливість на практичних заняттях зі студентами перейти від істини плюралістичної до істини, що дає однозначну відповідь на поставлене питання. Метод дає можливість акцент навчання переносити не лише на оволодіння готовими знаннями, а на їх вироблення, на спільну партнерську роботу студента та викладача, який від трансляції знання, що характерно класичному навчанню, переходить до управління дослідницькою і пошуковою роботою студента. Результатами застосування методу $є$ не тільки знання, але й навики професійної діяльності. Метод Case study розвиває такі професійні компетенції особистості майбутнього лікаря, як здатність до аналізу і діагностики проблем, вміння чітко формулювати і висловлювати свою позицію, спілкуватися, дискутувати, сприймати й оцінювати інформацію, яка надходить у вербальній і невербальній формах.

Для розвитку інтересу та формуванню умінь самостійно здобувати знання студентам, використовуючи метод Case study у навчанні «Медичної та біологічної фізики», можна запропонувати теми вивчення наукових відкриттів таких вчених: «Ернст Вебер та Густав Фехнер - творці психо-фізичного закону 
сприйняття звуку», «Томас Юнг - творець хвильової теорії світла», «Даніель Бернуллі та Леонард Ейлер - творці основ гідродинаміки.,«Юліус Роберт Майер, Джеймс Джоуль та Герман Гельмгольц - відкривачі закону збереження енергії», «Вільям Ейнтховен - творець методу електрокардіографії», «Алан Кормак та Годрі Хаунсфілд - творці методу рентгенівської комп’ютерної томографії», «Пітер Менсфілд та Пол Лотербур - творці методу магнітно-резонансної томографії.» та інші. Однією з найкращих форм використання методу Case study при вивченні фізико - технічних відкриттів є кейси-спогади, які характерні тим, що в них час прокручується назад, що дає можливість аналізу ситуації в минулому, хоч самі спогади можуть бути безсистемні, фрагментарні, що створює певні труднощі з відновленням подій. Аналіз кейса зводиться до реконструкцій ситуацій, її осмислення в аспекті тієї чи іншої парадигми.

В теорії і практиці даного питання важливе місце займають види аналізу кейсів: проблемний, причинно-наслідковий, прагматичний, аксіологічний, ситуаційний, прогностичний, програмно-цільовий. Формально можна виділити такі етапи кейсу: ознайомлення студентів 3 текстом кейсу, аналіз кейсу, організація обговорення кейса, дискусії, презентації, оцінювання учасників дискусії і підведення підсумків дискусії. Практика підтверджує, що найчастіше ознайомлення 3 текстом кейсу здійснюється до обговорення і реалізується як самостійна робота студентів, де в першу чергу, слід виявляти ключові проблеми кейсу та зрозуміти, які саме з представлених даних важливі для його вирішення. Завершальним етапом методу Case study є оцінювання учасників, враховуючи дидактичні принципи навчання: об’єктивність, обгрунтованість, систематичність, всебічність, оптимальність. Метод Case study - це особливий і гнучний педагогічний ресурс або універсальний засіб для реалізації завдань професійно-орієнтованого навчання і є однією з сучасних ефективних технологій навчання при вивченні фізико-технічних відкриттів у навчанні майбутніх лікарів [490].

Презентації наукових трендів $є$ ефективним методом сучасних технологій навчання. Однією з традиційних форм організації навчання студентів медиків у 
ЗВО залишається лекція, що є дієвим способом передавання знань. Сучасну лекцію ми вже не уявляємо без використання презентації, яка включає в себе три основні компоненти: промова лектора, слайди, додаткові матеріали (студент отримує індивідуально список літератури та інших посилань, що містять деталі інформації, що презентуються). Головним в презентації є промова лектора, а зображення на екрані є допоміжним. Презентації дають можливість поєднувати слайди різного змісту і форми, які мають бути наповнені науковими трендами (тенденціями в наукових відкриттях). Використання презентацій наукових трендів на практичних заняттях також забезпечує обсяг і глибину знань з фізикотехнічних відкриттів в медичній галузі та формує у студентів вміння та навички досліджувати та експериментувати. Для прикладу, пропонуємо тенденції розвитку досліджень в діагностичній радіології, які можуть стати базовими для використання кейс-методу та в підготовці презентацій наукових трендів:

\begin{tabular}{|c|c|}
\hline Рік & Зміст відкриття \\
\hline $1859 \mathrm{p}$. & $\begin{array}{l}\text { Німецький математик і фізик Ю. Плюккер досліджував катодні } \\
\text { промені та їх відхилення в магнітному полі }\end{array}$ \\
\hline $\begin{array}{l}1881- \\
1889 p p .\end{array}$ & $\begin{array}{l}\text { Український фізик І. Пулюй (одноліток К Рентгена) сконструював } \\
\text { катодну лампу, яка привела до відкриття X - променів, досліджував } \\
\text { іонізуючу їх здатність, природу і механізм утворення. І. Пулюй } \\
\text { опублікував статтю з описом катодної трубки, що випромінює Х - } \\
\text { промені, а Лондонське фізичне товариство надрукувало його } \\
\text { монографію про катодні промені }\end{array}$ \\
\hline $1895 \mathrm{p}$ & 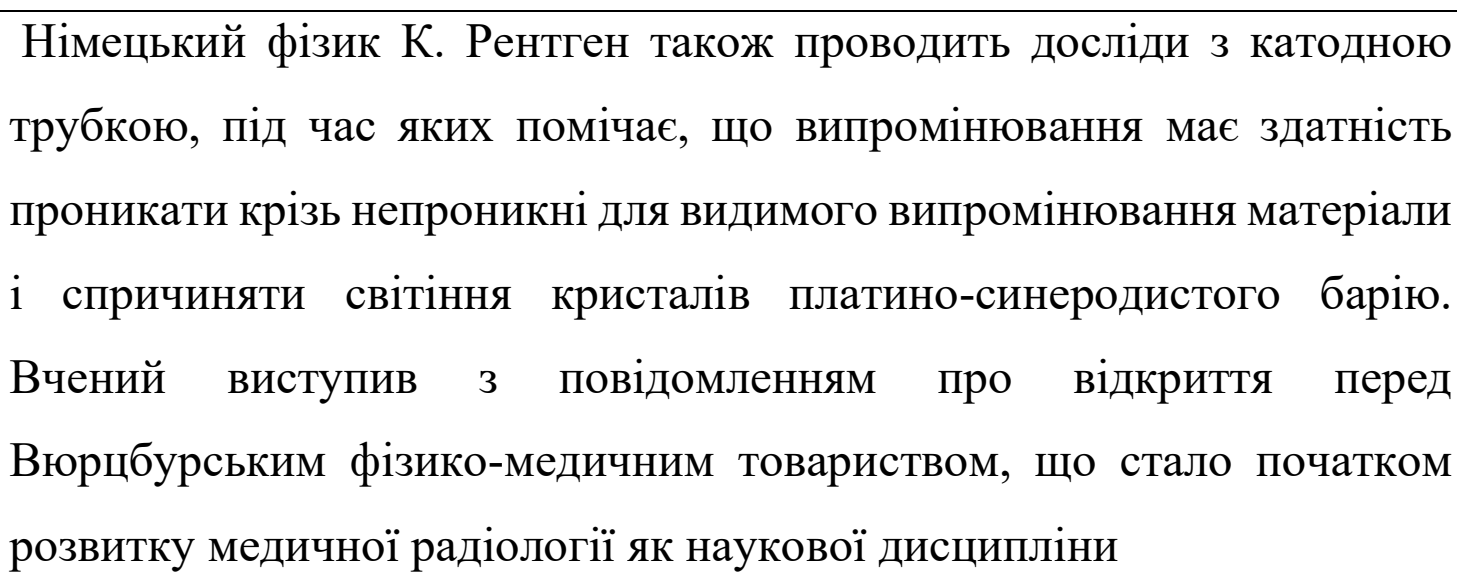 \\
\hline
\end{tabular}




\begin{tabular}{|c|c|}
\hline $1901 \mathrm{p}$. & $\begin{array}{l}\text { К. Рентген отримав першу в історії Нобелівську премію з фізики за } \\
\text { відкриття Х-променів, які потім за рішенням. Першого міжнародного } \\
\text { з'їзду з рентгенології назвали рентгенівськими }\end{array}$ \\
\hline $912 \mathrm{p}$. & $\begin{array}{l}\text { Німецький фізик Макс фон Лауе в дослідах } 3 \text { інтерференції та } \\
\text { дифракції показав, що рентгенівське випромінювання } \\
\text { електромагнітним і відрізняється від світла лише меншою довжиною } \\
\text { хвилі }\end{array}$ \\
\hline 1914 p. & $\begin{array}{l}\text { он Лауе отримав Нобелівську премію за відкриття дифракції } \\
\text { івських променів на кристалах }\end{array}$ \\
\hline 1939 p. & $\begin{array}{l}\text { Американський фізик Ернесто Лоуренс } \quad \text { запропонував } \\
\text { використовувати прискорення елементарних частинок для надання їм } \\
\text { високих енергій і створює циклотрон, що став одним } 3 \text { джерел } \\
\text { отримання штучних радіоактивних елементів і отримав Нобелівську } \\
\text { премію з фізики за цей винахід }\end{array}$ \\
\hline 1944 p. & $\begin{array}{l}\text { ик Е.К. Завойський відкрив явище електронного } \\
\text { резонансу }\end{array}$ \\
\hline $6 \mathrm{p}$. & $\begin{array}{l}\text { Американські фізики Ф. Блох та Е.М. Парселл незалежно один від } \\
\text { одного дослідили ядра деяких атомів в магнітному полі, які під дією } \\
\text { зовнішнього ЕМП здатні поглинати енергію, а потім випромінювати } \\
\text { ії у вигляді радіосигналу }\end{array}$ \\
\hline $1952 \mathrm{p}$ & $\begin{array}{l}\text { мериканські фізики Ф. Блох та Е.М. Парселл отримали Нобелівську } \\
\text { ремію за відкриття фундаментального фізичного явища - ядерного } \\
\text { агнітного резонансу }\end{array}$ \\
\hline 1963 p. & $\begin{array}{l}\text { В журналі з прикладної фізики з'явилася стаття маловідомого тоді } \\
\text { американського фізика } \text { А. Кормака, в якій він запропонував } \\
\text { математичний метод для визначення поглинання рентгенівських } \\
\text { променів біологічними тканинами, котрий пізніше, після появи } \\
\text { швидких комп'ютерів, отримав назву КТ-скануванням }\end{array}$ \\
\hline
\end{tabular}




\begin{tabular}{|c|c|}
\hline p. & $\begin{array}{l}\text { Англійський фізик-інженер } Г \text {. Хаунсфілд, розробив схожу } \\
\text { яатематичну модель для гамма }- \text { променів, використовуючи } \\
\text { Іотужніший комп'ютер для обробки інформації }\end{array}$ \\
\hline 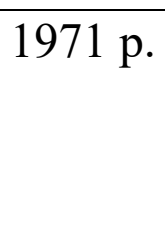 & $\begin{array}{l}\text { Зстановлений перший клінічний томограф в Уімблдонському } \\
\text { шпиталі (Великобританія) і почалися дослідження хворих } 3 \\
\text { гухлинами мозку та іншими захворюваннями }\end{array}$ \\
\hline $3 n$ & $\begin{array}{l}\text { В журналі «Nature» з'явилася стаття американського хіміка і } \\
\text { біофізика П. Лотербура про створення зображення за допомогою } \\
\text { індукованої локальної взаємодії неоднорідного магнітного поля } 3 \\
\text { ядрами атомів. Це дозволило П. Лотербуру створити перший } \\
\text { магнітно-резонансеий томограф. }\end{array}$ \\
\hline 1979 p. & $\begin{array}{l}\text { ериканський фізик А. М. Кормак та англійський фізик } \\
\text { Каунсфілд отримали Нобелівську премію в галузі фізіології та } \\
\text { дицини за розробку рентгенівської комп’ютерної томографії. }\end{array}$ \\
\hline $03 p$ & $\begin{array}{l}\text { Британський фізик П. Менсфілд та американський біофізик П. } \\
\text { Лотербур отримали Нобелівську премію за дослідження в галузі } \\
\text { магнітно-резонансної томографії }\end{array}$ \\
\hline
\end{tabular}

Важливою функцією наукових трендів $є$ своєчасне ознайомлення студентів з сучасними тенденціями розвитку, зокрема, в діагностичній радіології спираючись на інформаційні технології, які розвиваються і впливають на суспільне життя, за допомогою мобільних гаджетів можна забезпечити прямий зв’язок пацієнта з віддаленим центром діагностики. Сучасним трендом в радіології є вирішення проблеми консультацій пацієнтів на відстані, яким займається телемедицина, як один 3 напрямків практичної медицини, що тісно пов’язаний з сучасними цифровими технологіями і розвивається дуже швидкими темпами в світі [491].

Запропонована нами модель включає навчання учнів та студентів на всіх етапах підготовки, $€$ ефективною $\mathrm{i}$ позитивно впливає на формування професійних компетентностей сучасних лікарів. 
DOI 10.46299/ISG.2021.MONO.PED.II-532-544

\subsection{4 Компьютер - оқушының математиканы оқып-білу іс-әрекетінің негізгі бір құралы}

Жаңа ақпараттық технологиялар дегеніміз - білім беру ісінде ақпараттарды даярлап, оны білім алушыға беру үрдісі. Бұл үрдісті іске асыруда негізгі құрал компьютер болып табылады. Компьютер - білім беру ісіндегі бұрын шешімін таппай келген жаңа, тың дидактикалық мүмкіндіктерді шешуге мүмкіндік беретін зор құрал. Бірақ, әлі күнге дейін біз осы зор құралдың шексіз мүмкіндіктерінің оннан бірін де пайдалана алмай отырмыз.

Жаңа ақпараттық технологияларды тиімді түрде пайдаланудың негізгі шарты - дербес компьютерлердің орны мен рөлін дұрыс анықтау болып табылады, ол информатика сабағында ғана қолданылумен шектелмеуі тиіс.

Компьютерді оқу үрдісінде қолдану проблемаларының ішінен екі бағытты бөліп алуға болады, олардың біріншісі - компьютерлік сауаттылықты қамтамасыз ету, бұл жағдайда компьютер зерттеу объектісі болып табылады, екіншісі - компьютерді оку құралы ретінде пайдалану.

Екінші бағыт шеңберінде компьютер оқыту құралдары жүйесінің белгілі бір компоненті деп есептеледі.

Оқытудың осындай құралдар жүйесі оқу әдістемелік әдебиет пен курсты программалық қамтамасыз ету жағынан оқу-әдістемелік кешен (ОӘК) болып табылады. Мұнда ЖАТ пайдалану құралы болып табылатыны сөзсіз. И.В.Роберт атап өткендей, ОӘК компонеттерінің құраушыларының қатынасын және оның құрамын анықтау - келешектің ісі [492].

Математиканы оқып үйренуге арналған ОӘК -нің жобамен анықталған құралы 2- суретте көрсетілген.

Әдеттегі оқу құралдарын пайдаланудың қажеттілігі арнайы функцияларды қажет етеді, ал оны компьютердің мойнына жүктеу тиімсіз болады.

Мысалы, оқушылардың есінде сақтауға қажетті формулаларды, жүйеленген теориялық және анықтамалық мәліметтерді кестелер мен сызба түрінде ұсыну керек. Әрбір сабақта жүйелі түрде кестеде көрсетілген материалды оқушы жаттай береді. Компьютер бұл жағдайда тиімсіз болады. Егер 
анықтамалық материал қысқа мерзім ішінде пайдалануға қажет болса және есте сақтауды қажет етпесе, онда ақпараттық-іздестіру жүйесін қолданған дұрыс.

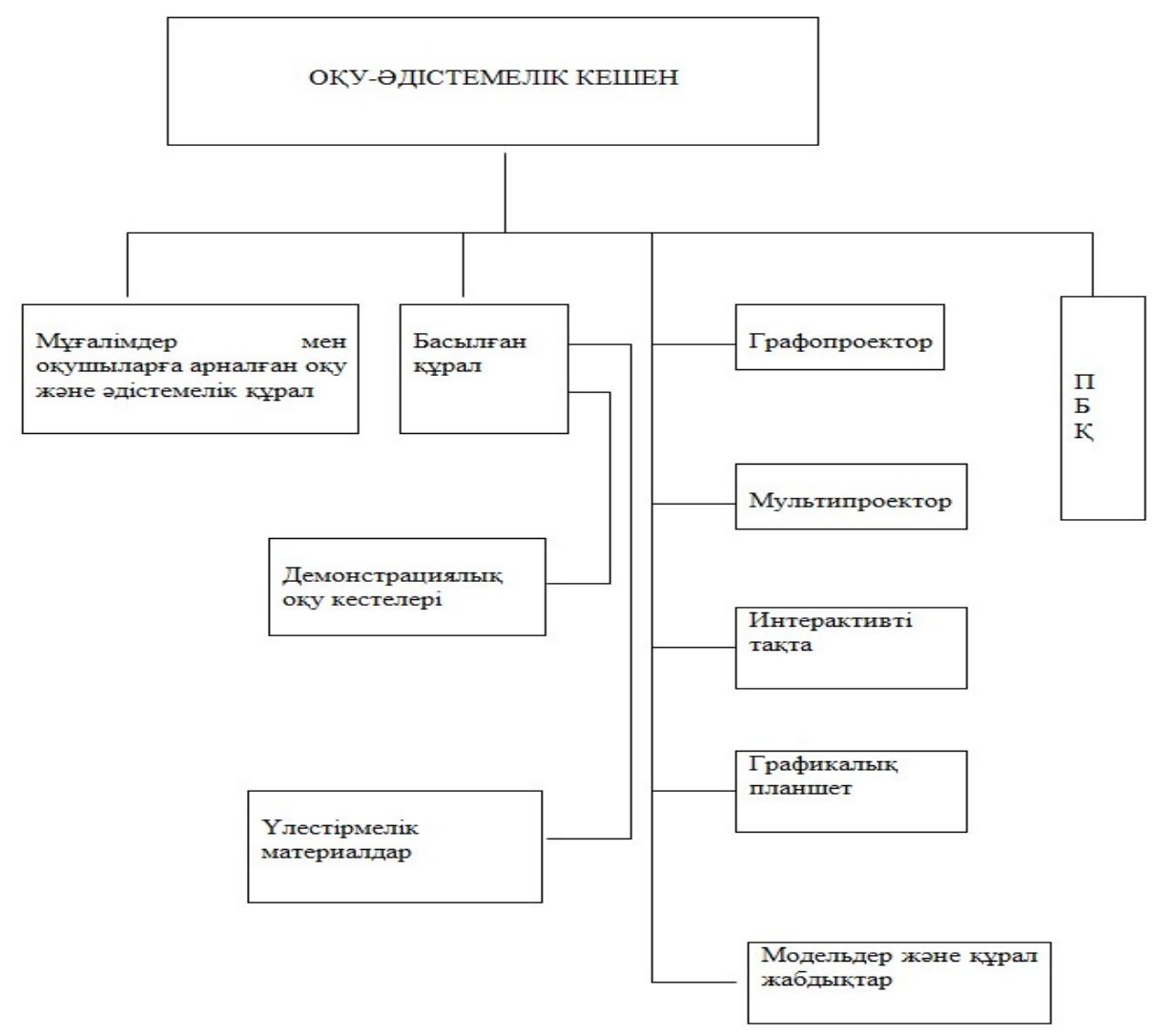

Сурет 1. Математиканы оқып үйренуге арналған ОӘК-ң сызба нұсқасы

Компьютерді оқу үрдісінде қолдану мәселелерін қарастырғанда оның екі функцияны атқаратынын ескеру қажет, олар: оқыту іс-әрекетінің құралы және оқу құралы.

Егер компьютер оқу іс-әрекеті құралы ретінде пайдаланылатын болса, онда оның қызметтерінің басқа бір іс-әрекеттерден аз ғана айырмашылығы болады, яғни оқушының компьютермен іс-әрекеті «Компьютерді пайдаланушы» деген өзара әрекеттестік схемасынан аспайды.

Дербес компьютерлердің адамдар іс-әрекетіндегі құрал ретіндегі және жаңа оқу құралы ретіндегі негізгі ерекшеліктері [493], [494] еңбектерінде көрсетілген. Аталған еңбектерді талдау компьютердің келесі ерекшеліктерін атап көрсетуге мүмкіндік береді:

- көлемі шектелмеген ақпаратқа және оны аналитикалық түрде өңдеуге қол жеткізуді қамтамасыз етеді: 
- адамның танымдық-зерттеу іс-әрекетінде әмбебап құрал ретінде пайдаланылады;

- психикалық іс-әрекет өнімдерін бекітудің жаңа белсенді формасын қамтамасыз етеді, білімнің жеке аспектілерін талдау сияқты түрлендірулерді дербес түрде автоматтандырады және оны толыққанды түрде орындайды, қолда бар мәліметтермен салыстырады, белгілі бір саланы жаңа ақпаратпен толықтырады, сонымен қатар, практикалық іс-әрекеттерді ұйымдастыруда пайдаланылады;

- әдеттегі жазбалардан кейінгі екінші саптағы мәні бар белгілі құрал болып табылады, оның көмегімен орындалатын іс- әрекеттің мазмұны бойынша жедел түрде ақпарат алмасуға болады;

- адамдар іс- әрекетіндегі қолданылатын саймандар мен құралдардың арасындағы байланыстарды орнату негізінде мағыналы заттық- бағыттық орта ретіндегі ерекшеліктері болады.

Компьютер қай уақытта оқу іс-әрекетінің құралы, қай уақытта оқыту құралы ретінде пайдаланылатындығын қалай ажыратуға болады? Компьютер және оны басқару іс-әрекеттерінде оқушымен шешілетін мәселе және қандай да бір оқу мақсаттары ескерілген жағдайда ғана дидактикалық қызметтер жүргізеді. Мысалы, эксперттік жүйелерді алайық. Оларда басқару жүйелері пәндік мәселелерді шешуге арналған, ал бұл жерде ешқандай оқу мақсаттары есепке алынбайды. Бұл жағдайда компьютер оқу құралы болады деп есептеуге негіз жоқ.

Е.И.Машбиц [495] компьютерлік оқытудың екі типін бөліп көрсетеді. Бірінші тип - оқушы мен компьютердің өзара іс-әрекетімен сипатталынады. Екінші типке компьютер мен педагогтың өзара іс-әрекеті жатады. Мұғалім компьютерді пайдалана отырып, оқыту нәтижесін тексеру арқылы оқыту үрдісін басқаруға мүмкіндік алады. Осылайша оқу үрдісін біліктілікпен анықтауға, жеке адамды оқытудың тиімді әдістерін және алынған мәліметтерді пайдалана отырып, оны оқытудың стратегиясын қалыптастыруға мүмкіндік тудырады. 
Шетелдерде компьютермен оқытудың екінші типіне көптеген жұмыстар арналған сонымен қатар, мамандар компьютерді екінші типте қолданылуына болашақта көптеген мүмкіндік бар екенін пайымдайды.

Оқып үйренушілердің қолдануына арналған компьютерлік жүйелер негізінен төмендегідей үш қызметті атқарады:

1) деректер базасын жүргізу: оқытылып жатқаны туралы, оқыту кезеңі туралы, оқу бағдарламалары жөнінде, оқу пәндері жөнінде т.с.с.;

2) оқыту жөніндегі деректерді өңдеу: оларды енгізу, ақпараттарды жинақтау, оны сұрыптау және статистикалық амалдар негізінде өңдеу;

3) нәтижелерді анықтау: нақты оқып-үйренушілердің көрсеткіштері туралы, окушылар тобының орта көрсеткіштері, оқу курсының жекелеген бөлімдерінің өту нәтижелері т.б. туралы.

[496], [497] зерттеулерді талдау нәтижелері оқыту үрдісінде компьютерді пайдалану негізінен төмендегі төрт типті есептерді шешуге бағытталатынын көрсетіп отыр.

Біріншіден, компьютер осы уақытқа дейін белгілі дидактикалық есептер жүйесін шешудегі тиімді көмекші құрал ретінде пайдаланылады. Бұл типтегі компьютерлік оқыту бағдарламасының мазмұны - анықтамалық мәліметтер, нұсқаулар, есептеу амалдары, демонстрациялар т.с.с. болады.

Екіншіден, компьютер машиналық емес оқытудың мақсаттары мен міндеттерін және жалпы құрылымын сақтай отырып, жеке дидактикалық есептерді шешу жүктелетін құрал бола алады. Компьютер бұл жағдайда бақылаушының, жаттықтырушының т.с.с. міндеттерін атқарады.

Үшіншіден, әдеттегі жағдайларда шешілмейтін дидактикалық есептерді ұсынуға және оларды шығара білуге мүмкіндік тудырады. Оның мысалы ретінде эксперименттерді жүргізуді имитациялайтын компьютерлік бағдарламаларды алуға болады.

Төртіншіден, компьютер меңгерілуге тиісті обьектілер мазмұнын құрастыру жолдарымен модельдеуге арналған құрал ретінде қолданылады. Бұл кезде оқытудың жаңа стратегиясы жүзеге асады. Бұл бағыттағы 
компьютерлендіру облысындағы өңдемелердің бірі ретінде "компьютерлік оқыту ортасын " алуға болады. Жоғарыда айтылғандарды ескере отырып, математиканы мектепте оқып үйретуде компьютерді қолданудың бағдарламалық-әдістемелік бағыттарын бөліп көрсетуге болады, олар:

1) компьютерлік оқулықтар;

2) пәндік-бағытталған орталар;

3) лабораториялық практикумдар;

4) жаттықтырушылар;

5) бақылаушы бағдарламалар;

6) ақпараттық-анықтамалық жүйелер.

Компьютерлік оқулық (КО) - ол белгілі бір курсты немесе оның үлкен бір бөлігін өз бетімен оқып үйренуге арналған программалық-әдістемелік кешен. КО әдеттегі оқулықтың, анықтамалықтың, есептер жинағының және лабораториялық практикумның қасиеттерін қамтиды. Бұл жағдайда КО аталған оқу құралдарымен салыстырғанда төмендегідей жетістіктерге ие болады:

- әрбір жекелеген пайдаланушыға оқушының теориялық курсты меңгерудегі әр түрлі жұмыс формаларының көлемі мен ретін ыңғайлы түрде анықтауына, мысалдарды талдай алуына, типтік есептерді шығару әдістерін үйренуіне, өз бетімен зерттеу жұмыстарын жүргізе білуіне және одан кейінгі танымдық іс-әрекетінің қалыптасуына жағдай тудырады;

- алған білімдері мен қалыптасқан дағдыларының сапасын өз бетімен бақылай алу мүмкіндігін қамтамасыз етеді;

- зерттеушілік іс- әрекетінің дағдыларын қалыптастырады;

- оқушының белгілі бір курсты меңгеруіне арналған уақытты үнемдейді.

Компьютерлік оқулық дискеттер жиынтығы бар кітап түрінде таратылуы тиіс. Кітап белгілі бір курсты меңгеруге арналған жетекші құрал ретінде жасалып, төмендегідей мәселелерді қамтуы қажет:

- теорияны, мысалдарды, есептерді шығару әдістерін түсіндіру;

- программалық өнімдермен жұмыс істеуге арналған нұсқаулар; 
- кешеннің программалық бөлігімен жұмыс жасауға арналған барлық нұсқаулар;

- алған білімді бақылау құралдары.

Компьютерлік оқулыққа қосымша берілген дискеттер курсты меңгеруге қажетті әр түрлі типті оқыту бағдарламаларын қамтуы мүмкін.

Лабораториялық практикум: бұл типтегі программалар математикалық эксперименттер жүргізуге, обьектілерді, олардың арасындағы өзара байланыстарды немесе олардың кейбір қасиеттерін бақылауға, бақылау нәтижелерін өңдеуге, оларды сандық немесе графиктік түрде ұсынуға және практикада осы объектілерді пайдаланудың әр түрлі аспектілерін зерттеуге бағытталған.

Окушылардың осындай бағдарламаларды пайдалану жөніндегі icәрекеттерін ұйымдастыру үшін эксперименттің мақсаты айқын болуы керек, сол сияқты эксперимент жүргізудің құралдары мен әдістемелері, эксперименттің нәтижесінде алынған нәтижелерді өңдеу мен талдау әдістері нақты түрде анықталуы тиіс. Құжаттарда есеп берудің формалары және мысалдары келтіріліп, оларды толық орындауды қамтамасыз ететін әдістемелік талаптар (жұмысты орындау үлгісі) келтірілуі тиіс.

Жаттықтырушылар есеп шығару дағдыларын өңдеу мен бекітуге арналады. Олар оқушыларды есеп шығарудың бір ғана тәсілмен шектеп қоймайды. Керісінше, оларды есептің дұрыс шешімін табуға арналған жолдарына жетелейді. Сонымен бірге компьютер қосымша құралдарды (теориялық анықтамалар, калькулятор, кестелер, жазу кітапшасы, көмекші есептерді автоматты түрде шығару) пайдалануды ұсынады, сол себепті оқушының есепті шығарудағы негізгі идеясынан ауытқымауына жағдай тудырады.

Жаттықтырушылар: теория, мысалдарды демонстрациялау, репетитормен жұмыс істеу, өзіндік жұмыс, өзін-өзі бақылау сияқты режимдерді қамтиды. 
Бақылау бағдарламалары - ол білім сапасын тексеруге (бағалауға) арналған бағдарламалық құралдар. Олар бақылау нәтижелерін тіркеуге, жинақтауға, шығаруға және статистикалық түрде талдау жасауға арналады.

Сәйкес бағдарламалық қамтамасыз етуі бар компьютер түріндегі мұғалім оқытудың өте куатты мүмкіндіктеріне ие болды деген пікірлер айтылып жүр. Онда компьютердің төмендегідей мүмкіндіктері ескеріледі, олар: оның түрлітүстілігі, мультипликациялық мүмкіндіктері, графикасы, дыбысы, оқу ақпараттарын кескіндеу мүмкіндігін кеңейтеді, сонымен бірге, әдеттегі көрнекілік принципін жаңа сапалы деңгейде іске асыруға мүмкіндік тудырады.

Компьютер оқытудың мотивациясын күшейту мүмкіндіктерін тудырады, яғни оқып үйренушілердің өзбетімен жұмыс істеуін белсенді етеді, білім мен біліктіліктердің жаңа жағдайлардағы қолданылу үрдісін күшейтеді, қажетті кері байланысты, бағаның шынайылығы мен нақтылығын, оқытуды жекешелендіруді т.б. қамтамасыз етеді. Компьютермен жұмыс істей отырып, оқушы өзінің алдына қойылған кез-келген оқу есептерінің шешімін аяғына дейін жеткізуіне мүмкіндік алады, себебі оған компьютер қажетті көмек бере алады, ал оқытудың ең тиімді жүйелерін пайдалана білгенде, оған есептердің тиімді жолмен шығарылу жағдайларын талқылауға мүмкіндік алады.

Дербес компьютерлер оқушының белсенділігін арттыруға көмектеседі. Окушының танымдық үрдісіндегі даму деңгейін есепке алудың ерекше жаңа мүмкіндіктері туады, сол сияқты берілген есептерді шығаруына көмектесетін мүмкіндіктер пайда болады.

Компьютерлерді пайдалану оқытудың мазмұнын анықтауға, оны модельдеуге алғышарттар тудырады. Зерттелетін үрдіске байланысты заңдылықтарды оқып-үйренуде оқушының модельдеуші бағдарламалық құралдарды пайдалана білуі оның жұмысындағы орталық кезең ретінде саналады. Пернетақтадан әр түрлі әрекеттерді бере отырып, оқушы жүйенің қандай күйге түсетінін бақылай алады, нәтижелерді талдай алады, нәтижеде шығатын заңдылықтармен фигуралардың қасиеттерін белгілі бір болжам түрінде 
тұжырымдайды, соңынан оны дәлелдейді. Осындай модельденетін жағдайлар оқып үйренушілер үшін проблемалық жағдайлар болуы мүмкін.

Бұл жағдайда оқытушының, оқушының зерттеу үрдісінде алған білімдеріне кеңесші ретіндегі рөлі арта түседі. Модельдеуші бағдарламаларды пайдалану оқу іс-әрекетінің әдіснамасын ғылыми-зерттеу жұмыстарының әдіснамасымен жақындасуына жағдай жасайды және оқушыларға оқу курсын меңгеруге мүмкіндік тудырып қана қоймай, модельдеу әдісінің өзінде меңгеруге мүмкіндік береді. Сонымен бірге, мектептегі зерттеу әдістері мен ғылыми зерттеу әдісі пара-пар емес екендігін ескерген жөн. Окушылардың зерттеу ісәрекеті, сұрақтар жүйесімен, танымдық есептермен және оқу тапсырмаларымен өрістейді және бағытталады.

Компьютер оқыту үрдісін басқару құралдарының диапазонын кеңейтеді, яғни оқушының өзіне-өзі сұрақ қоя алуынан бастап, оның оқу стратегиясының тиімді бағытын анықтауына дейін мүмкіндік береді, бұған баяндау деңгейін (абстрактылықтың дәрежесі, түсіндіруші мысалдардың саны т.с.с.), берілетін есептердің қиындық дәрежесін, оқу материалын баяндаудың бірізділігін қосады. Бұрынғы кездегі оқыту құралдарының ешқайсысы да оқушының есеп шығаруға көмектің қандай болатынын тұжырымдауына мүмкіндік тудырмайтын. Ең дамыған деген интелектуалдық жүйелердің міндеті - оқушылармен интерактивті түрде сұхбат жасау арқасында оқытудың байланысты стратегиясын жетілдіру болып табылады.

Компьютерді оқыту үрдісінде пайдалану - оқытуды жетілдірудің алғышарттары болғанымен, оның негативті әсерлерінің потенциалдық көзі болып табылады, олар төмендегі себептерден пайда болады:

- компьютерлік оқыту жүйелерін жасаушылардың тәжірибесінің жеткіліксіздігі;

- компьютердің потенциалдық мүмкіндіктерін толық іске асыра алмауы;

- компьютердің техникалық жүйе екендігіне байланысты кемістіктері.

Компьютерді оқытуда пайдалануда, көптеген сұхбаттық оқыту жүйелерінде кемістіктер болады. Олар: 
а) оқушыға берілетін оқыту әрекеттері (есептер, нұсқаулар, оку мәтіндері) көп жағдайларда олардың жеке мүмкіндіктерін ескермейді;

ә) оқушының ойлау іс-әрекетіндегі кейбір олқылықтарды есепке ала алмайды, соның салдарынан көрсетілуге тиісті көмек талап етілетін көмекпен үйлеспейді;

б) көптеген жағдайда ондай жүйелер ерекше шешімдерді бағалай және көптеген сұрақтарды түсіне алмайды, кейде сұрақты түсіну үшін оқушыға ұзақ уақыт керек болады.

Бұл жерде прогресс оқытудың ғылыми негіздерін жасауға, сол сияқты компьютердің интеллектуалдық мүмкіндіктерінің артуына байланысты. Компьютерді пайдалану «мұғалім-сынып» түріндегі бүтіндей жүйенің «оқушыкомпьютер» түріндегі жекелеген элементтерге бөлініп кетуіне әсер етеді. Сондықтан да, оқытудың компьютерлік технологиясын жобалаудағы арнайы мәселе - оқушы мен оқытушының бірлесе жұмыс істеуіне және олардың өзара түсінісуіне деген сұраныстарды іздестіру болып табылады, ал осы сияқты әдістерді құрастыру төмендегі бағыттар бойынша жасалуы тиіс:

- $\quad$ компьютерді пайдалануға негізделген окушылар мен мұғалімдердің оқыту үрдісіндегі өзара бірлесе жұмыс істеуіне арналған жағдайларды қалыптастыру;

- оқушылар тобының компьютермен жұмыс жасауын, олардың өзара жұмыс жасауын талап ететін ұжымдық жобаларды ұйымдастыру;

- $\quad$ компьютерлік және компьютерлік емес оқыту формаларының тиімді қатынастарын анықтау.

Оқыту үрдісінің тұтастығына компьютерлік оқыту жағдайында негізгі үш бағыт бойынша жетуге болады, олар:

- жекелеген оқушылардың танымдық белсенділігін басқара білу;

- «мұғалім-компьютер-оқушы» түріндегі жүйенің оқыту іс-әрекетін басқара білу;

- $\quad$ мұғалім мен оқушының, оқушылардың өзара бірлесе отырып, жұмыс істеуін басқару. 
Оку үрдісінде пайдаланылатын бағдарламалық құралдар әр түрлі көз қараста талдануы мүмкін. Жіктеуді негіздеу - білім беру жүйесінің қай саласында жататындығын түпкілікті зерттеу М.М. Буняевтің докторлық диссертациясында жүргізілген. Автор жіктеуді тиісті негізді бейнелейтін оқыту бағдарламалық құралдарын жіктеудің бір ғана тобының өзі әр түрлі білім салаларын, яғни, информатиканы, психологияны, дидактиканы қолдануды қажет ететіндігін айтады.

Оқыту бағдарламаларын сатылап жіктеуді құрастыруға бағытталған өңдемелер бар. Оқыту бағдарламаларын жіктеудің ғылыми негізделген түрі көп жақты және көп деңгейлі болу керектігі Е.И.Машбицтің [495] еңбегінде тұжырымдалған. Ол педагогикалық бағдарламалық құралдарды жіктеуде төмендегілерді ескеру қажеттігін айтады:

1) Окушы мен компьютер арасындағы тікелей өзара әрекеттің бар немесе жоқтығы;

2) Аяқталған оқыту фрагментінің барлық қажетті қызметтері іске асырылған ба, әлде жоқ па. Егер барлығы түгел болмаса, онда қандай қызметтер (қажетті іс-әрекетті демонстрациялау, есеп шығаруды басқарудың материалды бекітуге пайдаланылуы, бақылау т.с.с.) компьютерге жүктелгендігі;

3) Бағдарламаларда оқу тапсырмаларының қандай типтері келтірілген?

4) Оларда сұхбат жүзеге асырыла ма, жоқ па?

5) Оқушы тарапынан басқарыла ма?

6) Окушының жеке ерекшеліктері ескеріле ме, егер ескерілсе, онда рефлексивтік басқару қамтамасыз етіле ме?

Математикада компьютерді оқу құралы ретінде тиімді түрде пайдалану мәселесін қарастырғанда, педагогикалық бағдарламалық құралдарды жіктеуді олардың әдістемелік бағытталуы жағынан қарастырып, осы пәнді оның ерекшеліктері мен мазмұнын ескере отырып, ұйымдастыру мәселесі туындайды.

Бағдарламалық өнімді жобалауда жіктеу алдағы іс-әрекетті бағдарлауға қызмет етеді, әдістемелік жағынан тиімді бағдарламалық құралды жасауға, оның 
құрылымын анықтауға, оны оку үрдісін үйлесімді жоспарлауға, пайдалануға мүмкіндік тудырады.

Дидактикалық мәселелерді шешуге байланысты, оқушылардың icәрекетінің нәтижесінде іске асатын интеллектуалдық үрдістерге қатысты оқыту бағдарламаларының құрылымы анықталады. Дағдыларды қалыптастыру кезінде сызықтық бағдарламалардың рөлі зор; есеп шығаруды үйреткенде, сызықтық бағдарламалар алгоритмдік есептерді шығарғанда ғана қолданылады. Тармақталған және адаптивтік бағдарламалар есеп шығарушының ойлау ісәрекеті жартылай эвристикалық немесе эвристикалық үрдістерді қамтығанда ерекше мағынаға ие болады.

ҚБҚ - дың құрылымдарының бірнеше нұсқаларын қарастырайық.

\section{1 - нұсқа.}

Жалnы mun. Бағдарлама келесі блоктарды қамтиды: «енгізу», проблемалық жағдай, қимылдың бағытталған негізін (ҚБН) қалыптастыру, білімдерді және қорытуды қолдану, меңгерілгендердің диагностикасы, «шығу». Мұндай бағдарлама әртүрлі әдістемелік мәселелерді шешуде пайдаланылуы мүмкін.

\section{2 - нұсқа.}

Математикалық ұвымдарды қ̧алыптастыру. Ол мынандай блоктарды қамтиды: түсініктің маңызды және маңызды емес белгілерін айқындау, берілген математикалық объектінің анықтамасын тұжырымдау, осы фактіден объектінің анықтамаға сәйкес объектілер класына жататындығы жөнінде салдарлар алу.

\section{3 - нұсқа.}

Теоремаларды оқыл үйрену. Негізгі блоктары: теореманы оқып үйренуді негіздеу мен оның мазмұнын ашу, теореманың құрылымымен жұмыс істеу, дәлелдемені іздестіру, теореманы бекіту, теореманы қолдана отырып, есептер шығару.

\section{4 - нұска.}

Мектеп математика курсының жаңа алгоритмдері мен ережелерін меңгеру: онда әдеттегі проблеманы қоюды, алгоритмді (ережені) құрастыруды, 
алгоритмге енетін және оны орындау ретін меңгеруге арналған операцияларды өңдеуді, алгоритмнің қалыпты (алғашқы берілгендерді варияциялауда) және таныс емес жағдайдағы қолданылуын қамтитын «енгізу» мен «шығу» блоктары болады.

\section{5 - нұска.}

Оку іс-әрекеттерінің тәсілдерін құальптастыру. Мұндағы оқыту бағдарламасына: диагностика, тәсілді енгізу, тәсілді өңдеу, тәсілді қалыптастыру үрдісінде түзетулер мен оперативтік бақылау тәсілін қолдану, ауыстыруға үйрету және қорыту, қорытындыланған тәсілді бекіту, жаңа тәсілдерді табуға үйрету сияқты блоктар енеді.

\section{6 - нұсқа.}

Білімдердің кешеніне (оқу тақ̧ырыбы деңцгейінде) оқылту. Мұнда төмендегі блоктарды қамтитын интеллектуалдық оқыту жүйесі қажет, олар: оқушының динамикалық моделін құру, оқу есептерінің қойылымы және шешімдерді іздестіру, генерациялау, оқытушы әрекеттерді таңдау және ұсыну, оку есептерін шығарудың ағымдық және қорытынды бақылауы, жүйенің жұмыс режимін (Компьютер - тарапынан басқару, оқушы тарапынан басқару, оқу есептерін шығару үрдісіндегі алма-кезек басқару) анықтау.

Сөйтіп, оқытуды компьютерлендіру проблемасы бойынша ғылымиәдістемелік әдебиетті талдау бізге дербес компьютердің оқу құралы ретіндегі мәнін анықтауға мүмкіндік берді, оны оқу үрдісінде қолданудың артықшылықтарымен кемшіліктерін анықтады.

Қорыта келе, төмендегідей тұжырым жасай аламыз:

1. Компьютердің техникалық құрал ретінде мүмкіндіктерінің спектрі өте кең, бірақ олардың бар болуы дербес компьютерлерді оқу үрдісінде дұрыс және тиімді пайдаланылуына кепілдік бере алмайды. Осыған байланысты, жаңа ақпараттық технологияны оқыту үрдісіне пайдалануға бағытталған оқу тәрбие жұмысын сауатты түрде ұйымдастыру мәселесі өзекті және принциптік түрде маңызды. 
THEORETICAL FOUNDATIONS OF THE FUNCTIONING OF EDUCATION. WAYS TO IMPROVE THE EFFECTIVENESS OF EDUCATIONAL ACTIVITIES

Компьютерді оқыту құралы ретінде пайдалану үшін ол сәйкес бағдарламамен қамтамасыз етілуі керек. Сондықтан әртүрлі педагогикалық қызметтерді жүзеге асыру үшін оқытуға арналған бағдарламалық құралдарды жасау - компьютерлік оқытудың ең негізгі мәселелері болып табылады. 
DOI 10.46299/ISG.2021.MONO.PED.II-545-553

\subsection{5 Модель додаткової професійної підготовки майбутніх фахівців туристичного супроводу до реалізації програм культурно-пізнавального туризму}

Туризм сьогодні розвивається шаленими темпами не тільки у світі, але й і в нашій державі також. Це супроводжується виділенням нових видів туризму в окремі туристські напрямки та розвитком вже чинних видів, що, в свою чергу, вимагає поповнення туристської сфери професійно підготовленими туристськими кадрами.

Одним 3 найдинамічніших секторів туризму $є$ культурно-пізнавальний туризм, який відчуває в даний час дефіцит у професійно підготовлених, конкурентоспроможних на вітчизняному ринку праці фахівцях.

Під культурно-пізнавальним туризмом у нашому дослідженні розуміються туристські відвідування пам’яток історії та культури, туристських територій та об’єктів культурної спадщини [Любіцева, 2008].

Аналіз програм підготовки студентів у професійних закладах освіти різного ступеню акредитації туристичного профілю свідчить про недостатню представленість питань, пов'язаних 3 професійною підготовкою студентів до реалізації програм культурно-пізнавального туризму. У зв'язку з цим було виявлено об’єктивно наявне протиріччя: між, 3 одного боку, потребою туристського ринку в професійно-підготовлених фахівцях, які здійснюють діяльність з реалізації програм культурно-пізнавального туризму, а 3 іншого недостатньою представленістю в теорії та методиці професійної освіти питань, пов’язаних з підготовкою фахівців з культурно-пізнавального туризму.

Резюмуючи результати проведеної нами оцінки готовності студентів туристського закладу освіти до реалізації програм культурно-пізнавального туризму, необхідно відзначити наступне:

- оцінка готовності студентів проводилася за трьома критеріями: психологічним, діяльнісним і мотиваційним; 
- загальна готовність студентів, виходячи 3 сукупності показників, отриманих в ході діагностики, оцінюється як недостатня та вимагає відповідного педагогічного забезпечення;

- реалізація програм культурно-пізнавального туризму в умовах туристського навчального закладу вимагає додаткової професійної підготовки студентів.

3 огляду на сукупність даних, отриманих в ході діагностичного етапу нашого дослідження, ми приходимо до наступного висновку: готовність студентів до реалізації програм культурно-пізнавального туризму не відповідає необхідному професійному рівню. Враховуючи це, нами була розроблена модель додаткової професійної підготовки, яка покликана забезпечити необхідний психологічний і практичний рівень готовності майбутніх фахівців туристичного супроводу до реалізації програм культурно-пізнавального туризму.

Модель додаткової професійної підготовки студентів до реалізації програм культурно-пізнавального туризму формується з урахуванням базових принципів освіти в туризмі [Федорченко, 2004]:

- демократизація - відкритість туристської освіти, залучення до неї уваги туристських підприємств та установ в освітній системі відносин рівноправності, співробітництва, децентралізації управління, варіативність змісту, форм i методів навчання;

- гуманізація - орієнтація всіх складових навчально-виховного процесу на особистість слухача, повагу його професійної гідності, подолання відчуження слухачів та викладацького складу від освітнього процесу, відхід від звички озиратися на усередненого студента, створення умов для розвитку соціальної активності молодого фахівця, розкриття його творчих можливостей;

- гуманітаризація - надання значущості туристським наукам про єдність туристського світу, взаємозв’ язку суспільства та людини, що дозволяє збагатити ii духовний світ, сформувати життєву позицію й утвердитися в якості професіонала-фахівця; 
- фундаменталізація - впровадження в навчальний процес теорій високого ступеня узагальнення, які мають підвищену інформаційну місткість і універсальну застосовність;

- безперервність - єдиний процес, що охоплює всі ступені та рівні освіти, що обумовлює формування у студентів і слухачів навичок самоосвіти та вміння орієнтуватися в дедалі більшому потоці туристської інформації;

- індивідуалізація - облік всієї системи індивідуальних і колективних форм роботи 3 обдарованими студентами, а також введення індивідуальних навчальних планів, різних видів навчання з різним обсягом підготовки.

Модель додаткової професійної підготовки студентів до реалізації програм культурно-пізнавального туризму реалізує наступну мету - розширити знання студентів про культурно-історичну спадщину та сформувати у них вміння представляти об'єкти культурно-історичної спадщини в якості об'єктів культурно-пізнавального туризму.

Основою змісту навчальної діяльності додаткової професійної підготовки студентів до реалізації програм культурно-пізнавального туризму служить вивчення компонента «Культурно-пізнавальний туризм», що складається 34 модулів: «Пам'ятники та ансамблі», «Твори ландшафтної архітектури», «Визначні місця» та «Основи екскурсійної справи».

Обсяг знань і умінь, отриманих студентами в рамках професійної освіти, дає можливість здійснювати ефективну професійну діяльність в області розробки туристичних продуктів, їх реалізації та супроводу, але не $є$ достатнім для успішної професійної діяльності, тому що не передає студенту всієї повноти специфічних знань в цій області.

Відповідно до визначень модулів навчальної діяльності студентів i критеріями їх класифікації, будується зміст додаткової професійної підготовки.

У процесі додаткової професійної підготовки студентами освоюється 4 етапи:

I етап - теоретичний: освоєння теоретичних знань про об’єкти культурноісторичної спадщини (пам’ятники, ансамблі, твори ландшафтної архітектури, 
визначні місця). Даний етап є початковим (вступним); він характеризується первинним теоретичним ознайомленням студентів 3 об’єктами культурної спадщини через вивчення їх історії виникнення та розвитку (генезис), ознайомлення 3 загальними основами культурології, державними та міжнародними принципами охорони об’єктів культурно-історичної спадщини, українським і міжнародним законодавством, що регулює питання, пов’язані 3 категоруванням об’єктів культурно-історичної спадщини, їх охорони і таке інше.

II етап - ознайомлювальний: безпосереднє ознайомлення 3 об’єктами культурно-історичної спадщини (заняття у формі навчальних екскурсій та виїзних семінарів на об’єкти культурно-історичної спадщини). Даний етап супроводжується такою формою навчальної діяльності, як навчальні екскурсії на об’єкти культурно-історичної спадщини; студенти знайомляться 3 об'єктами культурно-пізнавального туризму та теоретично осмислюють їх при безпосередньому контакті на базі отриманих на першому етапі знань.

III етап - професійно-орієнтований: освоєння теоретичних знань про об’єкти культурно-історичної спадщини як об’єкти культурно-пізнавального туризму; вивчається зв’язок туризму 3 культурою; об'єкти культурнопізнавального туризму розглядаються вже не тільки з позиції їх культурологічної цінності, але також і 3 позиції дослідження цього об’єкта культурнопізнавальним туризмом як туристичного ресурсу.

IV етап - виробничий: виробнича практика в туристичних фірмах та екскурсійних бюро. Передбачає безпосередню участь студентів у розробці та проведенні екскурсій; спрямований на вироблення практичних умінь щодо реалізації програм культурно-пізнавального туризму. Необхідною теоретичною базою виступають знання, отримані студентами в ході перших трьох етапів.

Модель додаткової професійної підготовки студентів до реалізації програм культурно-пізнавального туризму передбачає супровід навчання такими формами навчальної діяльності, як: лекції, відеолекції, конференції, семінари, дискусії, круглі столи, навчальні та виробничі практики, навчальні екскурсії. Передбачається організація спецсемінарів 3 представниками туристичних 
організацій та екскурсійних бюро, що займаються організацією культурнопізнавальних турів з обговоренням проблем галузі.

Модель додаткової професійної підготовки студентів до реалізації програм культурно-пізнавального туризму охоплює базові принципи, такі як [Любчук, 2018]:

- гуманізація - принцип, який констатує пріоритет людських цінностей над виробничими, економічними, адміністративними;

- культуро-орієнтованість - принцип розгляду об'єктів культурноісторичної спадщини з позицій їх генезису та значення для сучасної культури;

- історизм - принцип розгляду об’єктів культурно-історичної спадщини, природних і соціально-культурних явищ в динаміці їх зміни, становлення в часі, у закономірний історичний розвиток, що передбачає аналіз об'єктів дослідження у зв'язку з конкретно-історичними умовами їх існування;

- ціннісна орієнтація - свій відбиток у свідомості людини цінностей, визнаних нею як стратегічних життєвих цілей i загальних світоглядних орієнтирів, без яких вона не мислить свого життя;

- наочність - практично реалізоване уявлення (безпосереднє або опосередковане) об'єктів культурно-пізнавального туризму студентом.

Модель додаткової професійної підготовки студентів до реалізації програм культурно-пізнавального туризму включає методи навчання - наочні, словесні, практичні, і засоби - наука, мораль, матеріальні цінності, персоналії, мистецтво.

Справжня модель відповідає вимогам компетентності фахівця туристичного супроводу у сфері культурно-пізнавального туризму.

Компетенції в самому узагальненому їх розумінні - це очікувані та вимірювані конкретні досягнення випускників, які визначають, що буде здатний робити випускник по завершенню освітньої програми [Галасюк, 2019].

Для апробації моделі додаткової професійної підготовки студентів до реалізації програм культурно-пізнавального туризму, нами був проведений формувальний експеримент. 
Зі студентами, майбутніми фахівцями сфери туризму, був проведений ряд теоретичних, практичних і мотиваційних занять, представлених як додаткова професійна підготовка фахівців до реалізації програм культурно-пізнавального туризму. В ході підготовки зі студентами були проведені наступні заняття:

1. Теоретичні, що охоплювали передачу знань 3 дисциплін спрямованих на вивчення різноманітних туристичних об'єктів, та включали дисциплінарні модулі: «Пам’ятники та Ансамблі», «Твори ландшафтної архітектури» та «Визначні місця». Зі студентами було вивчено різні класифікації об’єктів культурно-історичної спадщини, передано термінологічну базу в області культурно-пізнавального туризму, висвітлені питання потенціалу та перспектив розвитку культурно-пізнавального туризму в нашій державі та за іiі межами, вивчена діяльність організацій, що здійснюють діяльність в області культурнопізнавального туризму, нормативно-правова основа цієї діяльності, досвід підготовки фахівців в області культурно-пізнавального туризму інших країн. Об'єкти культурно-історичної спадщини вивчались студентами безпосередньо (в рамках навчальних екскурсій) і опосередковано - через літературні та аудіовізуальні джерела інформації. Формувалося ставлення студентів до культури як базової цінності людства, до гуманності та толерантності як до принципів взаємодії між людьми.

2. Практичні, представлені як підготовка рефератів, доповідей і повідомлень 3 проблематики культурно-пізнавального туризму, перспективи його розвитку, законодавчо-правового забезпечення в культурно-пізнавальному туризмі, бізнес-планування культурно-пізнавального туру (екскурсіі), практика в туристичних фірмах та екскурсійних бюро. Дані заняття забезпечувалися великим обсягом матеріалів, пов'язаних з історією, культурою, етнографією, екологією туризму; джерелами 3 проблематики культурно-пізнавального туризму, нормативними документами в галузі культурно-історичної спадщини, a також 3 документами ЮНЕСКО, концепціями розвитку культурнопізнавального туризму, матеріалами різних конференцій 3 проблематики культурно-пізнавального туризму. Таким чином, студенти отримали широкий 
теоретичний інструментарій для виконання робіт по культурно-пізнавальному туризму.

3. Мотиваційні, що включали проведення вільних дискусій зі студентами, дискусій на задані теми, обмін думок (в формах «студент-студент», «студентвикладач») і співбесіду. Більше уваги в рамках мотиваційних занять віддавалося особистісній активності студентів в процесі зміни відносин до навчальної діяльності та предмету вивчення. Встановлювалася динаміка зміни ставлення слухачів до пізнавальної діяльності, активного освоєння змісту освіти, зміни їх саморефлексії та мотивації. В ході підготовки студентами було продемонстровано інтенсивне опанування одержуваними знаннями.

Практичний блок містив підготовку доповідей, повідомлень i тез 3 проблематики культурно-пізнавального туризму. Підготовка матеріалів здійснювалася студентами на базі отриманих знань в області культурнопізнавального туризму. До матеріалів було пред’явлено наступні вимоги:

1. Робота повинна бути самостійно виконаним, закінченим науковим дослідженням. Робота може бути виконана як українською, так і іноземною мовою.

2. Робота може бути виконана як одним автором, так і авторським колективом студентів (не більше трьох авторів).

3. Відомості, представлені в роботі, повинні бути перевіреними та вірогідними.

4. Обсяг роботи повинен бути не менше 10 і не більше 40 друкованих сторінок.

5. Зміст роботи має бути пов'язаним з їі тематикою.

Тематичний перелік пропонованих до виконання робіт було максимально розширено з метою виявлення інтересу студентів до тієї чи іншої проблематики в області культурно-пізнавального туризму.

Мотиваційний блок підготовки охоплював проведення вільних дискусій зі студентами в режимі обміну думок з питань культурно-пізнавального туризму та культури в цілому, а також персональної співбесіди. Цей блок реалізував 
наступні завдання: виявлення мотивування студентів, що готуються до реалізації програм культурно-пізнавального туризму; визначення мотивів студентів, що реалізують програми культурно-пізнавального туризму; виявлення цільової аудиторії студентів, здатних реалізувати програми культурно-пізнавального туризму.

Процес проведення формувального експерименту можна відзначити такими особливостями: динамічністю й інтенсивністю додаткової підготовки; високим ступенем залученості в навчальний процес; високою часткою творчої роботи студентів в ході формувального експерименту; опануванню конкретними знаннями в питаннях культурно-пізнавального туризму та світової культури; опанування конкретними навичками наукової роботи (суспільно-колективна робота, індивідуальна робота, робота зі спеціальною літературою).

Отже, ефективність побудованої моделі доводять результати формуючого експерименту, що демонструє досягнення поставленої мети. Була отримана комплексна оцінка готовності студентів до реалізації програм культурнопізнавального туризму, виходячи з трьох базових критеріїв: знаннєвого (оцінка теоретичних знань студентів про об’єкти культурно-історичної спадщини); діяльнісного (практично напрацьовані вміння та навички студентів, необхідні для реалізації програм культурно-пізнавального туризму); мотиваційного (визначення особистісної потреби студента в додатковій професійній підготовці до реалізації програм культурно-пізнавального туризму). Показники кожного 3 критеріїв в експериментальній групі зросли щодо показників контрольної групи.

Студенти опанували знання в області культурно-пізнавального туризму, об’єктів культурно-історичної спадщини, культурології; змісті культурнопізнавального туризму, його роль у системі світового туризму; термінологічної бази в області культурно-пізнавального туризму. Студенти продемонстрували готовність професійного використання знань не тільки в науковій, але і в практичній роботі.

Студентами були отримані необхідні вміння та навички для реалізації програм культурно-пізнавального туризму, такі як: вміння працювати 3 
науковою літературою, оволодіння спеціальним лексичним апаратом англійської мови 3 культурно-пізнавального туризму та об'єктів культурно-історичної спадщини в цілому, навички комунікацій - вміння ясно, послідовно і професійно висловлюватися 3 питань культурно-пізнавального туризму. Опанування комунікативними навичками дозволяє студентам професійно реалізувати завдання взаємодії фахівця туристичного супроводу та туриста, вибудовувати комунікації всередині туристських груп, а також забезпечує можливість побудови комунікацій серед представників різних культурних груп. Зросла мотивація студентів до реалізації програм культурно-пізнавального туризму. 
DOI 10.46299/ISG.2021.MONO.PED.II-554-560

\subsection{6 Формування санітарно-гігіснічної компетентності у інженера-педагога харчового профіля як необхідна умова ефективної професійної діяльності}

На даному етапі розвитку України одне $з$ головних питань $є$ розвиток харчової галузі, тому необхідна підготовка висококваліфікованих інженерівпедагогів харчового профілю 3 володінням знань та вмінь професії, 3 пріоритетністю до збереження духовних, моральних, естетичних і гуманістичних цінностей та мати творчі здібності до удосконалення, впровадження інноваційних технологій в навчально-виробничий процес. Оптимальним шляхом забезпечення динамічних потреб суспільства в підготовці висококваліфікованих інженерів-педагогів харчової галузі є застосування компетентнісного підходу до навчання у закладах вищої освіти. Крім того, головне завдання вищої освіти передбачає, щоб не просто дати майбутньому фахівцю певний комплекс необхідних теоретичних знань i навичок, але i сприяти розвитку його особистісних якостей, закласти основи для подальшого професійного самовдосконалення [506, с.157].

Підготовка висококваліфікованих інженерно-педагогічних кадрів для закладів професійно-технічної освіти виконує роботу суспільно-державного значення, мета даної підготовки полягає у забезпеченні підвищення якості підготовки кваліфікованих робітничих кадрів [503, с.203].

Посилення уваги до якості підготовки інженерно-педагогічних кадрів обумовлено низкою причин, як реалізацією стратегії навчання «впродовж всього життя», яка створює оптимальні умови людині для професійної та особистісної самореалізації, так і необхідністю забезпечення конкурентоспроможності європейської економіки в умовах економічної глобалізації, що вимагає підвищення мобільності і конкурентоспроможності робочої сили через якісну їхню підготовку [509, с. 34].

Враховуючи думку Д. Гельфанової можна вважати, що інженернопедагогічна освіта $є$ специфічним різновидом вищої освіти, в ній інтегрується вища технічна i спеціальна гуманітарна освіта. Специфіка інженерно- 
педагогічної освіти зумовлює, з одного боку, необхідність засвоєння інженерних знань, а з іншого - здатність використовувати ці знання з педагогічною метою. При цьому спрямованість здобувача освіти має бути орієнтована на майбутню педагогічну діяльність в системі закладів професійно-технічної освіти. [502, c. 134]. Процес професійної підготовки інженера-педагога передбачає формування відповідних інженерно-педагогічних знань. Тобто, дані знання покликані для реалізації відповідної професійної педагогічної діяльності майбутніх інженерів-педагогів в системі закладів професійно-технічної освіти. Педагогічні знання формуються на основі існуючих компонентів змісту професійної підготовки майбутніх інженерів-педагогів, а саме творчому, методологічному, проектувальному, гностичному, комунікативному, науковому $[505$, с. 18]. Вказані компоненти фахової підготовки інженера-педагога розкриваються і конкретизуються у процесі вивчення циклу фахової підготовки 3 формуванням відповідних професійних знань, вмінь і навиків тобто певної професійної компетентності.

Специфіка професійної діяльність інженера-педагога харчового профіля пов'язана 3 професійно-специфічними складовими, що вимагає застосування особливих педагогічних умов під час формування готовності до професійної діяльності. Передбачена ефективність та успіх формування санітарно-гігієнічної компетентності у інженера-педагога харчового профіля напряму залежить від дотримання певних етапів освітнього процесу в закладах вищої освіти під час професійно-педагогічної підготовки.

Питаннями визначення змісту інженерно-педагогічної освіти у різних аспектах педагогічної науки займалися дослідники: Н. Брюханова, В. Безрукова, О. Коваленко, Л. Штефан, тощо. Суть і структура професійної компетентності інженера-педагога розкрита в працях І. Васильєвої, Н. Кузьміної, В. Кулешової, Н. Пахтусової та інших. Однак проблема професійно-педагогічної підготовки інженера-педагога харчового профіля, а саме формування санітарно-гігієнічної компетентності інженера-педагога харчового профіля, було поза увагою. 
Одним із ключових напрямків оновлення змісту освітнього процесу виступає формування професійної компетентності майбутнього фахівця, що тісно пов'язано з розвитком особистих професійних здібностей. Адже вища освіта України передбачає отримання сукупних систематизованих знань, умінь і практичних навичок, способів мислення, професійних, світоглядних i громадянських якостей, морально-етичних цінностей, інших компетентностей, здобутих у закладі вищої освіти у відповідній галузі знань за певною кваліфікацією на рівнях вищої освіти, що за складністю є вищими, ніж рівень повної загальної середньої освіти. В Законі «Про вищу освіту», компетентність $\epsilon$ динамічна комбінація знань, вмінь і практичних навичок, способів мислення, професійних, світоглядних i громадянських якостей, морально-етичних цінностей, яка визначає здатність особи успішно здійснювати професійну та подальшу навчальну діяльність і є результатом навчання на певному рівні вищої освіти.

3 позиції дослідника С.М. Ящука, компетентнісний підхід у вищій освіті пов'язаний з особистісно орієнтованим і діяльнісним підходами до навчання, оскільки торкається майбутнього фахівця й може бути реалізованим i перевіреним тільки в процесі виконання ним певного комплексу дій. Він потребує трансформації змісту освіти 3 перетворенням його з моделі, яка існує об'єктивно, для «всіх» фахівців навчального процесу, на суб'єктивні надбання окремого студента, які можна оцінити [504, с. 11].

Провідним показником готовності до професійної діяльності на сьогоднішній день $є$ професійна компетентність - інтеграційна характеристика ділових і особистих якостей фахівця, що відображає не лише рівень знань, умінь, досвіду, достатніх для досягнення цілей професійної діяльності, але і соціальноетичну позицію особистості [507, с. 113]. Компетентність інженера-педагога - це багатофакторне явище, що включає в себе систему теоретичних знань і способів ïx застосування в конкретних педагогічних ситуаціях, ціннісні орієнтації педагога, а також інтегративні показники його культури (мова, стиль 
спілкування, ставлення до себе й своєї діяльності, до суміжних галузей знань й ін.) $[508$, с.195].

Дослідники О.Є. Антонова, С.В. Кириленко, О.В. Соколюк та інші вказують на дотримання санітарно-гігієнічних норм під час професійної підготовки фахівців у системі вищої освіти, що передбачає створення позитивних умов для збереження та зміцнення здоров’я, тобто формує певну санітарно-гігієнічну компетентність кожного. Наголосимо, що санітарно-гігієнічна компетентність передбачає сукупність соціальних норм і цінностей, спрямованих на підвищення поінформованості людини в питаннях, пов'язаних 3 охороною здоров’я та профілактики захворювань, що сформувалися за рахунок плідної праці людини над розвитком матеріального, технічного i духовного світу 3 мотивацією до ведення здорового способу життя як окремих людей, так і суспільства в цілому.

Висвітлені погляди щодо збереження здоров’я і життя особистості потрібно віднести до формування санітарно-гігієнічної компетентності і у сучасних дослідженнях медицини, освіти, психології та ін. Це дасть можливість конкретизувати основні напрямки розвитку санітарно-гігієнічної компетентності, повноцінного психологічного та фізичного розвитку, трудового, естетичного, духовно-морального та розумового виховання майбутнього інженера-педагога харчового профілю. Адже, майбутній інженер-педагог харчового профілю, маючи глибокі вивчення технологій збереження здоров’я повинен вміти будувати правильний спосіб життя, удосконалити взаємодію між батьками та закладами професійно-технічної освіти 3 вивченням індивідуальні особливості.

Розробка та впровадження комплексних медико-педагогічних заходів у процесі підготовки майбутнього інженера-педагога харчового профілю повинно базуватися саме на санітарно-гігієнічних засадах, що є одним із важливих елементів проведення профілактики захворювань. Адже гігієна це наука, що вивчає закономірності впливу на організм людини та суспільне здоров’я комплексу чинників довкілля 3 метою розробки гігієнічних норм, санітарних правил, запобіжних і оздоровчих заходів, а санітарія - сукупність практичних 
заходів, спрямованих на оздоровлення оточення людини, впровадження у життя вимог та норм, яких обгрунтовує гігієна. Науково обгрунтоване використання гігієни та санітарії необхідно забезпечити ефективною взаємодією анатомї, фізіології, гігієни, зокрема гігієни дітей та підлітків, гігієни розумової праці, гігієни праці, комунальної гігієни, гігієни житла, особистої гігієни, гігієну харчування, психогігієни, гігієни фізичної культури і спорту та ін.

Таку взаємодію розділів гігієни необхідно не тільки будувати на сучасних відкриттях, дослідженнях у галузі медицини, гігієни та санітарії, алей потрібно враховувати історичні надбання цих галузей. Розвиток гігієни та санітарії має певний відбиток на історії розвитку людства. Тому доцільно використовувати накопичувальний досвід щодо створення умов для збереження здоров’я і життя людини, особливо під час засвоєння культури гігієни та основ санітарії.

У сучасних умовах удосконалення фахової підготовки майбутніх інженерів-педагогів харчового профілю до формування санітарно-гігієнічної компетентності є важливим завданням педагогіки вищої школи. Фахова підготовка майбутніх інженерів-педагогів харчового профілю до формування санітарно-гігієнічної компетентності на засадах компетентнісного підходу повинна передбачати розвиток здібностей самостійно вирішувати нестандартні професійні задачі, альтернативне мислення, постійне прагнення до вдосконалення професійної діяльності, науково-педагогічну діяльність у закладах вищої освіти.

Санітарно-гігієнічна компетентність - це сукупність соціальних норм i цінностей, спрямованих на підвищення поінформованості людини в питаннях, пов'язаних 3 охороною здоров'я та профілактикою захворювань, що сформувалися за рахунок плідної праці людини над розвитком матеріального, технічного i духовного світу 3 мотивацією дотримання людиною системи здоров’язберігання. Формування санітарно-гігієнічної компетентності під час підготовки інженерів-педагогів харчового профілю потрібно здійснювати на основі санітарно-гігієнічних знань, санітарно-гігієнічних умінь та санітарногігієнічних навиків, що полягають у дотриманні здорового способу життя 
учасниками освітнього процесу, а саме: у визначенні санітарно-гігієнічних рівнів; у проведенні профілактичних заходів для попередження захворювань; у дослідженні чинників середовища перебування, що можуть вплинути на стан здоров'я; у використанні педагогічних методів проведення санітарногігієнічного навчання та виховання.

Гігієнічне навчання та виховання передбачає педагогічну систему із навчальною та виховною діяльністю, спрямовану на підвищення рівня охорони здоров'я з мотивацією до дотримання здоров'язбереження кожної особи [509].

Рівень сформованої санітарно-гігієнічної компетентності в інженерапедагога харчового профілю цілком залежить від обсягу здобутих знань у цій галузі та передбачає підбір та ефективне використання педагогічних технологій. Рівень здобутих знань дозволяє інженеру-педагогу глибоко розуміти проблеми санітарногігієнічної галузі для зосередження уваги на постановці та вирішенні проблем використання санітарно-гігієнічної компетентності в інженерно-педагогічній діяльності. Дане демонструється чітким розумінням місця здоров'я в ієрархії цінностей, активності й мотиваційної спрямованості на досягнення успіху в професійній діяльності, психічних властивостей i станів валеологічномотивованої особистості здобувача вищої освіти. Також наявність педагогічних, біологічних, гігієнічних та фізично-гігієнічних знань, знань про формування, збереження та зміцнення індивідуального здоров’я особистості з прагненням до самоосвіти та орієнтація на реалізацію санітарно-гігієнічної компетентності серед учасників освітнього процесу ЗПТО також здатністю до самоконтролю та самокорекції в аспекті здоров'язбереження. Особлива увага приділяється сформованим гностичним, санітарно-гігієнічним, організаційнокомунікативним та методичним вмінням, навичкам, здатностям та професійноособистісним якостям.

Оволодіння майбутнім інженером-педагогом харчового профілю санітарно-гігієнічною компетентністю характеризується наявністю всіх показників у повному обсязі, таких, як: стійкий інтерес до окресленої проблеми; високий рівень теоретичних і практичних знань, умінь, навичок; реалізація 
кожної можливості для самостійної й творчої праці; володіння повною мірою гностичними, санітарно-гігієнічними, організаційно-комунікативними та методичними вміннями i навичками, сформованість вольових якостей; ініціативність, відповідальність, впевненість у собі; керування основними принципами деонтології; методичні вміння.

Інженер-педагог має сформовану готовність до реалізації власних професійної компетентності. Цілеспрямовано займається самоосвітою, самовихованням, що сприяє його мобільності та конкурентоспроможності на ринку праці. Уміє приймати ефективні рішення й готовий нести відповідальність за його наслідки, глибокими і системними науково-теоретичними та науковопрактичними знаннями в санітарно-гігієнічній галузі, здатний удосконалювати професійні знання шляхом самоосвіти, активно засвоюючи нову інформацію, систематизувати іiі, використовуючи новітні досягнення науки і техніки.

Формування майбутнього інженера-педагога харчового профілю як особистості, яка несе персональну відповідальність за прийняті рішення та здійсненні процеси у санітарно-гігієнічній галузі та формування в нього практичних умінь та навичок здійснювати санітарно-гігієнічну освіту, для створення санітарно-гігієнічного досвіду.

Висновки. Здійсненний теоретичний аналіз вказав на гігієну та санітарію, як на важливий елемент освітнього процесу закладу вищої освіти щодо формування у майбутнього інженера-педагога харчового профіля санітарногігієнічної компетентності. Це напряму пов'язано з тим, що гігієна вивчає фактори навколишнього середовища і фактори навчально-виробничого процесу та їх вплив на стан здоров'я учасників освітнього процесу в закладах професійнотехнічної освіти. А санітарія передбачає впровадження ряду профілактичних заходів і засобів для збереження здоров'я та життя. Високий рівень сформованої санітарно-гігієнічної компетентності в інженера-педагога харчового профілю полягає в глибокому розумінні проблеми збереження здоров'я в ієрархії цінностей під час професійної діяльності в закладах професійно-технічної освіти. 
DOI 10.46299/ISG.2021.MONO.PED.II-561-568

\subsection{7 Філософсько-педагогічні аспекти підготовки військових льотчиків}

Підготовка майбутніх військових льотчиків до виконання бойових польотів, як будь-яке педагогічне і психологічне явище, є складно організованим і багатоаспектним утворенням. Тому важливо досліджувати існуючі в науці підходи й погляди, що розкривають його сутність. Аналіз основних наукових джерел свідчить, що на сучасному етапі ще не сформована остаточна теорія підготовки майбутніх військових льотчиків до бойових польотів, хоча окремі іiі аспекти досліджувалися й продовжують вивчатися.

Підготовка майбутніх льотчиків до бойових польотів у контексті більш загальної проблематики професійної підготовки літного складу історично розбудовувалося переважно в області психологічної науки. Наприклад, у професійній психопедагогиці [510], теорії авіаційної психології віддається безумовно вихідна позиція, що домінує, залишаючи педагогічній складовій другорядне місце. Остання ідентифікується тільки в якості методик навчання, що безпосередньо випливають зі спеціальної психологічної теорії, насамперед, в області авіаційної психології (наведена автором методика індивідуальноорієнтованого аналізу авіаційної події у формі рольової гри заснована на психологічній теорії міжособистісних конфліктів).

На нашу думку, звуження ролі педагогічної складової у теорії професійної підготовки майбутніх льотчиків до винятково технічного (техніко-методичному) елементу не зовсім правомірно. Професійна підготовка майбутніх льотчиків до виконання бойових польотів $є$ частиною більш широкого освітнього процесу, що відбувається в певному освітньому середовищі, при певних психологопедагогічних умовах і закономірностях і має цілий комплекс педагогічних особливостей і властивостей. Философсько-педагогічні основи тут не менш важливі, ніж теоретико-психологічні. Як відзначає Р. Н. Макаров, «тільки на основі системного підходу можуть бути об'єднані численні області психології, а також знайдена загальна мова між педагогікою, філософією навчання й суміжними дисциплінами» [511]. 
Бреславец М. М., Кремешний О.I., Маренич С.Ю. розглядають підготовку майбутніх військових льотчиків із класичних педагогічних позицій - як комбінацію теорії і практики надання знань, умінь і навичок для виконання функціональних обов'язків у конкретних обставинах на певний строк (для підготовки військового льотчика необхідно додати - при наявності відповідних льотних здібностей, фізичних і психофізіологічних якостей) [512-514]. При цьому, конкретний зміст теорії підготовки літних екіпажів військової авіації вчені бачать у визначенні «необхідного утвору ... для оволодіння спеціальністю військового льотчика», розробці відповідних методик на всіх етапах підготовки, а також розробці керівних і організаційно-методичних документів, у тому числі, для різних типів літаків. Під об’єктом даної теорії розуміється льотчик (льотний екіпаж), під предметом - функціонування системи його (ix) підготовки. Практика ж підготовки - «льотна підготовка» - повинна, на думку авторів, безпосередньо надавати й формувати у курсантів систему професійних знань, умінь і навичок, а також психологічну готовність до виконання бойових польотів.

Структуру підготовки льотних екіпажів військової авіації вищевказані дослідники представили в кілька етапів:

- $\quad$ відбір льотного складу (попередній - при вступі до авіаційне ВВНЗ, що здійснюється - в умовах льотної підготовки);

- початкова підготовка льотного складу (первинна (по суті пропедевтична) - навчання техніці пілотування й «уведенню» у професію) i базова - комбінація досвіду первинної підготовки з освоєнням бойового літака;

- основна підготовка льотного складу і удосконалювання бойової виучки (здійснюється на бойових літаках у військових частинах);

- $\quad$ перенавчання льотного складу на нову для них авіаційну техніку (теоретичне - у спеціалізованому центрі бойової підготовки авіаційних фахівців і практичне - там же або у військових частинах).

Дозволимо собі наголосити, що елемент запропонованої ними структури підготовки льотного складу військової авіації - етап основної підготовки літного складу - розкритий досить традиційно й схематично. Фактично, це набір добре 
відомих фахівцям галузі організаційно-методологічних установок і методик навчання, де недостатньо фундаментальної теоретико-педагогічної основи (філософії навчання), комплексної системи педагогічного моделювання умов, закономірностей і принципів підготовки майбутніх військових льотчиків. Хоча крок у цьому напрямку безумовно здійснений - запропоноване адаптоване до військового льотного середовища бачення теорії й практики підготовки. До того ж, автори висловлюють зручну, за нашим переконанням, думку про необхідність підготовки військових льотчиків паралельно з одержанням ними вищої освіти (фактично за зразком наземних військових фахівців) і переходу на послідовну підготовку за моделлю «спочатку вища освіта (у військових ВНЗ) - потім льотна підготовка (у спеціалізованих установах)» [512], що буде сприяти «зануренню» курсантів-льотчиків у льотне середовище й додасть методологічної зв'язаності всім етапам підготовки.

Тому, підготовку майбутніх військових льотчиків ми будемо розуміти як спеціально організований процес навчання і виховання в умовах військового закладу вищої освіти, що має науково-педагогічну, організаційно-методичну й тактико-технічну специфіку та результатом якого $є$ їхня готовність до професійної військової діяльності внаслідок формування системи знань, умінь і навичок виконання бойових завдань у повітрі як мистецтва підготовки й виконання бойових польотів.

Деякі науковці ототожнюють професійну підготовку за професійною компетенцією, розуміючи під нею, відносно курсантів військових ВВНЗ, «інтегральну характеристику, що визначає його (курсанта) здатність як військового фахівця вирішувати професійні проблеми й типові професійні завдання, що виникають у реальних ситуаціях навчальної й бойової діяльності, використовуючи знання, професійний і життєвий досвід, цінності й нахили» [515]. У якості компонентів ії структури вчений висуває професійний досвід, системне сприйняття професійної реальності, вільне орієнтування в предметній області, технологічність, здатність інтегруватися з іншим досвідом, креативність i здатність до рефлексії. По суті, він зводить професійну підготовку до 
індивідуального, надбаного під час навчальної і навчально-професійної діяльності.

Інші, [516, 517] розглядають професійну підготовку курсантів-льотчиків як окрему філософсько-педагогічну категорію в трьох площинах (аспектах):

1) 3 боку суб'єктів керування - це процес створення державними інститутами, суб'єктами керування умов для цілеспрямованого формування й розвитку у курсантів-льотчиків певних можливостей для майбутньої професійної діяльності; 2) з боку курсантів - це процес досягнення необхідного рівня підготовленості до професійної діяльності за призначенням (компетенціями) і 3) як результат професійної підготовки. Така позиція, у цілому, корелює із тлумаченнями професійної підготовки, якої дотримуються в більшості енциклопедичних і словникових виданнях 3 педагогиці і більше імпонує нам, тому надалі ми будемо використовувати іiі як базову.

Проаналізовані джерела 3 питань розуміння професійної підготовки, об'єктивно відсилають нас до двох ключових моментів - процесу формування професійно значимих знань, умінь і навичок майбутнього фахівця в ході освітньої діяльності (професійної освіти) і результату цієї діяльності, який можна представити у вигляді сформованих професійних компетенцій з обов'язковим включенням психологічної готовності до майбутньої професії. У свою чергу, це вказує на те, що професійна підготовка є формою й інструментом реалізації професійної освіти: саме в ії ході відбувається ідентифікація дидактичних цілей, постановка педагогічних завдань, моделювання навчання, уточнюються, конкретизуються й корелюються методи і способи навчання, формується педагогічний результат. У той же час професійна підготовка сама може виступати індикатором успішності підготовки і готовності до професійної діяльності.

Виходячи з вище викладеного, під професійною підготовкою майбутніх льотчиків будемо розуміти дидактичну систему організаційно-освітніх i конкретно-методичних заходів, метою якої $є$ навчання і виховання особистості військового льотчика, здатного до виконання всього комплексу бойових завдань 
і конкретним результатом якої є його професійна й психологічна готовність до успішної професійної діяльності.

Тобто, професійна готовність майбутнього льотчика являє собою багатогранне явище, що включає не тільки знання про літальний апарат, техніку пілотування, навколишнє середовище, але й про льотчика, його можливості та обмеження, прийоми управління власним станом та ін. Причому значимість знань льотчика про себе у забезпеченні безпеки польотів не менш, чим значимість його знань про техніку пілотування та експлуатацію систем літака.

Поняття «професійна підготовка» $\mathrm{i}$ «підготовка за фахом» у вітчизняній науковій літературі досить часто ототожнюються [518]. Ми пропонуємо розуміти надалі професійну підготовку майбутніх льотчиків як комплекс спеціальних, спеціально-тактичних навчальних дисциплін і курсів, а також спеціалізованого тренажерного, фізичного й фізіологічного навчання, які становлять базовий компонент професійної підготовки військових льотчиків у ВВНЗ і спрямований на формування у них спеціальних військових льотних компетенцій й професійної готовності до виконання бойового польоту.

Якість в освітньому процесі є фундаментальною й інтернаціональною категорією, оскільки становить сутність їі мети.

У Національній доктрині розвитку освіти визначено, що «якість освіти $є$ національним пріоритетом i передумовою національної безпеки держави, дотримання міжнародних норм і вимог законодавства України щодо реалізації права громадян на освіту ... якість освіти визначається на основі державних стандартів освіти й оцінки громадськістю освітніх послуг».

За визначенням Міністерства освіти й науки України якість освіти - це комплекс характеристик освітнього процесу, що визначають послідовне і практично ефективне формування компетентності й професійної свідомості; певний рівень знань і вмінь, розумового, фізичного й морального розвитку, якого досягли випускники освітньої установи відповідно до запланованих цілей навчання й виховання. 
У сучасному розумінні якість освіти - це не лише характеристика суми знань, засвоєних людиною. У світі, де знання і технології оновлюються швидше, ніж життя одного покоління людей, слід спрямувати навчальний процес не тільки на засвоєння базових знань, а й на набуття потреби, умінь і навичок самостійно засвоювати нові знання та інформацію протягом усього життя й ефективно використовувати їх на практиці, вміння сприймати зміни, які стають невід’ємною рисою буття людини, готовності вчасно відмовитися від старого досвіду й норм поведінки. На думку В. Вікторова, особливої ваги у XXI ст. набуває і такий критерій якості освіти, як ступінь ії адекватності природним здібностям кожної людини, особистісно-орієнтований характер освіти [519]. Максимальне наближення освіти й виховання до розкриття природних здібностей кожної людини - мета педагогіки.

Якість вищої професійної освіти, характеризується такими складовими:

- по-перше, якістю навчально-методичної бази, що передбачає ресурсне забезпечення закладів освіти на належному рівні, залучення до навчального процесу не тільки таких якісних, традиційних компонентів, як підручники, а й нових сучасних засобів і методів пізнання, пов'язаних із сучасними технічними можливостями;

- по-друге, якістю педагогічних кадрів та професорсько-викладацького складу [520];

- по-третє, якістю об’єкта навчання - це рівень підготовки фахівців, здатних до ефективної професійної діяльності, до швидкої адаптації в умовах науково-технічного прогресу, які володіють технологіями в межах свого фаху, вмінням вик

У широкому сенсі якість освіти розуміється як збалансована відповідність процесу, результату і самої освітньої системи меті, потребам і соціальним нормам (стандартам) освіти; у вузькому розумінні - перелік вимог до особистості, освітнього середовища й системи освіти, яка реалізує їх на певних етапах навчання людини, якому відповідає певна сукупність показників. застосовувати свої знання при вирішенні професійних завдань. 
Отже, якість професійної підготовки майбутніх льотчиків слід розглядати як інтегрований показник відповідності придбаних ними професійних компетенцій, професійно значимих умінь і навичок, а також реальної готовності до виконання бойових завдань відносно конкретних вимог, запитів і очікувань суспільства до сучасних кадрових офіцерів-льотчиків.

Бойові польоти - це основа професійної діяльності військового льотчика, головний iї компонент, у якому він демонструє свій рівень професійної підготовки, фізичну й психологічну підготовленість, здатність до вдосконалювання й моральну витримку. Не будучи психолого-педагогічною категорією, як такою, бойовий політ стає додатковим об'єктом теорії авіаційної психології й педагогіки з проблеми професійної підготовки майбутніх льотчиків.

Підготовка майбутніх льотчиків до бойових польотів являє собою найважливішу за значенням частину їх професійної підготовки, оскільки їх основна професійна діяльність по призначенню - бойові (спеціальні бойові) польоти. Стрімкий технічний розвиток сучасних літальних апаратів, поява нових видів озброєння, навігаційного обладнання, систем наведення і вогню, нові бойові завдання і прийоми ведення повітряних боїв суттєво актуалізують звертання до даної проблематики.

Тому, пропонуємо розглядати бойовий політ як основний вид професійної діяльності військових льотчиків, спрямований на виконання бойового завдання, а готовність до нього (фізична, психологічна, технічна) - як ключовий компетентностний індикатор педагогічної системи забезпечення якості підготовки майбутніх льотчиків до виконання бойових завдань (польотів).

А до структури готовності випускника-льотчика до професійної діяльності після закінчення ВВНЗ включити наступні компоненти: мотиваційний позитивне відношення до професії, інтерес до неї); орієнтовний (уявлення про особливості та умови професійної діяльності, про її вимоги до особистості); операційний (володіння способами та прийомами професійної діяльності, необхідними знаннями, вміннями, навиками); вольовий (самоконтроль, вміння управляти собою під час виконання службових обов'язків); оціночний (самооцінка своєї 
професійної підготовленості). Високий рівень розвитку цих компонентів показник професійної готовності випускника до виконання поставлених завдань [521].

Таким чином, якісна професійна підготовка до бойових польотів майбутніх льотчиків - це комплекс спеціальних, спеціально-тактичних навчальних дисциплін і курсів, а також спеціалізованого тренажерного, фізичного й фізіологічного навчання, які забезпечують відповідний рівень підготовки й готовності курсантів-льотчиків ВВНЗ до ефективного виконання бойових завдань у відповідності з реальними вимогами ведення сучасної війни та запитів суспільства. Істотною складової цієї підготовки є наземне навчання бойовим польотам. При підготовці майбутніх військових льотчиків їх теоретичні компетенції здобуваються в навчальному закладі й уписуються в єдину ідеологію бойової підготовки літного складу авіації Збройних Сил. 
DOI 10.46299/ISG.2021.MONO.PED.II-569-577

\subsection{8 Артпроекти в системі дизайн-освіти}

Через аналіз прототипів чи архетипів, з чого і розпочинається будь-який творчий процес у навчальних дисциплінах для спеціальності 022 «Дизайн», сучасник має можливість пізнати секрети і етапи формотворення, прийоми та засоби, особливості творчого підходу видатних майстрів минулого. Ознайомлення з українськими традиціями та досвідом, напрацьованим в процесі важкого творчого становлення особистості, дозволяє дизайнерові формуватись, вчить черпати та трансформувати ідеї для створення нових сучасних форм, $\mathrm{i}$ водночас бути ретранслятором і особливим гарантом збереження й примноження національних традицій в предметно-просторовому дизайні. Досвід показує, що закономірність, яка побудована на принципі - першоджерело, артефакт, автентика, дають більш глибокий та концептуальний кінцевий результат. Поверхневе, часто ідеологічно заангажоване інформативне поле, може цілковито маргілізувати розвиток повноцінного дизайну у всіх напрямках життєдіяльності соціуму, що суттєво спотворює ціннісний і гармонійний розвиток культурного балансу суспільства, яке бажає зберегти свою державну ідентичність (Черкес, 2006). Водночас і категорія ремісничої, саме авторської рукотворчості в дизайні повинна бути піднесена до високого рівня мистецтва, що і формує поняття індивідуального авторського інтер'єру, а це явище, у сьогоднішніх реаліях, трактується такою дефініцією, як гармонійний дизайн просторового середовища (Бойчук, О., 2017, 2019).

Виявлення та аналіз ідейно-філософських та естетичних витоків мистецької та дизайн-діяльності у контексті нових соціокультурних викликів освітнього розвитку диктує необхідність вибудовувати системну аналітичну базу методологічних принципів, що синтезує усі прийоми та засоби суміжних наук: мистецтвознавства, теорії та практики архітектурно-проектної діяльності, філософії, естетики, педагогіки, консерваційно-реставраційних принципів збереження пам'яток з універсальними для цих наук методами історичного, типологічного та порівняльного аналізу (Шмагало, 2020). В цьому контексті 
практична значущість таких міждисциплінарних досліджень сприяє формуванню глибинного філософсько-естетичного світогляду та глибокому рівню усвідомлення, формуванню сприйняття нових цінностей у явищах мистецької та дизайнерської практики, виокремленню нових парадигм та орієнтирів щодо впровадження та проектування креативних ідей розвитку в сучасній українській освіті, дизайн-діяльності та культурологічній концепції на шляху пошуку самоідентичності.

Для формування нових підходів та принципів слід запропонувати вже опрацьовану достовірну аналітичну базу, до якої може апелювати кожен творець та проектант. Науково аргументована, автентична база імплементується у свідомість сучасного творця, і від того, наскільки вона здатна формувати переосмислення творчих ідей, залежить і степінь філософського трактування та шляхів створення фундаментальних тенденцій розвитку базових національних мистецьких та дизайнерських шкіл. Цеховий вишкіл кінця XIX ст. поступово замінювався на вишкіл у фахових школах (Шмагало, Р., 2020), де широку підтримку отримала проектна, ручна творчість для реалізації неповторності та облаштування візуального світу за естетичними законами мистецтва. Означені мистецькою критикою циклічність, незалежно від значного впливу цифрових технологій, все ж завжди повертається до феноменального мистецького процесу рукотворної естетики. Таке співвідношення у короткому проміжку часу значно коливається. Досвід показує, що повна всеохоплююча машинізація, стремління до прагматизму та функціонального проектування, динамічності виконання та реалізації проектів, не змогли цілковито витіснити рукотворний сегмент 3 дизайну предметно-просторового середовища.

3 метою інспірувати та зберегти творчі принципи монументальних стінописів в предметно-просторовому дизайні опорядження інтер'єрів чи екстер'єрів, здійснено ряд експериментальних спроб використання теоретичноаналітичних положень, досліджень у сучасній проектно-дизайнерській, художній діяльності для формування нових методів використання історичних зразків в проектуванні гармонійного предметно-просторового середовища 
сучасного простору.

Це було реалізовано у ряді студентських проектів, скерованих апробувати на практиці художньо-проектну компонентну в дизайні простору та її практичну реалізацію вже безпосередньо на об’єкті. Завдання таких навчальних процесів спрямовані на пошуки шляхів інтерпретації, трансформації та модифікації досвіду, принципів індивідуального творчого методу певного художника чи творчої групи. Зокрема, в позааудиторному режимі студенти кафедри дизайну та основ архітектури Інституту архітектури і дизайну Національного університету «Львівська політехніка» реалізували ряд артпроектів, які були інспіровані творчим доробком львівського митця першої чверті XX століття Модеста Сосенка. В методологічній основі закладено трансформацію, інтерпретацію аналогів та творчих принципів монументальних структур та орнаментальних схем в практиці художнього оздоблення та образно-стилістичній організації інтер’єрного громадського простору конкретної локації інтер’єру (рис.1.).

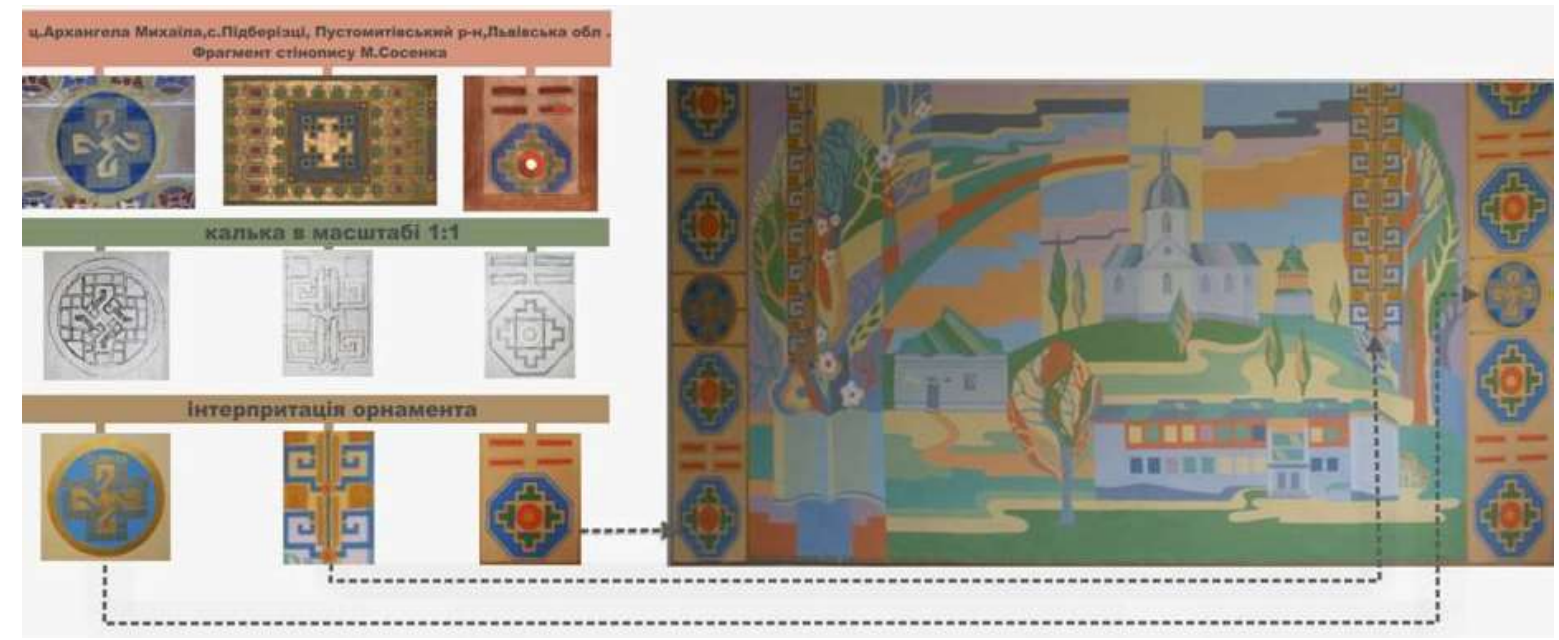

Рисунок 1.Художньо-виробнича практика студентів кафедри ДОА: виконання декоративномонументального панно, музична зала СШ №2, с. Підберізці (2011)

Втілення візуальних та морфологічних закономірностей орнаментальних схем М. Сосенка були використані для виконання великоформатного декоративного панно в актовій залі шкільного закладу с.Підберізців (куратор В.Радомська, 2011) у рамках живописно-пленерної практики студентів напрямку 022 «Дизайн» кафедри ДОА НУ «Львівська політехніка». Цей проект скерований на методично-науковий та практичний підхід формування концепції передпроектного аналізу, оскільки за визначеними критеріями було обрано 
візуальний ряд для ідейно-змістового наповнення настінного панно, продумано способи окреслення регіональних та краєзнавчих особливостей с. Підберізців (Львівська обл.). Оскільки це село відоме, перш за все, за визначною пам’яткою - стінописами Модеста Сосенка (1907-1910) в місцевій церкві Арх. Михаїла, прийнято концепцію інтегрувати композиційні принципи орнаментальних схем у структуру новоствореного проекту (художник Ю. Кіндзер). Була обрана наступна тактика: вирахувавши певну співмасштабність, знято кальки 3 автентичних орнаментальних елементів стінопису інтер'єру церкви вертикальний сегмент орнаментальної схеми з відкосу вікна північної стіни нави, хрещатий символ (сварга) орнаменту з нижнього регістру південної стіни нави, стрічковий орнамент з підпружної арки хорів, що дозволило студентам наочно ознайомитись 3 техніко-технологічними аспектами творчого методу М. Сосенка, визначити композиційну структуру самого орнаментального блоку, принцип його побудови та утворення, його співмасштабність та колористичну співтональність, визначити співвідношення величини архітектонічної деталі храму з масштабами проекту сучасного стінопису. Кальки виконані у масштабі 1:1 згідно оригіналу стінописів. Було обрано орнаментальний фриз віконного відкосу північної стіни рамена трансепту, який, згідно пропорцій, стилістики та масштабів, добре компонувався у загальну концепцію задуму проекту. Наступний взірець орнаменту було знято із орнаментального фризу підпружної арки на хорах. Процес зняття кальок проводили у декілька прийомів. 3 метою відтворення техніко-технологічних особливостей творчого підходу Модеста Сосенка було здійснено наступний етап роботи - виготовлення та апробування на практиці «припорохів», які митець застосовував як технічний прийом для перенесення рисунку на поверхню стін та склепінь. Звичайно, що у сучасних умовах художники-монументалісти використовують новітні методики перенесення та нанесення рисунку, композиційних частин задуму. Але згідно мети та завдання художньої практики, студенти повинні були пройти апробацію художньо-технічних процесів із застосуванням давніх технології та визначеного індивідуального творчого методу обраного художника. Для виготовлення 
«кальок» використано сучасний матеріал - цупка поліетиленова плівка, яку згодом перфоровано (проколювання певного калібру), через отвори наносили порошкоподібний пігмент, згодом уточнюючи деякі деталі рисунку графітним олівцем. Таким чином оригінальні сегменти орнаментальних схем М. Сосенка (натуральний масштаб) були вкомпоновані у загальну композиційну структуру задуму декоративного панно (рис. 2).

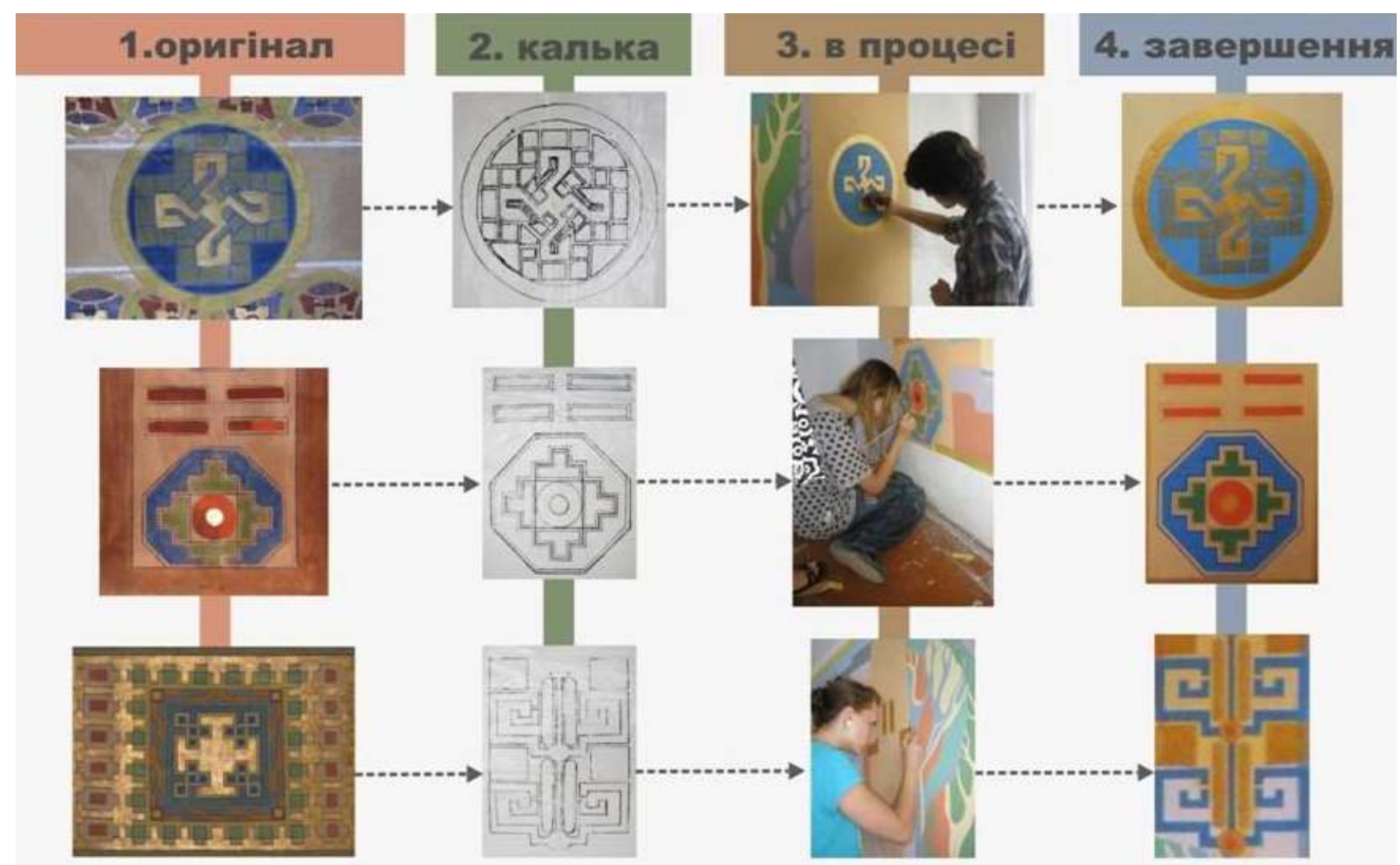

Рисунок 2. Техніко-технологічна методологія виконання декоративно-монументального панно для музичної зали СШ №2, с. Підберізці (2011), студенти Дз-22,кафедри ДОА,куратор В. Радомська.

Позитивний досвід був інтегрований у наступному проекті для образноестетичного наповнення музичної зали дошкільного закладу № 32 у Львові. Для реалізації цих стінописів було використано дещо інший підхід, площиннодекоративні елементи орнаментальних першовзорів зі стінописів Музичного інституту у Львові та елементів орнаментальних сегментів 3 інтер'єрного стінопису церкви Арх. Михаїла с. Підберізців, поєднані в одну образно-стильову композиційну систему, які і створили сучасну образно-стильову програму для даних стінописів (2011). 3 цією метою, згідно проекту, було виготовлено 
трафарети та шаблони, що дозволило в інший спосіб перенести рисунок задуму, оскільки високі стелі приміщення дещо ускладнювали застосування попередньої техніко-технологічної методики, апробованої при створенні декоративного панно для концертної зали в с.Підберізцях.

Монументальна спадщина М. Сосенка стала базовими аналогом для дипломного проектування студентки кафедри дизайну та основ архітектури Г. Піщук (Дз-42, 2011 р., ОКР «Бакалавр») - здійснено експериментальне проектування, яке було базоване на художньому конструюванні предметного обладнання, а саме розробці дизайну меблів-трансформерів та експозиційного обладнання для музейного простору краєзнавчого музею в с. Підберізці Львівської обл. Авторка проекту обрала певні елементи з композиційних блоків стінописів М.Сосенка, які стали формоутворюючими конструктивними елементами предметного обладнання музейного простору. В комплексному проектування було розроблено буклет музею та серію сувенірно-поліграфічної продукції (листівок, магнітів, постерів тощо), в яких композиційні та образноестетичні принципи схем орнаментальних мотивів стінописів М. Сосенка стали предметом творчої інспірації.

Проблематика сакрального дизайну піднята у дипломному проектуванні магістерської роботи М.Олійник, яка взяла участь у реальній розробці комплексної дизайн-пропозиції для організації предметно-просторового опорядження Патріаршого собору Воскресіння Господнього у Києві (УГКЦ), (2013, дизайн: А. Тирпич, М. Олійник, ст. ДЗ3В-11 ДОА ІАРД). Було розроблено усю богословську інфраструктуру опорядження храму, зокрема, компонентів обладнання для богословсько-обрядового освітлення. Мотивом для творчої інспірації у формотворенні послужила фрактальна структурність геометричних орнаментальних патернів стінопису М. Сосенка. У даній роботі розуміння орнаменту як засобу лише декоративного оздоблення і прикраси було цілковито відкинуте. В розробці домінувава принцип розкриття суті орнаменту, як складної формоутворючої структури, яка закладає силует і водночас стає об'ємнопростровою конструкцією з яскраво вираженою функціональною причетністю. 
Візуальне відтворення у формах ужитково-функціонального призначення, а літургійно-обрядове освітлення в інтер'єрі церкви відіграє конкретну та важливу богословську функцію, здійснено за допомогою образно-асоціативних прийомів формотворення. Образні асоціації сформовані за допомогою орнаменту, їх ажурів та переплетень, з використанням закономірностей психології візуального сприйняття, візуальних та морфологічних властивостей базових геометричних фігур. В проекті застосовано співмасштабування квадратного січення металічної конструкції та формотворення на основі геометричних співставлень хрещатих рівнораменних фігур та концентричних об'ємів, які одночасно виконують і конструктивно-технічну та образо-творчу функції. Доповнення елементів 3 гутного скла надають довершеності та функціонального призначення усьому запроектованому обладнанню. Тобто, у даній дизайн-пропозиції авторка вдало та органічно поєднала візуальні образні властивості та прикладне значення сакрального предметного наповнення. Використовуючи семантичну символіку хрещатих мотивів, автор підкреслює зміст, а це і є пряма функція та завдання орнаменту.

В контексті освітнього процесу в сучасній мистецько-дизайнерській освітній практиці для графічного дизайну використано прототипи орнаментальних напрацювань М. Сосенка для створення айдентики «Доброчинного фонду Модеста Сосенка». Орнаментальні мотиви, вітражні композиції авторства М.Сосенка, які знаходяться в інтер'єрному просторі святилища церкви Арх. Михаїла с. Підберізців, стали об’єктами інспірації у розробці серії поштових марок у графічному дизайні студентки кафедри дизайну та основ архітектури ІАРД О.Головатої (2021, Д3-42).

Мистецько-освітня практика, яка спрямована на вивчення й використання закономірностей орнаментальних мотивів, залежить від багатьох факторів, зокрема, від оригінальності представлених проектних ідей та вміння донести проектний задум на належному дизайнерському рівні. Виявлення шляхів та механізмів втілення візуальних закономірностей орнаментики чи іконографічної програми обраних прототипів в сучасній мистецько-дизайнерській практиці 
грунтується на основі використання теоретичного підходу й власного практичного досвіду дизайнера, розуміння тенденцій проектування сучасних інтер'єрів та їх предметного наповнення. Тому перший етап - збагачення та формування правдивої інформативної бази як в освітньому процесі, так і в індивідуальному фаховому проектуванні об’єктів, дозволяє виявити закономірності, методи, прийоми для оптимальної організації інтер'єру, зокрема і за посередництвом стінописів чи інших артоб'єктів. Предметно-просторове опорядження інтер'єру у значній мірі залежить від гармонізації усіх компонентів та коректного скерування усіх складових - образотворчої мистецької програми та ужитково-функціонального обладнання. Це реальна можливість отримати найвищий рівень синтезу художніх практик, підпорядкованих єдиному концептуальному задуму. Тобто на етапі проекту дизайнер не може залишати реалізацію задуму спонтанному виконанню, як правило, це завершується невдалою реалізацією.

Накопичені знання впливають на формування світоглядних пріоритетів теоретичного підгрунтя та мислення проектанта (студента), і можуть цільово, свідомо та на інтуїтивному рівні бути застосованими при виникненні відповідних проектних ситуацій. Зафіксована у пам'яті візуально-теоретична інформація згодом відображається як характерний та доцільний формоутворюючий та образний архетип. Цю тенденцію спостерігаємо в практиках більш сформованих дизайнерів.

Тому досвід реалізація позааудиторних артпроектів, які започатковані 3 2006 року в структурі дизайн-освіти для студентів напрямку 022 «Дизайн»на кафедрі Дизайну та основ архітектури (керівник та куратор - стар. вик. каф. ДОА В.Радомська), надали можливість творчо та неординарно застосувати академічні знання на практиці. 3 цією метою було реалізовано понад десяток цікавих художніх проектів у формі позааудиторних воркшопів. Основне завдання таких заходів - при допомозі стилістично об'єднаних живописних полотен, стінописів створити художньо-естетичне наповнення та організацію інтер'єрного простору конкретної локації. В основному, задіяні інтер'єри 
шкільних та дошкільних закладів, музеїв, лікарняних установ, геріатричні пансіонати тощо. Найбільш знакові проекти: облаштування художньомеморіального музею М. Сосенка в с. Підберізцях Львівскої області (2008р.); стінопис-панно актової зали СШ № 2 с. Підберізців (2009р.); айдентика, декоративне панно, копії творів Осипа Куриласа для експозиції меморіальнохудожнього музею О. Куриласа (2012-2016, м. Щирець Львів. обл.); ряд великоформатних панно за мотивами творів В. Зарицького для інтер'єрного наповнення актової зали СЗОШ № 28 (2013-2017, м. Львів); 2016-2018pp. реалізовано художній проект «С.Караффа-Корбут: трансформація і реалізація» на основі художньої та змістової інтерпретації циклу ілюстрацій художниці до творів І. Франко, А. Волощака, Л. Українки (СШ № 9, м. Львів), що дозволяє на практиці методично інтегрувати нові форми інтелектуального фахового сегменту у позааудиторний навчальний процес дизайнерів на кафедрі ДОА.

За посередництвом глибокого аналізу персоніфікованих інтер'єрів, оригіналів, ідентифікованих артефактів та визначених архетипів в сучасній дизайн-освіті формуються нові ідеї для подальшого створення актуальних форм та естетичних пріоритетів, які згодом стають ретрансляторами ідентичності. 
DOI 10.46299/ISG.2021.MONO.PED.II-578-584

\subsection{9 Шляхи впровадження фахових цифрових технологій при підготовіці молодших бакалаврів 3 агрономії}

Вступ. У статті розглянуто можливі шляхи впровадження у освітній процес вивчення сучасних фахових цифрових технологій на основі існуючих освітньо-професійних програм зі спеціальності 201 «Агрономія», кваліфікаційного рівня «Молодший бакалавр 3 агрономії». Зазначено перелік сучасних цифрових технологій, запропонована можлива структура на основі освітньо-професійної програми для впровадження в освітній процес сучасних фахових цифрових технологій шляхом залучення існуючих інформаційних систем, що використовуються у професійній діяльності. Такий підхід на нашу думку осучаснить освітній процес підготовки молодших бакалаврів аграрного профілю і створить умови одночасного набуття фахових і фахових цифрових компетентностей. Продемонстрований щільний зв'язок освітньо-професійної програми підготовки молодшого бакалавра 3 агрономії і сучасних цифрових технологій. У формі таблиць показаний зв'язок освітніх дисциплін і фахових цифрових технологій, продемонстроване наскрізне представлення фахових цифрових технологій на протязі усього періоду навчання, що у разі залучення, забезпечить неперервне використання фахових інформаційних систем i цифрових технологій. Показана різниця між поняттями «Компетенція» i «Компетентність». Розглянуто складові поняття фахова компетентність. Наведено уточнення поняття цифрова компетентність для молодших спеціалістів з агрономії. Розглянуто напрямки аграрного виробництва, що мають свою реалізацію у сучасних цифрових технологіях. Запропоновано структуру, яка представлена трьома тематичними напрями для охоплення широкого спектру фахових цифрових технологій у агрономії. Аналізуючи зв'язок фахових освітніх дисциплін і цифрових технологій дійшли до висновку що залучення фахових цифрових технологій у освітній процес в більшості потребує зміни освітнього інструменту і використання сучасних цифрових пристроїв, не обмежуючись лише персональним комп’ютером. 
Ключові слова: компетенція, компетентність, агрономія, молодший бакалавр, фахові цифрові технології, фахова цифрова компетентність, освітньопрофесійна програма.

Мета роботи: проаналізувати зв'язок існуючих освітньо-професійних програм молодшого бакалавра з агрономії з існуючими фаховими технологіями

Матеріали і методи: діючі освітньо професійні програми підготовки молодшого бакалавра 3 агрономії, існуючі фахові цифрові технології, порівняльний аналіз

Результати і обговорення: динамічний розвиток цифрових технологій останніх двох десятиліть знайшов своє відображення в усіх сферах людської діяльності, сільське господарство не стало винятком. Тому актуальність нашого дослідження полягає в уточненні поняття «фахова цифрова компетентність» для молодших бакалаврів аграрного профілю. Завданням с аналіз ключового поняття; встановлення зв'язку освітніх програм молодшого бакалавра 3 агрономії з сучасними цифровими технологіями для формування фахової цифрової компетентності.

Досліджуючи поняття «фахова цифрова компетентність», слід зауважити, що у науковій літературі зустрічаються два терміни «компетентність» i «компетенція». Термін «компетенція» використовується у розумінні вимог до знань, умінь і навичок кандидата для виконання професійної діяльності [532]. У свою чергу «компетентність» визначається як особистісна характеристика самої людини [533]. Тобто, оперуючи цими двома термінами, зазначимо, що «компетенція» $є$ критерієм відповідності у певній сфері діяльності, а «компетентність» якісною характеристикою особистості на відповідність визначеним критеріям у діяльності.

Для визначення поняття цифрова фахова компетентність молодшого бакалавра 3 агрономії звернемося до означення фахової компетентності. Формулювання фахової компетенції у більшості досліджень також називають «професійна компетентність» та ототожнюють ці поняття. Питанню дослідження фахової (професійної) компетентності присвячені роботи $\mathrm{H}$. 
Антіпової, I. Гушлевської, В.Ковальчука, Н. Ничкало, G.K. Britell, R.M. Jueger, W.E. Blank та інші.

Підсумовуючи результати досліджень і визначення, можна зробити висновок, що поняття фахової (професійної) компетентності більшість дослідників розуміють як комплексне поняття, не обмежене певним рівнем володіння фахових знань і рівнем професійного досвіду. Воно описує широке коло професійної діяльності, професійної взаємодії фахівця як у колективі, так і використання сучасних професійних технологій задля забезпечення ефективної професійної діяльності на високому професійному рівні, використовуючи актуальні знання і технології.

У дослідженні, присвяченому цифровій компетентності, іiі представляють як взаємодію трьох компонент:

- $\quad$ інформаційна (здатність ефективно працювати з інформацією);

- $\quad$ комп'ютерна або комп’ютерно-технологічна компонента (що визначає уміння та навички роботи з сучасними комп'ютерними засобами та програмним забезпеченням);

- $\quad$ компонента застосовності (яка визначає здатність застосовувати сучасні засоби інформаційних та комп'ютерних технологій до роботи 3 інформацією та розв'язання різноманітних задач) [537].

Наразі, у час широкого розвитку цифрових технологій фахова (професійна) компетентність має бути уточнена на науковому рівні. Адже сучасний фахівець за вимогами часу і ринку праці має володіти необхідним рівнем цифрових навичок, що в свою чергу реалізовують його фахові компетентності. Тому, уточнюючи поняття «фахова компетентність», ми говоримо про фахову цифрову компетентність. Аналізуючи науково-педагогічну літературу, можна зробити висновок, що у напрямі аграрної освіти дослідження фахової цифрової компетентності проводили у вигляді окремих наукових пошуків і воно не представлено у вигляді комплексного наукового дослідження. 
Говорячи про формування фахової цифрової компетентності, слід зазначити найпоширеніші, або ті що мають найбільший попит серед українського аграрного виробництва. Наразі за оцінками фахівців AgTech Ukraine використання цифрових технологій представлено лише у 20-30\% сільськогосподарських підприємств України і найпоширенішими слід виділити: облікові програми, трекінг техніки і пального, дистанційне зондування землі, GPS-обладнання, облік земельного банку, агрометеорологія. Ми у свою чергу пропонуємо, у контексті інтеграції фахових цифрових технологій у освітній процес, розглядати три великі напрями у підготовці здобувачів: Precision Farming - діджиталізація у рослинництві, діджиталізація й автоматизація у сфері агарної техніки й електротехніки, Інформаційні системи управління у сільському господарстві (FMIS) [538.]. Опираючись на запропоновані напрями, ми провели дослідження, де спробували дослідити зв'язок зазначених напрямів і типових для спеціальності 201 «Агрономія» освітніх дисциплін. Згідно з нашим аналізом, який грунтувався на зв'язку освітніх дисциплін із сучасними цифровими технологіями, існує щільний зв'язок, що в більшості освітньо-професійних програм рівномірно розподілений впродовж усього періоду навчання за винятком окремих освітніх програм, де вивчення фахових дисциплін починається з другого року навчання. Аналіз відповідності проводили на основі освітньо-професійних програм «Агрономія», спеціальності 201 «Агрономія», освітньо-кваліфікаційного рівня «Молодший бакалавр з агрономії» за період 2019-2020 pp. 
Таблиця 1.

Зв’язок освітніх дисциплін і фахових цифрових технологій в освітньому

процесі

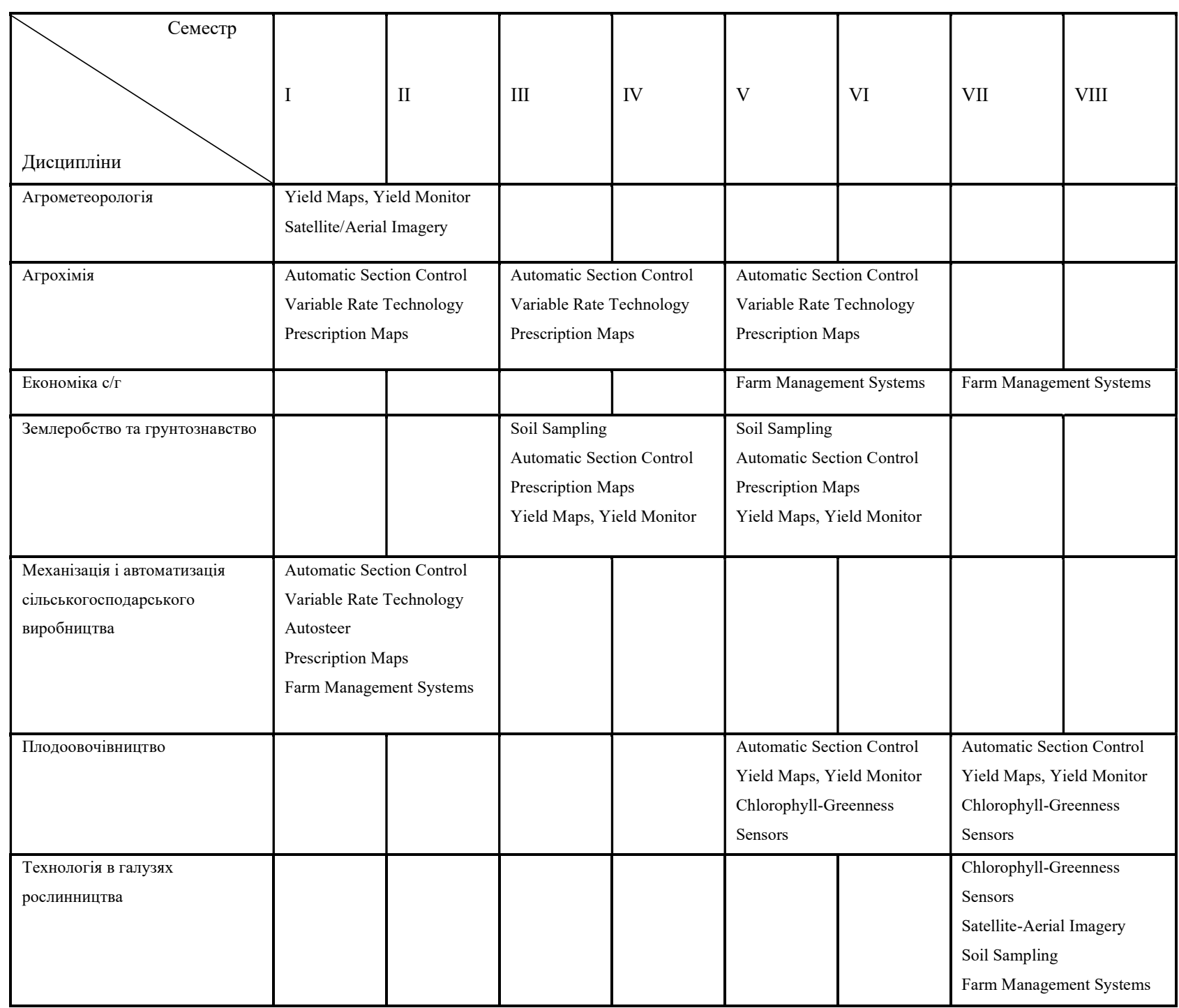

Існування зв'язку між фаховими цифровими технологіями і фаховими освітніми дисциплінами зрозуміло, тому у процесі аналізу ми спробували розглянути, яка щільність залучення фахових цифрових технологій, які ми прив'язуємо до освітніх дисциплін у освітньому процесі. Наступна таблиця демонструє, що залучати фахові цифрові технології можливо на протязі усього освітнього процесу, а деякі технології представлені практично в усіх семестрах. 
Таблиця 2. .

Щільність можливого представлення цифрових технологій у освітньому процесі

\begin{tabular}{|l|l|l|l|l|l|l|l|l|}
\hline $\begin{array}{l}\text { Lифрові Семестр } \\
\text { технологіi }\end{array}$ & I & II & III & IV & V & VI & VII & VIII \\
\hline $\begin{array}{l}\text { Yield Maps, Yield } \\
\text { Monitor }\end{array}$ & + & + & + & + & + & + & + \\
\hline $\begin{array}{l}\text { Soil Sampling } \\
\text { Shlorophyll/Greenness }\end{array}$ & & & + & + & + & + & + \\
\hline Satellite/Aerial Imagery & + & + & & & & & + \\
\hline $\begin{array}{l}\text { Farm Management } \\
\text { Systems }\end{array}$ & + & + & & & + & + & + \\
\hline $\begin{array}{l}\text { Variable } \\
\text { Technology }\end{array}$ & + & + & + & + & + & + & + \\
\hline $\begin{array}{l}\text { Automatic Section } \\
\text { Control }\end{array}$ & + & + & + & + & + & + & + \\
\hline Autosteer rate & + & + & & & & & \\
\hline Prescription Maps & + & + & + & + & + & + & \\
\hline
\end{tabular}

Аналізуючи далі ми спробували вияснити, який відсоток тем у освітніх дисциплінах перетинається з фаховими цифровими технологіями і згідно нашого аналізу перетин тем у робочих навчальних програмах склав від 8\% до 69\%.

Впровадження у освітній процес вивчення фахових цифрових технологій потребує використання певного набору освітніх інструментів, тому на нашу думку доцільно використовувати сучасні інформаційні системи які базуються на фахових цифрових технологіях. Такими інструментами можуть бути існуючі інформаційні системи, для прикладу можна навести Softfarm i AgroOnline, що мають широкий набір відповідних інструментів.

Висновки: поширення цифрових технологій, зокрема фахових, створило умови, які дають можливість осучаснити освітній процес і змінити освітній інструмент. Аналіз, що показує щільний зв'язок фахових цифрових технологій 3 освітніми дисциплінами, - це наслідок того, що аграрне виробництво потребувало впровадження цифрових технологій. Тому сучасний освітній процес також потребує змін, що передбачають впровадження фахових цифрових 
компетентностей. Слід зауважит, що впровадження цифрових технологій в освітній процес закладів освіти аграрного профілю сьогодні відбуваєтьсь не зважаючи на пандемію Covid19 про що свідчить робота проекту FABU «Сприяння розвитку професійної освіти в аграрних коледжах України» [539]. 
DOI 10.46299/ISG.2021.MONO.PED.II-585-592

\subsection{0 Методичні прийоми формування у молодших школярів навичок самоконтролю у процесі розв'язування сюжетних задач}

Самоконтроль в області самоосвіти стає постійним елементом навчальної діяльності і стосується всіх етапів у іiі структурі: учень зіставляє досягнуте 3 очікуваним кінцевим результатом і корегує хід розв’язання проблеми. За цих умов зовнішній контроль трактується ним як "ключ", що підтверджує або спростовує його власні висновки щодо виконаної дії, а з другого - як зовнішня форма самовираження. Мета самоконтролю - запобігання помилкам та їх виправлення. Самоконтроль $є$ засобом активізації свідомості, зміцнення знань, розвитку умінь та навичок учнів. Це метод спонукає школярів до підвищеної відповідальності.

Самоконтроль має дві важливі особливості: no-nерше, він $є$ постійним, безперервним і супроводить саму діяльність, no-дpyze, в його процесі беруть до уваги і приховані огріхи, відомі лише самому учневі, які часто залишаються поза полем зору зовнішнього контролю.

Займаючись розробкою технологічних прийомів розвитку самоконтролю у дітей на уроках в початковій школі, Волявко Д.М. виявила, що учень володіє самоконтролем, якщо уміє:

- свідомо підпорядковувати свої дії заданому комплексу вимог,

- змінювати або зберігати склад своїх дій в умовах діяльності, які змінюються,

- планувати склад дій, визначаючи суб’єктивні труднощі,

- порівнювати дії зі зразком [540].

Потребу розвивати спостережливість, оцінку своїх дій, самокритичність, здатність самому виявити свої помилки і вміти їх позбутися потрібно формувати постійно. Залучення учнів до самоконтролю і самооцінки знань $є$ важливим фактором розвитку у них цих якостей особистості. Перевіряючи й оцінюючи результати своєї роботи, школярі повинні визначити не лише правильність чи неправильність відповіді, засвоєння чи незасвоєння теми, а й те, як одержано результат, яким способом, чи оптимальний він. Але уміння самоконтролю 
нерідко формується недостатньо. Вчителі звертають увагу учнів на потребу перевіряти себе, але як це робити, вчать не завжди. На думку I.В.Тухман, це пов’язано з тим, що недостатньо уваги приділяється розробці загальних методів та прийомів формування самоконтролю у молодших школярів, бо саме в початкових класах починають закладатися способи навчальної роботи, прийоми дій, якими учні будуть користуватися в подальшому навчанні [541, с.20].

На сучасному етапі розвитку шкільної математичної освіти питання про цілі розв’язування сюжетних задач є центральним у методиці початкового курсу математики. Залучення учнів до самоконтролю i самооцінки у процесі розв'язування простих і складених задач $є$ важливим фактором розвитку в них таких якостей особистості як спостережливість, творче мислення, оцінка своїх дій, самокритичність, здатність самому виявляти свої помилки і вміти їх позбутися.

Сформувати вміння самоконтролю в процесі розв'язання сюжетної задачі означає [542, с.27]:

- підпорядкувативласну діяльність поставленій задачі,

- засвоювати правила розв'язання задачі,

- мисленнєво планувати власні дії та наслідки їх виконання у відповідності 3 планом,

- порівнювати заплановані та виконані дії,

- виправляти помилки,

- перевіряти правильність отриманого результату.

Ця методика дозволяс навчити дітей встановлювати взаємозв'язки між елементами умови задачі; врахувати зміни умови і результату в процесі планування; передбачати проміжні і кінцевий результати на певну «глибину»; відшукувати і обирати раціональний варіант розв'язування задачі.

Як зазначає Л.Ілійчук, для успішного використання прийомів формування навичок самоконтролю в учнів молодшого шкільного віку при розв'язуванні сюжетних задач необхідно враховувати наступні педагогічні умови [543, с.159]: - диференційований підхід у використанні самоконтролю; 
- врахування вікових та індивідуальних особливостей учнів;

- систематичність і послідовність використання прийомів у ході навчального процесу;

- різноманітність прийомів самоконтролю;

- сформованість у молодших школярів інтересу до здійснення самоконтролю.

Щоб робота вчителя 3 виховання навичок самоконтролю у процесі розв’язування сюжетних задач виявилася більш ефективною, треба переконати учнів у необхідності самоконтролю і конкретно показати їм як чинити в тому випадку, якщо при перевірці з'ясується, що отримана відповідь не задовольняє умові задачі. Потрібна систематична робота в цьому напрямку, а саме:

1. Треба створити потребу в самоконтролі. Учні повинні частіше зустрічатися 3 реальними умовами, що ставлять їх перед необхідністю самостійно контролювати правильність одержаної відповіді.

2. Зрідка доцільно пропонувати учням такі завдання, неправильність одержаної відповіді яких з'ясується тільки в результаті перевірки.

3. Треба повідомляти учням спосіб перевірки розв'язаної задачі. Пояснювати, що перевіряти треба не тільки остаточну відповідь, а й проміжні результати.

4. Під час аналізу іноді корисно спочатку розглянути не тільки неправильні розв’язки, а й шляхом перевірки довести учням їх неправильність, і лише після цього розглянути правильне рішення.

5. Інколи вчитель навмисно допускає помилки на дошці.

6. У тих темах, в яких це можливо, бажано проводити спостереження та практичні роботи з математики. Самоконтроль при виконанні практичних робіт здійснюється звичайно повторним вимірюванням та обчисленнями (по можливості іншим способом), іноді й безпосереднім вимірюванням шуканої величини.

7. Корисно іноді учням пропонувати самим оцінити свою роботу (контрольну або самостійну). Це підвищує відповідальність учня за її виконання і сприяє вихованню самоконтролю. 
8. Корисно іноді пропонувати учням перевірити i оцінити роботу товариша.

Дуже важливим прийомом навчання молодшого школяра самоконтролю $є$ застосування колективних перевірок у посднанні 3 контролем педагога, тому що в першу чергу школяра потрібно навчити знаходити помилки в іншої людини (контроль). 3 часом учень почне переносити отримані вміння на власну діяльність (самоконтроль). Таким чином, формування контролю йде від контролю за діями інших до самоконтролю. Суть цього прийому полягає в тому, що учні, уважно слухаючи відповідь одного учня, під керівництвом педагога проводять аналіз його відповіді, виявляють допущені помилки і здійснюють колективне їх усунення. Педагог по ходу обговорення розв'язаної задачі задає наступні запитання: «Чи правильний кінцевий результат?», «Чи правильно учень побудував план розв’язання?», «Чи правильний хід розв'язання?»

Фронтальні і взаємні перевірки представляють собою проміжну ланку між контролем педагога і самоконтролем учнів. Застосування їх має ряд переваг при навчанні самоконтролю:

- положення контролерів зобов'язує учнів краще готуватися до занять, щоб мати можливість вказати товаришеві на допущені ним помилки і встановити їх причини;

- колективний аналіз зразка дозволяє більш повно виявити його сигнальні ознаки і більш поглиблено їх засвоїти;

- розбираючи різні способи звірення зі зразком виконуваної роботи, учні відбирають ті з них, які найбільш доцільні в даних умовах. Завдяки цьому досягається велика точність звірення;

- колективний аналіз дозволяє більш повно виявити допущені помилки та встановити їх причини, в ході колективного пошуку виявляються найбільш доцільні способи виправлення помилок і внесення удосконалень у роботу.

Учням доцільно дати завдання, пояснити знайдені помилки того учня, чию роботу вони перевіряли. Це значить, їм доведеться не просто механічно виправляти те, що було неправильно, а обгрунтовувати своє рішення. Вміння не 
тільки бачити помилки, але і виправляти їх і пояснювати їх причини є складовою частиною формування самоконтролю.

Розвиваючи самоконтроль учнів під час розв'язування сюжетних задач, вчитель повинен спрямовувати їх діяльність за допомогою наступних вказівок: «Прочитай...», «Розкажи...», «Поміркуй і скажи...», «Що відомо...?» тощо. Це стимулює самостійність учнів при ознайомленні з текстом задачі та плануванні iiі розв’язання.

У початкових класах доцільно поступово запроваджувати такі прийоми самоконтролю при перевірці правильності розв'язання задачі:

- встановлення відповідності результату й умови, тобто здійснюється перевірка задачі через визначення відповідності між отриманою відповіддю і умовою задачі. Суть цього прийому полягає в тому, що відповідно до опису подій, про які йдеться в задачі, діти використовують необхідні дії над заданими і знайденими числами. Якщо після виконання дій отримують число, яке є в умові, то вважають, що задачу розв'язано правильно.

- розб'язування задачі різними способами веде до розвитку і вміння всебічно аналізувати задачну ситуацію. Суть цього прийому полягає в тому, що якщо задачу можна розв'язати різними способами і при цьому будуть отримані одинакові відповіді, то задача розв'язана правильно. Педагог спонукає учнів до визначення раціонального способу, пояснює, що розв'язання задачі другим способом є не що інше як перевірка вже розв'язаної задачі. Усвідомлення цього $\epsilon$ кроком до пошуку кращого способу, що призводить, у свою чергу, до встановлення нових зв'язків між величинами або використання відомих зв'язків у нових умовах. Вміння знаходити різні способи розв'язання задач означає оволодіння одним із прийомів самоконтролю. Зазвичай порівнюють, який із способів кращий, але необхідно підкреслити, що рішення задачі новим способом одночасно означає перевірку відповіді, отриманої першим способом.

- складання і розб'язування обернених і взаємообернених задач, тобто перетворення прямих задач в обернені і взаємообернені. При перетворенні простої арифметичної задачі в обернену треба шукане задачі взяти за одне 3 
відомих даних нової задачі, а одне з даних задачі вважати шуканим нової задачі. Взаємообернені задачі відрізняються від обернених зміною ключового поняття: наприклад, «більше» стає «меншим». В подібних завданнях правильність розв'язання прямої задачі перевіряється розв'язанням оберненої або взаємооберненої задачі, що дозволяє швидше знайти помилки, виявити причину їх виникнення, на основі зробленого аналізу внести відповідні виправлення. Якщо учні навчаться і звикнуть працювати з оберненими і взаємооберненими задачами, порівнювати умови та їх розв’язки, то поступово вони звикнуть контролювати рішення прямої задачі, а значить у них буде формуватися навичка самоконтролю.

- порівняння відповіді з певним даним числом. У підручниках з математики для початкових класів відповідей до задач не вміщено, але молодших школярів треба навчити звіряти результат 3 тим, який дає вчитель. Самостійне виправлення помилки свідчить про те, що учень зміг проаналізувати умову i запитання задачі, встановити необхідні зв'язки. Залежно від конкретної ситуації і поставленої мети відповіді можна давати як до початку розв'язання задачі, так i після іï розв'язання. Якщо учень зробив помилку, бажано дати йому час поміркувати, щоб він самостійно чи з допомогою вчителя знайшов правильний план розв'язання.

- повторне розв'язання задачі. Ми маємо на увазі повторне розв'язування задачі через деякий час, тобто через кілька днів або тижнів. Цей прийом не належить безпосередньо до творчої роботи, але він відіграє певну роль при формуванні і закріпленні вмінь розв’язувати задачі певного типу. Зустрічаючись із задачею вдруге, учень краще усвідомлює зв'язки між величинами, алгоритм ii розв’язування. Якщо при цьому він розв'яже задачу самостійно, то вона стане вже його “власною”.

- приблизна оцінка шуканих результатів (прикидка). Встановлення можливих меж очікуваної відповіді попереджає недоліки типу описок, пропуску цифр.

Учні повинні знати способи перевірки рішень сюжетних задач i 
застосовувати їх для доведення правильності відповіді. Це теж дуже важливо при формуванні навички самоконтролю, тому що сюжетні задачі складають вагому частину всього матеріалу, що вивчається в початковому курсі математики. Поряд 3 використанням певних прийомів формування самоконтролю, розвиток цієї навички вимагає виконання спеціальних вправ, структурно відмінних від звичайних поширених вправ. Специфіка цих вправ полягає в тому, що учням доводиться не просто виконувати завдання, а так чи інакше контролювати себе. Наведемо приклади деяких з них:

1. Учитель пропонує готове рішення сюжетної задачі, але воно є неправильним. Помилки пропонується виявити учням. Далі учні аналізують помилки, визначають причини їх виникнення, встановлюють, на якому етапі була зроблена помилка і можливість запобігання iï появі.

2. Вчитель приводить неповне розв'язання задачі, а учням пропонує завершити його.

3. Для розв'язування пропонується задача з неповними або надлишковими даними, а учні повинні їх виявити.

4. Розв'язання задачі, пропонованої вчителем, містить принципові прогалини, які пропонується знайти учням.

Ці завдання більше підходять для розвитку уваги дітей, але їх теж необхідно використовувати при підготовці до формування навички самоконтролю, тому що при відсутності уваги не може бути мови ні про самоконтроль, ні про контроль взагалі.

Звичайно у практиці організації самоконтролю при розв'язуванні задач часто виникає потреба забезпечувати учнів еталоном діяльності і очікуваного результату, або хоча б самого результату. Зразок розв'язання задачі, ключ до неї можна запропонувати в індивідуальних картках, в підручнику, на екрані, на дошці.

Відбір методичних засобів формування дій самоконтролю здійснюється на основі врахування як їх специфічного призначення і конкретного психологічного змісту відповідно до етапу діяльності, так і рівня розвитку дітей. Самоконтроль 
можна використовувати до тих знань, умінь та навичок учнів, рівень засвоєння яких вони можуть легко визначити самі [542, с.53].

Самоконтроль учнів не скасовує контролю вчителя і не знижує його ролі, а тільки передує, і тим самим посилює його. Учитель повинен систематично вивчати і аналізувати помилки учнів, звертати увагу на внутрішній зміст, а не на зовнішній, формальний їх бік, повинен виявляти причини їх появи і вживати заходів до попередження помилок. Звичайно це попередження має бути тактовним і не нав’язливим. 
DOI 10.46299/ISG.2021.MONO.PED.II-593-607

\subsection{1 Інформаційні технології в навчанні фахівців психолого-педагогічного напряму}

Сучасне суспільство живе в період небувалого зростання об'єму інформації. Ця обставина обумовлює бурхливе зростання інформатики як науки, що вивчає методи і способи збору, накопичення, зберігання, обробки, передачі і відтворення інформації засобами обчислювальної техніки.

Сучасне матеріальне виробництво і інші сфери діяльності все більше потребують інформаційного обслуговування, переробки величезної кількості інформації. Універсальним технічним засобом обробки будь-якої інформації $\epsilon$ комп'ютер, який грає роль підсилювача інтелектуальних можливостей людини і суспільства в цілому, а комунікаційні засоби, що використовують комп'ютери, служать для зв'язку і передачі інформації. Поява і розвиток комп'ютерів - це необхідна складова процесу інформатизації суспільства.

Процеси, що відбуваються у зв'язку 3 інформатизацією суспільства, сприяють не лише прискоренню науково-технічного прогресу, інтелектуалізації усіх видів людської діяльності, але і створенню якісно нового інформаційного середовища соціуму, що забезпечує розвиток творчого потенціалу людини.

Одним 3 напрямів процесу інформатизації суспільства являється інформатизація освіти - процес забезпечення сфери утворення використання нових інформаційних технологій, орієнтованих на реалізацію психологопедагогічних цілей навчання, виховання, що $є$ дуже важливим у роботі працівників психолого-педагогічного напряму [544].

Сучасні інформаційні та комунікаційні технології дозволяють індивідуалізувати й активізувати освітній процес навіть в межах колективного навчання. Медіа вносять принципові зміни в зміст навчання, якісно інакше будуючи навчальні предмети. З'явилася можливість в масовому масштабі використовувати особливий тип завдань, спрямованих на рефлексію учнями своєї діяльності, іiі саморегуляцію, що важко піддається реалізації навіть в умовах індивідуального навчання. 
Мультимедіа є засобом навчання, за допомогою якого плідно реалізуються ідеї інтенсифікації, спрямовані на пошук максимально ефективних методів і засобів навчання, відповідних його цілям і змісту; інтеграції педагогічної науки, практики; цілісності і безперервності педагогічного процесу. Однак під час розв'язання дидактичних завдань в межах використання мультимедіа в навчанні можна зустрітися з протиріччям між бажанням передати комп'ютеру максимум педагогічних функцій і можливостями комп'ютера ефективно здійснювати ці функції [545].

Актуальність проблеми визначається тим, що сучасні інформаційні технології, в тому числі мультимедіа, відкривають здобувачам знань (освіти) доступ до нетрадиційних джерел інформації, дозволяють реалізувати принципово нові форми i методи навчання із застосуванням засобів концептуального і математичного моделювання явищ і процесів, які дозволяють підвищити якість навчання і ефективність самостійної роботи.

Комп'ютерні технології глибоко впливають на підготовку майбутніх фахівців практично з усіх сучасних спеціальностей. Завдяки комп'ютерам, знайти необхідну інформацію та навчатися стало набагато легше, ніж раніше. Вони забезпечують швидку обробку даних 3 дуже невеликою вірогідністю помилок в обробці. В той же час, мережеві комп'ютери допомагають швидкому зв'язку і веб доступу [546].

3 усіх переваг комп'ютерів в освіті, в першу чергу, відмітимо такі:

- Можливість зберігання великих об'ємів інформації;

- Досить швидку обробку даних;

- Відтворення аудіовізуальних видів інформації;

- Можливість кращої презентація інформації;

- Доступ до мережі Інтернет (в тому числі глобальної).

Враховуючи це, треба відмітити, що комп'ютерне та інтерактивне навчання на сьогоднішній день грають одну з ключових ролей в здобуванні професійних знань. Тобто без застосування інформаційних технологій неможливо здійснити, як його ще називають електронне навчання й увесь освітній процес буде 
обмежено стінами спеціальних закладів. Найкращий спосіб зробити освіту доступною - це використовувати комп'ютерні технології. Електронне навчання $€$ доступним і надає можливості відточити свої професійні навички управління. Саме тому зараз дуже багато он-лайн курсів використовують для підвищення кваліфікації різних спеціалістів, в тому числі і психолого-педагогічного напряму включно [547].

Комп'ютер можна розглядати і використовувати як джерело знань, тому що Інтернет зараз практично теж саме, чим колись були бібліотеки. До того ж, до нього легше отримати доступ, він зручніше і досить надійніше джерело інформації. Комп'ютери нині 3 громіздких пристроїв, перетворилися на портативні, тому учні та студенти можуть отримувати інформацію буквально на кінчиках пальців.

Спеціалісту зараз простіше звернутися до Інтернету, ніж шукати інформацію у великій кількості товстих книг. Треба відмітити, що велика кількість традиційних бібліотек, особливо зі значними фондами зберігання, почали активну цифровізацію - тобто перенос інформації з паперових носіїв на більш компактні цифрові. Інтернет та цифрові бібліотекі являють собою великий і легкий доступ до різної професійної інформації. Коли справа доходить до зберігання одержаної інформації, то іiї значно легше зберігати на комп'ютерах, ніж зберігати рукописні замітки.

В Інтернеті є інформація буквально про все і комп'ютерні технології дозволяють отримати до неї легкий доступ. Інтернет може зіграти важливу роль у підготовці майбутніх педагогів, психологів, соціологів та інших спеціалістів, оскільки це величезна інформаційна база, яка може бути використана для отримання інформації на самі різні тематики. Студенти можуть одержати від нього велику користь коли звернуться до Інтернету за додатковою інформацією і посиланнями на теми, які потрібно вивчити, а також використають вебджерела для отримання додаткової інформації по темах, які їх цікавлять [548].

Комп'ютери дозволяють забезпечити ефективне зберігання даних. Комп'ютерні жорсткі диски і облаштування зберігання інформації являються 
відмінним способом для зберігання даних. В наш час йде постійне нарощування ємності окремих носіїв інформації, розробляються все більш компактні носії 3 більш високою щільністю інформації на одиницю об'єму носія, що дозволяє використовувати комп'ютери зберігання даних в електронному форматі, тим самим економлячи папір. Це дає їм можливість зберігати величезні масиви даних. Крім того, ці пристрої компактні, вони займають менше місця, але зберігають великі об'єми даних.

Таким чином майбутні спеціалісти дістають користь від використання комп'ютерних технологій. Презентації, конспекти, підручники, різного виду посібники, документи можуть зберігатися i переноситься легко через комп'ютерне облаштування збереження i передачі даних. Процес стає безпаперовим і тим самим економиться папір, що, в свою чергу, приводить до економії деревини, а значить і збереження лісів, що дуже важливо з точки зору екології. Також, в електронному форматі зберігання даних стає надійнішим. Електронні запам'ятовуючі пристрої можуть бути використані повторно. Вони пропонують ефективні рішення для зберігання даних i надійного їx використання.

Інформаційні технології навчання дозволяють запроваджувати в навчальний процес засоби мультимедіа. Мультимедіа (multimedia, від англ. multi - багато і media - носій, середа) - це сукупність комп'ютерних технологій, що одночасно використовують кілька інформаційних середовищ: текст, комп'ютерну графіку (фотографії, анімацію, схеми, 3D-графіку та інш.), звук, відео [549]. Це взаємодія візуальних i аудіоефектів під керуванням інтерактивного програмного забезпечення з використанням сучасних технічних і програмних засобів. Вони об'єднують текст, звук, графіку, фото, відео в одному цифровому поданні.

Мао Нео і Кен Т.К. $з$ факультету мультимедіа Малазійського університету розширили це визначення. Вони визначають мультимедіа як «з'єднання різних типів цифрового контенту, таких як текст, зображення, звук і відео, в інтегрований мультисенсорний інтерактивний додаток або «представлення» для 
доставки повідомлень чи інформації аудиторії» [550]. Це визначення включає в себе ті ключові моменти та положення, які визначають використання мультимедіа в навчанні, тобто при будь-якій комбінації або накладенні звичайних медіаформатів ціле містить в собі набагато більше, ніж просту суму складових.

Мультимедіа, безсумнівно, потенційно розширює обсяг і різноманітність інформації, доступної учням. Наприклад, онлайнові енциклопедії можуть надавати посилання на відео і додаткові статті щодо необхідної тематики. Новини можуть включати аудіокоментарі, програвати фонове відео і посилатися на веб-сайти $з$ додатковою інформацією. Онлайнові заняття можуть включати пояснення, посилання на ресурси, симуляції, ілюстрації, фотографії і безліч варіантів дій, які, в свою чергу, можуть включати різні медіафрагменти. У широкому сенсі «мультимедіа» означає спектр інформаційних технологій, які використовують різні програмні та технічні засоби і продукти з метою найбільш ефективного впливу на користувача, який став одночасно і читачем, i слухачем, і глядачем [551].

Мультимедійні технології збагачують процес навчання, дозволяють зробити навчання більш ефективним, залучаючи до процесу сприйняття навчальної інформації більшість чуттєвих компонентів того, хто навчається. На сьогодні мультимедіа-технології - це один 3 перспективних напрямків інформатизації навчального процесу. У вдосконаленні програмного й методичного забезпечення, матеріальної бази, а також в обов'язковому підвищенні кваліфікації викладацького складу можна розгледіти перспективу успішного застосування сучасних інформаційних технологій в освіті [552].

Наведемо основні особливості застосування мультимедійних засобів в освітньому середовищі, які забезпечують ефективність цього процесу [553]:

1) інтерактивність (від англ. «взаємодія»), або діалог - це надання користувачам можливості активної взаємодії з цими засобами. Дозволяє організувати самоатестацію без участі викладача; 
2) гнучкість - здатність перебудувати наявні способи розв’язання задачі, змінити спосіб, що перестає бути ефективним на оптимальний;

3) здатність до моделювання - перш за все, це моделювання реальних об'єктів і процесів з метою їхнього дослідження;

4) комунікативність - це можливість безпосереднього спілкування, оперативність подання інформації, контроль за станом процесу; все це досягається шляхом об'єднання комп'ютерів в глобальні та локальні мережі; (вирішує питання постачання інформації в найкоротші терміни, дозволяє дистанційно керувати навчальним процесом, забезпечує консультації 3 кваліфікованими педагогами де б вони не знаходилися);

5) продуктивність, тобто автоматизація нетворчих, рутинних операцій, що віднімають у людини багато сил і часу.

Мультимедійність створює психологічні умови, що сприяють сприйняттю i запам'ятовуванню матеріалу. Одна 3 найважливіших особливостей медіа як засобу навчання - його здатність в наочній формі представляти різного роду процеси, явища, події, залежності, числові співвідношення і тому подібне, тобто задіяти наочно-образні компоненти мислення, що грають виключно важливу роль в навчанні, в тому числі, під час роз'яснення та засвоєння багатьох теоретичних понять.

Використання медіа орієнтоване на індивідуалізацію навчання в умовах колективної діяльності, у межах єдиного навчально-виховного процесу. Тут медіа виступають як об'єкт вивчення i як засіб навчання. За умови індивідуалізації навчання кожен, хто навчається, втягується в активну, орієнтовану саме на нього діяльність. При цьому збуджується розумова діяльність, більш повно реалізуються пізнавальні потреби, стимулюється творча активність. Електронні медіа дають можливість вибирати оптимальний темп навчання. Якщо традиційна система навчання стимулює мотивацію досягнення (отримання гарної оцінки, успішне складання іспиту і т. д.), то використання інформаційних та комунікаційних технологій орієнтоване на формування пізнавальних мотивів учня [554]. 
Використання мультимедіа в навчальних посібниках доповнює аналітичні (обчислювальні та логічні) і навігаційні можливості комп'ютерів здатністю до образного, синтетичного опису досліджуваного предмета або об'єкта. Численні дослідження показали, що той, хто навчається, з першого разу запам'ятовує лише чверть почутого та третину побаченого, за умови комбінованого впливу на слух і зір запам'ятовується приблизно половина інформації, а за умови залучення учня ще й в активні дії (наприклад, під час використання інтерактивних мультимедійних технологій) частка засвоєного досягає 75\% [555].

Слід відмітити, що комп'ютери вплинули не лише на сектор освіти. Вони приносять велику користь у будь-якій області. Сьогодні життя без комп'ютерів немислиме. Це підкреслює важливість комп'ютерної освіти. Зі знанням комп'ютерів можна побудувати свою кар'єру в потрібному напрямі. Комп'ютери сьогодні є частиною майже кожній галузі. Вони використовуються в мережі, для доступу до інформації і зберігання даних, а також обробки і представлення інформації. Не буде перебільшенням сказати, що комп'ютерне навчання $є$ таким же фундаментальним, як вивчення української мови і математики.

Важливість комп'ютерного навчання дуже сильно проявилась 3 початком у світі глобальної короновірусної пандемії, яка унеможливила проведення освітнього процесу в традиційній аудиторній (класній) формі і потребувала іншої - дистанційної форми навчання. Не можна стверджувати, що освітні системи більшості країн світу виявилися практично неготові до такого виклику, але навить в найрозвинутіших багатих країнах рішення цісї проблеми потребувало значних зусиль урядів і освітянської спільноти.

В Україні, в терміновому порядку, за участю найкращих вчителів 3 окремих предметів була організована телевізійна дистанційна школа для учнів середніх та старших класів. Однак, не дивлячись на старанність та наполегливість наших вчителів, практично зразу стало ясно, що не так просто перейти до викладання перед камерою 3 класу. Крім того відомо, навіть вчителю-початківцю, що дитина-учень може зосереджено працювати-слухати вчителя не більше п'яти хвилин при самій цікавій розповіді, а при не дуже цікавій 
(з його точки зору) ще менше. Все це зробило не аби які труднощі у дистанційному навчанні школярів та студентів.

В цій складній ситуації викладачі вишів і студенти оказались у більш виграшній ситуації ніж школярі. По-перше: студенти були більше обізнані 3 методами і методикою практичної роботи з комп'ютерною технікою, по-друге: мали більший досвід застосування комп'ютерів та мережі інтернет для дистанційного навчання, по-третє: мали більший вік та кращі фізичні здібності.

Треба відмітити, що питання дистанційної освіти на кінець 2019 року не були новиною для більшості закладів освіти вищого рівня як в Україні, так і в інших державах світу $[556,557]$. Але до переходу на тотальне навчання в онлайн більшість освітніх систем світу виявились неготовими. В той же час і велика кількість шкільних вчителів да і викладачів вишів теж виявилась неготовою до різкого переходу з аудиторно-класовой роботи до роботи в он-лайн. Основними причинами цієї ситуації, на наш погляд [558], являються: відсутність глибоко і чітко розробленого контенту по матеріалах викладаємих дисциплін; недостатньо добре володіння методами і технікою використання комп'ютерів у викладацькій діяльності; недостатньо добре забезпечення комп'ютерною технікою; нестійким зв'язком, а іноді його повною відсутністю в час проведення занять; великою кількістю електронних ресурсів, які пропонували свої послуги для освітніх цілей.

Найбільш часто пропонувались такі добре відомі ресурси, як наприклад: ZOOM, Skype, GoogleHangouts, GoogleClassroom, Skype, Teams, а також декілька інших, розроблених окремими групами фахівців та організаціями спеціально, по їх заявам, для освітніх потреб, що привело до розгубленості фахівців-практиків при виборі кращої платформи. Однак, таке різноманіття ресурсів при практичному використанні досить скоро показало їх недоліки, хоча виявлення цих недоліків і привело до значних зусиль і витрат часу окремими вчителями та викладачами.

У процесі цієї напруженої роботи виявились особисті та професійні якості викладачів, їх вміння оволодівати новими технологіями по ходу навчального процесу не перериваючи саме навчання. Відмітимо, якщо викладачі природничо- 
математичного циклу дисциплін в своєї більшості впевнено володіли комп'ютерною технікою, то значної кількості викладачів гуманітарного профілю прийшлося терміново підвищувати вміння працювати на комп'ютері та вести заняття он-лайн. Однак практична викладацька робота дуже скоро показала навіть переваги викладання гуманітарних дисциплін, тому що практично увесь вивчаємий матеріал міг бути викладено у мовленій формі, а практичні заняття можна було проводити у вигляді повідомлень та діалогу.

В цьому сенсі викладачам природничо-математичного циклу дисциплін прийшлося значно складніше: проведення практичних занять - рішення задач потребувало безпосереднього безперевного контакту з аудиторією. И хоча рішення задач ще можна адаптувати, з деяким зниженням ефективності, для проведення дистанційно, то лабораторні роботи, тим більше в спеціалізованих лабораторіях, виявилось неможливим. Спроба провести лабораторні роботи в демонстраційному вигляді в дистанційній українській школі показало іiі дуже низкую эффективность і привело до відказу від цієї методики. Можливість проведення так званих «віртуальних» лабораторних робіт стримала мала кількість і недостатня якість розробленого контенту.

Всесвітня Організація Охорони Здоров'я прогнозує, що не дивлячись на масове щеплення і карантинні заходи епідемія короновірусу може йти ще одиндва роки з хвиле образними підйомами захворюваності, що вимагатиме уряди i місцеві власті вводити більш жорсткі карантинні обмеження, в тому числі і в освітньому процесі. Тому, на наш погляд, важно звернути більшу увагу i активніше розробляти якісний контент «віртуальних» лабораторних робіт, які при потребі можна було ефективно використовувати в дистанційному навчальному процесі.

Процес інформатизації суспільства міняє традиційні погляди на перелік умінь і навичок фахівців, в тому числі і психолого-педагогічного напряму. Якщо говорити про майбутніх фахівців-психологів, то в сучасних умовах вони повинні: 
1. Уміти працювати на комп'ютері, ставити і вирішувати 3 його допомогою практичні завдання;

2. Мати достатній рівень володіння технологіями доступу до локальних і глобальних мережевих інформаційних ресурсів;

3. Знати тенденції розвитку сучасних інформаційних технологій i можливості їх застосування в психологічній практиці.

Без використання обчислювальної техніки неможливе рішення ряду психологічних завдань :

1. Структуризація i iнтерпретація результатів психологічних експериментів;

2. Створення i використання систем адаптивного, ігрового i дистанційного тестування;

3. Математичне моделювання психологічних процесів;

4. Розробка нових автоматизованих психодіагностичних методик;

5. Вивчення людського чинника в техніці методами інженерної психології.

Сучасні інформаційні технології забезпечують психологів наступними основними можливостями:

1. Підвищення ефективності роботи за рахунок швидкості обробки даних і отримання результатів тестування;

2. Скорочення термінів проведення психологічного тестування за рахунок одночасного тестування декількох випробовуваних;

3. Звільнення від трудомістких рутинних операцій;

4. Підвищення "чистоти" експерименту за рахунок збільшення точності реєстрації результатів і виключення помилок обробки початкових даних;

5. Можливість для випробовуваного бути відвертішим і природнішим під час експерименту завдяки конфіденційності автоматизованого тестування;

6. Підвищення рівня стандартизації умов проведення дослідження за рахунок однакового інструктажу випробовуваних і пред'явлення завдання 
незалежно від індивідуальних особливостей об'єкту дослідження і експериментатора;

7. Використання часу не лише як керованого чинника, але і в якості діагностичного параметра;

8. Скорочення часу i підвищення якості аналізу результатів експерименту за рахунок використання прикладного програмного забезпечення, що реалізовує математичне моделювання психологічних процесів;

9. Поширення досвіду роботи психологів більш високої кваліфікації за рахунок комп'ютерної інтерпретації результатів тестування;

10. Систематичного накопичення, зберігання і передачі по мережевих каналах великих масивів інформації про об'єкти дослідження, а також дані про результати тестування;

11. Доступу до психологічних інформаційних ресурсів через локальні і глобальні комп'ютерні мережі;

12. Реалізації в психологічній практиці методології штучного інтелекту (наприклад, експертних систем).

Зупинимося детальніше на основних областях практичної діяльності психолога, де потрібне застосування IT. По-перше, це комп'ютерна психодіагностика яка припускає проведення психологічного тестування за допомогою мережі Інтернет. Цей спосіб тестування має ряд переваг, таких, як заощадження часу, економія коштів (відсутність необхідності друку роздавального матеріалу), швидкість і точність процесу обробки результатів, можливість тестування великої кількості людей з видачею індивідуальних рекомендацій для подальшої консультативної і корекційної роботи. Важливе значення має використання комп'ютерного ігрового і дистанційного тестування [559].

Широке застосування комп'ютерних технологій можливе і при проведенні корекційнорозвиваючої роботи. До подібних технологій відносяться комп'ютерні програми повчального і розвиваючого характеру. Використання цих програм сприяє розвитку сенсоромоторних, перцепетивних і вищих когнітивних 
функцій; підвищенню ефективності навчання учнів, підвищенню їх учбової мотивації, розвитку їх інтелектуальних і творчих можливостей. Можна виділити [560] два напрями використання IT в корекційнорозвиваючій роботі:

1) використання IT для розвитку пізнавальних здібностей (по цьому напряму зараз пропонується велика різноманітність комп'ютерних тренажерів $\mathrm{i}$ комплексів ігор, спрямованих на розвиток сенсомоторики, уваги, пам'яті i мислення;

2) використання IT при організації корекційнорозвиваючої роботи 3 дітьми, які мають особові, поведінкові і емоційні особливості. Застосовуючи комп'ютерні ігри при корекції основних емоційних і поведінкових порушень (агресивності, замкнутості, страхів та інш.), вони використовуються як такий же інструмент, як лялька і картинка, в якості деякого посередника, що, в деякому сенсі, заміщає живих учасників спілкування.

При організації психологічної просвіти і групового консультування старшокласників 3 питань професійного і особового самовизначення можна використовувати широкий спектр можливостей, пропонуємих інформаційнокомунікаційними технологіями, такі як: комп'ютерні програми, електронні книги, ресурси Інтернет i розроблені самим психологом іграшкамипрезентаціями (наприклад: гра "Орієнтир у світі професій" дозволяє в ігровій формі систематизувати отриману на занятті інформацію про світ професій). Створення із старшокласниками програми-презентації "Добрий настрій", можна спільно підбирати фотографії кольорів, водоспадів, пейзажів, дотримуючись переходам колірної гами з певним музичним супроводом, що вимагало від учнів попереднього ознайомлення з інформацією про вплив кольору і музики на настрій і фізичний стан людини [561].

Не можна переоцінити ресурси інформаційних технологій $\mathrm{i}$ для професійного саморозвитку особистості практикуючого психолога: це i можливість оцінювати в Інтернеті електронні підручники, посібники, статті інших авторів, знайомитися з новинами психологічних досліджень, шанувати "Психологічні консультації", обмінюватися 3 колегами інформацією за 
допомогою електронної пошти, приймати участь в професійних чатах, дистанційних конференціях i так далі, в тому числі із застосуванням мультимедійної технології, що містить дані різної «природи» (звук, музика, анімація, відео, текст, графіка) в одному файлі. Приклади мультимедіа документів можуть бути різні, наприклад: програма-енциклопедія, навчальна програма, програма-репетитор, слайд-фільми, відеофільми та анімаційні ролики, ігри. Найбільш поширеними програмами для створення та представлення мультимедіа продукту є: Word, Excel, Power Point, Nero, Fine Reader, Delphi, Studio, Movie Maker, Flash MX, CourseLab тощо [562].

Все вищесказане показує, що в наш час відкриваються широкі можливості подальшого розвитку IT в практичній педагогіці та психології і які вигоди несе використання інформаційних технологій в практичній діяльності фахівців цього напряму. Проте існує ряд недоліків використання інформаційних технологій в психологічній практиці. Серед них можна назвати неможливість контролювати умови проведення психологічного тестування в умовах он-лайн. Так, існує можливість впливу комп'ютерного монітора на сприйняття стимулюючого матеріалу тесту. Враховувати це особливо необхідно в тих випадках, коли сама форма пред'явлення матеріалу (колір, яскравість, конфігурація, час) відіграє важливу роль при проведенні дослідження. Треба враховувати також неможливість виключення впливу інших (присутніх) людей на сприйняття комп'ютерної версії тесту та відсутність зворотного зв'язку у випробовуваного і психолога при проведенні дослідження, що може приводити до невірного розуміння завдань і спотворення результатів [563].

Поза сумнівом, впровадження комп'ютерних ресурсів в психологічну діяльність відкриває безліч нових і неоцінимих можливостей. Звичайно, важливо відмітити, що психологічна практика - це, передусім, спілкування між психологом і його клієнтом, тому використання комп'ютерних можливостей має бути дуже обережним. Існує ряд проблем, пов'язаних 3 впровадженням комп'ютерних методів в психологічну практику. Проте для деяких людей саме on-line консультування є єдино можливим способом звернення по психологічну 
допомогу. Також використання комп'ютерних технологій $є$ обов'язковою умовою при проведенні наукового дослідження [564].

Розвиток сучасних інформаційних технологій пропонує ряд комп'ютерних програм, що забезпечують :

- підвищення ефективності роботи за рахунок швидкості обробки даних і отримання результатів тестування;

- скорочення термінів проведення психологічного тестування за рахунок одночасного тестування декількох випробовуваних;

- ввільнення від трудомістких рутинних операцій;

- підвищення "чистоти" експерименту за рахунок збільшення точності реєстрації результатів і виключення помилок обробки початкових даних;

наочніше і менш трудомістке надання отриманих даних.

Що стосується підвищення педагогічної ефективності навчання за умови використання мультимедіа, то під час використання мультимедіа-ресурсів на уроці вчитель отримує можливість гнучко змінювати форми навчальної взаємодії з учнями (зміна фронтальних, групових та індивідуальних форм; варіювання поля самостійності учнів, індивідуалізація навчання на основі врахування пізнавального стилю школяра , надання учню можливості працювати в індивідуальному темпі і т. п.), а також застосовувати нові форми навчальної взаємодії учнів між собою .

За рівнем творчих мотивів і ступеня впливу на людину мультимедіа необхідно віднести до нового виду синтетичного мистецтва, відмінною рисою якого $є$ висока інформативність і інтерактивність. Тому в майбутньому варто очікувати створення теорії педагогіки мультимедіа, що враховує психофізіологічні та естетичні закони сприйняття та засвоєння великого обсягу інформації. Не виключаючи традиційної форми навчання, яка передбачає творчє i виховне спілкування 3 викладачем, мультимедіа створює нові позитивні чинники, зокрема, значне зростання ефективності навчання за рахунок підвищення якості самостійної роботи студента з електронними навчальними матеріалами [562, 564]. 
В якості завершення викладем декілька думок про стан і перспективи застосування інформаційних технологій і комп'ютерної техніки при навчанні фахівців психолого-педагогічного напряму. На жаль, досі не існує єдиної точки зору відносно того, як реально повинні здійснюватися інформаційнокомунікаційна робота в цьому напрямі і які стратегічні і тактичні підходи $є$ оптимальними при розробці нових і модифікації наявних в інформаційнокомунікаційних технологіях методів на нинішньому рівні розвитку соціальної педагогіки і психології. Нестаток уваги до проблем розробки і використання інформаційно-комунікаційних технологій в психології та педагогіці кінець кінцем обертається далекосяжними наслідками: гальмується прогрес в області теорії, ставляться під сумнів результати прикладних досліджень, виникають серйозні труднощі при інтеграції психолого-педагогічного знання зі знанням, що придбавалося в інших наукових дисциплінах. Звичайно, комп'ютеризацію педагогіки і психології не можна вважати гарантією успішного вирішення виникаючих проблем, але, як показує досвід інших наук, це плідна, а у багатьох випадках і необхідна стратегія розробки таких проблем.

На сучасному етапі діяльність педагога і психолога вже не мислиться без використання комп'ютерних технологій. Впровадження сучасних комп'ютерних технологій в психолого-педагогічну практику і використання інформаційних технологій в науковій психології і педагогіці дозволяє зробити роботу фахівців цього напряму більш продуктивнішою і ефективнішою.

Що стосується використання інформаційних технологій в освіті, то важливість і необхідність впровадження IT у навчання обгрунтовується міжнародними експертами і вченими. IT торкаються всіх сфер діяльності людини, але, мабуть, найбільш сильний позитивний вплив вони мають на освіту, оскільки відкривають можливості впровадження абсолютно нових методів викладання і навчання, що в свою чергу свідчить не тільки про незаперечні переваги інформаційних технологій в цій сфері, але й про великі перспективи їх у майбутньому. 
DOI 10.46299/ISG.2021.MONO.PED.II-608-622

\subsection{2 Методичний супровід формування інструментально-виконавської компетентності майбутніх учителів музичного мистецтва}

Сучасні реалії компетенізації освітнього процесу потребують від закладів вищої педагогічної освіти впровадження компетентнісного підходу у викладання дисциплін музично-виконавського циклу та створення умов для повноцінної самореалізації майбутніх фахівців. Проте на теренах музично-педагогічної освіти впровадження названого підходу відзначається складністю як у теоретичній, так і в практичній площині, потребуючи систематизації у виокремленні фахових компетентностей майбутнього вчителя музичного мистецтва, зокрема висвітлення та деталізація змісту інструментальновиконавської компетентності.

Джерельну базу теоретико-методичної аргументації процесу впровадження компетентнісного підходу в освітній простір та формування інструментально-виконавської компетентності вчителя музичного мистецтва складає науковий доробок провідних українських та зарубіжних науковців Г. Селевка, І. Зимньої, Н. Кузьміної, Л. Митіної, А. Хуторського, Н. Гуральник, Т. Жигінас, О. Максимова, О. Михайличенка О. Олексюк, Н. Миропольської, Г. Ніколаї, О. Отич， Г. Падалки， О. Ростовського， О. Рудницької， в яких розкривається багатовекторність змісту музично-педагогічної підготовки та опосередковано висвітлюється сутність означеної компетентності. Дослідники акцентують увагу на розкритті сутності художньої творчості, символічній природі та специфіці виражальних засобів музичного мистецтва, різновидах мистецьки традицій у музичному виконанні.

Психологічний базис формування інструментально-виконавської компетентності вчителя музичного мистецтва віднайдено у працях Л. Бочкарьова, О. Винокурової, О. Готсдинера, С. Корлякової, О. Лучиніної, Г. Овсянкіної, А. Торопової, в яких окреслені основи сприйняття та розуміння художнього змісту музичних творів, суб'єктивні та об'єктивні чинники 
виконавської інтерпретації, специфіка процесу формування виконавських вмінь та сценічної витримки.

У музично-виконавській діяльності науковцями зосереджується увага на продукуванні оптимальної емоційної інтенсивності, тобто викликання емоцій, необхідних для втілення художнього образу музичного твору в потрібний час та утримування їх інтенсивності та продовжності на необхідний час, що має велике значення для проектування та досягнення піаністичного успіху при виконання музичних творів (Б.Берман)[565, с. 134]. Дане твердження апелює до акторської майстерності, притаманної театральному мистецтву. У концепції видатного театрального режисера, актора, педагога та реформатора К. Станіславського зазначається, що сценічні почуття грунтуються на глибинних пластах емоційної природи людини. Артист на сцені відчуває двоїсті почуття: 3 одного боку він проживає емоції, закладені у художньому образі, з іншого - відчуває естетичні почуття як творець, художник. Вступаючи між собою у взаємодію ці почуття і створюють феномен сценічності. К.С. Станіславський вважав, що творче сценічне самопочуття повинно і може бути створеним свідомо. Знаходячись в відповідно створеному сценічному самопочутті, актор проходить через етапи інтуїтивного, підсвідомого пошуку (передчуття образу), переживає момент відкриття і далі розвиває образ у емоціях та фізичній дії [566, с. 94-114].

В методиці А..Алексєєва розглядається емоційний взаємоконтакт слухацької аудиторії та музиканта-виконавця, що надає останньому творчих сил, відчуття повної духовної та фізичної свободи для безперешкодного втілення художніх намірів. Автор наголошує на тому, що це дорогоцінне самопочуття необхідно зберегти у емоційній пам'яті та намагатися кожного разу викликати його під час гри. Найкраще в цьому допомагає захопленість музикою, що виконується та проникнення до їі глибинного змісту [567, с. 274].

У площині психологічної науки виділяється оптимальний емоційний стан, необхідний для успішного виконання будь-якої діяльності. Конкретизуючи зміст цього поняття науковці апелюють до закону Йоркса-Додсона, згідно 3 яким певний рівень емоційної збудженості забезпечує підвищення ефективності 
діяльності людини, а емоційна перенапруга приводить до зниження працездатності. За твердженням авторів закону, залежність продуктивності діяльності від рівня пов’язаної з нею активації має вигляд інтровертованої Uобразної кривої, що відображає рівень продуктивності людини, яка спочатку зростає швидко, пропорційно до росту рівня емоційної збудженості, а потім іiі ріст уповільнюється і високий рівень збудженості вже вносить дестабілізацію у процес діяльності та приводить до зниження іiі інтенсивності. [568, с. 216-218]. Словесна характеристика музичних переживань не задовольняє нас тому, що саме почуття стає в музиці могутнім пізнавальним засобом, багатшим i зрозумілішим, ніж вербальна характеристика. Таке піднесення пізнавальної ролі емоції можливе завдяки позитивним змінам, які мистецтво вносить у свідомість людини. За визначенням О.Костюка, першоджерелом цих емоційно-естетичних переживань є виразний зміст прослуханого твору. Разом з тим, слід мати на увазі, що емоційно-естетичний відгук людини на музику обов'язково несе на собі відбиток тієї епохи і того суспільного середовища, в якому вона живе. Автор стверджує, що емоційно-естетичний відгук слухача має двоїстий характер. 3 одного боку емоція виступає як супровід сприймання, а з другого увіходить у процес сприймання як складова його частина. Ці дві сторони музичного переживання найтісніше між собою пов'язані, аж до ілюзорного заміщення однієї другою, але все ж суть справи визначає друга сторона, а саме те, що переживання є необхідним компонентом музичного сприймання [569, с. 72]. .

Б. Теплов справедливо наголошує на внутрішній емоційності музичного пізнання дійсності: “Переживання музики має бути емоційним, але воно не має бути тільки емоційним. Сприймання музики йде через емоції, але емоцією воно не закінчується. В музиці ми через емоцію пізнаємо світ. Музика є емоційне пізнання“" [570, с. 27]

Почуття та емоції в музичному мистецтві $\epsilon$ могутнім пізнавальним засобом, багатшим і зрозумілішим, ніж вербальна характеристика. Відмінність музичного пізнання полягає у взаємодії емоцій та інтелекту, оскільки музика породжує “знання-переживання”. Таке піднесення пізнавальної ролі емоції 
можливе завдяки позитивним змінам, які мистецтво вносить у свідомість людини.

У контексті формування інструментально-виконавської компетентності майбутнього педагога-музиканта виконавство розуміється як проникнення до художньої та змістової сутності музичного твору, осягнення музичного образу за допомогою реалізації аксіологічних детермінант його автора та передбачає наявність: 1) свідомого використання духовних ресурсів особистості у виклику психологічного стану готовності до творчого «подвижництва», до пошуку «художнього відкриття»; 2) розгляду творів, що виконуються у метафоричній множинності виконавських прочитань, включаючи “перевиконання” педагогом рекомендованого твору та “обігравання” його у самих різних концертних умовах виступу; 3) проведення у процесі підготовки виконуваної музики до публічного показу з широким обговоренням із застосуванням комплексних знань, які освоюються у циклі обов'язкових музичних, гуманітарних та мистецтвознавчих дисциплін музичного вишу; 4) використання «творчого експерименту» подання виконуваних творів у риторичній множинності, виходячи з орієнтації на тип аудиторії; 5) усвідомлення зіграної та планованої до виконання музики у контексті сукупних артистичних та педагогіко-просвітницьких умов діяльності музиканта.

Виконавська діяльність майбутнього вчителя музичного мистецтва потребує контакту зі слухацькою аудиторією, котрий створюється на основі спільного емоційно-почуттєвого проживання художньої ейдетики музичного твору. Виникнення «сценічних почуттів» музиканта безпосередньо пов’язане 3 його минулим емоційним досвідом. Адже викликати в собі та відчути необхідне переживання музикант-виконавець може тільки тоді, коли воно вже має аналог пережитого у емоційній пам'яті і його можна віднайти, порівняти та поєднати 3 умовним сценічним подразником та відтворити спеціальними зображальними засобами. В цьому випадку сила та яскравість почуттів, які переживає митець досягають такої інтенсивності, якої неможливо досягнути в реальному житті. 
Музично-емоційні враження суб’єкта важко реєструвати. Наука поки що не знайшла задовільних засобів фіксації музичного переживання, якому притаманні часовий розвиток i емоційна та естетична насиченість. Взаємопроникнення емоційно-естетичного переживання музики та формування інструментально-виконавської компетентності майбутнього педагога-музиканта відбувається у площині когнітивних та емочійних процесів віддзеркалюючи рівень художньо-музичних знань, розуміння мистецтва у єдності змісту та форми, сприйняття емоційної ейдетики музичного мистецтва, проникнення до змістовності та завдань художнього виконання з метою проектування власних емоційно-естетичних переживань на слухацьку аудиторію, рефлексивної трансформації музичних емоцій до рівня естетичного переживання. Змістовність музичних образів полягає в силі естетичного переживання, тобто слухач повинен насамперед пройматись тими почуттями, які відображені в музиці, не копіювати чиїсь переживання, а переживати власні, адже не існує емоцій поза конкретними обставинами та певними життєвими ситуаціями, якими вони викликані.

Розглядаючи емоції мистецтва, В. Н. Холопова виділяє серед них ті, що відображають різноманітні аспекти емоційного відгуку людини: 1) емоції захоплення майстерністю мистецтва; 2) суб'єктивні емоції музиканта-практикавиконавця; 3) відображення в музиці емоцій (емоції втіленого в музиці образу); 4) специфічні природні емоції музики (емоції природного музичного матеріалу) [571, c. 97].

Як було вказано раніше, виконавська діяльність майбутнього вчителя музичного мистецтва потребує контакту зі слухацькою аудиторією, котрий створюється на основі спільного емоційно-почуттєвого проживання художньої ейдетики музичного твору. Музично-емоційні враження суб'єкта важко реєструвати. Наука поки що не знайшла задовільних засобів фіксації музичного переживання, якому притаманні часовий розвиток і естетична наснаженість.

Проаналізувавши вказане вище, ми виділили чинники взаємопроникнення процесів емоційно-естетичного переживання музики та розвитку виконавської майстерності студента-піаніста, до них слід віднести: рівень художньо-музичних 
знань (широта їх знайомства 3 національним, російським, українським, слов'янським та зарубіжним мистецтвом); здатність розуміти мистецтво у єдності змісту та форми, тобто освоєння художньо-музичного сприймання, емоційної ейдетики музичного мистецтва, рефлексивної трансформації музичних емоцій до рівня естетичного переживання; вміння аналізувати музичні твори з точки зору їх змістовності та завдань художнього виконання з метою проектування власних емоційно-естетичних переживань на слухацьку аудиторію (спочатку у систему відносин “викладач-студент” 3 подальшим розширенням аудиторії слухачів до однокурсників, студентів старших курсів, слухачів масових концертних заходів); готовність студентів до музично-виконавської mворчості, котра спонукається емоційно-естетичним переживанням музичних творів.

У контексті формування інструментально-виконавської компетентності емоційно-естетичне переживання музики визначається як встановлення особистістю внутрішнього емоційного зв'язку зі змістом художньо-музичного образу з метою отримання естетичної насолоди та втіхи.

При побудові методичної моделі акцентуємо увагу саме на емоційному та естетичному аспектах формування інструментально-виконавської компетентності студентів-піаністів. і вважаємо доцільним розкрити етапність формування емоційно-естетичного переживання як інтеріорізованого процесу свідомості людини. Побудова моделі сприяє упорядкуванню та систематизації інформації про об’єкт, що досліджується, та створенню відповідного методичного супроводу..

Основою емоційно-естетичного переживання, за переконанням О.Костюка, є емоційний відгук, який породжується суб’єктивним оцінним ставленням людини до естетичного явища. Автор висвітлює сутність емоційноестетичного переживання, описуючи процес сприймання музики: “звучання музики пробуджують у серці слухача багатобарвну гаму витончених емоційних переливів i яскравих афективних спалахів, предметних почуттів та ледь вловимих настроїв” [569, с.20]. 
Більш складну схему переходу емоційного відгуку в емоційно-естетичне переживання ми споглядаємо у наукових працях представників феноменологічної естетики, зокрема у Р. Інгардена, який визначає найважливіші особливості естетичного переживання і вважає, що естетичне переживання не $\epsilon$ «миттєвим переживанням», «миттєвим відчуттям», а становить складний процес, який має різні фази та протікає дуже своєрідно. Зазначена Р. Інгарденом своєрідність залежить від рівня професійної підготовки реципієнта й зумовлюється складністю чи простотою самого предмета сприймання, адже естетичне переживання може викликати i кольорова пляма i звук голосу i звучання музичної інтонації. Весь реальний предмет може сприйматися на рівні чуттєвого споглядання, а потім, зазначає Р. Інгарден, починають формуватися фази естетичного переживання.

Специфіка виникнення естетичного переживання, за Р. Інгарденом, емоційне враження від певної якості предмета (кольору, гармонії поєднання барв, мелодії, тощо) Ці якості роблять нас небайдужими до предмета споглядання концентрують нашу увагу та викликають у нас особливу попередню емоцію, яка дає поштовх процесові естетичного переживання. Між попередньою емоцією і естетичним переживанням у концепції Р.Інгардена вибудовано певні етапи “сходинки”, спираючись на які можна аналізувати внутрішню складність естетичного-переживання: попередня емоція породжує стан збудження на основі якого актуалізується бажання оволодіти предметом споглядання, оскільки даний предмет викликає здивування і як результат формується складне інтенціальне естетичне переживання [цит. за 8., с. 94-99].

Складним та оригінальним у даному контексті є дослідження М. Сови, яка розглядає процес формування емоційно-естетичного-переживання через призму особистісної рефлексії, та іiі аналогії - “музичної рефлексії. Концептуальне уявлення про музичний твір та осмислення власної інтелектуальної та емоційної діяльності, на думку автора, відбувається в процесі рефлексивного акту. Музична рефлексія характеризується послідовними ієрархічно залежними рівнями свідомості реципієнта і веде до перехрещення його духовного світу та 
ейдетики (образності) музики. Відповідно властивостям музичної свідомості, що визначають контакт людини з музикою, М. Сова виокремлює чотири основні ступені рефлексивного акту:

I ступінь - на першому ступені емоційно-смислового пошуку «музичної істини» здійснюється входження в об’єктивну музичну реальність, відбувається сприйняття об'єктивного мистецького твору, особистісний смисл якого належить предметній стороні свідомості суб'єкта. Саме з відчуття об'єктивності музичного твору, занурення в його зміст з метою усвідомлення життєвого світу музики і починається рефлексія;

II ступінь - на даному ступені рефлексивного акту увага реципієнта переноситься з об'єктивного музичного буття на власні особливості сприйняття музики. Зацікавленість безпосередньою предметністю змінюється на контактування 3 більш глибинними прошарками власного «Я». Реципієнт класифікує музичні враження та реакції на них , сприймає самого себе в якості дослідника власних думок, почуттів, спостережень, міркувань, які виникають за рухом естетичних почуттів.

III ступінь - внаслідок своїх інтенціональних переживань музичні враження від твору набувають особистісно-суб'єктивного смислу, композиційні форми зводяться до поетично-інтенціональних форм, тому даний ступінь рефлексії можна розглядати як повернення від суб'єктивності до об'єкту сприйняття через комплекс об'єктивних і суб'єктивних інтерпретацій музики на основі уявлень, безпосередньо пов'язаних з конкретним мистецьким твором. У такий спосіб усвідомлюється смисл твору, а його ейдос поєднується зі суб'єктивною інтенціональністю реципієнта;

IV ступінь - на цьому ступені музичної рефлексії активізується включеність власного «Я» в концептуальне розуміння музики. Діяльність свідомості набуває синтетичного характеру, музичне мислення проявляється через двоєдині діалектичні пари: чуттєве і понятійне, абстрактне і конкретне, емоційне і раціональне, індивідуально-інтуїтивне і художньо-образне. Сплав акустичних процесів та репрезентованих ними психічних станів людської 
чуттєвості означає розкриття естетичної ейдетики музики та завершення переходу від зовнішньої предметності звукового матеріалу на початковому рівні музичної свідомості до внутрішнього суб'єктивного саморозвитку, тобто до саморефлексії особистості. На розглядуваному рівні рефлексивного акту завершується перетворення музичного твору в естетичний об'єкт [573, с.72-75].

У контексті нашої роботи саме останній - рефлексивний - підхід $є$ найбільш прийнятним та доцільним. Психологами виявлено, що студентству притаманна підвищена емоційність, висока самооцінка i, разом 3 тим, конформізм та часто буденне відношення до звичайного, здатність за одним фактом робити загальні висновки.

Процес виконання музичного твору - це складний пізнавальний акт. Рівень осягнення емоційно-естетичного змісту музики у кожного студента відбувається по різному, в залежності від їх індивідуальних особливостей та попередньо набутого досвіду. Для кращого освоєння музичних творів студентами, на нашу думку, необхідно врахувати наступні критерії добору творів для музичного виконання, а саме: 1) загальний емоційний настрій твору; 2) змістовність твору; 3) доступність для музичного осягнення; 4) рівень впливу даної музики на виконавця та його ставлення до музики, що виконується; 5) відповідність чи не відповідність складності музичного матеріалу до індивідуальних професійних можливостей студента-виконавця. Метою запропонованою нами моделі $\epsilon$ формування інструментально-виконавської компетентності майбутніх учителів музичного мистецтва. Стратегія побудови моделі передбачає опору на індивідуальні особливості музичного розвитку кожного студента, емоційне ставлення до інтонаційної природи музики, готовність до сприйняття нової музично-інтонаційної інформації.

Методична модель формування інструментально-виконавської компетентності майбутніх учителів шляхом актуалізації емоційно-естетичного переживання музики - це схематичне відображенням основних компонентів комплексного процесу музично-слухової, музично-аналітичної, музично-оцінної та музично-виконавської діяльності, метою якої $є$ створення музикантом 
переконливої виконавської концепції музичного твору та його досконале сценічне втілення з опорою на рефлексивне занурення до емоційно-естетичної ейдетики музики.

При створенні даної моделі ми враховували: психологічні особливості студентського віку; загальний рівень доуніверситетської музичної підготовки студентів та попередній на рівень їх виконавської майстерності у музичному виконанні твору; стан сформованості музично-виконавського досвіду та досвіду емоційно-естетичного переживання музики; методичну доцільність добору музичних творів, для збагачення музично-виконавського досвіду та емоційноестетичного відчуття студентів; особливості індивідуальної інтерпретації та індивідуальні відмінності сценічного втілення творів художнього змісту музичного мистецтва студентами у концертному виконанні.

Відповідно до вказаного вище, ми побудували методичну модель формування інструментально-виконавської компетентності майбутніх педагогів-музикантів, яка має три стадії із коплементарним (взаємопроникаючим) поєднанням компонентів. Особливість даної моделі у пріоритетному наближенні позицій «викладач» та «студент» до позиції «інструменталіст-виконавець» та у створенні на заняттях з основного музичного інструмента спільного поля емоційно-естетичних переживань.

I стадія - мотиваційно-підготовча - відображає послідовність процесу ознайомлення студентів 3 новим музичним матеріалом, завдяки якому народжується план емоційного проникнення до художнього змісту та ескіз виконавської інтерпретації в опорі на емоційно-естетичну ейдетику музичних творів. Послідовність процесу ознайомлення студентів з музичними творами передбачає: а) ескізне ознайомлення, при якому від студента вимагається самостійність осягнення емоційної палітри музичного твору, а роль викладач полягає у гнучкій-корекції емоційної ейдетики музичного твору, побудованої студентом; б) поникнення до художнього змісту на рівні фрагментарного сприймання та інтуїтивно-емоційного пережсивання передбачає створення студентом емоційної концепції за авторським задумом, в цьому випадку 
викладач покликаний також створити власну емоційну концепцію, яка співпадає iз задумом композитора та допомогти студенту скоригувати емоційний контент власної виконавської концепції; створення ескізу майбутньої художньої інтерпретації - позиції викладача i студента поєднуються спільному смисловому полі інтерпретації музичного образу та емоційного стану виконуваного твору. Схематично даний процес виглядає так:

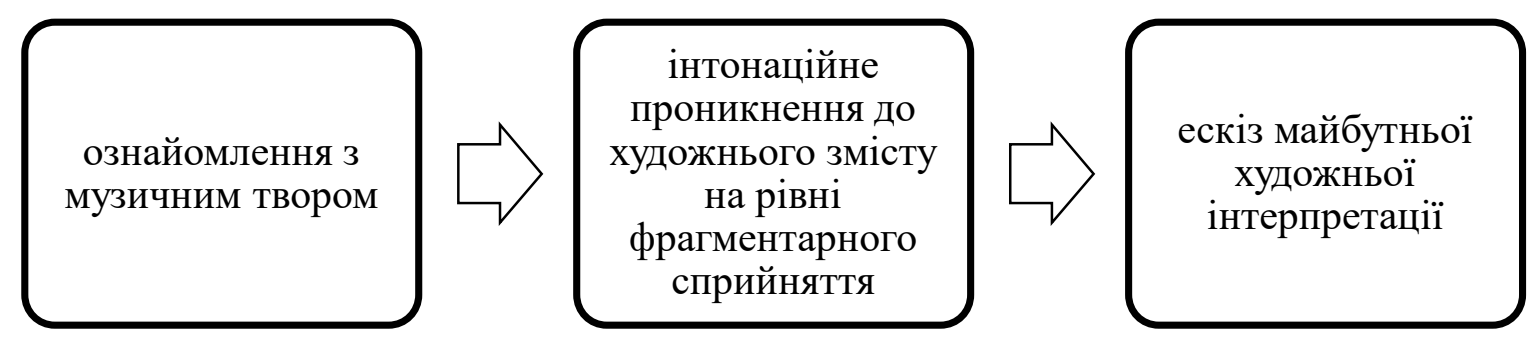

Рис.1. Послідовність прочесу ознайомлення студентів з музичним твором

Відповідно до вищезазначеного формуються складники I стадії методичної моделі:

- мотиваційний складник - має вигляд особистісних потреб студентамузиканта при ознайомленні 3 музичним твором, що відображається у визначенні виконавських цілей: «чув раніше - хочу спробувати», «хочу зможу», «чув в іншому виконанні - в мене вийде не гірше», «потрібно - значить зіграю» тощо;

- емоційний складник - характеризується впливом нових емоційних вражень, отриманих у процесі ознайомлення з музичним твором, на створення відповідного емоційно-піднесеного стану особистості, розкутості ініціативи, що відображається на якості емоційно-естетичного сприйняття твору;

- пізнавальний складник - при проникненні в емоційно-естетичну ейдетику виконуваної музики відображає комплексну дію взаємодоповнюючих компонентів, які базуються на попередньому досвіді музично-виконавського інтонування, а саме: асоціащуiŭ, що виникають у студентів при ознайомленні 3 музичними творами певних стилів, авторів, жанрів, фактурних особливостей 
тощо; осмисленому сприйманні нових музичних емоцій та емоційно-естетичних комплексів;

- рефлексивний складник - при ескізному «читанні» музичного твору виявляється як у посиленні слухового самоконтролю в особистості (тобто активізації в студентів інтонаційного слуху), так і в активізації їх музичного мислення, основу якого складає наявність органічного взаємовідношення орієнтуючої і контролюючої функцій (тобто роздвоєння уваги виконавця на звукову мету і на наступний контроль гри) в єдності з специфічними ігровими відчуттями.

II стадія - діяльнісно-практична - окреслює алгоритм процесу виконавського освоєння студентами музичних творів з детальним розумінням їх емоційно-естетичної і побудови та віднайденням шляхів сценічного втілення інтерпретації. Послідовність процесу засвоєння музичного твору на цій стадії зосереджена на технології виконавського втілення художнього образу, яка графічно відображається наступним чином:

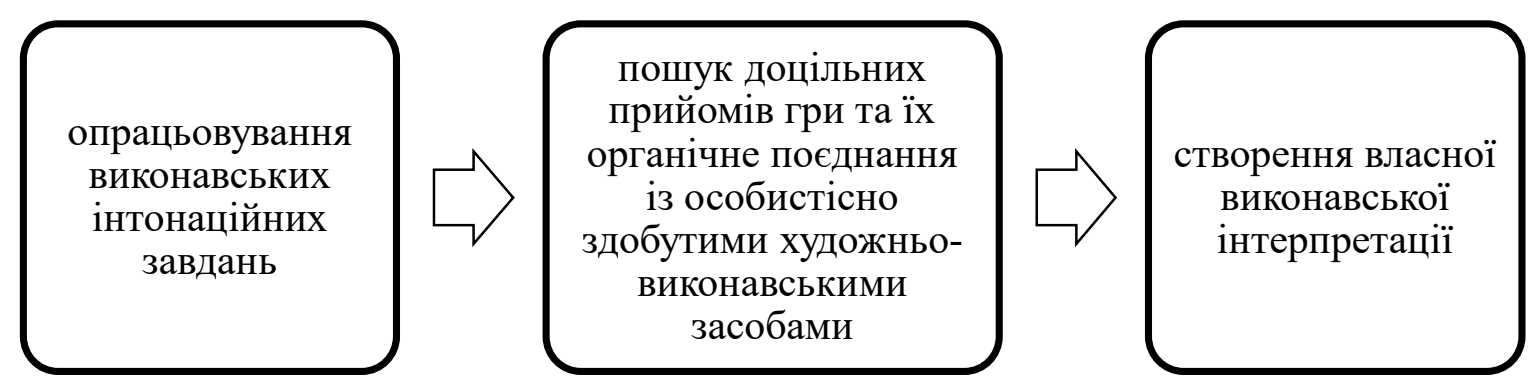

Рис.2. Послідовність процесу вивчення музичного твору

Еволюція змісту складників даної стаді зумовлюється актуалізацією виконавської технології втілення художнього образу:

- мотиваційний складник - віддзеркалює прагнення студента знайти індивідуально-неповторне поєднання загальновідомих виконавських прийомів та особистісних інтонаційно-виразних засобів втілення художньої інтерпретації музичного твору;

- емоційний складник - відображає переусвідомлення власного емоційного стану, а також його зіставлення із характерною для даного твору емоційно- 
смисловою сферою, що була закладена композитором, яке відбувається у виконавця в процесі інтонаційно-технічного опрацьовування музичного твору;

- пізнавальний складник - полягає у систематичному поповненні "емоційно-естетичного словника" студента, наявність відомостей у галузі музикознавства та додаткової історичної інформації 3 проведенням синестетичних паралелей. сприяє віднайденню власної інтерпретації;

- рефлексивний складник - уможливлює процес оволодіння емоційнохудожньо структурою твору 3 урахуванням існуючих норм i правил; співвіднесення та корекцію взаємовпливу внутрішньо-слухових і руховомоторних уявлень в процесі інтонування твору; посилення слухо-рухового контролю, для діагностування не лише стану роботи, але й усунення причин окремих недоліків та регуляції дій під час виконання твору; активізацію здатності керування власною виконавською діяльністю.

III стадія - аналітична - передбачає підведення підсумків щодо виконавського оволодіння емоційною ейдетикою музичного твору, а також практичними піаністичними прийомами та художньо-виразними засобами для iii втілення ï особливістю $є$ співпадання виконавських позицій викладача та студента під час аналізу кінцевих результатів процесу виконавського інтонування, вдосконалення емоційно-естетичної інтерпретації, музичної рефлексії у формі емоційно-естетичного переживання, постановки подальших виконавських цілей, шляхів збагачення барв емоційно-естетичного переживання у формуванні інструментально-виконавської компетентності майбутнього вчителя музичного мистецтва. Особливості даної стадії відображаються у наступному рисунку: 


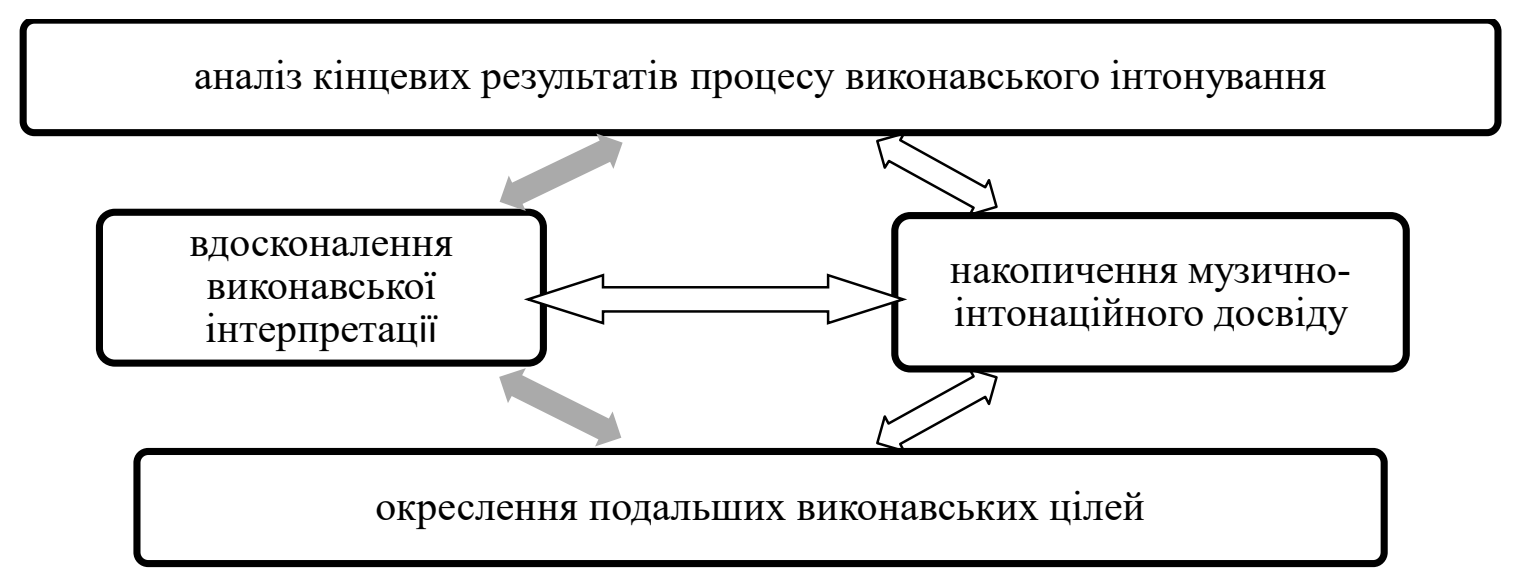

Рис.3. Послідовність процесу аналізу результатів сиенічного виконання музичного твору

На аналітичній стадії ії чотири складники виглядають наступним чином:

- мотиваційний складник - визначається знаходженням шляхів до подальшого вдосконалення власної інтерпретації вже виконаного музичного твору та віднаходженням підтвердження у наступній практичній діяльності власним здобутим виконавським вмінням та навичкам виконавського інтонування та емоційно-естетичного проживання художньої ейдетики музичного твору;

- емоційний складник - передбачає глибокий аналіз відповідності рівня емоційності інтонування із художньо-образним змістом твору та подальший пошук ключових інтонацій, що зроблять виконання ще більш емоційно забарвленим;

- пізнавальний складник - зорієнтований на осягнення виконавцем технології музично-виконавського інтонування даного твору з ії наступним креативно-модифікованим використанням, але вже на іншому музичному матеріалі;

- рефлексивний складник - передбачає враховування та збереження досягнутих результатів діяльності; надання об'єктивної оцінки власним проблемам при інтонуванні твору, коригування, згідно до потреб подальшої виконавської діяльності; формування найкращих якостей виконавця - 
стриманості, самовладання (включаючи емоційне), та витримки; аналіз якості набутих інтонаційно-виконавських умінь та навичок.

Підсумовуючи зазначимо, що методичний супровід формування інструментально-виконавської компетентності майбутніх педагогів-музикантів шляхом емоційно-естетичного переживання музики втілюється застосуванні методичної моделі як схематичного відображенням основних компонентів комплексного процесу музично-слухової, музично-аналітичної, музично-оцінної та музично-виконавської діяльності., Особливість даної моделі у пріоритетному зближенні позицій “викладач” та “студент” до позиції “піаніст-виконавець” та у створенні на заняттях 3 основного музичного інструмента (фортепіано) спільного поля емоційно-естетичних переживань, а результатом $є$ створення музикантом переконливої виконавської концепції музичного твору та його досконале сценічне втілення з опорою на рефлексивне занурення до емоційноестетичної ейдетики музики. 
DOI 10.46299/ISG.2021.MONO.PED.II-623-630

\subsection{3 Актуальність формування інформаційної грамотності учнів закладів загальної середньої освіти на уроках географії профільного рівня}

Одна 3 основних цілей розвитку інформаційного суспільства в Україні - забезпечення комп’ютерної та інформаційної грамотності населення. На виконання поставленої мети спрямовані завдання - створення системи освіти, орієнтованої у формуванні компетентного, всебічно розвиненого випускника, використання інформаційно-комунікаційних технологій (IКT) у сукупності методів, прийомів, спрямованих на підготовку особистості інформаційного суспільства, формування інформаційної грамотності, дослідницьких умінь роботи з інформацією, розвиток комунікаційних здібностей, добір оптимальних рішень щодо раціонального використання електронних засобів навчального призначення (ЕЗНП) у пошуку необхідної географічної інформації тощо.

Динамічні зміни в суспільстві зумовлюють необхідність постійної роботи над собою кожної людини. Особливо актуальним це питання є для педагога як фахівця, коуча, фасилітатора змін, транслятора нових ідей, мобільного консультанта учнів нової української школи (НУШ). Зважаючи на це, перед сучасним учителем географії постають завдання щодо оптимального поєднання форм, методів, засобів побудови освітнього процесу з географії, мотивування вихованців до стійкого інтересу щодо переосмислення інформації та використання нових форм ії подання.

У такий спосіб, нагальною потребою сучасної школи є створення організаційно-процесуальних умов (побудова процесу навчання, що уможливлює використання ІКТ, геоінформаційних систем (ГІС) в освітній діяльності), навчально-методичних умов (розробка та використання посібників, підручників; віртуальних лабораторій, практикумів; електронних тестуючих систем; інтерактивних географічних карт; диференційованих i компетентнісно орієнтованих завдань; спільний з учнями добір інструментів навчання; використання вчителями педагогічнх програмних засобів (ППЗ), освітніх інтернет-сервісів, відповідно до мети заняття тощо), за яких кожен учасник освітнього процесу мав би змогу самостійно здобувати необхідну 
інформацію, використовуючи іiї для власного розвитку, самореалізації, розв'язання навчальних проблем, формування самоосвітньої, геоінформаційної компетентності.

Питання інформатизації освітнього середовища, застосування IКТ,

своїх працях розглядали: В. Бондаренко [577], I. Варфоломєєва [574], М. Грузман [576], Д. Гукін [579], А. Гуржій [577], М. Жалдак [581], М. Камедія [582], Д. Корчевський [585], О. Ляшенко [587], Н. Морзе [581], О. Співаковський [577], В. Тарадайник [589], I. Шахіна [582] та ін.

Дидактичні аспекти формування інформаційної грамотності у процесі навчання географії у своїх роботах висвітлили: Н. Гончарова [575], В. Гудима [578], Л. Даценко [580], С. Кобернік [583]， Р. Коваленко [583], В. Корнєєв [584], К. Костиря [586], А. Некос [588], В. Остроух [580] та ін.

Однак, аналіз останніх досліджень і публікацій за обраним напрямом указує на те, що на додатковий розгляд заслуговують питання використання IКТ на уроках географії профільного рівня, у тому числі у контексті вимог НУШ.

Метою статті $\epsilon$ висвітлення питання значимості та особливостей використання IКТ, ЕЗНП, що дають змогу ефективно, зокрема, за допомогою використання інтернет-сервісу Learning Apps, програмного забезпечення Microsoft Office та вільної кросплатформеної геоінформаційної системи QGIS, формувати інформаційну грамотність учнів на уроках географії в закладах загальної середньої освіти (33СО) на сучасному етапі розвитку освіти.

Значні можливості в технополізованому світі перед учителем відкриває використання Інтернет матеріалу - ефективний спосіб зв'язку навчання географії 3 життям, трудовою діяльністю населення; засіб активізації пізнавальної діяльності школярів у процесі навчання, підвищення його виховного потенціалу, за умов ефективного використання Internet-pecyрсів і програмного забезпечення (Microsoft Office: Microsoft Office Word, Microsoft Office Excel, Microsoft Office PowerPoint, Microsoft Office Publisher Microsoft Office Outlook, Microsoft Office Access, Microsoft Office OneNote, Microsoft Office FrontPage, Microsoft Office Visio, Microsoft Office Project), ГІС, ЕЗНП, ППЗ [591]. 
У разі використання комп’ютера як засобу навчання та побудови процесу комунікації в єдності всіх його компонентів (комунікатор, інформація, комунікант, засоби, результат зворотного зв'язку) на уроках географії профільного рівня стають можливими: індивідуалізація та диференціація процесу навчання; здійснення контролю за зворотним зв'язком i результативністю роботи; здійснення самоконтролю та самокорекції; унаочнення (демонстрація динаміки процесів, що вивчаються; графічна інтерпретація досліджуваних закономірностей) навчального матеріалу; моделювання, імітація процесів, які вивчаються та досліджуються, явищ із «переходом» у «реальність - модель» і навпаки; проведення практичних робіт у режимі «приєднання» за допомогою спеціальних пристроїв демонстраційного обладнання до комп'ютера; створення та використання інформаційних баз даних, необхідних в освітній діяльності, забезпечення доступу до мережі інформації; посилення мотивації навчання; «озброєння» учнів стратегією засвоєння навчального матеріалу; формування відповідного стилю мислення, уміння обирати варіанти розв'язання завдань; розвиток творчих здібностей особистості; осучаснення процесу навчання географії з урахуванням психологопедагогічних особливостей учнів; формування компетентного випускника НУШ тощо [590].

Вихідною умовою, що забезпечує ефективне використання матеріалу інтернет-ресурсів на уроках географії, $є$ добір його змісту за сукупністю таких критеріїв: наукова достовірність, доступність для розуміння, коректність поданих формулювань, відповідність навчальним програмам із географії, своєчасність та актуальність презентації тощо.

Навчальною програмою з географії передбачено, що випускники НУШ мають: розвинений пізнавальний інтерес, інтелектуальні та творчі здібності, провадити самостійну навчальну діяльність шляхом пошуку та обробки географічної інформації, тобто набувати геоінформаційної компетентності сукупно з інформаційною грамотністю. Тож, навчання за допомогою комп’ютера та IKT упевнено торує шлях у методиці навчання географії. Застосування IКТ у 
навчанні географії- одна 3 методологічних проблем та потреб сьогодення. Навчання географії за допомогою ІКТ $є$ ефективним під час вивчення всіх шкільних курсів географії (від пропедевтичних до тих, що вивчаються на профільному рівні) й особливо курсів за вибором (на кшталт «Lean-логістика в географії»), адже сприяє унаочненню програмового матеріалу, кращому розумінню та засвоєнню абстрактних понять, формуванню в учнів практичних умінь просторової орієнтації, навичок віртуалізації, візуалізації.

Таким чином, на уроках географії учитель має можливість використовувати IKT із метою: пропедевтики навчання географії на профільному рівні, розкриття особливостей та закономірностей розвитку географічних і соціально-суспільних явищ; унаочнення певної інформації; комплексної характеристики території та виокремлення й опису типових її особливостей; демонстрації тематичних схем, карт, графіків, таблиць; контролю та корекції знань, умінь і навичок учнів; проведення навчальних географічних ігор; конструювання просторових моделей логістичних потоків; здійснення віртуальних подорожей і відкриттів та ін.

Сучасний урок географії в старшій школі неможливо уявити без використання мультимедійних технологій, учителю дедалі складніше вдосконалювати освітній процес без використання комп’ютера як засобу навчання. Урок із застосуванням мультимедійних технологій стає цікавішим для учнів, а отже, ефективнішим для засвоєння знань, відпрацювання умінь та набуття навичок, формування мотиваційних установок. Актуальною в цьому контексті є медіаосвіта, яка орієнтована на підготовку молоді до життя в нових інформаційних умовах. Швидкий розвиток ІКТ відкриває людству нові можливості в освіті, висуваючи, натомість, нові вимоги до навчання та того, хто навчає. Розвиток так званого інформаційного простору вимагає від сучасної школи модифікації окремих аспектів її діяльності, які вже не задовольняють усіх потреб інформаційного суспільства. Навчання медіа грамотності, критичного мислення учнів - аспекти вивчення географії на профільному рівні, засновані на процесах формування практичних навичок розуміння, аналізу, оцінювання 
змісту медіа продукту; здатності створювати власний медіа продукт, оцінювати власну медіа активність тощо [591].

Нині учні старших класів, особливо ті, що навчаються на профільному рівні, мають бути не лише ознайомлені з таким поняттям, як презентація, а вміти іï будувати та модифікувати з елементами анімації; не лише орієнтуватися в тому, що таке QR-код, а усвідомлювати його значення та вміти створювати й інтерпретувати; не тільки розумітися у просторових поняттях, а й уміти конструювати просторові моделі за допомогою IKT; не лише знати, що таке інтернет-ресурси, а використовувати їх у власній освітній діяльності, що, у свою чергу, доцільно використовувати вчителям на уроках географії 3 метою зацікавлення предметом, осучаснення процесу навчання, задоволення потреб учнів, зокрема щодо роботи з ЕЗНП.

Важливим аспектом у формуванні геоінформаційної культури, предметної географічної компетентності учнів старших класів відіграє правове виховання, яке за допомогою ЕЗНП може бути використано з метою навчання культури цитування, уміння посилатися в презентації на використані джерела інформації.

Використання анімації як засобу візуалізації на уроці географії сприяє акцентації уваги учнів на важливих фактах, подіях; посиленню зацікавленості змістом навчання. Так, у презентації PowerPoint доцільним є додавання анімації до тексту, фігур, таблиць, рисунків SmartArt та інших об’єктів із метою створення візуальних ефектів, зокрема ефектів входу й виходу, зміни розміру або кольору та навіть руху. Однак, у PowerPoint не слід плутати анімацію 3 переходами (ефекти типу: «вхід», «вихід», «виокремлення», «шляхи переміщення»). У процесі створення презентації як засобу навчання доцільним $€$ використання кількох прийомів реалізації ефекту анімації, один із яких - прийом типу «накладання», за допомогою чого реалізується ефект динамічного зображення. Застосування прийому «накладання» буде доцільним у процесі вивчення навчальної теми «Україна в міжнародному просторі» (10-й клас). У такий спосіб, на карту світу послідовно наносять країни і території, дотичні до території України, що утворилися в різні історичні періоди, i, поступово, - дедалі 
віддаленіші територіально. Прийом накладання, у переважній більшості, лежить в основі вправ настільних ГIC (QGIS), основним призначенням яких є обробка та аналіз просторових даних, підготовка різної картографічної продукції засобами пакету з інтерфейсу QGIS, що має гнучку систему розширень, завдяки чому можливим є побудова географічних карт із растрових і векторних шарів [588]. Типовим для такого роду програмного забезпечення є збереження векторних даних у вигляді площинного (материк, країна, озеро тощо), лінійного (магістралі тощо), крапкового (населені пункти тощо) зображення. Використання різних картографічних проєкцій дозволяє створювати географічні карти відповідного масштабу, тематики, змісту з поетапним нашаруванням необхідної конфігурації.

Аналогічно прийому накладання, у побудові географічних карт засобами ГІС шляхом 3(2)D-моделювання (простору, об'єкту тощо), можуть бути використані прийоми типу «приховування» або «виникнення». Об'єктами такого анімаційного ефекту можуть бути схеми, блок-схеми, частини лінійного тексту. Зокрема, такі анімаційні прийоми можна використати під час вивчення навчальних тем: «Населення України», «Економіка України у міжнародному поділі праці» (11-й клас), у яких значну кількість інформації подано в таблицях, опорних схемах, а використання елементів анімації дасть змогу тримати увагу учнів під час вивчення одноманітного статистичного навчального матеріалу [591].

Ще один прийом - типу «рух у просторі» - може бути використаний у процесі навчання географії, у поєднанні з ГІС, з метою ілюстрації туристичних маршрутів, пам’яток світової культури, історії, архітектури, археології, природи, населення та ін.

Використання ЕЗНП, ІКТ, ГІС на уроках географії в старших класах школи має свої особливості та закономірності. Так, критично оцінюючи інформацію, учні аналізують іiі на предмет головного та другорядного тексту в змісті; вибудовуючи презентацію, логічно добирають інструменти іiі побудови, використовуючи водночас інші засоби навчання (текстові, графічні, об'ємні тощо); порівнюють (екстраполюють на свою місцевість), узагальнюють, роблять 
висновки та умовиводи. Це сприяє формуванню в учнів навичок стисло, зручно для ефективної інтерпретації, представляти результати досліджень за допомогою IКТ, ГІС, майндмеппінг-софту, хотлисту, мультимедіа скрепбуку, бук-трейлерів, вдало дібраних діаграм і графіків, переконливих фактів для віртуальної демонстрації процесів, явищ, подій тощо. Осучаснює процес навчання географії використання інтернет-сервісу Learning Apps та вільної кросплатформеної геоінформаційної системи QGIS, як сучасного засобу навчання. До прикладу подібного поєднання - розроблений нами E-збірник «Lean-логістика в географії» у формі бук-трейлера, окремі сторінки якого доповнено прикладами мультимедіа скрепбуку інтерактивних вправ засобами Print Screen-візуалізації логістичного лото [591].

У такий спосіб, специфіка використання IKT на уроках географії визначається, удосконаленням системи національної освіти; зумовленістю таких стратегічних ліній, як інформаційна спрямованість змісту навчання, ऑii невід'ємність від світових надбань. Істотне зростання обсягу наукових знань позначається на обсягах інформаційної складової процесу навчання географії на профільному рівні, у свою чергу, потребуючи розвитку й модернізації методів трансляції, за допомогою IКТ. Сучасні прогресивні тенденції в освіті, зокрема компетентнісний підхід, зорієнтовують суб’єктів освітньої діяльності на багатоаспектну різнобічну змістову інтеграцію, використання IКТ, ЕЗНП, ГІС, які відображають динамізм нової наукової парадигми та педагогічної думки, синтезують багатогранність їх внутрішніх зв’язків і взаємозалежностей.

У такий спосіб, значні можливості щодо використання IКТ у різних видах діяльності мають учні старшої школи, за умов наявної матеріально-технічної бази, відповідних навичок роботи, мотивації, підтримки вчителів, навчаючись за програмами рівня стандарту, академічного, профільного. На підставі викладеного можна зробити висновок, що проблема підготовки вчителів до процесу створення та використання засобів навчання географії має міждисциплінарний характер. У такий спосіб, актуалізується питання тенденцій удосконалення професійної підготовки учителів географії у системі 
післядипломної освіти у контексті імплементації концептуальних засад НУШ у практику роботи 33СО та методичного обгрунтування системи засобів навчання географії на профільному рівні, що є предметом подальших наших наукових розвідок. 


\section{REFERENCES}

1. Дічек Н. П. Дослідження українських психологів у галузі індивідуалізації шкільного навчально-виховного процесу (60-70-х рр. ХХ ст.) / Н. П. Дічек // Педагогіка і психологія. - 2014. -№ 4. - С. 76 -83.

2. Выготский Л. С. Собрание сочинений. В 5-ти т. - М., 1983.

3. Эльконин Д. Б. Психологические вопросы формирования учебной деятельности в младшем школьном возрасте / Вопросы психологии обучения и воспитания // Под ред. Г. С. Костюка, П. Ф. Чаматы. - Киев, 1961.

4. Давыдов В. В. Психологические проблемы процесса обучения младших школьников / Хрестоматия по возрастной и педагогической психологии. Москва, 1981. - 298 с.

5. Запорожец А. В., Луков Г. Д. Развитие рассуждений у ребёнка младшего школьного возраста / Научные записки Харьковского гос. пед. Института. Харьков, T. VI, 1941.

6. [6] Осмоловская И. Дидактические принципы дифференциации процесса обучения в общеобразовательной школе. Дисс. ... докт. пед. наук. 2002, $314 \mathrm{c}$.

7. Барановська О. В. Індивідуалізація навчання як психолого-педагогічна проблема / Стан освітнього процесу в умовах викликів сьогодення / матеріали Міжнародної науково-практичної конференції (Дніпро, 12 лютого 2021 p). Дніпро : Міжнародний гуманітарний дослідницький центр, 2021, с. 9-11.

8. Барановська О. В. Індивідуалізація навчання: здобутки, труднощі, перспективи / Innovative technologies in science and education. Abstracts of IX International Scientific and Practical Conference. Jerusalem, Israel 2021. Pp.159-164.

9. Барановська О.В.Гуманістична парадигма фундаменталізації навчання у змісті освіти сучасної школи [Електронний ресурс] / Сайт лабораторії дидактики Інституту педа- гогіки НАПН України (2013). Доступно: http://didactics.ucoz.ua/load/materiali/http_didactics_ucoz_ua_load_ materiali_1/baranovska_o_v_gumanistichna_paradigma_fundamenta lizaciji_navchannja_u_zmisti_osviti_suchasnoji_shkoli/1-1-0-395

10. Барановська О. В. Теоретичні передумови гуманізації та гуманітаризації освіти на сучасному етапі розвитку української школи / Інноваційні пріоритети розвитку гімназії : практико зорієнтований посіб. / [ред. рада: С. В. Чумак (голова), І. Г. Срмаков (науковий редактор) та ін.]. - К. : ТОВ «Видавничий Дім «Особистості», 2014. - с. 107-118.

11. Барановська О. В. Дидактичні підходи до проблеми форм навчання в профільній школі / Профільне навчання: теорія і практика // Інститут педагогіки 
АПН України; Гімназія № 290 м. Києва: наук. ред. Л. А. Липова. - К.: ВВП «Компас», 2007. - 192 с. - С. 35-45 (Співавт. Прутас. А.В.,Грищенко О.В.).

12. Vasilchenko O. I. Formation of gender culture of University students as a subject and object of research. Visnyk Zaporizhia National University. 2008. Ch1. P. 48-52. (Series "Pedagogical Sciences").

13. Gender pedagogy: Reader: A textbook for university students / [ed. V. Gaidenko]. Sumy: University Book, 2006. 313p. mode:

14. Grytsak Ya. Course of lectures. Lecture 8 [Electronic resource]. Access http://er.ucu.edu.ua/bitstream/handle/1/841/8_Values_lectio.pdf?sequence=23\&amp; isAllowed $=\mathrm{y}$

15. Gogol-Savriy M. V. Gender approach in the education system of Ukraine as a pedagogical problem. Scientific notes Ternopil National Pedagogical University Vladimir Hnatiuk. Series: Pedagogy. 2011. № 5. P. 147-152.

16. State program to ensure equal rights and opportunities of women and men until 2016 [Electronic resource]. - Access mode: http://search.ligazakon.ua/1_doc2.nsf/link1/KP130717.html

17. Doronina T. O. Theory and practice of gender education and upbringing student youth in educational institutions of Ukraine (II half of the XX - beginning XXI century): author's ref. dis. for scientif. degree of Phd. Zaporozhye, 2012. 37p.

18. Zagainov I. A. Formation of gender competence of the teacher in the process of professional training: author's ref. dis. For scientif. Degree Ph.D. ped. Science: special. 13.00.08 "Theory and methodology professional education". Yoshkar-Ola, 2007.23p.

19. Ivchenko Yu. V. Gender approach in the educational process and its specifics in higher educational institutions. Philosophical and methodological problems of law: science. magazine. 2012. № 1 (3). P. 51-63.

20. Kikinezhdi O. Innovative approaches to the formation of gender culture of students / O. Kikinezhi // Psychological and pedagogical principles of professional development of the personality of a practical psychologist and social pedagogue in the conditions of higher school: coll. mater. All-Ukrainian scientific-practical conf. Ternopil: TSPU, 2003. P. 128-135.

21. Kovalchuk L. O. Gender education of student youth in Germany: author's ref. dis. for science. degree of Cand. ped. Science: special. 13.00.07 "Theory and methods of education". Ternopil, 2008.20 p.

22. Kondratska H. D., Kizlo N. B. Experimental study of the system of formation of professional speech culture of students of faculties of physical education. Scientific and practical Journal "Science and Education", PNU. K.D. Ushinsky, Odessa, 2017. P. 127-133. 
23. Kulish O. Gender features of modern pedagogical culture of teachers [Electronic resource]. Science and life: mat. Scientific-practical internet conference (May 20-22, 2009). Access mode: http://intkonf.org/category/arhiv/1- naukaizhittya20-22-travnya-2009-r/

24. Lionchuk R. A. Education and upbringing: a gender approach. Humanism and education: electronic scientific publication of materials of $\mathrm{X}$ international scientific-practical conference (Vinnytsia, September 14-16, 2010). Vinnytsia National Technical University. Access mode : http://conf.vntu.edu.ua/humed/2010/

25. Litvinova O. V. Gender approach in the study of basic components of organizational culture of collective subjects of activity. Theoretical and applied problems of psychology: collection. Science. 2011. № 2 (26). Lugansk: Knowledge, P. $50-57$.

26. Lukashchuk V. I. Features of gender socialization in sports. // Visnyk of Kharkiv National University Karazin. 2012, № 993, P.141.

27. Mazur L. M. Taking into account the sexual determinants of development of personalities in the organization of the educational process [Electronic resource]. Bulletin of the National Technical University of Ukraine "Kyiv Polytechnic Institute". Philosophy. Psychology. Pedagogy. 2005. № 3 (15), Part 1. Access mode: http://novyn.kpi.ua /2005-3-1/

28. Marchenko O. Yu. Gender aspect of value of formation of physical culture in students of higher educational institutions. Pedagogy, psychology and medical and biological problems of phys. and sports, collection of sciences. pr. № 9, Kharkiv, 2013, P. 50-53.

29. O. Kiselyova. Problems of gender equality in the field of physical culture and sports. Kyiv, 2017. Access mode: https://mof.gov.ua/storage/files/\%D0\% 93\%D0\%9E\%D0\%91\%20\%D1\%81\%D0\%BF\%D0\%BE\%D1\%80\%D1\%82.pdf

30. Chepelyuk Anna, Kondratska Halyna. Formation of psychological and pedagogical competence of the future teacher of physical culture in higher educational institution: [monograph]. Drohobych: RVV Ivan Franko State Pedagogical University, 2017. 176p.

31. Shcherbyna S. Formation of gender culture of future teachers at classes on the special course "Gender Pedagogy". Gender paradigm of educational space. 2016, №3/3 P. 153-159.

32. Petrovskyi, Arthur. Social psychology. Moscow: Prosvescheniye, 1978.

33. Ternopilska, Valentina. System of instilling social and communicative culture of pupils of a secondary school in extracurricular activities. (Dissertation for a Doctor of Pedagogical Sciences), Institute for Educational Problems of National Academy of Pedagogical Sciences of Ukraine, Kyiv, 2009.

34. Zaniuk, Svitlana. Psychology of motivation: manual. Kyiv: Lybid, 2002. 
35. Zhyrun, Oleg. Moral consciousness in professional development. Bulletin of the National Technical University of Ukraine "Kyiv Polytechnic Institute". Philosophy. Psychology. Pedagogics, 1, 2011: 109-112.

36. Soobin Choi, Xinyi Mao (2021). Teacher autonomy for improving teacher self-efficacy in multicultural classrooms: A cross-national study of professional development in multicultural education. International Journal of Educational Research, Volume 105, 101711. https://doi.org/10.1016/j.ijer.2020.101711.

37. Xuan Nhat Chi Mai Nguyen, Ian Walkinshaw (2018). Autonomy in teaching practice: Insights from Vietnamese English language teachers trained in Inner-Circle countries. Teaching and Teacher Education, Volume 69, Pages 21-32, https://doi.org/10.1016/j.tate.2017.08.015.

38. José F.O. Granjo, Maria G. Rasteiro (2020). Enhancing the autonomy of students in chemical engineering education with LABVIRTUAL platform. Education for Chemical Engineers, Volume 31. Pages 21-28, https://doi.org/10.1016/j.ece.2020.03.002.

39. Biljana Ivanovska (2015). Learner Autonomy in Foreign Language Education and in Cultural Context. Procedia - Social and Behavioral Sciences, Volume 180. Pages 352-356. https://doi.org/10.1016/j.sbspro.2015.02.128.

40. Cirocki, Andrzej, Anam, Syafi' 'ul (2021) 'How much freedom do we have?' The perceived autonomy of secondary school EFL teachers in Indonesia. Language Teaching Research. doi: https://10.1177/13621688211007472

41. Diane Railton, Paul Watson (2005). Teaching autonomy: 'Reading groups' and the development of autonomous learning practices. Active Learning in Higher Education. 2005;6(3):182-193. doi:10.1177/1469787405057665.

42. Arielle Bonneville-Roussy, Emese Hruska, and Hayley Trower (2020). Teaching Music to Support Students: How AutonomySupportive Music Teachers Increase Students' Well-Being. Journal of Research in Music Education. Vol. 68(1) 97-119. https://doi.org/10.1177/0022429419897611

43. Bergson A. Two sources of morality and religion / trans. from the French, afterword and notes by A. B. Hoffman. - M.: «Canon», 1994. - 384 p. - (History of philosophy in monuments).

44. Ackoff R. Ackoff about management. St. Petersburg: Peter, 2002. 448 p.

45. Ackoff R., Greenberg D. Transformation of education. Tomsk: Publishing House of the Tomsk State University, 2009. 196 p.

46. Ackoff R. Management in the XXI century. Transformation of the corporation. Tomsk: Tomsk University Publishing House, 2006. 418 p.

47. Bertalanfi L. F. General theory of systems: a critical review. A brief synopsis in the collection of translations: studies in general systems theory. Moscow: Progress Publishing House, 1969. 520 p. 
48. Beer S. Management in cybernetic terms. Scientific thought. Some underlying concepts methods and procedures. Mouton/Unesco. Paris, 1972. P. 167-186.

49. Barau OF Formation of civic competence of students by means of information and communication technologies // Information technologies and teaching aids. 2013. T. 38. Vip. 6. pp. 207-216.

50. M. Rafalska, O. Boyarchuk, N. Gerasim. Civic responsibility: 80 exercises for the formation of civic and social competencies in the study of various school subjects. Grades 5-9. Teacher's guide. Kyiv: 2017. 136 p.

51. Ensuring the formation of civic competence in the modern content of school education (Final document of the working group for the development of plans and programs of the project "Civic Education - Ukraine" // History in schools of Ukraine. 2006. № 8. P. 5.

52. Competence approach in modern Ukrainian education: world experience and Ukrainian prospects / For general. ed. О.Овчарук. - К.: «К.I.C.», 2004. C. 23

53. The concept of civic education of the individual in the development of Ukrainian statehood // The way of education. 2001. 67 p.

54. National strategy for the development of education in Ukraine for 2012-2021 [Electronic resource]. Access mode:

http://www.president.gov.ua/documents/15828.html

55. Nikitina A. Actualization of categorical concepts of the text as an important factor in the formation of linguistic personality: a collection of scientific papers. Pedagogical sciences. Kherson, 2002. Vip. 31. pp. 61-90.

56. New Ukrainian school: The concept of the New Ukrainian school. Conceptual principles of secondary school reform. Kyiv: 2017. 35 p.

57. Аксенова, О. Э., Моисеева, И. В. (2008). Программа первичной профилактики наркомании в общеобразовательной школе. Программа первичной профилактики наркомании в общеобразовательной школе, СПб; 16 22. (in Russian).

58. Аннотированный указатель научно-методической литературы по вопросам профилактики наркомании в помощь педагогам-практикам. Аннотированный указатель научно-методической литературы по вопросам профилактики наркомании в помощь педагогам-практикам, М. ; 2011, 3 - 8. (in Russian).

59. Бабаков, А. И. (2006). Исследование проблемы воспитания и самовоспитания детей и молодежи, имеющих предрасположенности к употреблению наркотиков, в процессе занятий спортом и туризмом. Физическая культура: воспитание, образование, тренировка. (4), 15 - 17. (in Russian). 
60. Бабич, В. (2005). Профілактика шкідливих звичок. Директор школи, (42), 25 - 27. (in Ukrainian).

61. Боярська, Л., Овдієнко, Л. (2003). Програма «Школа і здоров’я». Рідна школа, (11), 55 - 58. (in Ukrainian).

62. Боярська, Л., Солодова, І., Котлова, Ю. (2003). Досвід реалізації програми «Школа і здоров'я». Рідна школа, (11), 58 - 60. (in Ukrainian).

63. Виноградов, П. А., Моченов, В. П., Паршикова, Н. В. (2003). Разработка организационно-управленческих моделей профилактики наркомании средствами физической культуры и спорта. Современный олимпийский спорт и спорт для всех, (3), 8. (in Russian).

64. Голов, В. А. (2006). Физическая культура и спорт как профилактическое средство предупреждения правонарушений молодежью Республики Коми. Физическая культура: воспитание, образование, тренировка, (4), 11 - 14. (in Russian).

65. Гончаренко, Т. (2016). Знову про здоров’я наших дітей. Початкова освіта, (19), 10. (in Ukrainian).

66. Дегтярьова, Н. (2007). Категорії здорового способу життя студентської молоді. Проблеми формування здорового способу життя молоді, 150 - 152. (in Ukrainian).

67. Bakiko, I. V. (2017). The level of morbidity of children and youth in Ukraine. Family Practice. 6 (2), 34: 1492 - 1496.

68. Hrebik, O. (2017). Drug addiction - today's problem. British Medical Bulletin. 1 (2), 124: $821-825$.

69. Hrebik, O., Ischuk, E., Panasyuk, A. (2017). Preventing injuries in kickboxing. Psychological Review. 6 (2), 124: 948 - 952.

70. Galper, D. I., Trivedi, M. H., Barlow, C. E. (2006). Inverse association between physical inactivity and mental health in men and women. Med. Sci. Sports. Exerc. - (38), $173-178$.

71. Craig, C. L., Marshall, A. L., Sjöström, M. (2003). International physical activity questionnaire: 12-country reliability and validity. Medicine and Science in Sports and Exercise. 35 (8), 1381-1395.

72. Kaleta, D., Makowiec-Dabrowska, T., Jegier, A. (2004). Leisure-time physical activity, cardiorespiratory fitness and work ability. Med. Environ. Health. (17), 457-64.

73. Rejeski, J., Mihalko, S., Gerontol, J. (2001). Physical activity and quality of life in older adults. (56A), $23-35$.

74. Savchuk, S. (2017). Scandinavian walking - as a means of healing people. Psychological Review. 6 (2), 124: 979 - 982. 
75. Smolander, J., Blair, S., Kohl, H. (2000). Work ability, physical activity, and cardiorespiratory fitness: 2-year results from Project Active. Occup. Environ. Med. (42), 906-910.

76. Faydevych, V. V. (2017). Prevention of bad habits through physical culture. British Medical Bulletin. 1 (2), 124: 826 - 832.

77. Абульханова-Славская К.А. Стратегия жизни / К.А. АбульхановаСлавская. - М. : Мысль, 1991. - 299 с.

78. І. Бех Виховання особистості: У 2 к.н. Кн. 2: Особистісно орієнтований підхід: науково-практичні засади. - Київ: “Либідь”,2003. - 344с.

79. Ю.А. Корницька Виховання соціальних цінностей у студентів вищих технічних навчальних закладів. Дисертація на здоб. наук. ступ. кандидата педагогічних наук. К.: 2011. - 218c.

80. Т.Б. Котмакова Формирование личностной мобильности как профессионального качества будующих специалистов в процессе обучения в вузе ( на примере специальности “Электрический транспорт железных дорог”). Дис. на здоб. наук.ст. канд. пед.н. Хабаровск:2011. - 198с.

81. О.Я. Кучерук Свідомий вибір професії як фактор успішної професійної кар’єри . Наука і освіта. Одеса, №7, 2011, С.61-65.

82. Г.Е. Міхненко Формування інтелектуальної мобільності майбутніх інженерів в умовах освітнього середовища технічного університету. Дис. на здоб. наук.ст. канд. пед.н. К.:2016. - 245с.

83. Эриксон Э. Идентичность: юность и кризис: Пер.с англ./ Общ.ред.и предисл. Толстых А.В. - М.: Издательская группа «Прогресс», 1996. - 344с.

84. Гоноболин Ф.П. «Книга об учителе»,

85. Кан-Калик В.А.«Педагогическое творчество». Серия: «Библиотека учителя и воспитателя» Изд-во: «Педагогика»,1990

86. Ерментаева А.Р. Жоғары мектеп психологиясы. Оқулық «Дәуір», 2012.492 бет. Алматы: ЖШС РПБК

87. Ковалев Б.П.Личность воспитывает себя. - М., 1983

88. РоговЕ.И. Практическая психодиагностика личности: Учеб. пособие. СПб. 2001.

89. Атаханов Р. Педагогическая психология: психология обучения.Тюмень: Изд-во ТюмГУ, 2009

90. Панфилова А.П. Взаимодействие участников образовательного процесса [Текст]: учебник и практикум для академ. бакалавриата ред. А. П. Панфилова. - М. : Юрайт, 2017.

91. Сорока-Росинский В.Н. — «Педагогические сочинения».djvu. 
92. Мынбаева А. К. Когнитивные технологии обучения: учебное пособие Алматы: Қазақ университеті, 2014.

93. Назарова И. Б. Типология преподавателей высшей школы / Социологические исследования. - 2006. - №11. - С. 115-119.

94. Юревич А.В. Социальная психология науки

95. Столяренко Л.Д. Психология: Учебник для вузов - СПб.: Питер, 2010. $-592$

96. Иванова С.П. Психологическое сопровождение профессиональной подготовки психологов МЧС России: монография. - СПб.: Изд-во. Астерион, 2011.

97. Исследование процесса становления профессиональной компетентности будущих педагогов: коллективная монография / под ред. Г.А. Бордовского - СПб.: Изд-во «Лема», 2011.

98. Компетентностный подход в педагогическом образовании: коллективная монография / под ред. В.А. Козырева - СПб.: Изд-во РГПУ им. А.И. Герцена, 2004.

99. Лазарев В.С. Управление инновациями в школе. - М.: Центр педагогического образования, 2008.

100. Леонтьев А.Н. Деятельность. Сознание. Личность. - М., 2004.

101. Поляков С.Д. Педагогическая инноватика: от идеи до практики. - М.: Педагогический поиск, 2007.

102. Посталюк Н.Ю. Педагогика сотрудничества: путь к успеху. - Казань, 1992.

103. Пригожин А.И. Инноваторы как социальная категория // Методы активизации инновационных процессов. - М., 1998.

104. Сластенин В.А., Подымова Л.С. Педагогика: инновационная деятельность. - М.: Магистр, 1997 10. Совершенствование образовательных программ и технологий подготовки специалистов для инновационной деятельности в сфере образования: монография // под науч. редакцией Г.А. Бордовского - СПб.: Изд-во РГПУ им. А.И. Герцена, 2009.

105. Совершенствование образовательных программ и технологий подготовки специалистов для инновационной деятельности в сфере образования: монография // под науч. редакцией Г.А. Бордовского - СПб.: Изд-во РГПУ им. А.И. Герцена, 2009.

106. Хуторской А. В. Педагогическая инноватика: методология, теория, практика: научное издание. - М.: Изд-во УНЦ ДО, 2005. 
107. Humeniuk N. Klymenko V. (1985) Psykholohyia fyzycheskoho vospytanyia y sporta [Psychology of physical education and sports]. Kyev. Vыsshaia shkola. 311 s. [in Ukrainian]

108. Hohunov Э.N., Martianov B.Y. (2000) Psykholohyia fyzycheskoho vospytanyia y sporta : ucheb. posobye.[Psychology of physical education and sports] Moskva. Yzd. tsentr «Akademyia». 288 s. [in Russian]. $152 \mathrm{~s}$.

109. Volkova A.A. (2006) The English of Psychology in Use. - Novosybyrsk,

110. Akymova L.N. (2004) Psykholohyia sporta [Psychology of sport]: Kurs lektsyi. Odessa: Studyia «Nehotsyant», 127 s. [in Ukrainian]

111. Kornosenko O. K. ( 2020). Psykholohiia sportu [Psychology of sport]: kurs lektsii : navch.-metod. posib.; Poltav. nats. ped. un-t imeni V. H. Korolenka. Poltava: Simon,. 99 s. [in Ukrainian]

112. Fedyk O.V. (2013) Psykholohiia sportu [Psychology of sport]: materialy dlia samopidhotovky do seminarskykh zaniat dlia studentiv spetsialnosti «Psykholohiia». Ivano-Frankivsk : «Inin»,. 226 c. [in Ukrainian]

113. Yakovlev B.P. (2014) Motyvatsyia y emotsyy v sportyvnoi deiatelnosty [Motivation and emotions in sports activities] : ucheb. posob. Yzd-vo Sovetskyi sport, 312 s. [in Russian].

114. Профессия-учитель: учеб. пособие для профильной и профессиональной ориентации и профильного обучения школьников / А.С. Роботова, И.Г. Шапошникова, В.А. Родионова. Москва: Академия, 2005. 368 с.

115. Сущенко T.I. Магістерський педагогічний процес підготовки викладачів ВНЗ як зразок майбутньої професійної діяльності. Педагогіка формування творчої особистості у вищій і загальноосвітній школах : зб. наук. пр. Запоріжжя, 2012. Вип. 24(77). С.457-465.

116. Ибрагимов Г.И. Сущность и ведущие принципы концентрированного обучения. Инновации в образовании. 2013. № 5. С. 14-26.

117. Кремень В. Освіта в контексті сучасних соціокультурних змін. Філософія освіти. № 1-2(7). 2008. С. 15-21.

118. Андрущенко В. Формування особистості вчителя в сучасних умовах. Політичний менеджмент. 2005. № 1 (10). С. 58-69.

119. Про вищу освіту: Закон України від 23.04.2021 № 1556 - VII. URL: https://zakon.rada.gov.ua/laws/show/1556-18\#Text

120. Рібцун Ю. В. Вихователь у логопедичній групі : мол. дошкіл. вік : метод. рек. // Дошкіл. виховання. 2008. № 8. С. 17-19.

121. Про освіту: Закон України від 23.04.2021 № 2145 - VIII. URL: https://zakon.rada.gov.ua/laws/show/2145-19\#Text 
122. Конвенція про права осіб з інвалідністю, редакція від 06. 07. 2016 р. URL. : http://zakon3.rada.gov.ua/laws/show/995_g71.

123. Основи інклюзивної освіти. навчально - методичний посібник: / за заг. ред. Колупаєвої А. А. К: « А.С.К.», 2012. 308c.

124. Інклюзивна школа: особливості організації та управління: Навчально - методичний посібник/ заг. ред.. Даниленко Л. І., 2-ге видання, К.: ФО., 2010.128c.

125. Асистент учителя в інклюзивному класі: навчально-методичний посібник / заг. ред. М. Ф. Войцехівського. К.: ТОВ Видавничий дім «Плеяди», 2015. $172 \mathrm{c}$.

126. Наказ МОН України від 08.06.2018p №609 Про затвердження Примірного положення про команду психолого - педагогічного супроводу дитини з особливими освітніми потребами в закладі загальної середньої та дошкільної освіти. URL:https://mon.gov.ua/ua/npa/pro-zatverdzhennya-primirnogopolozhennya-pro-komandu-psihologo-pedagogichnogo-suprovodu-ditini-zosoblivimi-osvitnimi-potrebami-v-zakladi-zagalnoyi-serednoyi-ta-doshkilnoyi-osviti

127. Державний стандарт початкової загальної освіти від 21.02.2018 № 87. URL: https://zakon.rada.gov.ua/laws/show/87-2018-п (дата звернення: 06.05.2021).

128. Організаційно - методичні засади діяльності інклюзивно - ресурсних центрів: навчально - методичний посібник / за заг. ред. М. А. Порошенко та ін. Київ: 2018. 252c.

129. Порядок організації інклюзивного навчання у загальноосвітніх навчальних закладах: Постанова Кабінету Міністрів України від 15.08. 2011 р. № 872.

130. Алфеев Илларион, иеромонах. Таинство веры. Введение в православное догматическое богословие / Илларион Алфеев. - М., 1996. - 288 с.

131. Зеньковский В. В. Проблемы воспитания в свете христианской антропологии / В. В. Зеньковский. - М. : Изд-во Свято-Владимирского Братства, 1993. $-224 \mathrm{c}$.

132. Ильин И. А. Путь духовного обновления / И. А. Ильин. - СПб. : Библиополис, 2006. - 446 с.

133. Каледа Глеб, протоиерей. Домашняя Церковь. Очерки духовнонравственных основ созидания и построения семьи в современных условиях / Глеб Каледа - М., 1998. - 345 с.

134. Митрополит Сурожский Антоний. Таинство любви. Беседа о христианском браке / Антоний Сурожский. - СПб.: Сатись, 1994. - 36 с.

135. Морозова Е. А. Гармония в семье и браке: духовные и психологические аспекты / Е. А. Морозова. - Самара: СамГАПС, 2006. - 400 с. 
136. Пестов Н. Е. Путь к совершенной радости. Воспитание детей / Н. Е. Пестов. - Клин: Фонд «Христианская жизнь», 2003. - 175 с.

137. Рогозянский А. Б. Хочу или надо? / А. Б. Рогозанский. - СПб.: Знаки, 2001. $-190 \mathrm{c}$.

138. Ушинский К.Д. Человек как предмет воспитания / К. Д. Ушинский. М.; Л.: АПН, 1950.- Т. 8. -776 с; Т. 9. -628 c; Т. 10. -668 c.

139. Шестун Евгений, протоиерей. Основные проблемы современной школы / Евгений Шестун. - Самара, 2001. - 51 с.

140.

141. PISA 2006. Die Ergebnisse der dritten internationalen Vergleichsstudie [in Deutschland].

142. Салберг П. (2017). Фінські уроки 2.0. Пер. з англ. Харків: Ранок.

143. Enochsson, A.-B. \& Rizza, C.(2009). ICT in Initial Teacher Training. Researchreview.OECD:EDU/WKPURL:http://www.oecd.org/dataoecd/30/54/441046 18.pdf [in France].

144. Epper, R.M. \& Bates, A.W.T. (2001).Teaching Faculty How to Use Technology: Best Practices from Leading Institutions. Westport: CT: OryxPress. [in Finland].

145. Котун К. В. (2016). Педагогічна освіта Фінляндії у контексті європейського виміру. Київ. Інститут обдарованої дитини.

146. Hakkarainen, K., Ilomäki, L., Lipponen, L., Muukkonen, H., Rahikainen, M., Tuominen, T., Lakkala, M. \& Lehtinen, E. (2000). Students skills and practices of using ICT: results of a national assessment in Finland. Computers \& Education, (34), 103-117. [in Finland].

147. Hytönen J. The Development of Modern Finnish Teacher Education (1996). Teacher education in Finland: Present and future trends and challenges. Studia Paedagogic . Helsinki, Vantaa: University of Helsinki, (11), 1-10. [in Finland].

148.

CentralUniversitiesAct(2009).URL:http://www.finlex.fi/fi/laki/kaannokset/2009/en20 090558.pdf [in India].

149. ICT Development Index (2017). URL:http://www.itu.int/net4/ITUD/idi/2017/\#idi2017rank-tab

150. Norge (2001). Midtveisrapport for eNorge. URL//www.odin.dep.no/nhd/nor sk/publ/rapporter/024101-990023/index-dok000-bn-a.html. 
151. Чорногор, Я., Михайлюк, Т. (2009). Розвиток інформаційного суспільства у Скандинавських країнах. Журнал Верховної Ради України, issue 24:http://www.viche.info/journal/1784/.

152. Runnesto, R., Ristesund, G. (2002). Experiences with Learning Management Systems in Norvegian Universities and Collegeshttp. URL://www.nettskolen.com/forskning/Diploma\%20project.pdf.[in Norway].

153. Комп’ютерна грамотність вчителів з точки зору стандартів СС (2008): матеріали Всеукраїнської науково-практичної конференції. Полтава: Полтавський інститут післядипломної педагогічної освіти ім. $\mathrm{M} . \quad$ В. Остроградського, 96.

154. Hernwall, P. (2016). «We have to be professional» - Swedish preschool teachers' conceptualisation of digital media. Nordic Journal of Digital Literacy, (10), 5-23. [in Norway].

155. Chaib, M. \& Svensson, A. A. (2005). Lifelong Learning Perspective. ICT in Teacher Education. 5-20. [in Sweden].

156. Sorensen, B. (2005). ICT and schools in the information society: New Positions for Teachers. ICT in Teacher Education. 21-39. [Russia].

157. Runnesto, R., Ristesund, G. (2002). Experiences with Learning Management Systems in Norvegian Universities and Colleges, URL: http://www.nettskolen.com/forskning/Diploma\%20project.pdf. [in Norway].

158. Рождественский С. В. Исторический обзор деятельности Министерства народного просвещения. 1802-1902. - СПб., 1902. - С. 11.

159. РГИА. - Ф. 733. - Оп. 56 (1836). - Д. 506. - Л. 3-4.

160. РГИА. - Ф. 733. - Оп 56 (1826). - Д. 379. - Л. 62.

161. РГИА. - Ф. 733. - Оп. 2 (1832). - Д. 73. - Л. 462.

162. РГИА. - Ф. 733. - Оп. 21(1829). - Д. 147. - Л. 48-54.

163. РГИА. - Ф. 733. - Оп. 2 (1832). - Д. 73. - Л. 310, 462.

164. РГИА. - Ф. 733. - Оп. 42 (1839). - Д. 186. - Л. 11.

165. РГИА. - Ф. 733. - Оп. 2 (1832). - Д. 73. - Л. 100.

166. РГИА. - Ф. 735. - Оп. 1 (1833). - Д. 740. - Л. 24-26.

167. РГИА. - Ф. 733. - Оп. 2 (1832). - Д. 73. - Л. 462.

168. РГИА. - Ф. 733. - Оп. 30 (1835). - Д. 205. - Л. 2-3.

169. Деркач А.А. Акмеологические основы развития профессионала А.А. Деркач. // - М.: Издательство Московского психолого-социального института, 2004. $-752 \mathrm{c}$. 
170. Загвязинский В.И. Проектирование региональных образовательных систем / В.И. Загвязинский. // Педагогика. ( 1999. № 5. - С. 8-13.

171. Зеер Э.Ф. Психология личностно-ориентированного профессионального образования / Э.Ф. Зеер. // - Екатеринбург: Изд-во Урал. гос. проф. - пед. ун-та, 2000. - 258 с.

172. Инновации в образовании и социальные перемены // Материалы к конференции / Под ред. Ю.Н. Кулюткина, Л.И. Рожко, В.А. Соколовской. ( СПб., 1993. ( $120 \mathrm{c}$.

173. Кваша В.П. Управление инновационными процессами в образовании / В.П. Кваша. // ( Минск, 1994. ( 177 с.

174. Кларин М.В. Инновационные модели обучения в зарубежных педагогических поисках / М.В. Кларин. ( М.: Арена, 1995. ( 222 с.

175. Кузьмина Н.В. Профессионализм педагогической деятельности Н.В. Кузьмина, А.А Реан. - СПб.: 1993. - 418 с.

176. Кузьмина Н.В. Аттестация преподавателя и мастера производственного обучения / Н.В. Кузьмина, Г.И. Михайловская, $\quad$ М.Ю. Еремин, А.А. Реан. ( СПб.: 1992. ( 68 с.

177. Лифинцева Н.И. Формирование профессионально-психологической культуры учителя / Н.И. Лифинцева; под ред. В.А. Сластенина. - Москва - Курск: Изд-во Курского гос. пед. ун-та, 2000. - 204 с.

178. Лифинцева Н.И. Теоретические предпосылки формирования профессионально-психологической культуры учителя / Н.И. Лифинцева. // Теория и технология формирования профессионально-педагогической культуры. Белгород, 1999. - С. 23-26.

179. Ломов Б.Ф. Методологические и теоретические проблемы психологи / Б.Ф. Ломов. - М.: Наука, 1984. - 444 с.

180. Ломов Б.Ф. Личность в системе общественных отношений Б.Ф. Ломов. // Психологический журнал - 1981. - Т.2. - №1 - С. 3-17.

181. Ляудис В.Я. Новая парадигма педагогической психологии и практика инновационного образования / В.Я. Ляудис. // Вестник МГУ. Сер. Психология. 1998. - №2. - C. 88-97.

182. Педагогические основы проектирования образовательных систем нового вида / Под ред. А.П. Тряпициной. ( СПб.: Образование, 1995. ( 130 с.

183. Поляков С.Д. В поисках педагогической инноватики / С.Д. Поляков. ( М., 1993. ( 63 с.

184. Пригожин А.И. От существующего к возникающему / А.И. Пригожин. ( М., 1985. ( 327 с. 
185. Радугин А.А. Введение в менеджмент: социология и организация управления / А.А. Радуги, К.А. Радугин. ( Воронеж, 1995. ( 196 с.

186. Состояние, тенденции изменений и проблемы управления образованием / Под ред. В.С. Лазарева. ( М.: 1996. ( 40 с.

187. Сластенин В.А. Педагогика: Инновационная деятельность В.А. Сластенин, С.Л. Подылова. ( М.: Магистр, 1997. ( 224 с.

188. Турянська В.Е. Теоретична модель психологічної культури в педагогічній взаємодії освітнього середовища / В.Е. Турянська. // Вісник ХНПУ ім. Г.С. Сковороди. Сер. Психологія. - Харків: ХНПУ, 2008. - Вип. 26. - С. 198 $-203$.

189. Щербаков А.И. Психологические основы формирования личности советского учителя в системе высшего педагогического образования А.И. Щербаков. - Л.: Просвещение, 1967. - 266 с.

190. Berg Carin and Vlasctanu Lazar/ The Europeanization of Higher Education: Integration and Diversity as viewed from Eastern Europe// Higher Education in Europe.1991.- $164 \mathrm{p}$.

191. Linke R.D. Some Principes for Appilication of Performance indicators in Higher Edukation // Higher Edukation Management. - 1992. - №4. - P. 194-203.

192. Stenberg R. J. Metaphor of mind. - N.Y.: Cambridge University Press, 1990. $-286 \mathrm{p}$.

193. Андреева И.Н. Понятие и структура эмоционального интеллекта / И.Н. Андреева. // Социально-психологические проблемы ментальности: 6-я Международная научно-практическая конференция. Смоленск: СГПУ, 2004. Ч. 1. C. 22-26.

194. Андреева И.Н. Эмоциональный интеллект: исследование феномена / И.Н. Андреева. // Вопросы психологии. 2006. № 3. С. 78 - 86.

195. Андреева И.Н. Предпосылки развития эмоционального интеллекта /И.Н. Андреева. // Вопросы психологии. 2007. № 5. С. 57 - 65.

196. Вачков И.В. Основы технологии группового тренинга. / И.В. Вачков. // Психотехники: Учеб. пособие. - М., 2001. -224 с.

197. Гарднер Г. Структура разума. Теория множественного интеллекта. М.:, СПб.:, К.: Вильямс, 2007. - 512 с.

198. Гарскова Г.Г. Введение понятия «эмоциональный интеллект» в психологическую теорию / Г.Г. Гарскова // Ананьевские чтения: тез. науч.практ. конф.; редкол.: А.А. Крылов [и др.]. - СПб.: Изд-во Санкт-Петерб.ун-та, 2013. C. $25-26$. 
199. Гоулман Д. Эмоциональное лидерство: Искусство управления людьми на основе эмоционального интеллекта / Д. Гоулман. // Primal Leadership: Learning to Lead with Emotional Intelligence. — М.: «Альпина Паблишер», 2011. — C. 301.

200. Грецов А., Бедарева Т. Психологические игры для старшеклассников и студентов / - СПб.: Питер, 2008. - 190 с

201. Корнилова Т.В., Кондратчик А.Л. Интеллектуальные решения при использовании знаний конвенционального типа /Т.В. Корнилова, А.Л. Кондратчик. // Вестник Московского ун-та. Серия ХІY. Психология. 1993. № 3. C . 12-24.

202. Люсин Д.В. Современные представления об эмоциональном интеллекте // Социальный интеллект: Теория, измерение, исследования / под ред. Д.В. Люсина, Д.В.Ушакова. / Д.В. Люсин. // М.: Изд-во «Институт психологии РАН», 2004. c. 29-39.

203. Люсин Д.В. Опросник на эмоциональный интеллект ЭмИн: новые психометрические данные // Социальный и эмоциональный интеллект: от моделей к измерениям/Под ред. Д.В. Люсина, Д.В. Ушакова. М.: Институт психологии РАН, 2009. С. $264-278$.

204. Манойлова М. А. Развитие эмоционального интеллекта будущих педагогов. Псков: ПГПИ, 2004, 60 с.

205. Михайлова Е.С. Тест Дж. Гилфорда и М. Салливена. Диагностика социального интеллекта. Методическое руководство. - СПб.: ИМАТОН, 2006. $56 \mathrm{c}$.

206. Оганесян Н. Т. Технологии активного социально-педагогического взаимодействия (тренинги, игры, дискуссии) в обеспечении психологической безопасности образовательного процесса [Электронный ресурс]: учебнометодическое пособие / Н. Т. Оганесян. - М.:ФЛИНТА, 2013. 134 с.

207. Орме Г. Эмоциональное мышление как инструмент достижения успеха. / Г. Орме. // - М.: «КСП +», 2003, 272 с.

208. Практический интеллект Р. Дж. Стернберг, Дж.Б. Форсайт, Дж. Хедланд и др. / Р. Дж. Стернберг, Дж.Б. Форсайт, Дж. Хедланд и др. // - Спб.: Питер, 2002. - 272 с.

209. Рамендик Д. М. Тренинг личностного роста : учебник и практикум для СПО / Д. М. Рамендик. - 2-е изд., испр. и доп. - М. : Издательство Юрайт, 2018. $-136 \mathrm{c}$.

210. Семенова Е. М. Тренинг эмоциональной устойчивости педагога. Учебное пособие. - М.: Изд-во Инс-та Психотер., 2002. — 224 с.

211. Слепкова В.И. Развитие эмоциональной компетентности средствами психологического тренинга / В.И. Слепкова. // Актуальные проблемы кризисной психологии: Сб. науч. тр. Минск, 1997. С. 130-137. 
212. Юркевич В.С. Проблема эмоционального интеллекта / В.С. Юркевич. // Вестник практической психологии образования. 2005.№ 3 (4). Июль-сентябрь. C. 4-10.

213. Эмоциональный интеллект / Дэниел Гоулман; пер. с англ. А.П. Исаевой. - / Д. Гоулман // М.: АСТ: АСТ МОСКВА; Владимир: ВКТ, 2009. - 478 c.

214. Bar-On R. Emotional and social intelligence: Insights from the Emotional Quotient Inventory // R. Bar-On, J.D.A. Parker (eds.). Handbook of emotional intelligence. San Francisco: Jossey-Bass, 2000. P. 388.

215. Mayer J.D., Caruso D., Salovey P. Emotional intelligence meets traditional standards for an intelligence / J.D. Mayer, D. Caruso, P. Salovey. // Intelligence. 1999. Vol. 27. P. 267-298.

216. Montgomery J. E. Incorporating Emotional Intellegence concepts into Legal Education: strengthening the Professionalism of Law students / J. E. Montgomery // University of Toledo Law Review. 2008. V. 39. PP. 323-352

217. Salovey P., Brackett M., Mayer J.D. Emotional Intelligence: Key readings on the Mayer andSalovey Model. / P. Salovey, M. Brackett, J.D. Mayer // Port Chester, N.Y.: Dude Publishing, 2004.

218. Андрущенко В. П., Бех І. Д., Волощук І. С., Глузман О. В., Гузій Н. В., Дем 'яненко Н. М. Педагогіка вищої школи : підручник / АПН України; Інститут вищої освіти / Василь Григорович Кремень (ред.). - К. : Педагогічна думка, 2009. $-256 \mathrm{c}$.

219. Артемова Л. В. Педагогіка і методика вищої школи : навч.-метод. посіб. [для викл., аспір., студ. магістратури] / Любов Вікторівна Артемова. - К. : Кондор, 2008. - 272 с.

220. Барно О.М. Інноваційна педагогіка: навч. посіб Донецьк : ЛАНДОНXXI, 2013. $-286 \mathrm{c}$.

221. Биков В.Ю. Моделі організаційних систем відкритої системи освіти: монографія. - К.: Атіка, 2008. - 684 с.: іл.

222. Васьков Ю.В. Педагогічні теорії, технології, досвід (Дидактичний аспект). - Х.: Скорпіон, 2010.

223. Вишневський О.I. Теоретичні основи сучасної української педагогіки : навч. посіб. / О. І. Вишневський. - 3-те вид., доопрац. і доп. - К. : Знання, 2008. $-566 \mathrm{c}$.

224. Вихрущ В. О. Основи наукових досліджень у галузі педагогіки: підручник / В. О. Вихрущ, Ю. М. Козловський, Л. І. Ковальчук. - Тернопіль: Крок, 2017. - 340 c. 
225. Вітвицька С. С. Основи педагогіки вищої школи. Підручник за модульнорейтинговою системою навчання для студентів магістрантів. - К.: Центр навчальної літератури, 2006. - 384 с.

226. Галузяк В. М. Педагогіка : навч. посіб. для студ. вищ. пед. навч. закл. / В. М. Галузяк, М. І. Сметанський, В. І. Шахов. -5-е вид. випр. та доп. - Вінниця : Планер, 2012. - 400 c.

227. Гнєзділова К.М., Касярум С.О. Моделі та моделювання у професійній діяльності викладача вищої школи: навч. посібник / К.М. Гнєзділова, С.О. Касярум. - Черкаси: видавець Чабаненко Ю.А., 2011. - 124 с.

228. Горохівська Т. М. Методичні засади розвитку професійнопедагогічної компетентності викладачів фахових дисциплін технічних закладів вищої освіти: навчальний посібник / Т. М. Горохівська. - Дрогобич: Дрогобич: Посвіт, 2020. - 164 с.

229. Гуревич Р. С. Компетентнісна освіта у вищій педагогічній школі : методичний посібник / Р. С. Гуревич, М. Ю. Кадемія, Л. С. Шевченко. - [2-ге вид. доп]. - Вінниця : Планер, 2010. - 166 с.

230. Доброскок I.I. Педагогіка професійної освіти: навч. посіб. [для студ. вищ. навч. закл.] / Ірина Іванівна Доброскок. - К: Педагогічна думка, 2016. - 120 c.

231. Енциклопедія освіти / [Бех І. Д., Бібік Н. М., Биков В. Ю. та ін.]; гол. ред. В. Г. Кремень. - К : Юрінком Інтер, 2008. - 1040 с.

232. Ієвлєв О. М. Професійно-педагогічна мобільність викладача: навчальний посібник / О. М. Ієвлєв. - Львів: Видавництво Львівської політехніки, 2020. $-136 \mathrm{c}$.

233. Зязюн І.А. Філософія педагогічної дії: Монографія. - Черкаси: Вид. від. ЧНУ імені Богдана Хмельницького, 2008. - 608 с.

234. Кузьмина Н. В. Профессионализм деятельности преподавателя и мастера производственного обучения профтехучилища / Н.В.Кузьмина. Москва : Высш. шк., 1989. - 99 с.

235. Мукан Н. В. Лідерство в освіті Великої Британії: порівняльнопедагогічний дискурс: колективна монографія / Н. В. Мукан, М. В. Гаврилюк, І. С. Миськів, Г. В. Яремко. - Львів: Панорама, 2019. - 176 с.

236. Микитюк О.М. Теорія і практика організації науково-дослідної роботи у вищих навчальних закладах освіти України в XIX ст. : автореф. дис. доктора пед. наук, спец. : 13.00.04. / О.М. Микитюк. - Інститут педагогіки АПН України, Київ, 2004. - 42 с.

237. Професійно-педагогічна освіта: сучасні концептуальні моделі та тенденції розвитку: Монографія / Авт. кол. О.А. Дубасенюк, О.С. Антонова, С.С. Вітвицька, Н.Г. Сидорчук, О.М. Спірін, Н.В. Якса та ін. / За заг. ред. проф. О.А. 
Дубасенюк. - Вид. 2-е, доп. - Житомир: Вид-во ЖДУ ім. І. Франка, 2008. - 396 c.

238. Фіцула М. М. Педагогіка: навч. посіб. [для студ. вищ. навч. закл.] / Михайло Миколайович Фіцула. - [2-ге вид., випр., доп.]. - К. : Академвидав, 2007. $-560 \mathrm{c}$.

239. Сікорський П. І. Моделювання нових навчальних технологій у закладах вищої освіти: монографія. Львів: Сполом, 2020. 228 с.

240. Швай Р. І. Педагогіка творчості: підручник. Львів: Видавництво Львівської політехніки, 2020. 200 с.

241. Mulder A. The University as a Community in the Digital age. Plases of Engagement / A.Mulder. - Amsterdam University press. 2018. - 160 P.

242. Widmer J. Beitrag von [osef Widmer. Die Digitalisierung verandert die Arbeitswelt: was heiGt das fur the Berufsbildung? 2017. htlps:// www.digitaldialog.de/die-digitalisierung-veraendert-die-arbeitswelt-was-heisst-dasfuer-die-berufsbildung.

243. Blommaert J. Sociolinguistics \& English language studies // Working Papers in Urban Language \& Literacies. Paper 85. - Tilburg University, 2012.

244. Cogo Alessia and Martin Dewey. Analysing English as a Lingua Franca // A Corpusdriven Investigation. - London: Continuum, 2012.

245. Dewey M. (King's College London). Pedagogic Criticality and English as a Lingua Franca // Revista de la Asociación Española de Estudios AngloNorteamericanos 36.2. King's College. - London, 2014.

246. Jenkins Jennifer. The Phonology of English as an International Language. - Oxford, 2000.

247. Kachru B.B. \& C.L. Nelson. World Englishes // S. McKay \& N.H. Hornberger (eds.), Sociolinguistics and Language Teaching, 71-102. - Cambridge: Cambridge University Press, 1996.

248. Kankaanranta A. and Louhiala-Salminen L. Aalto University (Finland). "What language does global business speak?" - The concept and development of BELF // Ibérica 26: 17-34 ISSN: 1139-7241 / e-ISSN: 2340-2784. Aalto University (Finland). - Helsinki, 2013. URL: http://www.aelfe.org/documents/01_26_Kankaanranta.pdf

249. Mauranen Anna. The Corpus of English as a Lingua Franca in Academic Settings // TESOL Quarterly, 37 (3): 513-27. - Helsinki, 2003.

250. Mauranen Anna. Exploring elf: Academic English Shaped by Non-native Speakers. - Cambridge, 2012. URL: http://www.amazon.com/Exploring-ELF-Nonnative-CambridgeLinguistics/dp/0521177529. 
251. Seidlhofer Barbara. Closing a Conceptual Gap: The Case for a Description of English as a Lingua Franca // International Journal of Applied Linguistics. - 2001. - № 11 (2).

252. Seidlhofer B. Research perspectives on teaching English as a Lingua Franca // Annual Review of Applied Linguistics. - 2004. - № 24. - P. 209-239.

253. Baeva L. V. Problemyi i perspektivyi razvitiya otkryitogo distantsionnogo obrazovaniya $\mathrm{V}$ usloviyah elektronnoy kulturyi. URL: http://emag.iis.ru/arc/infosoc/emag.nsf/BPA/9883a19543e0bbc144258264003ec19f

254. Tsyigalov Yu. M. Effektyi i riski distantsionnogo obrazovaniya v vyisshey shkole. URL: https://www.acjournal.ru/jour/article/view/1548

255. Balandina A., Shturma Ya. «S kashey v golove»: kak distantsionka povliyaet na ryinok truda. Gazeta.ru. URL: https://www.gazeta.ru/social/2020/11/14/13360747.shtml

256. Marchuk M. Yu. Psihologo-pedagogicheskie osobennosti distantsionnogo obucheniya.

257. CyberLeninka. URL: https://cyberleninka.ru/article/n/psihologopedagogicheskie-osobennosti-distantsionnogo-obucheniya

258. Berg Gary. Distance Learning in Higher Education, VL - 6, DOI 10.14507/epaa.v6n11.1998. Education Policy Analysis Archives. URL: https://epaa.asu.edu/ojs/article/view/578/701

259. Electronic source available at: https://kabzon.livejournal.com/1136332.html

260. Electronic source available at: https://korrespondent.net/ukraine/4272992opros-ukrayntsy-protyv-dystantsyonnoho-obuchenyia-v-shkolakh

261. Amor, M.I. y Serrano Rodríguez, R. (2019). The generic competences the initial teacher training. A comparative study among students, teachers and graduates of university education degree. Educación XX1, 22(1), 239-261, doi: 10.5944/educXX1.21341

262. Barthélémy Durette, M.Fournier \& M. Lafon. (2014). The core competencies of PhDs. Higher Education, V.41, 1355-1370 https://doi.org/10.1080/03075079.2014.968540

263. Bogle, D., M. Dron, J. Eggermont and J. Willem van Henten. 2010. Doctoral degrees beyond 2010: Training talented researchers for society. DOI:10.1016/j.sbspro.2011.03.003

264. Hill, M., Overton, T., Thompson, C., Kitson, R., \& Coppo, P. (2018). Undergraduate recognition of curriculum-related skill development and the skills employers are seeking. Chemistry Education Research and Practice, https://doi.org/10.1039/C8RP00105G 
265. Jorre de St Jorre, T., \& Oliver, B. (2018). Want students to engage? Contextualise graduate learning outcomes and assess for employability. Higher Education Research \& Development, 37(1), 44-57. https://doi.org/10.1080/07294360.2017.1339183

266. Matthews K. E. and Mercer-Mapstone L. D., (2016), Toward curriculum convergence for graduate learning outcomes: academic intentions and student experiences, Stud. High. Educ., 1-16, DOI:10.1080/03075079.2016.1190704.

267. Marilyn Clarke, "Rethinking Graduate Employability: The Role of Capital, Individual Attributes and Context", Studies in Higher Education, 43, no. 11 (23 de febrero de 2017), 1923-1937, https://doi.org/10.1080/03075079.2017.1294152

268. Tuning Educational Structures in Europe. Competences. http://www.unideusto.org/tuningeu/competences.html

269. Zabalza, M. Á. (2011). Metodología docente. REDU Revista de Docencia Universitaria, 75-98. 8. DOI: https://doi.org/10.4995/redu.2011.6150

270. Ministry of Education and Science of Ukraine Project. https://mon.gov.ua/ua/news/mon-proponuye-dlya-gromadskogo-obgovorennyaproyekt-strategiyi-rozvitku-vishoyi-osviti-ukrayini

271. Gautam P. Advantages And Disadvantages Of Online Learning [Електронний ресурс] : Режим доступу : https://elearningindustry.com/advantagesand-disadvantages-online-learning.

272. Doug V. Distance Learning: Promises, Problems, and Possibilities [Електронний ресурс] : Режим доступу https://www.westga.edu/ distance/ojdla/fall53/valentine53.html

273. Merriam Webster SINCE 1828 [Електронний ресурс] : Режим доступу : https: //www.merriam-webster.com/dictionary/distance $\% 20$ learning? $\mathrm{src}=$ search-dictbox

274. What are the Pros \& Cons of Distance Learning? [Електронний ресурс] : Режим доступу : https://scholarship-positions.com/pros-cons-distancelearning/2014/07/25/

275. Степанянц М.Т. Мир Востока: Философия: Прошлое, настоящее, будущее. М. : Восточная литература, 2005. 375 с.

276. Kipling R. Poems. Short Stories. M. : Raduga Publishers, 1983. 457 p.

277. Рікер П. Толерантність, нетолерантність, неприйнятне // Рікер П. Навколо політики / пер. 3 франц. В. Андрушка, О. Мокровольського, А. Плеханової та ін. К. : Дух і літера, 1995. С. 313-332.

278. Бахтин М.М. Проблемы поэтики Достоевского. М.: Советская Россия, $1979.318 \mathrm{c}$. 
279. Мандельштам О. Шум времени: Воспоминания. Статьи. Очерки. Спб. : Азбука, 1999. 382 с.

280. Roebben B. Living and learning in the presence of the other. Defining religious education inclusively // International Journal of Inclusive Education. June, 2011. P. 1-13

281. Більченко Є.В. Розмаїття релігій і культур світу: На допомогу вчителю / Міністерство освіти і науки України, Управління освіти Волинської облдержадміністрації, Луцька гімназія № 18 Луцької міської ради Волинської області. Луцьк, 2007. 121 с.

282. Закон України «Про освіту». Режим доступу : https://zakon.rada.gov.ua/laws/show/2145-19\#Text

283. Концепція розвитку дистанційної освіти в Україні (затверджено Постановою МОН України В.Г.Кременем 20 грудня 2000 р.).

284. Биков В.Ю. Дистанційне навчання в країнах Свропи та США i перспективи для України / В.Ю. Биков // Інформаційне забезпечення навчальновиховного процесу: інноваційні засоби і технології : кол. монографія / В.Ю.Биков, О.О.Гриценчук, Ю.О.Жук та ін. / Академія педагогічних наук України, Інститут засобів навчання. - К. : Атіка, 2015. - С. 77-140.

285. «Тайм-менеджмент: 5 порад для тих, хто нічого не встигає». Режим доступу : https://happymonday.ua/jeffektivnyj-tajm-menedzhment-5-sovetov

286. «Система управления временем Бенджамина Франклина». Режим доступу : $\quad$ http://timestep.ru/2010/11/30/sistema-upravleniya-vremenembendzhamina-franklina

287. Інтернет-ресурс - Посилання https://blog.agrokebety.com/matrytsyaeyzenkhauera

288. Концепция внедрения новых информационных технологий в учебный процесс общеобразовательной школы/Разработано: Роберт И.В.-М.:НИИ ШОТСО СССР, 1990-93c.

289. Концепция информатизации образования//Информатика и образование, 1990, №1-с. 3-8.

290. Роберт И.В. Теоретические основы создания и использования средств информатизации образования: Дис... докт. пед. наук. - М., 1994-287с.

291. Дидактика средней школы. Некоторые проблемы современной дидактики/Под. ред. М.А. Данилова, М.Н. Скаткина. - М.: Просвещение, 1995$257 \mathrm{c}$.

292. Есенгабылов И.Ж. Дидактические возможности средств информационно-коммуникационных технологий //Поиск, 2011г., №4 
293. Осин А.В. Мультимедиа технологии раскрывают возможности компьютера// Компьютерные технологии в высшем образовании: Программа «Университеты России» - М.: Издательство МГУ, 2004-с. 197-204.

294. Авдеєнко А. П. Організація самостійної роботи студентів / А. Авдеєнко, Л. В. Дементій // Проблеми освіти : Науково-методичний збірник.2012. - № 27. - С. 246.

295. Сайт Українського інституту інформаційних технологій в освіті Національного Технічного Університету України «КПІ» [Електронний ресурс]. - Режим доступу : http://www.udec.ntu-kpi.kiev. ua/ua/resources/dc/.

296. Ястребов Л. Й. Создание мультимедийных презентаций в программе Microsoft Power Point [Електронний ресурс] // Вопросы Интернет-образования, № 41 - Режим доступу : http://vio.fi o.ru/vio_41/cd_site/Articles/glava-00/02.htm.2

297. Закон України „Про вищу освіту” (Із змінами, внесеними згідно із Законами № 1415-VIII від 14.06.2016, ВBP, 2016, № 30, ст.543) [Електронний pecypc]. - Режим доступу : http://www. http://zakon5.rada.gov.ua/

298. Ждан В. М. Роль сучасних технологій у становленні майбутніх лікарів / В.М. Ждан, В.М. Бобирьов, О.В. Шешукова [та ін.] //Медична освіта. - 2012. №3 (додаток). - С. 55-57.

299. Доценко В. І. Інформаційно-комп'ютерні технології як засіб підвищення ефективності навчально-пізнавальної діяльності студентів / В. I. Доценко, Ю. П. Ткаченко // Інноваційні освітні технології у підготовці медичних кадрів. - Полтава, 2010. - С. $59-61$.

300. Тарасевич Е. Б. Использование веб-квестов при организации самостоятельной работы учащихся в обучении иностранным языкам / Е. Б. Тарасевич // Межкультурная коммуникация и профессионально ориентированное обучение иностранным языкам : материалы III Международной научной конференции, посвященной 88-летию образования Белорусского государственного университета. - Минск, 2009. - С. 219-221.

301. Морозова Н. В. Инновационные средства организации самостоятельной работы студентов / Н. В. Морозова // Молодой ученый. - 2011. — T. 2, № 2. - С. 102-104.

302. Бойко Н.I. Організація самостійної роботи студентів вищих навчальних закладів в умовах застосування інформаційно-комунікаційних технологій : автореф. дис. на здобуття наук. ступеня канд. пед. наук : спец. 13.00.04 «Теорія та методика професійної освіти» / Н. І. Бойко. - К., 2008. — 20 $\mathrm{c}$

303. Носач І. Ділові ігри як основа інтерактивного модуля курсу інтерактивних фахових дисциплін з напрямку «Економіка» / I. Носач // Молодь і ринок. - 2008. - № 5. - С. 148-152. 
304. Катеруша О.П. Ділові ігри як засіб пізнавальної діяльності студентів / О. Катеруша // Вища школа. - 2009. - № 12. - С. 53- 60.

305. Ковалевский И. Организация самостоятельной работы студента / И. Ковалевский // Высшее образование. - 2000. - № 1. - С.114-115.

306. Савельев А.Я. Инновационное образование и научные школы / А. Савельев // Вестник высшей школы. - 2000. - № 3. - С. 15-18.

307. Абдулгалімов Р. М. Використання іноваційних технологій як основа розвитку професійної інформаційно - технологічної компетентності лікаря / Р. М. Абдулгалімов, М. А. Ризаханов, Г. Н. Абдулгалімова //Сучасні проблеми науки та освіти.-М.,2015.-№4.

308. Пищик О. В. Методика використання мультимедіа-технологій на уроці / О. В. Пищик // Класному керівнику. Усе для роботи. - 2013. - № 2 (50). C. 6-11.

309. Шестопалюк О. В. Мультимедійні технології в навчальному процесі / О. В. Шестопалюк // Актуальні проблеми трудової професійної підготовки молоді. - Вінниця. - 2004. - Вип.10. - С. 23-25.

310. Шутенко А. В. Методы проведения учебных занятий с использованием средств информационных и коммуникационных технологий / А. В. Шутенко [Электронный ресурс]. - Режим доступа : http://pedsovet.su/publ/261-0-841. 05.04.2010.

311. Кліщ Г. І. Реформування медичної освіти в Австрії: зразок успішного проведення і приклад для наслідування / Г. І. Кліщ // Медична освіта. - 2011. № $1 .-$ C. $58-65$.

312. Поляков Н. В. Классический университет: от идей античности к идеям Болонского процесса / Н. В. Поляков, В. С. Савчук. - Д. : Изд-во ДНУ, 2007. $596 \mathrm{c.}$

313. Медична освіта в світі та Україні / Ю. В. Поляченко, В. Г. Передерій, О. П. Волосовець [та ін.]. - К. : Книга плюс, 2005. - 383 с.

314. Рейтмаєр М. Й. Інтеграція України в Європейський простір вищої освіти. Основні переваги і недоліки. Частина друга: недоліки / М. Й. Рейтмаєр // Галицький лікарський вісник. - 2012. - Т. 19, № 4. - С. 115-118.

315. Лєвітас Ф.Л. Інноваційні підходи до викладання гуманітарних дисциплін у вищій школі с.23-27. Аактуальні проблеми викладання історії україни та історії української культури у вищій школі: матеріали міжвузівського науково-методичного семінару (м. Київ, 18 грудня 2009 р.). Київ: «Політехніка», 2010. 89 c.

316. Закон України «Про інноваційну діяльність». Відомості Верховної Ради України (ВВР). 2002. № 36. ст.266. 
317. Кочубей А.В. Оновлення змісту, форм та методів навчання i виховання в закладах освіти: Збірник наукових праць. Наукові записки Рівненського державного гуманітарного університету. Рівне. 2013 Випуск 7 (50). C.47-53.

318. Національна доктрина розвитку освіти. Затверджена Указом Президента України від 17 квітня 2002 року N 347/2002 [Електронний ресурс] // Режим доступу: https://zakon.rada.gov.ua/laws/show/347/2002

319. Бистрова Ю. В. Інноваційні методи навчання у вищій школі України Право та інноваційне суспільство. 2015. № 1 (4). С. 27-32

320. Прокопів Л. Інноваційні технології навчання і виховання у ВНЗ: навчально-методичний посібник. Івано-Франківськ. 2017. 166 с.

321. Дичківська I. М. Інноваційні педагогічні технології. Київ: Академвидав. 3-тє видання, виправлене. 2015. 304 с.

322. Стрельніков В. Ю. Сучасні технології навчання у вищій школі: модульний посібник для слухачів авторських курсів підвищення кваліфікації викладачів МІПК ПУЕТ. Полтава : ПУЕТ, 2013. 309 с.

323. Бедулина Г.Ф. Интерактивные методы преподавания социально гуманитарных дисциплин: редакция от 12.08.2010 г. - [Электронный ресурс]// Режим доступу URL: http://www.pacademy.edu.by/public/academ.phtml yanushevich. htm

324. Васин Е.К. Об оценке продуктивности смешанного обучения на основе функционирования деятельностного треугольника. Современные проблемы науки и образования. 2016. Вип. 2. С. 33 - 41.

325. Гуркова М.В. Технология «перевернутый класс», как средство повышения методологической культуры учащихся. Повышение качества образования в условиях поликультурного социума. 2017. С. 201-204.

326. Логинова А. В. Смешанное обучение: преимущества, ограничения и опасения. Молодой ученый. 2015. №7. С. $809-811$.

327. Локшина O.I. Теоретико-методологічні підходи до проблеми змісту шкільної освіти. Зміст шкільної освіти в країнах СС: теорія і практика (друга половина XX - початок XXI ст.): монографія / O.I. Локшина. Київ: СПД Богданова А.М., 2009. С. 57-82.

328. Мясникова Т.С., Мясников С.А. Система дистанционного обучения Moodle. Харьков: Изд-во Шейниной Е.В., 2008. 232 с.

329. Нагаева И.А. Моделирование процесса преподавания в виртуальном, образовательном пространстве ВУЗа. Перспективы науки и образования. 2013. №4. С. $79-92$. [Электронный pecypc]. URL: https://pnojournal.wordpress.com/archive/13-04/ (дата обращения 01.12.2020). 
330. Про затвердження Положення про дистанційне навчання: Наказ Міністерства освіти і науки України від 25 квітня 2013 року № 466/2013 / Міністр освіти і науки України. URL: https://zakon.rada.gov.ua/laws/show/z0703-13\#Text (дата обращения 30.11.2020).

331. Abeysekera, L., \& Dawson, P. (2015). Motivation and cognitive load in the flipped classroom:definition, rationale and a call for research. Higher Education Research \& Development, 1-14.

332. Журавльова, Л. В., Лопіна, Н.А. Значення освітнього веб-квесту як важливої складової практично-орієнтованої безперервної післядипломної підготовки лікарів. Матеріали XIII Всеукраїнської науково-практичної конференції з міжнародною участю: Актуальні питання якості медичної освіти ( з дистанційним під'єднанням ВМ(Ф)НЗ України за допомогою відеоконференцзв'язку) (м. Тернопіль, 12-13 травня 2016 року) - Тернопіль, 2016. Т. 2, С. 268269.

333. Михайловська Н.С., Стецюк I.О. Зміни педагогічних аспектів при впроваджені інформаційних технологій на клінічних кафедрах медичних вузів. Актуальні питання дистанційної освіти та телемедицини 2020: тези за матеріалами науково-методичної відеоконференції (м. Запоріжжя, 19-20 листопада 2020 р.) - Запоріжжя, 2020. С. 115-116.

334. Aboobacker Mohammed Rafi, Pulikkottil Raphael Varghese and Praveenlal Kuttichira The Pedagogical Shift During COVID 19 Pandemic: Online Medical Education, Barriers and Perceptions in Central Kerala Journal of Medical Education and Curricular Development, 2020, 7, 1-4.

335. Marina Kawaguchi-Suzuki, Naomi Nagai, Rita Oghenekevwe Akonoghrere, James A. Desborough.COVID-19 Pandemic Challenges and Lessons Learned by Pharmacy Educators Around the Globe American Journal of Pharmaceutical Education, 2020, 84 8, Article 8197.

336. А. А. Котвіцька, О. С. Овакімян, А. В. Волкова. Особливості організації навчання в умовах загальнонаціонального карантину на прикладі досвіду національного фармацевтичного університету. Фармацевтичний часопис, 2020, 2, 84-91.

337. Ю. М. Степанов, І. М. Кононов, І. Я. Будзак, С. В. Косинська, А. В. Саленко Роль педагогічного спілкування між викладачами та слухачами курсів післядипломної підготовки 3 терапії та гастроентерології в оптимізації навчального процесу Медична освіта. 2015, 4, 54-57.

338. Положення про організацію дистанційного навчання в Приватній установі «Вищий навчальний заклад «Міжнародний гуманітарно-педагогічний інститут «Бейт-Хана» URL: https://690a6833-7626-4322-94cc6f6bde8377c6.filesusr.com/ugd/de9706_f0726462a9f649369189e4adbc923fa4.pdf 
339. Осадча К. П. Теоретико-методологічні засади професійної підготовки майбутніх учителів до тьюторської діяльності : дис. ... д-ра пед. наук : 13.00.04. Мелітополь, 2020. 705 с.

340. Бакуліна Н. В. Мова іврит: навч. програма для 1-4 класів загальноосвіт. навч. закладів 3 навчанням українською мовою URL: https://mon.gov.ua/ua/osvita/zagalna-serednya-osvita/navchalni-programi/navchalniprogrami-dlya-pochatkovoyi-shkoli

341. Adams E. and Freeman C. (2009). Selecting tools for online communities: Suggestions for learning technologists. Retrieved from http://ts.mim.org/default/asp?show+artcle\&id=994 [in English].

342. Bykov V.Iu. (2015). Zabezpechennia navchalno-vykhovnoho protsesu: innovatsiini zasoby i tekhnolohii [Ensuring the educational process: innovative means and technologies]: kol. monohrafiia / V.Iu. Bykov, O.O. Hrytsenchuk, Yu.O. Zhuk ta in. / Akademiia pedahohichnykh nauk Ukrainy, Instytut zasobiv navchannia. K.: Atika, S. 77-140. [in Ukrainian].

343. Erben T., Ban R., Castaneda M. Teaching English Language Learners through Technology. Routledge, New York. 2009. P.138. [in English].

344. Kontseptsiia rozvytku dystantsiinoi osvity v Ukraini (2010) [The concept of distance education development in Ukraine], K.: KPI, 12 s. [in Ukrainian].

345. Kraevsky V.V. (2019) Obrazovatelnyey nauki I nauka obrazovaniya ( Metodologicheskiye problemy sovremennoy pedagogiki) [ Education Sciences and Education Science (Methodological Problems of Modern Pedagogy)] // Philosophy Questions. №3. - pp. 77-83. [in Russian]

346. Morozov V. (2014) Philosophiya peredovych innovatsiy v pedagogicheskom protsese [Philosophy in a promoted innovation at the pedagogical process] // News of the Institute for Development of Personal Information. Ser.: Philosophy, Pedagogy, Psychology, - VIP. 33. - pp. 37-43. [in Russian].

347. Morze N.V. (2004) Informatsiini tekhnolohii v navchanni [Information technologies at studying] navch. posib. / Za red. N.V. Morze. - K.: Vydavnycha hrupa BHV, 240 s. [in Ukrainian].

348. Polozhennia pro dystantsiine navchannia [Distance learning principles]. (Zatverdzheno nakazom Ministerstva osvity i nauky Ukrainy 21.01.2004 № 40) Retrieved from: http://zakon4.rada.gov.ua/laws/show/z0703-13\#n18 [in Ukrainian].

349. Pro Natsionalnu prohramu informatyzatsii: Zakon Ukrainy vid 4 liut. 1998 r. № 74/98-VR [About the national program of informatization: Law of Ukraine dated February 04, 1998 No. 74/98-VR] Vidomosti Verkhovnoi Rady Ukrainy. - 1998. №27-28. - St. 181.9.3. [in Ukrainian].

350. Балакірєва О., Бондар Т., Галустян Ю. та ін. (2012). Секс-бізнес в Україні: спроба соціального аналізу. 
351. Балакірєва О., Бондар Т., Сазонова Я., Сакович О. (2018). Підлітки груп ризику: оновлені оцінки. УІСД ім. О. Яременка та ЮНІСЕФ. Режим доступу : https://www.unicef.org/ukraine/media/581/file/risk_teens_HIV.pdf

352. Гіденс Е. (1999). Соціологія.

353. Закон України «Про запобігання та протидії домашньому насильству». (2017). Режим доступу: https://zakon.rada.gov.ua/laws/show/2229-19\#Text

354. Звєрєва I., Безпалько О., Марченко С. та ін. (2004). Соціальна робота в Україні.

355. Комерційна сексуальна експлуатація дітей і підлітків. Ставлення до проблеми. Дослідницький звіт. (2011). Режим доступу: https://rescentre.org.ua/images/Uploads/Files/statistika_dl/report_campaign_ukraine. pdf

356. Мінц М. (2009). Соціологія девіантної поведінки.

357. Протопопов А., Савельєва Н. (2009). Проституція як соціальнопедагогічна проблема. Режим доступу: http://publichealth.org.ua/

358. Тимків Н. (2019). Проституція неповнолітніх: минуле та сучасне в Україні.

Режим

доступу:

https://genderindetail.org.ua/community/comments/prostitutsiya-nepovnolitnihminulogo-ta-suchasnosti-v-ukraini.html

359. Факультативний протокол до Конвенції про права дитини щодо торгівлі дітьми, дитячої проституції і дитячої порнографії. (2000). Режим доступу: https://zakon.rada.gov.ua/laws/show/995_b09\#Text

360. Швед О. (2005). Комерційна сексуальна експлуатація дітей (КСЕД) як нове соціальне явище в світі, країнах СНД та Україні. Режим доступу: https://doi.org/10.15407/socium2005.02-03.079

361. Шиделко А. В. (2011) Проституція неповнолітніх як крайній прояв статевої деморалізації. Режим доступу: http://soctechjournal.kpu.zp.ua/archive/2011/50/54.pdf

362. Global study on sexual exploitation of children in travel and tourism. country-specific report. Ukraine. (2015). Режим доступу: https://www.ecpat.org/

363. Abrams, D., Hogg, M. A., and Marques, J. M. (2004). Social Psychology of Inclusion and Exclusion. New York, NY: Psychology Press.

364. Alroe, H. F., and Noe, E. (2014). Second-order science of interdisciplinary research: a polyocular framework for wicked problems. Constr. Found. 10, 65-95.

365. Anderson, C. A., Carnagey, N. L., and Eubanks, J. (2003). Exposure to violent media: the effects of songs with violent lyrics on aggressive thoughts and feelings. J. Pers. Soc. Psychol. 84, 960-971. 
366. Bryman, A. (2004). Qualitative research on leadership: a critical but appreciative review. Leadersh. Q. 15, 729-769.

367. DeWall, C. N., and Richman, S. B. (2011). Social exclusion and the desire to reconnect. Soc. Pers. Psychol. Compass. 5, 919-932.

368. Gilman, R., Carter-Sowell, A., DeWall, C. N., Adams, R. E., and Carboni, I. (2013). Validation of the ostracism experience scale for adolescents. Psychol. Assess. $25,319-330$.

369. Hales, A. H., Ren, D., and Williams, K. D. (2016b). "Protect, correct, and eject: ostracism as a social tool" in The Oxford handbook of social influence. eds. Harkins, S. J., Burger, J. M., and Williams, K. D. (New York: Oxford University Press).

370. Kelley, K., Clark, B., Brown, V., and Sitzia, J. (2003). Good practice in the conduct and reporting of survey research. Int. J. Qual. Health Care 15, 261-266.

371. Richman, L., and Leary, M. R. (2009). Reactions to discrimination, stigmatization, ostracism, and other forms of interpersonal rejection: a multimotive model. Psychol. Rev. 116, 365-383.

372. Shiffrin, R. M., and Schneider, W. (1977). Controlled and automatic human information processing: II. Perceptual learning, automatic attending, and a general theory. Psychol. Rev. 84, 127-190.

373. Waldeck, D., Tyndall, I., and Chmiel, N. (2015). Resilience to ostracism: a qualitative inquiry. Qual. Rep. 20, 1646-1670.

374. Williams, K. D. (2009). Ostracism: a temporal need-threat model. Adv. Exp. Soc. Psychol. 41, 279-314.

375. Подласый И. П. Педагогика. Учебник для СПО. В 2-х томах. Том 1. Теоретическая педагогика. В 2-х книгах. Книга 1. М.: Юрайт, 2019. 404 с.

376. Подласый И. П. Педагогика. Учебник для СПО. В 2-х томах. Том 2. Практическая педагогика. В 2-х книгах. Книга 1. М.: Юрайт, 2019. 492 с.

377.Рубинштейн, С.Л. Проблемы общей психологии [Текст] / С.Л. Рубинштейн; отв. ред. Е.В. Шорохова. - 2-е изд. - М. : Педагогика, 1976. - 414 с.

378. Фромм, Э. Революция надежды. Навстречу гуманизированной технологии (1968) [Текст] / Перевод Т. В. Панфиловой. - М. : Аст, 2006. - 283 с.

379. Антология педагогической мысли Древней Руси и Русского государства, XIV-XVII вв. / АПН СССР. - М.: Педагогика, 1985. - 367 с.

380. Антология педагогической мысли Украинской ССР. - М.: Педагогика, 1988. - 635, c.

381. Жураковский Г. Е. Очерки по истории античной педагогики. - М.: Изд-во Акад. пед. наук РСФСР, 1963. - 510 с. 
382. Коменский Я.А., Локк Д., Руссо Ж.-Ж., Песталоцци И.Г. Педагогическое наследие.- М.: Педагогика- 1989. - 416 с.

383. Львов М. Р. Основы теории речи М. Р. - М. : Academia, 2000. - 245,

384. Львов М. Р. Методика преподавания русского языка в начальных классах / М. Р. Львов, В. Г. Горецкий, О. В. Сосновская /. - М.: Академия, 2017. -461 ,

385. Методика навчання української мови в початковій школі. - К.: Літера ЛТД, 2011. - $364 \mathrm{c}$.

386. Основы методики начального обучения русскому языку. - М.: Просвещение, 1965. - 534 с.

387. Русова, С. Вибрані педагогічні твори.. - К.: Либідь, 1997. - 272 с.

388. Русский язык в начальных классах. - М. : Линка-пресс, 1994. - 383,

389. Сухомлинский В. А. О воспитании. - М.: Политиздат, 1982. - 270 с.

390. Начальная школа: Настольная книга учителя. - М.: Учпедгиз, 1950. $916 \mathrm{c}$.

391. Учителю начальной школы. - М.: Просвещение, 1964. - 287 с.

392. Ушинский К.Д. Избранные педагогические произведения. - М.: Просвещение, 1968. - 557 с.

393. Федоренко Л. П. Закономерности усвоения родной речи. - М. : Просвещение, 1984. - 159 с.

394. Чуйко, Г. А. Методика викладання української мови в початкових класах. - К. : Вища шк., 1975. - 384 с.

395. Галян, І. М. (2018). Мотиваційно-ціннісні детермінанти професійного становлення майбутніх учителів фізичної культури. Наука і освіта, 3, 36-42. DOI: $10.24195 / 2414-4665-2018-3-5$

396. Георгієв, В. М. (2014). Мотиваційний компонент у структурі професійної компетентності майбутніх офіцерів високомобільних десантних військ. Наука і освіта, 7, 51-56.

397. Ігнатенко, С. О. (2016). формування мотивації студентів до самостійних занять фізичною культурою. Наука і освіта, 4, 125-130. DOI: $10.24195 / 2414-4665-2016-4-25$

398. Калюжна, Ю. І. \& Перетятько, Л. Г. (2016). Особливості розвитку пізнавальної мотивації майбутніх педагогів у процесі викладання психологічних дисциплін. Наука і освіта, 2-3, 125-129. DOI: 10.24195/2414-4665-2016-2-3-22

399. Клибанівська, Т. М. (2015). Мотивація як детермінанта навчальної діяльності студентів вищих закладів освіти. Наука і освіта, 10, 61-68. 
400. Костишина, Г. І. (2003). Формування навчально-пізнавальної діяльності студентів вищих технічних навчальних закладів. (Автореф. канд. пед. наук). Терноп. держ. пед. ун-т ім. В. Гнатюка, Тернопіль.

401. Лузан, П. \& Зайцева, I. (2013). Актуалізація навчання студентівподатківців засобами проектних технологій. Ірпінь: Вид-во Національного університету ДПС України.

402. Лузан, П. Г. (2015). Наукові основи організації педагогічного процесу в аграрному вищому навчальному закладі. Київ: Міленіум.

403. Мельнік, А. О. \& Черній, В. П. (2017). Формування мотивації до навчальної діяльності майбутніх учителів фізичної культури. Наука і освіта, 8 , 150-156. DOI: 10.24195/2414-4665-2017-8-22

404. Методика изучения мотивов учебной деятельности (модификация А.А. Реана, В.А. Якунина). (2004). Retrieved from http://psylist.net/praktikum/00108.htm

405. Нова українська школа. (2016). Retrieved from https://mon.gov.ua/ua/tag/nova-ukrainska-shkola

406. Пакулина, С. А. \& Кетько С. М. (2010). Методика диагностики мотивации учения студентов педагогического вуза. Психологическая наука и образование, 1, 1-11. Retrieved from http://www.psyedu.ru/files/articles/1657/pdf_version.pdf

407. Патик, Ю. В. (2016). Мотиваційні тенденції майбутніх соціальних працівників. Наука і освіта, 1, 47-50. DOI: 10.24195/2414-4665-2016-1-11

408. Плагина, М. И., Соколова, И. Ю., Горбунков, В. Я., Знаменская, С. В. $\&$ Гоман, М. В. (2016). Развитие учебной мотивации студентов с помощью инновационных образовательных технологий. Общественные науки, 11(4), 523528.

409. Рубинштейн, С. Л. (2002). Основы общей психологи. Санкт-Петербург: Питер.

410. Сербін, Ю. (2018). Вплив особистісного адаптивного потенціалу студентів-гуманітаріїв на процес їхньої адаптації до навчання. Наука і освіта, 5/6, 19-25. DOI: $10.24195 / 2414-4665-2018-5-3$

411. Сільвейстр, А. М. \& Моклюк, М. О. (2014). Мотивація навчання стулентів як психолого-педагогічна проблема. Наукові записки. Серія: Проблеми методики фізико-математичної і технологічної освіти, 5, 152-158.

412. Стукалина, Ю. (2016). Моделирование удовлетворенности и мотивации студентов в интегрированной образовательной среде: эмпирическое исследование. Международный журнал управления образованием, 30(6), 10721087. DOI:10.1108/IJEM-01-2015-0008 
413. Фрицюк, В. А. (2016). Діагностика готовності майбутніх педагогів до професійного саморозвитку. Наука і освіта, 10, 189-194. DOI: 10.24195/24144665-2016-10-34

414. Яланська, С. П. (2017). Психологічні аспекти формування креативної компетентності майбутніх учителів. Наука і освіта, 9, 11-15. DOI: 10.24195/24144665-2017-9-2

415. Anderman, L. H. \& Leake, V. S. (2005). The ABCs of Motivation : An Alternative Framework for Teaching Preservice Teachers about Motivation. The Clearing House: A Journal of Educational Strategies, 78(5), 192.

416. Chan, H. \& Wang, X. (2016). Interact for what? the relationship between interpersonal interaction based on motivation and educational outcomes among students in manufacturing programs at two-year technical colleges. Community College Review, 44(1), 26-48. DOI: 10.1177/0091552115612560

417. Charikova, I. \& Zhadanov, V. (2017). Teacher to student epistemological interaction in the contemporary paradigm of university education. Journal of Social Studies Education Research, 8(2), 117-129. DOI: 10.17499/jsser.360868

418. Hamizan, N. \& Zaid, N. M. (2014). Enhancement of student motivation in learning through BLOSSOMS video activity. Advanced Science Letters, 20(10-12), 2014-2017. DOI: 10.1166/ASL.2014.5634

419. Öqvist, A. \& Malmström, M. (2018). What motivates students? A study on the effects of teacher leadership and students' self-efficacy. International Journal of Leadership in Education, 21(2), 155-175. DOI: 10.1080/13603124.2017.1355480

420. Schlag, B. (2013). Lern- und Leistungsmotivation (4. Auflage). Wiesbaden: Springer. DOI: 10.1007/978-3-531-18959-8_11

421. Simon-Dack, Stephanie L., P. Dennis Rodriguez \& Marcum, Geoff D. (2016). Study Habits, Motives, and Strategies of College Students With Symptoms of ADHD. Retrieved from. DOI: 10.1177/1087054714543369

422. Tuckerman, B., W. (2003). The Effect of Learning and Motivation Strategies Training on College Students' Achievement. Journal of College Student Development, 44(3), 430-437. Retrieved from https://serc.carleton.edu/resources/37498.html

423. Wagner, R. F. (2009). Lernen und Motivation. In R. F. Wagner, A. Hinz, A. Rausch , \& B. Becker (Hrsg.), Modul Pädagogische Psychologie (pp. 23-55). Stuttgart: UTB.

424. Israel Yu.A. Ecology and control of the state of the natural environment. Moscow: Gidromethioizdat, 1984, 560 p.

425. Ecology of the city: Textbook. Under total. ed. Stolberg F.V., - K .: Libra, 2000 .-- 464 p. 
426. Environmental protection: Textbook for technical. specialist. Universities / S.V. Belov, F.A. Barbinov, A.F. Koziakov and others: Ed. S.V. Belova. - M .: Higher. school, 1991 .-- 319 p.

427. Kobyakov DO, Remez AO, Poleva Yu.L. Pre-hydraulic changes in the middle of the village of Bazavluk along with natural and anthropogenic factors // Nutrition of steppe forestry and steppe land reclamation. T. - 49, Dnipro, 2020 .-- S. 94-100.

428. Poleva Ju. L. Characteristics of the bottom fauna of small reservoirs of the Steppe zone of Ukraine // Ecology and noospherology, 31 (2), Dnipro, 2020. - pp. 5961.

429. Bogeruk A.K. Towards the development of a strategy for the development of aquaculture in the region of Central and Eastern Europe, taking into account natural and climatic conditions and socio-economic situation // Fish farming and fish industry. No 3, 2011. - P. 3-8.

430. The State of World Fisheries and Aquaculture 2014. Opportunities and Challenges // FAO Fisheries and Aquaculture Department. Food and Agriculture Organization of the United Nations: Rome, 2014 .-- 233 p.

431. Zolotova Z.K. World aquaculture at the turn of the century: statistics and forecasts // Actual issues of freshwater aquaculture: Collection. scientific. tr. - M .: VNIIPRKh, 2000. Issue. 75. - S. 23-37.

432. Results of the activities of the Federal Agency for Fisheries in 2015 and tasks for 2016. Collegium of the Federal Agency for Fisheries. Materials for the meeting. 2016 .-- 165 p.

433. Kozlov V.I., Nikiforov-Nikishin A.L., Borodin A.L. Aquaculture. - M .: MGUTU, 2004 .-- 433 p.

434. Bogeruk A.K., Lukanova I.A. World Aquaculture: Experience for Russia. - M .: FGNU "Rosinfor- magrotech", 2010. - 364 p.

435. Grinzhevsky M.V., Sherman I.M. Organization of breeding and breeding robots in Ribnastics. Kiev, 2006, 338 p.

436. Kovalenko V.O. Methodical instructions for independent robots of students for the course "Aquaculture of piece water. Chastina 1. Aquaculture of natural freshwater waters "(for students in direct training 6.090201" Water biological resources and aquaculture "/ V.O. Kovalenko. - K.: Agrar Media Group, 2014. - 79p.

437. Каніболоцька О. А. Формування Соціолінгвістичної Компетенції Студентів-Філологів На Сучасному Етапі Модернізації Гуманітарної Освіти. [Електронний Pесурс]. - Режим Доступу: Http://Www.Rusnauka.Com/Article/Filology/1-3/19.Html

438. Aguirre A. Cultura E Identidad Cultural. Introducción A La Antropología. - Barcelona: Ediciones Bárdenas, 1997. - 273 P. 
439. Byram M. Context And Culture In Language Teaching And Learning // Multilingual Matters, 2002. - [Електронний Ресурс]. - Режим Доступу: Https://Doi.Org/10.1080/07908310208666643

440. Сепир Э. Язык. - Москва; Ленинград: Государственное СоциальноЭкономическое Издательство, 1934. - 243 С.

441. Pastor Cesteros S. Aprendizaje De Segundas Lenguas: Linguistica Aplicada A La Ensenanza De Idiomas // Studies In Second Language Acquisition, Vol. 28, N ${ }^{\circ}$ 1, Universitat D'Alacant, Servicio De Publicaciones, 2006. - 140 P.

442. Загальноєвропейські Рекомендації 3 Мовної Освіти: Вивчення, Викладання, Оцінювання / Науковий Редактор Українського Видання Доктор Пед. Наук, Прф. С.Ю.Ніколаєва. - К.: Ленвіт, 2003. - 273с.

443. López García M. Aspectos Didácticos Del Componente Cultural De La Lengua: Las Unidades Didácticas Interculturales // Enseñanza De La Lengua Y La Cultura Españolas A Extranjeros, 2005. - Pp. 31-46.

444. Носенко Т.К. Соціокультурна Компетенція Як Невід'ємна Складова Частина Навчання Іноземної Мови. - [Електронний Ресурс]. - Режим Доступу: Http://Www.Rusnauka.Com/Article/Filology/1-3/27.Html $-289 \mathrm{P}$.

445. Carrol J.B. The Study Of Language. - Cambridge: Cambridge Mass, 1999.

446. Kramsh C. Context And Culture In Second Language Learning. - Oxford: Oxford University Press, 1993. - 295 P.

447. Brock-Utne, B. The Global Forces Affecting the Education Sector Today The Universities in Europe as an Example / Birgit Brock-Utne// Higher Education in Europe. - 2002. - XXVII. - № 3. - P. 283-299.

448. Marginson S. Dynamics of National and Global Competition in Higher Education. Higher Education. 2006. Vol. 52. № 1. Pp. 1-39.

449. Richards, Jack C., Theodore S.Rodgers. Approaches and Methods in Language Teaching. - Cambridge University Press, 2011.

450. Toryanik L. A. Podcasts as the main aspect to improve communicative skills in teaching English. - III International scientific and practical conference.-Tokyo, Japan, 2020. p. 146-150.

451. Чирчик С. В. Теоретичні і методичні основи формування професійної компетентності майбутніх бакалаврів з дизайну інтер'єру: дис. на здобуття наук. ступеня канд. пед. наук : 13.00.04 / Житомирський держ. ун-т ім. Івана Франка. Житомир, 2017. 774 с.

452. Шикирінська О. А. Підготовка майбутніх учителів початкових класів до художньо-педагогічної інтерпретації мистецьких творів : дис. на здобуття 
наук. ступеня канд. пед. наук : 13.00 .04 / Вінницький держ. пед. ун-т ім. Михайла Коцюбинського. Вінниця, 2013. 187 с.

453. Критичне мислення як інструмент проведення правоосвітніх заходів у загальноосвітніх навчальних закладах

URL: http://sites.znu.edu.ua/interactiv.edu.lab/Posibnyky/ReaderCT.pdf (дата звернення: 1.06.2021).

454. Терно С. Теорія розвитку критичного мислення. Запоріжжя: Запорізький національний університет, 2011. 108 с.

455. Баранюк I. Василь Сухомлинський про вплив природи на розумове виховання дитини. Педагогічні науки. 2011. Вип. 101. С. 44-51.

456. Рубинштейн С. Л. Основы общей психологии. Санкт-Петербург: «Питер», 2000. 712 с.

457. Дорошенко Т. В. К. Д. Ушинський про виховання естетичних почуттів дитини. Вісник Чернігівського національного педагогічного університету. Педагогічні науки. 2013. Вип. 110. С. 39-42.

458. Станко, А.А. (1995). Исполнительский аппарат скрипача. Одесса. (in Russian).

459. Шульпяков, О.Ф. (1986). Музыкально-исполнительская техника и художественный образ. Ленинград : Музыка. (in Russian).

460. Wronski, Tadeusz. (1996). Technika gry skrzypcowej. Warszawa - Lodz : PWM. (in Polish).

461. Падалка, Г.М. ( 2008). Педагогіка мистецтва : теорія і методика викладання мистецьких дисциплін. Київ : Освіта України. ( in Ukrainian).

462. Андрейко, О.I. (2013). Виконавська культура скрипаля : теорія та методика формування. Львів. ( in Ukrainian).

463. Назайкинский, Е.В. (1982). Логика музыкальной композиции. Москва : Музыка. (in Russian).

464. Harnoncourt, Nikolaus. ( 1998). Muzyka mowo dzwiekow. Warszawa : Ruch Muzyczny. (in Polish).

465. Бабинцева Л.Ю., Выдыборец С. В., Гайдукова С.Н. и соавт. Инновационная деятельность кафедры гематологии и трансфузиологии Национальной медицинской академии последипломного образования имени П. Л. Шупика. Гематология. Трансфузиология. Восточная Европа. 2018; 4(1): 9-15.

466. Вороненко Ю.В., Бойченко Т.С. Стратегії і методи навчання в післядипломній медичній освіті: навчально-методичний посібник. К.: Вересень, 2004: $160 \mathrm{c}$. 
467. Вороненко Ю.В., Мінцер О.П., Краснов В.В. Електронні навчальні посібники для відображення медичних процедурних знань: принципи, етапи створення, методологія. К., 2009: 160 с.

468. What are the top 10 job skills for the future? | World Economic Forum [online]// Kate Whiting, 21 Oct 2020. Доступно: <http:// weforum.org > (Дата звернення 02 червня 2021)

469. Mind, 2020 UBS i PwC виділили три риси характеру, які відрізняють багатих людей від всіх інших [on-line] (Останнє оновлення 05 лютого 2020) Доступно: <http://mind.ua> (Дата звернення 25 лютого 2021)

470. Bulavina Olena Productive economic thinking - the basis of formation of professional competences of students of the specialty «Professional education (Economics)» / O.А. Булавіна // Scientific Herald of the Institute of Vocational Education and Training of the National Academy of Pedagogical Sciences of Ukraine. Vocational pedagogy: collection of researches: $18 \mathrm{~h}$ ed. Editorial board: Institute of Vocational Education of NAPS of Ukraine; [V.O. Radkevych (head) et al]. Vyd. "Polissia", 2019. P. 180-186

471. Бьюзен Т. и Б. Супермышление / Пер. с англ. Е. А. Самсонов; Худ. обл. М. В. Драко. 2-е изд. Серия «Живите с умом». М.: ООО «Попурри», 2003. 304 с.:ил. +16 с. вкл.

472. Халперн Д. Психология критического мышления. СПб.: Издательство «Питер», 2000. 512 с.: ил.

473. Психологія та педагогіка: Навч.-метод. посіб. для самост. вивч. дисц. / Л.В. Музичко, А.В. Тімакова, Л.В. Корват та ін.; За ред. Л.В. Музичко. К.: КНЕУ, 2008. $304 \mathrm{c}$.

474. Булавіна О.А. Особистісний потенціал підприємницької діяльності: формування економічного мислення та комерційного інтелекту в умовах навчальної дисципліни «Психологія підприємницької діяльності» / Наукові записки Національного університету «Острозька академія». Серія «Психологія»: науковий журнал. - Острог: Вид-во НаУОА, 2020.- № 11. - С. 107-114.

475. Пеллегрино Р. Как повысить свой интеллект / Р. Пеллегрино, М. Политис; Пер. с англ. Н. Ю. Чехонадской. М.: ООО «Издательство АСТ»: ООО «Издательство Астрель», 2003. 282, [2] с.:ил.

476. Forbes, 2016 Як стати мільйонером: ТОП-16 найперспективніших сфер роботи [on-line] Доступно: <http://forbes.ru> (Дата звернення 25 травня 2021).

477. Большой энциклопедический словарь: философия, социология, религия, эзотеризм, политэкономия / глав. науч. ред. и сост. С. Ю. Солодовников. - Мн. : МФЦП. 2002. - 1008 с. 
478. Москалець В. П. Психологічний зміст духовності і духовність мистецтва / В. П. Москалець // Ментальність. Духовність. Саморозвиток особистості. - I част. - III розд. - К., 1994. - С. 284-286

479. Помиткін Е. О. Психолого-педагогічний супровід духовнокультурного виховання особистості у XXI столітті / Е. О. Помиткін, Л. В. Помиткіна // Духовність особистості: методологія, теорія і практика. - 2019. - Вип. 2. - С. 153-167. - Режим доступу: http://nbuv.gov.ua/UJRN/domtp_2019_2_17

480. Савчин М.В. Духовний потенціал людини. (Навчальне видання): (монографія). - Вид. 2- ге, пер., доп. - Івано-Франківськ: Місток НВ, 2010. - 508 $\mathrm{c}$

481. Сластёнин, В.А. Введение в педагогическую аксиологию: учеб. пособие для студ. высш. пед. учеб. заведений / В.А. Сластёнин, Г.И. Чижакова. М.: Академия, 2003.- 192 с.

482. Франкл, В. Человек в поисках смысла / В. Франкл. - М.: Прогресс, 1990. - $166 \mathrm{c}$.

483. Чалий О.В. Медична фізика: історія розвитку, досягнення, перспективи.// Біомедична інженерія та медична фізика.-2016. №1.-58c.

484. Стучинська Н.В. Формування фундаменту професійних компетентностей майбутніх лікарів у процесі навчання фізико-математичних дисциплін.// Наукові дослідження. Теорія і практика.-2015. - 73c. URL: http://xn-e1aajfpcds8ay4h.com.ua/files/image/konf\%208/sb8_2_15.pdf/

(дата звернення: 30.05.2021)

485. Попов Н.В. Философия и методология научно-медицинского познания./ Курс лекций для аспирантов. - К, 2002. - 27с.

486. Медична i біологічна фізика (підручник для студентів вищих медичних (фармацевтичних) навчальних закладів), за ред. О.В.Чалого. Вінниця: Нова Книга, 2017.

487. Medical and Biological Physics (Textbook for Students of Higher Medical Institutions), edited by A. Chalyi. Vinnytsia: Nova Knyha, 2017.

488. Медична і біологічна фізика. Практикум. За ред. О.В.Чалого. К.: Книга плюс, 2003.

489. Закон України « Про вищу освіту» URL: https://zakon.rada.gov.ua/laws/show/1556-18/ (дата звернення: 31.05.2021)

490. Гриценко Н.Л. Кейс - метод як форма інтерактивного навчання при вивченні фізико-технічних відкриттів в курсі медичної та біологічної фізики.// Вища освіта України в контексті інтеграції до Європейського освітнього простору. Додаток 1 до Вип. 36, том IV - К., Гнозис, 2015. - 177с. 
491. Гриценко Н.Л. Презентації наукових трендів як навчальний засіб: про фізико-технічні відкриття у медичній радіології. // Вища освіта України в контексті інтеграції до Свропейського освітнього простору. Додаток 1до Вип.31, том IV - К., Гнозис, 2013. - 482c.

492. Медешова А.Б. Бастауыш сынып оқушыларының оқу икемділігін ақпараттық технология арқылы дамытудың педагогикалық шарттары: пед.ғылым.канд. ... автореф. - Атырау, 2006. - $26 б$.

493. Исаева Г.Б., Алдабергеноа А.О., Есенгабылов И.Ж., Смагулова Л.А., Contemporary Period of Civilized Society Development is Characterized the Process of Informatization, International Journal of Applied Engineering Research ISSN 09734562 Volume 11, Number 2 (2016) pp 955-957C Research India Publications. http:www.ripublication.com

494. Лавина Т.А. Непрерывная подготовка учителей в области использования средств информационных и коммуникационных технологий в профессиональной деятельности //—М.; Чебоксары:-ЧГПУ, 2006.-Б.171 стр.

495. Машбиц Е.И. Психолого-педагогические проблемы компьютеризации образования.-М.: Педагогика, 1988.-192с.

496. Есенғабылов И.Ж., Алдабергенова А.О., Жиембаев Ж.Т., «Мектеп курсындағы математикалық есептерді жіктеу мәселесі», Қазақстанның ғылымы мен өмірі, Халықаралық ғылыми-көпшілік журнал, Педагогика сериясы, №1(74) 2019., Б. 198-203.

497. Есенғабылов І.Ж., Жиембаев Ж.Т., Оку үрдісінде ақпараттыққатынастық технологияларды қолдану, Қазақстанның ғылымы мен өмірі, Халықаралық ғылыми-көпшілік журнал, Педагогика сериясы, №12/5 (151) 2020., Б. 149-154.

498. Галасюк С. С., Нездоймінов С. Г. Організація туристичних подорожей та екскурсійної діяльності. Київ : Центр навчальної літератури, 2019. 178 с.

499. Любіцева О. О., Бабарицька В. К. Туризмознавство: вступ до фаху. Київ : Видавничо-поліграфічний центр «Київський університет», 2008. 335 с.

500. Любчук О. К. Організація туризму. Основи туризмознавства : навчальний посібник. Маріуполь : ГВУЗ «ПДТУ», 2018. 154 с.

501. Федорченко В. К., Фоменко Н. А., Скрипник М. І., Цехмістрова Г. С. Педагогіка туризму. Київ : Видавничий дім «Слово», 2004. 296 с.

502. Гельфанова Д. Особливості фахової підготовки майбутніх інженерівпедагогів. Наукові записки Тернопільського національного педагогічного університету імені Володимира Гнатюка. Серія: Педагогіка. Тернопіль, 2009. № 3. C. 131-135.

503. Джантіміров А. Ю. Сучасні вимоги до інженерно-педагогічної освіти. Теоретичні та методичні засади розвитку педагогічної освіти: педагогічна 
майстерність, творчість, технології : зб. наук. праць / за заг. ред. Н. Г. Ничкало. Харків : НТУ «ХПІ», 2007. С. 203-209.

504. Компетентнісний підхід у професійній підготовці майбутніх учителів технологій : кол. монографія / А. М. Гедзик [та ін.]. Умань : Сочінський М. М., 2017. 280 c.

505. Ліненко А. Ф. Теорія і практика формування готовності студентів педагогічних вузів до професійної діяльності : автореф. дис. ... канд. пед. наук : 13.00.01. Київ, 1996. 18 с.

506. Романовський О. Г. Формування психологічної готовності майбутніх фахівців до професійної діяльності : монографія. Харків : ХПІ, 2011. 336 с.

507. Ткачук С. I. Професійна компетентність вчителя трудового навчання як складова педагогічної майстерності. Вісник Чернігівського національного педагогічного університету. Серія: Педагогічні науки. Чернігів, 2017. Вип. 144. C. 113-116. URL: http://nbuv.gov.ua/UJRN/VchdpuP_2017_144_29 (дата звернення: 15.07.2018).

508. Ткачук С. I. Теоретичні аспекти формування компетенції майбутніх інженерів-педагогів у процесі вивчення спецдисциплін. Сучасні інформаційні технології та інноваційні методики навчання в підготовці фахівців: методологія, теорія, досвід, проблеми. 2014. Вип. 37. С. 192-196. URL: http://nbuv.gov.ua/UJRN/Sitimn_2014_37_36 (дата звернення: 15.07.2018).

509. Щербак О. І. Зміст і форми підготовки майстрів виробничого навчання в індустріально-педагогічних технікумах України (1967-1994pp.) : дис. ... канд. пед. наук : 13.00.01. Київ, 1995. 236 с.

510. Гандер Д. В. Профессиональная психопедагогика. М. : «Воентехиниздат», 2007. 336 с.

511. Макаров Р. Н. Психологические основы дидактики летного обучения : учебник. М. : МАКЧАК, ГЛАУ, 2000. 534 с.

512. Бреславець М. М. Методологія підготовки льотних екіпажів військової авіації. Наука і техніка Повітряних Сил Збройних Сил України. 2014. № 2(15). C. 25-31.

513. Кремешний О. І., Ковтонюк I. Б. Використання тренажерів для удосконалення навчального процесу в системах підготовки авіаційних фахівців. Збірник наукових праць Харківського університету Повітряних Сил. 2007. Вип. 2(14). C. 165-167.

514. Маренич С. Ю. Петренко М. М. Особливості теоретичної підготовки курсантів льотних спеціалізацій з бортового обладнання конкретного типу літального апарата. Збірник наукових праць Харківського університету Повітряних Сил. 2011. Вип. 2(28). С. 200-203. 
515. Доломанюк Л. В. Формирование военно-профессиональной компетенции курсантов в процессе обучения в военно-учебных заведениях. Казанский педагогический журнал. 2010. № 5-6. С. 29.

516. Керницький О. М. Формування готовності курсантів льотних навчальних закладів до професійної діяльності. Педагогіка формування творчої особистості у вищій і загальноосвітній школах. 2015. Вип. 41 (94). С. 155-162.

517. Пухальська Галина Анатоліївна. Формування комунікативної компетентності майбутніх пілотів цивільної авіації: навч.-метод. посіб. Кіровоград : Вид. ДЛАУ, 2010.91 с.

518. Семененко I. Є. Аналіз теоретичних підходів до визначення поняття «фахова підготовка» іноземних студентів. Педагогіка та психологія. 2015. Вип. 51. C. $228-237$.

519. Вікторов В. Основні критерії та показники якості освіти. Вища освіта України. 2006. № 1. С.54-59.

520. Грінченко Г.Ф., Гришенкова Т.О., Кудряшова В.В. Нові тенденції в навчально-виховній роботі вчителя школи. Теоретичні та методологічні засади соціально-педагогічної підготовки вчителя. зб. наук.-метод. праць К. : IЗМН. Житомир : Держ. пед. інститут, 1999. С.122-124.

521. Онипченко П.М., Невзоров Р.В. Роль авіаційної педагогіки у професійній підготовці курсанта-льотчика в умовах багатопрофільного ВВНЗ. Науковий вісник Льотної академії. Серія: Педагогічні науки. Вип. 4. Кропівницький : ЛА НАУ, 2018. С.162-169.

522. Боднар, О., 2012. Особливості творчого і науково-дослідного процесу в дизайні та архітектурі 1960-1980-х років. Нариси з історії українського дизайну ХХ століття. Київ: ФЕНІКС, с.181-204.

523. Бойчук, О., 2017. Дизайн постіндустріальної епохи: нові виміри, нові вимоги. Вісник Харківської академії дизайну і мистецтв. Харків: ХДАМ, 5, с.6672 .

524. Бойчук, О., 2019. Чинник системності в інноваційному дизайні. Вісник Харківської академії дизайну і мистецтв. Харків: ХДАМ,1, с.5-11.

525. Даниленко, В., 2012. Дизайн України в європейському вимірі XX століття. Нариси з історії українського дизайну XX століття. Київ: ФЕНІКС, с.6 -34 .

526. Ідак, Ю. В., 2014. У пошуках креативних ідей. В.: Черкеса Б. та Петришин Г., ред. Креативний урбанізм: до століття містобудівної освіти у Львівській політехніці. Львів: Видавництво Львівської політехніки. с. 623-630.

527. Мигаль, С. П., 2012. Дизайн середовища: проблеми та перспективи. Вісник Національного університету «Львівська політехніка». Архітектура, 728, c. $197-202$. 
528. Радомська, В. Р., 2020. Фрактальна геометрія в структурі стінописів інтер'єрного простору (на прикладі поліхромій Модеста Сосенка). Актуальні питання гуманітарних наук: Міжвузівський збірник наукових праць молодих вчених Дрогобицького державного педагогічного університету імені Івана Франка, 30.T. I., с. 212-217.

529. Черкес, Б. С., 2006. Національна ідентичність в архітектурі громадських центрів столичних міст в умовах ідеологічної детермінації. Автореферат. Доктор архітектури. Київський національний університет будівництва і архітектури.

530. Шмагало, Р. 2020..Ідейно-філософські витоки мистецької та дизайносвіти України в епоху модерну та постмодерну. Актуальні проблеми сучасного дизайну, с.103-106.

531. Шмагало, Р., 2012. Історичний розвиток, структурування та методологія дизайн-освіти в Україні кінця XIX - середини XX століття. Нариси з історії українського дизайну ХХ століття. Київ: ФЕНІКС, с.132- 172.

532. Куйбіда В.С., Петроє О.М., Федулова Л.І., Андрощук Г.О. Цифрові компетенції як умова формування якості людського капіталу. URL: http://academy.gov.ua/pages/dop/198/files/90a7d5c8-d10a-4f8f-89874d1077fdc8f6.pdf

533. Ведерніков М. Д. Сучасні технології управління персоналом: компетенційний підхід / М. Д. Ведерніков, О. О. Чернушкіна, О. С. МантурЧубата // Науковий вісник Ужгородського національного університету. Серія : Міжнародні економічні відносини та світове господарство. - 2018. - Вип. 19(1). C. 39-43. - Режим доступу: http://nbuv.gov.ua/UJRN/Nvuumevcg_2018_19(1)_11.

534. Ковальчук В.В. Сутнісно-містовна характеристика категорії «професійна компетентність» як показника рівня фахової підготовки студентів. Проблеми інженерно-педагогічної освіти, 2007. № 18. С. 84-88.

535. Підлипняк І.Ю. Реалізація компетентнісного підходу в сучасній освітній парадигмі. Вісник Черкаського університету, 2015. №10 (343). С.105110

536. Пасинчук К. Сутність поняття «Фахова компетентність» майбутнього працівника служби цивільного захисту [Електронний ресурс] / Кирило Пасинчук // Збірник наукових праць Уманського державного педагогічного університету. - 2013. - Режим доступу до pесурсу: http://znp.udpu.edu.ua/article/view/197744. DOI: $10.31499 / 2307-4906.0 .2013 .197744$

537. Запорожцева Ю. С. Інформаційно-цифрова компетентність як складник сучасного навчально-виховного процесу [Електронний ресурс] / Ю. С. Запорожцева // Інноваційна педагогіка. - 2019. - Режим доступу до ресурсу: http://www.innovpedagogy.od.ua/archives/2019/12/part_1/17.pdf. 
538. С. Свстрат’єв, «Цифрові компетентності у підготовці молодших бакалаврів з агрономії», OD, вип. 3, с. 185-205, Bep 2020.

539. agrarausbildung-ukraine.net [Електронний ресурс] - Режим доступу: http://agrarausbildung-ukraine.net/?lang=uk (дата звернення 16.04.2021). - Назва 3 екрана.

540. Волявко Д.М. Самоконтроль - найважливіший компонент продуктивної навчальної діяльності / Д.М.Волявко. - К.: „Академія”, 2004. - 130с.

541. Тухман І.В. Розвиток самоконтролю в навчальній діяльності молодших школярів / І.В.Тухман // Початкова школа. - 2004. - № 2. - С.20-24.

542. Прохоренко Л.І. Формування самоконтролю на уроках математики у молодших школярів із ЗПР. Науково-метод. посібник / Л.І.Прохоренко. - 2011. $65 \mathrm{c}$.

543. Ілійчук Л. Формування навичок самоконтролю молодших школярів у навчальному процесі початкової школи / Л.Ілійчук // Гірська школа українських Карпат. - 2015. - № 12-13. - С.155-159.

544. Романова Ю. Д. Інформатика і інформаційні технології. Вид. 5. М.: Ексмо-прес, 2011.704 с.

545. Економічна інформатика. Підручник і практикум для бакалавриата i магістрату/ за ред. Романової Ю.Д. М.: Видавництво Юрайт, 2016. 312 с.

546. Романова Ю.Д. та ін. Інформаційні технології в управлінні (менеджменті). М.: Видавництво Юрайт, 2016. 275с.

547. Матюшок В.М. Інформатика для економістів: Підручник. 2-е вид., перероб. і доп. Инфра-м, 2016. 217 с.

548. Вдовенко Л.А. Інформаційна система підприємства : Навчальний посібник. 2-е вид., перероб. і доп. Инфра-м, 2015. 342 с.

549. Роль і місце технологій мультимедіа в сучасних інформаційних технологіях. Психологічні аспекти використання в навчанні мультимедіа засобів : веб-сайт. URL: https://thelib.info/programmirovanie/529983-rol-i-mesto-tehnologijmultimedia-v-sovremennyh-informacionnyh-tehnologiyah-psihologicheskie-aspektyispolzovaniya-v-obuchenii-multimedia-sredstv/ (дата звернення: 18.05.2021).

550. Бент Б., Андерсен. Мультимедіа в освіті: спеціалізований навчальний курс. М.: «Обучение-Сервис», 2012. 286 с.

551. Долженко О.В. Современные методы и технология обучения. Минск: Высшая школа, 2014. 278 с.

552. Основи web-технологій. Курс лекцій / П. Б. Храмцов та ін. Київ : Університет Інформаційних Технологій, 2016. 386 с. 
553. Бондаренко О.В. Применение мультимедийных технологий в образовательном процессе высшего учебного заведения. Современные проблемы науки и образования. Электронный научный журнал. 2017. № 3.; URL: http://www.science-education.ru/ru/article/view?id=26397 (дата звернення: 20.05.2021).

554. Отеген Г.Ж., Акзула Л., Туреханова С.І. Застосування мультимедіа технологій в освітньому процесі. Міжнародний журнал експериментальної освіти. 2017. № 4, ч. 2. С. 174-175.

555. Бордовский Г.А. Использование электронных образовательных ресурсов нового поколения в учебном процессе. Москва: РГПУ, 2013. 484 с.

556. Теорія та практика змішаного навчання. Монографія / За редакцією В.М. Кухаренка. Харків : «Міськдрук», НТУ «ХПІ». 2016. 284 с.

557. Кухаренко В.М., Бондаренко В.В. Екстрене дистанційне навчання в Україні: Монографія. Харків:. Вид-во КП «Міська друкарня», 2020. 409 с.

558. Tarasov A. The Role of A Teacher In Selecting A Resource For Adaptaton For Distance Learning. Higher education in a pandemic time Proc. Intern. e-conf., 5 nov. 2020, SNPU Ushynsky (Ukraine), Central University of Haryana (India), Ariel University (Israel). Pp 28-29.

559. Королько В.Г. Паблик рілейшнз. Наукові основи, методика, практика : підручник. 2-е вид., доп. Київ : ВД "Скарби", 2001. 265 с.

560. Буйницька О.П. Інформаційні технології та технічні засоби навчання: навч. посіб. Київ: Центр учбової літератури, 2012. 240 с.

561. Дибкова Л.М. Інформатика і комп'ютерна техніка: навчальний посібник. 2-е вид., переробл., доп. Київ: Академвидав, 2007. 416 с.

562. Злобін Г.Г. Основи інформатики, комп'ютерної техніки і комп’ютерних технологій: підручник. Київ: Каравела, 2007. 240с.

563. Жарких Ю. С., Лисоченко С. В., Сусь Б. Б. Комп'ютерні технології в освіті : навч. посібник. Київ: Університет, 2012 . 239 с.

564. Тарасов А. Ф. Основи інформаційних технологій та мультимедійних засобів навчання: метод. посібник. Одеса: ПНПУ. 2015. 137 с.

565. Berman B. Notes from the Pianist's Bench.- Yale: Hilles Publication Funds of Yale University, 2000. - 223 p.

566. Станиславский К.С. Работа актера над собой / Станиславский К.С. М.: Мысль, 1957. - 468.

567. Алексеев А.Д. Методика обучения игре на фортепіано / А.Д.Алексеев - М.: Музыка, 1978. - 287c. 
568. Психология музыкальной деятельности: Теория и практика: [учебное пособие для студ. муз. фак.. высш. пед. учеб. Заведений]/ Д.К. Кирнарская, К.В.Тарасова и ДР.; [под ред. Г.М.Цыпина]. - М.: Издательский центр “академия”, 2003. - 368 с.

569. Костюк О.Г. Сприймання музики і художня культура слухача. - К.: Наукова думка, 1965. - 117 с

570. Теплов Б.М. Психология музыкальных способностей / Б.М.Теплов .М: Изд-во "Лань", "Планета музыки",2020, - 488 с..

571. Холопова В. Н. Музыка как вид искусства. Часть первая. Музыкальное произведение как феномен / [учебное пособие для музыковедов консерваторий] /. В. Н. Холопова - «Печатник», 1990.- 140 с.

572. Левчук Л.Т. Західноєвропейська естетика XX століття: [навч. посібник] / Лариса Левчук. - К.: Либідь, 1997. - 224 с.

573. Сова М.О. Свідоме і несвідому в музичній рефлексії / М.О.Сова // Теоретичні та практичні питання культурології: [зб.статей]. - Ч.ІІ. - К.: Логос, 1997. - C.72-75

574. І.М. Варфоломєєва, «Формування пізнавальних інтересів учнів в умовах комп’ютерного навчання», Географія, № 3, с. 8-9, 2008.

575. Н.О. Гончарова, Система навчально-методичного забезпечення навчання географії в 7 класі. (Електронний ресурс(. Доступно: http://irbis-nbuv. gov.ua/cgi-bin/irbis_nbuv/cgiirbis_64. exe.pdf., 1964. 1998.

576. М.З. Грузман, Эвристика в информатике. Винница, Украина: Арбат,

577. А.М. Гуржій, та В.В. Бондаренко, та О.В. Співаковський, Всеукраїнські та міжнародні олімпіади 3 інформатики в задачах та рішеннях. Херсон, Україна: Айлант, 2007.

578. В.М. Гудима, Використання інформаційно-комунікативних технологій у викладанні географії. (Електронний ресурс(. Доступно: http://nbuv.gov.ua/e-journals/ NarOsv/2007-2/07gvmtvg.htm, 2007.

579. Д. Гукін, Word for Windows. Київ, Україна: Діалектика, 2004.

580. Л.М. Даценко, та В.І. Остроух, «Вивчення основ геоінформаційних систем і технологій у профільних класах», Проблеми безперервної географічної освіти і картографії, вип. 6, с. 67-70, 2010.

581. М.I. Жалдак, та Н.В. Морзе, «Яким бути шкільному курсу інформатики», Комп’ютер в школі та сім’ї, № 1, с. 3-9, 1998.

582. М.Ю. Кадемія, та І. Ю. Шахіна, Інформаційно-комунікаційні технології в навчальному процесі. Вінниця, Україна: ТОВ «Планер», 2011. 
583. С. Кобернік, та Р. Коваленко, «Сучасний стан і перспективи комп'ютерного навчання географії», Географія та основи економіки в школі, № 3, c.10-13, 2002.

584. В.П. Корнєєв, «Комп’ютер і географія», Освіта, № 12, с. 10-11, 2003.

585. Д.О. Корчевський, «Теоретико-методичні основи інтеграції змісту практично-технічної підготовки фахівців з комп’ютерної графіки і дизайну», автореф. дис. д-ра пед. наук, Нац. пед. ун-т ім. М.П. Драгоманова, Київ, 2017.

586. К. Костиря, «Використання комп'ютерів 3 метою особистісноорієнтованого навчання на уроках географії», Рідна школа, № 10, с. 28-31, 2004.

587. О.О. Ляшенко, «Теоретично-методичні засади організації профільного навчання в старшій загальноосвітній школі», Директор школи, ліцею, гімназії, № 5, c. 4-12, 2008.

588. А.Н. Некос, та Ю.В. Медведєва, «Використання системи Moodle для контролю знань 3 екології учнів закладів загальної середньої освіти», Інформаційні технології і засоби навчання, том 63, № 1, с. 56-72, 2018.

589. В.М. Тарадайник, Використання інформаційно-соціального середовища розвитку обдарованої дитини. Київ, Україна: Інститут обдарованої дитини НАПН України, 2014.

590. І.В. Удовиченко, «Використання інформаційно-комунікаційних технологій на уроках географії в старшій профільній школі», Проєктування розвитку та психолого-педагогічного супроводу обдарованої особистості. Київ, Україна: Ін-т обдарованої дитини НАПНУ, № 1 (68), с. 257-259, 2018.

591. І.В. Удовиченко, Концептуальні засади змісту навчання географії учнів старшої школи на профільному рівні, монографія. Київ, Україна: Педагогічна думка, 2018. 